\title{
Modeling Report of the CEA Cadarache MINERVE Reactor for the OSMOSE Project
}

Nuclear Engineering

Argonne National Laboratory 
About Argonne National Laboratory

Argonne is operated by The University of Chicago for the U.S. Department of Energy Office of Science, under contract W-31-109-Eng-38. The Laboratory's main facility is outside Chicago, at 9700 South Cass Avenue, Argonne, Illinois 60439. For information about Argonne and its pioneering science and technology programs, see www.anl.gov.

\section{Availability of This Report}

This report is available, at no cost, at http://www.osti.gov/bridge. It is also available on paper to U.S. Department of Energy and its contractors, for a processing fee, from:

U.S. Department of Energy

Office of Scientific and Technical Information

P.O. Box 62

Oak Ridge, TN 37831-0062

phone (865) 576-8401

fax (865) 576-5728

reports@adonis.osti.gov

\section{Disclaimer}

This report was prepared as an account of work sponsored by an agency of the United States Government. Neither the United States Government nor any agency thereof, nor The University of Chicago, nor any of their employees or officers, makes any warranty, express or implied, or assumes any legal liability or responsibility for the accuracy, completeness, or usefulness of any information, apparatus, product, or process disclosed, or represents that its use would not infringe privately owned rights. Reference herein to any specific commercial product, process, or service by trade name, trademark, manufacturer, or otherwise, does not necessarily constitute or imply its endorsement, recommendation, or favoring by the United States Government or any agency thereof, Argonne National Laboratory, or The University of Chicago. 
Modeling report of the CEA Cadarache MINERVE reactor for the OSMOSE project

\author{
G. Perret ${ }^{1}$, R. Klann ${ }^{1}$, JP. Hudelot ${ }^{2}$, M. Antony ${ }^{2}$ \\ ${ }^{1}$ Argonne National Laboratory \\ 9700 South Cass Ave. \\ Argonne, IL 60439 \\ USA \\ ${ }^{2}$ Commissariat à l'Energie Atomique \\ Cadarache \\ 13109 St Paul lez Durance \\ France
}

December 17, 2004

Argonne, IL 


\section{TABLE OF CONTENT}

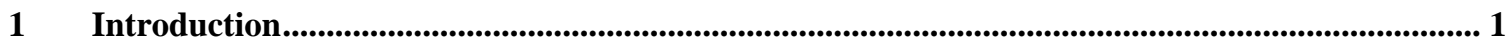

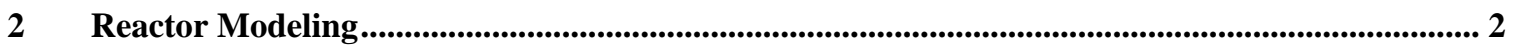

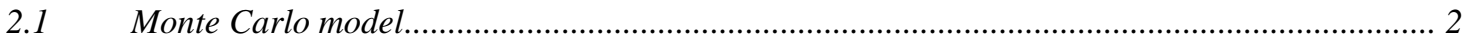

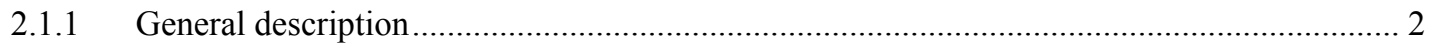

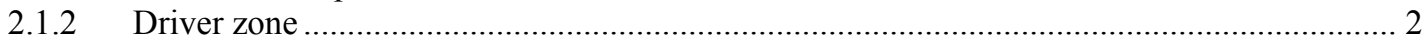

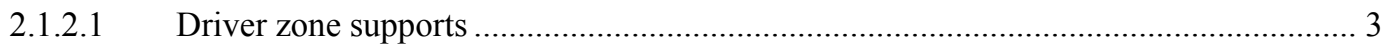

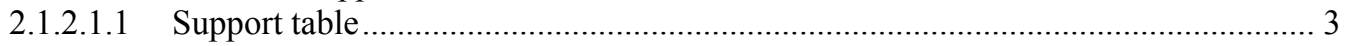

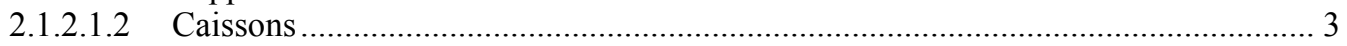

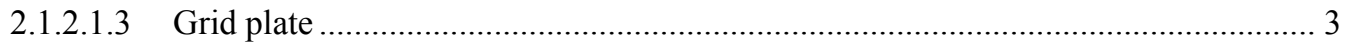

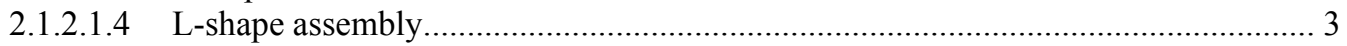

2.1.2.2 Graphite blocks and driver element ………........................................................... 3

2.1.2.2.1 Graphite blocks ........................................................................................ 3

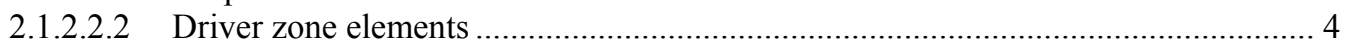

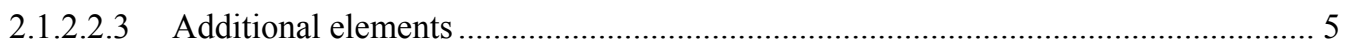

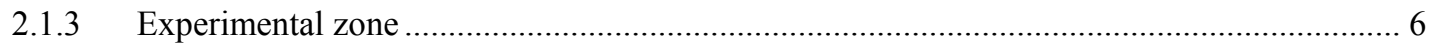

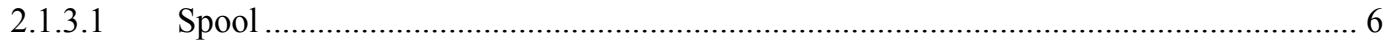

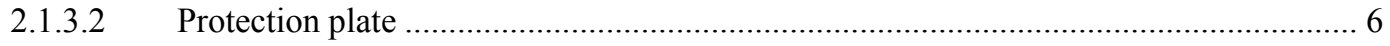

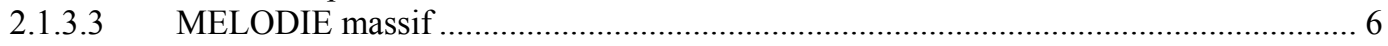

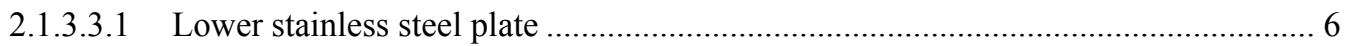

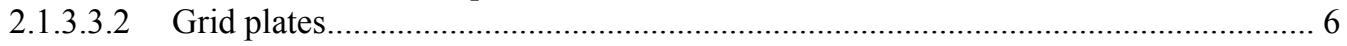

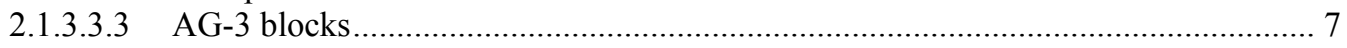

2.1.3.4 Experimental lattice - Pins and POLINE overclad ...................................................... 7

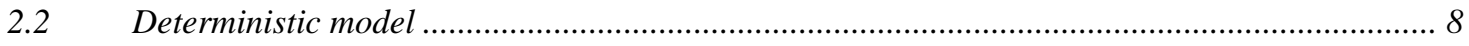

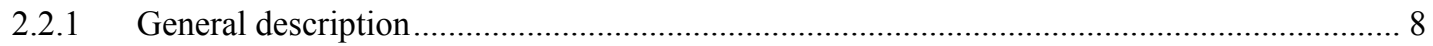

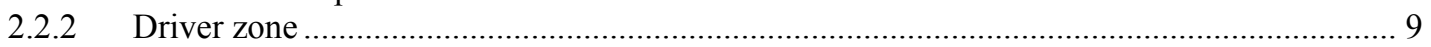

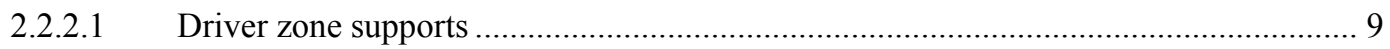

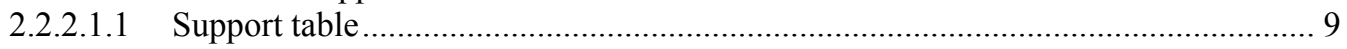

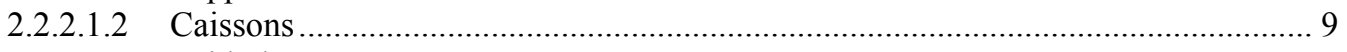

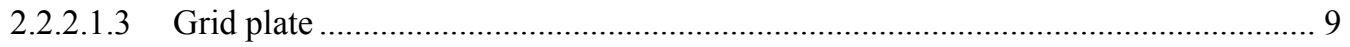

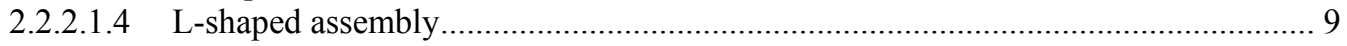

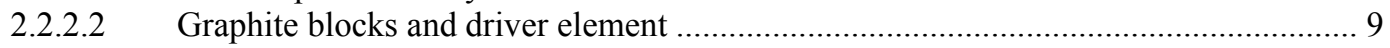

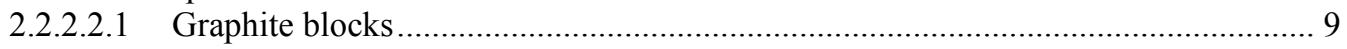

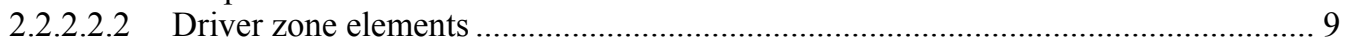

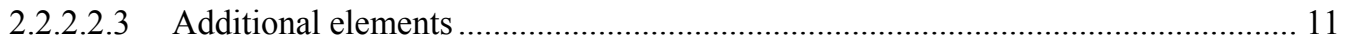

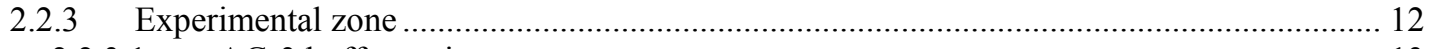

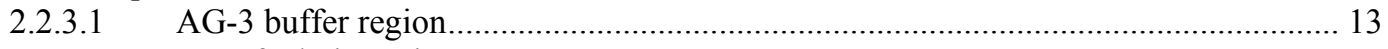

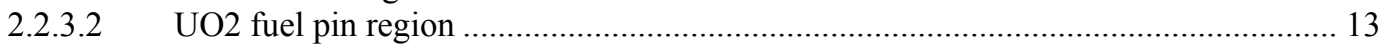

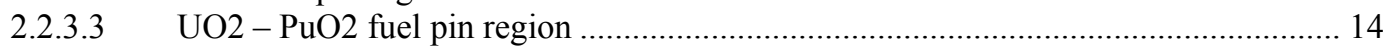

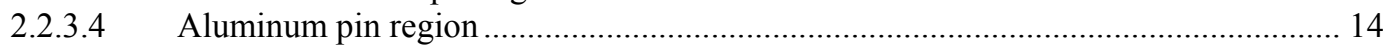

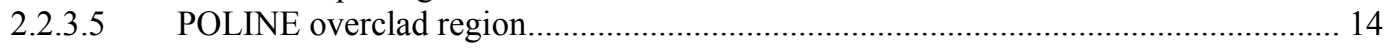

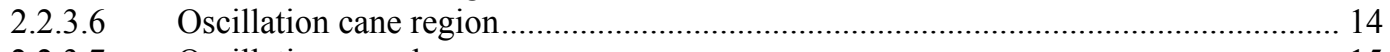

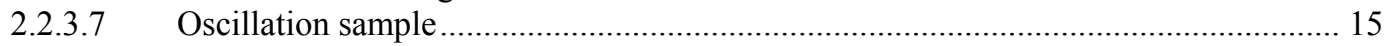

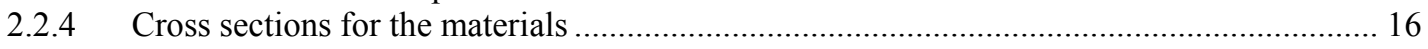

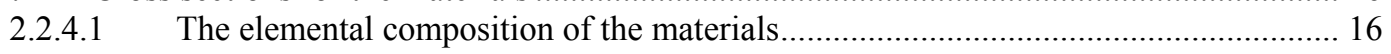

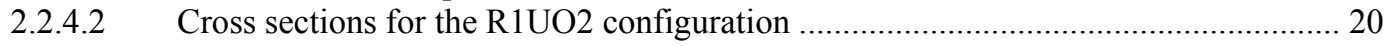

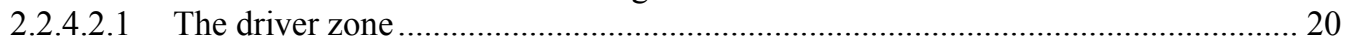

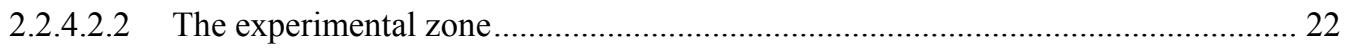

2.2.4.3 Cross sections for the R1MOX configuration ....................................................... 26

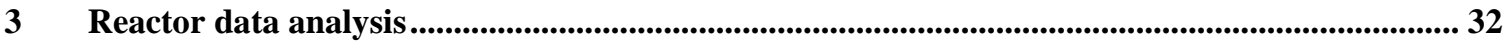

3.1 The control rod reactivity worth.............................................................................................. 32 


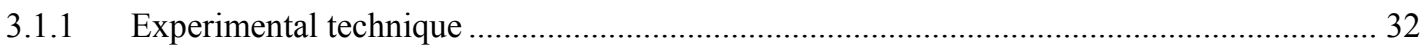

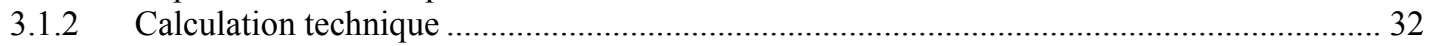

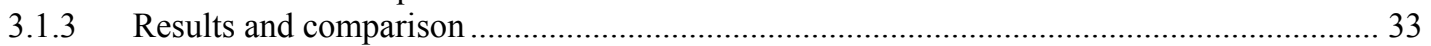

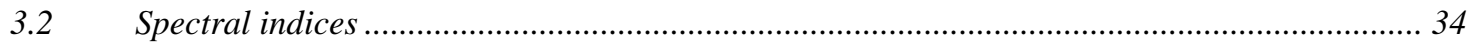

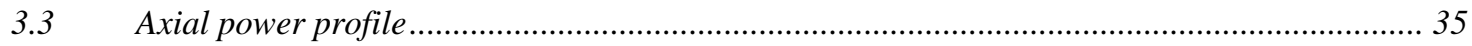

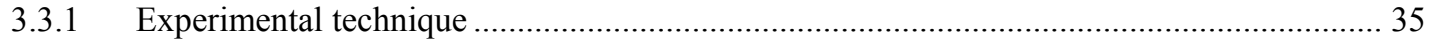

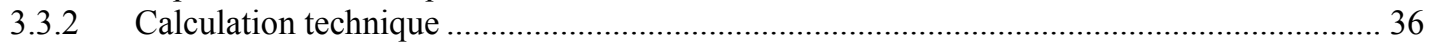

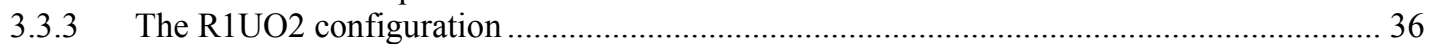

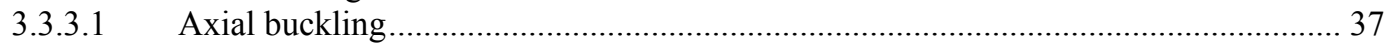

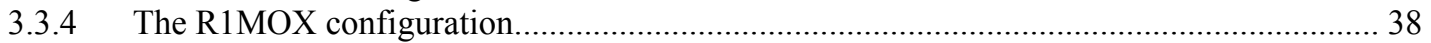

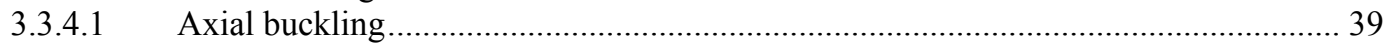

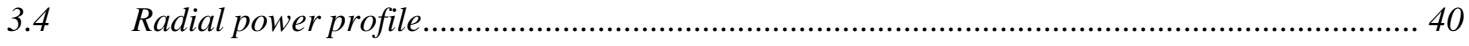

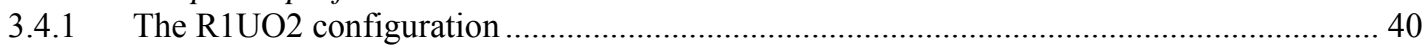

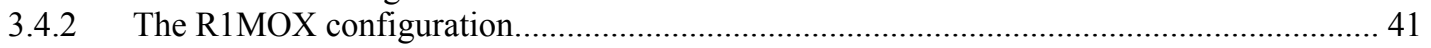

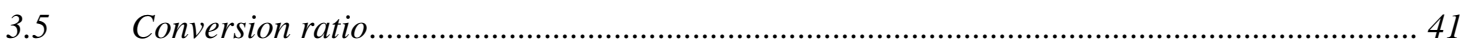

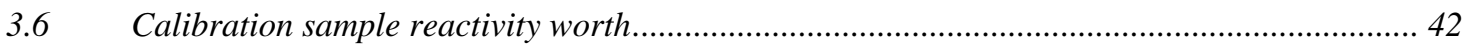

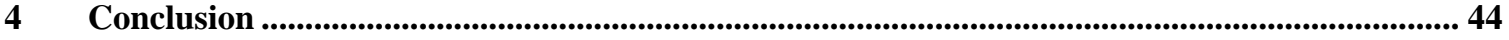

Appendix 1: MCNP input files .......................................................................................................................... 121

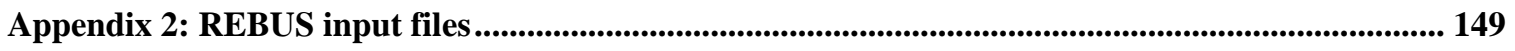

Appendix 3: WIMS input files.................................................................................................................... 203

Appendix 4: Elemental compositions........................................................................................................... 234 


\section{LIST OF TABLES}

Table 1:Geometry specification of the graphite blocks .................................................. 4

Table 2:Geometry specification of the graphite element ................................................. 4

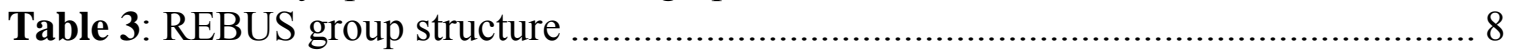

Table 4: Geometry and material specification of the graphite blocks................................ 9

Table 5: Geometry and material specification of the graphite element ........................... 10

Table 6: Geometry and material specification of the 18-plate fuel element .................... 10

Table 7: Geometry and material specification of the 12-plate fuel element .................... 10

Table 8: Geometry and material specification of the 9-plate fuel element ...................... 11

Table 9: Geometry and material specification of the control element ............................. 11

Table 10: Geometry and material specification of the chimney region ............................ 12

Table 11: Geometry and material specification of the AG-3 buffer region...................... 13

Table 12: Geometry and material specification of the $\mathrm{UO}_{2}$ fuel pins region................... 13

Table 13: Geometry and material specification of the $\mathrm{UO}_{2}-\mathrm{PuO}_{2}$ fuel pins region ......... 14

Table 14: Geometry and material specification of the Aluminum pin region ................. 14

Table 15: Geometry and material specification of the oscillation cane region................. 15

Table 16: Geometry and material specification of the U-235 calibration sample ............ 15

Table 17: Volume fraction of the homogenized U-235 calibration sample inserted in the

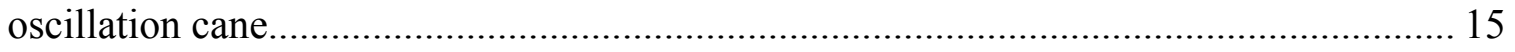

Table 18: Geometry and material specification of the borated $\mathrm{UO}_{2}$ calibration sample.. 16

Table 19: Volume fraction of the homogenized boron calibration sample inserted in the

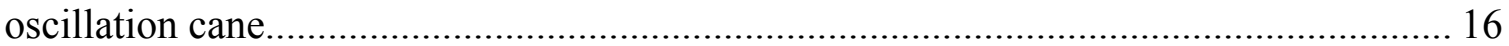

Table 20: AG-3 aluminum alloy composition.......................................................... 17

Table 21: AL5 aluminum alloy composition .............................................................. 17

Table 22: AW-2017 aluminum alloy composition........................................................ 18

Table 23: Zr-4 zirconium alloy composition............................................................ 18

Table 24: Zr-2 zirconium alloy composition.............................................................. 19

Table 25: Stainless steel composition .................................................................... 19

Table 26: Number density of the U-235 calibration samples.......................................... 20

Table 27: Number density of the Boron calibration samples.......................................... 20

Table 28: Characteristic of the WIMS calculation used to generate cross sections for the

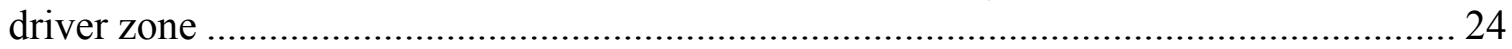

Table 29: Characteristic of the WIMS calculation used to generate cross sections for the

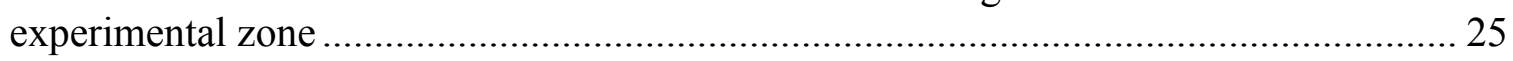

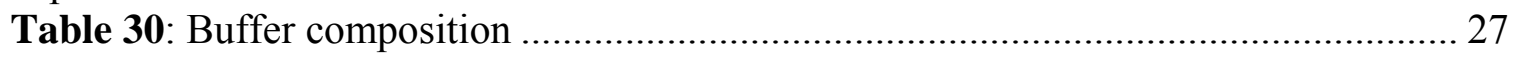

Table 31: Buffer composition in the "PuPOL" calculation.............................................. 29

Table 32: Characteristics of the WIMS calculations used to generate cross sections for

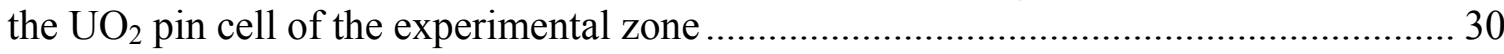

Table 33: Characteristics of the WIMS calculations used to generate cross sections for the $\mathrm{UO}_{2}-\mathrm{PuO}_{2}$ pin cells of the experimental zone .......................................................... 31

Table 34: Experimental rod worth in the R1UO2 configuration ..................................... 33

Table 35: Experimental and calculated rod worth in the R1UO2 configuration .............. 34

Table 36: Calculated rod worth reactivity in the R1MOX configuration ......................... 34

Table 37: Spectral indices for the R1UO2 configuration................................................ 35

Table 38: Spectral indices for the R1MOX configuration ............................................... 35 
Table 39: Spectral indices calculated with MCNP ................................................... 35

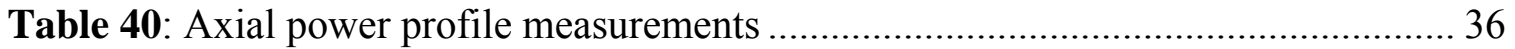

Table 41: Buckling vs. fitting range issued from pin measurement in the R1UO2

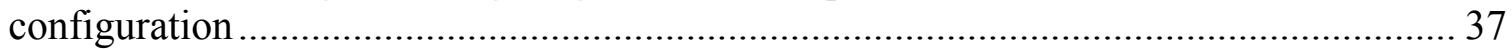

Table 42: Buckling vs. fitting range issued from MCNP simulation of the R1UO2 configuration

Table 43: Experimental and calculated axial buckling (*1e-3) in the R1UO2 configuration

Table 44: Experimental buckling as a function of the fitting range in the R1MOX configuration

Table 45: MCNP buckling as a function of the fitting range in the R1MOX configuration

Table 46: Experimental and calculated axial buckling (*1e3) in the R1MOX

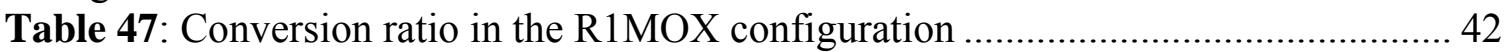

Table 48: $\mathrm{UO}_{2}$ calibration sample in the R1-UO2 configuration................................. 42

Table 49: Borated $\mathrm{UO}_{2}$ calibration sample in the $\mathrm{R} 1-\mathrm{UO} 2$ configuration ....................... 42

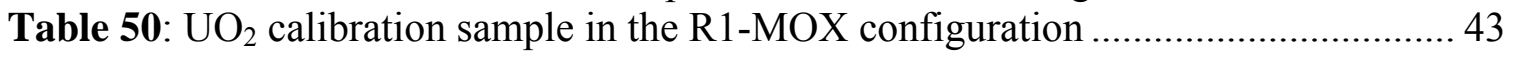

Table 51: Borated $\mathrm{UO}_{2}$ calibration sample in the $\mathrm{R} 1-\mathrm{MOX}$ configuration...................... 43 


\section{LIST OF FIGURES}

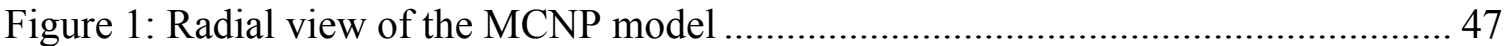

Figure 2: Axial view of the MCNP model............................................................... 48

Figure 3: Support element and graphite blocks of the driver zone - MCNP model ......... 49

Figure 4: Graphite element - MCNP model ............................................................. 50

Figure 5: 18-plate fuel element - MCNP model......................................................... 51

Figure 6: 12-plate fuel element - MCNP model..................................................... 52

Figure 7: 9-plate fuel element - MCNP model......................................................... 53

Figure 8: Details of the fuel elements - MCNP model................................................... 54

Figure 9: Control element - MCNP model ................................................................. 55

Figure 10: Details of the control element and the rods - MCNP model........................... 56

Figure 11: Pilot rod element - MCNP model ……………………………………….... 57

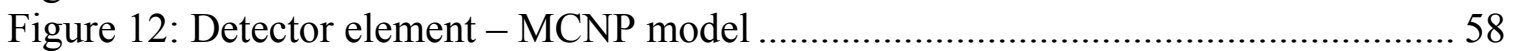

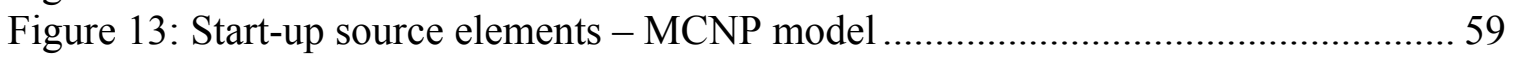

Figure 14: Thermal column - MCNP model ................................................................. 60

Figure 15: AG-3 wedges and additional graphite element - MCNP model..................... 61

Figure 16: Experimental zone \& MELODIE massif - MCNP model ............................... 62

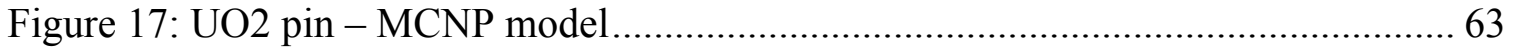

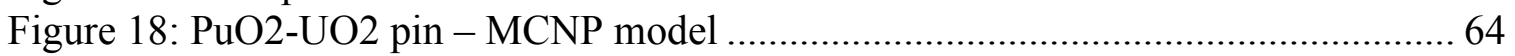

Figure 19: Details of the PuO2-UO2 pin - MCNP model................................................... 65

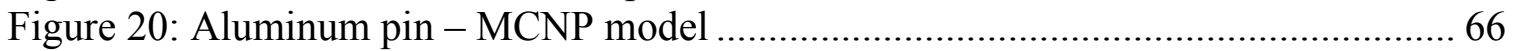

Figure 21: POLINE overclad - MCNP model.............................................................. 67

Figure 22: Radial view of the REBUS model in the R1UO2 configuration...................... 68

Figure 23: Axial view of the REBUS model in the R1UO2 configuration ....................... 69

Figure 24: Graphite element - MCNP \& REBUS models .............................................. 70

Figure 25: 18-plate fuel element - MCNP \& REBUS models ........................................ 71

Figure 26: 12-plate fuel element - MCNP \& REBUS models ......................................... 72

Figure 27: 9-plate fuel element - MCNP \& REBUS models ........................................... 73

Figure 28: Control element - MCNP \& REBUS models ............................................... 74

Figure 29: Radial decomposition of the chimney interface ………................................. 75

Figure 30: AG-3 wedges - REBUS models …………........................................... 76

Figure 31: Chimney - MCNP \& REBUS models ....................................................... 77

Figure 32: Aluminum buffer - MCNP \& REBUS models ............................................. 78

Figure 33: $\mathrm{UO}_{2}$ fuel pin region-MCNP \& REBUS models ......................................... 79

Figure 34: $\mathrm{UO}_{2}-\mathrm{PuO}_{2}$ fuel pin region - MCNP \& REBUS models................................. 80

Figure 35: Aluminum fuel pin region - MCNP \& REBUS models ................................. 81

Figure 36: POLINE region - MCNP \& REBUS models................................................ 82

Figure 37: Oscillation rod region in the up position - REBUS models........................... 83

Figure 38: Geometry of the WIMS calculation "18p90", "18p93" and "CElt"............... 84

Figure 39: Geometry of the WIMS calculation "rod" .................................................. 85

Figure 40: Geometry of the WIMS calculation "G18p90"........................................... 86

Figure 41: Cross sections used in the REBUS model in the R1UO2 configuration......... 87

Figure 42: Geometry of the WIMS calculation "U(3)" and "U(3)Ax" ............................ 88

Figure 43: Geometry of the WIMS calculation "Sample" in the R1UO2 configuration.. 89

Figure 44: Cross sections used in the REBUS model in the R1UO2 configuration......... 90 
Figure 45: Geometry of the WIMS calculation "UAl" and "UAlB" ............................ 91

Figure 46: Geometry of the WIMS calculation "UPuPu1" and "UPuPu2" ..................... 92

Figure 47: Geometry of the WIMS calculation " $\mathrm{Pu}(4)$ " and " $\mathrm{Pu}(4) \mathrm{Ax}$ "............................ 93

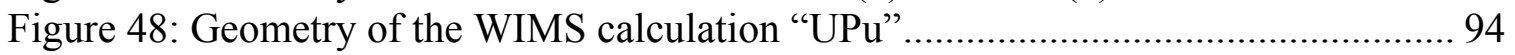

Figure 49: Geometry of the WIMS calculation "PuPOL" .......................................... 95

Figure 50: Geometry of the WIMS calculation "Sample" in the R1MOX configuration 96

Figure 51: Studied pins for axial power profile measurements .................................... 97

Figure 52: Axial power profile for specific pins in the R1UO2 configuration -

Comparison of REBUS results to measurements ....................................................... 98

Figure 53: Axial power profile for specific pins in the R1UO2 configuration -

Comparison of MCNP results to measurements ....................................................... 99

Figure 54: Axial fission rate profile of U-235 and Np-237 fission chambers in the R1UO2 configuration - Comparison of MCNP results to measurements ................................ 100 Figure 55: Axial fission rate profile of U-235 and Np-237 fission chambers in the R1UO2 configuration - Comparison of MCNP results to measurements over range of $\pm 20 \mathrm{~cm} 101$ Figure 56: Buckling for the R1UO2 configuration calculated with experimental data

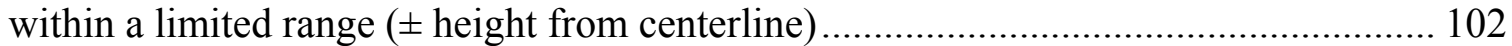
Figure 57: Fit of the experimental axial power profile of the pin 17-21 of the R1UO2 configuration over the range $[-20 \mathrm{~cm}, 20 \mathrm{~cm}]$

Figure 58: Buckling for the R1UO2 configuration calculated with data from MCNP within a limited range ( \pm height from centerline).

Figure 59: Buckling for the R1UO2 configuration calculated with data from REBUS within a limited range ( \pm height from centerline)....

Figure 60: Buckling calculated from the fission rate profile measured by U-235 fission chamber in the R1UO2 configuration using data within a limited range ( \pm height from centerline)

Figure 61: Axial power profile for specific pins in the R1MOX configuration Comparison of REBUS results to measurements

Figure 62: Axial power profile for specific pins in the R1MOX configuration -

Comparison of MCNP results to measurements

Figure 63: Axial fission rate profile of U-235 and Np-237 fission chambers in the R1MOX configuration - Comparison of MCNP results to measurements .

Figure 64: R1MOX Axial fission rate profile of U-235 and Np-237 fission chambers in the R1MOX configuration - Comparison of MCNP results to measurements over range of $\pm 20 \mathrm{~cm}$. ....

Figure 65: Buckling for the R1MOX configuration calculated with experimental data within a limited range ( \pm height from centerline)....

Figure 66: Buckling for the R1MOX configuration calculated with data from MCNP

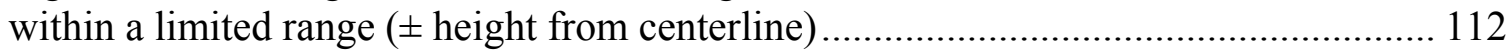

Figure 67: Location of the studied fuel pins for the radial power profile measurements in the R1MOX configuration.

Figure 68: Fission rate distribution in the R1UO2 configuration for the S-N traverse .. 114 Figure 69: Fission rate distribution in the R1UO2 configuration for the SE-NW traverse

Figure 70: Fission rate distribution in the R1MOX configuration for the S-N traverse. 116 
Figure 71: Fission rate distribution in the R1MOX configuration for the $\mathrm{S}-\mathrm{N}$ traverse

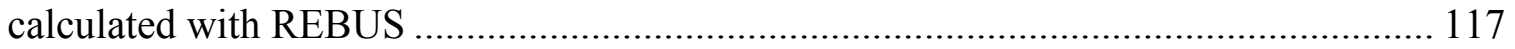

Figure 72: Fission rate distribution in the R1MOX configuration for the SE-NW traverse

Figure 73: Experimental and calculated reactivity worth of the calibration samples in the R1UO2 configuration..... 119

Figure 74: Experimental and calculated reactivity worth of the calibration samples in the R1MOX configuration. 120 


\section{INTRODUCTION}

The OSMOSE program (Oscillation in Minerve of isotopes in "Eupraxic" spectra) is a collaboration between the U.S. Department of Energy (DOE) and the Commissariat à l'Energie Atomique (CEA). It aims at measuring integral absorption rates of minor actinides by the oscillation technique in the MINERVE experimental facility located at the CEA Cadarache Research Center. The OSMOSE program also includes a complete analytical program to understand and resolve potential discrepancies between calculated and measured values. The OSMOSE program began in 2001 and will continue until 2013.

The Argonne National Laboratory has developed Monte Carlo and deterministic calculation models of the MINERVE facility to determine core and safety parameters such as axial and radial fission rate distributions, control rod worth, spectral indices, and the reactivity worth of oscillated samples. Oscillation samples include calibration samples with different uranium enrichments and boron concentrations and the OSMOSE samples - separated actinides including ${ }^{232} \mathrm{Th},{ }^{233} \mathrm{U},{ }^{234} \mathrm{U}$, ${ }^{235} \mathrm{U},{ }^{236} \mathrm{U},{ }^{238} \mathrm{U},{ }^{237} \mathrm{~Np},{ }^{238} \mathrm{Pu},{ }^{239} \mathrm{Pu},{ }^{240} \mathrm{Pu},{ }^{241} \mathrm{Pu},{ }^{242} \mathrm{Pu},{ }^{241} \mathrm{Am},{ }^{243} \mathrm{Am},{ }^{244} \mathrm{Cm}$ and ${ }^{245} \mathrm{Cm}$. Seven different neutron spectra will be created in the MINERVE facility: an overmoderated $\mathrm{UO}_{2}$ matrix (representative of a fuel processing plant or flooded storage cask), a $\mathrm{UO}_{2}$ matrix in water (representative of LWRs), a mixed oxide fuel matrix (representative of cores containing MOX fuels), two epithermal spectra (representative of under-moderated reactors), a moderated fast spectrum (representative of fast reactors which have some slowing down due to moderators such as lead-bismuth or sodium), and a very hard spectrum (representative of fast reactors with little moderation from reactor coolant). The different spectra are achieved by changing the experimental lattice within the MINERVE reactor. The currently investigated core configurations are R1UO2 and R1MOX, representative of a LWR loaded with $\mathrm{UO}_{2}$ and a mixed oxide matrix, respectively.

The goal of this report is to synthesize the reactor analysis work performed within the framework of the OSMOSE program by Argonne National Laboratory until September 2004. The Monte Carlo and deterministic models are detailed, and the calculated safety and core parameters as well

as the reactivity worth of the calibration samples are compared with the experimental data for the R1UO2 and R1MOX core loadings. 


\section{REACTOR MODELING}

Monte Carlo and deterministic models of the MINERVE facility in the R1UO2 and R1MOX configurations were developed to assess core and safety parameters. The deterministic model is also used to calculate the reactivity worth of oscillation samples in the central channel of the core. The models are based on the composition and geometry specifications identified in the Material Specification Report for the MINERVE reactor (ref. 1).

\subsection{Monte Carlo model}

The Monte Carlo model was created using the MCNP-4C code system (ref. 2) and the continuous energy cross sections of the ENDFB-VI library. This model fully describes the neutronic region of interest of the MINERVE reactor by avoiding any unnecessary homogenization. It is extensively based on the material specification report (ref. 1).

\subsubsection{General description}

The MCNP model describes the MINERVE core surrounded by at least $30 \mathrm{~cm}$ of water and/or structural material, resulting in a $271.5 \mathrm{~cm}$ by $271.5 \mathrm{~cm}$ by $220 \mathrm{~cm}$ region. The core can be schematically described as an experimental zone surrounded by a driver zone (in 4 quadrants). Fuel pins in the experimental zone are used to generate the appropriate flux spectrum in the center and the driver zone feeds the experimental zone with neutrons. The experimental fuel pin lattice is surrounded by an aluminum buffer within a chimney. The driver zone is located outside the chimney and graphite is used as reflector around it. Figure 1 and Figure 2 show radial and axial views of the complete MCNP geometry.

To describe the different regions of the core, the core has been arbitrarily subdivided into:

- The driver zone for all regions outside the chimney

- The experimental zone for all regions inside the chimney

Descriptions of the modeled regions are listed in the next two sections. Differences in composition and geometry between the MCNP model and the material specification report (ref. 1) are emphasized. MCNP input files for the R1UO2 and R1MOX configurations are listed in Appendix 1.

\subsubsection{Driver zone}

The driver zone is subdivided into the driver zone supports (including the support table, the caissons and part of the grid plate), the driver elements and the graphite blocks (Figure 2). 


\subsubsection{Driver zone supports}

\subsection{Support table}

The support table is modeled as a $22.1 \mathrm{~cm}$-thick plate with a $211.36 \mathrm{~cm}$ by $211.36 \mathrm{~cm}$ squared cross section and sits below the caissons of the driver zones (Figure 3). This plate is perforated in its center by a $45 \mathrm{~cm}$-diameter hole to insert the lower portion of the chimney. The table is modeled as a mixture of $82 \%$ AG-3 aluminum and $18 \%$ water. The composition of this region is not listed in ref. 1 because of the minimal effect on the neutronic behavior of the reactor.

\subsection{Caissons}

The caissons supporting the grid plates of the driver zone are modeled by $40.3 \mathrm{~cm}$-thick blocks of a homogenized material composed of $20 \%$ AG-3 aluminum and $80 \%$ water. This region was considered as water in ref. 1. The radial dimensions of the caissons are adjusted to fit those of the grid plates.

The caissons supporting the large graphite blocks surrounding the driver elements have a height of $51.3 \mathrm{~cm}$ and are composed of the same homogenized material as that used for the caissons supporting the grid plates.

\subsection{Grid plate}

The grid plates located above the caissons are modeled in two different ways depending on if it supports an element. If it does not support an element, it is modeled as a $16 \mathrm{~cm}$-thick AL-5 aluminum plate (Figure 3). If it supports an element, the grid plate region is as described in section 2.1.2.2.2.

\subsection{L-shape assembly}

L-shape assemblies are attached to the 4 grid plates to support 4 additional graphite elements in the corners of the aluminum wedges (as shown in Figure 1 and described in section 2.1.2.2). The L-shape assemblies have not been modeled.

\subsubsection{Graphite blocks and driver element}

\subsection{Graphite blocks}

The large, medium and small graphite blocks and their AG-3 aluminum clads (Figure 1 and Figure 3) are modeled according to ref. 1. No description of the lower and upper hardware used for positioning and handling has been included in the model. The dimension of the graphite blocks are listed in Table 1. The clad thickness is the same above and below the graphite block and right and left the graphite block. 


\begin{tabular}{|c|c|c|c|c|c|c|}
\hline \multicolumn{7}{|c|}{ Table 1:Geometry specification of the graphite blocks } \\
\hline & \multicolumn{2}{|c|}{ Large } & \multicolumn{2}{c|}{ Medium } & \multicolumn{2}{c|}{ Small } \\
\hline & Graphite & $\begin{array}{c}\text { Graphite } \\
\text { clad* }\end{array}$ & Graphite & $\begin{array}{c}\text { Graphite }+ \\
\text { clad* }\end{array}$ & Graphite & $\begin{array}{c}\text { Graphite }+ \\
\text { clad* }\end{array}$ \\
\hline Height $(\mathrm{cm})$ & 70.0 & 81.0 & 74.5 & 75.0 & 69.5 & 70.0 \\
\hline Length $(\mathrm{cm})$ & 92.0 & 92.55 & 32.0 & 32.5 & 18.0 & 18.5 \\
\hline Width $(\mathrm{cm})$ & 45.0 & 45.55 & 22.5 & 23.0 & 7.5 & 8.3 \\
\hline
\end{tabular}

* The clad thickness is the same on both sides of the graphite region

\subsection{Driver zone elements}

The driver zone is composed of the following types of elements:

- Graphite elements

- Fuel elements (18-plates of $90 \%$ or $93 \%$ enriched uranium, 12-plates, or 9-plates)

- Control elements (12-plates with two regions to allow the insertion of the control rods)

- Special elements (automatic pilot rod, start-up source element, detector element and thermal column)

Each driver zone element type has been described as a separate universe and used in four lattices to make the inner part of the driver zone. Each universe can be seen as a lower portion made of the foot of the element inserted in the grid plate and an upper portion, made of graphite or fuel plates, which is surrounded by water.

\section{Graphite elements}

The MCNP geometry and composition of the graphite elements is shown in Figure 4. The lower portion of the graphite element is made of the foot inserted in the grid plate. The foot has been modeled by AG-3 aluminum cylinder and plate accommodating a void tube in the center. The geometry specification of the foot is presented in Figure 4 and Table 2. This description is based on the plan in ref. 1 and differs from the homogenization recommended by CEA. The upper portion of the element is composed of the graphite block and AG-3 aluminum overclad. Both are described according to ref. 1 and reported in Table 2.

\begin{tabular}{|c|c|c|c|c|c|}
\hline \multicolumn{5}{|c|}{ Table 2:Geometry specification of the graphite element } \\
\hline & \multicolumn{3}{|c|}{ Foot } & \multicolumn{2}{c|}{ Upper portion } \\
\hline & AG-3 cylinder & AG-3 plate & Void tube & Graphite & Graphite + clad \\
\hline Height $(\mathrm{cm})$ & 13.8 & 3.7 & 74.5 & 63.25 & 70.00 \\
\hline Diameter $(\mathrm{cm})$ & 6.1 & - & 1.21 & - & - \\
\hline Length $(\mathrm{cm})$ & - & 8.0 & - & 7.5 & 8.00 \\
\hline Width $(\mathrm{cm})$ & - & 7.61 & - & 7.2 & 7.61 \\
\hline
\end{tabular}

\section{Fuel elements}

The fuel element is composed of an upper portion made of fuel plates and a lower portion called the foot. The foot has been modeled as an AG-3 aluminum cylinder $(\varnothing 6.1 \mathrm{~cm})$ inserted in the grid plate, and an AG-3 aluminum plate $(8.0 \mathrm{~cm}$ by $7.61 \mathrm{~cm})$ above the grid plate. Both pieces have a $5.08 \mathrm{~cm}$-diameter water hole in their centers. The position and dimension of the foot is illustrated in Figure 5. The upper portion is composed of an array of fuel plates. The 18-plate and 12-plate fuel elements are described in Figure 5 and Figure 6, respectively. The dimensions and 
compositions are listed in ref. 1 and details of the upper portions are shown in Figure 8. Note that the border plates surrounding the graphite blocks in the 12- and 9-plate fuel elements do not contain notches.

\section{Control rod elements}

The control element is a standard 18-plate element where six fuel plates have been removed leaving 12 fuel plates. Four of the plates are replaced with AG-3 aluminum plates to center the fork-type control rods. The AG-3 aluminum plates are modeled with the same dimensions as the fuel plate with the expectation that the height is $62.5 \mathrm{~cm}$ instead of $60.3 \mathrm{~cm}$.

The control element has been modeled with the control rods in different positions according to ref. 1. Figure 9 shows an elevation view and cross sections of the control element when the absorbers are withdrawn. In this case, the hafnium lines up with the upper part of the fuel meat (Figure 10).The control rods are described according to ref. 1 except for the stainless steel extender (upper portion of the rod) which is $0.439 \mathrm{~cm}$ thick instead of $0.339 \mathrm{~cm}$.

The travel of the control rods is $60 \mathrm{~cm}$. The portion of the control rod above the fuel plates is always modeled. When a control rod is inserted in the core, the stainless steel extender is lengthened to reach the upper boundary of the model.

\section{Special elements - Automatic pilot rod}

The automatic pilot rod element is shown in Figure 11. The foot is the same as for the graphite element. The cadmium sheets of the rotor and the stator have been homogenized with AG-3. The rotor is composed of $89 \%$ of AG-3 and $11 \%$ of cadmium; the stator is composed of $93.22 \%$ of AG-3 and $6.78 \%$ of cadmium. The height of the rotor, the stator and the pipe is $72.2 \mathrm{~cm}$. The homogenization of the cadmium on both the stator and the rotor has an influence on the multiplication factor such that any comparison of absolute reactivity between experiments and calculations cannot be made.

\section{Special elements -Detector}

The detector element is modeled as a standard graphite element with a 5.0 cm-diameter hole in the center. The homogenized foot recommended in ref. 1 has been replaced by the foot of a graphite element. The other dimensions are shown in Figure 12. A detector has been simulated in the void space.

\section{Special elements -Start-up source}

The source element is modeled as an AG-3 aluminum tube with an AG-3 aluminum base plate on top of a standard graphite element foot. An elevation view and cross sections of the element are shown in Figure 13. A source has not been modeled in the calculation.

\section{Special elements - Thermal column}

The thermal column is modeled as a graphite element containing two holes. Only the lower portion of the thermal column presented in ref. 1 is modeled, the upper portion is outside of the boundary of the MCNP model. The dimensions and regions are described in Figure 14.

\subsection{Additional elements}

The four quadrants of the driver zone form a $74 \times 74 \mathrm{~cm}^{2}$ square cavity as shown in Figure 1. In order to fill the gap between this cavity and the cylindrical chimney, AG-3 aluminum wedges and 4 additional graphite elements are used. Figure 15 presents an axial and a radial view of the AG-3 aluminum wedges. The axial position of the AG-3 wedges is not specified in ref. 1. Only an 
approximate $80 \mathrm{~cm}$ height is mentioned. In the model, the AG-3 wedges extend from the lower boundary of the grid plate to the upper boundary of the graphite element (Figure 15). The additional graphite elements are located at the same height as the elements of the driver zone (Figure 15).

\subsubsection{Experimental zone}

The experimental zone is defined as all regions within the chimney. It is composed of the MELODIE massif, a supporting spool and a protection plate.

\subsubsection{Spool}

The spool supporting the MELODIE massif is recommended to be homogenized as water in ref. 1. Only the upper supporting plate of the spool has been modeled by a $56 \mathrm{~cm}$-diameter cylindrical plate. A central $3.2 \times 3.2 \mathrm{~cm}^{2}$ square cavity allows the oscillation of samples in the central channel of the experimental fuel lattice (Figure 16).

\subsubsection{Protection plate}

The protection plate is located above the MELODIE massif and is a $71.2 \mathrm{~cm}$-diameter cylindrical plate. This plate is usually modeled without a hole in its center except for measurement with the POLINE overclad (section 2.1.3.4).

\subsubsection{MELODIE massif}

The MELODIE massif is composed of:

- A lower stainless steel plate

- An upper and a lower AG-3 grid plate drilled with 801 holes forming a lattice with a square pitch of $1.26 \mathrm{~cm}$

- Aluminum blocks filling the space around the lattice

An elevation view and cross sections are presented in Figure 16.

\subsection{Lower stainless steel plate}

The lower stainless steel plate supporting the AG-3 aluminum blocks and the lower grid plate is modeled according to ref. 1 with a diameter of $71.2 \mathrm{~cm}$ and a height of $1.75 \mathrm{~cm}$. Like the spool, it includes a central square cavity (cross section: $3.2 \times 3.2 \mathrm{~cm}^{2}$ ).

\subsection{Grid plates}

The grid plates are modeled somewhat differently than from ref. 1. The lower grid plate is made of AG-3 aluminum and has a cross section matching the experimental lattice. It is $2.15 \mathrm{~cm}$ thick except where the 801 holes of the lattice where the thickness is $1.65 \mathrm{~cm}$ (see Figure 33 of ref. 1). The upper grid plate is modeled as a $2.0 \mathrm{~cm}$-thick AG-3 aluminum plate with a cross section matching the experimental lattice. It is extended by a stainless steel plate to form a $71.2 \mathrm{~cm}$ diameter plate (Figure 16, section E). The grid plates are joined by aluminum tubes - internal 
diameter of $0.970 \mathrm{~cm}$ and external diameter of $1.10 \mathrm{~cm}$. These tubes are the overclad of the pins. The geometry specification of the grid plates and the overclad are shown in Figure 16 and Figure 17.

\subsection{AG-3 blocks}

The AG-3 aluminum blocks fill the gap between the experimental lattice and the chimney forming a cylinder with an outer diameter of $71.2 \mathrm{~cm}$. The height of the AG-3 aluminum blocks is $81.65 \mathrm{~cm}$. The blocks line up with the lower stainless steel plate and the upper grid plate.

\subsubsection{Experimental lattice - Pins and POLINE overclad}

The experimental lattice has a square pitch of $1.26 \mathrm{~cm}$. The R1UO2 and R1MOX experimental loadings have been modeled. These loadings include $\mathrm{UO}_{2}$ fuel pins, $\mathrm{UO}_{2}-\mathrm{PuO}_{2}$ fuel pins and aluminum pins. Some models also included an overclad inserted in the central channel of the core to perform measurements. The POLINE overclad has been modeled as well.

$\mathrm{UO}_{2}$ fuel pin cell

The $\mathrm{UO}_{2}$ fuel pins are completely described in agreement with ref. 1. The geometry specification is shown in Figure 17.

$\mathrm{UO}_{2}-\mathrm{PuO}_{2}$ fuel pin cell

The $\mathrm{UO}_{2}-\mathrm{PuO}_{2}$ fuel pins are completely described in agreement with ref. 1. The geometry specification is shown in Figure 18 and Figure 19.

\section{Aluminum pin cell}

The aluminum pins are completely described in agreement with ref. 1. The geometry specification is shown in Figure 20.

\section{POLINE overclad cell}

The POLINE overclad cell is used in the center of the experimental lattice to measure spectral indices, axial fission distribution and reactivity rod worth. The stainless steel cane used to move the detector inside the POLINE overclad has not been modeled. Note that the POLINE overclad is lengthened above the experimental lattice to the upper boundary of the MCNP model (Figure 21). 


\subsection{Deterministic model}

The deterministic model is based on the REBUS code system (ref. 3). REBUS has been used to solve the diffusion equation in XYZ geometry with the finite difference method. The selfshielded cross sections used in REBUS are provided by the one-dimensional-transport-codesystem WIMS-ANL 5.07 (ref. 4).

Contrary to the Monte Carlo model, regions and materials need to be homogenized in the REBUS calculation due to the $\mathrm{X}-\mathrm{Y}-\mathrm{Z}$ coordinate geometry. In the next sections, the REBUS model is fully described. Particularly, each homogenized region and its volume fraction is reported. The WIMS calculations providing the microscopic cross sections used in REBUS are then described. Each cross section is linked to specific regions of the REBUS geometry.

\subsubsection{General description}

The physical size of the REBUS and MCNP model are the same (section 2.1.1). Figure 22 and Figure 23 show a radial and an axial view of the complete geometry.

The number of mesh used in the R1UO2 and R1MOX configurations is $190 \times 190 \times 116$ and $202 \times 202 \times 116$, respectively. In the XY plan, one mesh is used for each cell of the experimental fuel pin lattice (every $1.26 \mathrm{~cm}$ ) and the mesh size is roughly the same in all the driver elements. The graphite blocks (large and medium) are mapped using a mesh every $2 \mathrm{~cm}$ in the $\mathrm{X}$ and $\mathrm{Y}$ dimension and an approximate $5 \mathrm{~cm}$-mesh-size is used for the surrounding water in the XY plan. Axially, the mesh size is mainly defined by the fuel elements and pins of the geometry. The surrounding water is mapped with a $10 \mathrm{~cm}$ mesh size, the structural material around the fuel (grid plate of the driver regions, lower and upper end plug and stainless steel spacers) is mapped using a 1-2 $\mathrm{cm}$ mesh size, and the fuel and the Plexiglas spacers of the experimental zone are mapped with a $1 \mathrm{~cm}$ mesh size.

Microscopic cross sections for the different homogenized regions have been calculated using the one-dimensional-transport-code-system WIMS-ANL 5.07. The starting 69 group structure of the ENDFB-VI library was collapsed to 7 groups (Table 3).

\begin{tabular}{|c|c|}
\hline \multicolumn{2}{|c|}{ Table 3: REBUS group structure } \\
\hline Group & Energy \\
\hline 1 & $500 \mathrm{keV}-10 \mathrm{MeV}$ \\
\hline 2 & $9.118 \mathrm{keV}-500 \mathrm{keV}$ \\
\hline 3 & $1.123 \mathrm{eV}-9.118 \mathrm{keV}$ \\
\hline 4 & $0.4 \mathrm{eV}-1.123 \mathrm{eV}$ \\
\hline 5 & $0.14 \mathrm{eV}-0.4 \mathrm{eV}$ \\
\hline 6 & $0.05 \mathrm{eV}-0.4 \mathrm{eV}$ \\
\hline 7 & $-0.05 \mathrm{eV}$ \\
\hline
\end{tabular}

REBUS input files for the R1UO2 and R1MOX configurations are listed in Appendix 2. 


\subsubsection{Driver zone}

\subsubsection{Driver zone supports}

\subsection{Support table}

The support table is homogenized in the same way as in the MCNP model (section 2.1.2.1.1).

\subsection{Caissons}

The caissons are homogenized in the same way as in the MCNP model (section 2.1.2.1.2).

\subsection{Grid plate}

The portions of the grid plates containing no graphite or fuel element are modeled as bare AL-5 aluminum plates (section 2.1.2.1.3). The portions of the grid plates containing driver elements are described in section 2.2.2.2.2.

\subsection{L-shaped assembly}

The L-shaped assemblies are not modeled.

\subsubsection{Graphite blocks and driver element}

\subsection{Graphite blocks}

The AG-3 aluminum cladding of the large, medium and small graphite blocks have been homogenized with the graphite. The dimension and volume fraction of each material is given in Table 4.

\begin{tabular}{|c|c|c|c|}
\hline \multicolumn{2}{|c|}{ Table 4: Geometry and material specification of the graphite blocks } \\
\hline Type & Large & Medium & Small \\
\hline Height $(\mathrm{cm})$ & 81.0 & 75.0 & 70.0 \\
\hline Length $(\mathrm{cm})$ & 92.55 & 32.5 & 18.5 \\
\hline Width $(\mathrm{cm})$ & 45.55 & 23.0 & 8.3 \\
\hline \multirow{2}{*}{ Volume fractions } & $\begin{array}{c}\text { Graphite: } 84.87 \% \\
\text { AG-3: } 15.13 \%\end{array}$ & $\begin{array}{c}\text { Graphite: } 95.68 \% \\
\text { AG-3: } 4.32 \%\end{array}$ & $\begin{array}{c}\text { Graphite: } 95.68 \% \\
\text { AG-3: } 4.32 \%\end{array}$ \\
\hline
\end{tabular}

\subsection{Driver zone elements}

\section{Graphite elements}

The radial dimensions of the graphite elements are the same as in the MCNP model. Individual graphite elements are not defined. Figure 22 shows the graphite element region (in red).

The graphite element region has been homogenized in 3 axial zones: the foot inside the grid plate, the graphite block, and the upper end plug. The REBUS model of the graphite element region is compared with the MCNP model of a graphite element in Figure 24. The geometry and volume fraction of the different sections are shown in Table 5. 


\begin{tabular}{|c|c|c|c|}
\hline \multicolumn{4}{|c|}{ Table 5: Geometry and material specification of the graphite element } \\
\hline & Foot & Graphite & Upper end plug \\
\hline Height (cm) & 19.7 & 63.25 & 2.95 \\
\hline \multirow{3}{*}{ Volume fractions } & AL-5: $84.87 \%$ & Graphite: $86.47 \%$ & \\
& AG-3: $15.13 \%$ & AG-3: $11.02 \%$ & AG-3: $97.49 \%$ \\
& Water: $4.48 \%$ & Water: $2.51 \%$ & Water: $2.51 \%$ \\
& Void: $1.84 \%$ & & \\
\hline
\end{tabular}

\section{Fuel elements}

The 18-plate fuel element has been homogenized into 4 axial regions: the foot, the lower and upper plate-clad region and the fuel plate region. The fuel plate region includes all of the fuel in the element. The upper and lower ends of the fuel plates are made of aluminum clad. These portions are homogenized with water and the AG-3 aluminum border plate of the element in the plate-clad region. The homogenized regions have a cross section of $8.1 \times 7.61 \mathrm{~cm}^{2}$. The axial dimensions and the volume fractions of the different regions are presented in Table 6 and in Figure 25.

\begin{tabular}{|c|c|c|c|c|}
\hline \multicolumn{5}{|c|}{ Table 6: Geometry and material specification of the 18-plate fuel element } \\
\hline & Foot & Lower plate-clad & Fuel plate & Upper plate-clad \\
\hline Height (cm) & 22 & 1.3 & 60 & 1.25 \\
\hline & Water: $43.46 \%$ & Water: $58.56 \%$ & Water: $58.56 \%$ & Water: $58.56 \%$ \\
Volume fractions & AL-5: $38.58 \%$ & Al: $31.20 \%$ & Al: $21.68 \%$ & Al: $31.20 \%$ \\
& AG-3: $17.96 \%$ & AG-3: $10.24 \%$ & AG-3: $10.24 \%$ & AG-3: $10.24 \%$ \\
\hline
\end{tabular}

The lower and upper plate-clad region should have slightly different volume fractions because of a minor height difference. To simplify, the same volume fractions are used for both regions.

The 12- and 9-plate fuel elements have been homogenized into 5 different regions. Two distinctive regions have been created for the graphite block and for the fuel plates (Figure 26 and Figure 27). The foot region is the same as the foot for the 18-plate fuel element. The geometry and material specification of the other regions is described for the 12- and 9- plate fuel element in Table 7 and Table 8 , respectively.

\begin{tabular}{|c|c|c|c|c|}
\hline \multicolumn{5}{|c|}{ Table 7: Geometry and material specification of the 12-plate fuel element } \\
\hline & Lower plate-clad & Fuel plate & Graphite & Upper plate-clad \\
\hline Height $(\mathrm{cm})$ & $1.3 / 1.25$ & 60 & 60 & $1.3 / 1.25$ \\
\hline Length $(\mathrm{cm})$ & 8.1 & 5.4 & 2.7 & 8.1 \\
\hline Width $(\mathrm{cm})$ & 7.61 & 7.61 & 7.61 & 7.61 \\
\hline & Water: $43.16 \%$ & Water: $52.46 \%$ & Graphite: $71.44 \%$ & Water: $43.16 \%$ \\
Volume fractions & Graphite: $22.86 \%$ & Al: $21.68 \%$ & AG-3: $16.16 \%$ & Graphite: $22.86 \%$ \\
& Al: $20.79 \%$ & AG-3: $16.34 \%$ & Water: $12.40 \%$ & Al: $20.79 \%$ \\
& AG-3: $13.19 \%$ & Fuel: $9.52 \%$ & & AG-3: $13.19 \%$ \\
\hline
\end{tabular}




\begin{tabular}{|c|c|c|c|c|}
\hline \multicolumn{5}{|c|}{ Table 8: Geometry and material specification of the 9-plate fuel element } \\
\hline & Lower plate-clad & Fuel plate & Graphite & Upper plate-clad \\
\hline Height $(\mathrm{cm})$ & $1.3 / 1.25$ & 60 & 60 & $1.3 / 1.25$ \\
\hline Length $(\mathrm{cm})$ & 8.1 & 4.1 & 4.0 & 8.1 \\
\hline Width $(\mathrm{cm})$ & 7.61 & 7.61 & 7.61 & 7.61 \\
\hline & Water: $33.84 \%$ & Water: $58.92 \%$ & Graphite: $76.60 \%$ & Water: $33.84 \%$ \\
Volume fractions & Graphite: $36.32 \%$ & Al: $21.27 \%$ & AG-3: $15.26 \%$ & Al: $15.60 \%$ \\
& Al: $15.60 \%$ & AG-3: $10.27 \%$ & Water: $8.14 \%$ & AG-3: $14.24 \%$ \\
\hline
\end{tabular}

The lower and upper plate-clad regions have been homogenized in the same manner as before.

\section{Control elements}

The control element has been modeled with the rods completely inserted or withdrawn. The control element is homogenized in four regions: the foot (similar to the fuel element), the lower and upper plate clad and the control rod-fuel plate region. The insertion of the rods has been modeled by changing the composition of the control rod-fuel plate region. The control rod has not been modeled above this region. When the rods are inserted, it is necessary to homogenize the hafnium with the water and the fuel because of the diffusion approximation used. The dimension and volume fractions of the control element are listed in Table 9 and Figure 28.

\begin{tabular}{|c|c|c|c|}
\hline \multicolumn{3}{|c|}{ Table 9: Geometry and material specification of the control element } \\
\hline & Plate-clad & $\begin{array}{c}\text { Control rod - fuel plates } \\
\text { (absorber withdrawn) }\end{array}$ & $\begin{array}{c}\text { Control rod - fuel plates } \\
\text { (absorber inserted) }\end{array}$ \\
\hline Height (cm) & $1.3 / 1.25$ & 60 & 60 \\
\hline Length $(\mathrm{cm})$ & 8.1 & 8.1 & 8.1 \\
\hline Width $(\mathrm{cm})$ & 7.61 & 7.61 & 7.61 \\
\hline & & Water: $61.82 \%$ & Water: $52.68 \%$ \\
& Water: $61.82 \%$ & Al: $21.38 \%$ & AG- $21.38 \%$ \\
Volume fractions $10.46 \%$ \\
& Al: $27.72 \%$ & AG-3: $10.46 \%$ & Fuel: $6.34 \%$ \\
& AG-3: $10.46 \%$ & Fuel: $6.34 \%$ & Hf: $6.95 \%$ \\
& & & SS: $2.19 \%$ \\
\hline
\end{tabular}

Other simulations where the control rods have been modeled above the fuel plates and at the critical positions have been performed. In these cases, the results do not change except for the absolute value of the multiplication factor.

\section{Special elements}

No special element like the pilot rod, the detector, the start-up source and the thermal column have been modeled.

\subsection{Additional elements}

The additional elements include the four graphite elements located in the corner of the $74 \times 74 \mathrm{~cm}^{2}$ square cavity, the AG-3 wedges and the chimney. Because of the XYZ geometry, the chimney (and the material at the circular interface) was homogenized in different radial regions (Figure 22). Figure 29 represents a quarter of the central square cavity with the chimney, and the chosen radial decomposition. It has been divided into: 
- 8 different regions that contain the chimney (Type-1 and Type-2)

- 8 different regions containing the AG-3 wedges outside of the chimney (Type-3)

- 4 graphite elements in the corners of the cavity

The four graphite elements are considered as standard graphite elements and their lower part has not been changed to take into account the AG-3 aluminum wedges or the L-shape plate. The radial description is given in Figure 24.

The radial description of the AG-3 wedges region is presented in Figure 30. No homogenization has been performed.

The radial description of the region containing the chimney is shown in Figure 31 . This region is homogenized in 6 axial sections. Table 10 summarized the contents and volume fractions of each region.

\begin{tabular}{|c|c|c|c|c|c|c|}
\hline \multicolumn{7}{|c|}{ Table 10: Geometry and material specification of the chimney region } \\
\hline Section & A & B & C & D & E & F \\
\hline \multirow{4}{*}{ Description } & $\begin{array}{c}\text { Water } \\
\text { Chimney } \\
\text { Wedge }\end{array}$ & $\begin{array}{c}\text { SS plate } \\
\text { Chimney } \\
\text { Water }\end{array}$ & $\begin{array}{c}\text { AG-3 block } \\
\text { Chimney } \\
\text { Wedge } \\
\text { Water }\end{array}$ & $\begin{array}{c}\text { AG-3 block } \\
\text { Chimney } \\
\text { Water }\end{array}$ & $\begin{array}{c}\text { SS plate } \\
\text { Chimney } \\
\text { Water }\end{array}$ & $\begin{array}{c}\text { AG-3 } \\
\text { plate } \\
\text { Chimney } \\
\text { Water }\end{array}$ \\
\hline Height (cm) & 48.7 & 2.25 & 75.25 & 6.4 & 2 & 6.4 \\
\hline & & SS: & & & SS: & \\
& Water: & $43.65 \%$ & & & $56.13 \%$ & Water: \\
Volume & $78.44 \%$ & AG-3: & AG-3: $97.96 \%$ & AG-3: $69.61 \%$ & Water: & $68.98 \%$ \\
fractions & AG-3: & $41.84 \%$ & Water: $2.04 \%$ & Water: $30.39 \%$ & $30.39 \%$ & AG-3: \\
& $21.56 \%$ & Water: & & & & AG-3: \\
& & $14.51 \%$ & & & & $31.02 \%$ \\
& & & & \\
\hline
\end{tabular}

The tank-region above the elements is composed of water only (Figure 31). The chimney was not considered above the core.

The AG-3 aluminum blocks inside the chimney are described in section 2.2.3.1.

\subsubsection{Experimental zone}

The same element descriptions for the MCNP model have been used for the REBUS model, except they have been homogenized into different regions. The experimental zone is divided into different radial regions including:

- The AG-3 buffer region

- The $\mathrm{UO}_{2}$ fuel pin region

- $\mathrm{The} \mathrm{UO}_{2}-\mathrm{PuO}_{2}$ fuel pin region

- The AG-3 pin region

- The POLINE overclad region

- The Oscillation tube region

Each radial region is divided into several axial regions. 


\subsubsection{AG-3 buffer region}

The radial location of the AG-3 aluminum buffer region is shown in Figure 22. The radial decomposition of the AG-3 aluminum buffer region is presented in Figure 32. The height and volume fraction of each section is shown in Table 11.

\begin{tabular}{|c|c|c|c|c|c|}
\hline \multicolumn{5}{|c|}{ Table 11: Geometry and material specification of the AG-3 buffer region } \\
\hline Section & A & B & C & D & E \\
\hline Description & $\begin{array}{c}\text { Water } \\
\text { Chimney } \\
\text { Table }\end{array}$ & $\begin{array}{c}\text { SS plate } \\
\text { Water }\end{array}$ & AG-3 block & SS plate & $\begin{array}{c}\text { AG-3 plate } \\
\text { Water }\end{array}$ \\
\hline Height (cm) & 70.8 & 2.25 & 81.65 & 2 & 6.4 \\
\hline Volume fractions & $\begin{array}{c}\text { Water: } 70.26 \% \\
\text { AG-3: } 29.74 \%\end{array}$ & $\begin{array}{c}\text { SS: } 86.17 \% \\
\text { Water: } 13.83 \%\end{array}$ & AG-3: $100 \%$ & SS: $100 \%$ & $\begin{array}{c}\text { Water: } 68.75 \% \\
\text { AG-3: } 31.25 \%\end{array}$ \\
\hline
\end{tabular}

\subsubsection{UO2 fuel pin region}

$\mathrm{The} \mathrm{UO}_{2}$ fuel pin region is divided into six axial regions (Figure 33). Three other zones describe the water above and below the fuel pin cell, the stainless steel plates composing the upper part of the spool and the lower stainless steel plate (sections 2.1.3.1 and 2.1.3.3.1). The lower stainless steel plate and the spool contain a $3.2 \times 3.2 \mathrm{~cm}^{2}$ square cavity in the center of the experimental zone. The 9-pin region modeled in the center of the experimental zone does not take this cavity into account.

The homogenization for each axial region A-F included the following items:

(A) The lower end plug, the lower grid plate and the lower stainless steel spacer

(B) The lower Plexiglas spacer with the clad and overclad

(C) The fuel

(D) The upper Plexiglas spacer

(E) The upper stainless steel spacer, the upper grid plate and the upper end plug

(F) The gripping device and the protection plate

The volume fractions and the heights of the sections are presented in Table 12 and Figure 33.

\begin{tabular}{|c|c|c|c|c|c|c|c|}
\hline \multicolumn{7}{|c|}{ Table 12: Geometry and material specification of the $\mathrm{UO}_{2}$ fuel pins region } \\
\hline \multicolumn{2}{|c|}{ Section } & $\mathrm{A}$ & $\mathrm{B}$ & $\mathrm{C}$ & $\mathrm{D}$ & $\mathrm{E}$ & $\mathrm{F}$ \\
\hline \multicolumn{2}{|c|}{ Height $(\mathrm{cm})$} & 4.65 & 13 & 50 & 13 & 3 & 6.4 \\
\hline \multirow{4}{*}{$\begin{array}{c}\text { Volume } \\
\text { fractions } \\
(\%)\end{array}$} & $\mathrm{AG}-3$ & 48.39 & 13.31 & 13.31 & 13.31 & 40.07 & 31.25 \\
\cline { 2 - 9 } & Water & 27.81 & 42.98 & 42.98 & 42.98 & 16.22 & 66.74 \\
\cline { 2 - 9 } & $\mathrm{SS}$ & 11.32 & - & - & - & 17.04 & 2.01 \\
\cline { 2 - 9 } & ZR4 & 11.29 & 10.45 & 10.45 & 10.45 & 25.09 & - \\
\cline { 2 - 8 } & Void & 1.19 & 3.17 & 1.23 & 3.17 & 1.58 & - \\
\cline { 2 - 8 } & Plexiglas & - & 30.09 & - & 30.09 & - & - \\
\cline { 2 - 8 } & Fuel & - & - & 32.03 & - & - & - \\
\hline
\end{tabular}




\subsubsection{UO2 - PuO2 fuel pin region}

The $\mathrm{UO}_{2}-\mathrm{PuO}_{2}$ fuel pin region is divided into the same axial regions as the $\mathrm{UO}_{2}$ fuel pin region. Table 13 and Figure 34 show the height and the volume fraction of each region. The volume fractions are the same for the pins with $3.6 \%$ and $4 \%$ plutonium oxide enrichment.

\begin{tabular}{|c|c|c|c|c|c|c|c|}
\hline \multicolumn{2}{|c|}{ Section } & $\mathrm{A}$ & B & $\mathrm{C}$ & $\mathrm{D}$ & $\mathrm{E}$ & $\mathrm{F}$ \\
\hline \multicolumn{2}{|c|}{ Height $(\mathrm{cm})$} & 4.85 & 12.8 & 50 & 13 & 3 & 6.4 \\
\hline \multirow{8}{*}{$\begin{array}{c}\text { Volume } \\
\text { fractions } \\
\quad(\%)\end{array}$} & AG-3 & 45.85 & 13.31 & 13.31 & 13.31 & 40.07 & 31.25 \\
\hline & Water & 27.28 & 42.98 & 42.98 & 42.98 & 13.54 & 61.65 \\
\hline & SS & 13.22 & - & - & - & 10.17 & 7.10 \\
\hline & ZR2 & 6.78 & 8.71 & 8.71 & 8.71 & 31.89 & $\begin{array}{ll}- \\
-\end{array}$ \\
\hline & Styrene & 5.35 & - & - & - & - & - \\
\hline & Void & 1.52 & 4.91 & 2.79 & 4.91 & 4.33 & - \\
\hline & Plexiglas & - & 30.09 & - & 30.09 & - & - \\
\hline & Fuel & - & - & 32.21 & - & - & - \\
\hline
\end{tabular}

\subsubsection{Aluminum pin region}

The aluminum pin region is homogenized into four axial sections plus the three sections used for water above and below the core and the lower stainless steel plate and spool section. The homogenization for each axial region A-D included the following items:

(A) The lower grid plate and the bottom of the aluminum pins

(B) The aluminum pin between the upper and lower grid plate

(C) The upper grid plate and the head of the aluminum pin

(D) The gripping device of the aluminum pin and the protection plate

The volume fractions and heights of the different sections are summarized in Table 14 and Figure 35.

\begin{tabular}{|c|c|c|c|c|}
\hline \multicolumn{5}{|c|}{ Table 14: Geometry and material specification of the Aluminum pin region } \\
\hline Section & A & B & C & D \\
\hline Height (cm) & 4.85 & 12.8 & 50 & 13 \\
\hline \multirow{2}{*}{ Volume fractions } & AG-3: $96.54 \%$ & Water: $55.03 \%$ & AG-3: $85.11 \%$ & AG-3: $35.55 \%$ \\
& Water: $3.46 \%$ & AG-3: $44.97 \%$ & Water: $14.89 \%$ & Water: $64.45 \%$ \\
\hline
\end{tabular}

\subsubsection{POLINE overclad region}

The POLINE overclad is used in the central channel of the experimental lattice for safety and core parameter measurements. The POLINE overclad is homogenized with the surrounding water and an inner void (Figure 36). The composition is $44.65 \%$ void, $43.36 \%$ water and $11.99 \%$ AW2017 aluminum.

\subsubsection{Oscillation cane region}

The oscillation cane is used to oscillate two samples between the center of the core and a position of negligible neutronic importance. For static calculations there are two positions of interest: the 'up' position when the first sample and the fuel mid-plane are lined up and the second sample is 
above the core, and the 'down' position when the second sample is lined up with the fuel midplane and the first sample is below the core. Both 'up' and 'down' positions have the same geometry within the fuel pin region. Considering that the materials of the oscillation cane located above and below the fuel pins lattice are of negligible neutronic importance, both positions 'up' and 'down' are modeled using the same geometry. A schematic of the oscillation cane in the 'up' position and the chosen homogenized volumes are shown in Figure 37. The corresponding volume fractions are listed in Table 15.

\begin{tabular}{|c|c|c|c|}
\hline \multicolumn{4}{|c|}{ Table 15: Geometry and material specification of the oscillation cane region } \\
\hline Section & SS bottom & AG-3 rod & Oscillation sample \\
\hline Height $(\mathrm{cm})$ & 1.5 & $30 \& 99.125$ & 10.35 \\
\hline \multirow{3}{*}{ Volume fractions } & AG-3: $36.15 \%$ & AG-3: $55.59 \%$ & \\
& Water: $49.06 \%$ & Water: $33.03 \%$ & See section 2.2 .3 .7 \\
& SS: $14.79 \%$ & SS: $11.38 \%$ & \\
\hline
\end{tabular}

\subsubsection{Oscillation sample}

There are several different kinds of oscillation samples: uranium calibration samples, boron loaded calibration samples, OSMOSE separated actinide samples, and absorber samples. Only the calibration samples have been considered in this report. The samples are composed of fuel pellets (height $9.35 \mathrm{~cm}$, diameter $\sim 0.81 \mathrm{~cm}$ ) clad with zircomium-4 (inner diameter $=0.836$, outer diameter $=0.956 \mathrm{~cm}$ ) and terminated by two zirconium-4 end plugs (same outer diameter, height of $0.2 \mathrm{~cm}$ ). The sample has a second clad (inner diameter $=1.02 \mathrm{~cm}$, outer diameter $=1.06 \mathrm{~cm}$ ) with a lower end plug of $0.2 \mathrm{~cm}$ height and two upper end plug of $0.2 \mathrm{~cm}$ height. The external diameter of the entire sample is $1.06 \mathrm{~cm}$ with a total height of $10.35 \mathrm{~cm}$ (ref. 5).

The total height of the fuel pellets height is often larger than $9.35 \mathrm{~cm}$. In order to keep the total height constant $(10.35 \mathrm{~cm})$ the upper end plug of the outer clad was modeled with a smaller height to accommodate the different fuel pellet heights.

The characteristics of the U-235 calibration sample fuel pellets are listed in ref. 6 and are reported in Table 16. The associated volume fractions of the homogenized oscillation sample in the oscillation cane are shown in Table 17.

\begin{tabular}{|c|c|c|c|c|c|c|c|c|}
\hline \multicolumn{10}{|c|}{ Table 16: Geometry and material specification of the U-235 calibration sample } \\
\hline Sample & F0025 & F0050 & N0071 & S0100 & S0200 & S0300 & S0400 & S0495 \\
\hline U235 enrichment (\%) & 0.25 & 0.49 & 0.71 & 1.00 & 2.01 & 3.01 & 4.00 & 4.93 \\
\hline Height $(\mathrm{mm})$ & 94.08 & 94.1 & 94.06 & 94.04 & 94.1 & 94.08 & 94.06 & 94.1 \\
\hline Diameter $(\mathrm{mm})$ & 8.0943 & 8.0946 & 8.0943 & 8.1114 & 8.0986 & 8.1032 & 8.0999 & 8.1036 \\
\hline Density $(\mathrm{g} / \mathrm{cc})$ & 10.442 & 10.464 & 10.515 & 10.594 & 10.606 & 10.62 & 10.629 & 10.648 \\
\hline
\end{tabular}

Table 17: Volume fraction of the homogenized U-235 calibration sample inserted in the oscillation cane

\begin{tabular}{|c|c|c|c|c|c|c|c|c|c|}
\hline \multicolumn{2}{|c|}{ Sample } & F0025 & F0050 & N0071 & S0100 & S0200 & S0300 & S0400 & S0495 \\
\hline \multirow{4}{*}{$\begin{array}{c}\text { Volume fractions } \\
(\%)\end{array}$} & Sample & 29.46 & 29.47 & 29.46 & 29.58 & 29.50 & 29.53 & 29.50 & 29.53 \\
\cline { 2 - 11 } & Void & 7.9 & 7.89 & 7.89 & 7.76 & 7.87 & 7.83 & 7.85 & 7.83 \\
\cline { 2 - 11 } & Zr4 & 18.23 & 18.22 & 18.24 & 18.24 & 18.22 & 18.23 & 18.24 & 18.22 \\
\cline { 2 - 10 } & SS & 11.38 & 11.38 & 11.38 & 11.38 & 11.38 & 11.38 & 11.38 & 11.38 \\
\cline { 2 - 10 } & Water & 33.04 & 33.04 & 33.04 & 33.04 & 33.04 & 33.04 & 33.04 & 33.04 \\
\hline
\end{tabular}


The characteristics of the borated $\mathrm{UO}_{2}$ calibration sample fuel pellets are reported in Table 18 . The associated volume fractions of the homogenized oscillation sample in the oscillation cane are shown in Table 19.

\begin{tabular}{|c|c|c|c|c|c|c|c|c|}
\hline \multicolumn{1}{|c|}{ Table 18: Geometry and material specification of the borated $\mathrm{UO}_{2}$ calibration sample } \\
\hline Sample & $1 \mathrm{~B} 0000$ & $1 \mathrm{~B} 0071$ & $1 \mathrm{~B} 0150$ & $1 \mathrm{~B} 0419$ & $2 \mathrm{~B} 0000$ & $2 \mathrm{~B} 0333$ & $2 \mathrm{~B} 1062$ & $2 \mathrm{~B} 2360$ \\
\hline U235 enrichment (\%) & 0.25 & 0.25 & 0.25 & 0.25 & 0.53 & 0.53 & 0.53 & 0.53 \\
\hline Boron fraction $(\mathrm{ppm})$ & 0 & 71 & 150 & 419 & 0 & 333 & 1062 & 2360 \\
\hline Height $(\mathrm{mm})$ & 99.96 & 100 & 99.98 & 99.82 & 99.7 & 99.5 & 99.62 & 98.7 \\
\hline Diameter $(\mathrm{mm})$ & 8.079 & 8.08 & 8.106 & 8.084 & 8.203 & 8.2 & 8.202 & 8.2 \\
\hline Density $(\mathrm{g} / \mathrm{cc})$ & 9.551 & 9.545 & 9.380 & 9.523 & 2.854 & 9.801 & 9.701 & 9.504 \\
\hline
\end{tabular}

Table 19: Volume fraction of the homogenized boron calibration sample inserted in the oscillation cane

\begin{tabular}{|c|c|c|c|c|c|c|c|c|c|}
\hline \multicolumn{2}{|c|}{ Sample } & $1 \mathrm{~B} 0000$ & $1 \mathrm{~B} 0071$ & $1 \mathrm{~B} 0150$ & $1 \mathrm{~B} 0419$ & $2 \mathrm{~B} 0000$ & $2 \mathrm{~B} 0333$ & $2 \mathrm{~B} 1062$ & $2 \mathrm{~B} 2360$ \\
\hline \multirow{3}{*}{$\begin{array}{l}\text { Volume } \\
\text { fractions } \\
(\%)\end{array}$} & Sample & 31.19 & 31.21 & 31.40 & 31.18 & 32.07 & 31.98 & 32.03 & 31.72 \\
\cline { 2 - 11 } & Void & 8.49 & 8.49 & 8.28 & 8.44 & 7.51 & 7.52 & 7.51 & 7.46 \\
\cline { 2 - 11 } & $\mathrm{Zr} 4$ & 15.91 & 15.89 & 15.90 & 15.96 & 16.01 & 16.09 & 16.04 & 16.41 \\
\cline { 2 - 10 } & $\mathrm{SS}$ & 11.38 & 11.38 & 11.38 & 11.38 & 11.38 & 11.38 & 11.38 & 11.38 \\
\cline { 2 - 10 } & Water & 33.04 & 33.04 & 33.04 & 33.04 & 33.04 & 33.04 & 33.04 & 33.04 \\
\hline
\end{tabular}

\subsubsection{Cross sections for the materials}

The cross sections used in the REBUS code for the materials are calculated in two steps. First microscopic cross sections for different elements (such as Al-27, U-235, Fe-54...) are calculated using WIMS. The macroscopic cross sections of the materials are then generated in REBUS from the microscopic cross sections and the atom densities of the different elements.

Because the self shielding of the microscopic cross sections is performed in WIMS, it is often necessary to define different sets of cross sections for a given element. It is particularly important for the constituents of the fuel and the absorber.

In this section, the compositions of the materials used in REBUS in terms of atom density, and the minor adjustments to be able to use the WIMS 69-group library are addressed. The WIMS models are described and related to the different REBUS regions for the R1UO2 and the R1MOX configurations. The WIMS input files are included in Appendix 3.

\subsubsection{The elemental composition of the materials}

The elemental composition of each material is based on the composition listed in Appendix 2 of ref. 1. Because the WIMS 69-group library (ref. 4) extracted from ENDFB-VI does not contain cross sections for Zn, Sn, S and P, the number densities of AG-3, AL5, AW-2017, SS, Zr-4 and $\mathrm{Zr}-2$ have been slightly changed. Some elements like iron, chromium, nickel and copper have cross sections listed for individual isotopes. The natural abundance used to calculate the corresponding number densities are reported in Appendix 4.

The atom densities of the structural material used in the deterministic model are reported in Table 20-Table 25. 
Table 20: AG-3 aluminum alloy composition

\begin{tabular}{|c|c|}
\hline Element & Number density $($ at $/$ b.cm) \\
\hline $\mathrm{Al}$ & $5.457 \mathrm{E}-02$ \\
\hline $\mathrm{Mg}$ & $1.959 \mathrm{E}-03$ \\
\hline $\mathrm{Mn}$ & $6.988 \mathrm{E}-05$ \\
\hline $\mathrm{Fe}-54$ & $3.215 \mathrm{E}-06$ \\
\hline $\mathrm{Fe}-56$ & $5.046 \mathrm{E}-05$ \\
\hline $\mathrm{Fe}-57$ & $1.165 \mathrm{E}-06$ \\
\hline $\mathrm{Fe}-58$ & $1.551 \mathrm{E}-07$ \\
\hline $\mathrm{Cr}-50$ & $1.925 \mathrm{E}-06$ \\
\hline $\mathrm{Cr}-52$ & $3.712 \mathrm{E}-05$ \\
\hline $\mathrm{Cr}-53$ & $4.209 \mathrm{E}-06$ \\
\hline $\mathrm{Cr}-54$ & $1.048 \mathrm{E}-06$ \\
\hline $\mathrm{Ti}$ & $2.406 \mathrm{E}-05$ \\
\hline $\mathrm{Si}$ & $1.094 \mathrm{E}-04$ \\
\hline $\mathrm{Cu}-63$ & $8.358 \mathrm{E}-06$ \\
\hline $\mathrm{Cu}-65$ & $3.725 \mathrm{E}-06$ \\
\hline total & $\mathbf{5 . 6 8 4 E - 0 2}$ \\
\hline
\end{tabular}

Table 21: AL5 aluminum alloy composition

\begin{tabular}{|c|c|}
\hline Element & Number density (at / b.cm) \\
\hline $\mathrm{Al}$ & $6.010 \mathrm{E}-02$ \\
\hline $\mathrm{Mg}$ & $1.676 \mathrm{E}-05$ \\
\hline $\mathrm{Mn}$ & $7.413 \mathrm{E}-06$ \\
\hline $\mathrm{Fe}-54$ & $3.410 \mathrm{E}-06$ \\
\hline $\mathrm{Fe}-56$ & $5.353 \mathrm{E}-05$ \\
\hline $\mathrm{Fe}-57$ & $1.236 \mathrm{E}-06$ \\
\hline $\mathrm{Fe}-58$ & $1.645 \mathrm{E}-07$ \\
\hline $\mathrm{Ti}$ & $8.508 \mathrm{E}-06$ \\
\hline $\mathrm{Si}$ & $7.250 \mathrm{E}-05$ \\
\hline $\mathrm{Cu}-63$ & $4.433 \mathrm{E}-06$ \\
\hline $\mathrm{Cu}-65$ & $1.976 \mathrm{E}-06$ \\
\hline total & $\mathbf{6 . 0 2 7 E - 0 2}$ \\
\hline
\end{tabular}




\begin{tabular}{|c|c|}
\hline \multicolumn{2}{|c|}{ Table 22: AW-2017 aluminum alloy composition } \\
\hline Element & Number density (at / b.cm) \\
\hline $\mathrm{Al}$ & $5.827 \mathrm{E}-02$ \\
\hline $\mathrm{Mg}$ & $4.839 \mathrm{E}-04$ \\
\hline $\mathrm{Mn}$ & $2.141 \mathrm{E}-04$ \\
\hline $\mathrm{Fe}-54$ & $6.155 \mathrm{E}-06$ \\
\hline $\mathrm{Fe}-56$ & $9.662 \mathrm{E}-05$ \\
\hline $\mathrm{Fe}-57$ & $2.231 \mathrm{E}-06$ \\
\hline $\mathrm{Fe}-58$ & $2.970 \mathrm{E}-07$ \\
\hline $\mathrm{Cr}-50$ & $7.020 \mathrm{E}-07$ \\
\hline $\mathrm{Cr}-52$ & $1.354 \mathrm{E}-05$ \\
\hline $\mathrm{Cr}-53$ & $1.535 \mathrm{E}-06$ \\
\hline $\mathrm{Cr}-54$ & $3.821 \mathrm{E}-07$ \\
\hline $\mathrm{Si}$ & $2.991 \mathrm{E}-04$ \\
\hline $\mathrm{Cu}-63$ & $4.433 \mathrm{E}-06$ \\
\hline $\mathrm{Cu}-65$ & $1.976 \mathrm{E}-06$ \\
\hline total & $5.940 \mathrm{E}-02$ \\
\hline
\end{tabular}

Table 23: $\mathrm{Zr}$-4 zirconium alloy composition

\begin{tabular}{|c|c|}
\hline Element & Number density $($ at $/$ b.cm) \\
\hline $\mathrm{Zr}$ & $4.247 \mathrm{E}-02$ \\
\hline $\mathrm{H}$ & $4.899 \mathrm{E}-05$ \\
\hline $\mathrm{Fe}-54$ & $8.683 \mathrm{E}-06$ \\
\hline $\mathrm{Fe}-56$ & $1.363 \mathrm{E}-04$ \\
\hline $\mathrm{Fe}-57$ & $3.148 \mathrm{E}-06$ \\
\hline $\mathrm{Fe}-58$ & $4.189 \mathrm{E}-07$ \\
\hline $\mathrm{Cr}-50$ & $3.301 \mathrm{E}-06$ \\
\hline $\mathrm{Cr}-52$ & $6.366 \mathrm{E}-05$ \\
\hline $\mathrm{Cr}-53$ & $7.219 \mathrm{E}-06$ \\
\hline $\mathrm{Cr}-54$ & $1.797 \mathrm{E}-06$ \\
\hline $\mathrm{O}$ & $3.086 \mathrm{E}-04$ \\
\hline $\mathrm{C}$ & $4.440 \mathrm{E}-05$ \\
\hline Hf & $1.107 \mathrm{E}-06$ \\
\hline total & $\mathbf{4 . 3 1 0 E - 0 2}$ \\
\hline
\end{tabular}




\begin{tabular}{|c|c|}
\hline \multicolumn{2}{|c|}{ Table 24: Zr-2 zirconium alloy composition } \\
\hline Element & Number density (at / b.cm) \\
\hline $\mathrm{Zr}$ & $4.248 \mathrm{E}-02$ \\
\hline $\mathrm{H}$ & $4.899 \mathrm{E}-05$ \\
\hline Fe-54 & $5.582 \mathrm{E}-06$ \\
\hline Fe-56 & $8.763 \mathrm{E}-05$ \\
\hline Fe-57 & $2.024 \mathrm{E}-06$ \\
\hline Fe-58 & $2.693 \mathrm{E}-07$ \\
\hline Cr-50 & $3.301 \mathrm{E}-06$ \\
\hline $\mathrm{Cr}-52$ & $6.366 \mathrm{E}-05$ \\
\hline $\mathrm{Cr}-53$ & $7.219 \mathrm{E}-06$ \\
\hline $\mathrm{Cr}-54$ & $1.797 \mathrm{E}-06$ \\
\hline $\mathrm{O}$ & $3.086 \mathrm{E}-04$ \\
\hline $\mathrm{C}$ & $4.440 \mathrm{E}-05$ \\
\hline Hf & $1.107 \mathrm{E}-06$ \\
\hline total & $\mathbf{4 . 3 0 5 E - 0 2}$ \\
\hline
\end{tabular}

\begin{tabular}{|c|c|}
\hline \multicolumn{2}{|c|}{ Table 25: Stainless steel composition } \\
\hline Element & Number density (at / b.cm) \\
\hline Fe-54 & $3.387 \mathrm{E}-03$ \\
\hline Fe-56 & $5.316 \mathrm{E}-02$ \\
\hline Fe-57 & $1.228 \mathrm{E}-03$ \\
\hline Fe-58 & $1.634 \mathrm{E}-04$ \\
\hline $\mathrm{C}$ & $5.904 \mathrm{E}-05$ \\
\hline $\mathrm{Cr}-50$ & $7.111 \mathrm{E}-04$ \\
\hline $\mathrm{Cr}-52$ & $1.371 \mathrm{E}-02$ \\
\hline $\mathrm{Cr}-53$ & $1.555 \mathrm{E}-03$ \\
\hline $\mathrm{Cr}-54$ & $3.870 \mathrm{E}-04$ \\
\hline $\mathrm{Ni}-58$ & $6.031 \mathrm{E}-03$ \\
\hline $\mathrm{Ni}-60$ & $2.323 \mathrm{E}-03$ \\
\hline $\mathrm{Ni}-61$ & $1.010 \mathrm{E}-04$ \\
\hline $\mathrm{Ni}-62$ & $3.220 \mathrm{E}-04$ \\
\hline $\mathrm{Ni}-64$ & $8.201 \mathrm{E}-05$ \\
\hline $\mathrm{Mn}$ & $8.605 \mathrm{E}-04$ \\
\hline $\mathrm{Si}$ & $8.416 \mathrm{E}-04$ \\
\hline $\mathrm{Mo}$ & $4.927 \mathrm{E}-04$ \\
\hline total & $\mathbf{8 . 5 4 2 E - 0 2}$ \\
\hline
\end{tabular}

The fuel material number densities used in the WIMS and REBUS codes are taken directly from ref. 1. The $\mathrm{UO}_{2}-\mathrm{PuO}_{2}$ fuel atom density used is the one calculated for the year 2004 .

The number density of the U-235 calibration sample has been deduced from measurements in ref. 6 and is reported in Table 26. On the contrary, the number density of the borated calibration sample has not been measured. The number density of the borated calibration sample is reported in Table 27 and was calculated using the total density, geometry and boron enrichment of the sample from ref.7 and listed in Table 18. 


\begin{tabular}{|c|c|c|c|c|c|c|c|c|}
\hline \multicolumn{10}{|c|}{ Table 26: Number density of the U-235 calibration samples } \\
\hline \multirow{3}{*}{ Isotope } & \multicolumn{10}{|c|}{ Sample identification } \\
\cline { 2 - 10 } & $\begin{array}{c}\text { 0025 } \\
(0.25 \%)\end{array}$ & $\begin{array}{c}\text { F0050 } \\
(0.49 \%)\end{array}$ & $\begin{array}{c}\text { N0071 } \\
(0.71 \%)\end{array}$ & $\begin{array}{c}\text { S0100 } \\
(1.00 \%)\end{array}$ & $\begin{array}{c}\text { S0200 } \\
(2.01 \%)\end{array}$ & $\begin{array}{c}\text { S0300 } \\
(3.01 \%)\end{array}$ & $\begin{array}{c}\text { S0400 } \\
(4.00 \%)\end{array}$ & $\begin{array}{c}\text { S0495 } \\
(4.93 \%)\end{array}$ \\
\hline U-234 & $2.328 \mathrm{E}-07$ & $7.933 \mathrm{E}-07$ & $1.290 \mathrm{E}-06$ & $1.913 \mathrm{E}-06$ & $4.258 \mathrm{E}-06$ & $6.513 \mathrm{E}-06$ & $8.773 \mathrm{E}-06$ & $1.093 \mathrm{E}-05$ \\
\hline U-235 & $5.849 \mathrm{E}-05$ & $1.154 \mathrm{E}-04$ & $1.666 \mathrm{E}-04$ & $2.367 \mathrm{E}-04$ & $4.745 \mathrm{E}-04$ & $7.124 \mathrm{E}-04$ & $9.479 \mathrm{E}-04$ & $1.171 \mathrm{E}-03$ \\
\hline U-236 & $6.985 \mathrm{E}-08$ & $7.000 \mathrm{E}-08$ & $1.172 \mathrm{E}-07$ & $1.181 \mathrm{E}-07$ & $1.183 \mathrm{E}-07$ & $9.474 \mathrm{E}-08$ & $1.186 \mathrm{E}-07$ & $1.188 \mathrm{E}-07$ \\
\hline U-238 & $2.322 \mathrm{E}-02$ & $2.322 \mathrm{E}-02$ & $2.328 \mathrm{E}-02$ & $2.338 \mathrm{E}-02$ & $2.317 \mathrm{E}-02$ & $2.297 \mathrm{E}-02$ & $2.276 \mathrm{E}-02$ & $2.257 \mathrm{E}-02$ \\
\hline O & $4.663 \mathrm{E}-02$ & $4.672 \mathrm{E}-02$ & $4.695 \mathrm{E}-02$ & $4.734 \mathrm{E}-02$ & $4.736 \mathrm{E}-02$ & $4.747 \mathrm{E}-02$ & $4.747 \mathrm{E}-02$ & $4.762 \mathrm{E}-02$ \\
\hline total & $\mathbf{6 . 9 9 1 E - 0 2}$ & $\mathbf{7 . 0 0 6 E - 0 2}$ & $\mathbf{7 . 0 3 9 E - 0 2}$ & $\mathbf{7 . 0 9 6 E - 0 2}$ & $\mathbf{7 . 1 0 1 E - 0 2}$ & $\mathbf{7 . 1 1 6 E}-02$ & $\mathbf{7 . 1 1 8 E}-02$ & $\mathbf{7 . 1 3 7 E - 0 2}$ \\
\hline
\end{tabular}

\begin{tabular}{|c|c|c|c|c|c|c|c|c|}
\hline \multicolumn{10}{|c|}{ Table 27: Number density of the Boron calibration samples } \\
\hline \multirow{3}{*}{ Isotope } & \multicolumn{10}{c|}{ Sample identification } \\
\cline { 2 - 10 } & $\begin{array}{c}1 \mathrm{~B} 0000 \\
(0 \mathrm{ppm})\end{array}$ & $\begin{array}{c}1 \mathrm{~B} 0071 \\
(71 \mathrm{ppm})\end{array}$ & $\begin{array}{c}1 \mathrm{~B} 0150 \\
(150 \mathrm{ppm})\end{array}$ & $\begin{array}{c}1 \mathrm{~B} 0419 \\
(419 \mathrm{ppm})\end{array}$ & $\begin{array}{c}2 \mathrm{~B} 0000 \\
(0 \mathrm{ppm})\end{array}$ & $\begin{array}{c}2 \mathrm{~B} 0333 \\
(333 \mathrm{ppm})\end{array}$ & $\begin{array}{c}2 \mathrm{~B} 1062 \\
(1062 \mathrm{ppm})\end{array}$ & $\begin{array}{c}2 \mathrm{~B} 2360 \\
(2360 \mathrm{ppm})\end{array}$ \\
\hline $\mathrm{U}-235$ & $5.393 \mathrm{E}-05$ & $5.389 \mathrm{E}-05$ & $5.356 \mathrm{E}-05$ & $5.375 \mathrm{E}-05$ & $1.180 \mathrm{E}-04$ & $1.173 \mathrm{E}-04$ & $1.160 \mathrm{E}-04$ & $1.135 \mathrm{E}-04$ \\
\hline $\mathrm{U}-238$ & $2.125 \mathrm{E}-02$ & $2.123 \mathrm{E}-02$ & $2.110 \mathrm{E}-02$ & $2.117 \mathrm{E}-02$ & $2.186 \mathrm{E}-02$ & $2.173 \mathrm{E}-02$ & $2.150 \mathrm{E}-02$ & $2.103 \mathrm{E}-02$ \\
\hline O & $4.260 \mathrm{E}-02$ & $4.257 \mathrm{E}-02$ & $4.231 \mathrm{E}-02$ & $4.246 \mathrm{E}-02$ & $4.395 \mathrm{E}-02$ & $4.370 \mathrm{E}-02$ & $4.322 \mathrm{E}-02$ & $4.229 \mathrm{E}-02$ \\
\hline B-10 & - & $7.513 \mathrm{E}-06$ & $1.578 \mathrm{E}-05$ & $4.423 \mathrm{E}-05$ & - & $3.618 \mathrm{E}-05$ & $1.142 \mathrm{E}-04$ & $2.486 \mathrm{E}-04$ \\
\hline B-11 & - & $3.024 \mathrm{E}-05$ & $6.350 \mathrm{E}-05$ & $1.780 \mathrm{E}-04$ & - & $1.456 \mathrm{E}-04$ & $4.597 \mathrm{E}-04$ & $1.001 \mathrm{E}-03$ \\
\hline total & $\mathbf{6 . 3 9 0 E - 0 2}$ & $\mathbf{6 . 3 8 9 E - 0 2}$ & $\mathbf{6 . 3 5 4 E - 0 2}$ & $\mathbf{6 . 3 9 1 E - 0 2}$ & $\mathbf{6 . 5 9 3 E - 0 2}$ & $\mathbf{6 . 5 7 3 E - 0 2}$ & $\mathbf{6 . 5 4 1 E - 0 2}$ & $\mathbf{6 . 4 6 8 E - 0 2}$ \\
\hline
\end{tabular}

\subsubsection{Cross sections for the R1UO2 configuration}

For the R1UO2 configuration, 7 WIMS calculations generate all the necessary cross sections when the central channel is filled with the POLINE overclad or a standard $\mathrm{UO}_{2}$ fuel pin. An additional WIMS calculation is performed to generate each calibration sample cross section.

\subsection{The driver zone}

The driver zone cross sections have been generated using calculations for:

- The 18- 12- and 9- plate fuel element (90\% U-235 enrichment) [file: 18p90]

- The 18- plate fuel element (93\% U-235 enrichment) [file: $18 \mathrm{p} 93$ ]

- The Control elements with the rod withdrawn [file: CElt]

- The Graphite elements and blocks [file: G18p90]

- The Control elements with the rod inserted [file: rod ]

The methodology of these calculations is described and the input files are included in Appendix 3.

\section{Calculation 18p90 and 18p93}

The purpose of these calculations was to generate the fuel-plate and water cross sections for the 18-plate fuel element with enrichment of $90 \%$ and $93 \%$ in U-235. The cross sections generated from the $18 \mathrm{p} 90$ calculation are also used for the fuel portion of the 12- and 9- plate fuel elements.

The calculation is a simple cell model with no leakage treatment. The geometry is presented in Figure 38. The composition of each material is reported in ref. 1 and in section 2.2.4.1. The U235, U-238, Al, $\mathrm{O}$ and $\mathrm{H}$ microscopic cross sections are generated by smearing materials over the 3 regions. 
The cross sections from the "18p90" calculation are used in REBUS to describe:

- the water and the aluminum of the 'plate clad' region of the 18-plate (90\%), 12-plate and 9-plate fuel elements (Figure 25-Figure 27)

- the water, the aluminum and the fuel of the 'fuel plate' region of the 18-plate (90\%), 12 plate and 9-plate fuel elements (Figure 25-Figure 27)

- the water of the 'graphite' region of the 12-plate and 9-plate fuel elements (Figure 26 and Figure 27)

Similarly, the cross sections from the "18p93" calculation are used to describe:

- the water and the aluminum of the 'plate clad' region of the 18-plate fuel element (93\%) (Figure 25)

- the water, the aluminum and the fuel of the 'fuel plate' region of the 18-plate fuel element (93\%) (Figure 25)

\section{Calculation CElt}

The calculation CElt is used to generate the cross sections for water and aluminum in a control element when the rods are withdrawn. The WIMS calculation is a cell model (without leakage treatment) where half the radial section of the control rod element is described when the rod is withdrawn (Figure 38). The composition of each material is reported in ref. 1 and in section 2.2.4.1.

More precisely, the generated cross sections are smeared on all the regions of the WIMS calculation and are used in the REBUS calculation to describe:

- The fuel, water and aluminum of the fuel plate sections of the control rod element (Figure 28)

- The water and aluminum of the plate clad regions of the control rod element (Figure 28)

\section{Calculation rod}

The calculation Rod is used to generate the microscopic cross sections for the fuel, the AG-3 alloy, the stainless steel, the hafnium and the water in the control element when the rods are inserted in the core.

This is a Super-cell calculation with two auxiliary cells (Figure 39). The first auxiliary cell describes an infinite array of fuel plates (93\% U-235 enrichment) and is used to homogenize the fuel material in the Super-cell. The second auxiliary cell helps define the spectra for the hafnium, the water, the stainless steel and the AG-3 used in the Super-cell.

These microscopic cross sections are only used in REBUS for the fuel-plate and the plate-clad regions of the control rod element when the rods are fully inserted in the core (Figure 28).

\section{Calculation G18p90}

The calculation G18p90 is used to generate the cross sections for the graphite, the AG-3 alloy, and the water of the graphite element and graphite blocks.

It is a Super-Cell model describing an 18-plate fuel element (90\% U-235 enrichment) that is homogenized from an auxiliary cell, 2 graphite elements and a large graphite block. This arrangement allow the generation of different cross sections for the graphite elements for each row in the driver zone. The geometry of the WIMS calculation is presented in Figure 40. 
The cross sections smeared over the fuel element region of the WIMS calculation are used to generate the AG-3 cross section for the fuel elements of the REBUS model. The cross sections smeared over the $1^{\text {st }}$ graphite element region of the WIMS calculation are used to generate the Graphite, AG-3 and water cross section for the graphite elements adjacent to a fuel element in the REBUS model. The cross sections smeared over the $2^{\text {nd }}$ graphite element region of the WIMS calculation are used to generate the Graphite, AG-3 and water cross section for the graphite elements not adjacent to a fuel element in the REBUS model. The cross sections smeared over the graphite block region of the WIMS calculation are used to generate the graphite, AG-3 and water cross sections for the graphite blocks of the REBUS model.

Figure 41 shows the two graphite element regions used in the REBUS model for the R1UO2 configuration.

Substituting 93\% U-235 enrichment resulted in cross sections for these materials that were similar to the results with $90 \%$ U-235 enrichment. Therefore, 93\% U-235 enrichment fuel was not used to generate cross sections for these materials.

\subsection{The experimental zone}

The cross sections used in the experimental zone resulted from calculations of:

- The $\mathrm{UO}_{2}$ pin cell, files: $\mathrm{U}(3)$ and $\mathrm{U}(3) \mathrm{Ax}$ for the radial and axial views

- The samples inside the oscillation cane, file: sample

\section{Calculation $U(3)$ and $U(3) A x$}

The calculation $\mathrm{U}(3)$ describes the $\mathrm{UO}_{2}$ pin cell. It is the radial description in the fuel mid-plane. The geometry is presented in Figure 42. The calculation is a cell model with no leakage treatment. The $\mathrm{UO}_{2}$ fuel, the $\mathrm{Zr}-4$, the AG-3 alloy and the water cross sections were generated.

In order to obtain the cross sections of all the elements composing the stainless steel, the calculation $\mathrm{U}(3) \mathrm{Ax}$ was run. It is an axial view of the $\mathrm{UO}_{2}$ fuel pin with its Plexiglas and stainless steel spacer. The calculation also used the cell model without leakage. The geometry is reported in Figure 42.

The generated cross sections are used in the REBUS model for:

- Every section of the $\mathrm{UO}_{2}$ pin cell (Figure 33)

- Every section of the Al pin cell (Figure 35)

- Every section of the AG-3 buffer (Figure 32)

- Every section of the Chimney (Figure 31)

- The foot section of the fuel and control element of the driver zone (Figure 25 and Figure 28)

- The foot and upper section of the graphite element (Figure 24)

- The grid plates, caisson, supporting table and tank water of the driver zone

\section{Calculation Sample}

A calculation, file: sample, is performed for each calibration sample. These calculations are Super-Cell models. The main cell describes the radial view of the sample inside the oscillation cane surrounded by a circular buffer composed of a homogenized $\mathrm{UO}_{2}$ fuel pin cell that constitutes the auxiliary cell (Figure 43). The cross sections for U-235, U-238, U-234, U-236, O, B-10, B-11 and H, are generated by smearing the material over the sample region. 
A summary of the main characteristics of the WIMS calculations and of the generated microscopic cross sections are reported in Table 28 for the driver zone and in Table 29 for the experimental zone. Figure 41 illustrates the cross sections that are used in the REBUS model for the different regions in the R1UO2 configuration. 


\begin{tabular}{|c|c|c|c|c|c|}
\hline \multicolumn{6}{|r|}{ ons for the driver zone } \\
\hline File name & 18 p90 & 18 p93 & Celt & G18p90 & Rod \\
\hline Title & $\begin{array}{c}\text { Fuel plate } \\
(90 \% \text { U-235) }\end{array}$ & $\begin{array}{c}\text { Fuel plate } \\
(93 \% \text { U-235) }\end{array}$ & $\begin{array}{l}\text { Control } \\
\text { element } \\
\text { (rods up) }\end{array}$ & Graphite element & $\begin{array}{l}\text { Control element } \\
\text { (rods down) }\end{array}$ \\
\hline $\begin{array}{l}\text { Calculation } \\
\text { Type }\end{array}$ & Cell & Cell & Cell & SuperCell & SuperCell \\
\hline $\begin{array}{l}\text { Boundary } \\
\text { condition }\end{array}$ & Infinite lattice & Infinite lattice & Infinite lattice & Infinite lattice & Infinite lattice \\
\hline Description & $\begin{array}{l}90 \% \mathrm{U}-235 \\
\text { fuel plate and } \\
\text { Clad and } \\
\text { water }\end{array}$ & $\begin{array}{l}93 \% \text { U-235 } \\
\text { fuel plate and } \\
\text { Clad and } \\
\text { water }\end{array}$ & $\begin{array}{c}\text { Half the } \\
\text { control } \\
\text { element : } \\
93 \% \text { U-235 } \\
\text { fuel plate and } \\
\text { Clad and water } \\
\end{array}$ & $\begin{array}{c}\text { Homogenized 18-plate fuel } \\
\text { element } \\
+ \\
3 \text { graphite elements }\end{array}$ & $\begin{array}{c}\text { Homogenized } 93 \% \text { U-235 fuel plate }+ \text { Clad } \\
+ \text { water } \\
+ \\
\text { AG-3 plate and water } \\
+ \\
\text { Hafnium and SS and water }\end{array}$ \\
\hline $\begin{array}{l}\text { Cross sections } \\
\text { generated }\end{array}$ & $\begin{array}{c}\text { U-235, U-238, } \\
\text { A1, H, O }\end{array}$ & $\begin{array}{c}\mathrm{U}-235, \mathrm{U}-238 \\
\text { Al, H, O }\end{array}$ & $\begin{array}{c}\mathrm{U}-235, \mathrm{U}-238 \\
\mathrm{Al}, \mathrm{H}, \mathrm{O}\end{array}$ & $\begin{array}{c}\text { A1, Mg, Mn, Fe-54,Fe-56, Fe-57, } \\
\text { Fe-58, Cr-60, Cr-62, Cr-63, Cr- } \\
\text { 63, Cr-64, Ti, Si, Cu-63, Cu-65, } \\
\text { H, O, C }\end{array}$ & $\begin{array}{c}\text { Al, Mg, Mn, Fe-54,Fe-56, Fe-57, Fe-58, Cr- } \\
\text { 60, Cr-62, Cr-63, Cr-63, Cr-64, Ti, Si, Cu- } \\
\text { 63, Cu-65, H, O, Mo, C, Hf, Ni-58, Ni-60, } \\
\text { Ni61, Ni62, Ni-64 }\end{array}$ \\
\hline
\end{tabular}




\begin{tabular}{|c|c|c|c|}
\hline \multicolumn{2}{|c|}{ Table 29: Characteristic of the WIMS calculation used to generate cross sections for the experimental zone } \\
\hline File name & $\mathrm{U}(3)$ & $\mathrm{U}(3)$ Ax & Sample \\
\hline Title & $\mathrm{UO}_{2}(3 \%)$ pin cell & $\begin{array}{c}\mathrm{UO}_{2}(3 \%) \text { pin cell } \\
\text { In axial view }\end{array}$ & $\begin{array}{c}\text { Sample in the } \\
\text { oscillation cane }\end{array}$ \\
\hline Calculation Type & Cell & Cell & SuperCell \\
\hline $\begin{array}{c}\text { Boundary } \\
\text { condition }\end{array}$ & Infinite lattice & Infinite lattice & Infinite lattice \\
\hline Description & $\mathrm{UO}_{2}(3 \%)$ pin, void, clad, water, overclad, water & $\begin{array}{c}\text { Sample, water, } \\
\text { Oscillation cane, water } \\
+\end{array}$ \\
$\begin{array}{c}\text { Cross sections } \\
\text { generated }\end{array}$ & $\begin{array}{c}\mathrm{U}-234, \mathrm{U}-235, \mathrm{U}-236, \mathrm{U}-238, \mathrm{O}, \mathrm{H}, \mathrm{Zr}, \mathrm{ZH}, \mathrm{Fe}-54, \mathrm{Fe}-56, \mathrm{Fe}-57, \mathrm{Fe}-58, \mathrm{Cr}- \\
60, \mathrm{Cr}-62, \mathrm{Cr}-63, \mathrm{Cr}-63, \mathrm{Cr}-64, \mathrm{C}, \mathrm{Hf}, \mathrm{Al}, \mathrm{Mg}, \mathrm{Mn}, \mathrm{Ti}, \mathrm{Si}, \mathrm{Cu}-63, \mathrm{Cu}-65\end{array}$ & $\begin{array}{c}\text { Ni-58, Ni-60, Ni61, } \\
\text { Ni62, Ni-64, Mo }\end{array}$ & $\begin{array}{c}\mathrm{U}-235, \mathrm{U}-238, \mathrm{O}, \mathrm{B}-10, \\
\text { region }\end{array}$ \\
\hline
\end{tabular}




\subsubsection{Cross sections for the R1MOX configuration}

The cross sections for the driver zone are calculated in the same manner as for the R1UO2 configuration. In the R1MOX experimental zone, there are $\mathrm{UO}_{2}$ fuel pin cells, Al fuel pin cells and $\mathrm{UO}_{2}-\mathrm{PuO}_{2}$ fuel pin cells $\left(3.6 \%\right.$ and $4 \%$ of $\left.\mathrm{PuO}_{2}\right)$. Cross sections have been generated depending on the pin cell and its surrounding cells. The chosen configuration to take into account the interface between regions is:

- $\mathrm{UO}_{2}$ fuel pin cell near Al fuel pin: UAl calculation

- $\mathrm{UO}_{2}$ fuel pin cell near Al buffer: UAlB calculation

- $\mathrm{UO}_{2}$ fuel pin adjacent to $\mathrm{UO}_{2} \mathrm{PuO}_{2}$ fuel pin : $\mathrm{UPuPu} 1$ calculation

- $\mathrm{UO}_{2}$ fuel pin cell surrounded by $\mathrm{UO}_{2}$ fuel pin cell: $\mathrm{U}(3)$ and $\mathrm{U}(3) \mathrm{Ax}$ calculation

- $\mathrm{UO}_{2}-\mathrm{PuO}_{2}(4 \%)$ fuel pin adjacent to $\mathrm{UO}_{2}$ pin cell: $\mathrm{UPu}$ calculation

- $\mathrm{UO}_{2}-\mathrm{PuO}_{2}(4 \%)$ fuel pin adjacent to POLINE cell: UPOL calculation

- $\mathrm{UO}_{2}-\mathrm{PuO}_{2}$ (4\%) fuel pin surrounded by $\mathrm{UO}_{2}-\mathrm{PuO}_{2}$ pin cell: $\mathrm{Pu}(4)$ and $\mathrm{Pu}(4) \mathrm{Ax}$ calculation

- $\mathrm{UO}_{2}-\mathrm{PuO}_{2}(3.6 \%)$ fuel pin between a $\mathrm{UO}_{2}-\mathrm{PuO}_{2}$ (4\%) pin cell and a $\mathrm{UO}_{2}$ pin cell: UPuPu2 calculation

- Aluminum pins: U(3) calculation

- POLINE: U(3) calculation

- Calibration sample inside the oscillation channel : Sample calculation

The configuration of the experimental zone is shown in Figure 44. The WIMS calculations are detailed in the following sections. Table 32 and Table 33 summarize the characteristics of the WIMS models.

\section{Calculation $U(3)$ and $U(3) A x$}

These calculations are the same as for the R1UO2 configuration. The use of the cross sections in the REBUS model differs slightly. These calculations were used to generate cross sections for the following regions:

- Every section of the $\mathrm{UO}_{2}$ pin cell completely surrounded by the same fuel pins (Figure 33)

- Every section except section $\mathrm{C}$ (fuel) of the other $\mathrm{UO}_{2}$ pin cell (Figure 33)

- Every section of the Al pin cell (Figure 35)

- Every section of the AG-3 buffer (Figure 32)

- Every section of the Chimney (Figure 31)

- The foot section of the fuel and control element of the driver zone (Figure 25 and Figure 28)

- The foot and upper section of the graphite element (Figure 24)

- The grid plates, caisson, supporting table and tank water of the driver zone

Only the cross sections of section $\mathrm{C}$ of the fuel pin cell in Figure 33 is treated differently for the $\mathrm{UO}_{2}$ pin cell located near a $\mathrm{UO}_{2}-\mathrm{PuO}_{2}$ pin cell, aluminum cell or aluminum buffer.

\section{Calculation UAl and UAlB}

The goal of these calculations is to take into account the effect of an aluminum pin or aluminum buffer on the cross sections for the neighboring $\mathrm{UO}_{2}$ pin cell. A simple cell model representative of a $\mathrm{UO}_{2}$ pin cell surrounded by $5 \mathrm{UO}_{2}$ pin cells and 3 aluminum pin (or buffer) cells is considered. In the model, the $\mathrm{UO}_{2}$ pin cell is surrounded by a buffer where the materials of the 8 
adjacent cells have been homogenized. The geometry of the calculation is shown in Figure 45. The material composition of each region is reported in ref. 1 and section 2.2.4.1 except for the buffer region composition which is listed in Table 30.

Cross sections are generated for the $\mathrm{Zr}-4$ alloy, the AG-3 alloy, the $\mathrm{UO}_{2}$ fuel and the water and are only used in section $\mathrm{C}$ (Figure 33) of the $\mathrm{UO}_{2}$ pins adjacent to aluminum pins and aluminum buffer (Figure 44).

\begin{tabular}{|c|c|c|}
\hline \multicolumn{3}{|c|}{ Table 30: Buffer composition } \\
\hline Element & $\begin{array}{c}\text { "UAl" } \\
\text { Number density (at / b.cm) }\end{array}$ & $\begin{array}{c}\text { "UAlB" } \\
\text { Number density (at / b.cm) }\end{array}$ \\
\hline U-234 & $9.243 \mathrm{E}-07$ & $9.243 \mathrm{E}-07$ \\
\hline $\mathrm{U}-235$ & $1.381 \mathrm{E}-04$ & $1.381 \mathrm{E}-04$ \\
\hline $\mathrm{U}-236$ & $1.100 \mathrm{E}-06$ & $1.100 \mathrm{E}-06$ \\
\hline $\mathrm{U}-238$ & $4.404 \mathrm{E}-03$ & $4.404 \mathrm{E}-03$ \\
\hline $\mathrm{O}-16$ & $2.517 \mathrm{E}-02$ & $1.829 \mathrm{E}-02$ \\
\hline $\mathrm{Zr}$ & $2.773 \mathrm{E}-03$ & $2.774 \mathrm{E}-03$ \\
\hline $\mathrm{Zr}$ in ZRH & $3.199 \mathrm{E}-06$ & $3.200 \mathrm{E}-06$ \\
\hline Fe-54 & $1.377 \mathrm{E}-06$ & $2.040 \mathrm{E}-06$ \\
\hline Fe-56 & $2.161 \mathrm{E}-05$ & $3.202 \mathrm{E}-05$ \\
\hline Fe-57 & $4.989 \mathrm{E}-07$ & $7.394 \mathrm{E}-07$ \\
\hline Fe-58 & $6.641 \mathrm{E}-08$ & $9.842 \mathrm{E}-08$ \\
\hline $\mathrm{Cr}-50$ & $7.003 \mathrm{E}-07$ & $1.098 \mathrm{E}-06$ \\
\hline $\mathrm{Cr}-52$ & $1.350 \mathrm{E}-05$ & $2.117 \mathrm{E}-05$ \\
\hline $\mathrm{Cr}-53$ & $1.531 \mathrm{E}-06$ & $2.400 \mathrm{E}-06$ \\
\hline $\mathrm{Cr}-54$ & $3.812 \mathrm{E}-07$ & $5.975 \mathrm{E}-07$ \\
\hline $\mathrm{C}$ & $2.873 \mathrm{E}-06$ & $2.874 \mathrm{E}-06$ \\
\hline $\mathrm{Hf}$ & $7.229 \mathrm{E}-08$ & $7.230 \mathrm{E}-08$ \\
\hline $\mathrm{H}$ & $3.170 \mathrm{E}-02$ & $1.793 \mathrm{E}-02$ \\
\hline $\mathrm{Al}$ & $1.374 \mathrm{E}-02$ & $2.500 \mathrm{E}-02$ \\
\hline $\mathrm{Mg}$ & $4.933 \mathrm{E}-04$ & $8.976 \mathrm{E}-04$ \\
\hline $\mathrm{Mn}$ & $1.760 \mathrm{E}-05$ & $3.202 \mathrm{E}-05$ \\
\hline $\mathrm{Ti}$ & $6.058 \mathrm{E}-06$ & $1.102 \mathrm{E}-05$ \\
\hline $\mathrm{Si}$ & $2.755 \mathrm{E}-05$ & $5.013 \mathrm{E}-05$ \\
\hline $\mathrm{Cu}-63$ & $2.105 \mathrm{E}-06$ & $3.830 \mathrm{E}-06$ \\
\hline $\mathrm{Cu}-65$ & $9.380 \mathrm{E}-07$ & $1.707 \mathrm{E}-06$ \\
\hline & & \\
\hline
\end{tabular}

\section{Calculation UPuPu1}

The calculation "UPuPul" is used to generate cross sections for the $\mathrm{UO}_{2}$ pin cells that are adjacent to a $\mathrm{UO}_{2}-\mathrm{PuO}_{2}(3.6 \%)$ pin cell (Figure 44). The calculation used a Multi-Cell model with one cell for the $\mathrm{UO}_{2}$ pin, one for the $\mathrm{UO}_{2}-\mathrm{PuO}_{2}(3.6 \%)$ and another for the $\mathrm{UO}_{2}-\mathrm{PuO}_{2}(4 \%)$. The geometry of each cell and the interaction probabilities used are presented in Figure 46.

The cross section of the $\mathrm{Zr}-4$ alloy, the AG-3 alloy, the $\mathrm{UO}_{2}$ fuel and the water are smeared on the $\mathrm{UO}_{2}$ fuel pin cell region. They are only used in the REBUS model for section C (Figure 33) of the $\mathrm{UO}_{2}$ pins adjacent to $\mathrm{UO}_{2}-\mathrm{PuO}_{2}(3.6 \%)$ pins (Figure 44).

\section{Calculation $\mathrm{Pu}(4)$ and $\mathrm{Pu}(4) \mathrm{Ax}$}

The calculations $\mathrm{Pu}(4)$ and $\mathrm{Pu}(4) \mathrm{Ax}$ have a similar purpose as the calculation " $\mathrm{U}(3)$ " and "U(3)Ax" used for the $\mathrm{UO}_{2}$ fuel pins. They provide the fuel, the water, the AG-3 alloy, the $\mathrm{Zr}-2$ 
alloy, the stainless steel and the Styrene cross sections for the $\mathrm{UO}_{2}-\mathrm{PuO}_{2}(4 \%)$ pin cells. The calculation used the cell model without leakage treatment and the geometry is presented in Figure 47. The generated cross sections are used in the REBUS model for:

- Every section of the $\mathrm{UO}_{2}-\mathrm{PuO}_{2}(4 \%)$ fuel pin cell (Figure 34) completely surrounded by the same pins

- Sections $\mathrm{A}, \mathrm{B}, \mathrm{D}, \mathrm{E}$ and $\mathrm{F}$ (Figure 34) of the $\mathrm{UO}_{2}-\mathrm{PuO}_{2}$ fuel pins (regardless of the $\mathrm{PuO}_{2}$ enrichment or the location of the pin)

Only the cross sections for section $\mathrm{C}$ (Figure 34) of the $\mathrm{UO}_{2}-\mathrm{PuO}_{2}$ pin cell differs for different $\mathrm{PuO}_{2}$ enrichment and different neighboring pins.

\section{Calculation UPu}

The purpose of the calculation UPu is to provide the cross sections for section $\mathrm{C}$ (fuel section) of the $\mathrm{UO}_{2}-\mathrm{PuO}_{2}(4 \%)$ pin cells next to $\mathrm{UO}_{2}$ pin cells (Figure 44). The WIMS calculation is a MultiCell model with one cell for the $\mathrm{UO}_{2}$ pin and the other for the $\mathrm{UO}_{2}-\mathrm{PuO}_{2}(4 \%)$. The geometry is reported in Figure 48. The $\mathrm{Zr}-2$ alloy, the AG-3 alloy, the $\mathrm{UO}_{2}-\mathrm{PuO}_{2}(4 \%)$ fuel and the water cross sections are generated by smearing materials over the $\mathrm{UO}_{2}-\mathrm{PuO}_{2}(4 \%)$ fuel pin cell.

\section{Calculation PuPOL}

The purpose of the calculation PuPOL is to provide the cross sections for section $\mathrm{C}$ (fuel section) of the $\mathrm{UO}_{2}-\mathrm{PuO}_{2}(4 \%)$ pin cells which are next to the POLINE overclad inserted in the central channel of the experimental lattice for some experiments (Figure 44). The WIMS calculation is a cell model of the $\mathrm{UO}_{2}-\mathrm{PuO}_{2}(4 \%)$ pin cell surrounded by a buffer taking into account the materials of the 8 surrounding pins. The geometry is presented in Figure 49. The material of one POLINE overclad cell and seven $\mathrm{UO}_{2}-\mathrm{PuO}_{2}(4 \%)$ pin cells is homogenized to form the buffer. The number density of the buffer is reported in Table 31.

Cross sections for the $\mathrm{Zr}-2$ alloy, the AG-3 alloy, the $\mathrm{UO}_{2}-\mathrm{PuO}_{2}(4 \%)$ fuel and the water are generated by smearing the materials over the $\mathrm{UO}_{2}-\mathrm{PuO}_{2}(4 \%)$ fuel pin cell. They are only used in the REBUS model for section $\mathrm{C}$ (Figure 34) of the $\mathrm{UO}_{2}-\mathrm{PuO}_{2}(4 \%)$ pins (Figure 44).

\section{Calculation UPuPu2}

The calculation UPuPu2 is the same as "UPuPu1" except that the Zr-2 alloy, the AG-3 alloy, the $\mathrm{UO}_{2}-\mathrm{PuO}_{2}(3.6 \%)$ fuel and the water cross sections are generated by smearing materials over the $\mathrm{UO}_{2}-\mathrm{PuO}_{2}(3.6 \%)$ fuel pin cell region. They are only used in the REBUS model for section $\mathrm{C}$ (Figure 34) of the $\mathrm{UO}_{2}-\mathrm{PuO}_{2}(3.6 \%)$ pins (Figure 44). 


\begin{tabular}{|c|c|}
\hline \multicolumn{2}{|c|}{ Table 31: Buffer composition in the "PuPOL" calculation } \\
\hline Element & Number density $($ at $/$ b.cm $)$ \\
\hline U-234 & $8.847 \mathrm{E}-07$ \\
\hline $\mathrm{U}-235$ & $4.456 \mathrm{E}-05$ \\
\hline $\mathrm{U}-238$ & $6.144 \mathrm{E}-03$ \\
\hline $\mathrm{Pu}-238$ & $2.036 \mathrm{E}-06$ \\
\hline $\mathrm{Pu}-239$ & $1.799 \mathrm{E}-04$ \\
\hline $\mathrm{Pu}-240$ & $4.349 \mathrm{E}-05$ \\
\hline $\mathrm{Pu}-241$ & $6.012 \mathrm{E}-06$ \\
\hline $\mathrm{Pu}-242$ & $5.076 \mathrm{E}-06$ \\
\hline $\mathrm{Am}-241$ & $1.890 \mathrm{E}-05$ \\
\hline $\mathrm{Np}-237$ & $5.671 \mathrm{E}-07$ \\
\hline $\mathrm{O}-16$ & $2.727 \mathrm{E}-02$ \\
\hline $\mathrm{Zr}$ & $3.238 \mathrm{E}-03$ \\
\hline $\mathrm{Zr}$ in $\mathrm{ZRH}$ & $3.734 \mathrm{E}-06$ \\
\hline $\mathrm{Fe}-54$ & $8.921 \mathrm{E}-07$ \\
\hline $\mathrm{Fe}-56$ & $1.400 \mathrm{E}-05$ \\
\hline $\mathrm{Fe}-57$ & $3.234 \mathrm{E}-07$ \\
\hline $\mathrm{Fe}-58$ & $4.304 \mathrm{E}-08$ \\
\hline $\mathrm{Cr}-50$ & $4.863 \mathrm{E}-07$ \\
\hline $\mathrm{Cr}-52$ & $9.378 \mathrm{E}-06$ \\
\hline $\mathrm{Cr}-53$ & $1.063 \mathrm{E}-06$ \\
\hline $\mathrm{Cr}-54$ & $2.647 \mathrm{E}-07$ \\
\hline $\mathrm{C}$ & $3.384 \mathrm{E}-06$ \\
\hline $\mathrm{Hf}$ & $8.437 \mathrm{E}-08$ \\
\hline $\mathrm{H}$ & $2.872 \mathrm{E}-02$ \\
\hline $\mathrm{Al}$ & $7.229 \mathrm{E}-03$ \\
\hline $\mathrm{Mg}$ & $2.354 \mathrm{E}-04$ \\
\hline $\mathrm{Mn}$ & $1.135 \mathrm{E}-05$ \\
\hline $\mathrm{Ti}$ & $2.802 \mathrm{E}-06$ \\
\hline $\mathrm{Si}$ & $1.722 \mathrm{E}-05$ \\
\hline $\mathrm{Cu}-63$ & $1.040 \mathrm{E}-06$ \\
\hline & $4.634 \mathrm{E}-07$ \\
\hline & \\
\hline
\end{tabular}

\section{Calculation Sample}

A different calculation sample is performed for each calibration sample. The geometry and composition of the regions are the same as for the R1UO2 configuration except that the buffer region is now composed of homogenized $\mathrm{PuO}_{2}-\mathrm{UO}_{2}(4 \%)$ fuel pin cells (Figure 50). The cross sections for U-235, U-238, U-234, U-236, O, B-10, B-11 and $\mathrm{H}$ are generated by smearing the materials over the sample region.

The characteristics of the WIMS calculation are summarized in Table 32 and Table 33. The input files are included in Appendix 3. 


\begin{tabular}{|c|c|c|c|c|c|}
\hline File & & & & & Dי \\
\hline Title & $\mathrm{UO}_{2}(3 \%)$ pin cell & $\begin{array}{c}\mathrm{UO}_{2}(3 \%) \\
\text { pin cell } \\
\text { In axial view }\end{array}$ & $\begin{array}{c}\mathrm{UO}_{2}(3 \%) \text { pin cell adjacent } \\
\text { to an } \mathrm{Al} \text { pin }\end{array}$ & $\begin{array}{c}\mathrm{UO}_{2}(3 \%) \text { pin cell adjacent } \\
\text { to an } \mathrm{Al} \text { pin }\end{array}$ & $\begin{array}{c}\mathrm{UO}_{2}(3 \%) \text { pin cell adjacent } \\
\text { to an } \mathrm{Al} \text { pin }\end{array}$ \\
\hline $\begin{array}{l}\text { Calculation } \\
\text { Type }\end{array}$ & Cell & Cell & Cell & Cell & Multi-Cell \\
\hline $\begin{array}{l}\text { Boundary } \\
\text { condition }\end{array}$ & Infinite lattice & $\begin{array}{l}\text { Infinite } \\
\text { lattice }\end{array}$ & Infinite lattice & Infinite lattice & Infinite lattice \\
\hline Description & $\begin{array}{l}\mathrm{UO}_{2}(3 \%) \text { pin, void, clad, } \\
\text { water, overclad, water }\end{array}$ & $\begin{array}{c}\text { Fuel, } \\
\text { Plexiglas, SS }\end{array}$ & $\begin{array}{c}\mathrm{UO}_{2}(3 \%) \text { pin, void, clad, } \\
\text { water, overclad, water } \\
+ \\
\text { Buffer }(3 / 8 \mathrm{Al} \text { pin and } 5 / 8 \\
\left.\mathrm{UO}_{2} \text { pin }\right)\end{array}$ & $\begin{array}{c}\mathrm{UO}_{2}(3 \%) \text { pin, void, clad, } \\
\text { water, overclad, water } \\
+ \\
\text { Buffer }(3 / 8 \mathrm{Al} \text { block and } \\
\left.5 / 8 \mathrm{UO}_{2} \text { pin }\right)\end{array}$ & $\begin{array}{c}\mathrm{UO}_{2}(3 \%) \text { pin cell } \\
+ \\
\mathrm{UO}_{2}-\mathrm{PuO}_{2}(3.6 \%) \text { pin cell } \\
+ \\
\mathrm{UO}_{2}-\mathrm{PuO}_{2}(4 \%) \text { pin cell }\end{array}$ \\
\hline $\begin{array}{c}\text { Cross } \\
\text { sections } \\
\text { generated }\end{array}$ & $\begin{array}{l}\text { U234, U235, U236, U238, } \\
\text { O, H, Zr, ZH, Fe54, Fe56, } \\
\text { Fe57, Fe58, Cr50, Cr52, } \\
\text { Cr53, Cr54, C, Hf, A1, Mg, } \\
\text { Mn, Ti, Si, Cu63, Cu65 }\end{array}$ & $\begin{array}{l}\text { Ni58, Ni60, } \\
\text { Ni61, Ni62, } \\
\text { Ni64, Mo }\end{array}$ & $\begin{array}{c}\text { U234, U235, U236, U238, } \\
\text { O, H, Zr, ZH, Fe54, Fe56, } \\
\text { Fe57, Fe58, Cr50, Cr52, } \\
\text { Cr53, Cr54,C ,Hf, A1, Mg, } \\
\text { Mn, Ti, Si, Cu63, Cu65 }\end{array}$ & $\begin{array}{c}\text { U234, U235, U236, U238, } \\
\text { O, H, Zr, ZH, Fe54, Fe56, } \\
\text { Fe57, Fe58, Cr50, Cr52, } \\
\text { Cr53, Cr54, C, Hf, A1, Mg, } \\
\text { Mn, Ti, Si, Cu63, Cu65 }\end{array}$ & $\begin{array}{c}\text { U234, U235, U236, U238, } \\
\text { O, H, Zr, ZH, Fe54, Fe56, } \\
\text { Fe57, Fe58, Cr50, Cr52, } \\
\text { Cr53, Cr54, C, Hf, Al, Mg, } \\
\text { Mn, Ti, Si, Cu63, Cu65 }\end{array}$ \\
\hline
\end{tabular}




\begin{tabular}{|c|c|c|c|c|c|}
\hline \multicolumn{6}{|c|}{ ristics of the WIMS calculations used to generate cross sections for the $\mathrm{UO}_{2}-\mathrm{PuO}_{2}$ pin cells of the experimental zone } \\
\hline File name & $\mathrm{Pu}(4)$ & $\mathrm{Pu}(4) \mathrm{Ax}$ & UPu & PuPOL & UPuPu2 \\
\hline Title & $\mathrm{UO}_{2}-\mathrm{PuO}_{2}(4 \%)$ pin cell & $\begin{array}{c}\mathrm{UO}_{2}-\mathrm{PuO}_{2} \\
(4 \%) \text { pin } \\
\text { cell } \mathrm{In} \text { axial } \\
\text { view }\end{array}$ & $\begin{array}{l}\mathrm{UO}_{2}-\mathrm{PuO}_{2}(4 \%) \text { pin cell } \\
\text { adjacent to a } \mathrm{UO}_{2} \text { pin cell }\end{array}$ & $\begin{array}{l}\mathrm{UO}_{2}-\mathrm{PuO}_{2}(4 \%) \text { pin cell } \\
\text { adjacent to the POLINE } \\
\text { overclad }\end{array}$ & $\begin{array}{c}\mathrm{UO}_{2}-\mathrm{PuO}_{2}(3.6 \%) \text { pin cell } \\
\text { in between a } \mathrm{UO}_{2} \text { pin cell } \\
\text { and a } \mathrm{UO}_{2}-\mathrm{PuO}_{2}(4 \%) \text { pin } \\
\text { cell }\end{array}$ \\
\hline $\begin{array}{c}\text { Calculation } \\
\text { Type }\end{array}$ & Cell & Cell & Multi-Cell & Cell & Multi-Cell \\
\hline $\begin{array}{l}\text { Boundary } \\
\text { condition }\end{array}$ & Infinite lattice & $\begin{array}{l}\text { Infinite } \\
\text { lattice }\end{array}$ & Infinite lattice & Infinite lattice & Infinite lattice \\
\hline Description & $\begin{array}{c}\mathrm{UO}_{2}-\mathrm{PuO}_{2}(4 \%) \text { pin, void, } \\
\text { inner clad, void, outer clad, } \\
\text { water, overclad, water }\end{array}$ & $\begin{array}{l}\text { Fuel, } \\
\text { Plexiglas, } \\
\text { SS, foot }\end{array}$ & $\begin{array}{c}\mathrm{UO}_{2}-\mathrm{PuO}_{2}(4 \%) \text { pin cell } \\
+ \\
\mathrm{UO}_{2}-\mathrm{PuO}_{2}(3.6 \%) \text { pin cell } \\
+ \\
\mathrm{UO}_{2}-\mathrm{PuO}_{2}(4 \%) \text { pin cell }\end{array}$ & $\begin{array}{c}\mathrm{UO}_{2}-\mathrm{PuO}_{2}(4 \%) \text { pin cell } \\
+ \\
\text { Buffer }\left(7 / 8 \mathrm{UO}_{2}-\mathrm{PuO}_{2}(4 \%)\right. \\
\text { pin and } 1 / 8 \mathrm{POLINE} \text { cell })\end{array}$ & $\begin{array}{c}\mathrm{UO}_{2}-\mathrm{PuO}_{2}(4 \%) \text { pin cell } \\
+ \\
\mathrm{UO}_{2}-\mathrm{PuO}_{2}(3.6 \%) \text { pin cell } \\
+ \\
\mathrm{UO}_{2}-\mathrm{PuO}_{2}(4 \%) \text { pin cell }\end{array}$ \\
\hline $\begin{array}{l}\text { Cross } \\
\text { sections } \\
\text { generated }\end{array}$ & $\begin{array}{c}\text { U234, U235, U238, Pu238, } \\
\text { Pu239, Pu240, Pu241, } \\
\text { Pu242, Np237, Am241, O, } \\
\text { H, Zr, ZH, Fe54, Fe56, } \\
\text { Fe57, Fe58, Cr50, Cr52, } \\
\text { Cr53, Cr-54, C, Hf, Al, Mg, } \\
\text { Mn, Ti, Si, Cu63, Cu65 }\end{array}$ & $\begin{array}{l}\text { Ni58, Ni60, } \\
\text { Ni61, Ni62, } \\
\text { Ni64, Mo, N }\end{array}$ & $\begin{array}{l}\text { U234, U235, U238, Pu238, } \\
\text { Pu239, Pu240, Pu241, } \\
\text { Pu242, Np237, Am241, O, } \\
\text { H, Zr, ZH, Fe54, Fe56, } \\
\text { Fe57, Fe58, Cr50, Cr52, } \\
\text { Cr53, Cr-54, C, Hf, A1, } \\
\text { Mg, Mn, Ti, Si, Cu63, } \\
\text { Cu65 }\end{array}$ & $\begin{array}{l}\text { U234, U235, U238, Pu238, } \\
\text { Pu239, Pu240, Pu241, } \\
\text { Pu242, Np237, Am241, O, } \\
\text { H, Zr, ZH, Fe54, Fe56, } \\
\text { Fe57, Fe58, Cr50, Cr52, } \\
\text { Cr53, Cr-54, C, Hf, Al, Mg, } \\
\text { Mn, Ti, Si, Cu63, Cu65 }\end{array}$ & $\begin{array}{c}\text { U234, U235, U238, Pu238, } \\
\text { Pu239, Pu240, Pu241, } \\
\text { Pu242, Np237, Am241, O, } \\
\text { H, Zr, ZH, Fe54, Fe56, } \\
\text { Fe57, Fe58, Cr50, Cr52, } \\
\text { Cr53, Cr-54, C, Hf, Al, } \\
\text { Mg, Mn, Ti, Si, Cu63, } \\
\text { Cu65 }\end{array}$ \\
\hline
\end{tabular}




\section{REACTOR DATA ANALYSIS}

The MCNP and REBUS models have been used to predict safety and core parameters for the R1UO2 and R1MOX configurations. Results of the MCNP and REBUS calculations are compared with one another and also with the experimental results whenever possible. The experimental results reported in this section are provided by CEA in accordance with an agreement between CEA and DOE (ref. 8). The safety and core parameters of interest are:

- The reactivity worth of the control rods

- The spectral indices in the oscillation channel at core mid-plane

- The axial power profile

- The radial power profile

- The conversion ratio

The reactivity worths of the calibration samples calculated with the REBUS model are compared with the experimental values in the R1UO2 and R1MOX configuration.

\subsection{The control rod reactivity worth}

\subsubsection{Experimental technique}

The reactivity worth of each control rod and of the four rods taken together is assessed for safety purposes. When measuring the reactivity worth of a control rod, all rods are withdrawn except the studied rod which is inserted in the core to achieve criticality. The studied rod is then completely withdrawn to measure the asymptotic period and reinserted to the critical height. After stabilization, the rod is completely inserted to perform a rod drop measurement. The sum of the reactivity derived from the asymptotic period and the rod drop measurements is the rod worth (ref. 9).

During the rod drop, the time dependant neutron population is recorded using a U-235 fission chamber located either in the central channel of the experimental lattice, or in the thermal column (ref. 9). Analysis of the rod-drop measurement is based on the point kinetic model. Considering that the investigated reactivity worth is greater than $700 \mathrm{pcm}^{1}$, it is necessary to take into account spatial and energetic effects. One method is to calculate Modified Source Multiplication factors (ref. 10) and use these to adjust the values for the rod worths.

\subsubsection{Calculation technique}

In the MCNP model, the reactivity worths of the rods have been evaluated using two static calculations: one when all rods are withdrawn and the other when the rod of interest is fully inserted in the core.

${ }^{1} 1 \mathrm{pcm}=10^{-5}$ 
The REBUS calculation used the same two static cases, except that the rods are never modeled above the core (section 2.2.2.2.2).

\subsubsection{Results and comparison}

The reactivity worth determined experimentally is relative to the delayed neutron fraction and expressed in dollars. MCNP and REBUS calculate multiplication factor. The conversion in relative reactivity uses a delayed neutron fraction of $716 \mathrm{pcm}$ and $681 \mathrm{pcm}$ for the R1UO2 and R1MOX configuration, respectively. The uncertainty on the reactivity worth of the rod determined by MCNP does not take into account the uncertainty on the delayed neutron fraction. A statistical uncertainty is not derived for the REBUS model.

The rods are designated as R1, R2, R3 and R4 and are inserted in the east, south, west and north driver zone, respectively (ref. 1). The experimental reactivity worths of rods in the R1UO2 configuration are reported in Table 34 for the two locations of the fission chamber (during the rod drop). The difference between the two experiments range from $5 \%$ to $20 \%$ for individual rods and is approximately $40 \%$ for the four rods; advocating the need for spatial and energy corrections. Spatial and energy effects appear to be less critical in the thermal column than in the center of the core. Therefore, a primary comparison between experiment and calculation can be made when the fission chamber is located in the thermal column.

\begin{tabular}{|c|c|c|c|}
\hline \multicolumn{4}{|c|}{ Table 34: Experimental rod worth in the R1UO2 configuration } \\
\hline $\begin{array}{c}\text { Rods } \\
\text { inserted }\end{array}$ & $\begin{array}{c}\text { Detector in the central } \\
\text { channel }(\$)\end{array}$ & $\begin{array}{c}\text { Detector in the thermal } \\
\text { column }(\$)\end{array}$ & $\begin{array}{c}\text { Central/Thermal - } \\
1\end{array}$ \\
\hline R1 & $1.18 \pm 0.06$ & $1.37 \pm 0.06$ & $16.1 \%$ \\
\hline R2 & $1.32 \pm 0.06$ & $1.25 \pm 0.06$ & $-5.3 \%$ \\
\hline R3 & $1.40 \pm 0.07$ & $1.52 \pm 0.07$ & $8.6 \%$ \\
\hline R4 & $1.32 \pm 0.08$ & $1.55 \pm 0.08$ & $17.4 \%$ \\
\hline 4 rods & $5.62 \pm 0.43$ & $7.98 \pm 0.43$ & $42.0 \%$ \\
\hline
\end{tabular}

Experiments and MCNP calculations are reported in Table 35 and agree within one standard deviation for all rods but R3. This agreement is still valid for the large reactivity worth of the four rods; suggesting small spatial and energy corrections. On the contrary, the difference between experiments and REBUS calculations increases with the reactivity worth. The REBUS calculations result in lower reactivity worth estimates than the MCNP calculations except for the rod R1. The MCNP and REBUS rod worths differ by more than $10 \%$ for the rods R 3 and R4 and the four rods. The difference in the MCNP and REBUS geometries, i.e. is the description of the pilot rod and the control rods when withdrawn from the core (section 2.2.2.2.2), does not explain the discrepancy. The WIMS model used to smear, condense to 7 groups and self shield the cross sections for the absorber and the high enriched uranium fuel plates might be inadequate because of the strong flux gradient at the fuel plates, water and absorber interfaces. In the REBUS model, the difference of composition between the rod element (when the rod is inserted) and a standard fuel element induces a flux gradient at the interface that can be more accurately described by increasing the number of mesh (currently one mesh every $1.26 \mathrm{~cm}$ ). Additional tests of the REBUS and WIMS models are being performed to identify the source of the discrepancy between the MCNP and REBUS control rod worths. 


\begin{tabular}{|c|c|c|c|c|c|c|}
\hline \multicolumn{7}{|c|}{ Table 35: Experimental and calculated rod worth in the R1UO2 configuration } \\
\hline $\begin{array}{c}\text { Rods } \\
\text { inserted }\end{array}$ & $\begin{array}{c}\text { Exp. } \\
(\$)\end{array}$ & $\begin{array}{c}\text { MCNP } \\
(\$)\end{array}$ & $\begin{array}{c}\text { REBUS } \\
(\$)\end{array}$ & $\begin{array}{c}\text { MCNP } \\
\text { C/E-1 }\end{array}$ & $\begin{array}{c}\text { REBUS } \\
\text { C/E }-1\end{array}$ & $\begin{array}{c}\text { REBUS/MCNP } \\
-1\end{array}$ \\
\hline R1 & $1.37 \pm 0.06$ & $1.38 \pm 0.03$ & 1.45 & $1.0 \%$ & $5.8 \%$ & $4.8 \%$ \\
\hline R2 & $1.25 \pm 0.06$ & $1.33 \pm 0.03$ & 1.29 & $6.0 \%$ & $3.0 \%$ & $-2.8 \%$ \\
\hline R3 & $1.52 \pm 0.07$ & $1.66 \pm 0.03$ & 1.35 & $9.4 \%$ & $-10.9 \%$ & $-18.5 \%$ \\
\hline R4 & $1.55 \pm 0.08$ & $1.60 \pm 0.03$ & 1.38 & $3.0 \%$ & $-11.2 \%$ & $-13.8 \%$ \\
\hline 4 rods & $7.98 \pm 0.43$ & $7.83 \pm 0.03$ & 6.81 & $-1.9 \%$ & $-14.6 \%$ & $-13.0 \%$ \\
\hline
\end{tabular}

In the R1MOX configuration, the rod-drop experiments have only been recorded with a U-235 fission chamber located in the central channel of the experimental lattice. The MCNP and REBUS rod worths are compared in Table 36. The trend between the MCNP and the REBUS calculations is the same as in the R1UO2 configuration.

Table 36: Calculated rod worth reactivity in the R1MOX configuration

\begin{tabular}{|c|c|c|c|}
\hline Rods inserted & MCNP $(\$)$ & REBUS $(\$)$ & MCNP/REBUS -1 \\
\hline R1 & $1.51 \pm 0.03$ & 1.77 & $17.3 \%$ \\
\hline R2 & $1.61 \pm 0.03$ & 1.61 & $-0.2 \%$ \\
\hline R3 & $1.76 \pm 0.03$ & 1.58 & $-10.4 \%$ \\
\hline R4 & $1.69 \pm 0.03$ & 1.62 & $-4.2 \%$ \\
\hline 4 rods & $10.03 \pm 0.03$ & 9.43 & $-6.0 \%$ \\
\hline
\end{tabular}

Further investigations require calculation of spatial/energy correction factors such as Modified Source Multiplication factors to correct measurements in the thermal column or at least make sure that such corrections are negligible. Complementary REBUS models and experiments will be needed.

\subsection{Spectral indices}

Spectral indices have been measured using U-235, Pu-239, Pu-241 and Np-237 fission chambers located inside the POLINE overclad in the middle of the experimental lattice. The reactor is held critical during the measurement by inserting the rods R1 and R3 in the core.

The spectral indices have been determined in MCNP by using the track length estimate of the cell flux tally (ref. 2) on a $10 \mathrm{~cm}$ height and a $0.9 \mathrm{~cm}$ diameter void cylinder located in the center of the core. The height matches that of the oscillation samples and the diameter maximizes the statistic of the tally. Calculations are performed with all rods withdrawn, which should not influence the spectrum in the center of the core.

The spectral indices are reported in Table 37 and Table 38 for the R1UO2 and R1MOX configurations, respectively. Calculated and measured spectral indices agree within one standard deviation except for the $\mathrm{Np}-237 / \mathrm{Pu}-239$ index in the R1UO2 configuration which agrees within two standard deviations. 
Table 37: Spectral indices for the R1UO2 configuration

\begin{tabular}{|c|c|c|c|}
\hline Spectral Index & Experiment & MCNP & MCNP/Exp. -1 \\
\hline $\mathrm{Pu}-239 / \mathrm{U}-235$ & $1.913(1.2 \%)$ & $1.918(1.1 \%)$ & $-0.3 \%$ \\
\hline $\mathrm{Pu}-241 / \mathrm{Pu}-239$ & $1.133(1.3 \%)$ & $1.142(1.1 \%)$ & $0.8 \%$ \\
\hline $\mathrm{Np}-237 / \mathrm{Pu}-239$ & $0.00383(3.6 \%)$ & $0.00361(0.9 \%)$ & $-5.7 \%$ \\
\hline
\end{tabular}

\begin{tabular}{|c|c|c|c|}
\hline \multicolumn{4}{|c|}{ Table 38: Spectral indices for the R1MOX configuration } \\
\hline Spectral Index & Experiment & MCNP & MCNP/Exp. -1 \\
\hline $\mathrm{Pu}-239 / \mathrm{U}-235$ & $1.941(1.2 \%)$ & $1.954(1.9 \%)$ & $0.7 \%$ \\
\hline $\mathrm{Pu}-241 / \mathrm{Pu}-239$ & $1.158(1.3 \%)$ & $1.147(1.8 \%)$ & $-0.9 \%$ \\
\hline $\mathrm{Np}-237 / \mathrm{Pu}-239$ & $0.00742(3.6 \%)$ & $0.00745(1.4 \%)$ & $0.4 \%$ \\
\hline
\end{tabular}

Due to problems with the calibration of the Pu-240, Pu-242, U-238 and Am-241 fission chambers, the spectral indices performed with these detectors are not reliable. Corresponding spectral indices calculated with MCNP are reported in Table 39 for future consideration.

\begin{tabular}{|c|c|c|}
\hline \multicolumn{3}{|c|}{ Table 39: Spectral indices calculated with MCNP } \\
\hline Spectral Index & R1UO2 configuration & R1MOX configuration \\
\hline $\mathrm{U}-238 / \mathrm{U}-235$ & $0.001323(0.98 \%)$ & $0.002827(1.45 \%)$ \\
\hline $\mathrm{Pu}-240 / \mathrm{Pu}-239$ & $0.004312(0.93 \%)$ & $0.008697(1.48 \%)$ \\
\hline $\mathrm{Pu}-242 / \mathrm{Pu}-239$ & $0.003029(0.90 \%)$ & $0.006270(1.41 \%)$ \\
\hline $\mathrm{Am}-241 / \mathrm{Pu}-239$ & $0.009162(0.89 \%)$ & $0.007452(1.40 \%)$ \\
\hline
\end{tabular}

\subsection{Axial power profile}

\subsubsection{Experimental technique}

Axial power profiles have been measured in the R1UO2 and R1MOX configurations using an integral gamma counting technique on selected pins and U-235 and Np-237 fission chambers inserted in the POLINE overclad in the oscillation channel.

In the R1UO2 configuration, two experimental-zone loadings have been used. In the first one, the POLINE overclad is inserted in the oscillation channel and the fission chamber measurements are performed. In the second, the oscillation channel is filled with a standard $\mathrm{UO}_{2}$ pin and the integral gamma counting measurements are performed.

In the R1MOX configuration both integral gamma counting and fission chamber measurements are performed with the POLINE overclad inserted in the oscillation channel.

The types of measurements and the location of the studied pins are reported in Table 40 and Figure 51. 


\begin{tabular}{|c|c|c|}
\hline \multicolumn{3}{|c|}{ Table 40: Axial power profile measurements } \\
\hline Configuration & Fission chamber & Pins \\
\hline \multirow{2}{*}{ R1UO2 } & U-235 & $17-17$ (central pin $)$ \\
& Np-237 & $17-18\left(1^{\text {st }}\right.$ pin East $)$ \\
& U-235 & $17-21\left(4^{\text {th }}\right.$ pin East $)$ \\
\hline \multirow{2}{*}{ R1MOX } & Np-237 & $20-17\left(1^{\text {st }}\right.$ pin North $)$ \\
& \multicolumn{2}{|c}{ pin North $)$} \\
\hline
\end{tabular}

Fission chamber measurements using the linear positioning device POLINE have been performed with a non constant step which does not exceeded $2 \mathrm{~cm}$. The fission rate of the pins is measured every $2 \mathrm{~cm}$ by integral gamma counting.

\subsubsection{Calculation technique}

The REBUS model has been used to generate the axial power profile in the studied pins of the R1UO2 and R1MOX configurations. The fission rate is evaluated for each axial mesh; corresponding to at least one data point every centimeter.

Axial power profiles are also computed with the MCNP model for comparison with the fission chamber and integral gamma counting measurements. The power profile is calculated every $2 \mathrm{~cm}$ using the track length estimate of the cell flux tally (ref. 2). This resolution is time consuming but necessary to have enough points for comparisons.

The oscillation basket, regrouping the 9 holes in the center of the experimental zone, has two plates of Styrene at about $\pm 12-15 \mathrm{~cm}$ of the fuel center line (ref. 1). Because Styrene contains carbon and hydrogen, neutrons are locally slowed down enhancing the thermal neutron fission rate. The styrene plates have not been included in the MCNP and REBUS models.

\subsubsection{The R1UO2 configuration}

The measured and calculated axial power profile for the 17-17, 17-18 and 17-21 pins are shown in Figure 52 and Figure 53. For all pins, the REBUS and experimental power profiles match each other in the range of $\pm 19 \mathrm{~cm}$ of the core mid-plane. MCNP power profiles exhibit fluctuations due to an insufficient number of particles in each tallied cell (section 3.3.2). The effect of the Styrene plate on the experimental fission rates (section 3.3.1) can not be detected. On the contrary, the neutron slowing down induced by the lower and upper Plexiglas spacer of the pins is starting to be observed at $20 \mathrm{~cm}$ from the core mid-plane.

The axial power profiles derived from U-235 and Np-237 fission chamber measurements are compared with MCNP calculations in Figure 54. There is a very good overall agreement between calculation and experiment for the U-235 and Np-237 fission chamber profiles. The region of interest (between $-20 \mathrm{~cm}$ and $20 \mathrm{~cm}$ ) is shown in Figure 55. MCNP profiles oscillated near the core mid-plane. The influence of the styrene spacers is shown in the U-235 fission chamber measurement at about $-13 \mathrm{~cm}$ and $15 \mathrm{~cm}$, but does not appear in the Np-237 fission chamber measurement because of the threshold for the Np-237 fission. 


\subsubsection{Axial buckling}

Considering the fundamental mode established on an axial region centered on the core mid-plane, the axial fission rate distribution is a cosine function characterized by the axial buckling $\mathrm{B}^{2}$. The fission rate distribution can be fitted by the function $\mathrm{f}(\mathrm{z})=\mathrm{A} \cos \left(\mathrm{B}\left(\mathrm{z}-\mathrm{z}_{0}\right)\right)$, where $\mathrm{z}_{0}$ accounts for any offset.

Practically, the cosine function can be used in a region where the influence of the Plexiglas and Styrene spacer are negligible. The effect of the Plexiglas spacer can be neglected by narrowing the region around the core mid-plane. The influence of Styrene spacers are difficult to remove but are generally too small to significantly disturb the cosine shape.

To find the best value of the axial buckling from the measurements, parametric studies of the buckling versus the height of the axial region have been performed. Results of the buckling parametric study for the experimental power profiles of the studied pins are reported in Table 41 and Figure 56. When the axial region is larger than $[-12 \mathrm{~cm}, 12 \mathrm{~cm}]$, values of the buckling agree within one standard deviation for all pins. The buckling converges when increasing the axial region from $[-12 \mathrm{~cm}, 12 \mathrm{~cm}]$ to $[-20 \mathrm{~cm}, 20 \mathrm{~cm}]$. The influence of the styrene spacers on pin 1717 can be noticed by the significant increase of $\chi^{2}$ when the fitting range is larger than $[-14 \mathrm{~cm}, 14$ $\mathrm{cm}$. A similar effect is not observed for pin 17-18. The influence of the Plexiglas is negligible for the fitting range $[-20 \mathrm{~cm}, 20 \mathrm{~cm}]$ (Figure 57).

\begin{tabular}{|c|c|c|c|c|c|c|}
\hline \multicolumn{6}{|c|}{ Table 41: Buckling vs. fitting range issued from pin measurement in the R1UO2 configuration } \\
\hline \multirow{2}{*}{ Range $(\mathrm{cm})$} & \multicolumn{2}{|c|}{ Pin $17-17$} & \multicolumn{2}{c|}{ Pin $17-18$} & \multicolumn{2}{c|}{ Pin 17-21 } \\
\cline { 2 - 7 } & $\mathrm{B}\left({ }^{*} 1 \mathrm{e}-3 \mathrm{~cm}^{-2}\right)$ & $\chi^{2}$ & $\mathrm{~B}\left({ }^{*} 1 \mathrm{e}-3 \mathrm{~cm}^{-2}\right)$ & $\chi^{2}$ & $\mathrm{~B}\left({ }^{*} 1 \mathrm{e}-3 \mathrm{~cm}^{-2}\right)$ & $\chi^{2}$ \\
\hline$[-20,20]$ & $1.944 \pm 0.010$ & 2.94 & $1.940 \pm 0.010$ & 1.43 & $1.934 \pm 0.010$ & 1.53 \\
\hline$[-18,18]$ & $1.939 \pm 0.013$ & 3.02 & $1.932 \pm 0.013$ & 1.53 & $1.940 \pm 0.013$ & 1.39 \\
\hline$[-16,16]$ & $1.899 \pm 0.018$ & 2.67 & $1.925 \pm 0.017$ & 1.64 & $1.914 \pm 0.018$ & 1.13 \\
\hline$[-14,14]$ & $1.849 \pm 0.025$ & 1.66 & $1.899 \pm 0.024$ & 1.66 & $1.886 \pm 0.025$ & 1.07 \\
\hline$[-12,12]$ & $1.861 \pm 0.037$ & 1.54 & $1.908 \pm 0.035$ & 1.66 & $1.914 \pm 0.037$ & 1.03 \\
\hline$[-10,10]$ & $1.915 \pm 0.057$ & 1.22 & $2.057 \pm 0.054$ & 0.37 & $1.838 \pm 0.057$ & 0.37 \\
\hline
\end{tabular}

For the MCNP calculations, a similar study was performed and the results are displayed in Table 42 and Figure 58. Bucklings agree within one standard deviation and converge when increasing the fitting zone until the range $[-18 \mathrm{~cm}, 18 \mathrm{~cm}]$. The sudden increase of $\chi^{2}$ for the range $[-20 \mathrm{~cm}$, $20 \mathrm{~cm}]$ is due to the effect of the Plexiglas reflector.

The REBUS estimate of the buckling was performed without considering statistical uncertainty. It is therefore hard to interpret the buckling convergence with the increase of the fitting region (Figure 59).

Table 42: Buckling vs. fitting range issued from MCNP simulation of the R1UO2 configuration

\begin{tabular}{|c|c|c|c|c|c|c|}
\hline \multirow{2}{*}{ Range $(\mathrm{cm})$} & \multicolumn{2}{|c|}{ Pin 17-17 } & \multicolumn{2}{c|}{ Pin 17-18 } & \multicolumn{2}{c|}{ Pin 17-21 } \\
\cline { 2 - 7 } & $\mathrm{B}\left(* 1 \mathrm{e}-3 \mathrm{~cm}^{-2}\right)$ & $\chi^{2}$ & $\mathrm{~B}\left(* 1 \mathrm{e}-3 \mathrm{~cm}^{-2}\right)$ & $\chi^{2}$ & $\mathrm{~B}\left(* 1 \mathrm{e}-3 \mathrm{~cm}^{-2}\right)$ & $\chi^{2}$ \\
\hline$[-20,20]$ & $1.872 \pm 0.024$ & 1.37 & $1.875 \pm 0.024$ & 1.01 & $1.867 \pm 0.023$ & 1.71 \\
\hline$[-18,18]$ & $1.906 \pm 0.030$ & 1.14 & $1.926 \pm 0.030$ & 0.58 & $1.930 \pm 0.031$ & 1.26 \\
\hline$[-16,16]$ & $1.873 \pm 0.041$ & 1.16 & $1.933 \pm 0.041$ & 0.59 & $1.971 \pm 0.041$ & 1.19 \\
\hline$[-14,14]$ & $1.961 \pm 0.056$ & 0.87 & $1.941 \pm 0.058$ & 0.63 & $1.910 \pm 0.058$ & 1.14 \\
\hline$[-12,12]$ & $1.979 \pm 0.084$ & 1.03 & $2.031 \pm 0.084$ & 0.52 & $1.878 \pm 0.086$ & 1.11 \\
\hline$[-10,10]$ & $1.955 \pm 0.131$ & 0.87 & $2.029 \pm 0.130$ & 0.58 & $1.741 \pm 0.134$ & 1.11 \\
\hline
\end{tabular}


The evolution of the buckling for the U-235 fission chamber measurement is particularly sensitive to the styrene spacers. Figure 60 presents the bucklings with the styrene plate and 'without' - that is by removing the obvious distorted points. The buckling values become more uniform (particularly in the range of $12-15 \mathrm{~cm}$ ) and $\chi^{2}$ is reduced from approximately 3.5 to 1.5 . For the range $[-18 \mathrm{~cm}, 18 \mathrm{~cm}]$, the buckling has converged to an asymptotic value. The Np-237 measurement shows a similar convergence for the fitting range $[-18 \mathrm{~cm}, 18 \mathrm{~cm}]$.

The MCNP simulation does not include the styrene spacers. Based on $\chi^{2}$ estimates and analysis of the residuals and the convergence of the buckling with the fitting range, the best value for the buckling is shown to be for the range $[-18 \mathrm{~cm}, 18 \mathrm{~cm}]$.

The best estimates of the buckling for the measurements and calculations is for the range $[-18 \mathrm{~cm}$, $18 \mathrm{~cm}$ ]. The range can fluctuate slightly because of the position of the mesh size in REBUS and of the offset in the measurements. The bucklings are reported in Table 43.

\begin{tabular}{|c|c|c|c|c|c|c|}
\hline \multicolumn{7}{|c|}{ Table 43: Experimental and calculated axial buckling $(* 1 \mathrm{e}-3)$ in the R1UO2 configuration } \\
\hline Source & Experiment & MCNP & REBUS & MCNP-Expt & REBUS-Expt & REBUS-MCNP \\
\hline U-235 & $1.917 \pm 0.011$ & $1.901 \pm 0.032$ & - & -0.016 & - & - \\
\hline Np-237 & $1.973 \pm 0.011$ & $1.877 \pm 0.020$ & - & -0.096 & - & - \\
\hline Pin 17-17 & $1.939 \pm 0.013$ & $1.906 \pm 0.030$ & 1.944 & -0.033 & 0.005 & 0.038 \\
\hline Pin 17-18 & $1.932 \pm 0.013$ & $1.926 \pm 0.030$ & 1.942 & -0.006 & 0.010 & 0.016 \\
\hline Pin 17-21 & $1.940 \pm 0.013$ & $1.930 \pm 0.031$ & 1.921 & -0.010 & -0.019 & -0.009 \\
\hline
\end{tabular}

The experimental bucklings agree within one standard deviation except for the Np-237 fission chamber measurement. The bucklings calculated using MCNP all agree within one standard deviation. There is also a good agreement between the bucklings calculated using REBUS. The same conclusion can be drawn when comparing experimental and calculated results for a given pin. The only source of disagreement is observed for the Np-237 axial buckling. The reason can be an error in the measurement or an inaccuracy of the Np-237 cross section in ENDF-BVI as pointed out by the spectral indices (section 3.2).

\subsubsection{The R1MOX configuration}

The axial power profile obtained by integral gamma scanning for the pins $18-17$ and $20-17$ are compared with the REBUS and MCNP calculations in Figure 61 and Figure 62. The uncertainty for the experimental data is not shown in the figures to ease comparison with the calculated values. REBUS profiles are in very good agreement with the experimental profiles whereas the MCNP profiles fluctuate because of poor statistics.

The experimental and MCNP axial power profiles are compared for the U-235 and Np-237 fission chambers in Figure 63. The U-235 fission profile calculated with MCNP overestimates the experimental profile by approximately 10 to $20 \%$ at $\pm 30 \mathrm{~cm}$ from the core mid-plane. The increases are due to the Plexiglas spacers in the pins. The increase in fission rate occurs slightly closer (less than $1 \mathrm{~cm}$ ) to the core mid-plane for the MCNP U-235 fission profile. This may be due to uncertainty in the exact location and composition of the Plexiglas spacers in the $\mathrm{UO}_{2}-\mathrm{PuO}_{2}$ pins. The region of interest $[-20 \mathrm{~cm}, 20 \mathrm{~cm}]$ is shown in Figure 64 . The MCNP profiles are not well converged and the effect of the Styrene spacers is readily observed in the experimental U235 fission profile at around $\pm 14 \mathrm{~cm}$ from the core mid-plane. 


\subsubsection{Axial buckling}

The evolution of the buckling as a function of the fitting range has also been investigated. The experimental results are reported in Figure 65 and Table 44. The convergence of the buckling when increasing the number of points is difficult to observe. The buckling of the pins 18-17 exhibit a drop near 13 to $15 \mathrm{~cm}$ that can be due to the styrene spacer (section 3.3.3). The U-235 fission chamber measurement has been corrected for the styrene spacers and therefore fewer buckling values are reported. From the $\chi^{2}$ value of Table 44, the range $[-18 \mathrm{~cm}, 18 \mathrm{~cm}]$ seems the most appropriate with the exception of the pin 18-17. However, the buckling for the U-235 fission profile should be considered as less reliable because of the uncertainty in the correction needed to account for the Styrene spacers.

\begin{tabular}{|c|c|c|c|c|c|c|c|c|}
\hline \multicolumn{3}{|c|}{ Table 44: Experimental buckling as a function of the fitting range in the R1MOX configuration } \\
\hline \multirow{2}{*}{$\begin{array}{c}\text { Range } \\
(\mathrm{cm})\end{array}$} & \multicolumn{2}{|c|}{ Pin 18-17 } & \multicolumn{2}{c|}{ Pin $20-17$} & \multicolumn{2}{c|}{$\begin{array}{c}\text { U-235 fission } \\
\text { chamber }\end{array}$} & \multicolumn{2}{c|}{$\begin{array}{c}\text { Np-237 fission } \\
\text { chamber }\end{array}$} \\
\cline { 2 - 9 } & $\begin{array}{c}\mathrm{B} \\
\left(* 1 \mathrm{e}-3 \mathrm{~cm}^{-2}\right)\end{array}$ & $\chi^{2}$ & $\begin{array}{c}\mathrm{B} \\
\left(* 1 \mathrm{e}-3 \mathrm{~cm}^{-2}\right)\end{array}$ & $\chi^{2}$ & $\begin{array}{c}\mathrm{B} \\
\left(* 1 \mathrm{e}-3 \mathrm{~cm}^{-2}\right)\end{array}$ & $\chi^{2}$ & $\begin{array}{c}\mathrm{B} \\
\left(* 1 \mathrm{e}-3 \mathrm{~cm}^{-2}\right)\end{array}$ & $\chi^{2}$ \\
\hline$[-20,20]$ & $1.854 \pm 0.007$ & 3.47 & $1.859 \pm 0.007$ & 2.36 & $1.900 \pm 0.010$ & 2.24 & $1.873 \pm 0.009$ & 1.36 \\
\hline$[-18,18]$ & $1.840 \pm 0.009$ & 2.65 & $1.863 \pm 0.009$ & 0.92 & $1.883 \pm 0.016$ & 1.79 & $1.885 \pm 0.012$ & 1.10 \\
\hline$[-16,16]$ & $1.803 \pm 0.013$ & 1.94 & $1.844 \pm 0.013$ & 0.76 & - & - & $1.880 \pm 0.015$ & 1.07 \\
\hline$[-14,14]$ & $1.801 \pm 0.017$ & 1.77 & $1.827 \pm 0.017$ & 0.66 & - & - & $1.847 \pm 0.021$ & 0.89 \\
\hline$[-12,12]$ & $1.827 \pm 0.024$ & 1.82 & $1.856 \pm 0.024$ & 0.63 & - & - & $1.856 \pm 0.029$ & 0.92 \\
\hline$[-10,10]$ & $1.858 \pm 0.034$ & 1.58 & $1.842 \pm 0.033$ & 0.67 & $1.848 \pm 0.053$ & 1.38 & $1.840 \pm 0.040$ & 0.85 \\
\hline
\end{tabular}

The evolution of the buckling as a function of the fitting range obtained with MCNP is reported in Figure 66 and Table 45. The convergence of the buckling with the increase of the fitting range is readily seen. Because of the values of $\chi^{2}$, we can reject the range $[-20 \mathrm{~cm}, 20 \mathrm{~cm}]$ for the pin $18-17$ and the U-235 fission chamber. The range $[-18 \mathrm{~cm}, 18 \mathrm{~cm}]$ is appropriate for all profile.

The buckling calculated with REBUS evolves similarly for the R1UO2 configuration (section 3.3.3). The lack of statistical uncertainty on the calculations precludes judging the convergence of the buckling when the fitting range is increased.

\begin{tabular}{|c|c|c|c|c|c|c|c|c|}
\hline \multicolumn{8}{|c|}{ Table 45: MCNP buckling as a function of the fitting range in the R1MOX configuration } \\
\hline \multirow{2}{*}{$\begin{array}{c}\text { Range } \\
(\mathrm{cm})\end{array}$} & \multicolumn{2}{|c|}{ Pin 18-17 } & \multicolumn{2}{c|}{ Pin 20-17 } & \multicolumn{2}{c|}{$\begin{array}{c}\text { U-235 fission } \\
\text { chamber }\end{array}$} & \multicolumn{2}{c|}{$\begin{array}{c}\text { Np-237 fission } \\
\text { chamber }\end{array}$} \\
\cline { 2 - 10 } & $\begin{array}{c}\mathrm{B} \\
\left(* 1 \mathrm{e}-3 \mathrm{~cm}^{-2}\right)\end{array}$ & $\chi^{2}$ & $\begin{array}{c}\mathrm{B} \\
\left(* 1 \mathrm{e}-3 \mathrm{~cm}^{-2}\right)\end{array}$ & $\chi^{2}$ & $\begin{array}{c}\mathrm{B} \\
\left(* 1 \mathrm{e}-3 \mathrm{~cm}^{-2}\right)\end{array}$ & $\chi^{2}$ & $\begin{array}{c}\mathrm{B} \\
\left(* 1 \mathrm{e}-3 \mathrm{~cm}^{-2}\right)\end{array}$ & $\chi^{2}$ \\
\hline$[-20,20]$ & $1.752 \pm 0.037$ & 1.61 & $1.835 \pm 0.037$ & 0.52 & $1.761 \pm 0.039$ & 0.89 & $1.775 \pm 0.018$ & 0.71 \\
\hline$[-18,18]$ & $1.753 \pm 0.050$ & 1.09 & $1.836 \pm 0.050$ & 0.57 & $1.830 \pm 0.052$ & 0.66 & $1.778 \pm 0.024$ & 0.69 \\
\hline$[-16,16]$ & $1.732 \pm 0.067$ & 1.23 & $1.773 \pm 0.068$ & 0.48 & $1.854 \pm 0.070$ & 0.56 & $1.743 \pm 0.028$ & 0.56 \\
\hline$[-14,14]$ & $1.767 \pm 0.093$ & 1.41 & $1.750 \pm 0.095$ & 0.43 & $1.881 \pm 0.098$ & 0.62 & $1.737 \pm 0.045$ & 0.60 \\
\hline$[-12,12]$ & $1.763 \pm 0.135$ & 1.55 & $1.693 \pm 0.139$ & 0.49 & $1.858 \pm 0.145$ & 0.70 & $1.758 \pm 0.068$ & 0.49 \\
\hline$[-10,10]$ & $2.050 \pm 0.206$ & 1.50 & $1.739 \pm 0.214$ & 0.60 & $2.071 \pm 0.191$ & 0.45 & $1.766 \pm 0.100$ & 0.61 \\
\hline
\end{tabular}

The buckling of the experimental data obtained from the pin 18-17 and the U-235 fission chamber is not compatible with the other data regardless of the data range. Nevertheless, the most appropriate fitting region is $[-18 \mathrm{~cm}, 18 \mathrm{~cm}]$ for the other data. The data range varies slightly 
between the experimental data and the REBUS model due to the axial offset of the measurement and the position of the mesh size. The final bucklings are reported in Table 46.

\begin{tabular}{|c|c|c|c|c|c|c|}
\hline \multicolumn{6}{|c|}{ Table 46: Experimental and calculated axial buckling (*1e3) in the R1MOX configuration } \\
\hline Source & Experiment & MCNP & REBUS & MCNP-Exp & REBUS-Exp & REBUS-MCNP \\
\hline U-235 & $1.900 \pm 0.010$ & $1.830 \pm 0.052$ & - & -0.070 & - & - \\
\hline Np-237 & $1.885 \pm 0.012$ & $1.778 \pm 0.024$ & - & -0.107 & - & - \\
\hline Pin 18-17 & $1.840 \pm 0.009$ & $1.753 \pm 0.050$ & 1.875 & -0.087 & 0.035 & 0.122 \\
\hline Pin 20-17 & $1.863 \pm 0.009$ & $1.836 \pm 0.050$ & 1.865 & -0.027 & 0.002 & 0.029 \\
\hline
\end{tabular}

The experimental bucklings agree within two standard deviations. The uncertainties on the bucklings from MCNP are 2 to 5 times larger than the experimental uncertainties. The bucklings from MCNP are in agreement within one standard deviation. The MCNP and experimental bucklings agree within two standard deviations (4 to 5\%) for the pins 18-17 and 20-17 and for the U-235 fission chamber measurement. The bucklings from REBUS is well predicted $(0.1 \%)$ for the 20-17 pin but not for the $18-17$ pin (2\%).

The use of MCNP to determine the axial buckling is strongly limited by the poor statistics on the power profile even for a huge number of particles (300 million). An experimental buckling is also hard to be derived for pin 18-17 and the U-235 fission chamber because of the influence of the Styrene spacers.

\subsection{Radial power profile}

The radial power profiles have been determined experimentally on a horizontal and a diagonal traverse in the R1MOX configuration (Figure 67). Each pin of the traverse has been measured by integral gamma scanning. The fission rate of specific $\mathrm{UO}_{2}$ and $\mathrm{UO}_{2}-\mathrm{PuO}_{2}$ pins (Figure 67) was obtained by gamma spectroscopy of the La-140 peak at $1596.17 \mathrm{keV}$. The fission rate of the other pins was calculated assuming that the ratio of integral counting to fission rate is the same for a given fuel pin type (ref. 9).

The horizontal and diagonal radial power profiles have been calculated in both configurations by MCNP and REBUS. The MCNP fission rates are calculated using the track length estimate of the cell flux tally (ref. 2) on the fuel meat of the studied pins. The REBUS fission rates were calculated on regions accounting for individual pins $\left(1.26 \times 1.26 \mathrm{~cm}^{2}\right)$ composed of homogenized materials (Figure 33 and Figure 34 ).

\subsubsection{The R1UO2 configuration}

The horizontal and the diagonal radial power profiles are compared for the MCNP and REBUS models in Figure 68 and Figure 69. The power profiles are normalized to the total power of the traverse. In both cases, there is a poor agreement between REBUS and MCNP. The absence of specific self-shielding for the $\mathrm{UO}_{2}$ pins close to the AG-3 buffer in the REBUS model might be a source of error. Further investigation to determine the source of the difference will require experimental data. 


\subsubsection{The R1MOX configuration}

The measured horizontal power profile is compared to the calculated values from REBUS and MCNP in Figure 70. The power of each pin is normalized to the total power of the traverse. The pin numbers are centered on the oscillation channel (pin 0). The interface between the $\mathrm{UO}_{2}-\mathrm{PuO}_{2}$ $(4 \%)$ and $\mathrm{UO}_{2}$ pins is observed for pins $[-6,-7,6,7]$. The pins $[-15,15]$ are adjacent to AG-3 pins.

The MCNP power profile matches the experimental values on the North side of the traverse, especially the interface between $\mathrm{UO}_{2}-\mathrm{PuO}_{2}(4 \%)$ and $\mathrm{UO}_{2}$ pins. On the South side, the change of power between the adjacent $\mathrm{UO}_{2}$ and $\mathrm{UO}_{2}-\mathrm{PuO}_{2}$ pins predicted by MCNP is $50 \%$ higher than the change of power obtained experimentally. The power of the $\mathrm{UO}_{2}-\mathrm{PuO}_{2}(4 \%)$ pins is well predicted with MCNP and the power of the $\mathrm{UO}_{2}$ pins agrees within nearly one standard deviation.

The power of the $\mathrm{UO}_{2}$ pins calculated with REBUS underestimates the experimental power on both sides of the traverse. On the contrary, the power of the $\mathrm{UO}_{2}-\mathrm{PuO}_{2}(4 \%)$ pins calculated with REBUS, overestimates the experimental values. The power at the interface between the $\mathrm{UO}_{2}$ $\mathrm{PuO}_{2}(4 \%)$ and $\mathrm{UO}_{2}$ pins is similar to the MCNP values.

The REBUS model uses slightly different cross sections for pins \# 1, 5, 6 and 15 to account for self-shielding due to an adjacent buffer region (section 2.2.4.3). From a model where the effect of the buffer was not taken into account for pins \#1 and 15, Figure 71 shows an improvement of the results for the pins next to the POLINE overclad (cell \# 0) but no significant change for the power of the pins next to the Aluminum buffer.

To improve the REBUS power profile, the cross sections of the $\mathrm{UO}_{2}-\mathrm{PuO}_{2}(4 \%)$ and the $\mathrm{UO}_{2}$ pins might have to be self-shielded by taking into account more than the 8 adjacent pins.

The South East - North West traverse calculated with MCNP and REBUS is compared with the experimental value in Figure 72. The MCNP model well predicts the fission rates in the $\mathrm{UO}_{2}$ pins and the change of fission rate at the interface between the $\mathrm{UO}_{2}$ and $\mathrm{UO}_{2}-\mathrm{PuO}_{2}$ fuel pins (nearly within one standard deviation). The fission rates of the $\mathrm{UO}_{2}-\mathrm{PuO}_{2}$ fuel pins calculated with MCNP agree with the experimental values within two standard deviations. The REBUS model has similar problems to estimate the fission rate of the pins in the South-North traverse and the South East - North West traverse. The REBUS model underestimates the power of the pins near the aluminum buffer and tends to overestimate the $\mathrm{UO}_{2}-\mathrm{PuO}_{2}(4 \%)$ power on the South East side of the traverse.

\subsection{Conversion ratio}

The conversion ratio is defined as the ratio of neutron capture in U-238 to the total fission rate. The conversion ratios of the pins 24-17 and 27-17 have been measured in the R1MOX configuration (Figure 67). The two conversion ratios have been calculated with MCNP and are compared with the experimental values in Table 47. The measured and calculated conversion ratios agree within one standard deviation for the pin 24-17 and within two standard deviations for the pin 27-17. The overestimation of the calculated conversion ratio for the pin 27-17 implies an overestimation of the U-238 capture because the total fission rate is in good agreement with the experimental value as shown in Figure 70 for pin \#10. 


\begin{tabular}{|c|c|c|c|}
\hline \multicolumn{4}{|c|}{ Table 47: Conversion ratio in the R1MOX configuration } \\
\hline Pin & Experiment & MCNP & MCNP-Exp \\
\hline $24-17$ & $0.583(2.1 \%)$ & $0.592(1.5 \%)$ & $1.6 \%$ \\
\hline $27-17$ & $0.502(2.0 \%)$ & $0.527(1.5 \%)$ & $5.0 \%$ \\
\hline
\end{tabular}

\subsection{Calibration sample reactivity worth}

Experimentally, the oscillation of two calibration samples induces a change in position of the pilot rod to sustain criticality. The mean change of the pilot rod, noted $\Delta \theta$, is expressed in an arbitrary unit (pilot units) and is proportional to the change in reactivity of the core. The value $\Delta \theta$ is characteristic of the two calibration samples used.

In the REBUS model, a multiplication factor is calculated when each calibration sample is inserted in the core (the other sample not being modeled). A reactivity value $\rho$ is deduced for each calibration sample. The variation of reactivity $\Delta \rho$ between the calibrated sample and the reference sample (sample 1B0071) is then derived. The relation $\Delta \theta=\mathrm{f}(\Delta \rho)$ should be linear and the slope should only be dependant on the configuration. The measured pilot rod angle variation $\Delta \theta$ and the calculated reactivity variation $\Delta \rho$ are listed in Table 48 for the $\mathrm{UO}_{2}$ calibration samples oscillated in the R1-UO2 configuration. The linear fit of the points $(\Delta \rho, \Delta \theta)$ is shown in Figure 73 and the results of the fit, that is the slope $\Delta \theta / \Delta \rho$ and the $\chi^{2}$ are listed in Table 48.

\begin{tabular}{|c|c|c|c|c|c|c|c|c|}
\hline \multicolumn{1}{|c|}{ Table 48: $\mathrm{UO}_{2}$ calibration sample in the R1-UO2 configuration } \\
\hline Sample & $\mathrm{F} 0025$ & $\mathrm{~F} 0050$ & $\mathrm{~N} 0071$ & $\mathrm{~S} 0100$ & $\mathrm{~S} 0200$ & $\mathrm{~S} 0300$ & $\mathrm{~S} 0400$ & $\mathrm{~S} 0495$ \\
\hline${ }^{235} \mathrm{U}$ enrichment $(\%)$ & 0.25 & 0.49 & 0.71 & 1.00 & 2.01 & 3.01 & 4.00 & 4.93 \\
\hline \multirow{2}{*}{ Measured $\Delta \theta$ (pilot unit) } & 11528 & 42000 & 73467 & 104953 & 219321 & 313875 & 403243 & 475926 \\
& \pm 2153 & \pm 2153 & \pm 2153 & \pm 2153 & \pm 2153 & \pm 4734 & \pm 2153 & \pm 2153 \\
\hline Calculated $\Delta \rho(\mathrm{pcm})$ & 1.315 & 1.945 & 2.479 & 3.195 & 5.434 & 7.421 & 9.178 & 10.71 \\
\hline Linear fit & \multicolumn{7}{|c|}{$\Delta \theta / \Delta \rho=49491 \pm 234$ pilot unit / pcm } & $\chi^{2}=1.0$ \\
\hline
\end{tabular}

The measured pilot rod angle variation, the calculated reactivity and the results of the linear fit for the borated oscillation sample oscillated in the R1-UO2 configuration are listed in Table 49 and shown in Figure 73.

\begin{tabular}{|c|c|c|c|c|c|}
\hline Table 49: Borated $\mathrm{UO}_{2}$ calibration sample in the R1-UO2 configuration \\
\hline Sample & $1 \mathrm{~B} 0000$ & $1 \mathrm{~B} 0150$ & $1 \mathrm{~B} 0419$ & $2 \mathrm{~B} 0000$ & $2 \mathrm{~B} 0333$ \\
\hline Boron fraction (ppm) & 0 & 150 & 419 & 0 & 333 \\
\hline${ }^{235} \mathrm{U}$ enrichment (\%) & 0.25 & 0.25 & 0.25 & 0.53 & 0.53 \\
\hline Measured $\Delta \theta$ (pilot unit) & 22299 & -124638 & -428772 & 34973 & -316500 \\
& \pm 3757 & \pm 4417 & \pm 2153 & \pm 2153 & \pm 2153 \\
\hline Calculated $\Delta \rho(\mathrm{pcm})$ & 1.411 & -1.524 & -6.355 & 2.085 & -4.424 \\
\hline Linear fit & $\Delta \theta / \Delta \rho=55535 \pm 322$ pilot unit / pcm & $\chi^{2}=30.3$ \\
\hline
\end{tabular}

For the R1-UO2 configuration, the value of the $\chi^{2}$ confirm the linear trend of $\Delta \theta=\mathrm{f}(\Delta \rho)$ for the $\mathrm{UO}_{2}$ calibration samples. The relation $\Delta \theta=\mathrm{f}(\Delta \rho)$ obtained with the borated calibration samples is clearly not linear $\left(\chi^{2}=30.3>>1\right)$ and the slope $\Delta \theta / \Delta \rho$ does not agree with that of the $\mathrm{UO}_{2}$ calibration sample. 
The same study is performed for the R1-MOX configuration and the results are listed in Table 50 and Table 51 for the $\mathrm{UO}_{2}$ and borated calibration samples. The linear fits are shown in Figure 74.

\begin{tabular}{|c|c|c|c|c|c|c|c|c|}
\hline \multicolumn{10}{|c|}{ Table 50: $\mathrm{UO}_{2}$ calibration sample in the R1-MOX configuration } \\
\hline Sample & $\mathrm{F} 0025$ & $\mathrm{~F} 0050$ & $\mathrm{~N} 0071$ & $\mathrm{~S} 0100$ & $\mathrm{~S} 0200$ & $\mathrm{~S} 0300$ & $\mathrm{~S} 0400$ & $\mathrm{~S} 0495$ \\
\hline${ }^{235} \mathrm{U}$ enrichment (\%) & 0.25 & 0.49 & 0.71 & 1.00 & 2.01 & 3.01 & 4.00 & 4.93 \\
\hline \multirow{2}{*}{ Measured $\Delta \theta$ (pilot unit) } & -11907 & -5157 & -67 & 6856 & 36727 & 61321 & 85974 & 104687 \\
& \pm 5027 & \pm 1552 & \pm 1700 & \pm 1267 & \pm 2349 & \pm 3768 & \pm 3152 & \pm 4720 \\
\hline Calculated $\Delta \rho$ (pcm) & 0.3857 & 0.5760 & 0.7402 & 0.9591 & 1.656 & 2.273 & 2.833 & 3.327 \\
\hline Linear fit & \multicolumn{7}{|c|}{$\Delta \theta / \Delta \rho=40379 \pm 151$ pilot unit / pcm } & $\chi^{2}=0.6$ \\
\hline
\end{tabular}

\begin{tabular}{|c|c|c|c|c|c|c|c|}
\hline \multicolumn{8}{|c|}{ Table 51: Borated $\mathrm{UO}_{2}$ calibration sample in the $\mathrm{R} 1-\mathrm{MOX}$ configuration } \\
\hline Sample & $1 \mathrm{~B} 0000$ & 1B0150 & 1B0419 & 2B0000 & 2B0333 & 2B1062 & 2B2360 \\
\hline Boron fraction & 0 & 150 & 419 & 0 & 333 & 1062 & 2360 \\
\hline${ }^{235} \mathrm{U}$ enri & 0.25 & 0.2 & 0 & 0.53 & 0 . & & 0 \\
\hline Meas & $\begin{array}{c}-10964 \\
\pm 1343 \\
\end{array}$ & \begin{tabular}{|l|}
-41613 \\
\pm 5013 \\
\end{tabular} & $\begin{array}{c}-104193 \\
\pm 3232 \\
\end{array}$ & $\begin{array}{l}-7551 \\
\pm 1551\end{array}$ & $\begin{array}{r}-72967 \\
\pm 3844 \\
\end{array}$ & $\begin{array}{c}-216175 \\
\pm 1699 \\
\end{array}$ & $\begin{array}{c}-389847 \\
\pm 1699\end{array}$ \\
\hline Calculated $\Delta \rho(\mathrm{pcm})$ & 0.4172 & -0.4523 & -1.898 & 0.6317 & -1.311 & -4.883 & -9.628 \\
\hline Linear fit & & $\Delta \theta / \Delta p$ & 650 & pi & ${ }^{\circ}$ & $\chi^{2}=2$ & \\
\hline
\end{tabular}

For the R1-MOX configuration, the same conclusion as for the R1-UO2 configuration can be drawn for the $\mathrm{UO}_{2}$ and borated calibration samples.

The bad agreement between the experimental signal issued from the oscillations of the borated calibration samples and their calculated reactivity is thought to come from uncertainties in the composition of the borated samples and a possible migration of the boron to the periphery of the sample during the sintering of the fabrication process inducing self shielding effects. New borated calibration samples with a well known composition are under fabrication and will permit to confirm these conclusions.

The $\mathrm{UO}_{2}$ calibration samples have been recently fabricated and the uncertainty on their compositions is well known (ref. 6). As expected, the linear trend is excellent for the R1-UO2 and R1-MOX configurations.

Because the predictions of the reactivity worth of the $\mathrm{UO}_{2}$ calibration samples are well behaved compared to the experimental measurements, the REBUS model can be used to calculate the reactivity worth of the OSMOSE samples with a high degree of confidence for the R1-UO2 and $\mathrm{R} 1-\mathrm{MOX}$ configurations. If a difference is observed between measurements and calculations for an OSMOSE sample, it will most likely be the result of an error in the isotopic cross section. 


\section{CONCLUSION}

Monte Carlo and deterministic models using the MCNP and REBUS code systems have been developed to interpret safety and core parameters of the MINERVE reactor and to calculate the reactivity effect of the $\mathrm{UO}_{2}$ and borated $\mathrm{UO}_{2}$ calibration samples in the R1UO2 and R1MOX configurations. The complete description of the models was provided in this document.

The safety and core parameters (control rod worth, spectral indices, axial and radial power profile, and conversion ratio) were studied. MCNP and REBUS estimates have been compared with the experimental values.

In the R1UO2 configuration, the reactivity worth of the control rods calculated by MCNP agrees within $10 \%$ with the experimental values measured with a U-235 fission chamber located in the thermal column. The REBUS calculations tend to underestimate the MCNP results when the reactivity worth increases and agree within $15 \%$ with the experimental data. A more accurate comparison between experimental and calculated values will need to consider spatial and energy effects on the measurements.

The Pu-239/U-235 and Pu-241/Pu-239 spectral indices calculated with MCNP agree within one standard deviation $(<2.2 \%)$ in both R1UO2 and R1MOX configurations. The Np-237/Pu-239 spectral index only agrees within one standard deviation in the R1MOX configuration. The reason is thought to be an inaccuracy in the Np-237 fission cross section at thermal energies in the ENDFB-VI library.

The axial power profile, in the region within $\pm 20 \mathrm{~cm}$ from the core mid-plane, is well estimated by the REBUS code system. The use of MCNP requires long run times and results in a profile that is not well-behaved (fluctuation due to poor statistics). The effect of the styrene spacers located in the core is observed with the U-235 fission chamber.

In the R1UO2 configuration, REBUS predicts the experimental axial buckling extracted from measurement on $\mathrm{UO}_{2}$ pins within one standard deviation $(<1 \%)$. The MCNP calculations predict the experimental bucklings within one standard deviation except for the $\mathrm{Np}-237$ fission chamber measurement. The experimental axial buckling obtained with the Np-237 fission chamber is significantly different ( 3 standard deviations) from the other experimental bucklings.

In the R1MOX configuration, the experimental buckling does not agree within one standard deviation. The reason might be the emphasized spectrum perturbation due to the Styrene and Plexiglas spacers. MCNP bucklings agree within one standard deviation but uncertainties are high ( 3\%). MCNP predicts the experimental buckling within two standard deviations except for the Np-237 measurement. The agreement between the REBUS results and the experiments is better than $2 \%$.

The radial power profiles determined by REBUS and MCNP differ significantly in the R1UO2 configuration. This is due to the absence of specific self shielding in REBUS for the $\mathrm{UO}_{2}$ pins close to the AG-3 buffer. In the R1MOX configuration, the radial profile for the horizontal traverse was well predicted by MCNP except for the $\mathrm{UO}_{2} / \mathrm{UO}_{2}-\mathrm{PuO}_{2}$ interface in the south region where the change in power is overestimated by $50 \%$. The REBUS model does not predict well the power of the individual $\mathrm{UO}_{2}$ and $\mathrm{UO}_{2}-\mathrm{PuO}_{2}$ pins. A more complex self-shielding procedure in the WIMS calculations might improve the REBUS results. Similar conclusions apply for the diagonal traverse. 
In the R1MOX configuration, the conversion ratios are estimated within $5 \%$ by MCNP (2 standard deviations).

Finally, the REBUS model can accurately calculate the reactivity worth of the $\mathrm{UO}_{2}$ and borated $\mathrm{UO}_{2}$ calibration samples. Comparison with the experimental signal, proportional to reactivity, is excellent. The REBUS model can thus be used to assess the reactivity of the OSMOSE samples and the oscillation technique can be used to assess the integral cross-sections of the actinide isotopes in the R1UO2 and R1MOX configurations.

\section{Acknowledgment}

Argonne National Laboratory's work was supported by the U.S. Department of Energy, Office of Nuclear Energy, under contract W-31-109-Eng-38 


\section{REFERENCES}

1 G. Perret, R.T. Klann, M. Antony, JP. Hudelot, Geometry and material specification of the MINERVE facility with the MELODIE IV experimental, ANL - 04/17, Dec. 2004

2 J.F. Briesmeister, MCNP ${ }^{\mathrm{TM}}$ - A General Monte Carlo N-Particle Transport Code (Version 4C), LA-13709-M

3 A.P. Olson, A users guide for the REBUS-PC code, Version 1.4, ANL/RERTR/TM0232, Dec. 2001

4 J.R. Deen and L.Woodruff, WIMS-ANL user manual Rev.4, ANL/RERTR/TM-23, Jan. 2001

5 Fabrication d'échantillons étalons en UO2 fritte à concentration variable en Bore, CEA NT SPRC/LPEx 92-65, 1992

6 C. Döderlein, Bilan matière des échantillons de calibration des programmes OSMOSE et VALMONT, NT SPRC/LPN 03-1367, 2003

$7 \quad$ JP. Hudelot, Personal Communication

8 Implementation agreement of the CEA-DOE agreement regarding the scientific and technical cooperation in the area of advanced nuclear reactors, V.3324.001, October 2003

9 JP. Hudelot, et al., MINERVE Reactor Characterization in Support of the OSMOSE Program: Safety parameters, PHYSOR 2004, 24-29 April, Chicago, USA

10 G. Perret, Amélioration et développement des méthodes de détermination de la réactivité - Maîtrise des incertitudes associées, PhD, University Joseph Fourier, 15th October 2003

11 R. Klann et al, MINERVE Reactor Characterization in Support of the OSMOSE Program: Spectral Indices, PHYSOR 2004, 24-29 April, Chicago, USA 


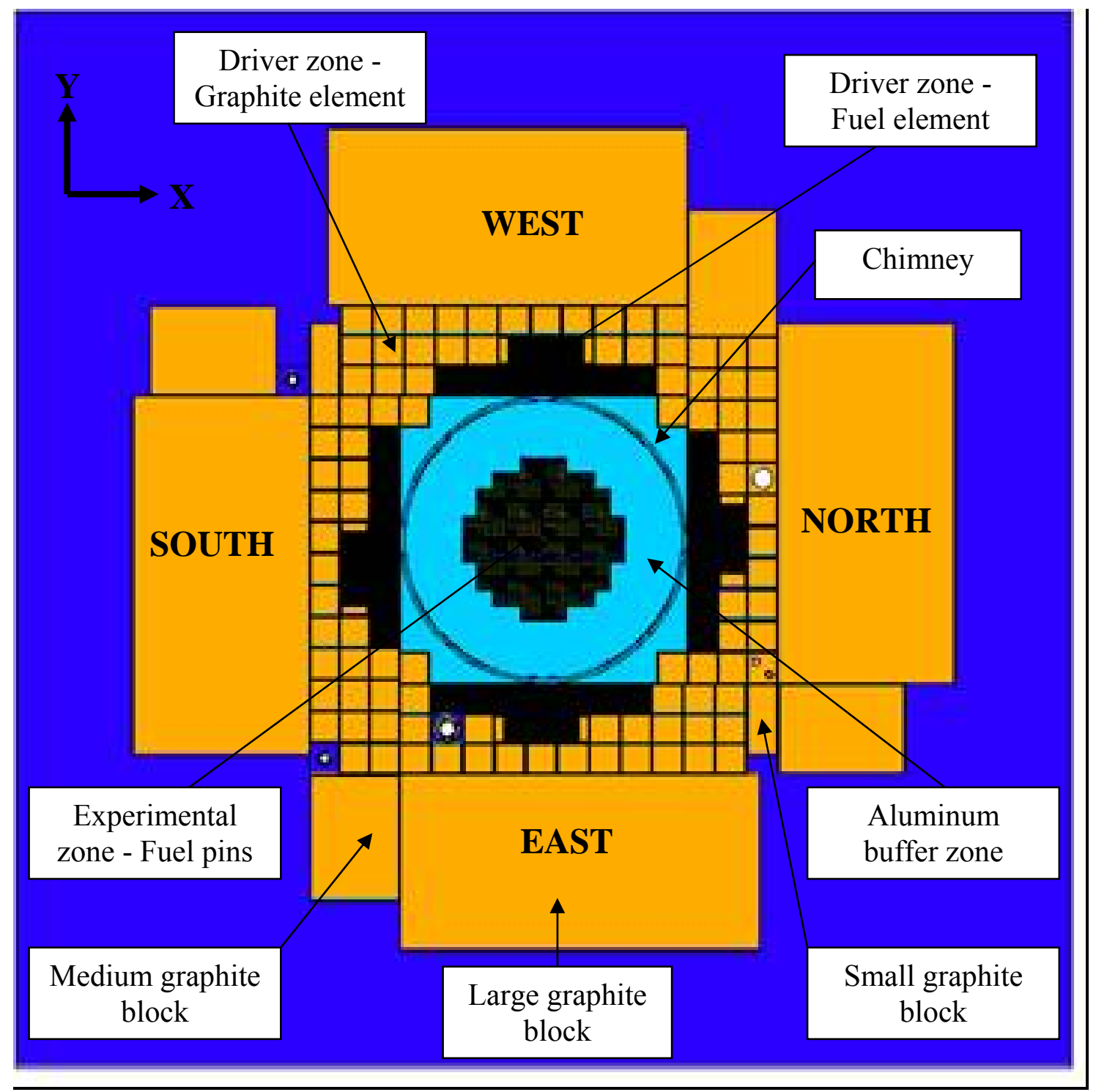

Figure 1: Radial view of the MCNP model 


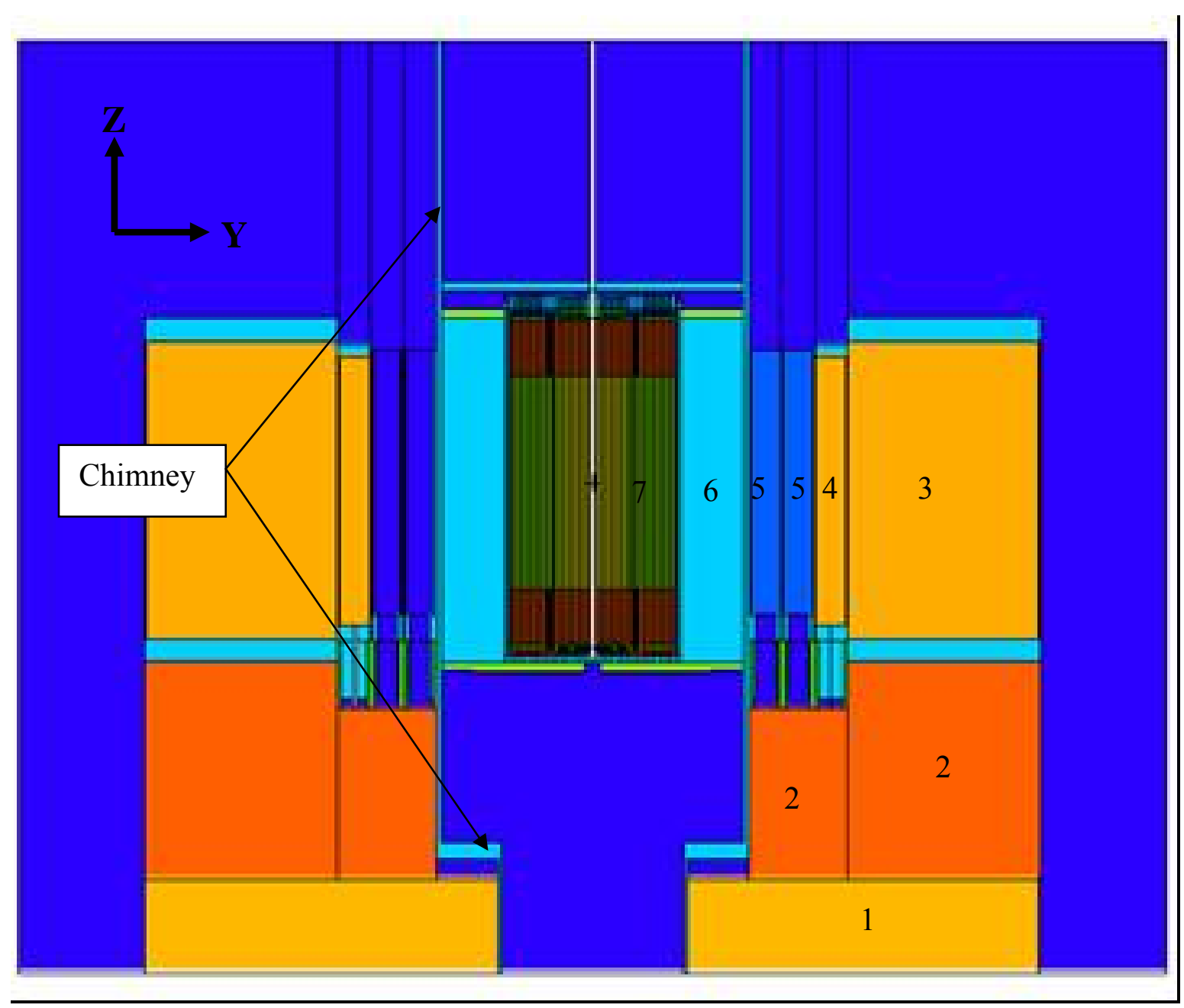

1: Support table

2: Caissons

3: Large graphite block

4: Driver zone -Graphite element

5: Driver Zone - Fuel element

6: Experimental zone - Aluminum buffer

7: Experimental Zone - Fuel Pins

Figure 2: Axial view of the MCNP model 


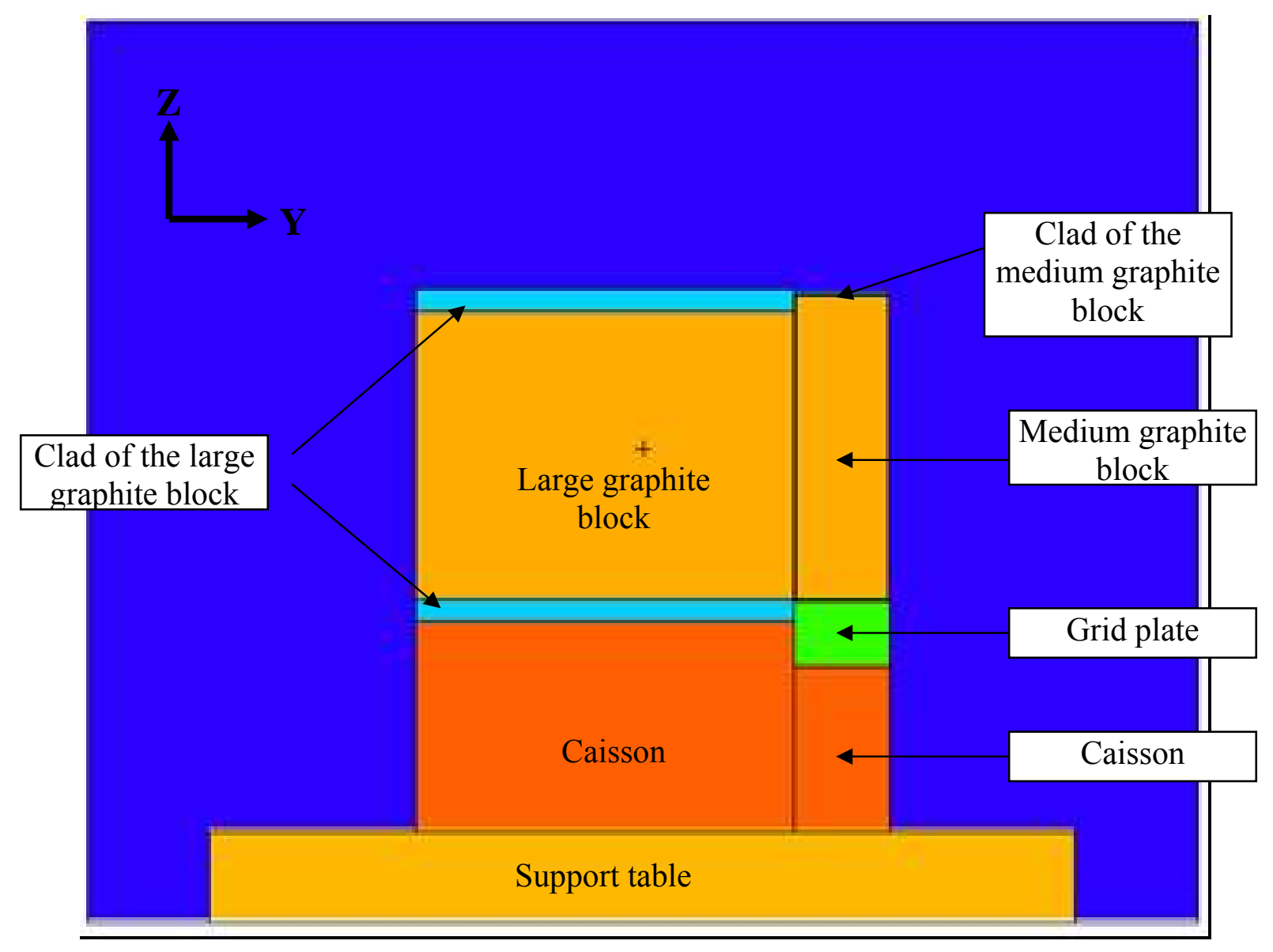

Figure 3: Support element and graphite blocks of the driver zone - MCNP model 

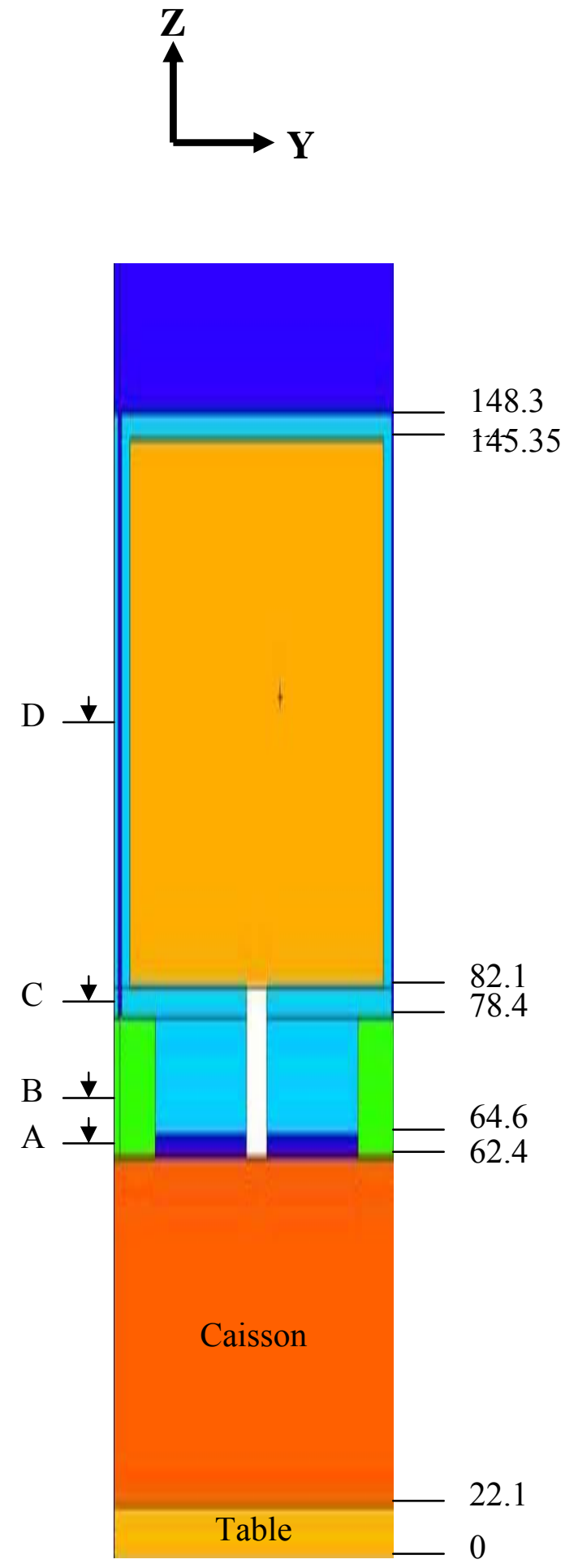

All dimensions in $\mathrm{cm}$
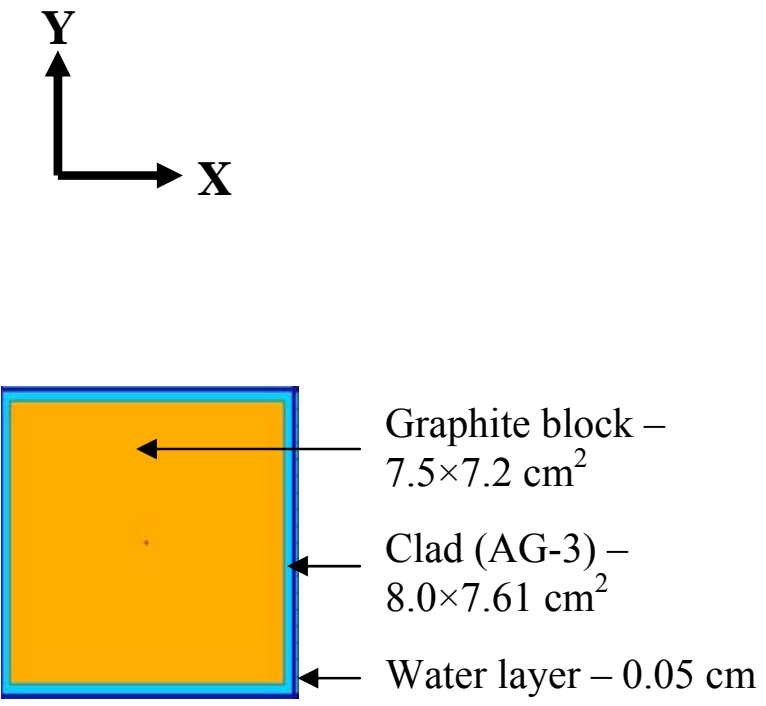

C

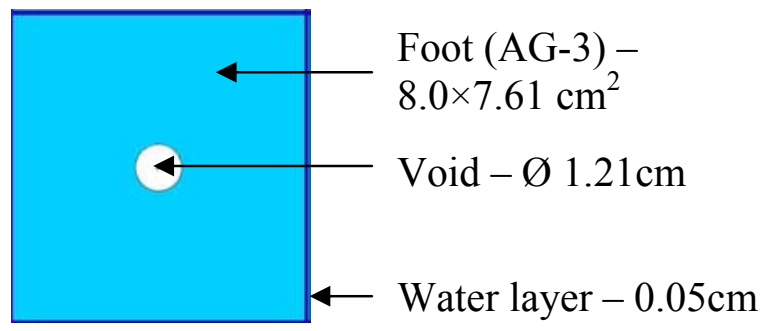

B

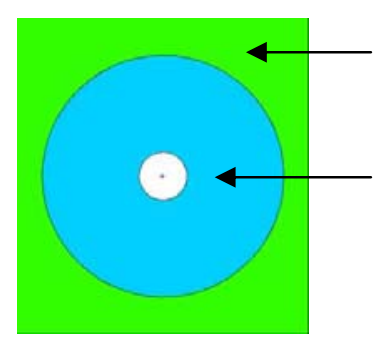

Grid plate (AL5) $8.1 \times 7.71 \mathrm{~cm}^{2}$ Foot (AG-3) $\varnothing 6.1 \mathrm{~cm}$

A

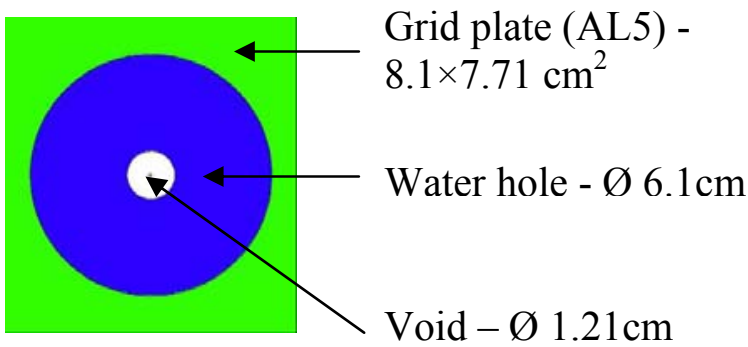

Figure 4: Graphite element - MCNP model 

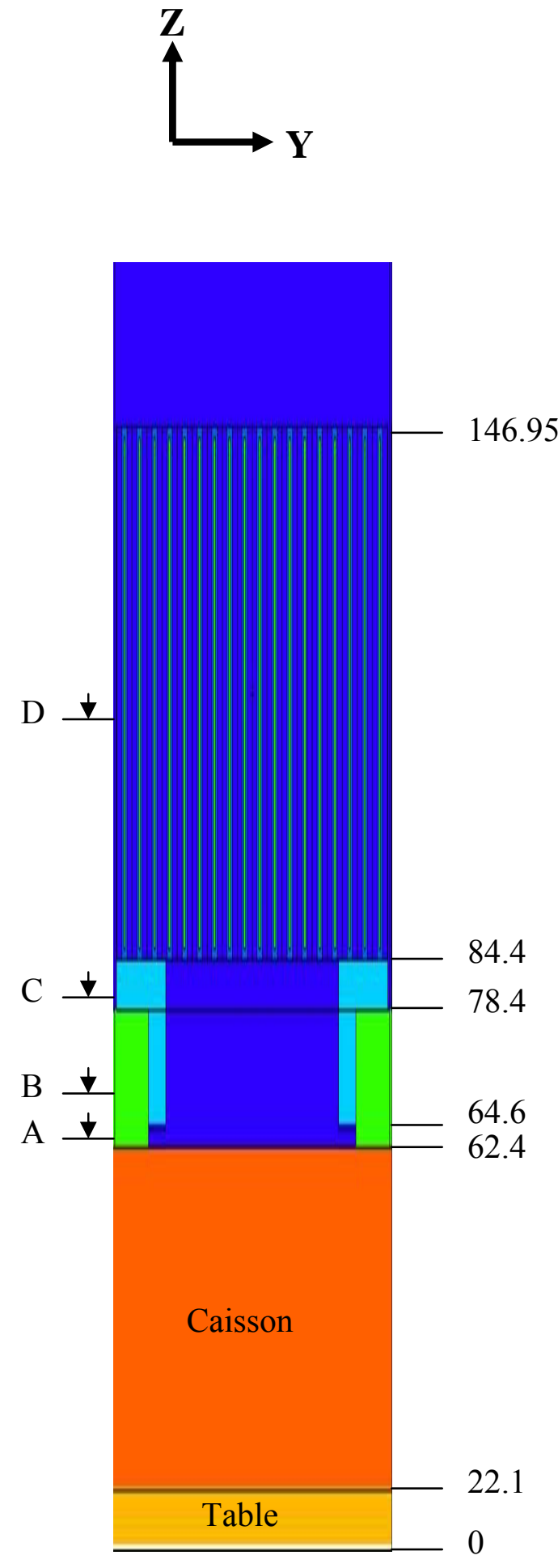

All dimensions in $\mathrm{cm}$

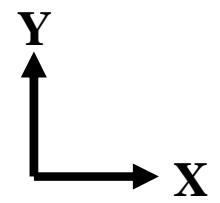

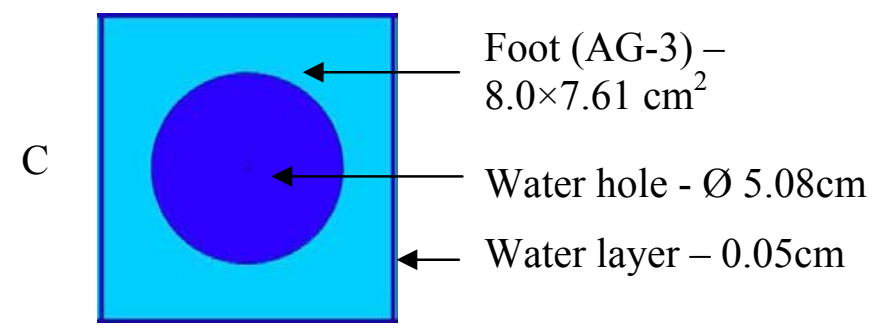
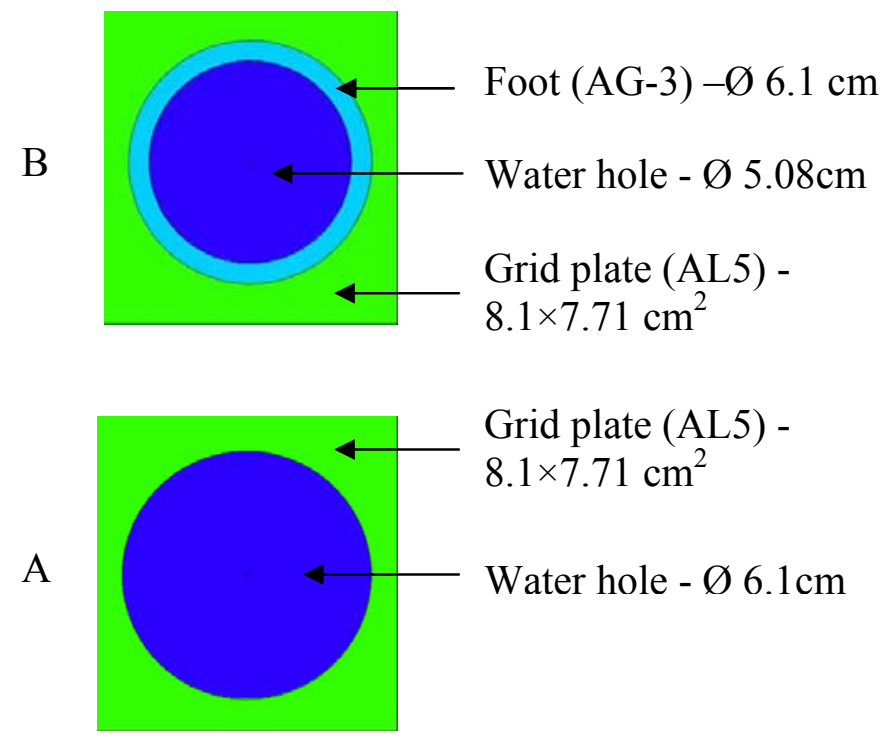

Figure 5: 18-plate fuel element - MCNP model 

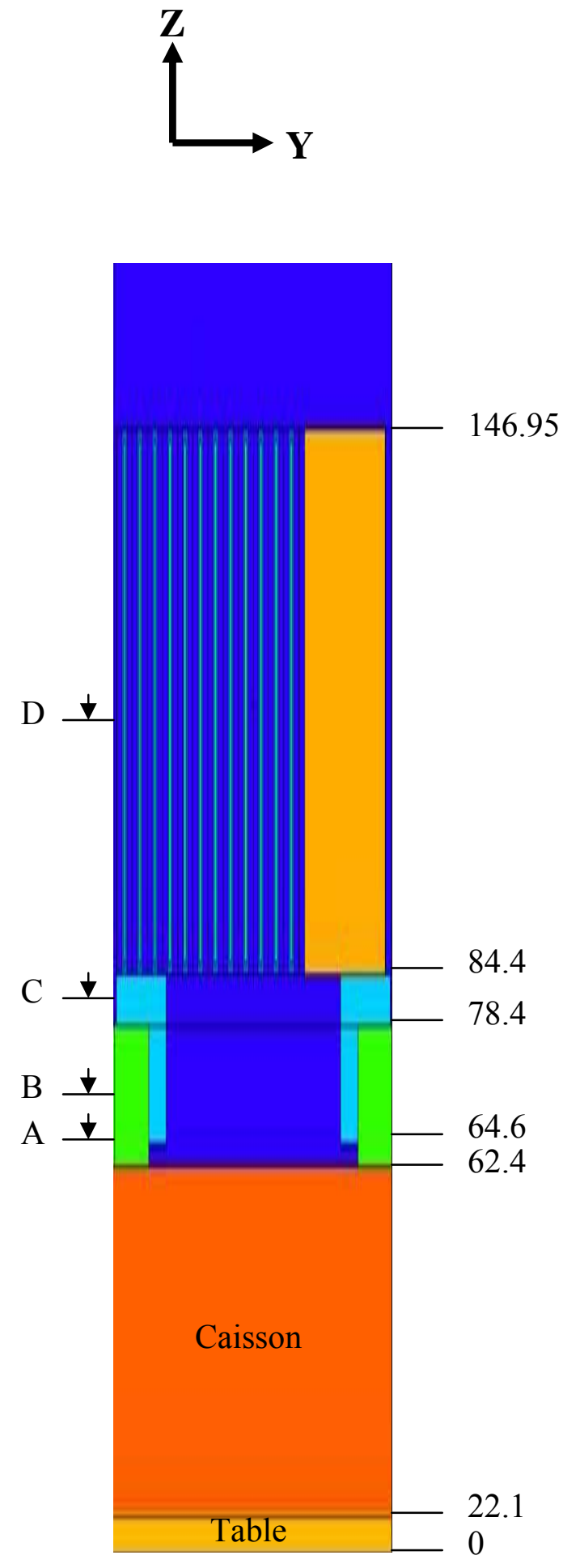

All dimensions in $\mathrm{cm}$

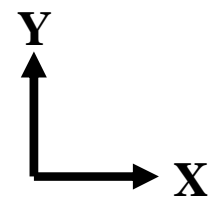

D

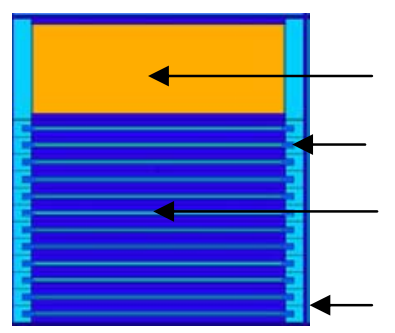

Graphite block

Border plate (AG-3)

Fuel plates \& water gaps

Water layer $-0.05 \mathrm{~cm}$

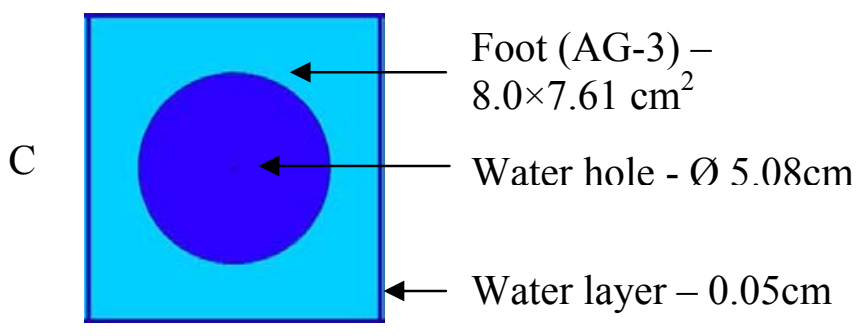

B

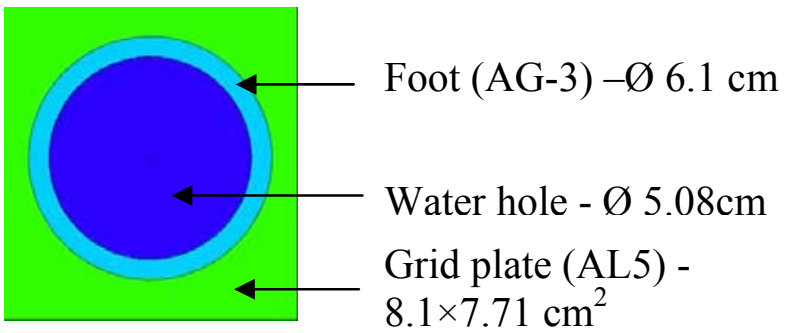

A

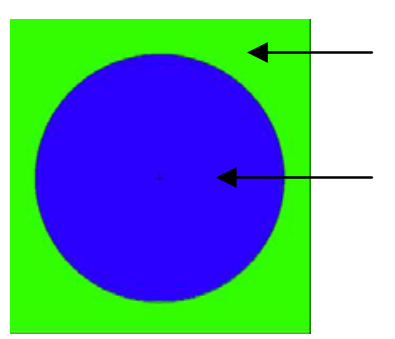

Grid plate (AL5) -

$8.1 \times 7.71 \mathrm{~cm}^{2}$

Water hole - Ø $6.1 \mathrm{~cm}$

Figure 6: 12-plate fuel element - MCNP model 

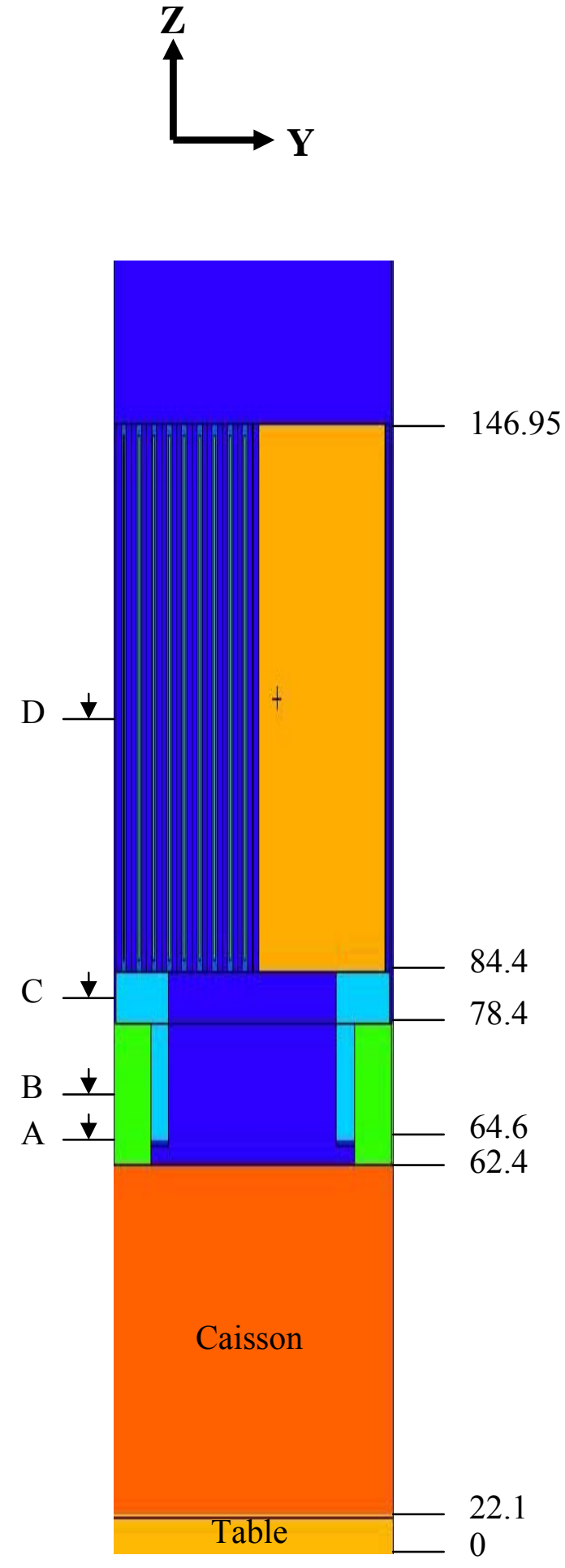

All dimensions in $\mathrm{cm}$

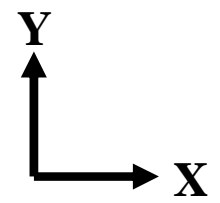

D

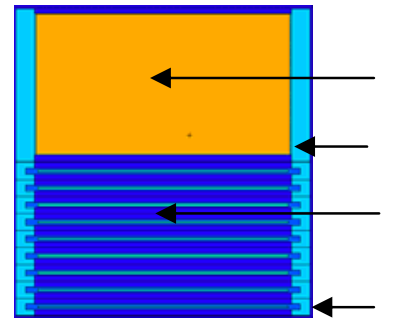

Graphite block

Border plate (AG-3)

Fuel plates \& water gaps

Water layer $-0.05 \mathrm{~cm}$

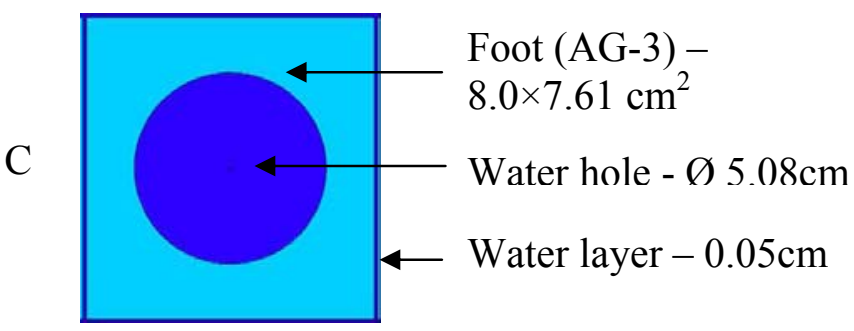

B

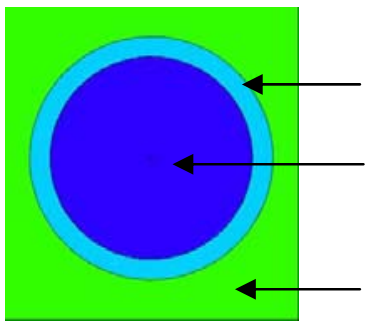

Foot (AG-3) -Ø $6.1 \mathrm{~cm}$

Water hole - Ø 5.08cm

Grid plate (AL5) -

$8.1 \times 7.71 \mathrm{~cm}^{2}$

Grid plate (AL5) -

$8.1 \times 7.71 \mathrm{~cm}^{2}$

A

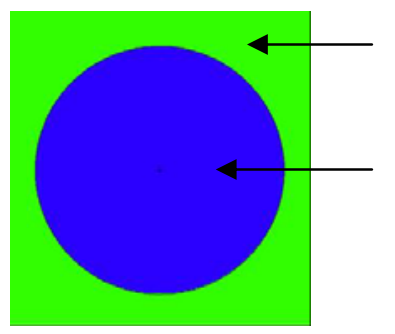

Water hole - $\varnothing 6.1 \mathrm{~cm}$

Figure 7: 9-plate fuel element - MCNP model 
All dimensions in $\mathrm{cm}$

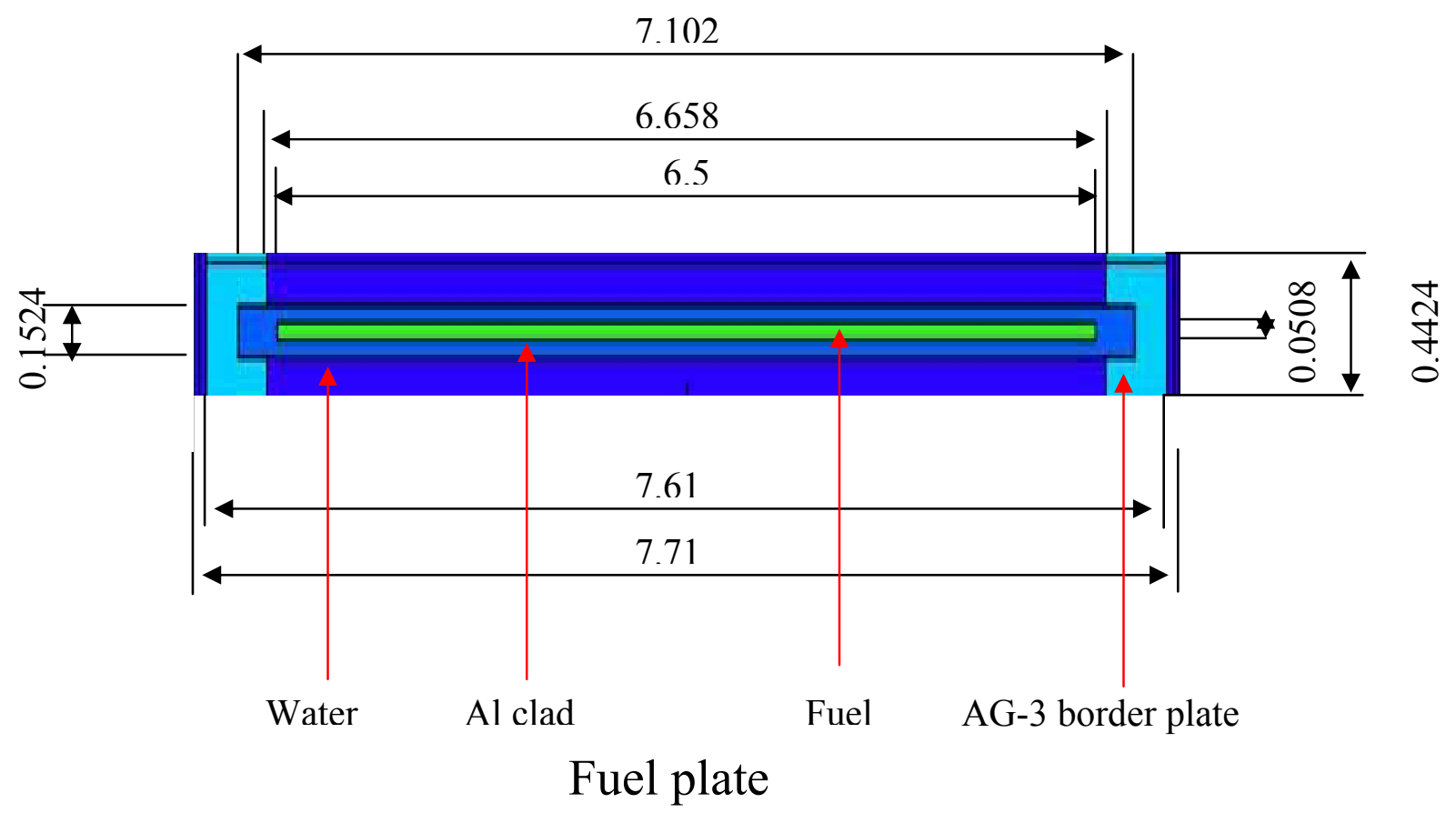

Graphite block: $6.58 \times 2.35 \mathrm{~cm}^{2}$

AG-3 clad: $6.658 \times 2.36 \mathrm{~cm}^{2}$

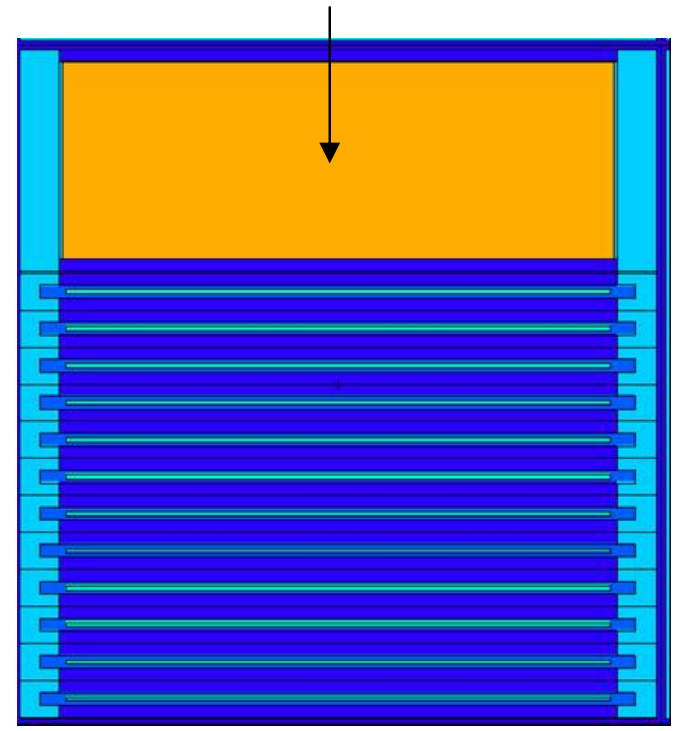

12-plate fuel element
Graphite block: $6.58 \times 3.68 \mathrm{~cm}^{2}$ AG-3 clad: $6.658 \times 3.69 \mathrm{~cm}^{2}$

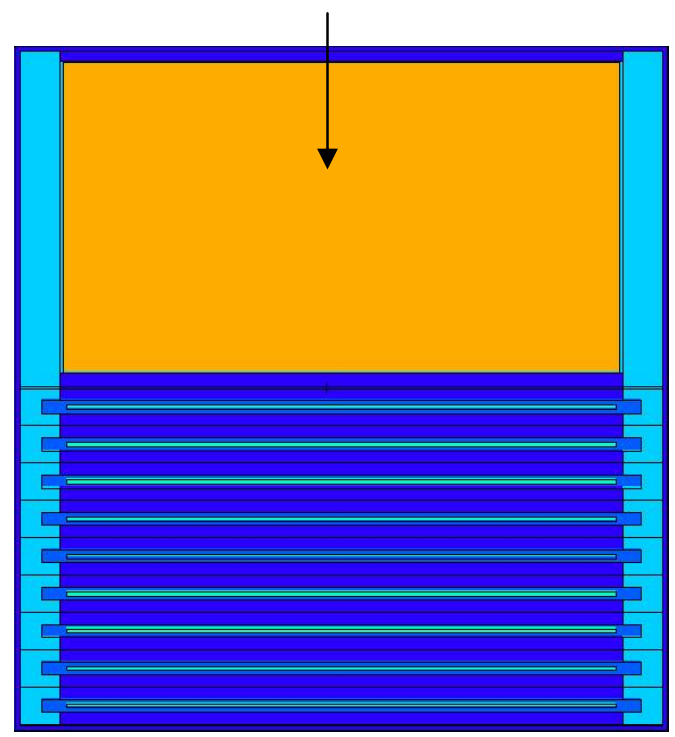

9-plate fuel element

Figure 8: Details of the fuel elements - MCNP model 
All dimensions in $\mathrm{cm}$
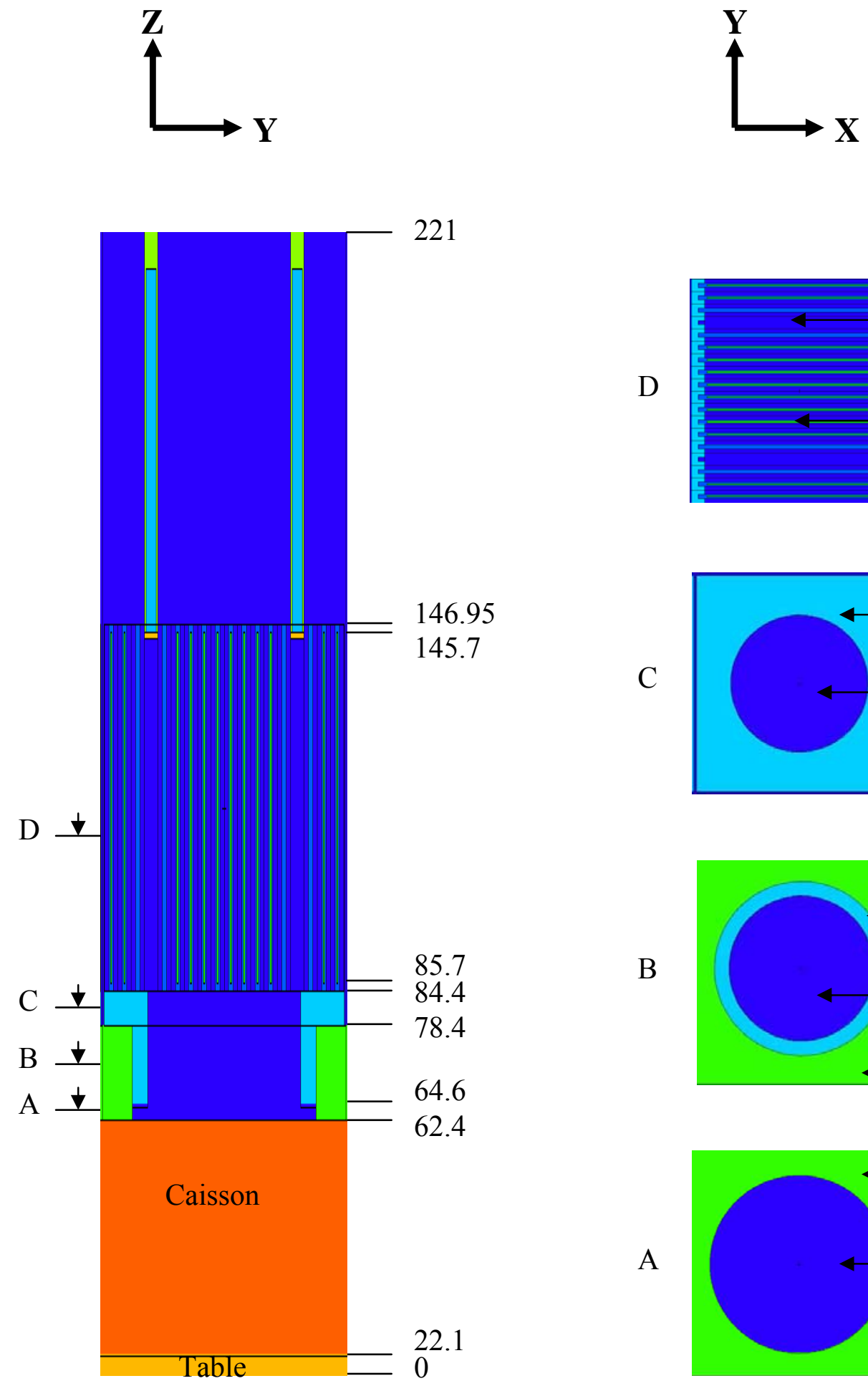

$\mathrm{D}$

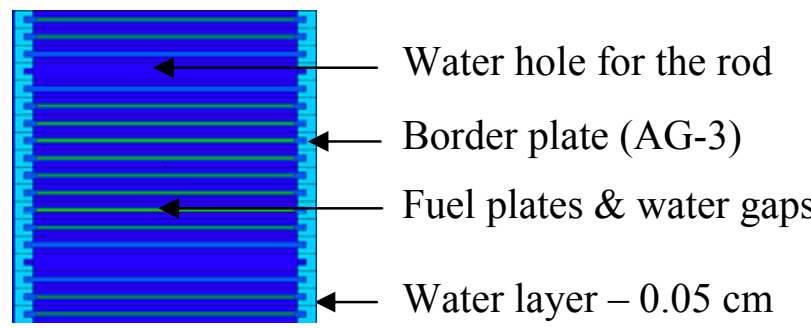

C

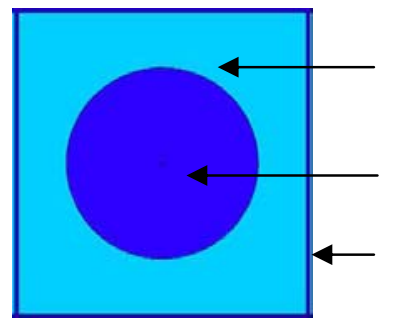

Foot (AG-3) $8.0 \times 7.61 \mathrm{~cm}^{2}$ Water hole - Ø $5.08 \mathrm{~cm}$ Water layer $-0.05 \mathrm{~cm}$

B

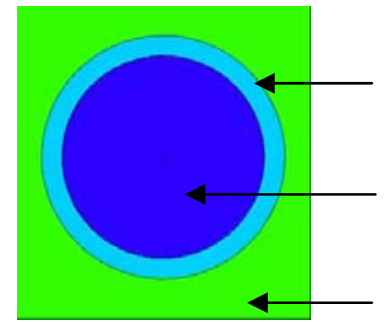
Foot (AG-3) -Ø $6.1 \mathrm{~cm}$ Water hole - Ø 5.08cm Grid plate (AL5) $8.1 \times 7.71 \mathrm{~cm}^{2}$

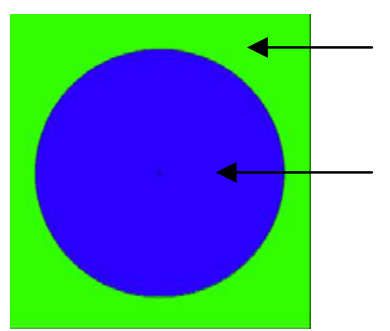

Grid plate (AL5) $8.1 \times 7.71 \mathrm{~cm}^{2}$

Water hole - Ø $6.1 \mathrm{~cm}$

Figure 9: Control element - MCNP model 


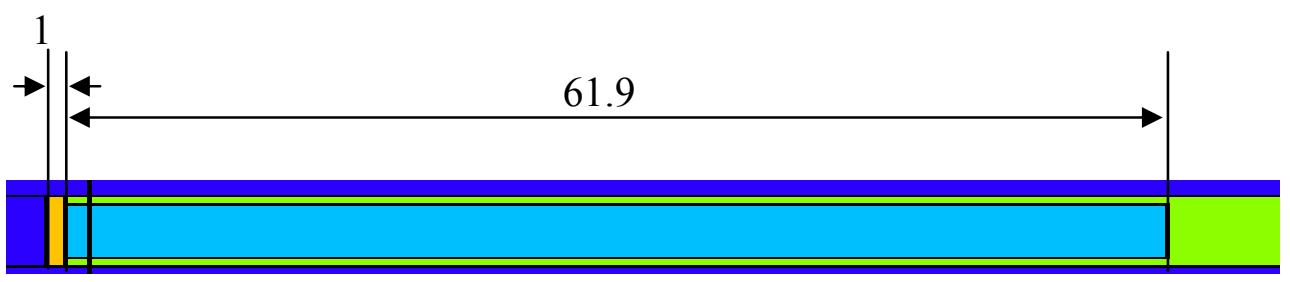

Bevel (SS \& water) $\square$ Hafnium plate $\quad \square$ Clad and extender (SS) Absorber rod

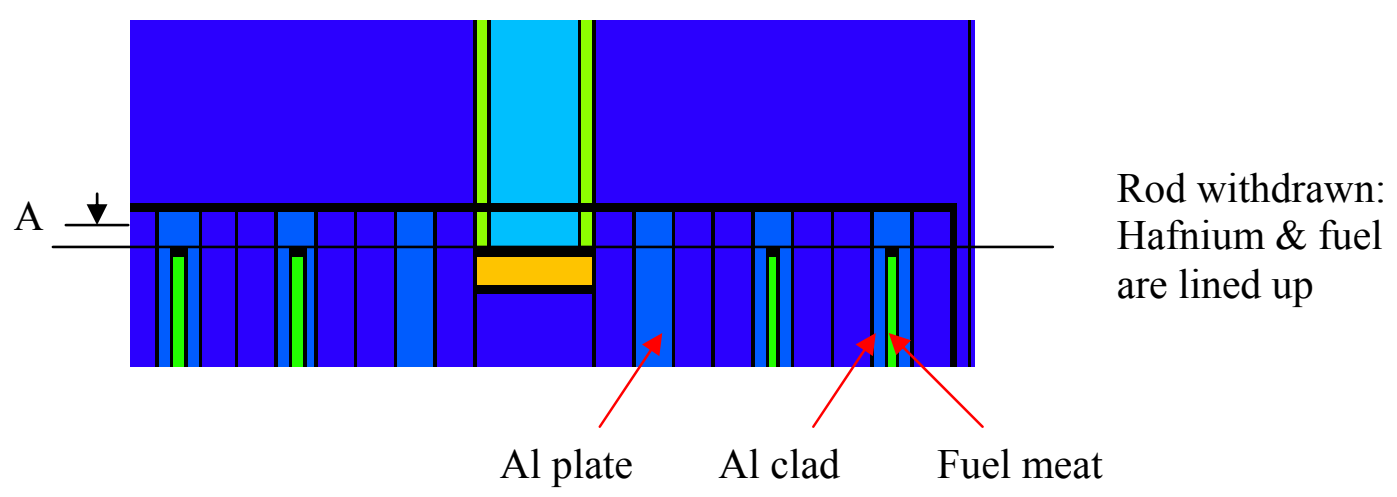

Absorber rod withdrawn

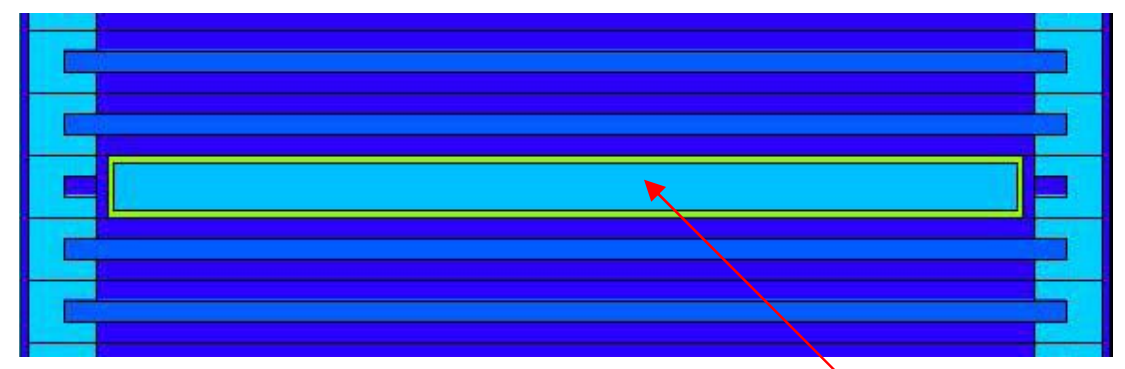

Hafnium plate $\left(6.4 \times 0.339 \mathrm{~cm}^{2}\right)$ Section A SS clad $\left(6.5 \times 0.439 \mathrm{~cm}^{2}\right)$

Figure 10: Details of the control element and the rods - MCNP model 

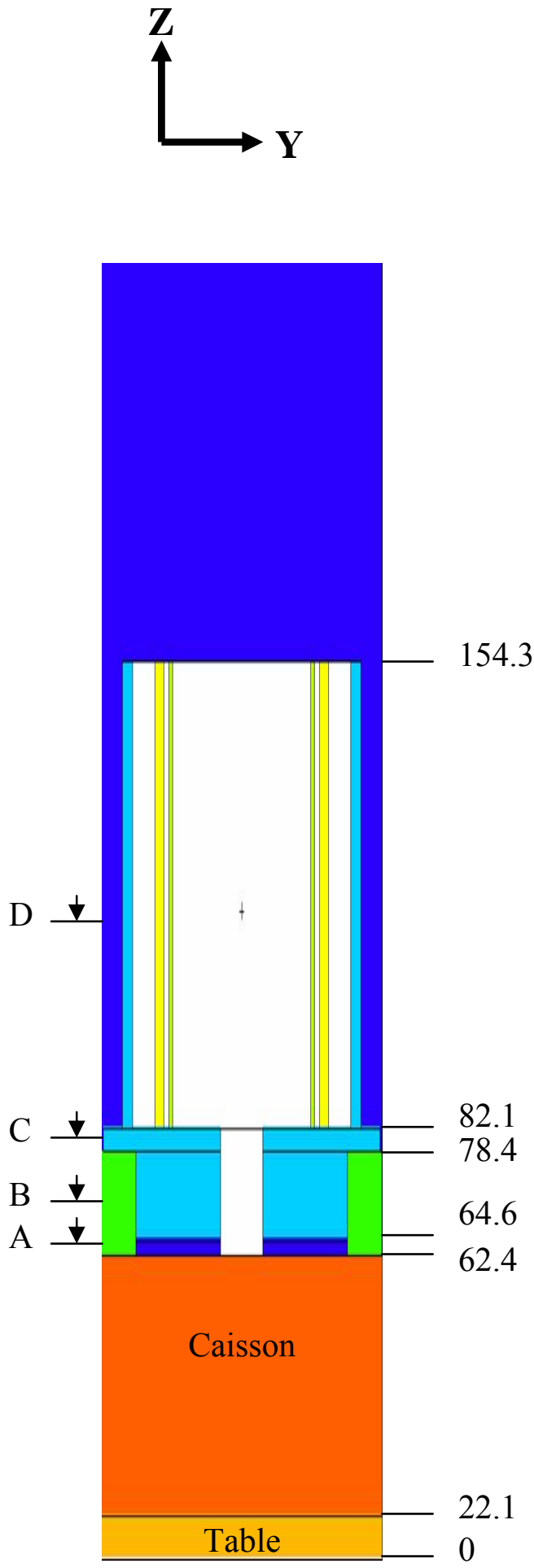

All dimensions in $\mathrm{cm}$
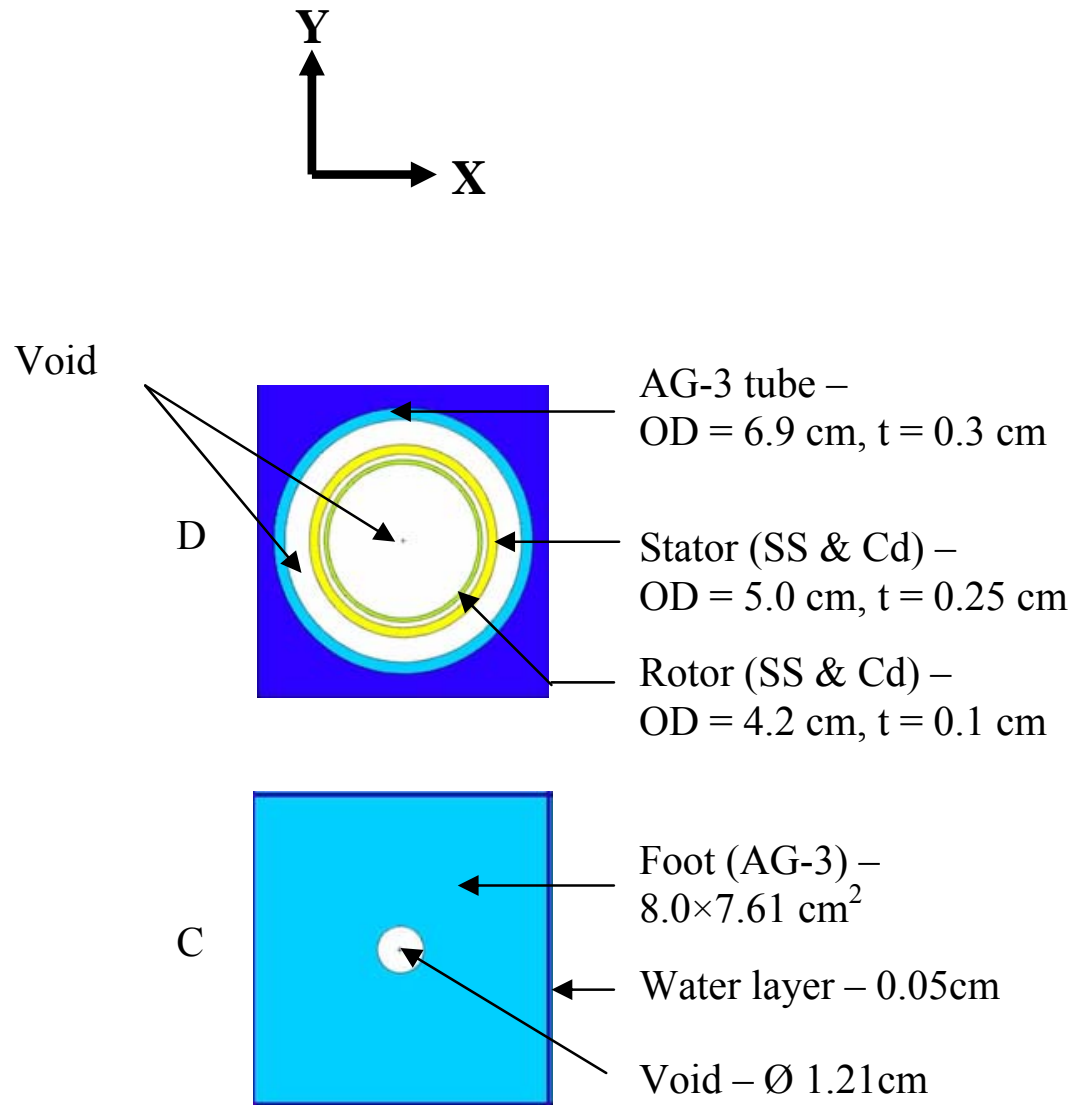

Grid plate (AL5) $8.1 \times 7.71 \mathrm{~cm}^{2}$

B

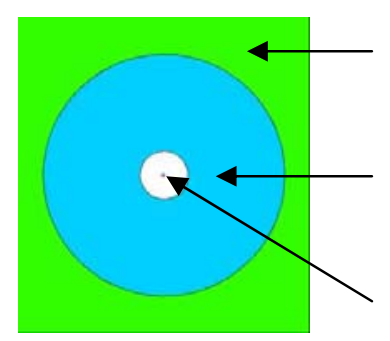

Foot (AG-3) $\varnothing 6.1 \mathrm{~cm}$

Void - Ø $1.21 \mathrm{~cm}$

Grid plate (AL5) $8.1 \times 7.71 \mathrm{~cm}^{2}$

A

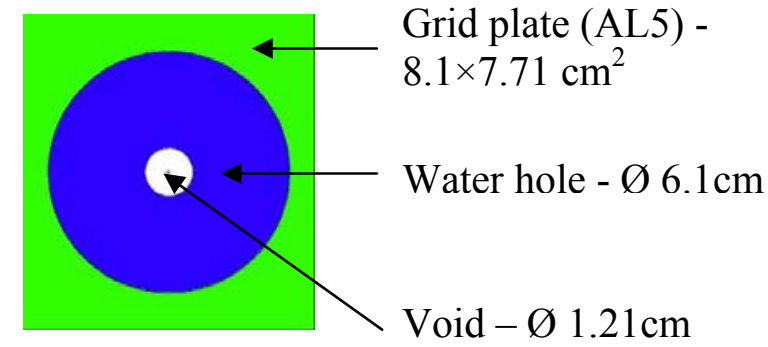

Figure 11: Pilot rod element - MCNP model 

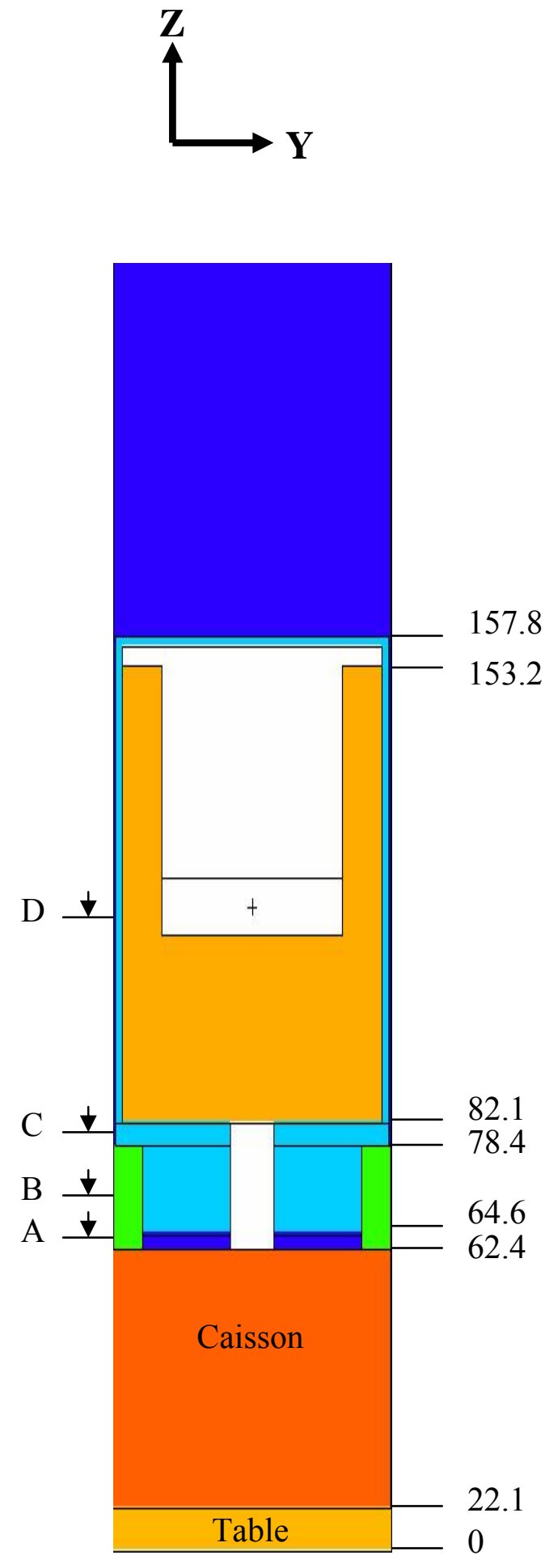

All dimensions in $\mathrm{cm}$

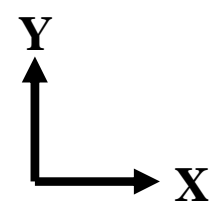

D

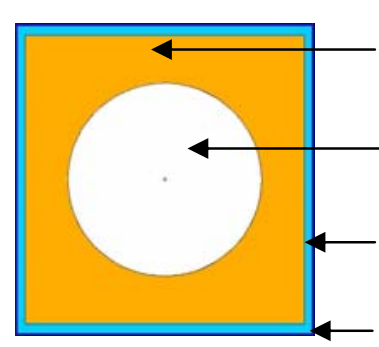

Graphite block $7.5 \times 7.2 \mathrm{~cm}^{2}$

Cavity (void) $-\varnothing 5.0 \mathrm{~cm}$

Clad (AG-3) -

$8.0 \times 7.61 \mathrm{~cm}^{2}$

Water layer $-0.05 \mathrm{~cm}$

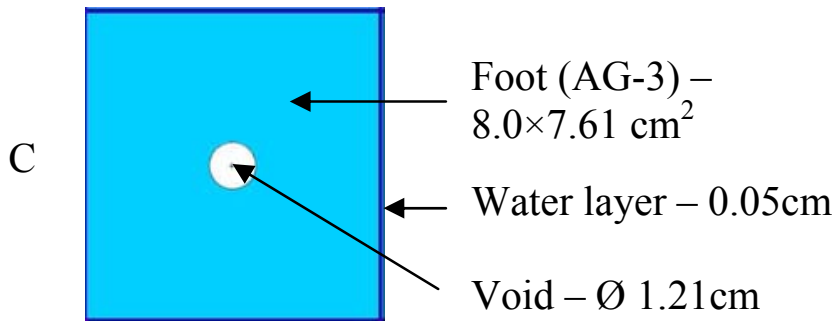

Grid plate (AL5) -

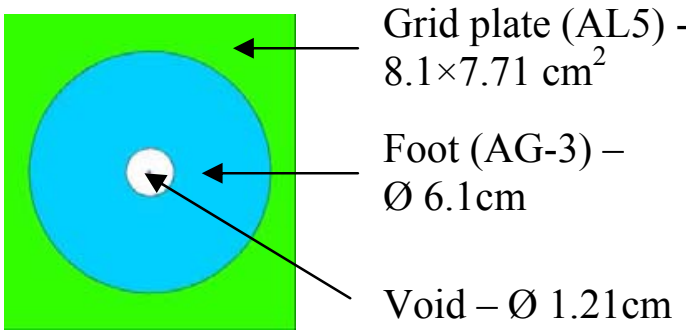

B

Foot (AG-3) $\varnothing 6.1 \mathrm{~cm}$

Void - Ø $1.21 \mathrm{~cm}$

Grid plate (AL5) -

$8.1 \times 7.71 \mathrm{~cm}^{2}$

A

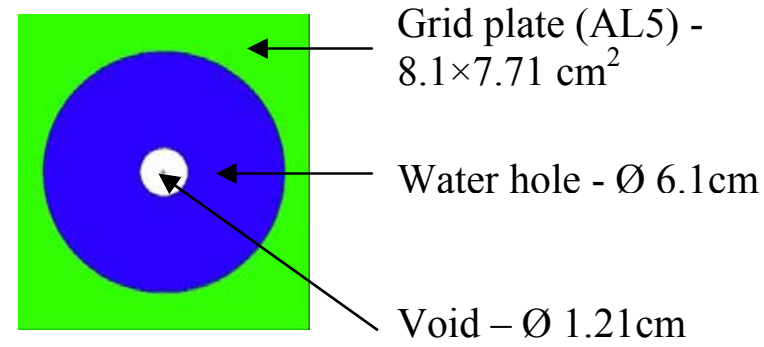

Figure 12: Detector element - MCNP model 

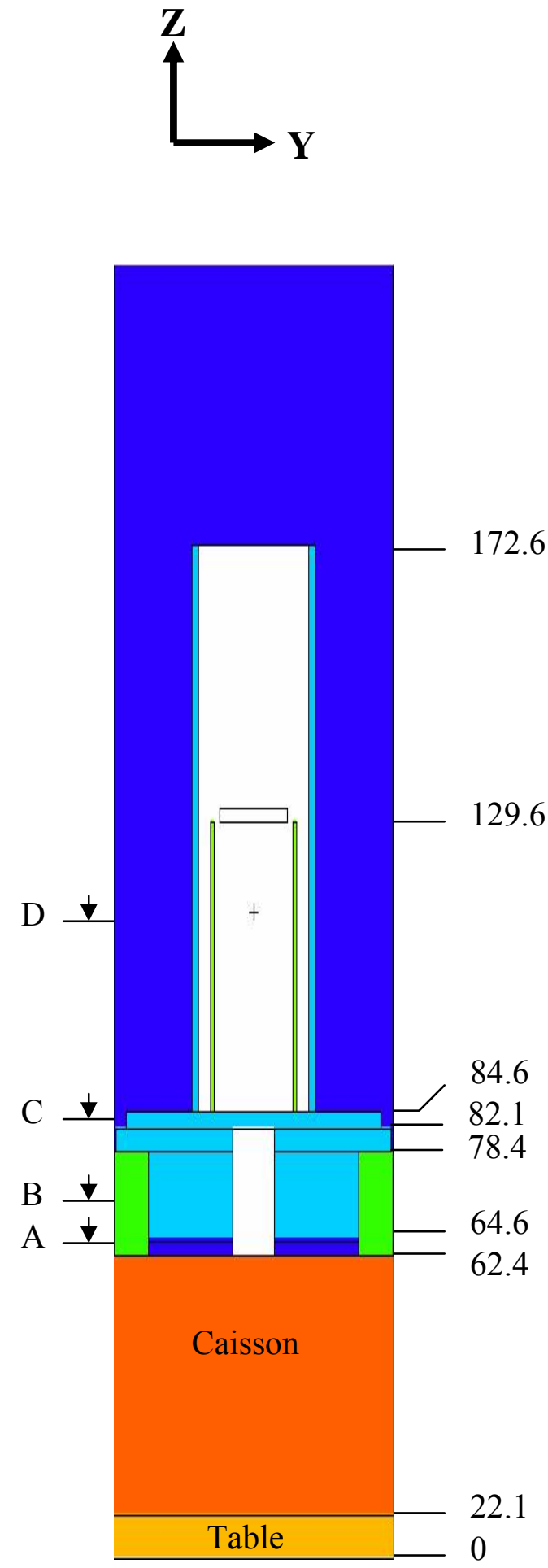

All dimensions in $\mathrm{cm}$
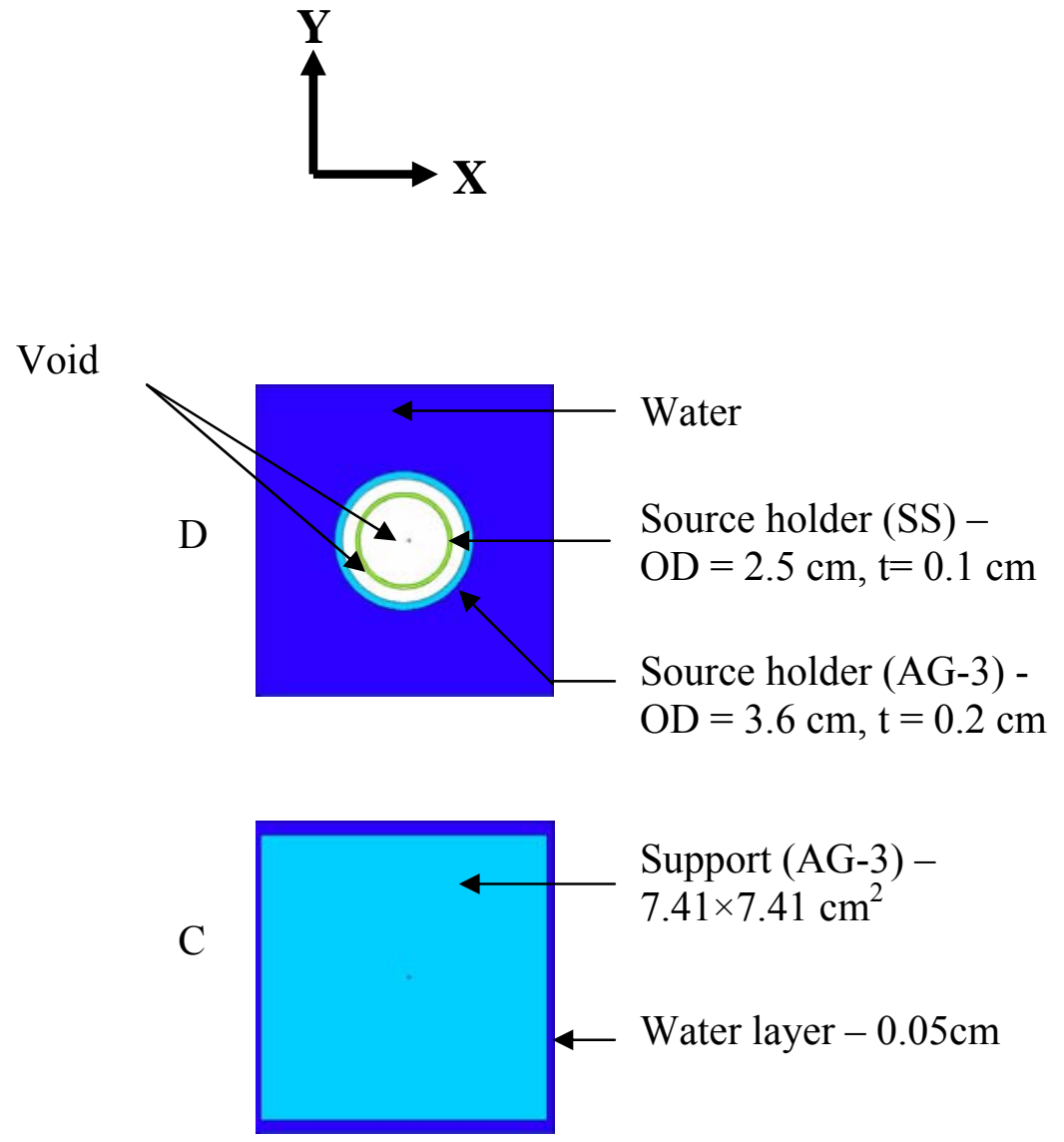

Grid plate (AL5) $8.1 \times 7.71 \mathrm{~cm}^{2}$

B
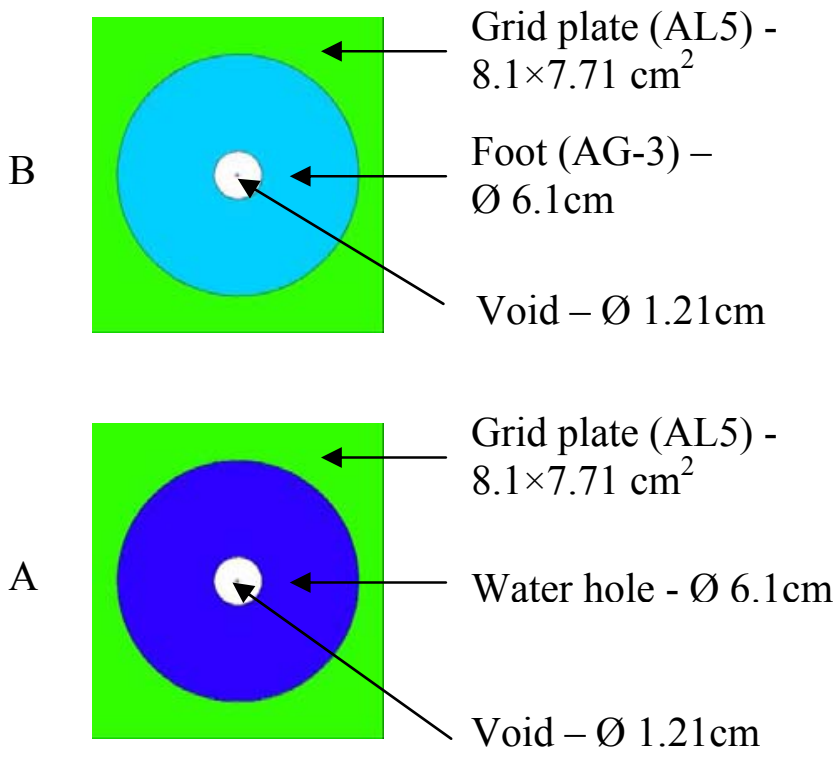

Figure 13: Start-up source elements - MCNP model 

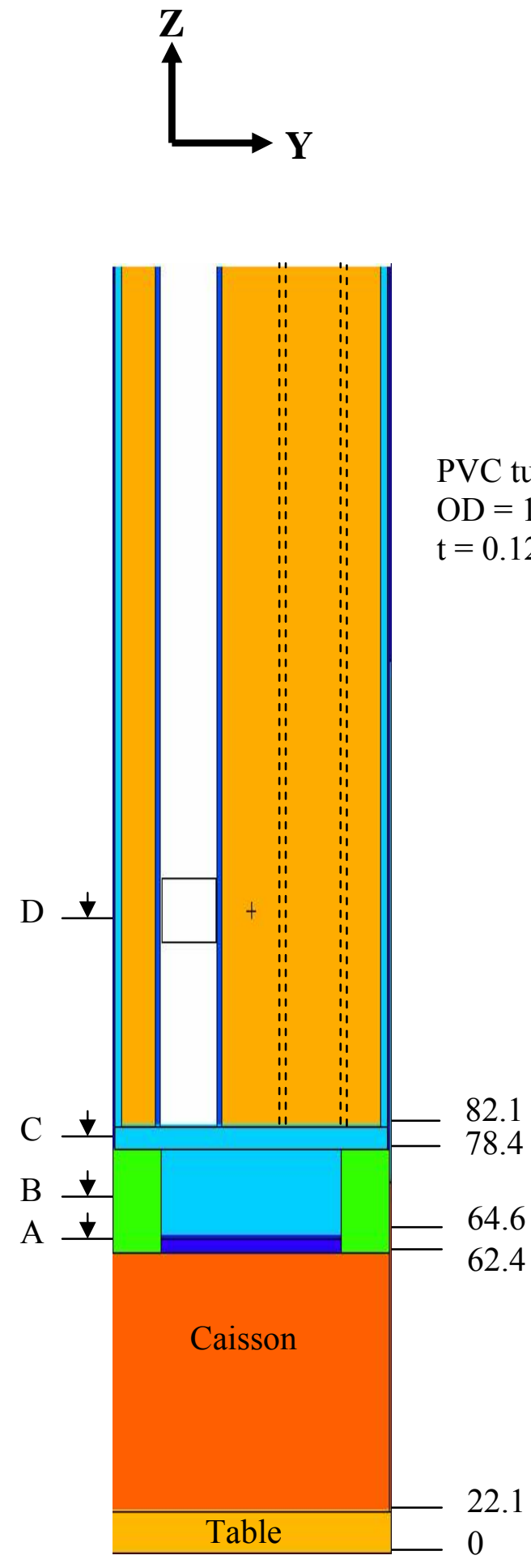

All dimensions in $\mathrm{cm}$

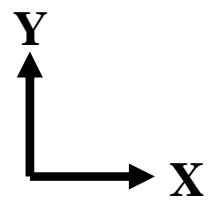

Void
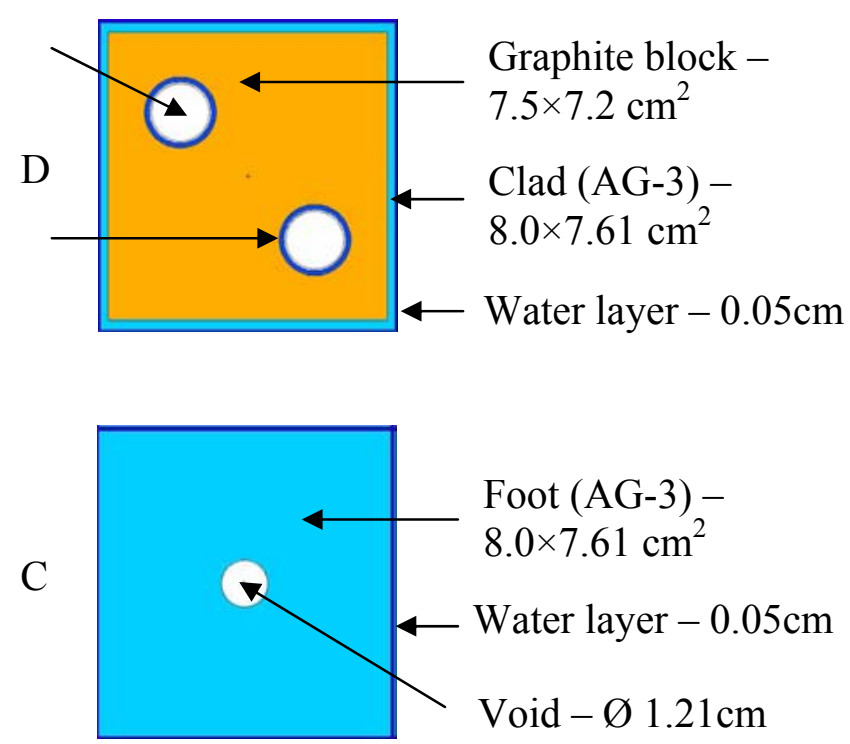

Grid plate (AL5) $8.1 \times 7.71 \mathrm{~cm}^{2}$

B
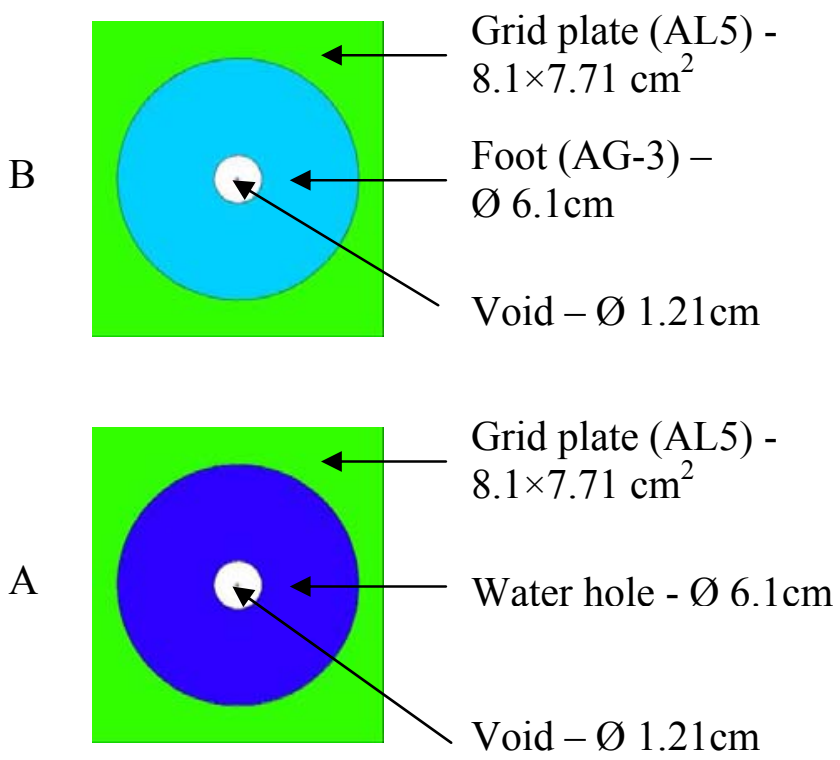

Figure 14: Thermal column - MCNP model 


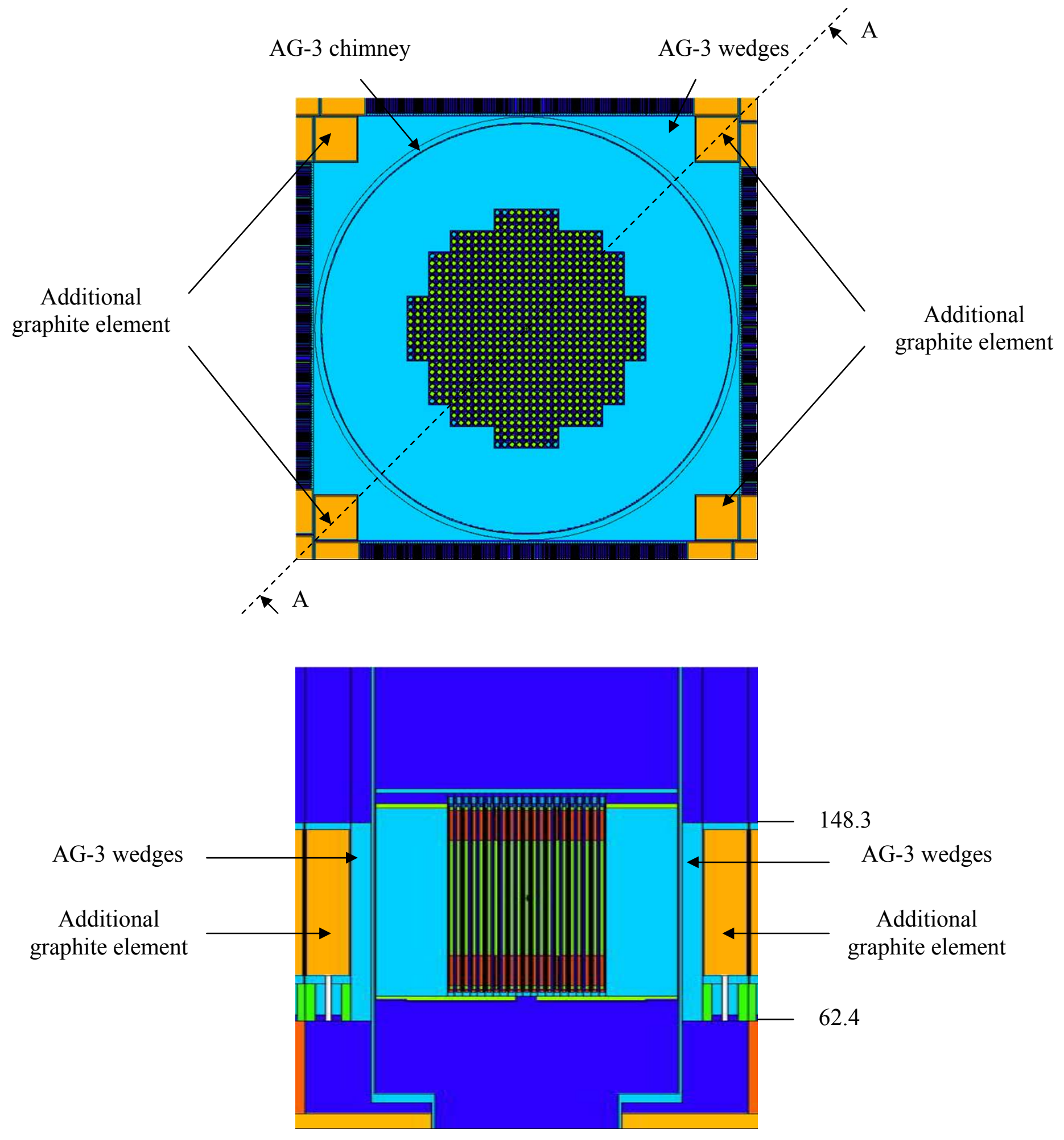

Section A-A

Figure 15: AG-3 wedges and additional graphite element - MCNP model 

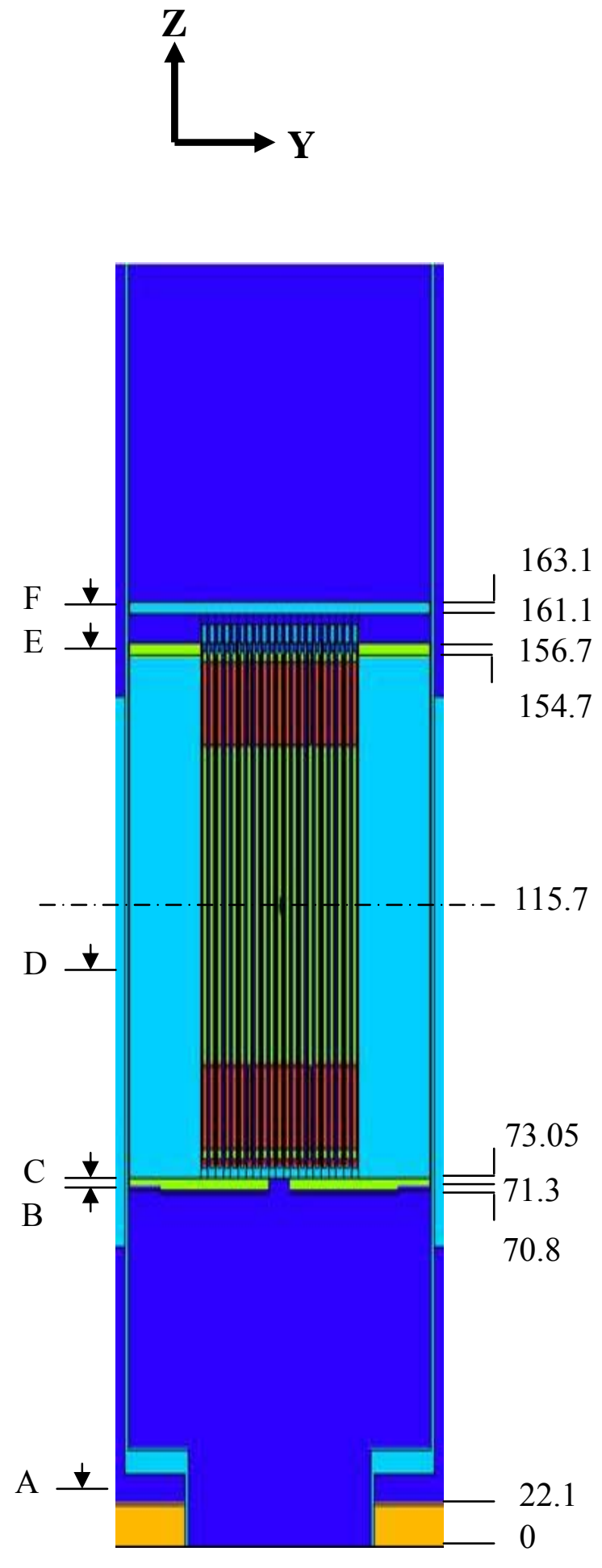

All dimensions in $\mathrm{cm}$

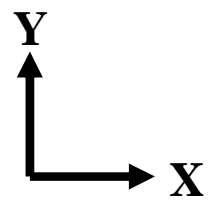

\section{Experimental lattice}

E

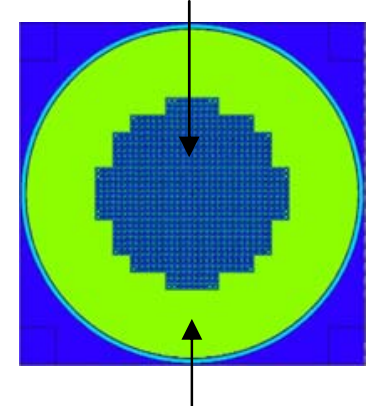

Upper plate (SS)

$\varnothing 71.2 \mathrm{~cm}$

Lower plate (SS)

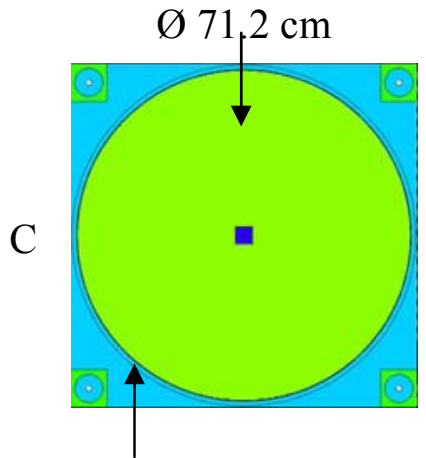

Chimney - Upper part $\mathrm{OD}=73.5 \mathrm{~cm}, \mathrm{t}=1 \mathrm{~cm}$

Chimney - Lower part $\mathrm{OD}=45 \mathrm{~cm}, \mathrm{t}=1 \mathrm{~cm}$

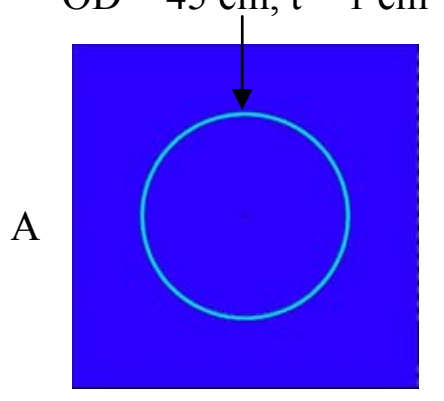

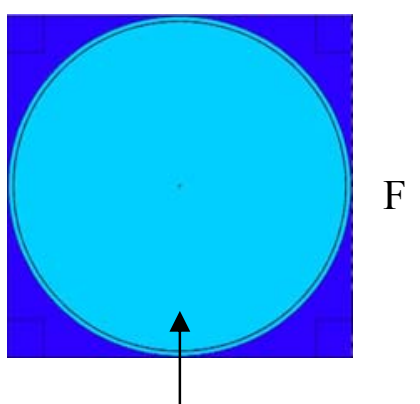

Upper protection plate (AG-3) $\varnothing 71.2 \mathrm{~cm}$

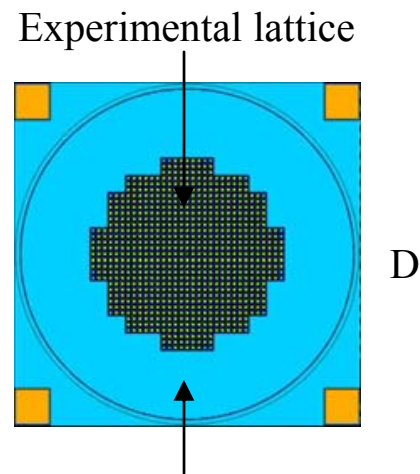

AG-3 blocks

Spool - Upper plate $\varnothing 56 \mathrm{~cm}$

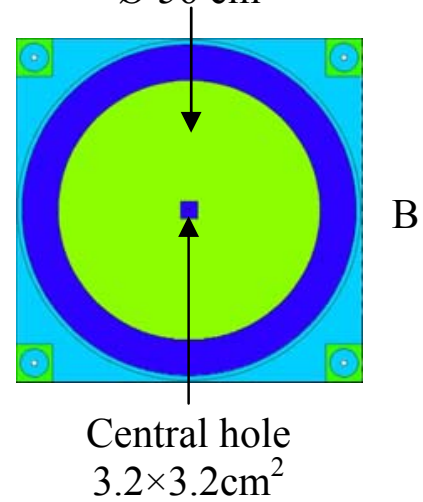

Figure 16: Experimental zone \& MELODIE massif - MCNP model 
All dimensions in $\mathrm{cm}$

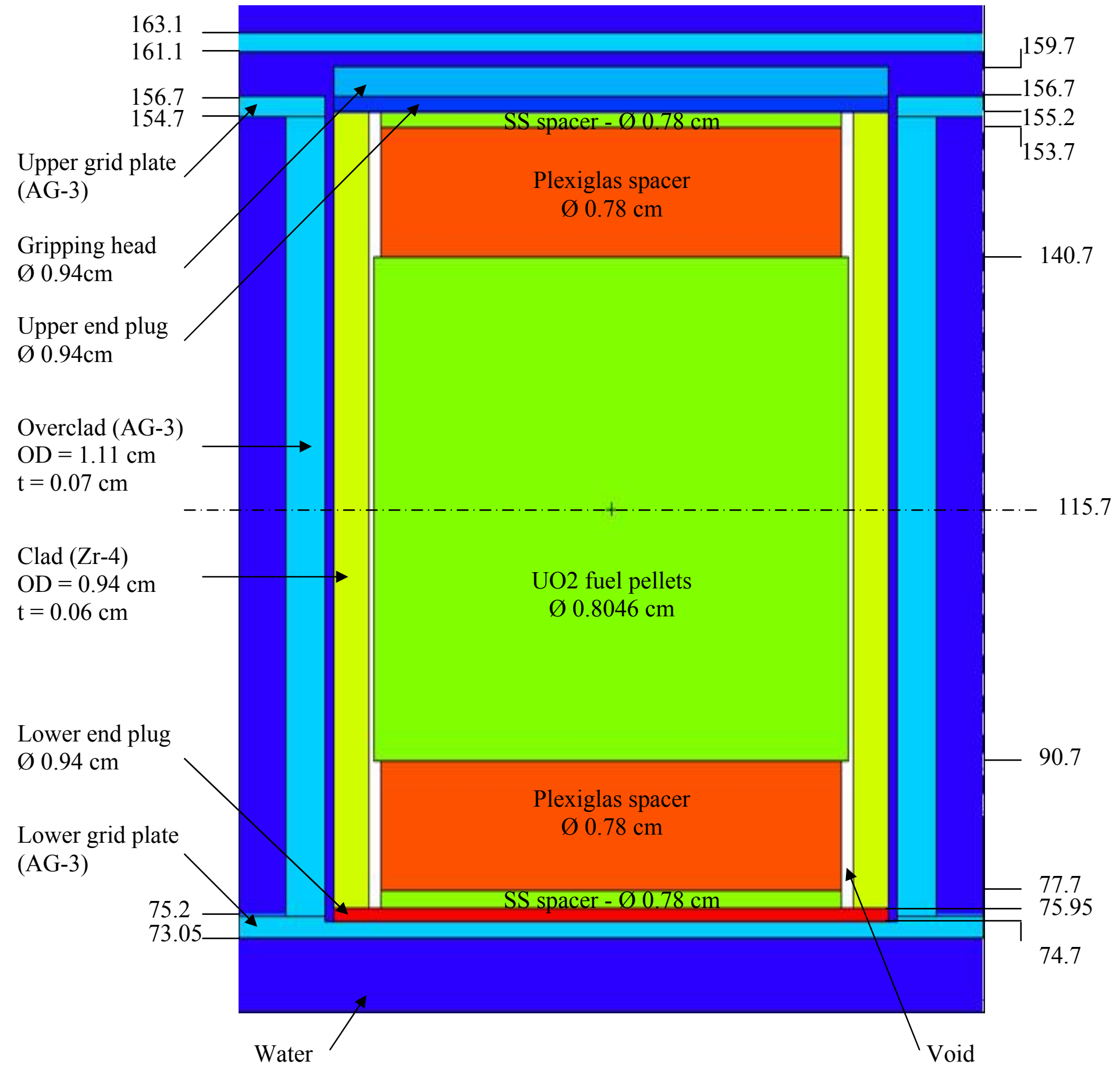

Figure 17: UO2 pin - MCNP model 
All dimensions in $\mathrm{cm}$

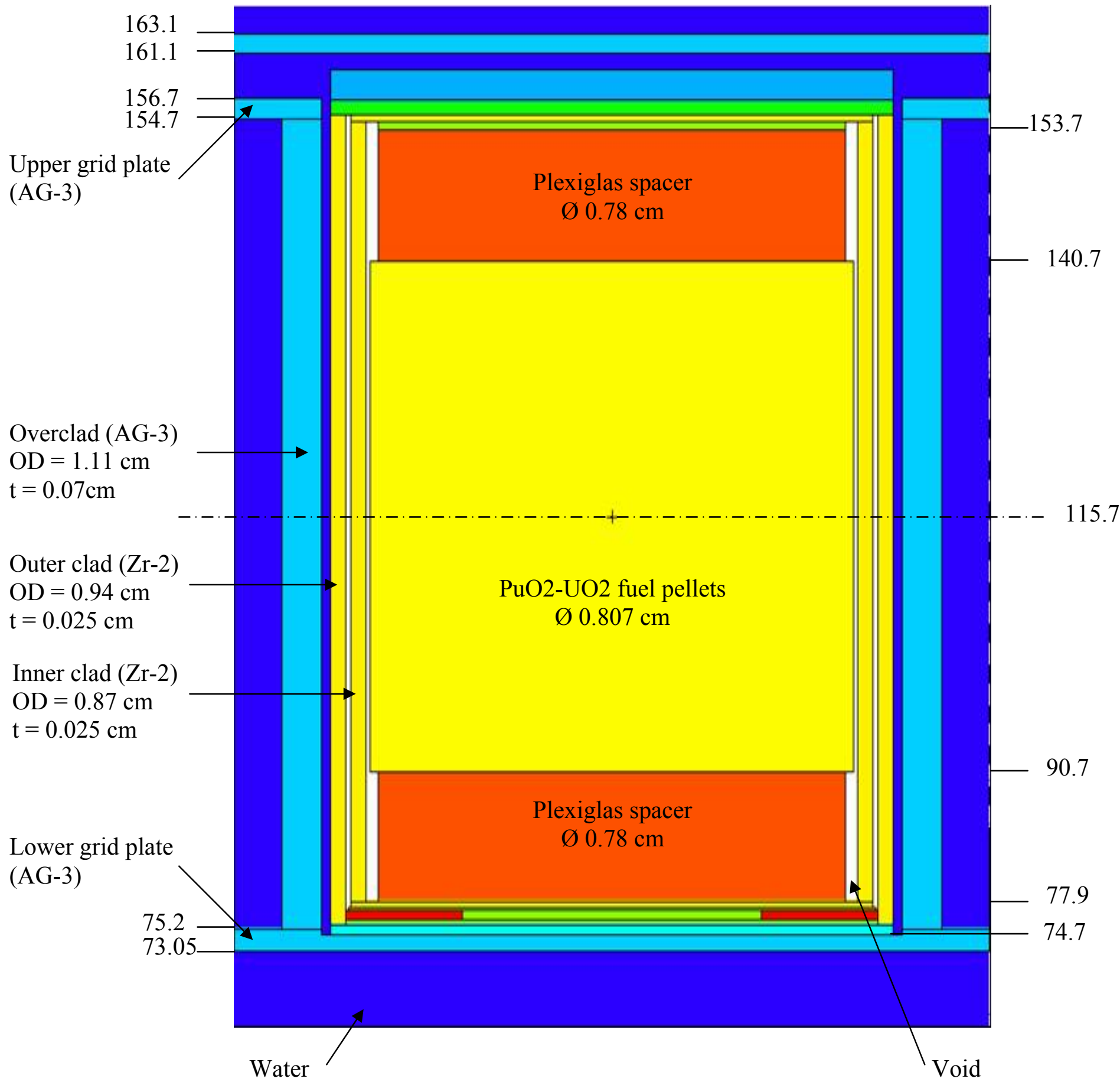

Figure 18: $\mathrm{PuO} 2-\mathrm{UO} 2$ pin - MCNP model 
All dimensions in $\mathrm{cm}$

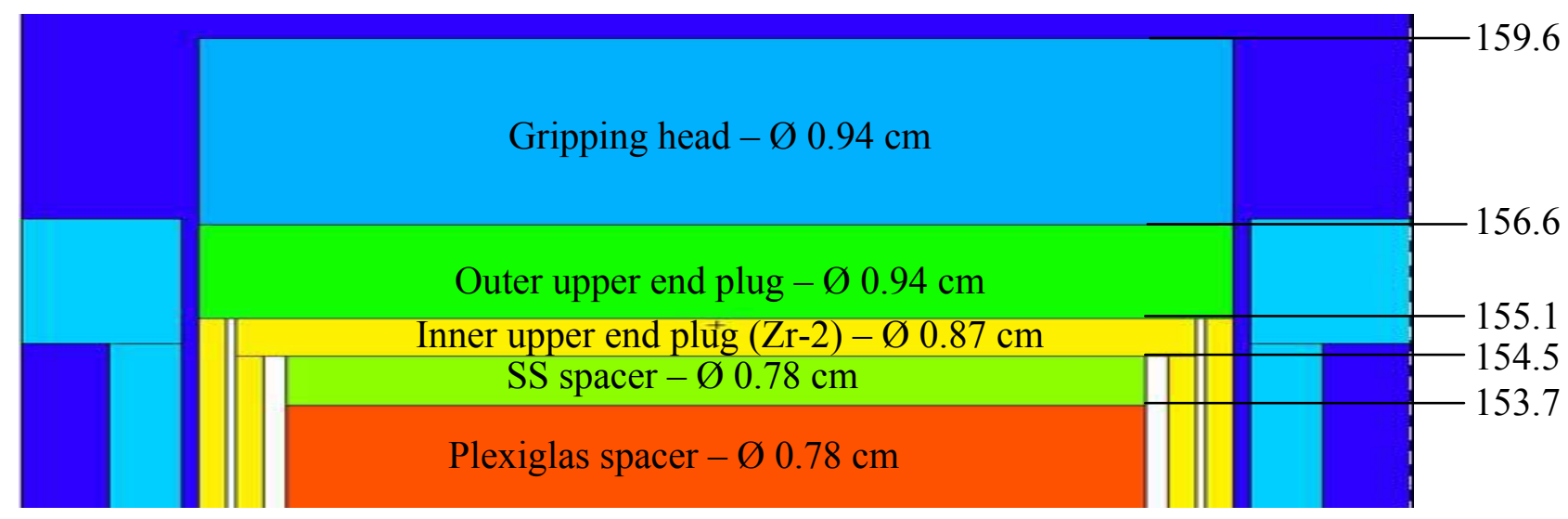

Upper portion of the fuel pin

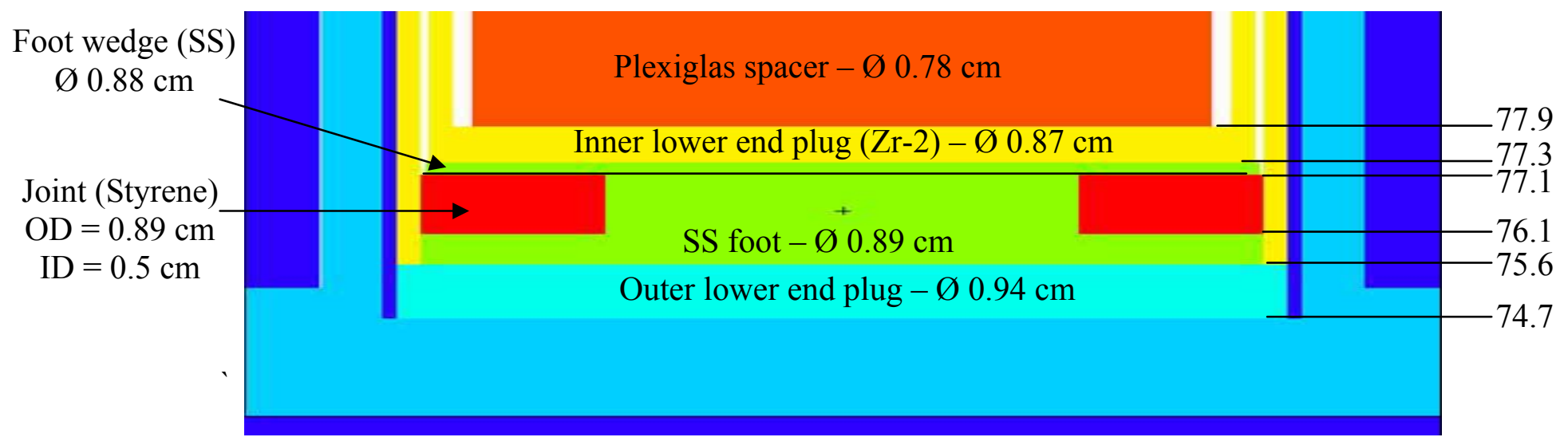

Lower portion of the fuel pin

Figure 19: Details of the PuO2-UO2 pin - MCNP model 
All dimensions in $\mathrm{cm}$

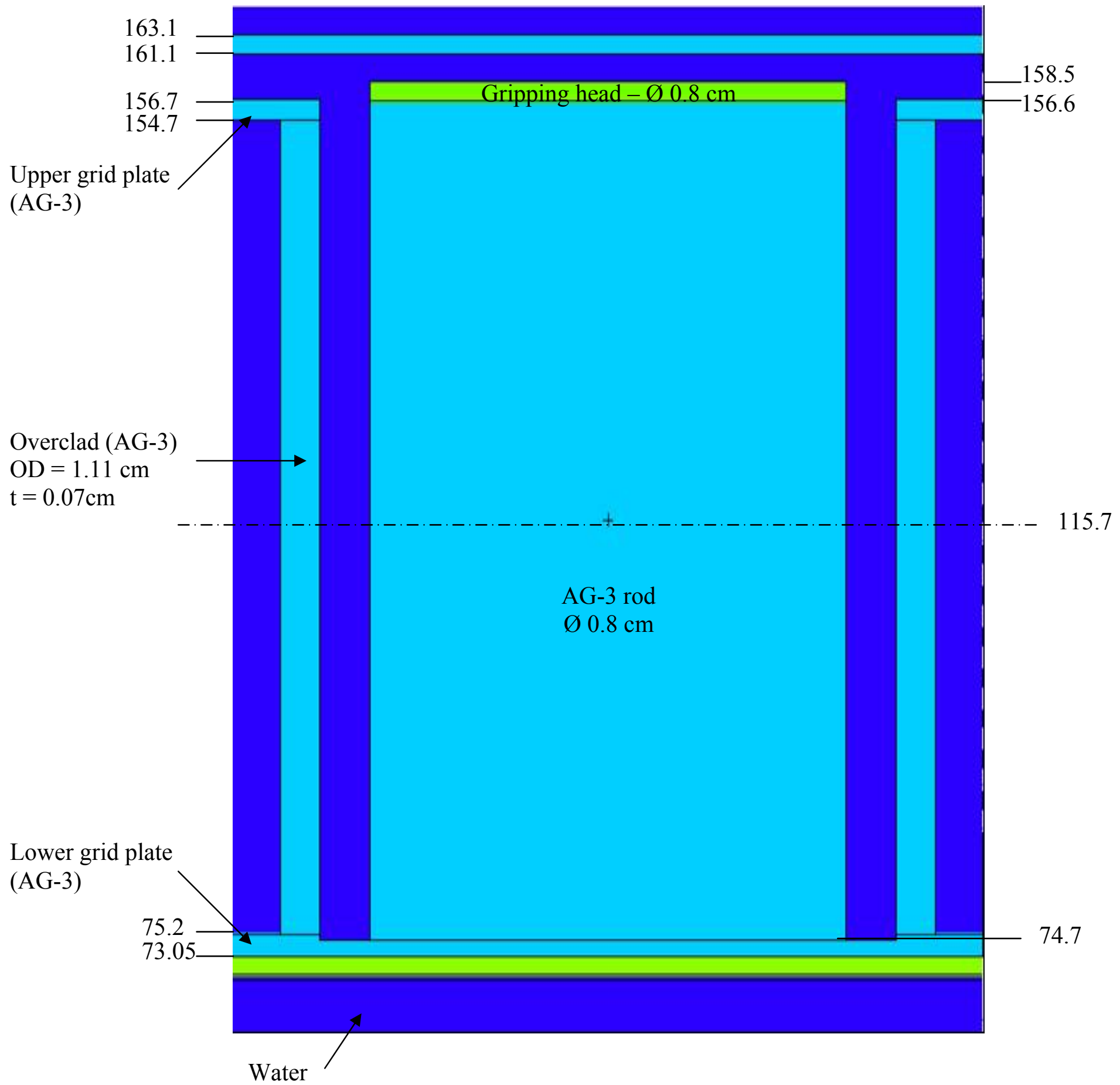

Figure 20: Aluminum pin - MCNP model 


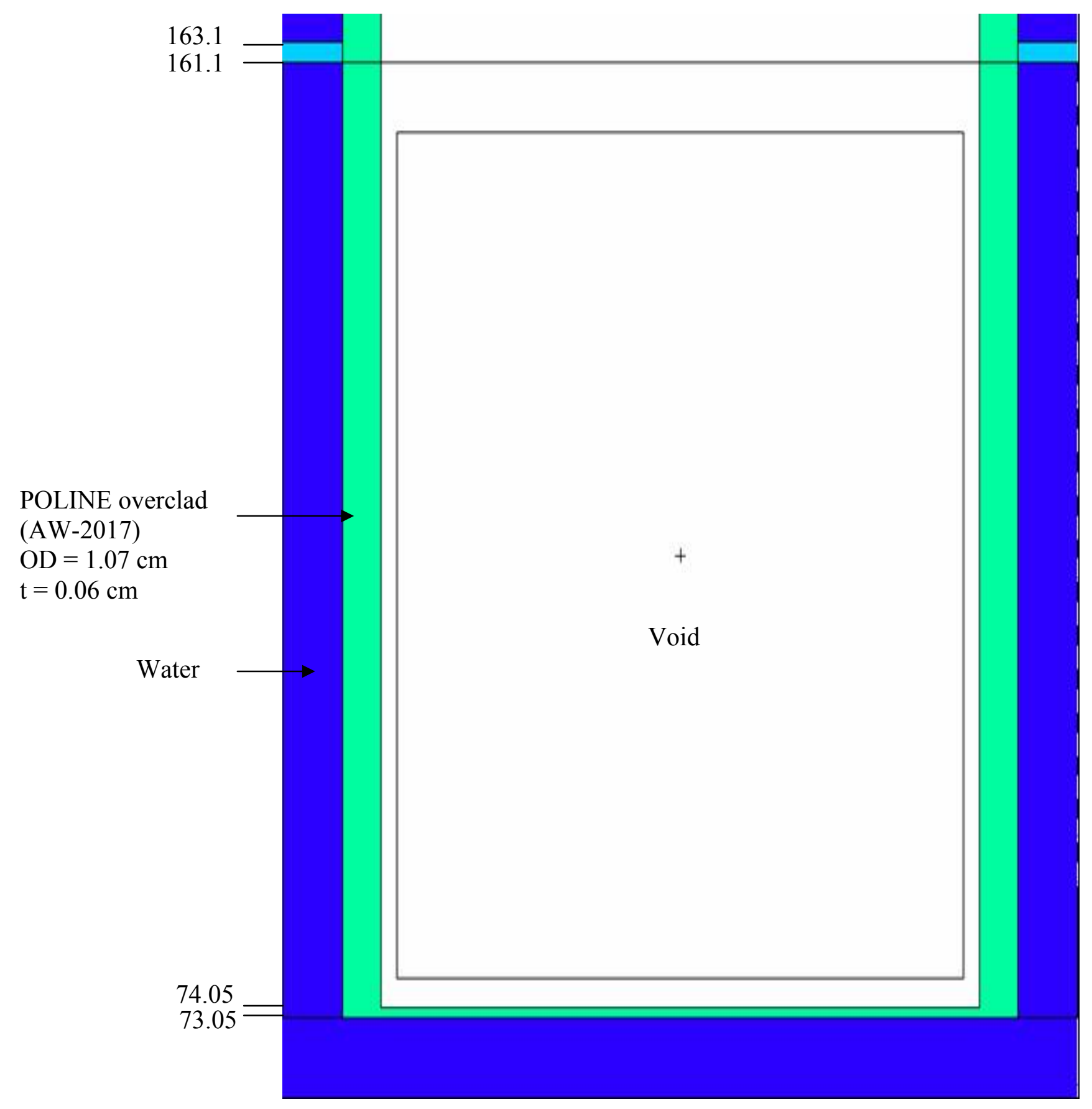

Figure 21: POLINE overclad - MCNP model 


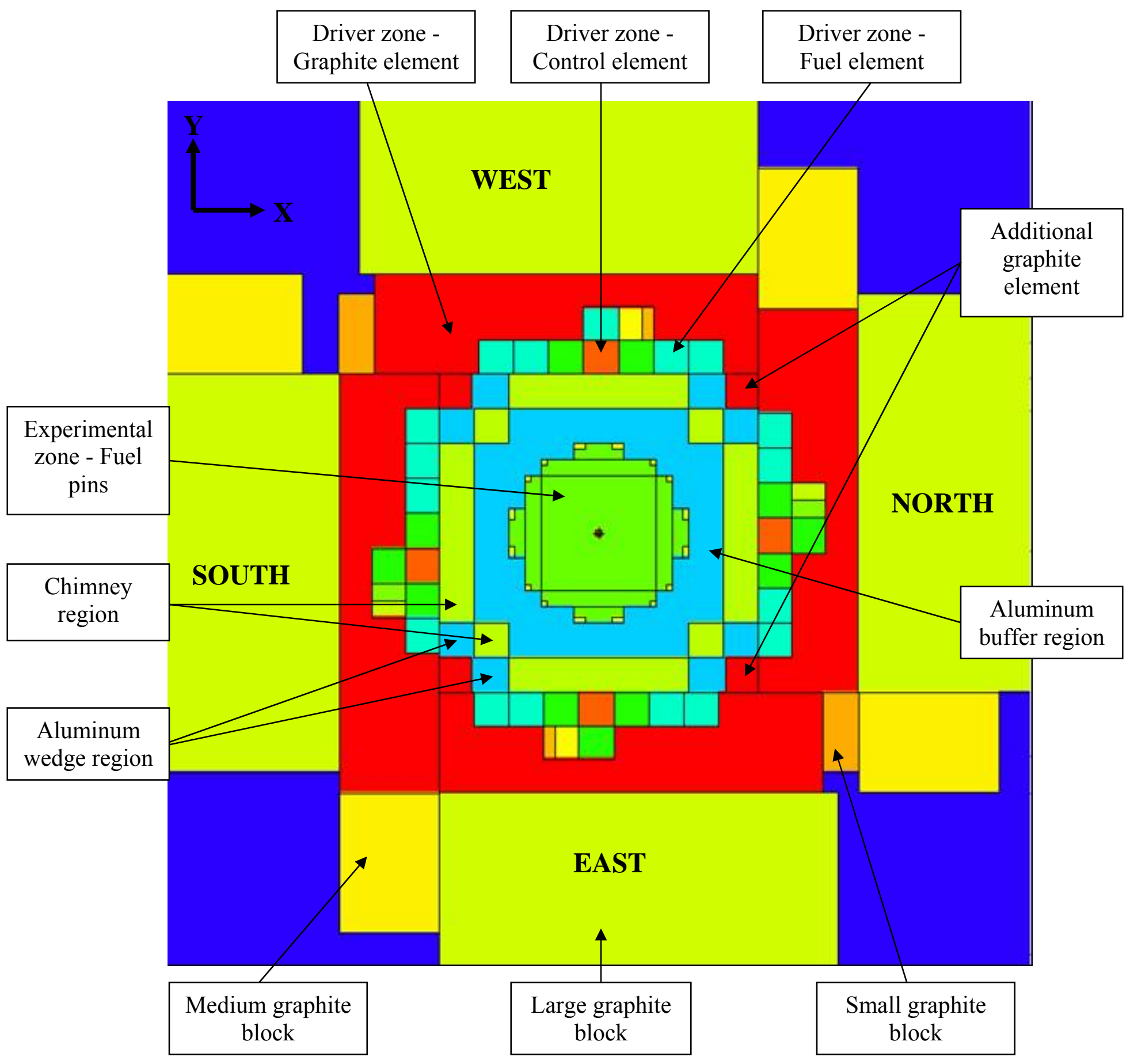

Figure 22: Radial view of the REBUS model in the R1UO2 configuration 


\section{POLINE overclad}

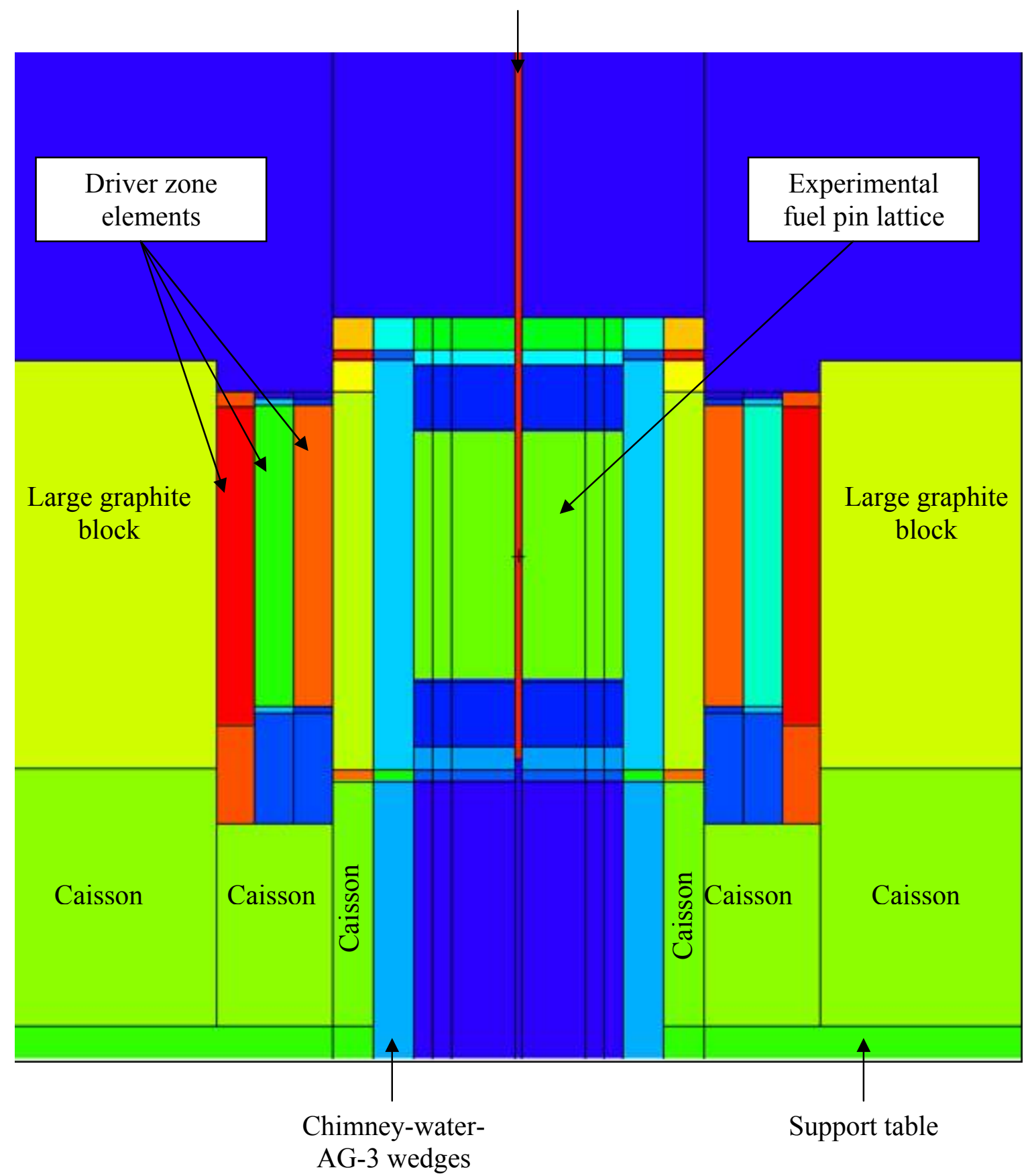

Figure 23: Axial view of the REBUS model in the R1UO2 configuration 

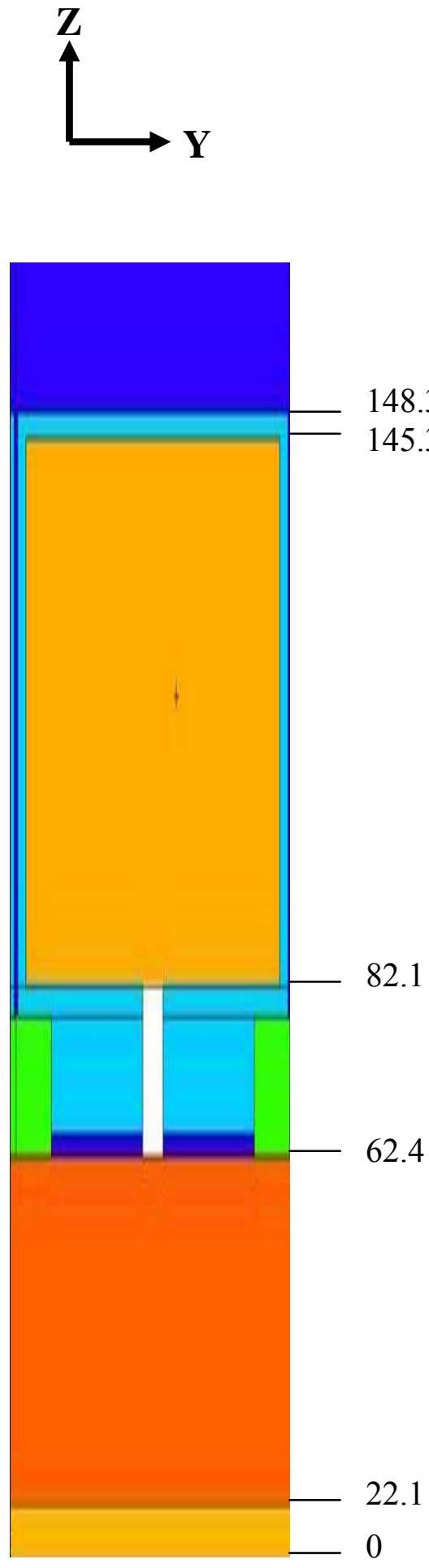

MCNP
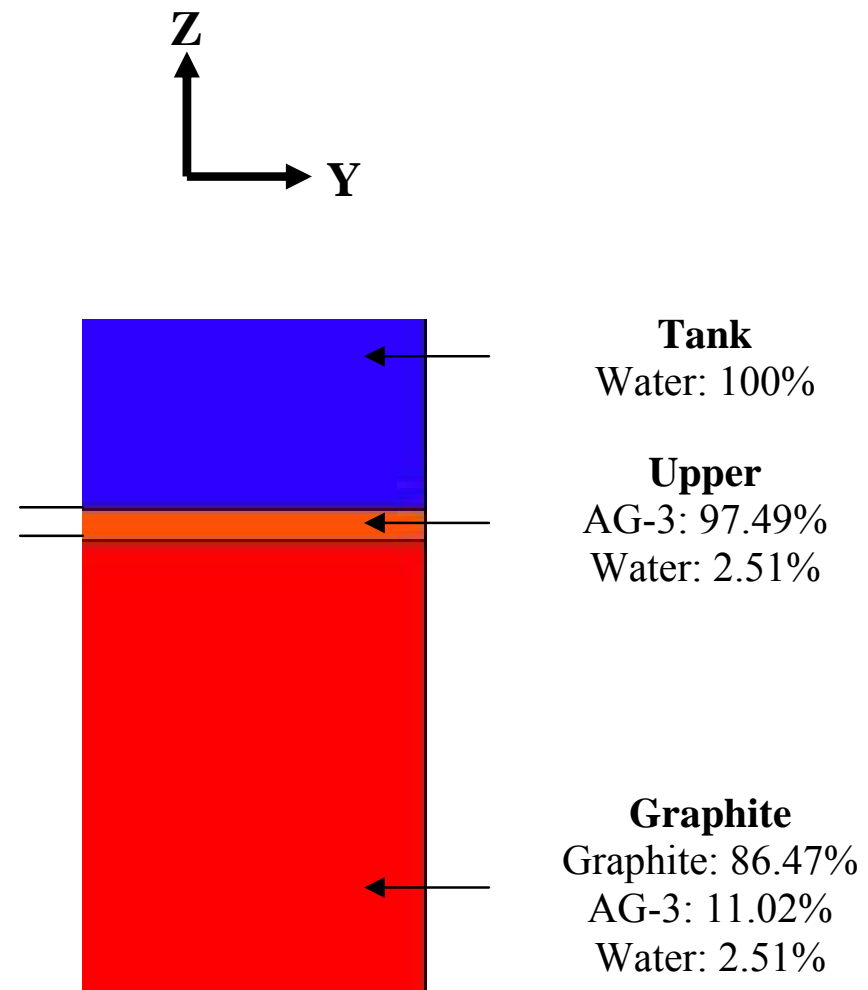

\section{Foot}

AL-5: $52.58 \%$ AG-3: $41.10 \%$ Water: $4.48 \%$ Void: $1.84 \%$

\section{Caisson}

Water: 80\%

AG-3: 20\%

\section{Table}

AG-3: 82\%

Water: 18\%

\section{REBUS}

Figure 24: Graphite element - MCNP \& REBUS models 

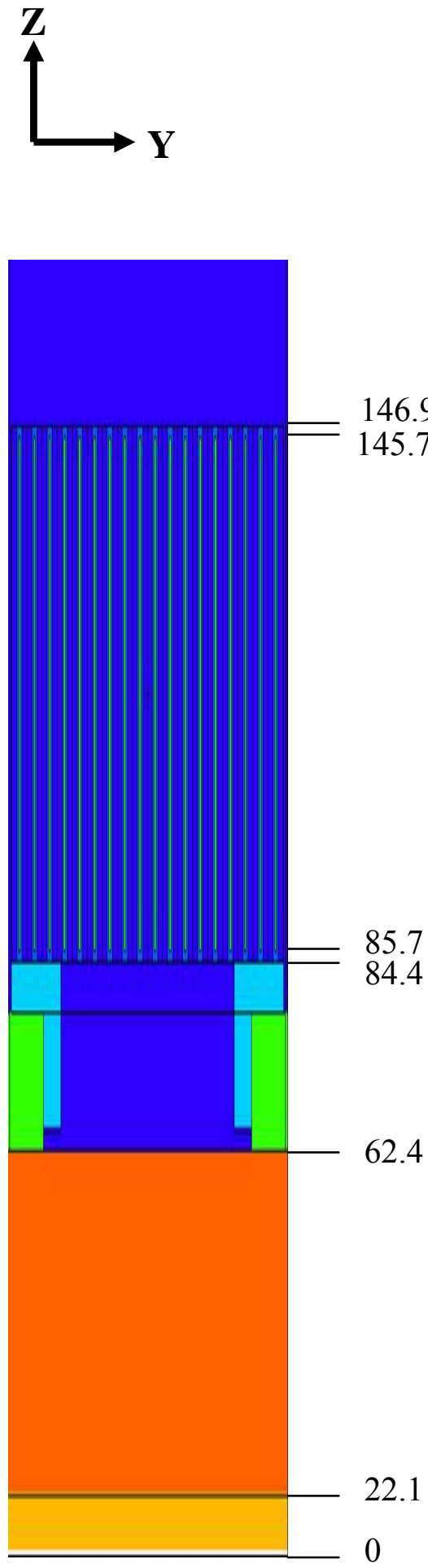

MCNP
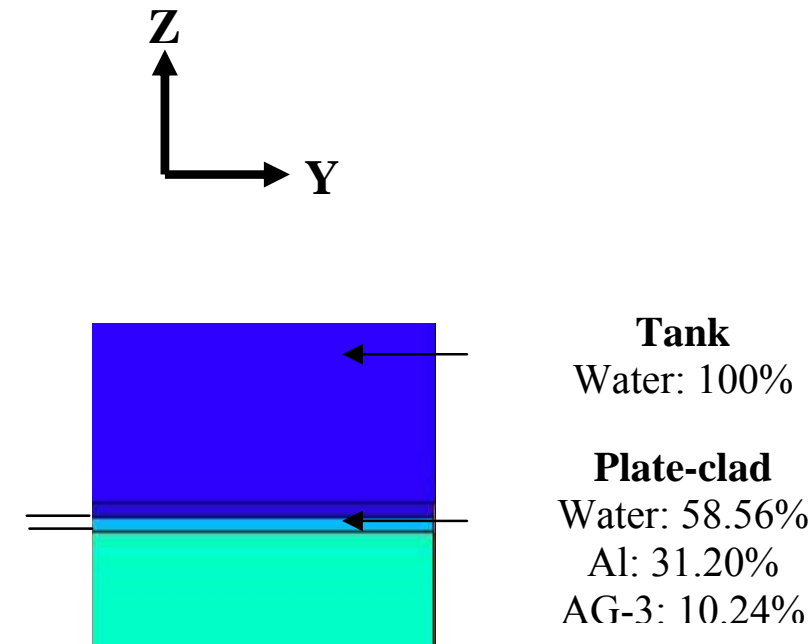

\section{Fuel plate}

Water: $58.56 \%$

Al: $21.68 \%$

AG-3: $10.24 \%$

Fuel: $9.52 \%$

\section{Plate-clad}

\section{Foot}

Water: $43.46 \%$

AL-5: $38.58 \%$

AG-3: 17.96\%

\section{Caisson}

Water: $80 \%$

AG-3: 20\%

\section{Table}

AG-3: 82\%

Water: 18\%

Figure 25: 18-plate fuel element - MCNP \& REBUS models 

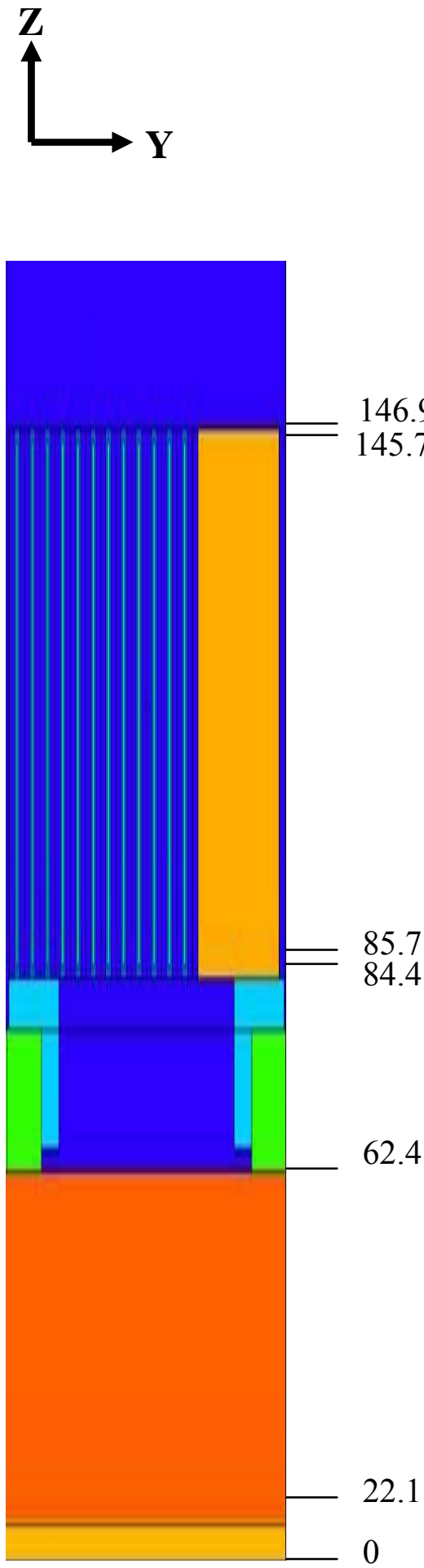

MCNP

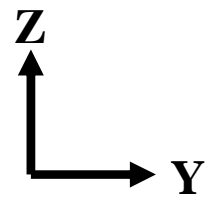

Tank

Water: $100 \%$

Plate-clad

Water: 43.16\% - Graphite: $22.86 \%$ Al: 20.79\% - AG-3: 13.19\%

\section{Graphite}

Graphite: $71.44 \%$

AG-3: $16.16 \%$

Water: $12.40 \%$

Fuel plate

Water: $52.46 \%$

Al: $21.68 \%$

AG-3: $16.34 \%$

Fuel: $9.52 \%$

Plate-clad

\section{Foot}

Water: $43.46 \%$ AL-5: $38.58 \%$ AG-3: $17.96 \%$

\section{Caisson}

Water: $80 \%$

AG-3: 20\%

\section{Table}

AG-3: $82 \%$

Water: $18 \%$

Figure 26: 12-plate fuel element - MCNP \& REBUS models 

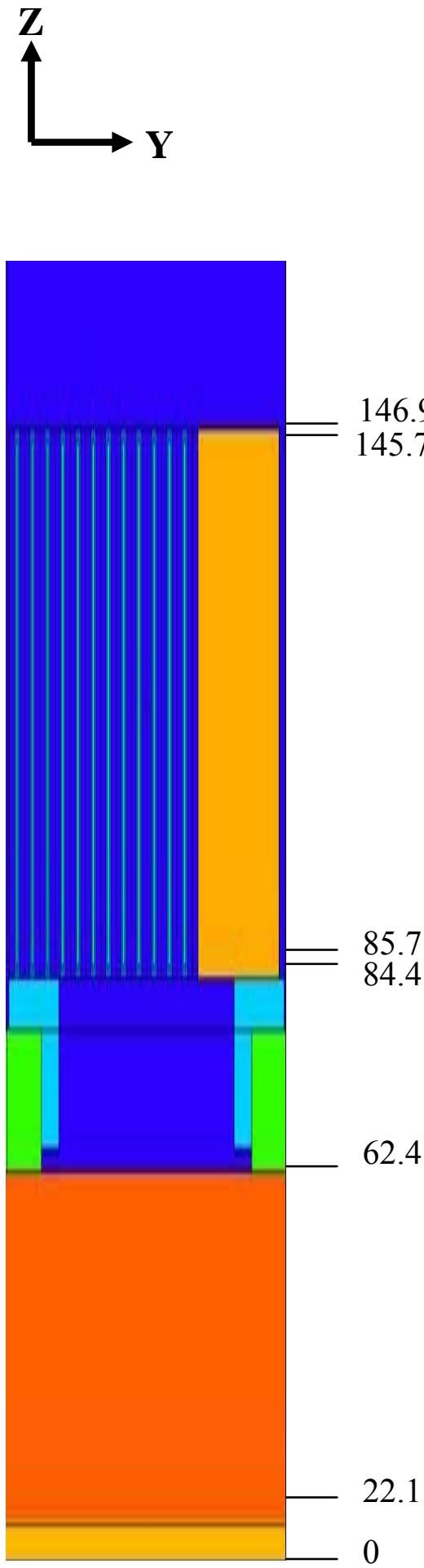

MCNP

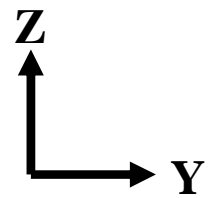

Tank

Water: $100 \%$

Plate-clad

Water: 33.84\% - Graphite: $36.32 \%$ Al: 15.60\% - AG-3: 14.24\%

\section{Graphite}

Graphite: $76.60 \%$

AG-3: $15.26 \%$

Water: $8.14 \%$

Fuel plate

Water: $58.92 \%$

Al: $21.27 \%$

AG-3: $10.27 \%$

Fuel: $9.40 \%$

Plate-clad

\section{Foot}

Water: $43.46 \%$ AL-5: $38.58 \%$ AG-3: $17.96 \%$

\section{Caisson}

Water: $80 \%$

AG-3: 20\%

\section{Table}

AG-3: $82 \%$

Water: $18 \%$

Figure 27: 9-plate fuel element - MCNP \& REBUS models 

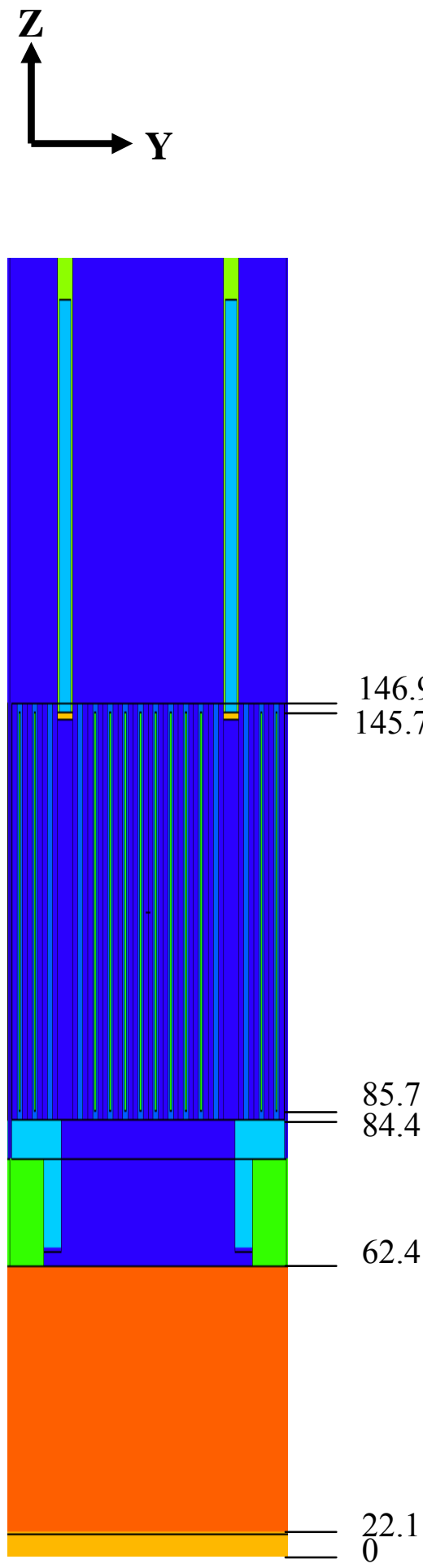

MCNP

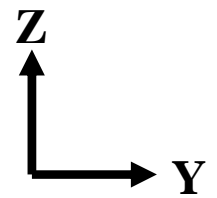

Tank

Water: $100 \%$

Plate-clad

Water: $61.82 \%$

Al: $27.72 \%$

AG-3: $10.46 \%$

46.95

145.7

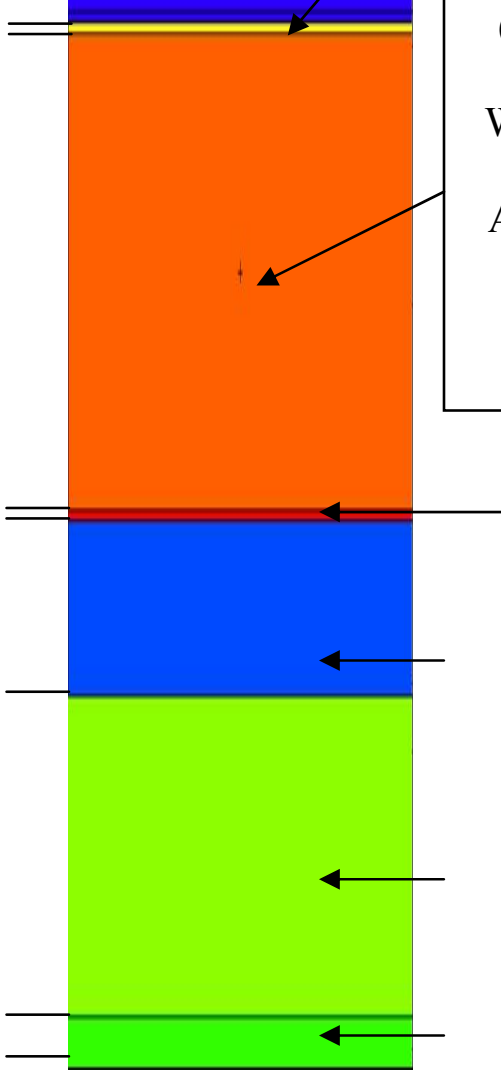

REBUS

\section{Caisson}

Water: $80 \%$

AG-3: 20\%

\section{Table}

AG-3: $82 \%$

Water: $18 \%$
Fuel plate (Control rod inserted)

Water: $52.68 \%$

Al: $21.38 \%$

AG-3: $10.46 \%$

Fuel: $6.34 \%$

Hf: $6.95 \%$

SS: $2.19 \%$

\section{Plate-clad}

Water: $61.82 \%$ - Al: $27.72 \%$

AG-3: $10.46 \%$

\section{Foot}

Water: $43.46 \%$ - AL-5: $38.58 \%$

AG-3: $17.96 \%$

Figure 28: Control element - MCNP \& REBUS models 


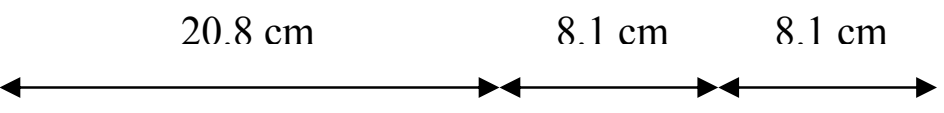

Chimney

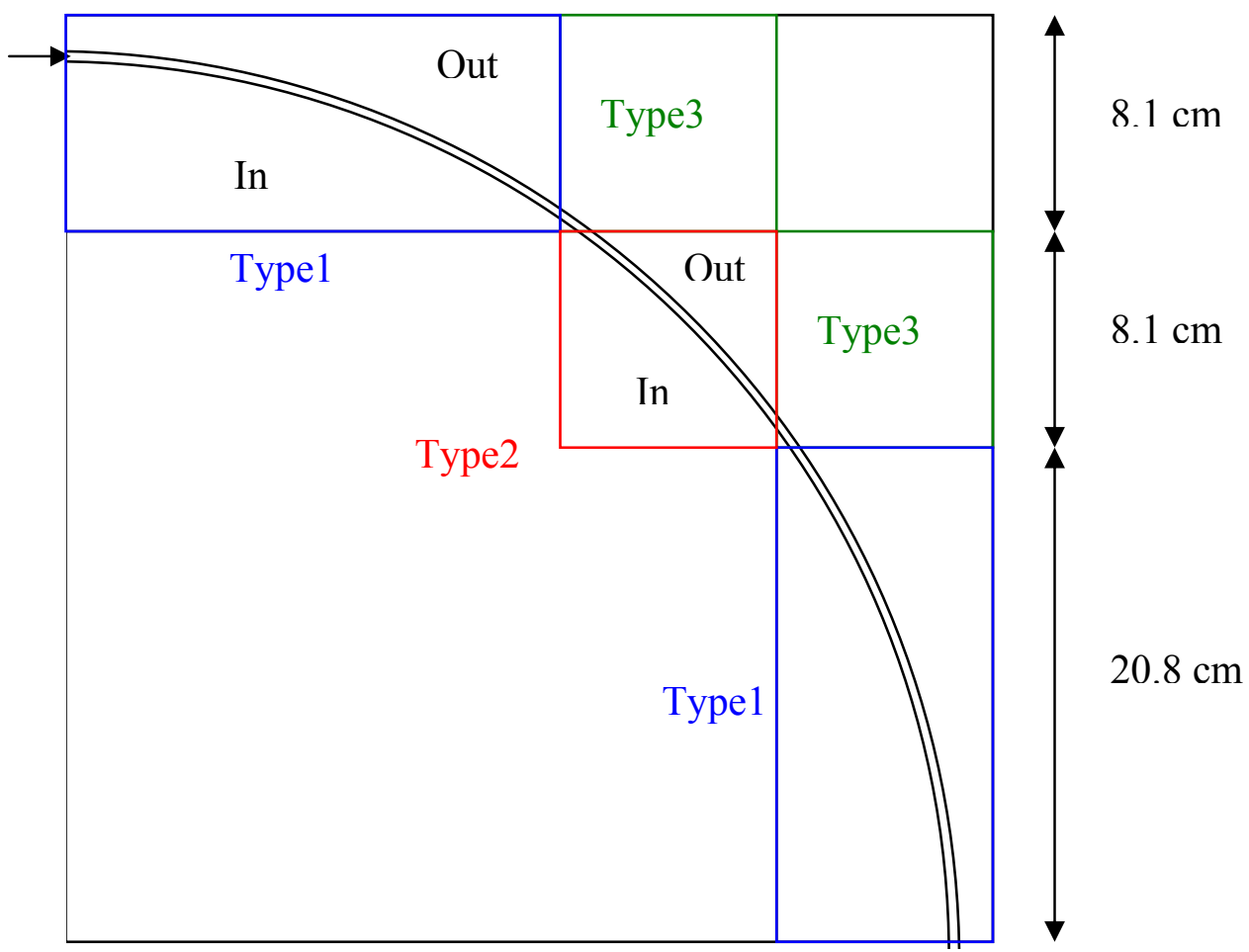

Type 1

(Surface: 83.7\%)

In: $58.22 \%$

Chimney: $13.15 \%$

Out: $28.63 \%$
Type 2

(Surface: 16.3\%)

In: $57.88 \%$

Chimney: $15.18 \%$

Out: $26.94 \%$
Type 3

Considered 100\%

out

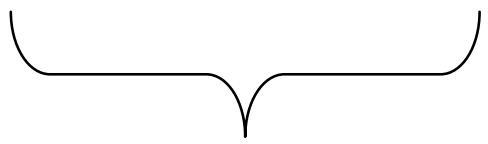

Final (Type1 \& 2)

In: $58.17 \%$

Chimney: $13.48 \%$

Out: $28.35 \%$

Figure 29: Radial decomposition of the chimney interface 

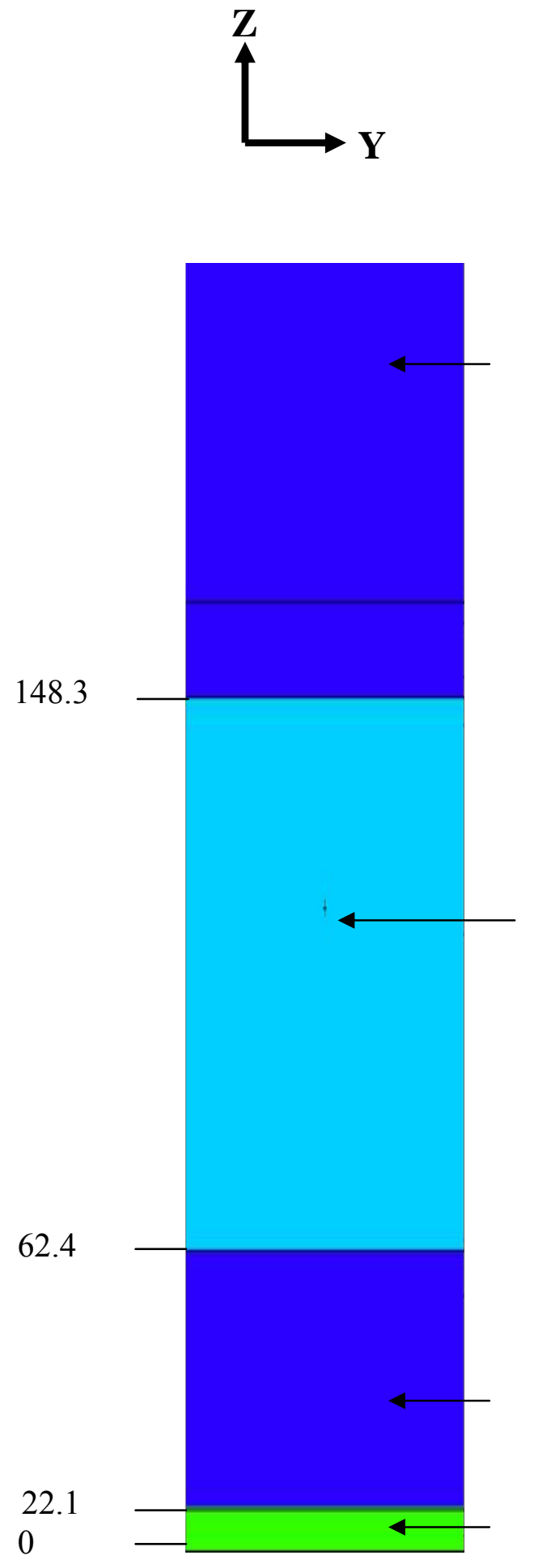

AG-3 wedges

AG-3: 100\%

Experimental zone

Water: $100 \%$

Table

AG-3: $82 \%$

Water: $18 \%$

Figure 30: AG-3 wedges - REBUS models 
All dimensions in $\mathrm{cm}$
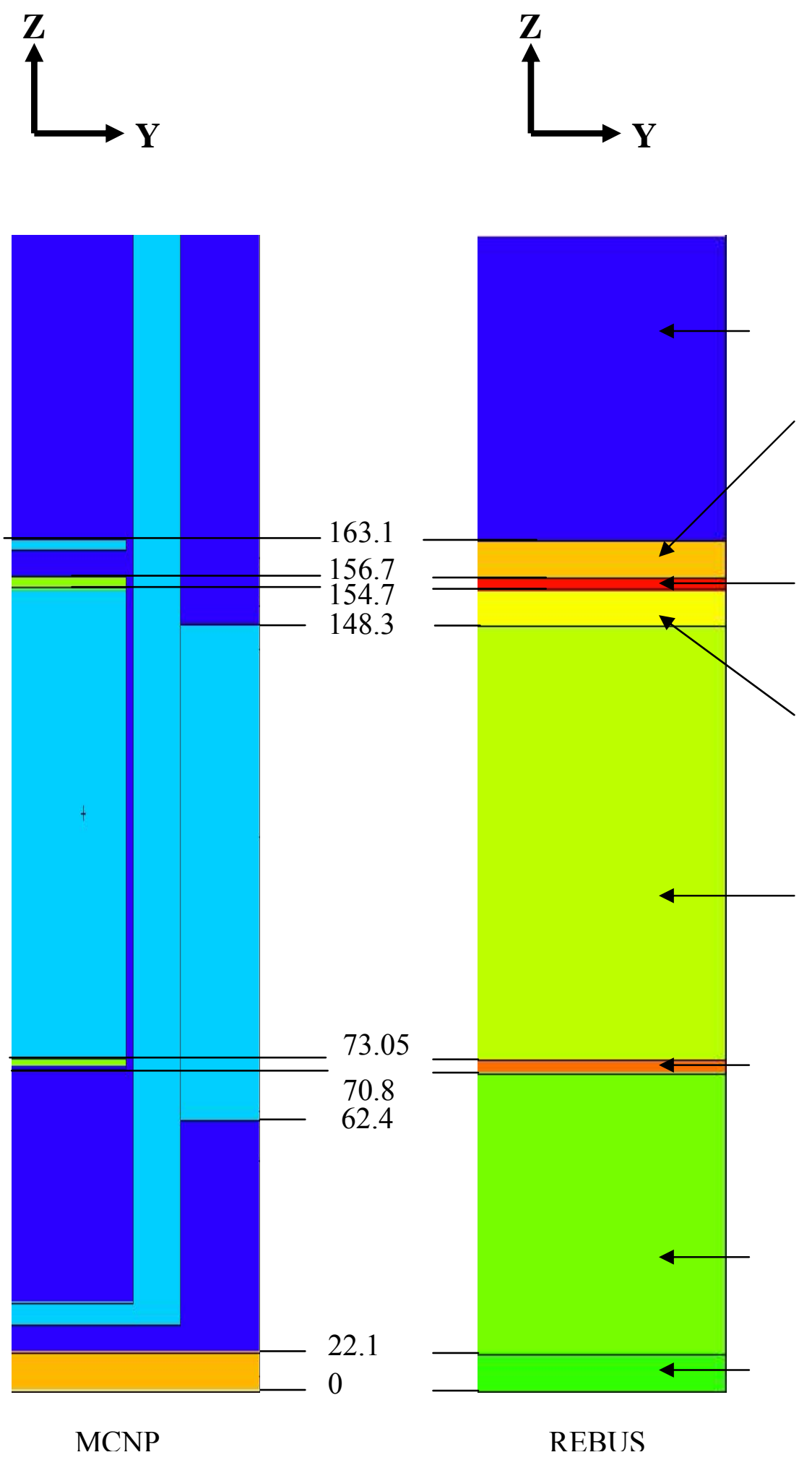

Tank

Water: $100 \%$

Section F

Water: $68.98 \%$ AG-3: $31.02 \%$

\section{Section E}

SS: $56.13 \%$

Water: $30.39 \%$

AG-3: $13.48 \%$

Section D

AG-3: $69.61 \%$

Water: $30.39 \%$

\section{Section C}

AG-3: $97.96 \%$

Water: $2.04 \%$

\section{Section B}

SS: $43.65 \%$

AG-3: 41.84\%

Water: $14.51 \%$

\section{Section A}

Water: $78.44 \%$

AG-3: $21.56 \%$

\section{Table}

AG-3: 82\%

Water: $18 \%$

Figure 31: Chimney - MCNP \& REBUS models 
All dimensions in $\mathrm{cm}$
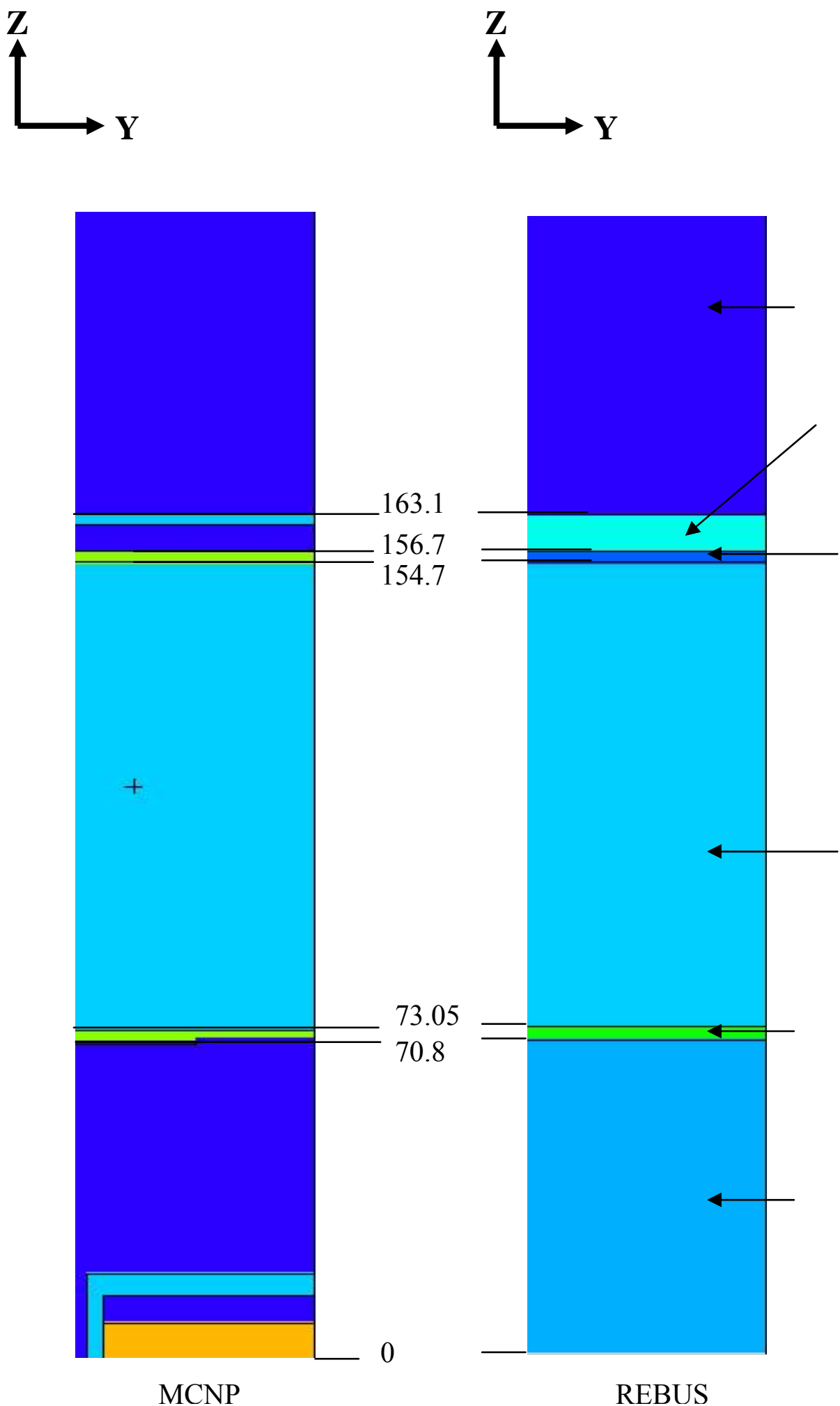

Tank

Water: $100 \%$

Section E

Water: $68.75 \%$

AG-3: $31.25 \%$

Section D

SS: $100 \%$

\section{Section C}

AG-3: 100\%

\section{Section B}

SS: $86.17 \%$

Water: $13.83 \%$

\section{Section A}

Water: $65.21 \%$

Table: $28.06 \%$

AG-3: $6.73 \%$

0

MCNP

REBUS

Figure 32: Aluminum buffer - MCNP \& REBUS models 
All dimensions in $\mathrm{cm}$
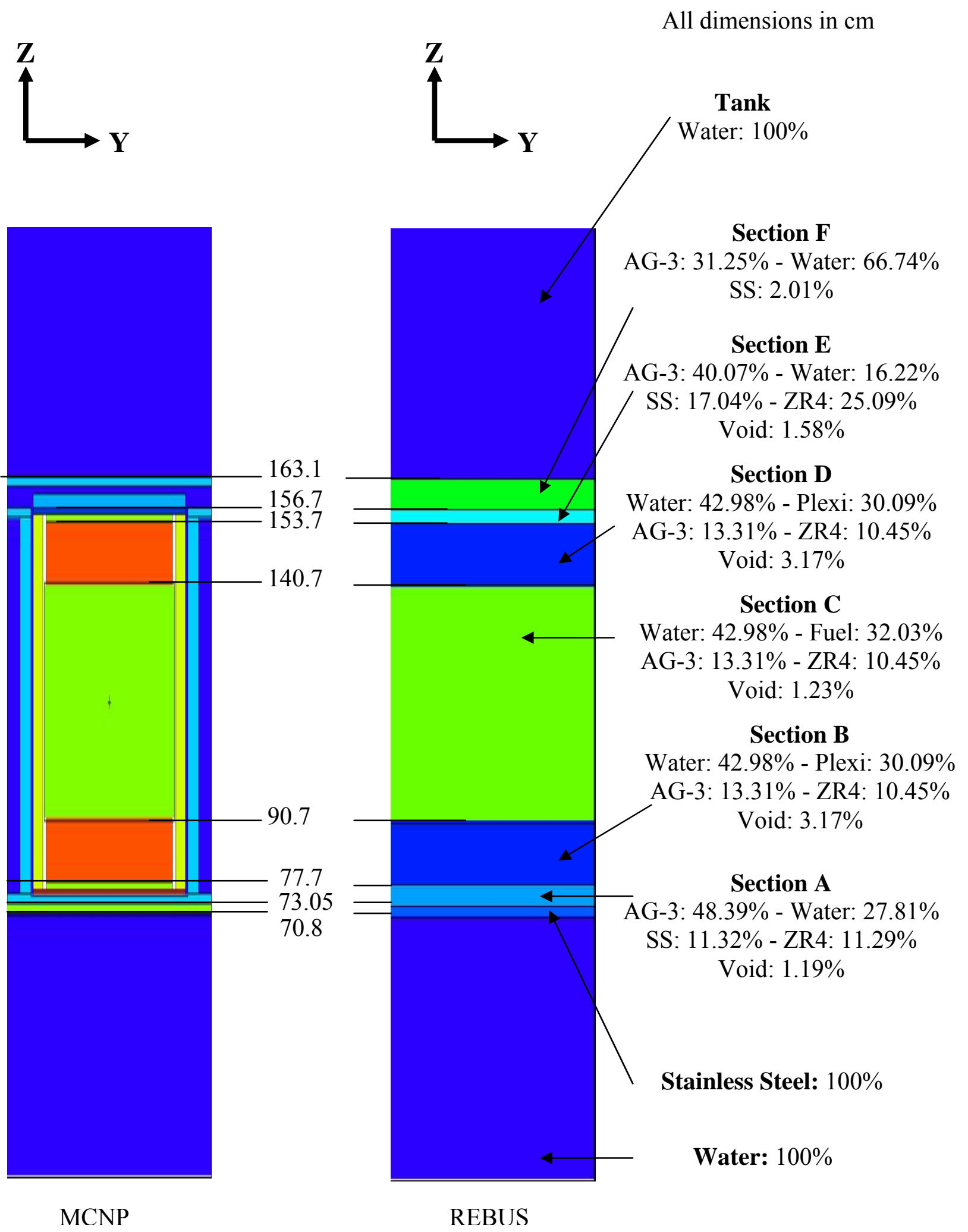

Figure 33: $\mathrm{UO}_{2}$ fuel pin region - MCNP \& REBUS models 
All dimensions in $\mathrm{cm}$
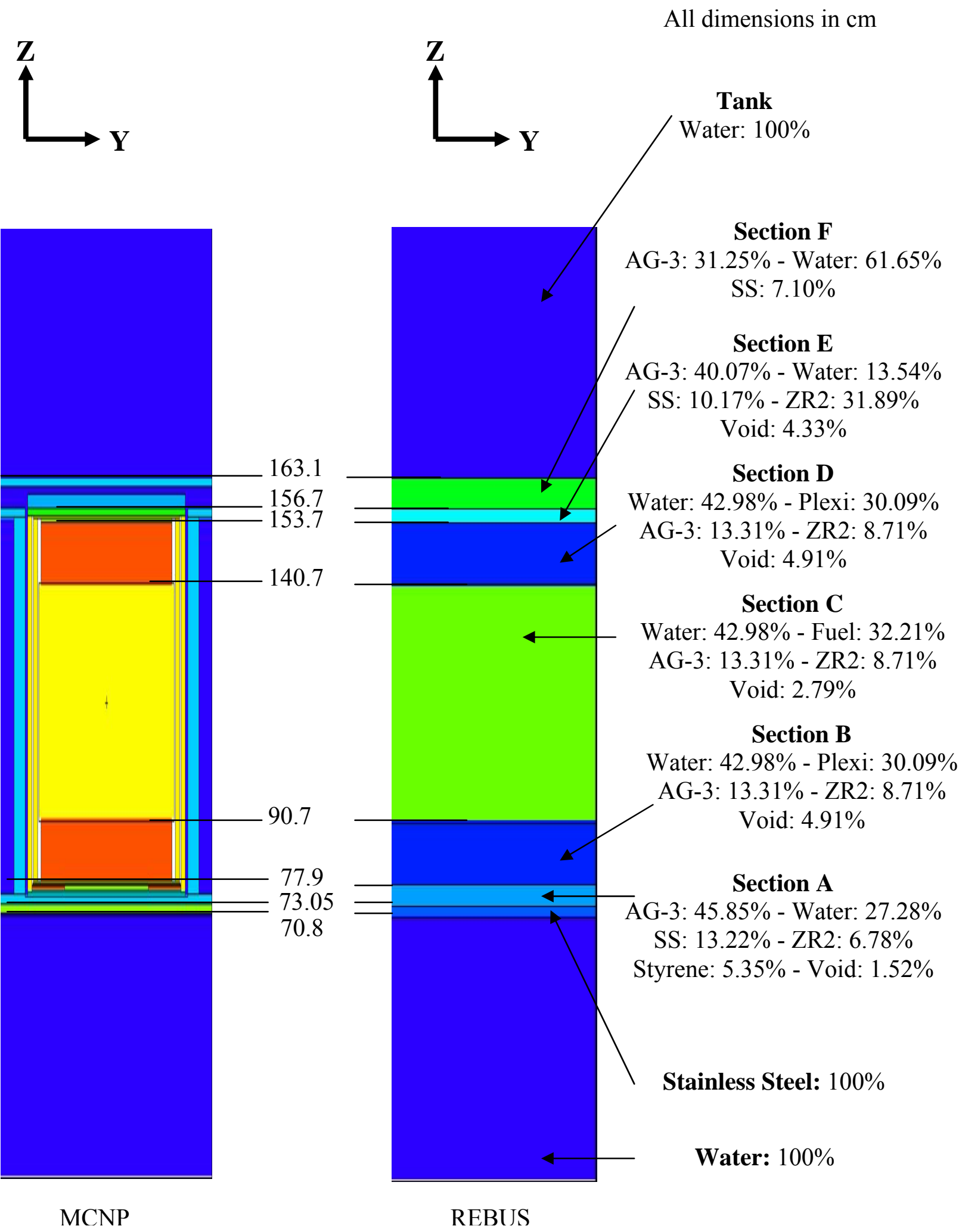

Figure 34: $\mathrm{UO}_{2}-\mathrm{PuO}_{2}$ fuel pin region - MCNP \& REBUS models 
All dimensions in $\mathrm{cm}$
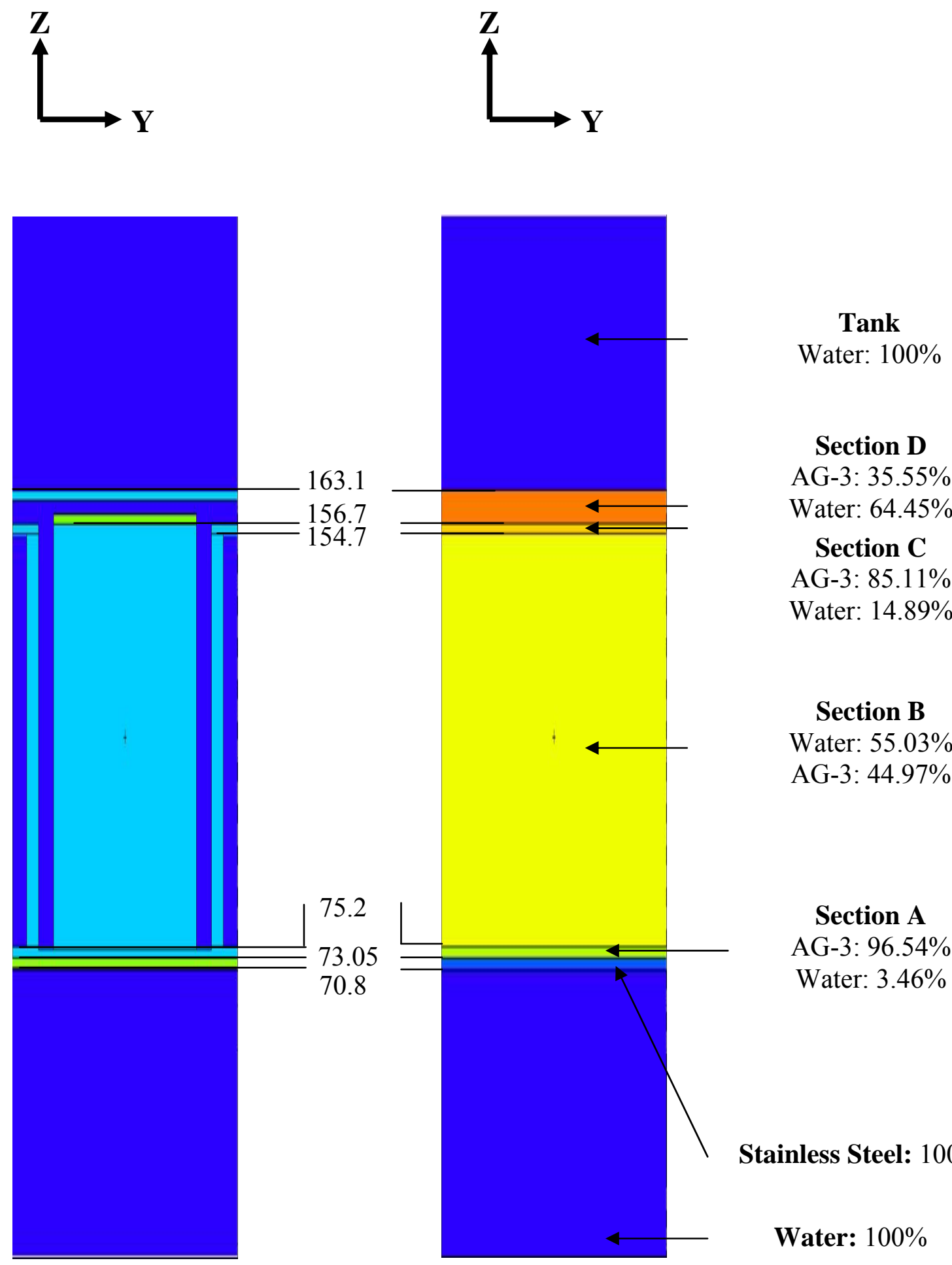

156.7

154.7

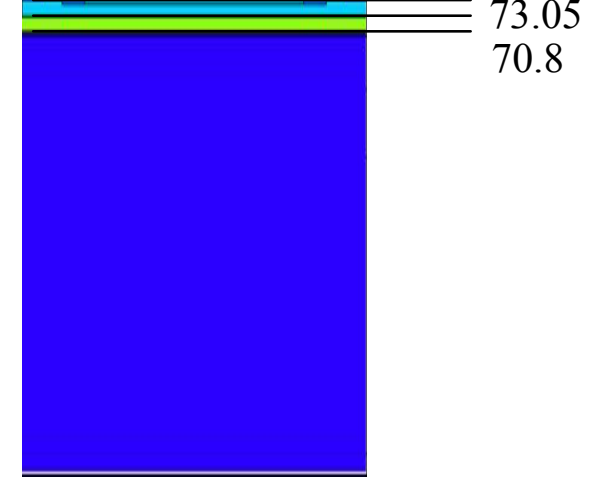

MCNP

Water: $100 \%$

\section{Section D}

AG-3: $35.55 \%$

Water: $64.45 \%$

Section C

AG-3: $85.11 \%$

Water: $14.89 \%$

\section{Section B}

Water: $55.03 \%$

AG-3: 44.97\%

\section{Section A}

AG-3: $96.54 \%$

Water: $3.46 \%$

Stainless Steel: $100 \%$

Water: $100 \%$

Figure 35: Aluminum fuel pin region - MCNP \& REBUS models 

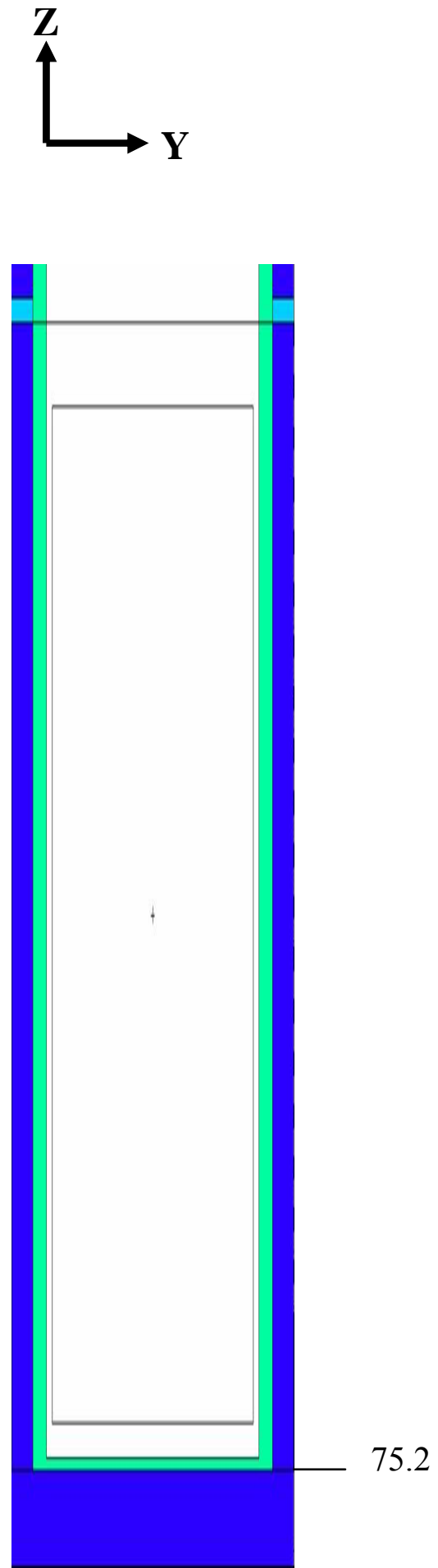

MCNP
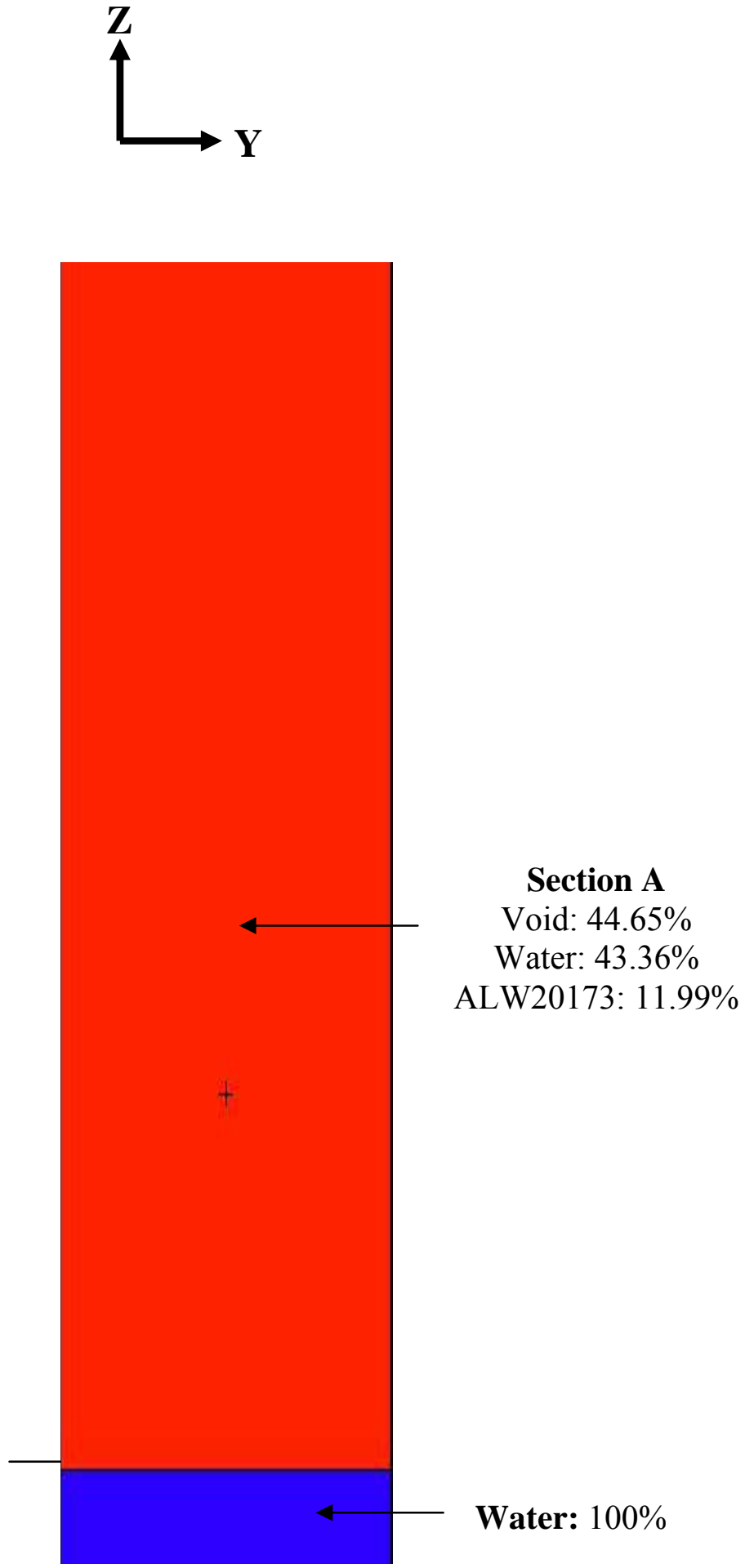

REBUS
Section A

Void: $44.65 \%$

Water: $43.36 \%$

ALW20173: 11.99\%

Water: $100 \%$

All dimensions in $\mathrm{cm}$

Figure 36: POLINE region - MCNP \& REBUS models 

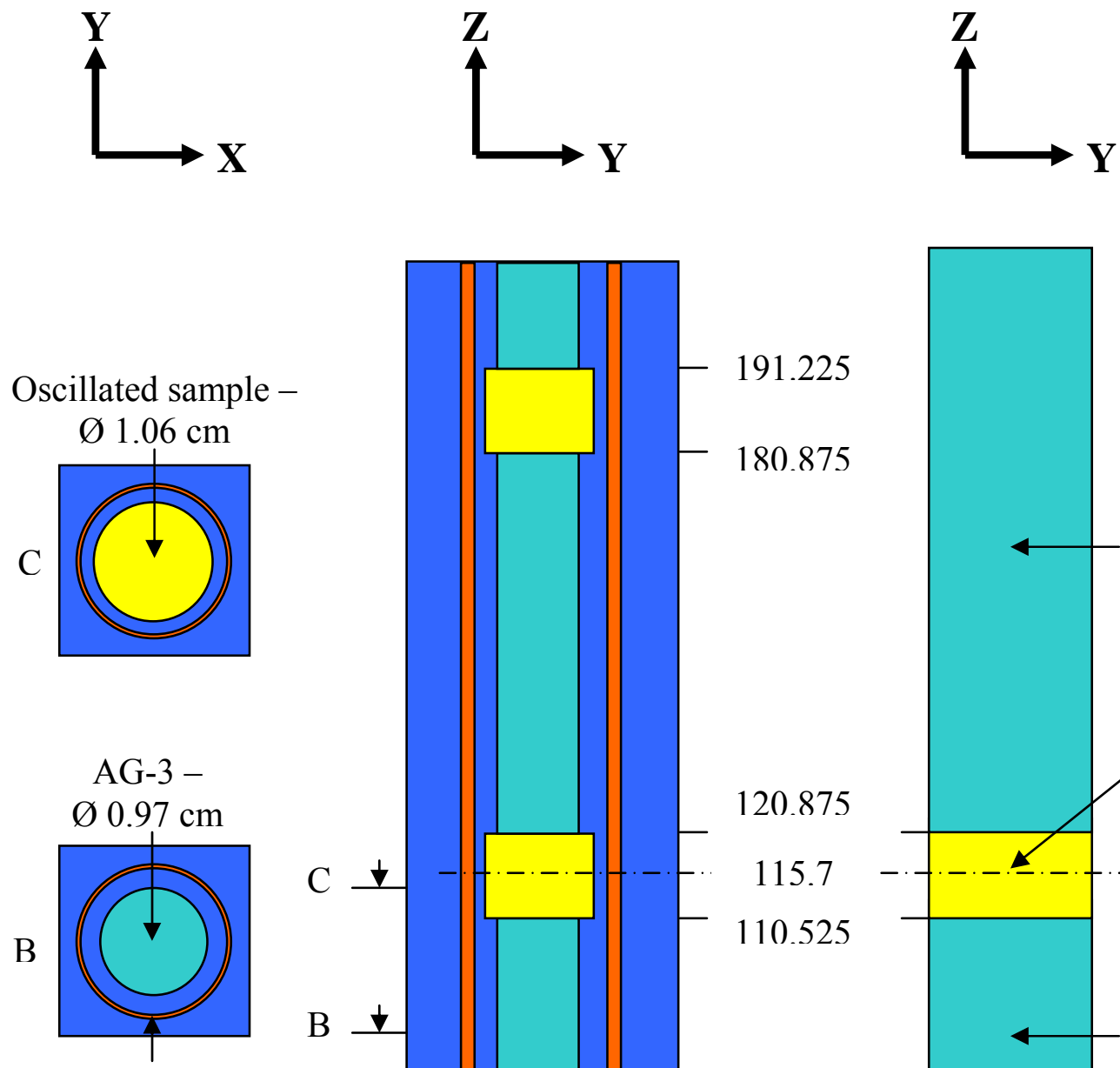

$\mathrm{SS}-$

$\emptyset 1.2 \times 1.1 \mathrm{~cm}$
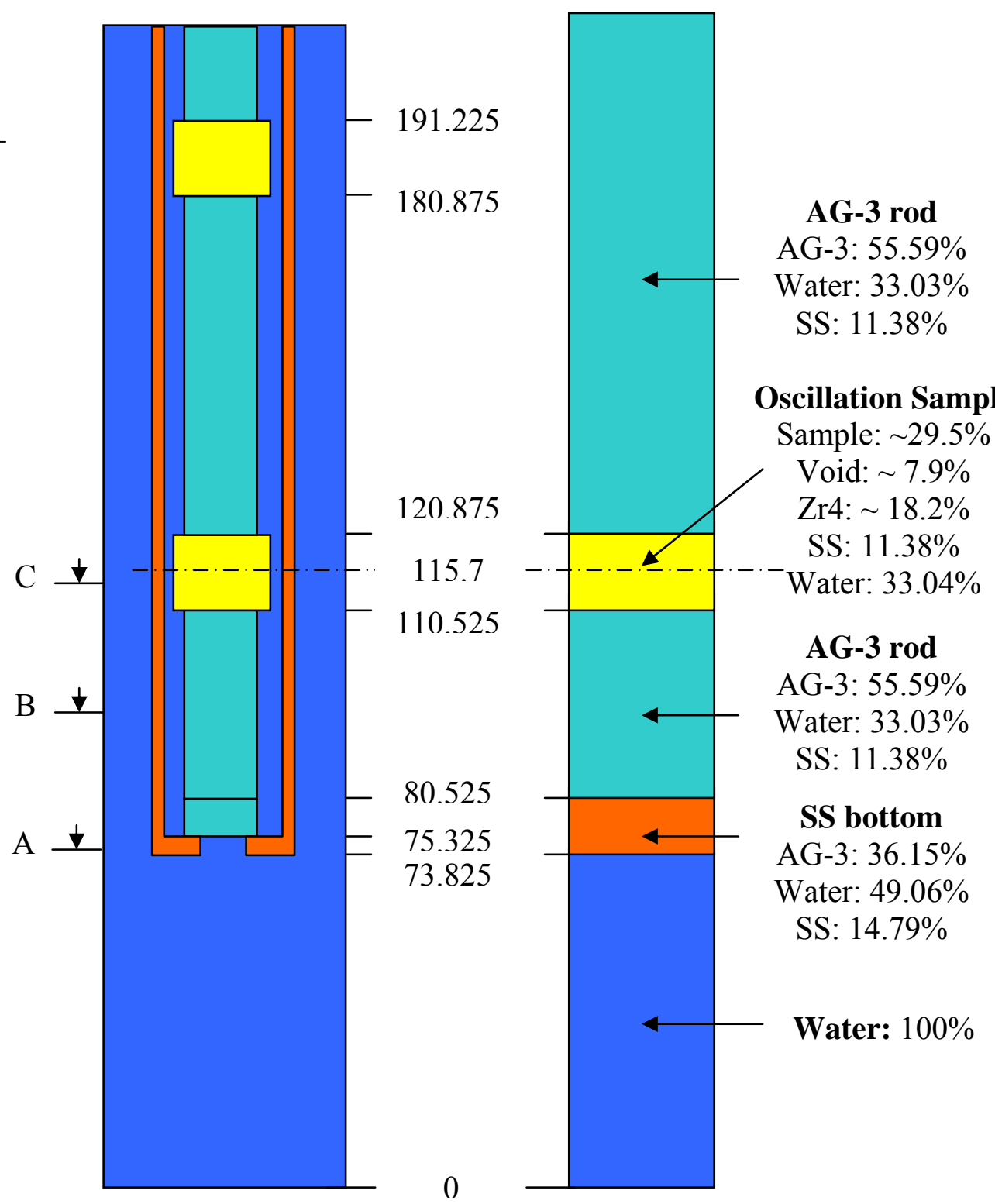

Schematic

Homogenized

Figure 37: Oscillation rod region in the up position - REBUS models 


\section{“18p90” and “18p93” calculation}
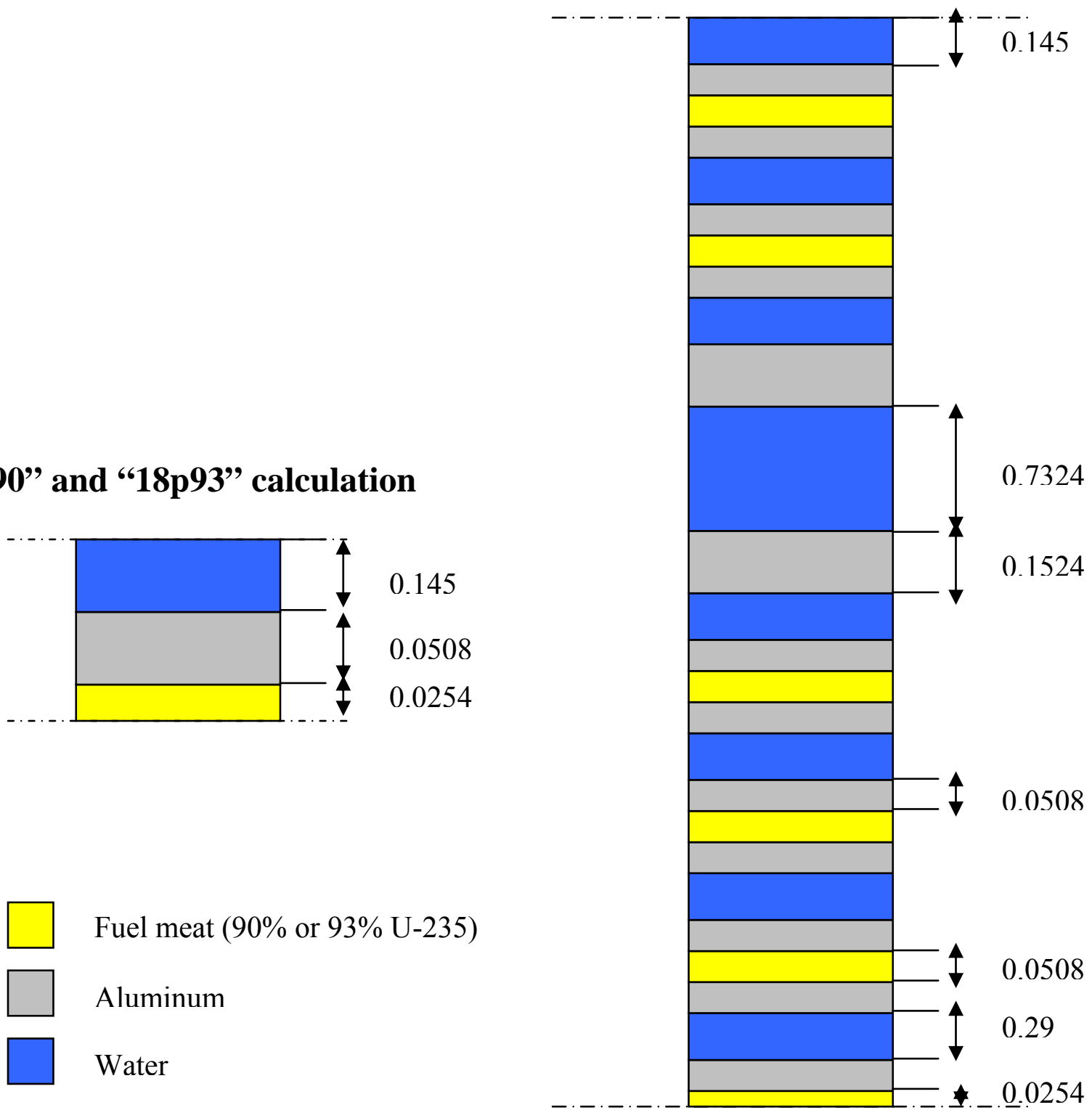

Fuel meat $(90 \%$ or $93 \%$ U-235)

Aluminum

Water

Fuel meat (93\% U-235)

Aluminum

Water

Figure 38: Geometry of the WIMS calculation "18p90", "18p93" and "CElt" 
All dimensions in $\mathrm{cm}$

\section{Auxiliary Cell \#1}

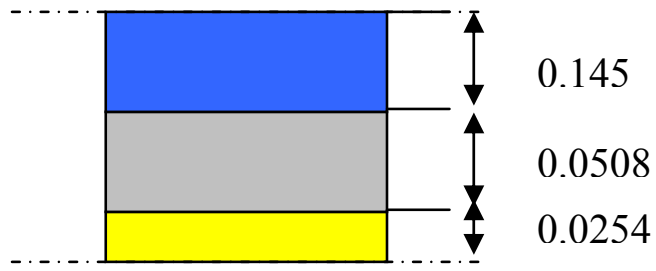

Fuel meat (93\% U-235)

Aluminum

Water

\section{Auxiliary Cell \#2}

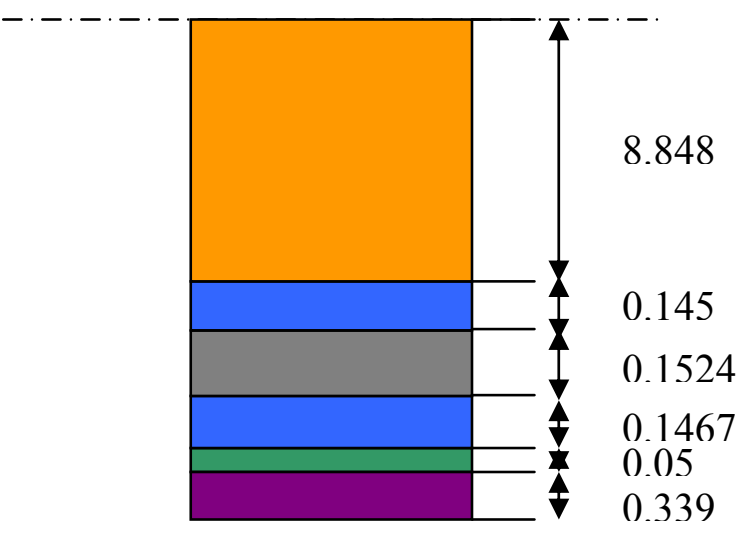

Homogenized 18-plate fuel element (from Auxiliary cell \#1)

AG-3

Water

SS

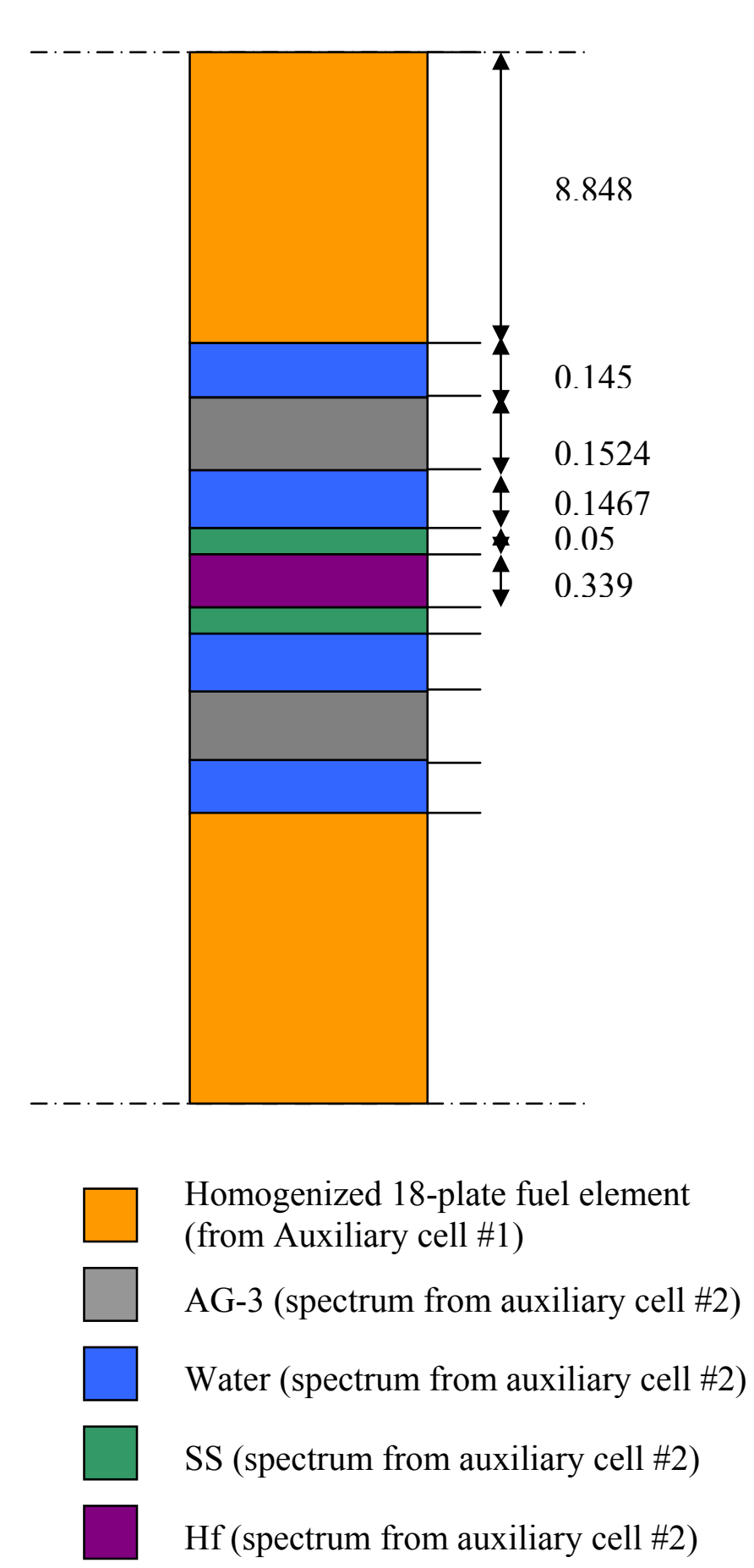

Super Cell

Hf

Figure 39: Geometry of the WIMS calculation "rod" 
All dimensions in $\mathrm{cm}$

Auxiliary Cell

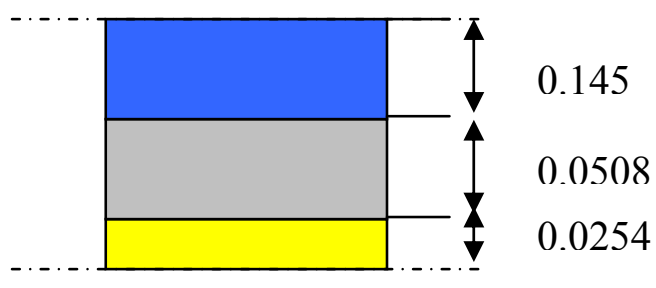

Fuel meat (93\% U-235)

Aluminum

Water
Homogenized 18-plate fuel element

(90\% U-235) (from Auxiliary cell)

AG-3

Water

Graphite

Aluminum and water
Super Cell

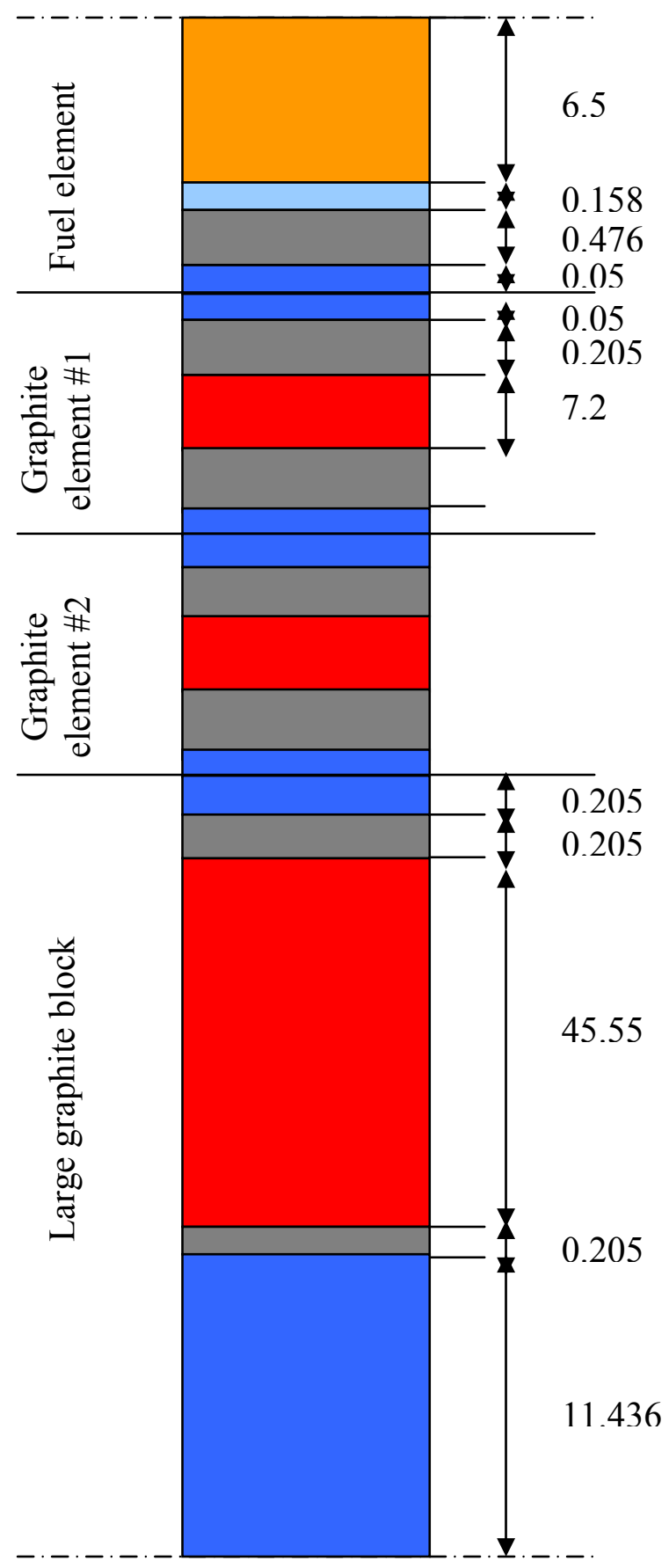

Figure 40: Geometry of the WIMS calculation "G18p90" 


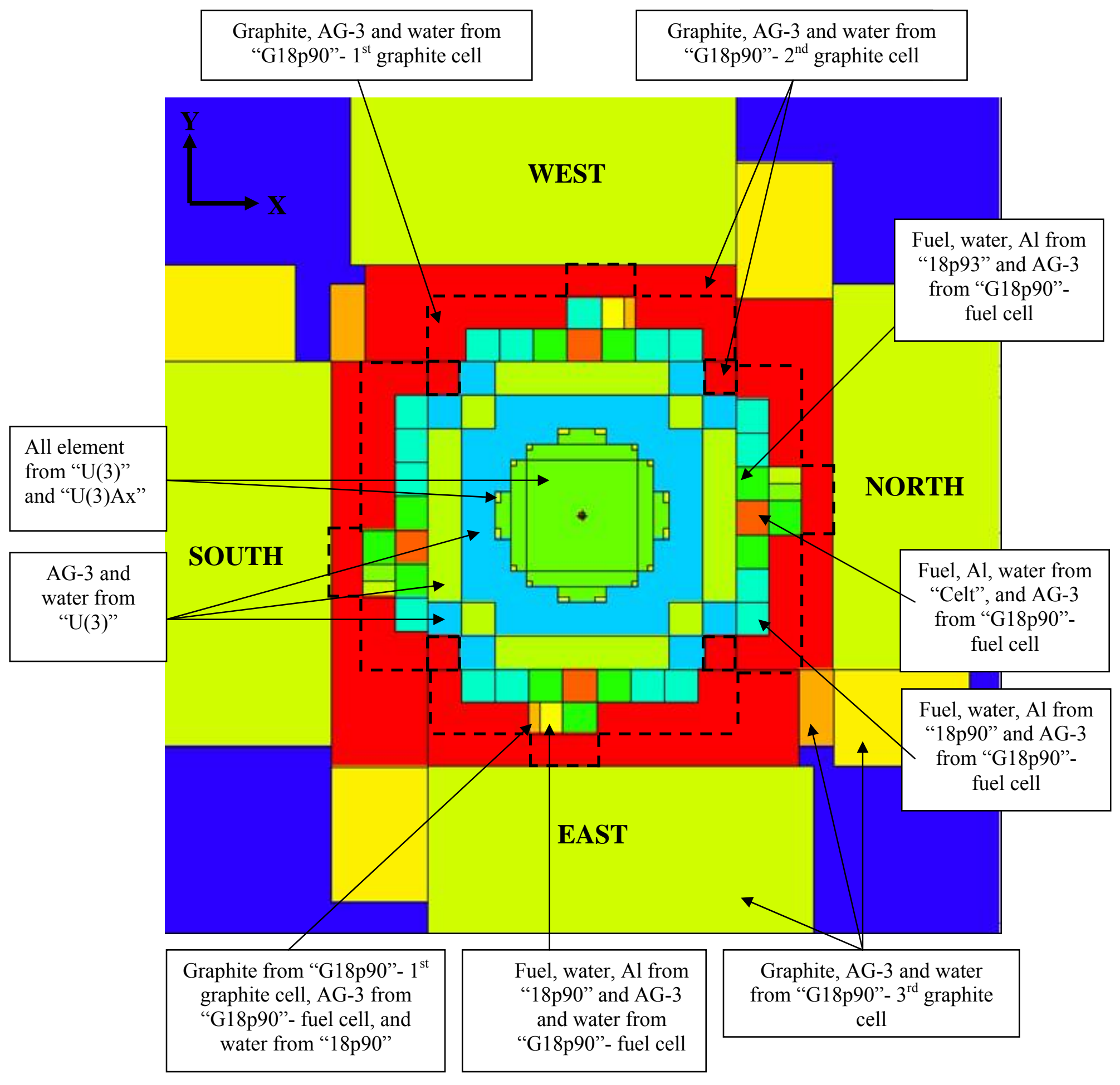

Figure 41: Cross sections used in the REBUS model in the R1UO2 configuration 


\section{Calculation “U(3)”}

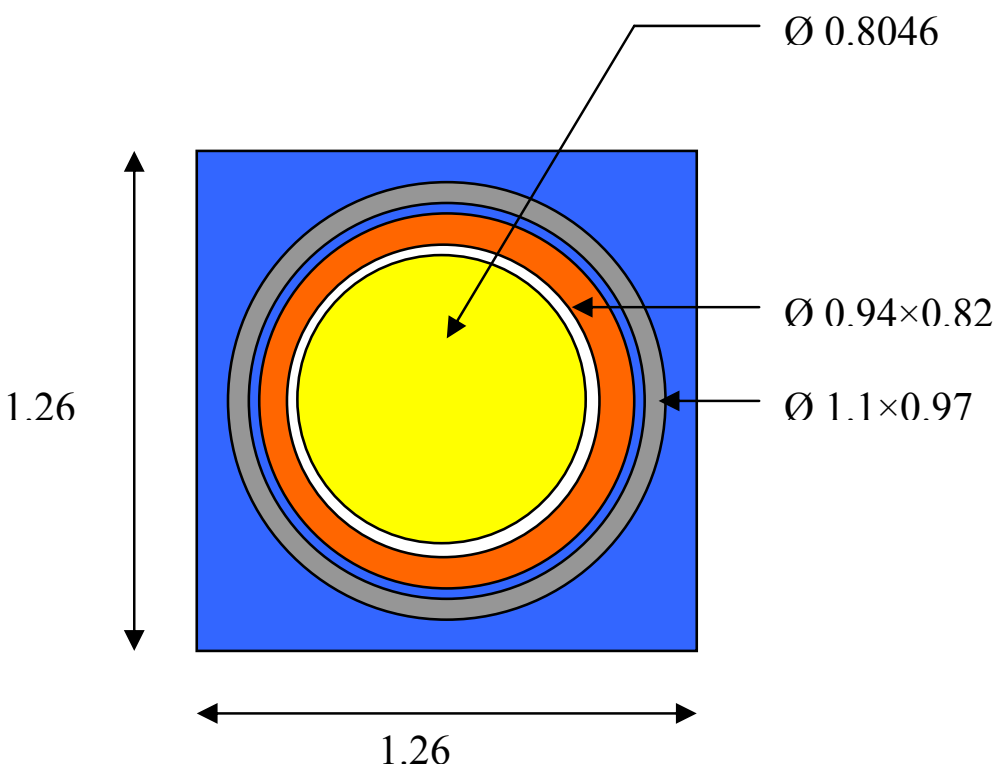

$\mathrm{UO}_{2}$ fuel pin meat

AG-3

Water

Zr-4

Void
Calculation "U(3)Ax"

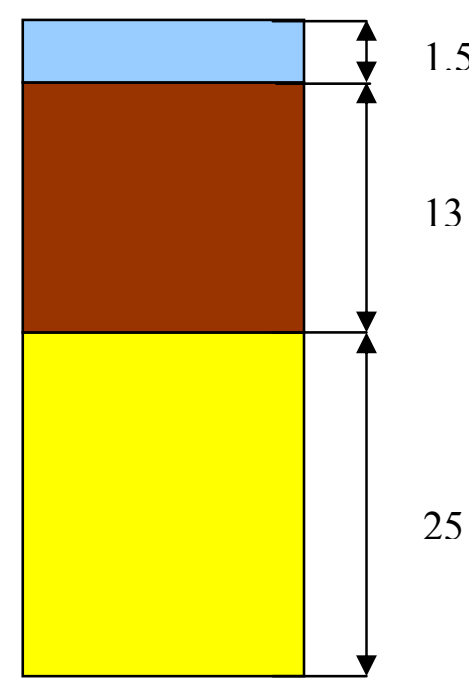

$\mathrm{UO}_{2}$ fuel pin meat

Plexiglas

Stainless steel

Figure 42: Geometry of the WIMS calculation "U(3)" and "U(3)Ax" 
All dimensions in $\mathrm{cm}$

\section{Auxiliary Cell}

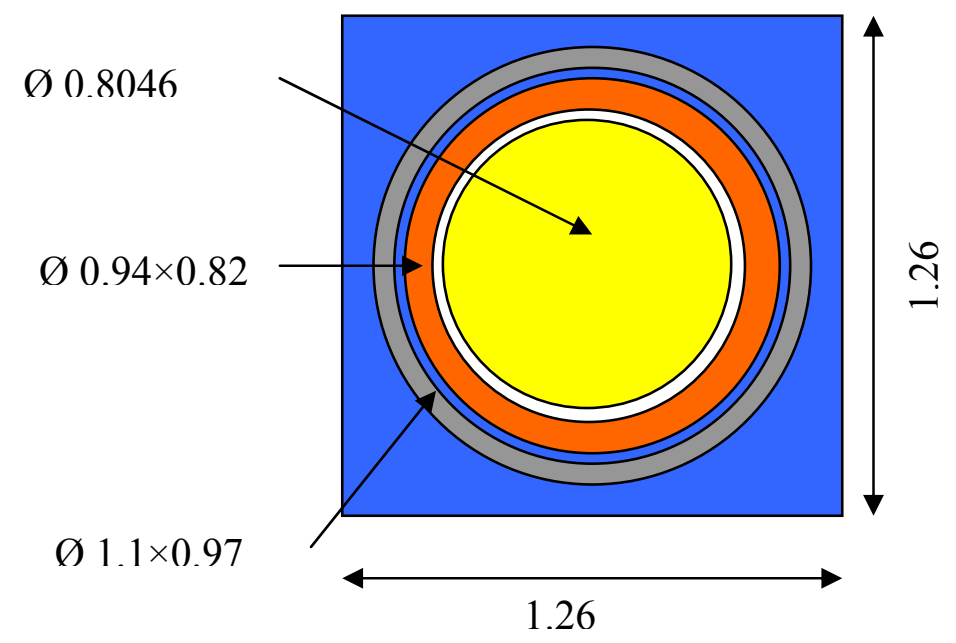

$\mathrm{UO}_{2}$ fuel pin meat

AG-3

Water

$\mathrm{Zr}-4$

Void
Super Cell

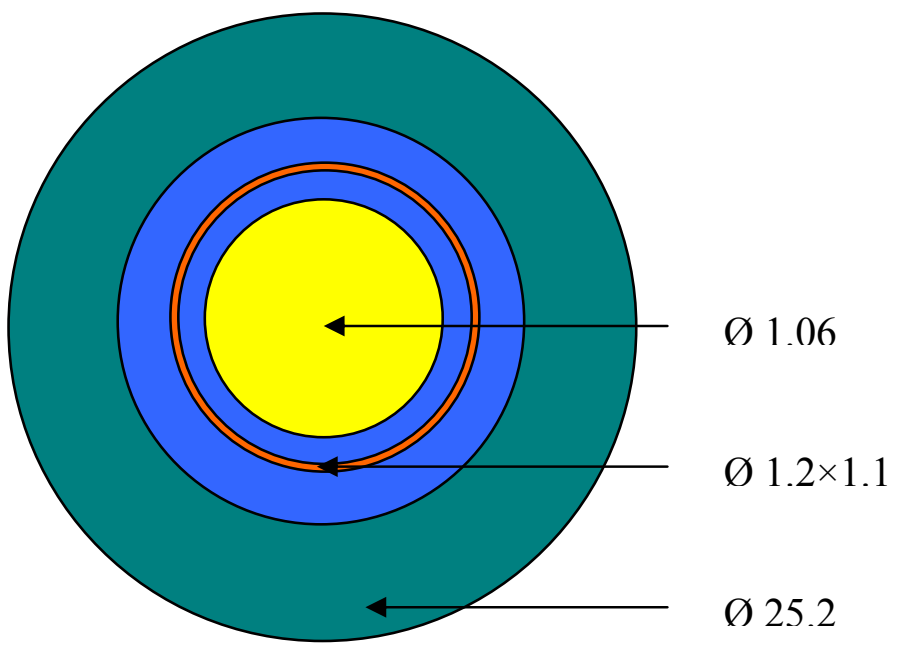

Figure 43: Geometry of the WIMS calculation "Sample" in the R1UO2 configuration 


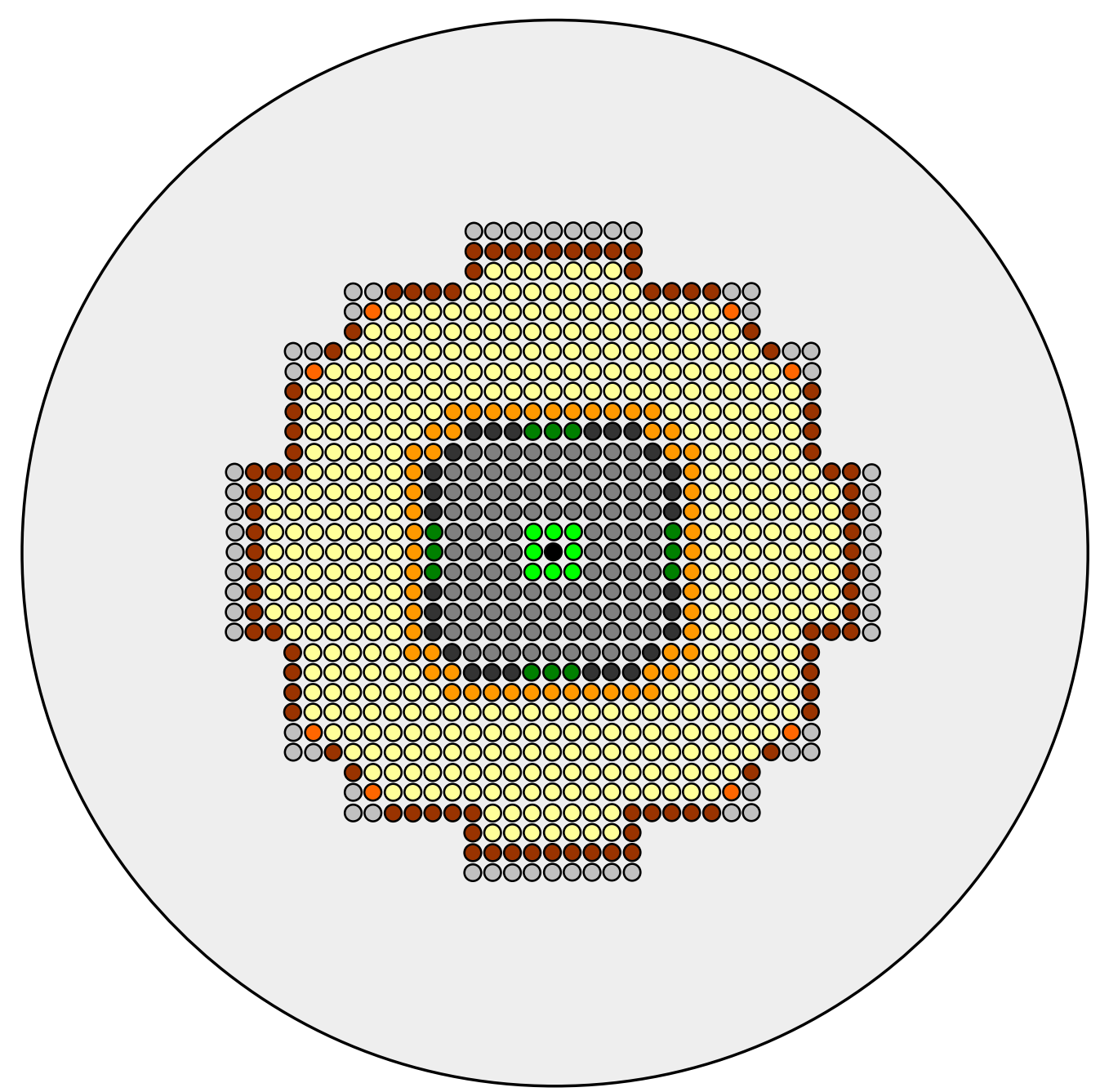

Aluminum pins - cross section from " $\mathrm{U}(3)$ "

$\bigcirc \mathrm{UO}_{2}$ pins with $3 \% \mathrm{U}-235$ enrichment - cross sections from "U(3)" - Homogeneous

$\mathrm{UO}_{2}$ pins with 3\% U-235 enrichment - cross sections from "UAl" - Interface U pin / Al pin $\mathrm{UO}_{2}$ pins with $3 \% \mathrm{U}-235$ enrichment - cross sections from "UAl" - Interface U pin / Al block

$\bigcirc \mathrm{UO}_{2}$ pins with $3 \% \mathrm{U}-235$ enrichment - cross sections from "UPuPu2" - Interface $\mathrm{Pu}(4 \%)$ pin $\mathrm{Pu}(3.6 \%) / \mathrm{U}$ pin

$\mathrm{UO}_{2}-\mathrm{PuO}_{2}$ pins with $4 \%$ of $\mathrm{PuO}_{2}$ - cross sections from " $\mathrm{Pu}(4)$ " - Homogeneous

$\mathrm{UO}_{2}-\mathrm{PuO}_{2}$ pins with $4 \%$ of $\mathrm{PuO}_{2}$ - cross sections from "UPu" - Interface $\mathrm{Pu}(4 \%)$ pin / Upin

$\bigcirc \mathrm{UO}_{2}-\mathrm{PuO}_{2}$ pins with $4 \%$ of $\mathrm{PuO}_{2}$ - cross sections from "UPOL" - Interface $\mathrm{Pu}(4 \%)$ pin / POLINE

$\bigcirc \mathrm{UO}_{2}-\mathrm{PuO}_{2}$ pins with $3.6 \%$ of $\mathrm{PuO}_{2}$ - cross sections from "UPuPu2" - Interface $\mathrm{Pu}(4 \%)$ pin $\mathrm{Pu}(3.6 \%) / \mathrm{U}$ pin

Oscillation position: POLINE

Figure 44: Cross sections used in the REBUS model in the R1UO2 configuration 
All dimensions in $\mathrm{cm}$
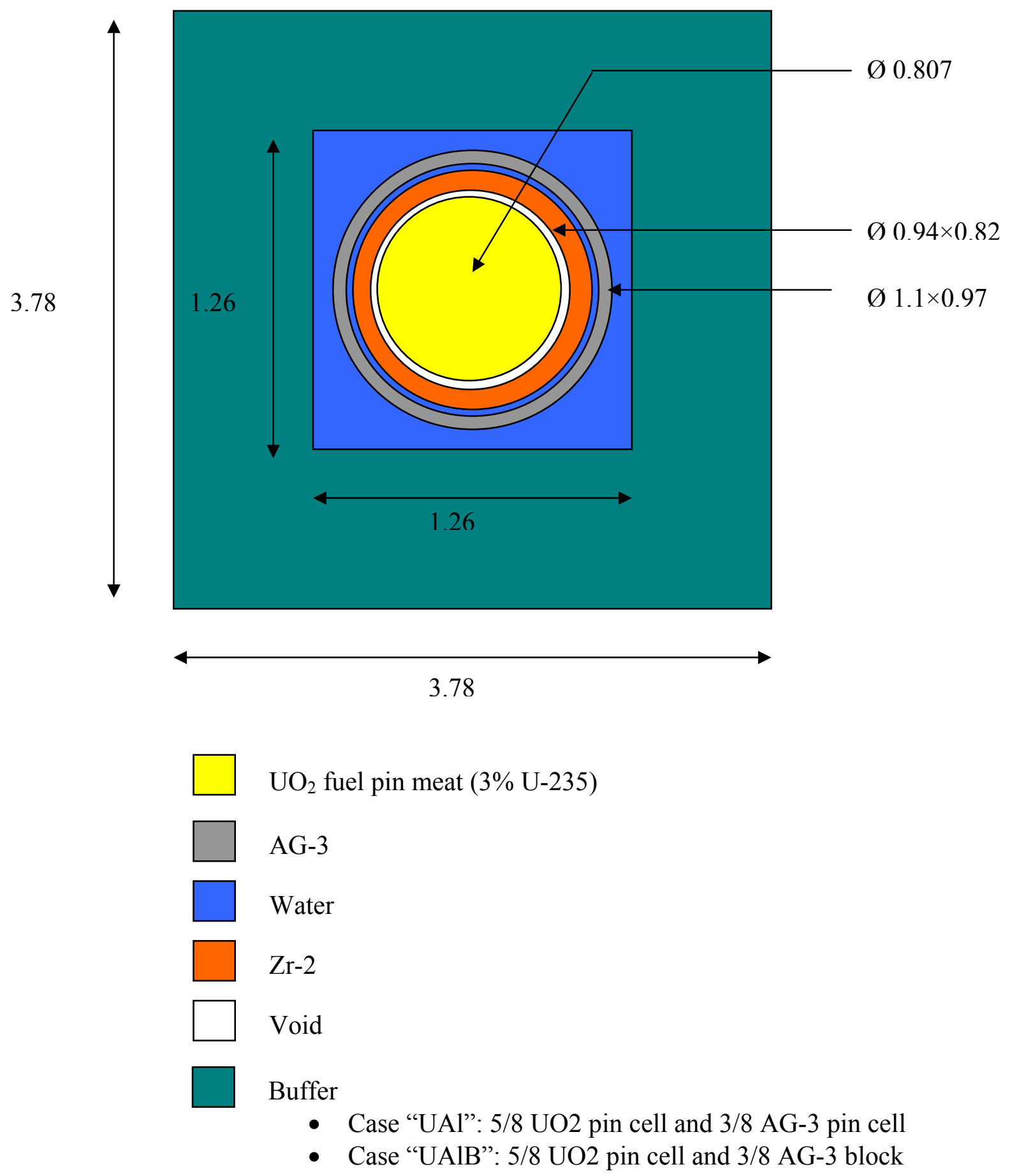

Figure 45: Geometry of the WIMS calculation "UAl" and "UAlB" 


\section{$\mathrm{UO}_{2}-\mathrm{PuO}_{2}(4 \%)$ pin cell $\quad \mathrm{UO}_{2}-\mathrm{PuO}_{2}(4 \%)$ pin cell $\quad \mathrm{UO} 2$ pin cell (Figure 47) \\ (Figure 42)}

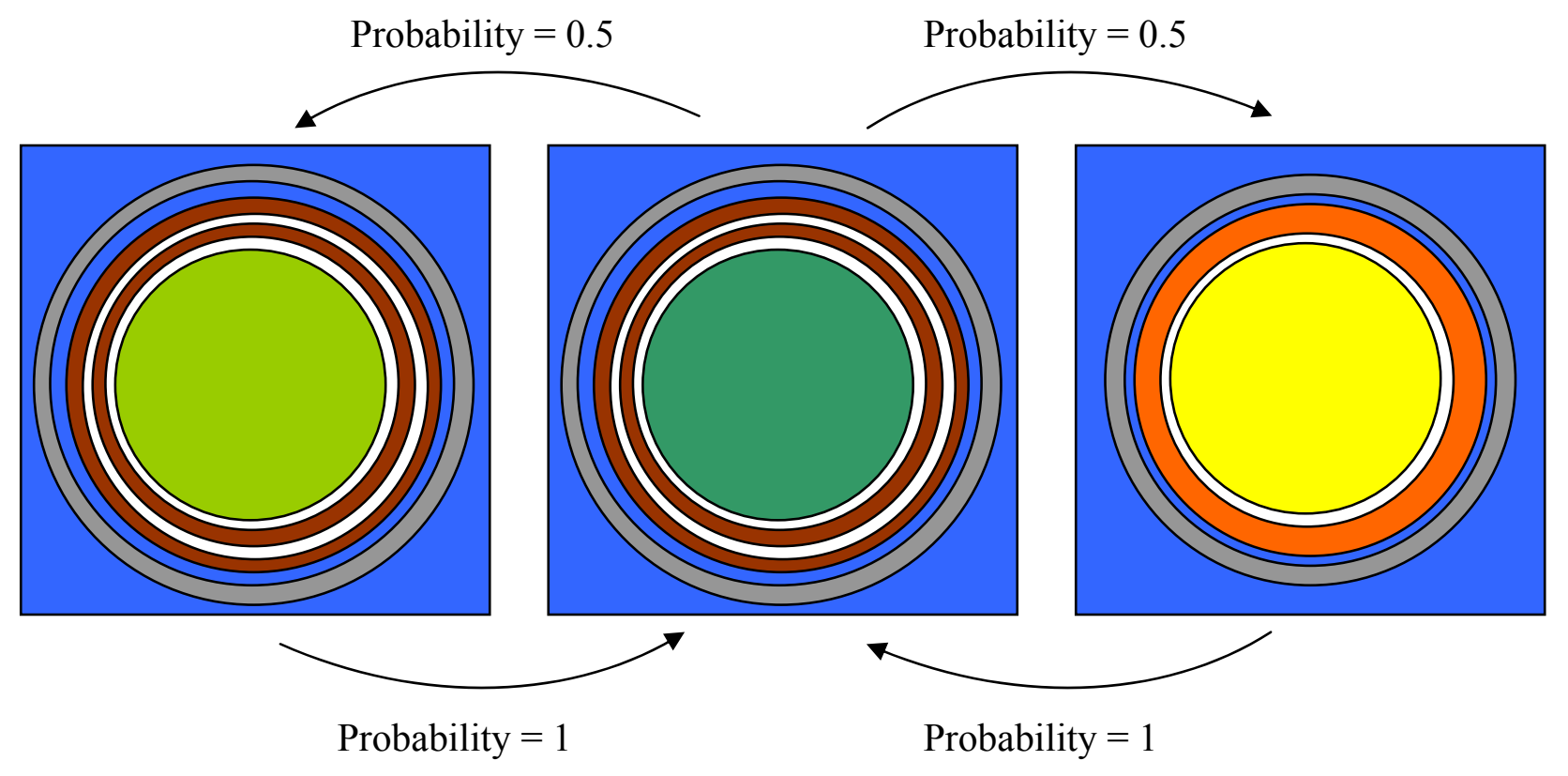

\begin{tabular}{|c|c|}
\hline $\mathrm{UO}_{2}-\mathrm{PuO}_{2}$ fuel pin meat $\left(4 \% \mathrm{PuO}_{2}\right)$ & $\mathrm{UO}_{2}$ fuel pin meat $(3 \% \mathrm{U}-235)$ \\
\hline $\mathrm{UO}_{2}-\mathrm{PuO}_{2}$ fuel pin meat $\left(3.6 \% \mathrm{PuO}_{2}\right)$ & AG-3 \\
\hline AG-3 & Water \\
\hline Water & $\mathrm{Zr}-4$ \\
\hline $\mathrm{Zr}-2$ & Void \\
\hline
\end{tabular}

Figure 46: Geometry of the WIMS calculation "UPuPu1" and "UPuPu2" 
All dimensions in $\mathrm{cm}$

\section{Calculation "Pu(4)”}

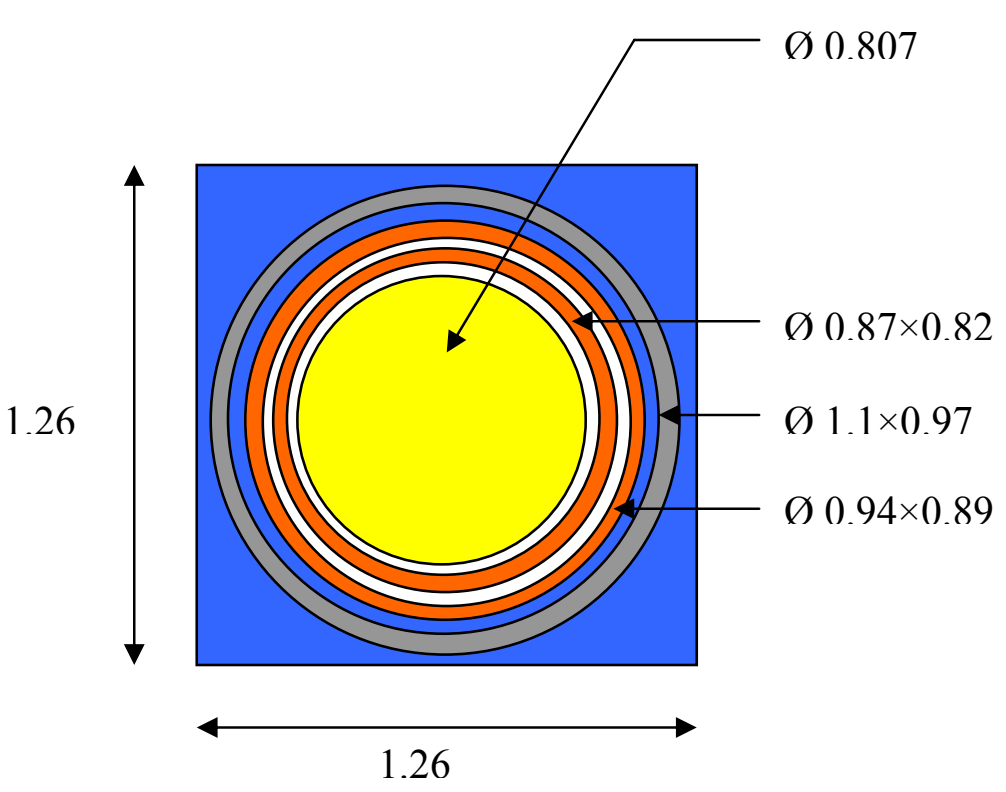

$\mathrm{UO}_{2}-\mathrm{PuO}_{2}$ fuel pin meat $\left(4 \% \mathrm{PuO}_{2}\right)$

AG-3

Water

$\mathrm{Zr}-2$

Void

\section{Calculation “Pu(4)Ax"}

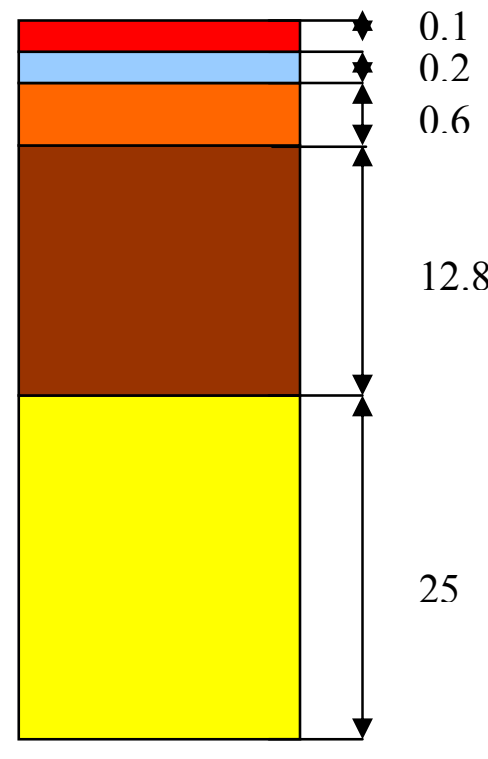

$\mathrm{UO}_{2}$ fuel pin meat

Plexiglas

Stainless steel

Zr-2

Styrene

Figure 47: Geometry of the WIMS calculation " $\mathrm{Pu}(4)$ " and " $\mathrm{Pu}(4) \mathrm{Ax}$ " 


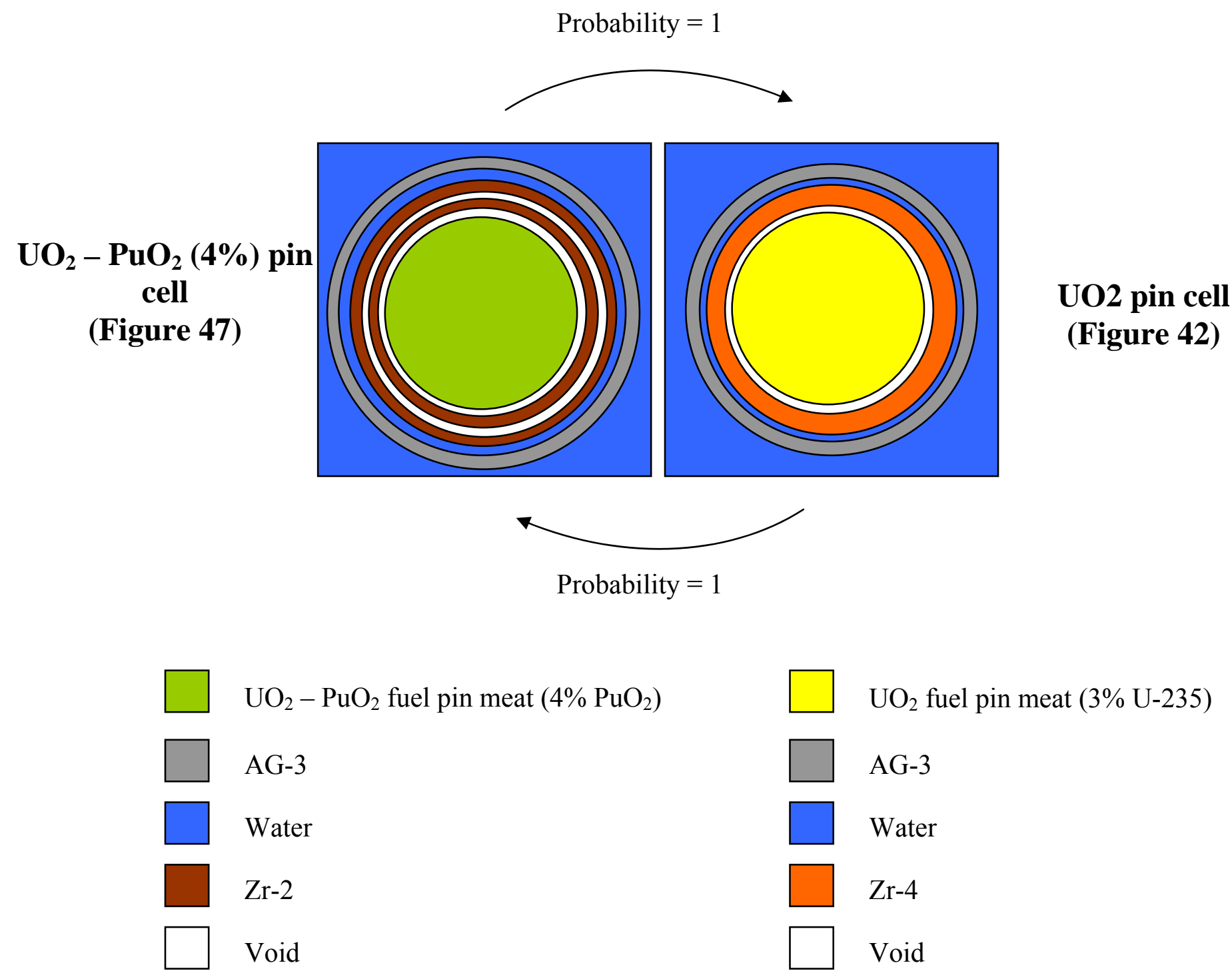

Figure 48: Geometry of the WIMS calculation "UPu" 
All dimensions in $\mathrm{cm}$

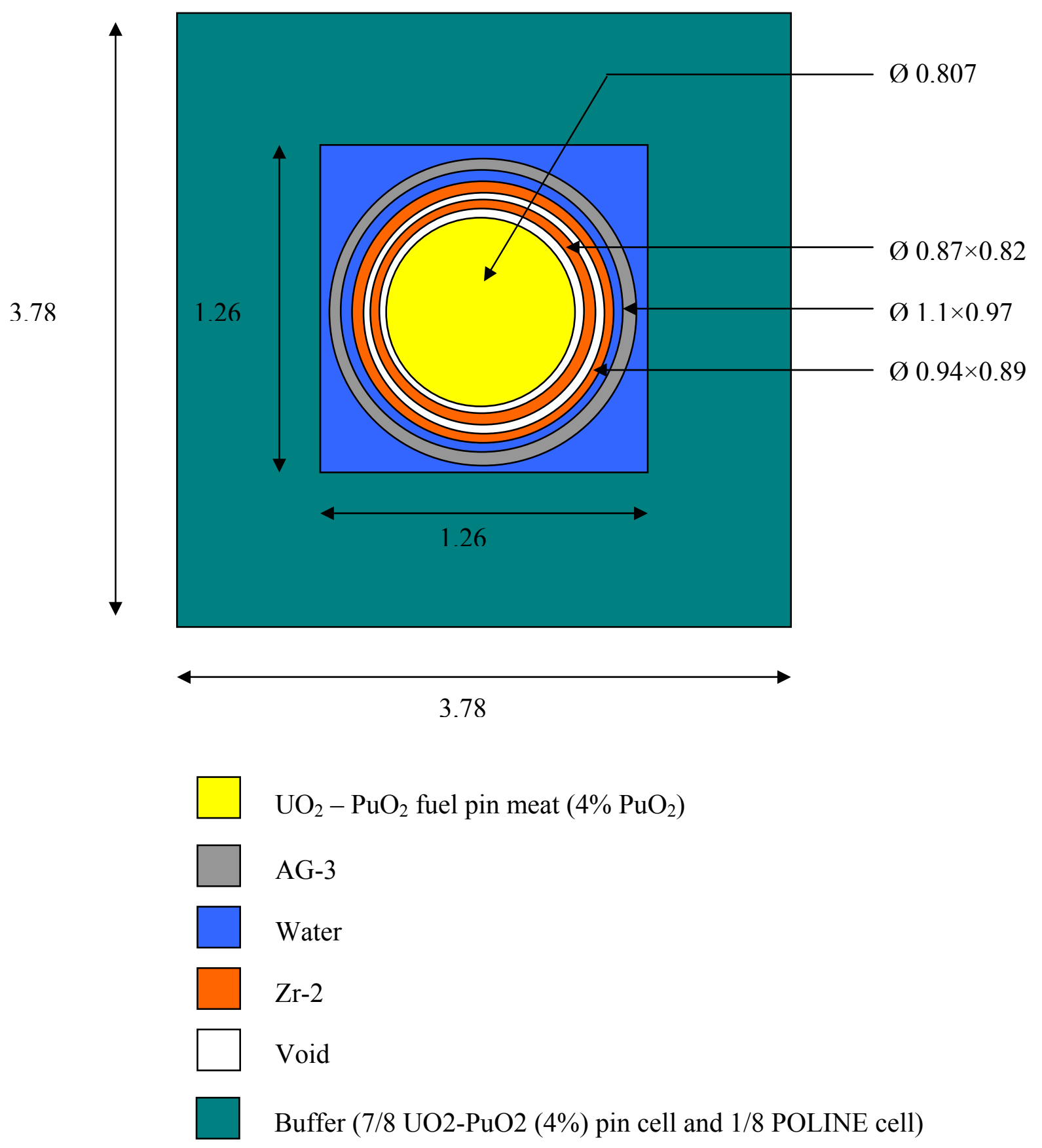

Figure 49: Geometry of the WIMS calculation "PuPOL" 


\section{Auxiliary Cell}

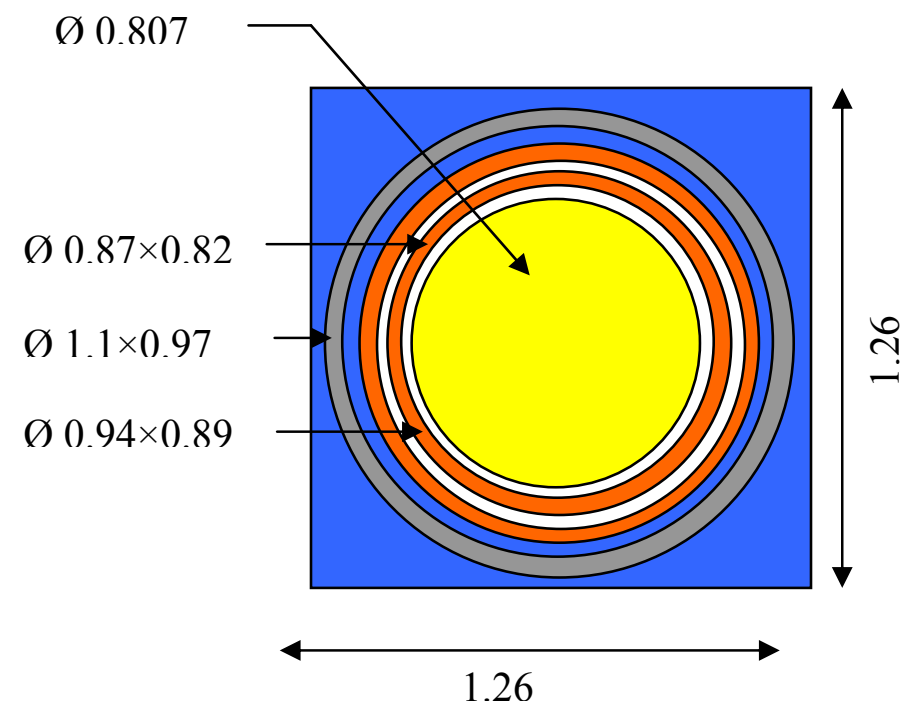

$\mathrm{UO}_{2}-\mathrm{PuO}_{2}$ fuel pin meat $\left(4 \% \mathrm{PuO}_{2}\right)$

AG-3

Water

$\mathrm{Zr}-2$

$\square$ Void

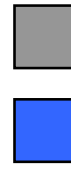

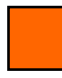

\section{Super Cell}

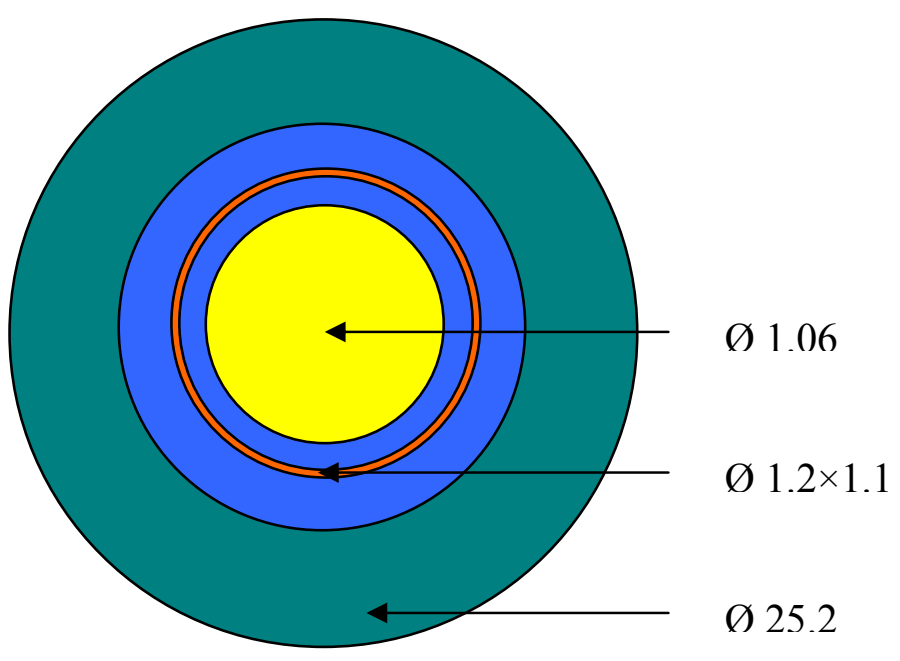

Sample

Water

Stainless steel

Homogenized $\mathrm{UO}_{2}-\mathrm{PuO}_{2}(4 \%)$ pin cell

Figure 50: Geometry of the WIMS calculation "Sample" in the R1MOX configuration 


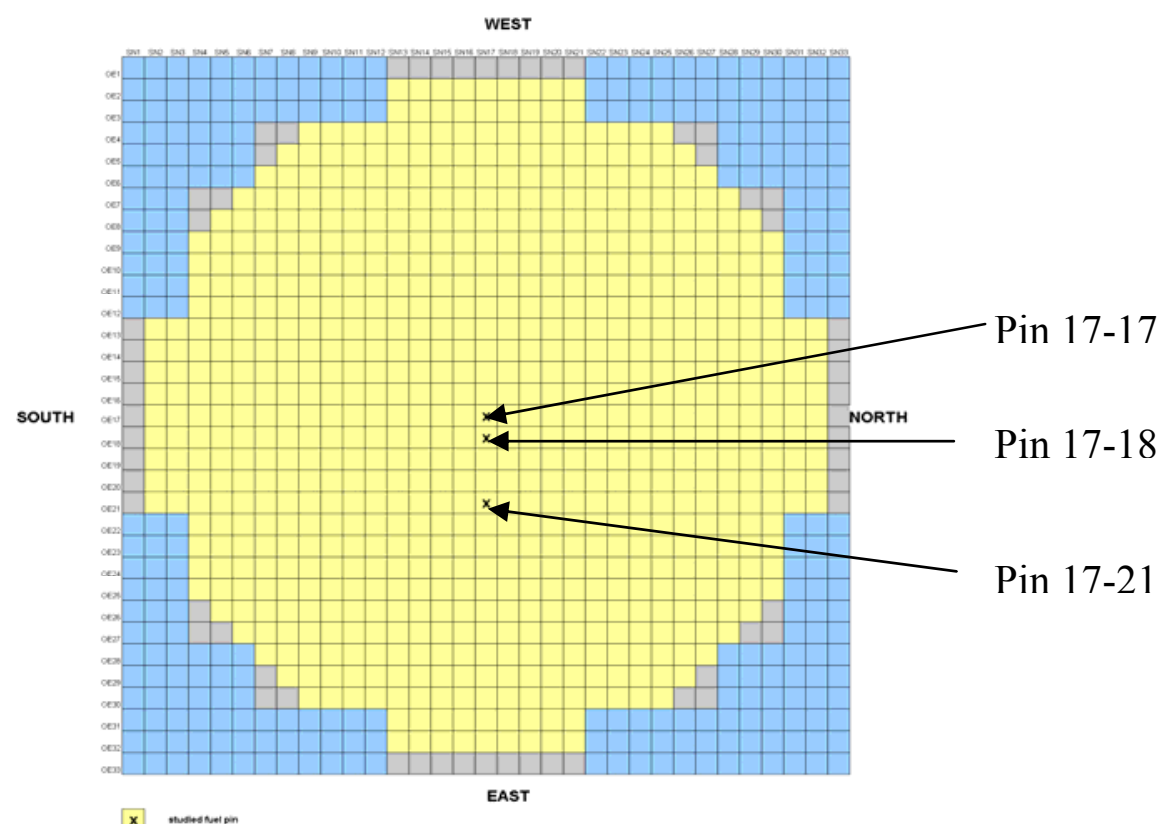

\section{R1UO2 homogeneous configuration}

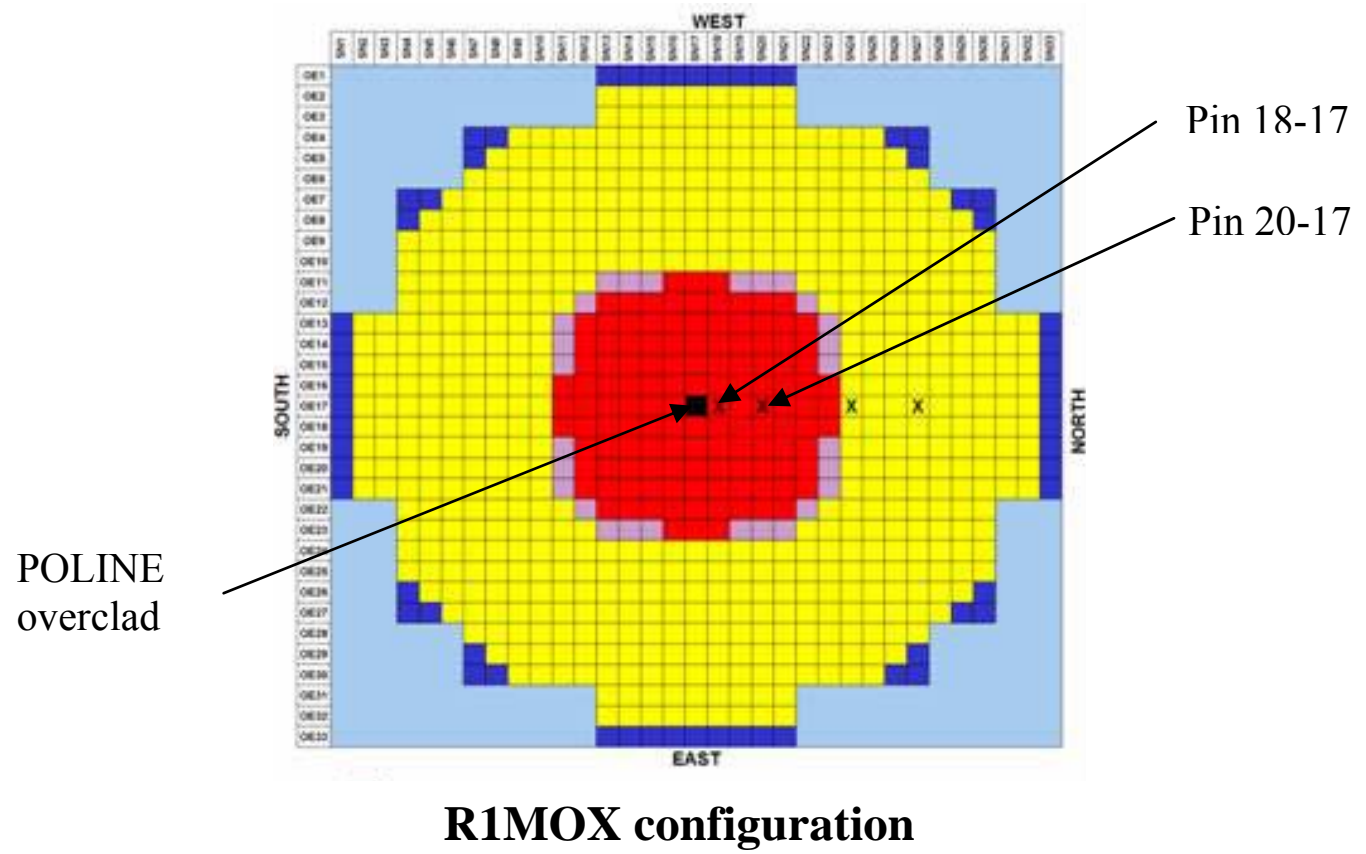

Figure 51: Studied pins for axial power profile measurements 


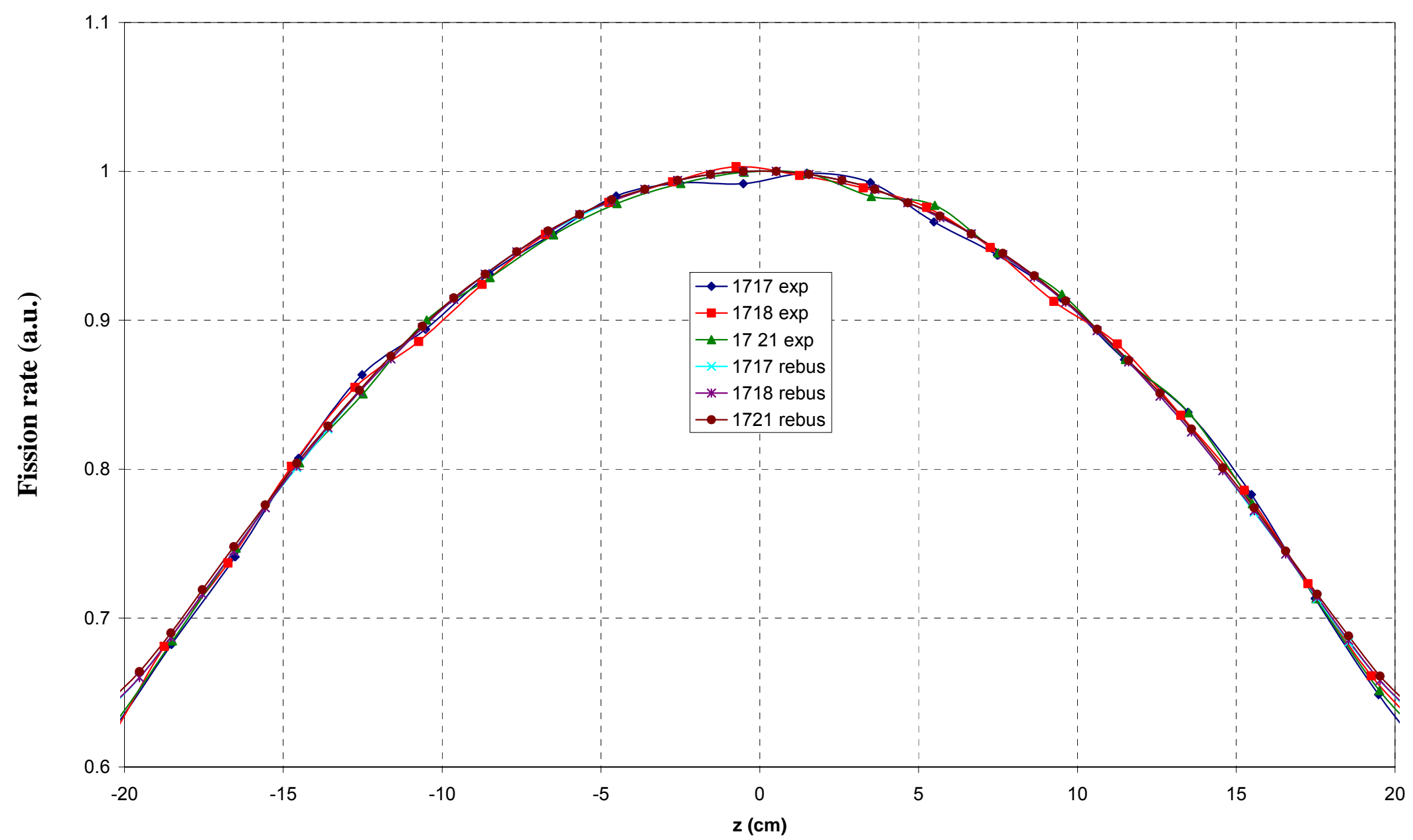

Figure 52: Axial power profile for specific pins in the R1UO2 configuration - Comparison of REBUS results to measurements 


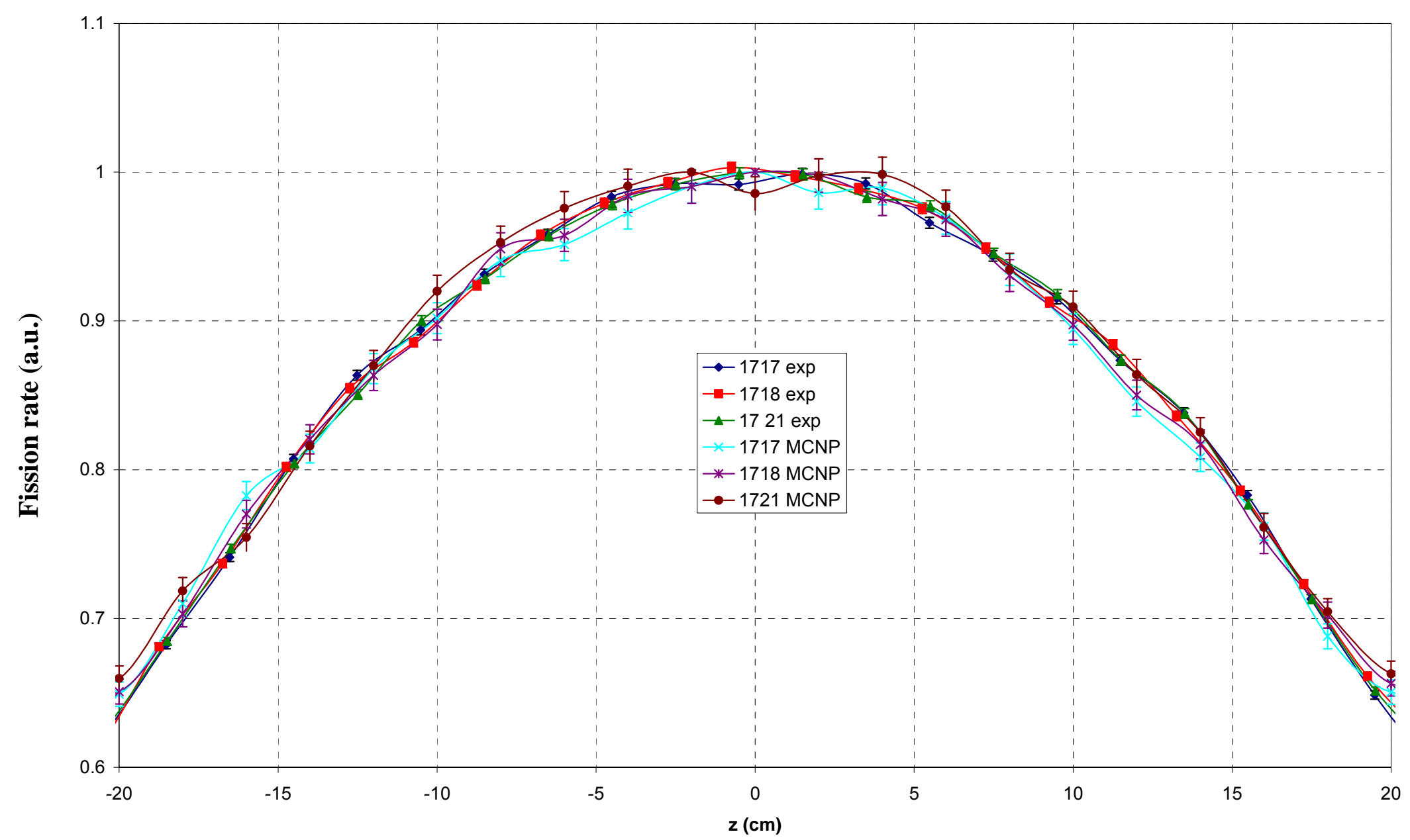

Figure 53: Axial power profile for specific pins in the R1UO2 configuration - Comparison of MCNP results to measurements 


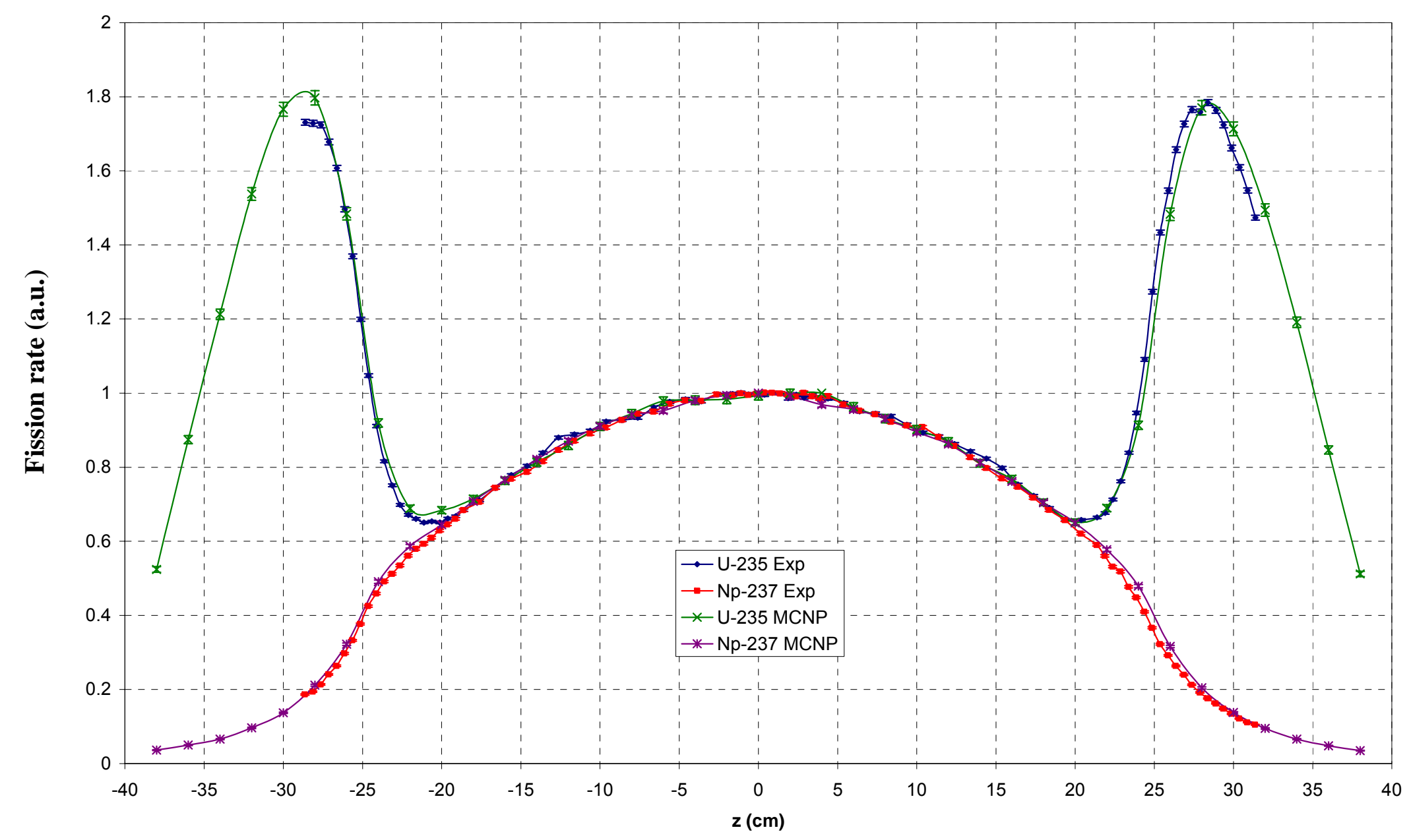

Figure 54: Axial fission rate profile of U-235 and Np-237 fission chambers in the R1UO2 configuration - Comparison of MCNP results to measurements 


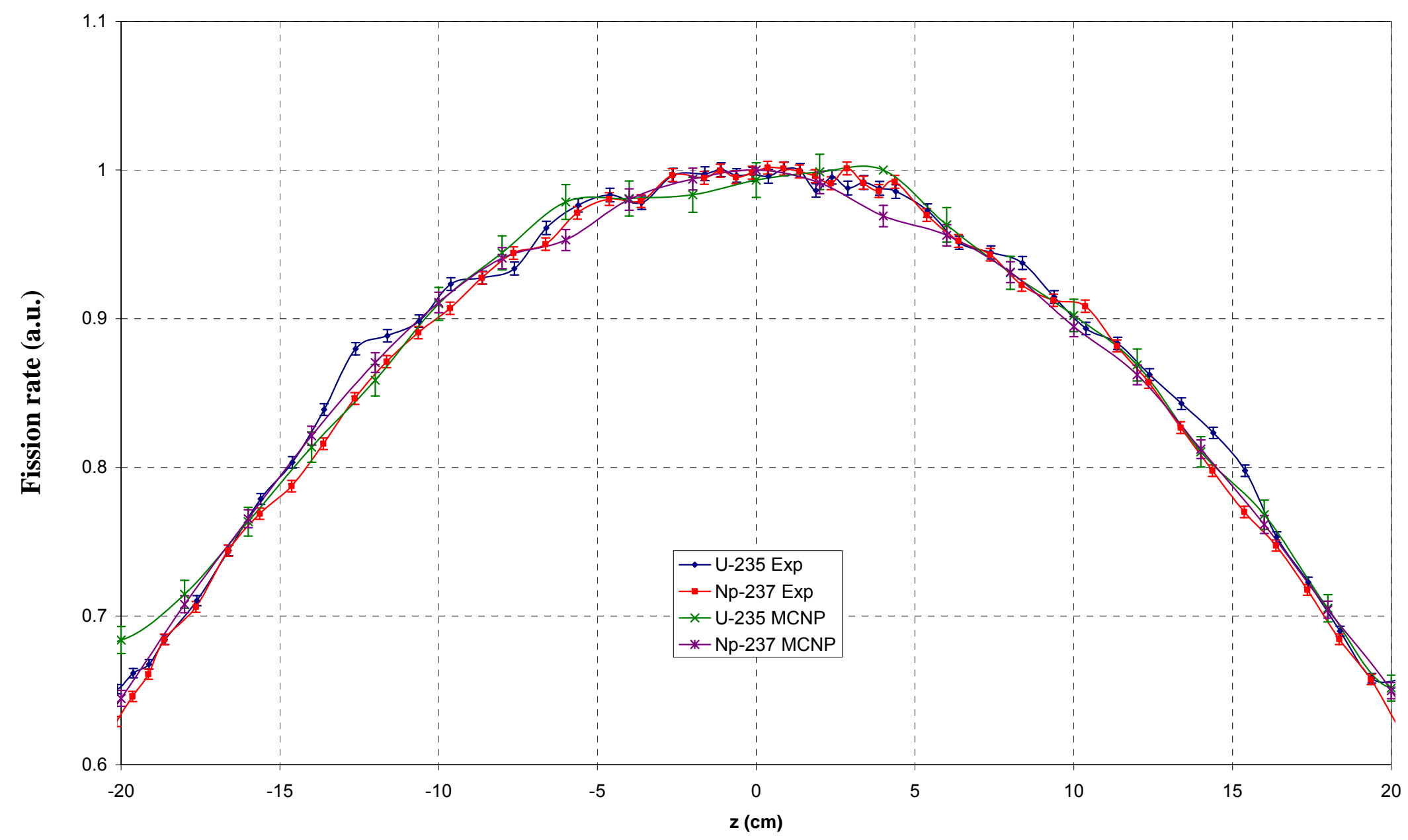

Figure 55: Axial fission rate profile of U-235 and Np-237 fission chambers in the R1UO2 configuration - Comparison of MCNP results to measurements over range of $\pm 20 \mathrm{~cm}$ 


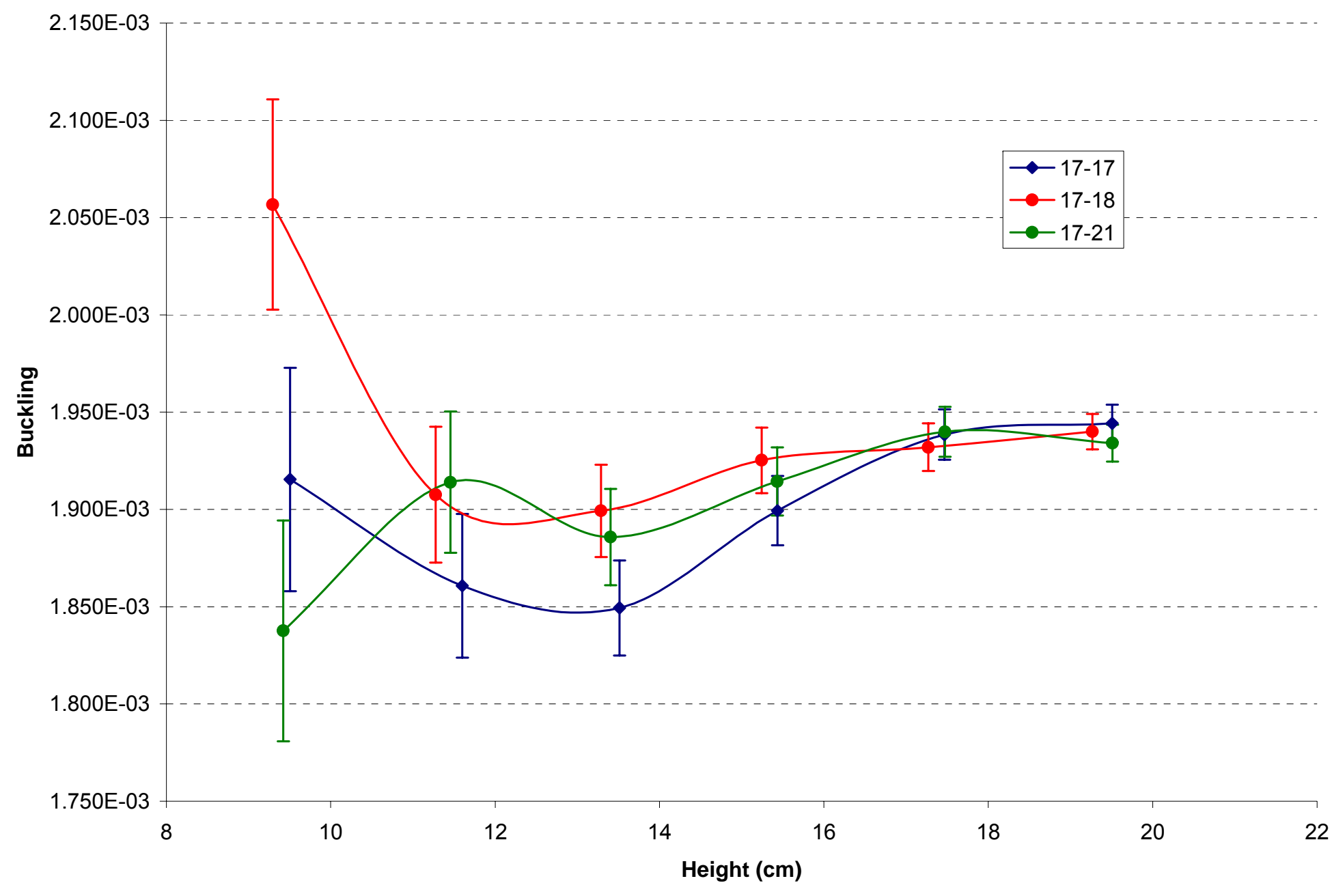

Figure 56: Buckling for the R1UO2 configuration calculated with experimental data within a limited range ( \pm height from centerline) 


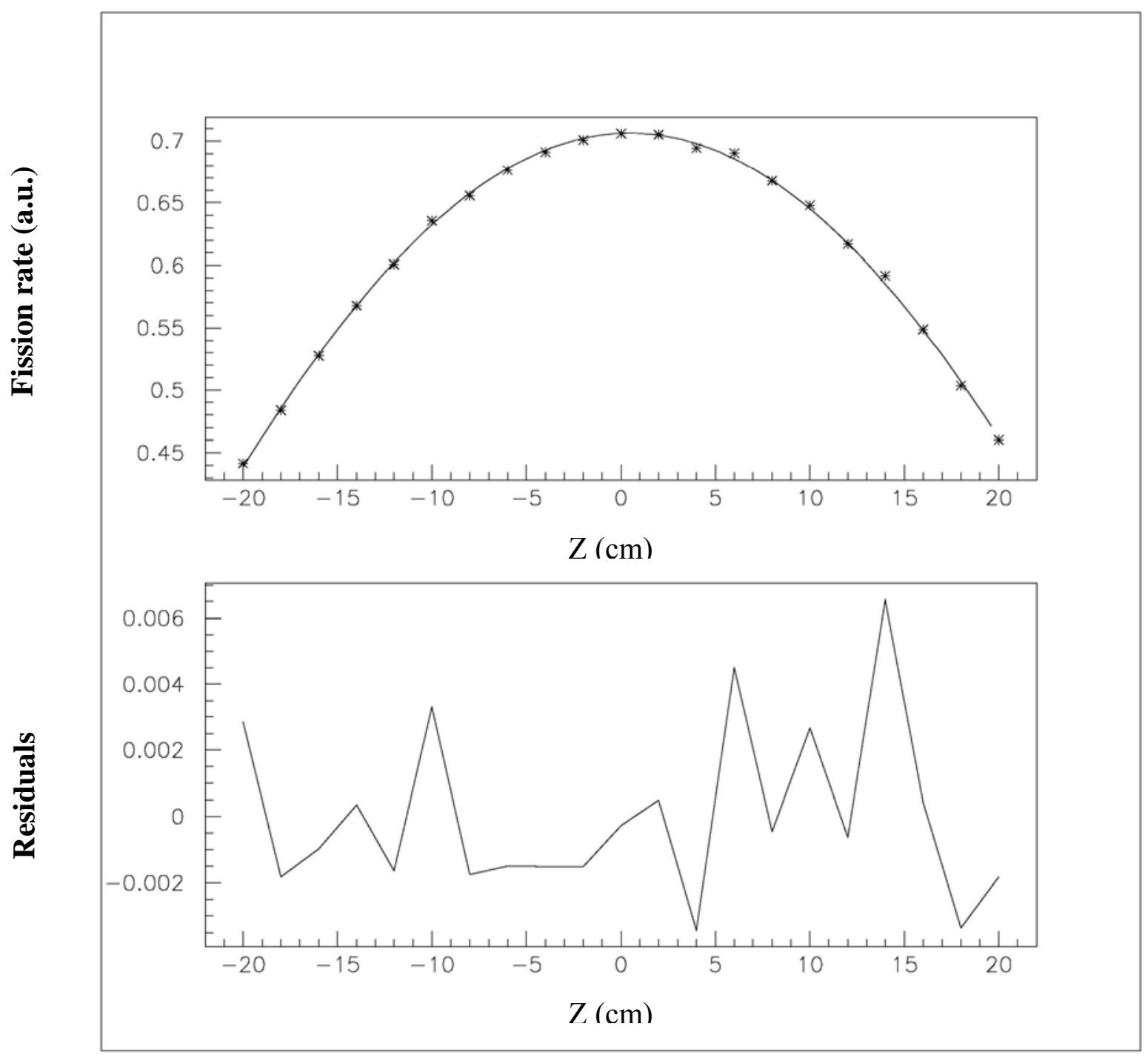

Figure 57: Fit of the experimental axial power profile of the pin 17-21 of the R1UO2 configuration over the range $[-20 \mathrm{~cm}, 20 \mathrm{~cm}]$ 


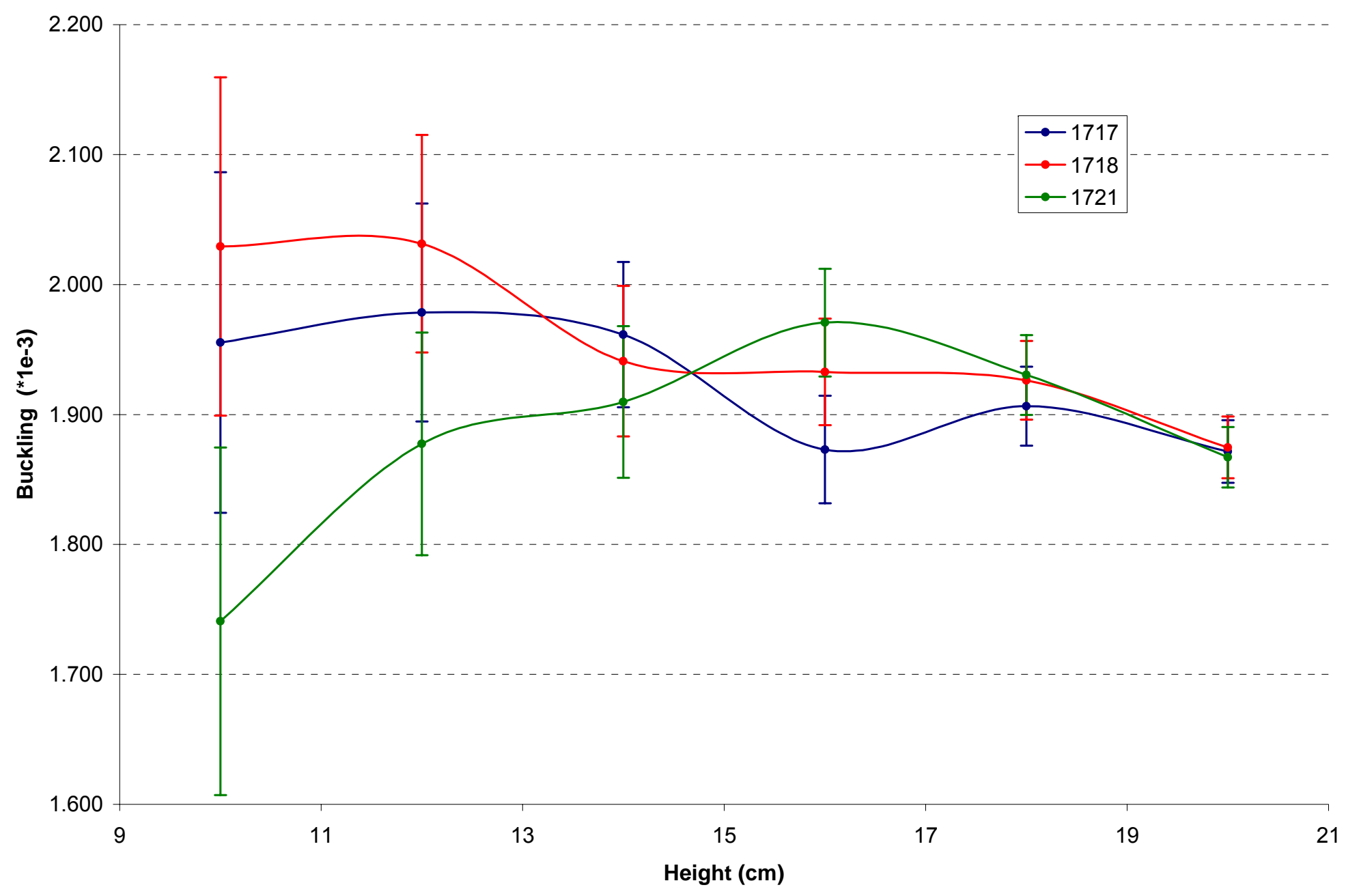

Figure 58: Buckling for the R1UO2 configuration calculated with data from MCNP within a limited range ( \pm height from centerline) 


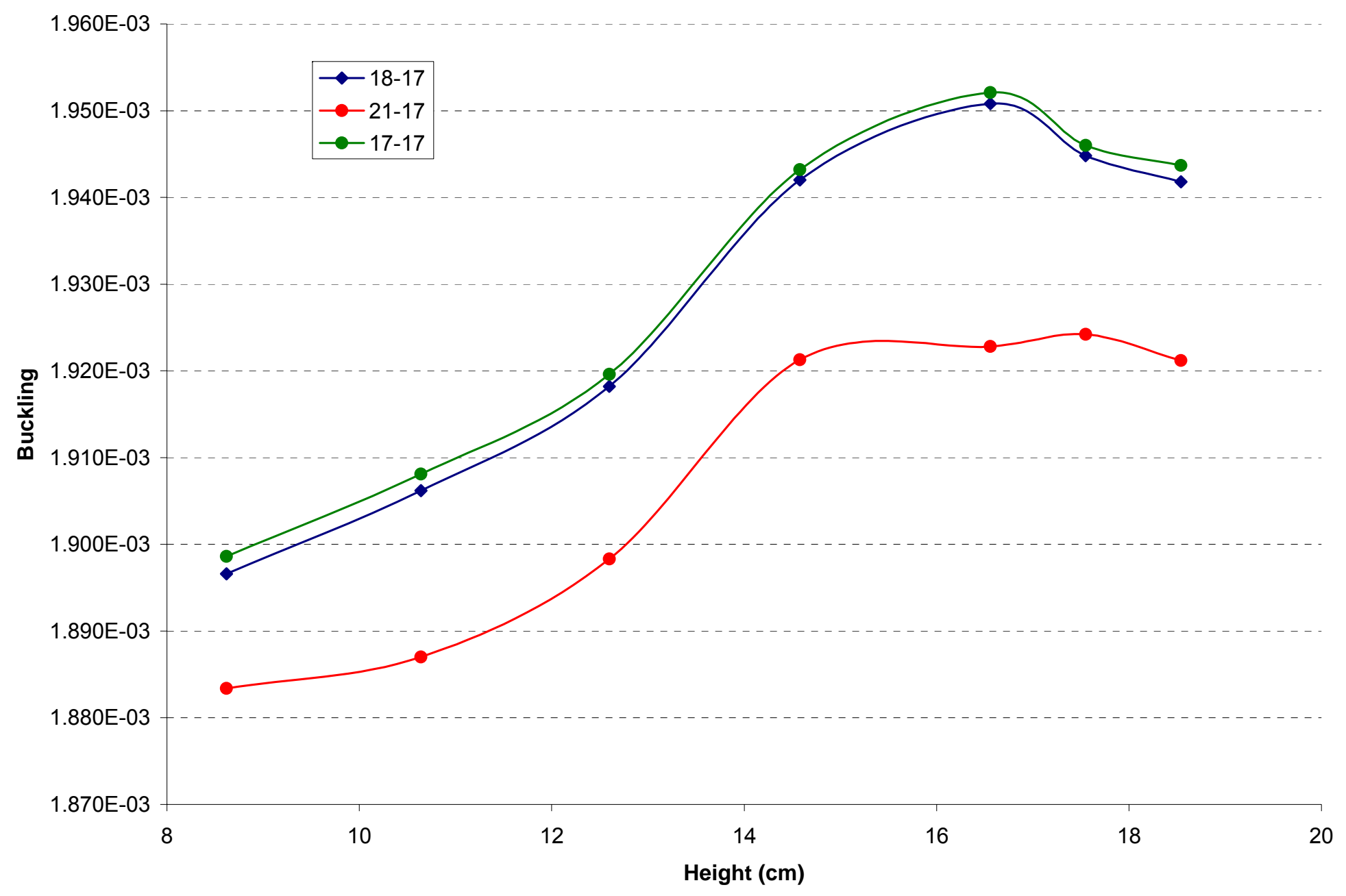

Figure 59: Buckling for the R1UO2 configuration calculated with data from REBUS within a limited range ( \pm height from centerline) 


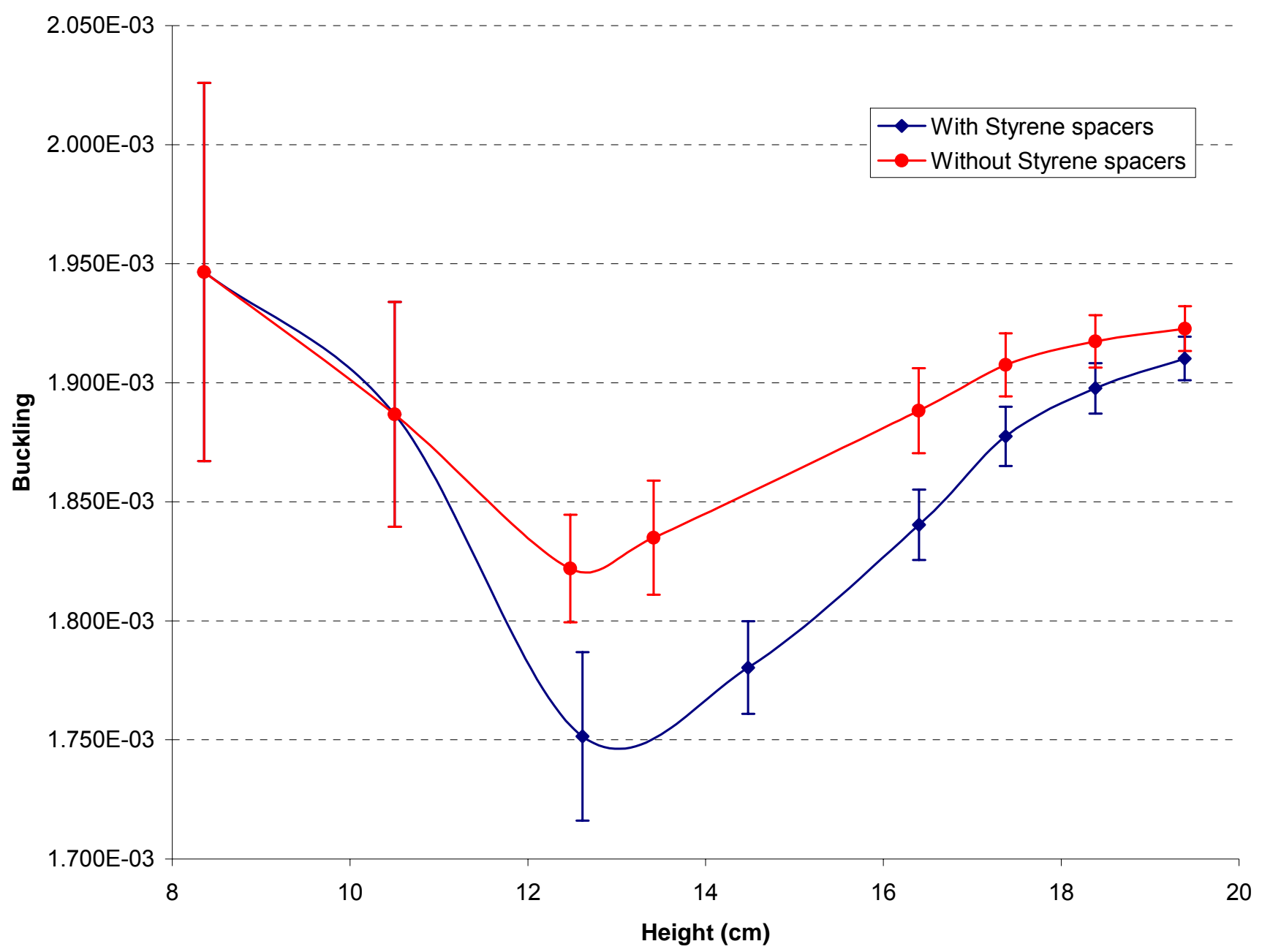

Figure 60: Buckling calculated from the fission rate profile measured by U-235 fission chamber in the R1UO2 configuration using data within a limited range ( \pm height from centerline) 


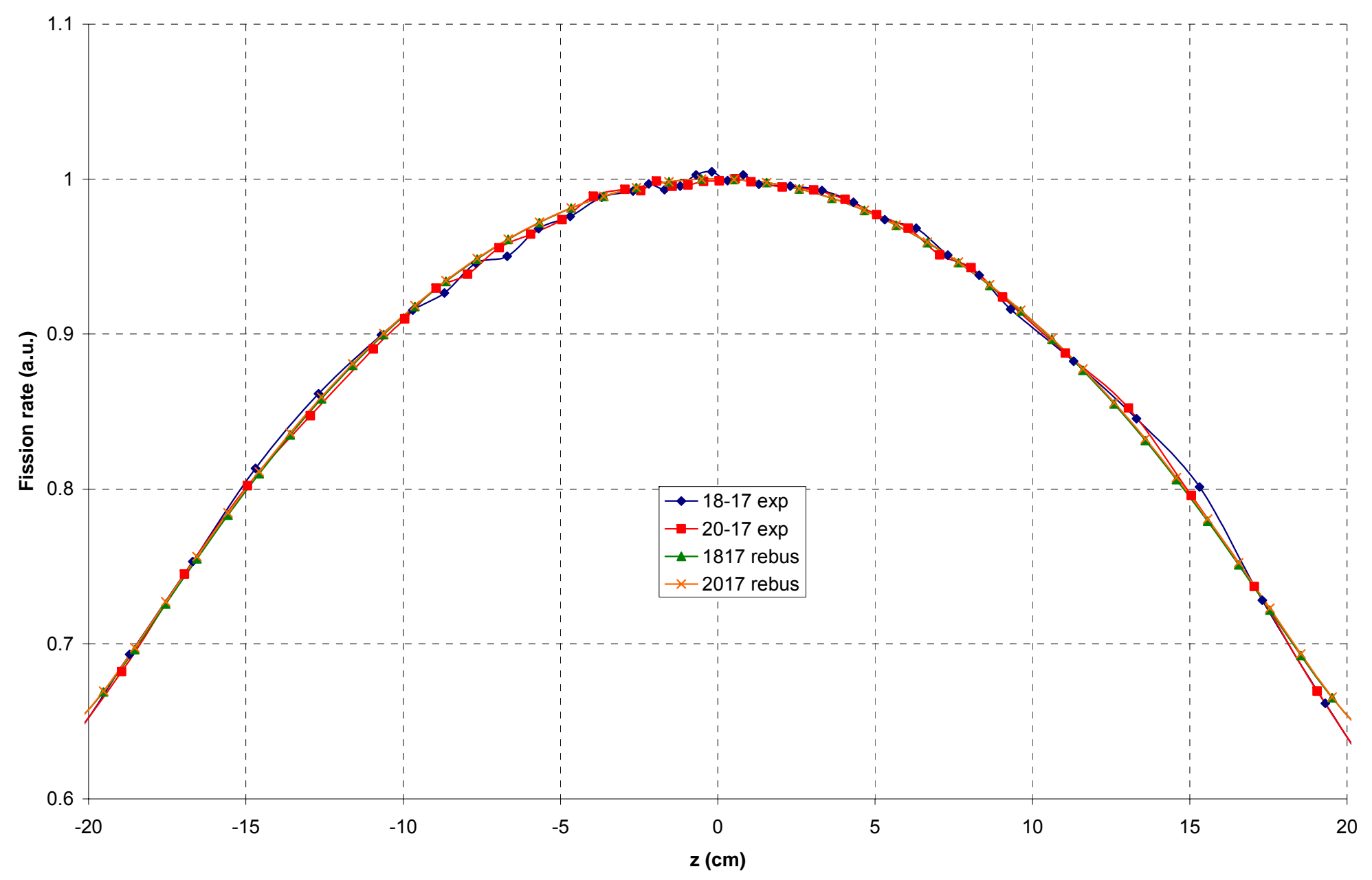

Figure 61: Axial power profile for specific pins in the R1MOX configuration - Comparison of REBUS results to measurements 


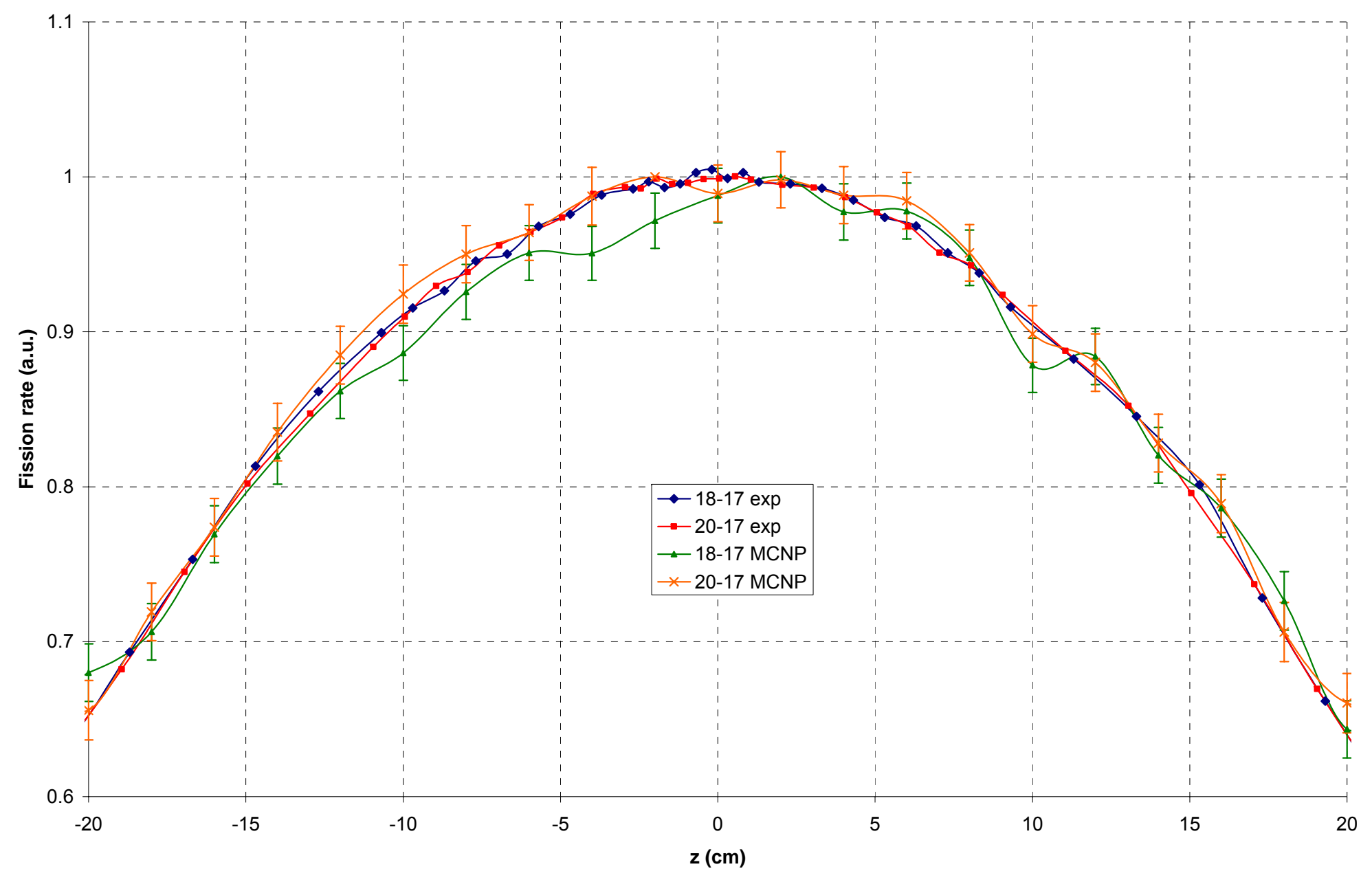

Figure 62: Axial power profile for specific pins in the R1MOX configuration - Comparison of MCNP results to measurements 


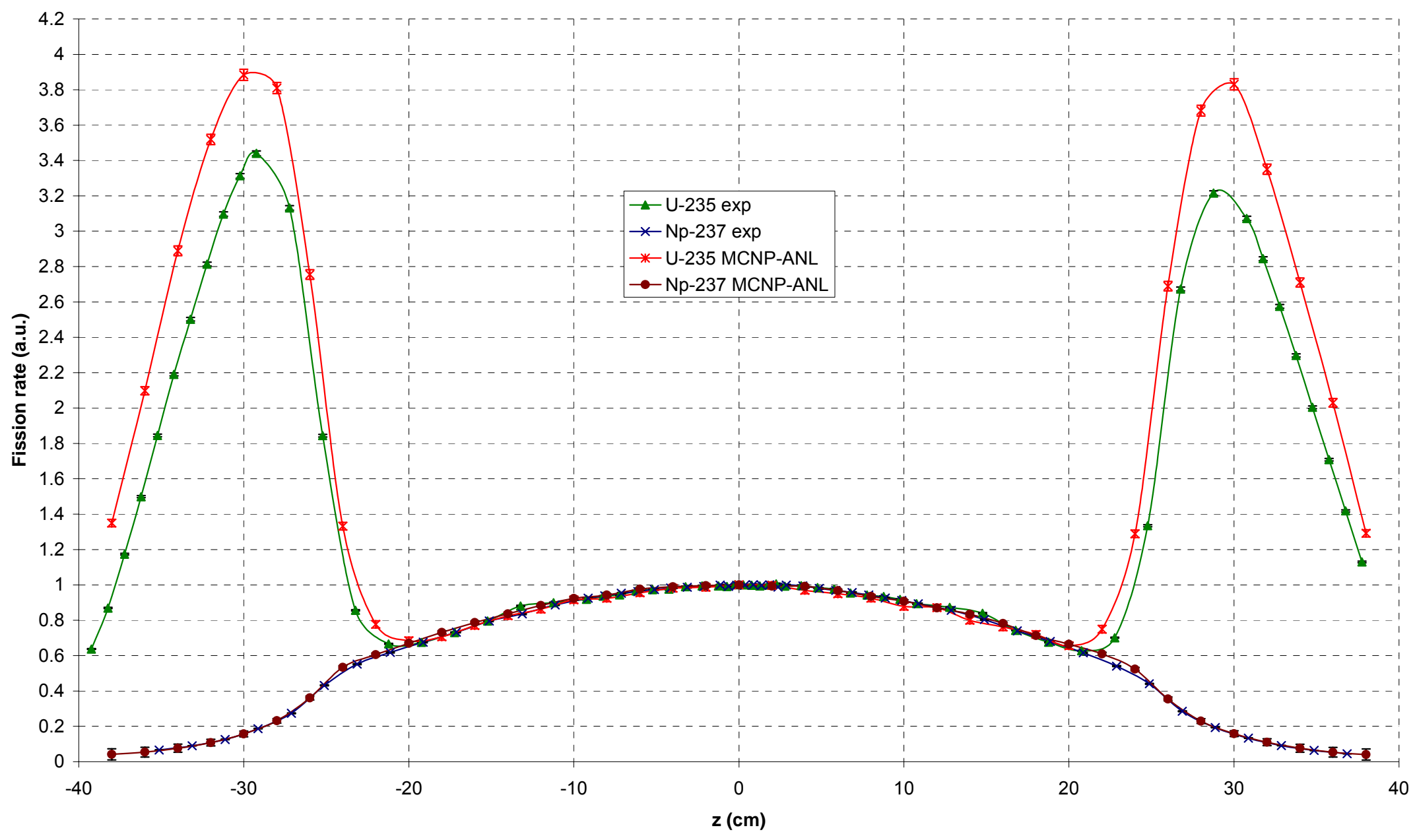

Figure 63: Axial fission rate profile of U-235 and Np-237 fission chambers in the R1MOX configuration - Comparison of MCNP results to measurements 


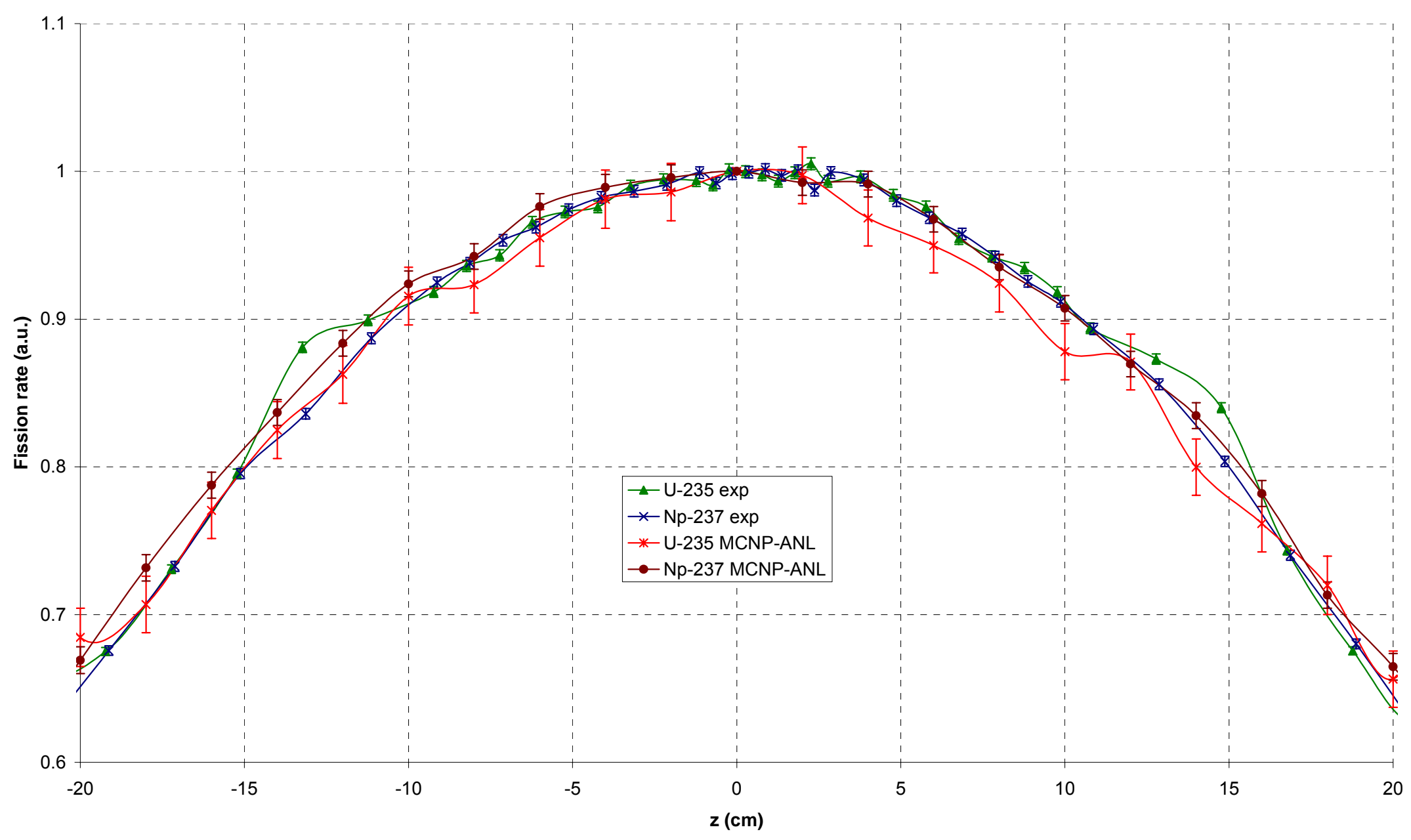

Figure 64: R1MOX Axial fission rate profile of U-235 and Np-237 fission chambers in the R1MOX configuration - Comparison of MCNP results to measurements over range of $\pm 20 \mathrm{~cm}$ 


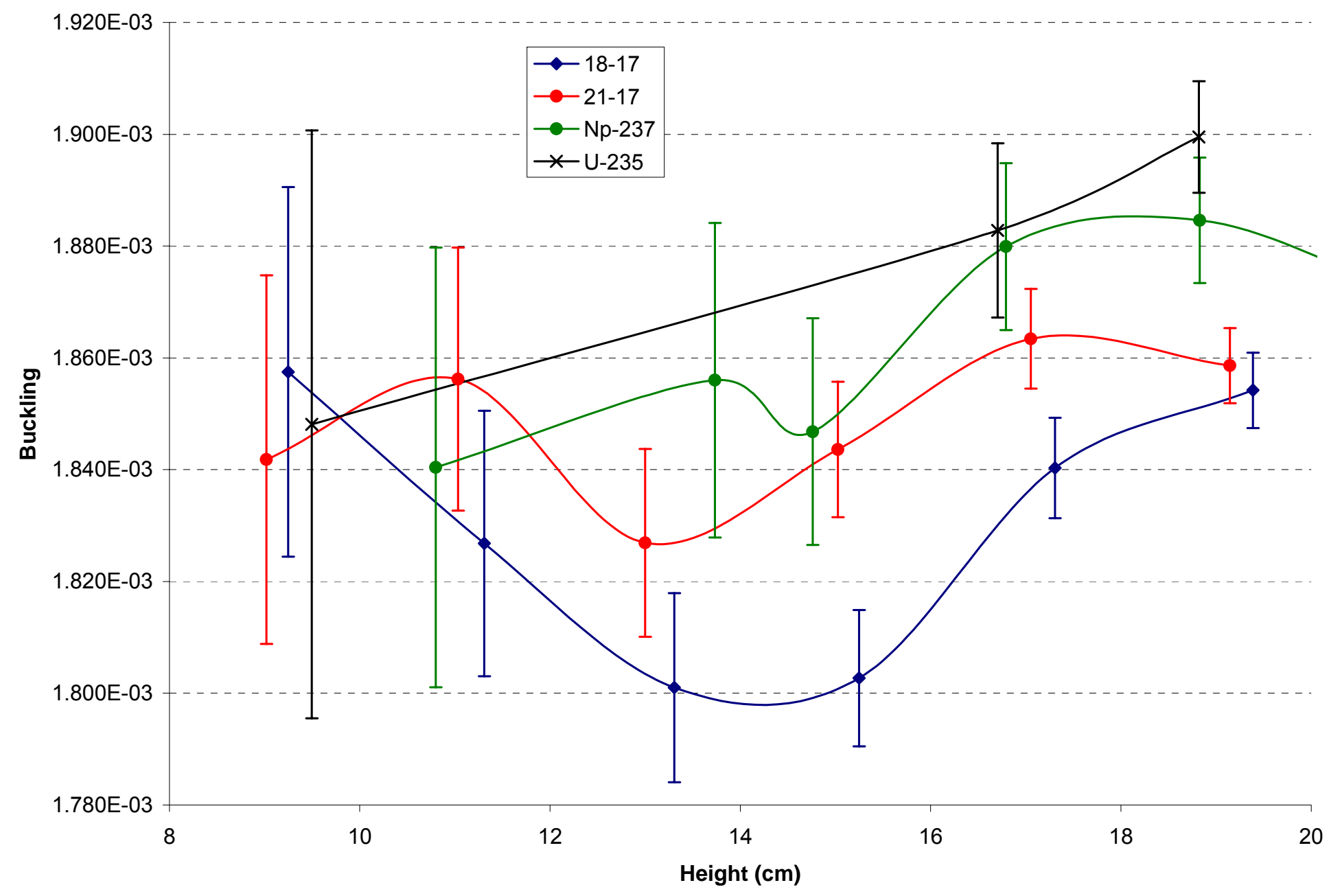

Figure 65: Buckling for the R1MOX configuration calculated with experimental data within a limited range ( \pm height from centerline) 


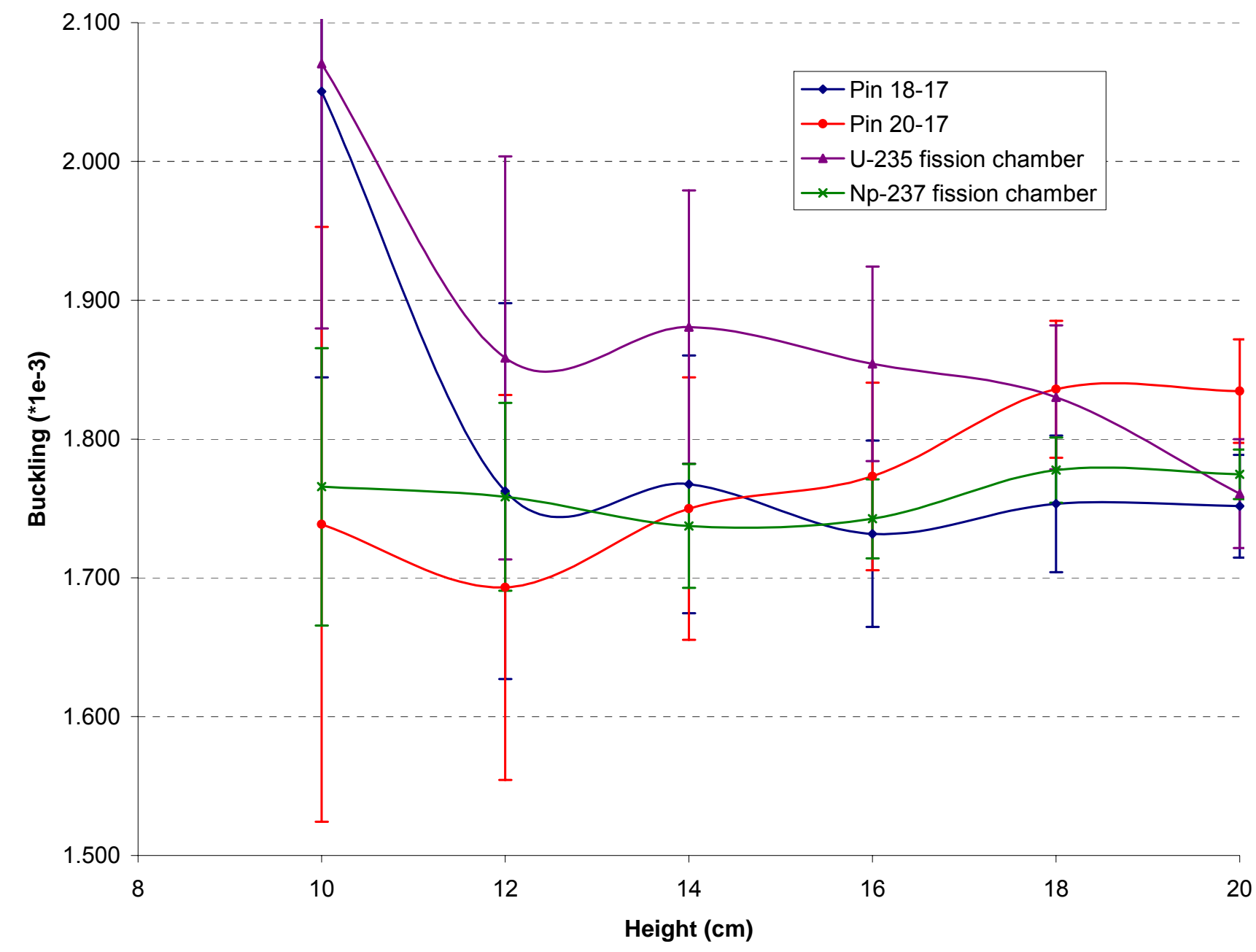

Figure 66: Buckling for the R1MOX configuration calculated with data from MCNP within a limited range ( \pm height from centerline) 


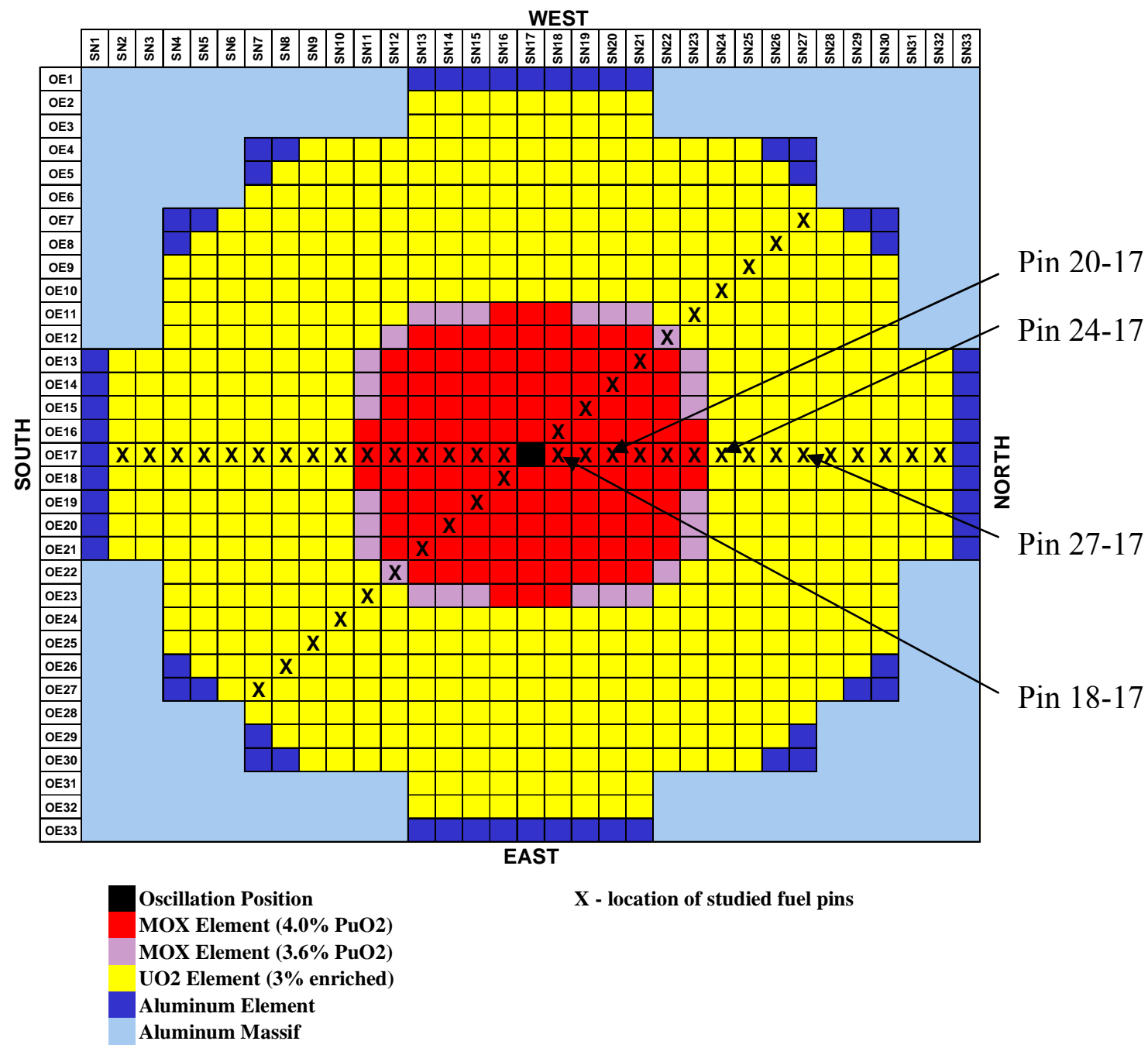

Figure 67: Location of the studied fuel pins for the radial power profile measurements in the R1MOX configuration 


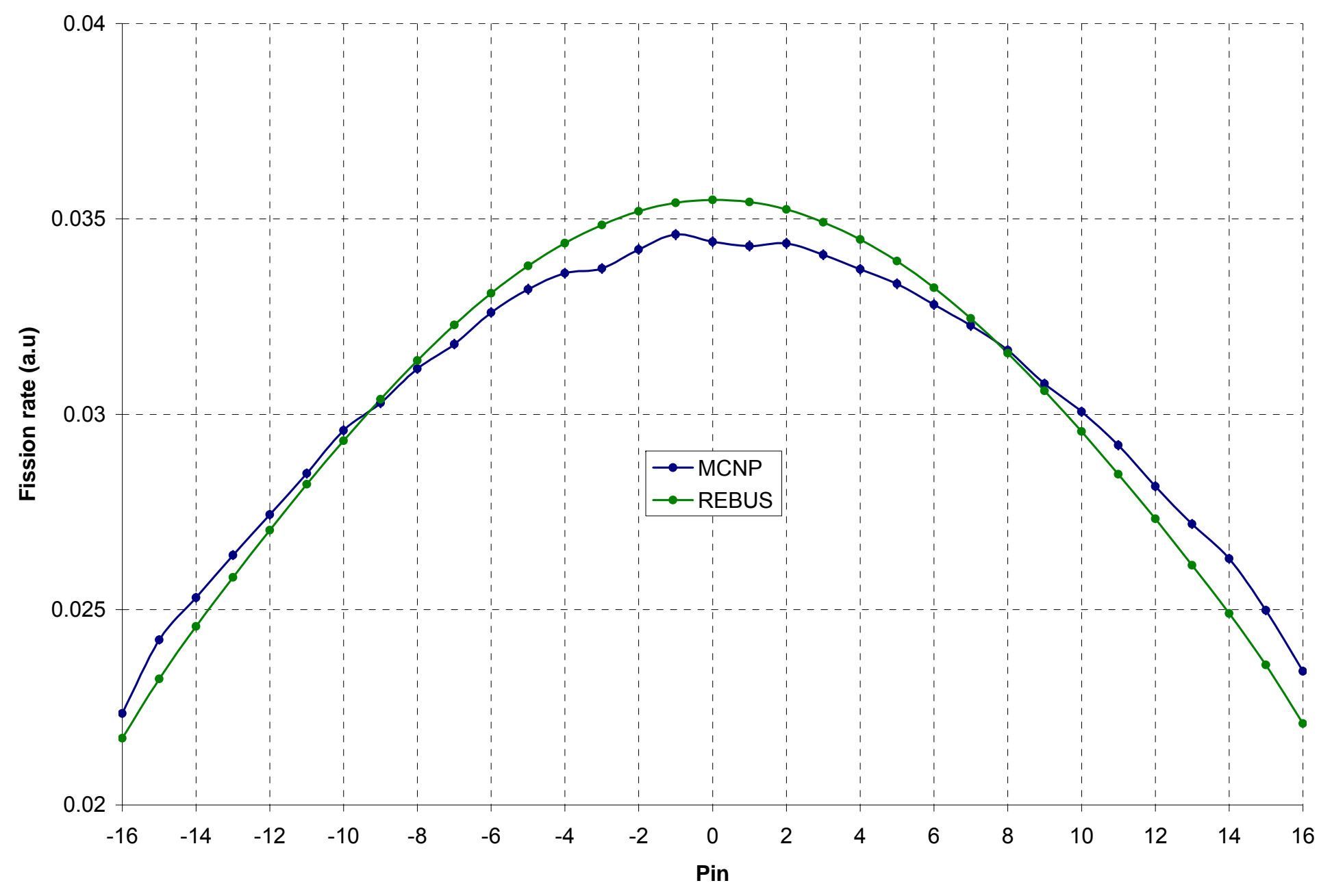

Figure 68: Fission rate distribution in the R1UO2 configuration for the $\mathrm{S}-\mathrm{N}$ traverse 


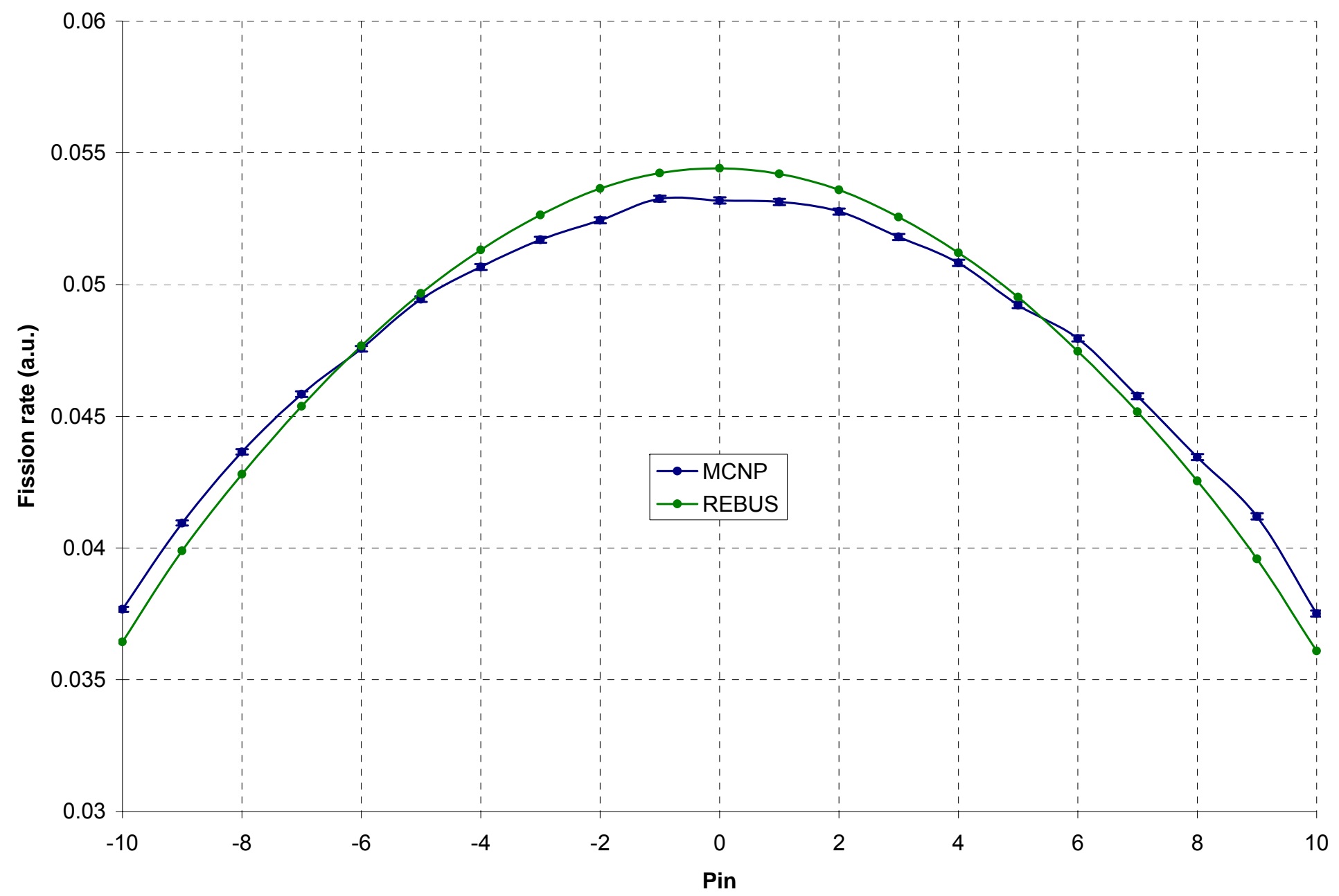

Figure 69: Fission rate distribution in the R1UO2 configuration for the SE-NW traverse 


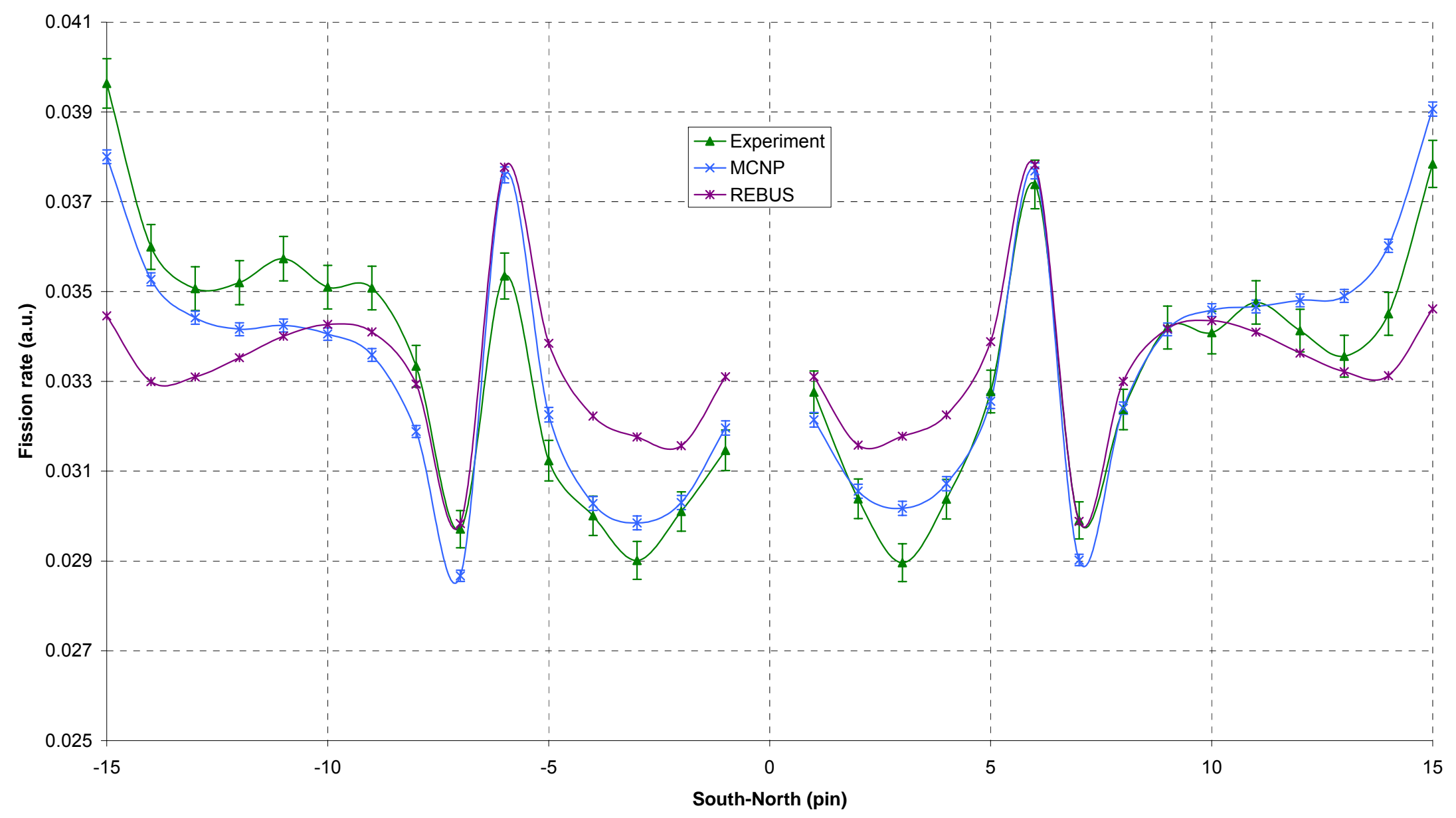

Figure 70: Fission rate distribution in the R1MOX configuration for the S-N traverse 


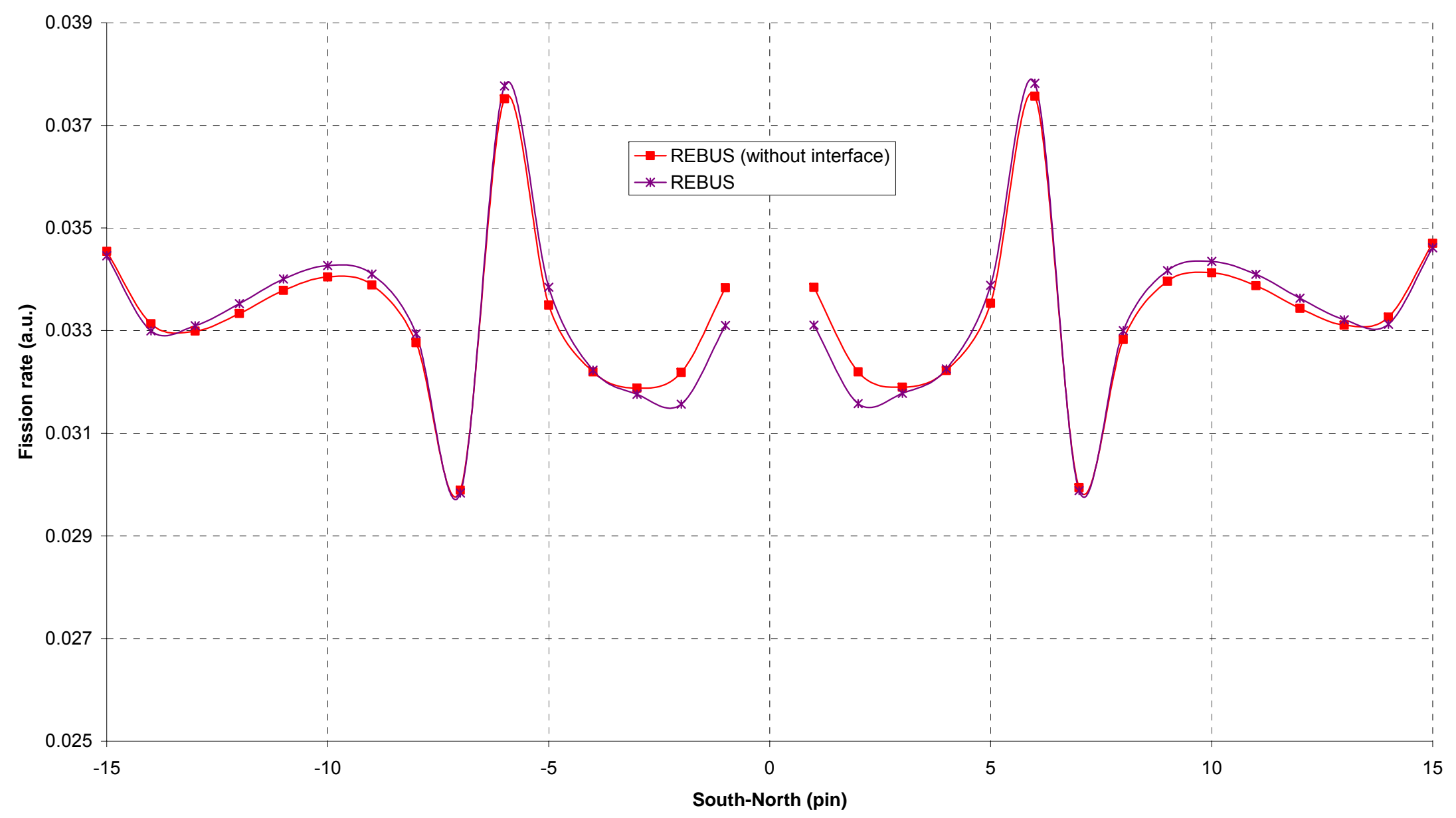

Figure 71: Fission rate distribution in the R1MOX configuration for the S-N traverse calculated with REBUS 


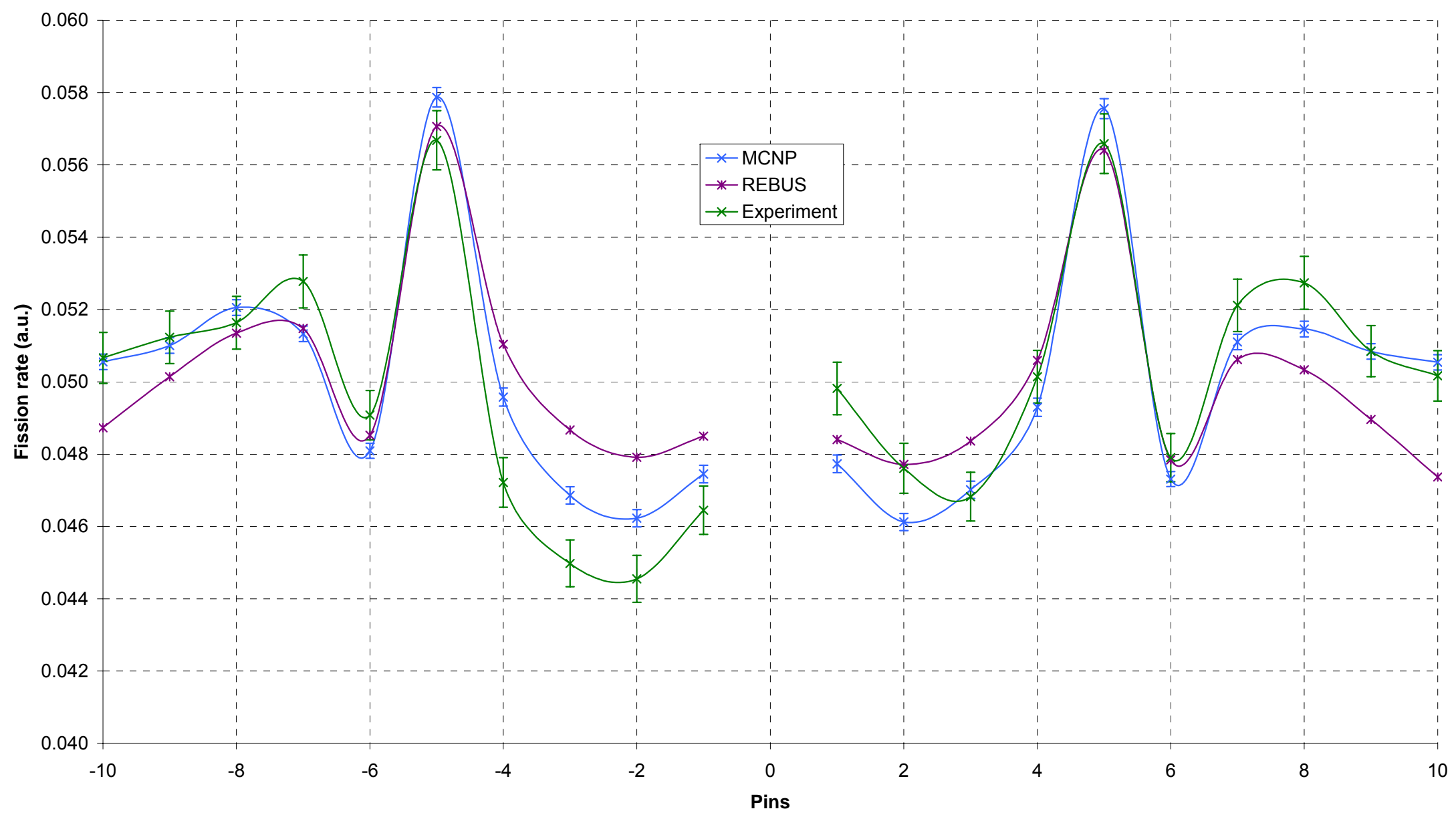

Figure 72: Fission rate distribution in the R1MOX configuration for the SE-NW traverse 
$\mathrm{UO}_{2}$ calibration sample

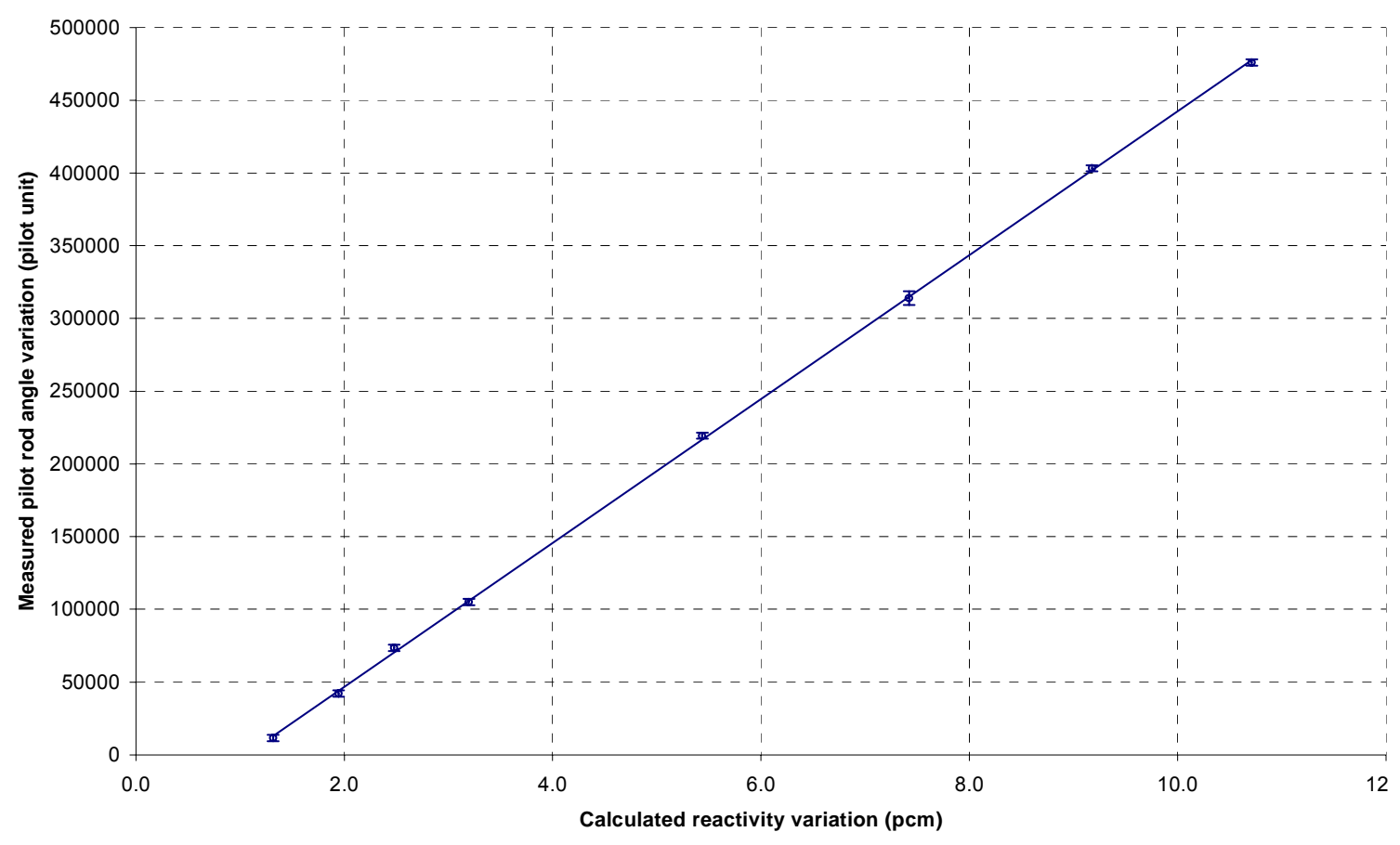

Borated calibration sample

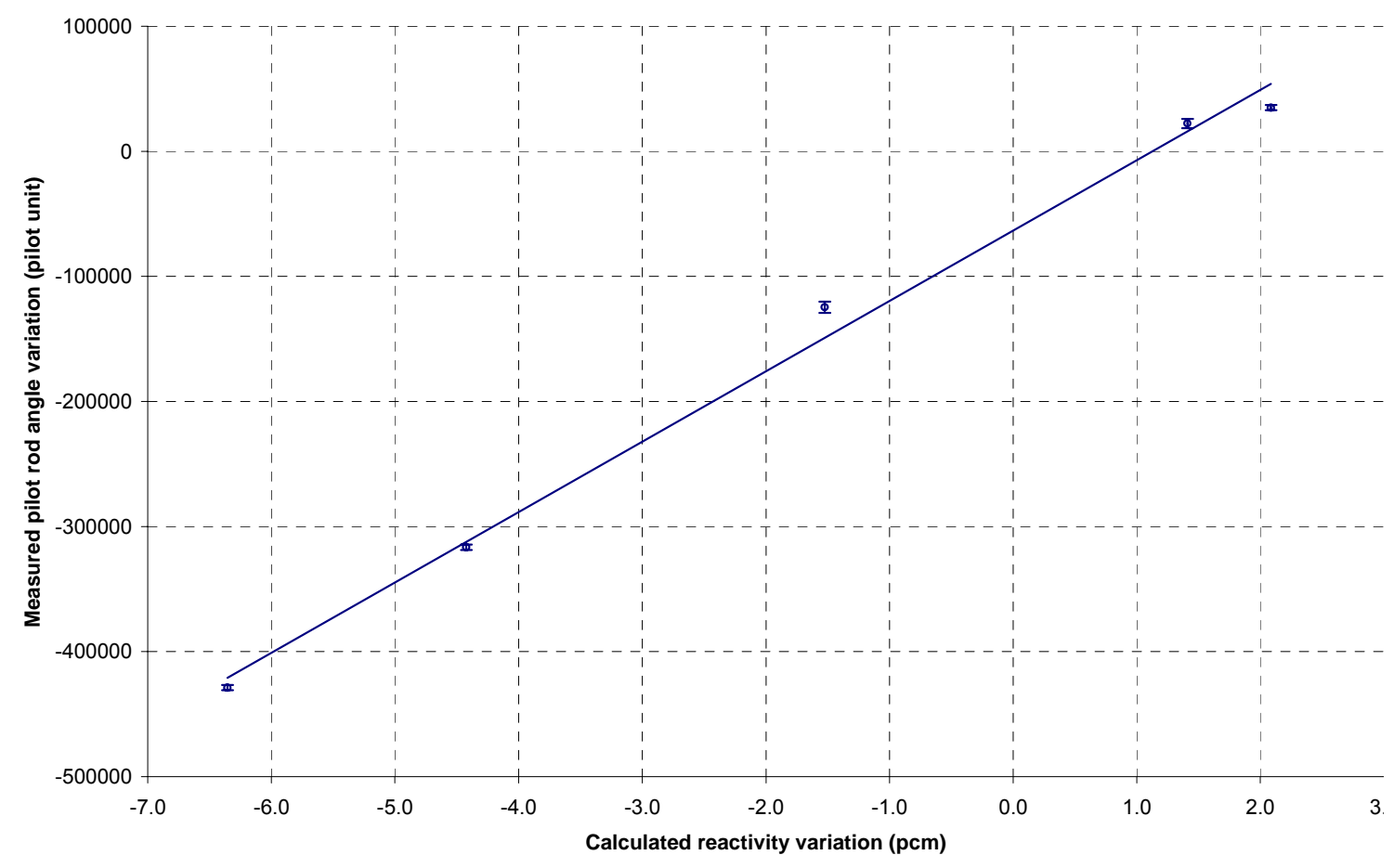

Figure 73: Experimental and calculated reactivity worth of the calibration samples in the R1UO2 configuration 
$\mathrm{UO}_{2}$ calibration sample

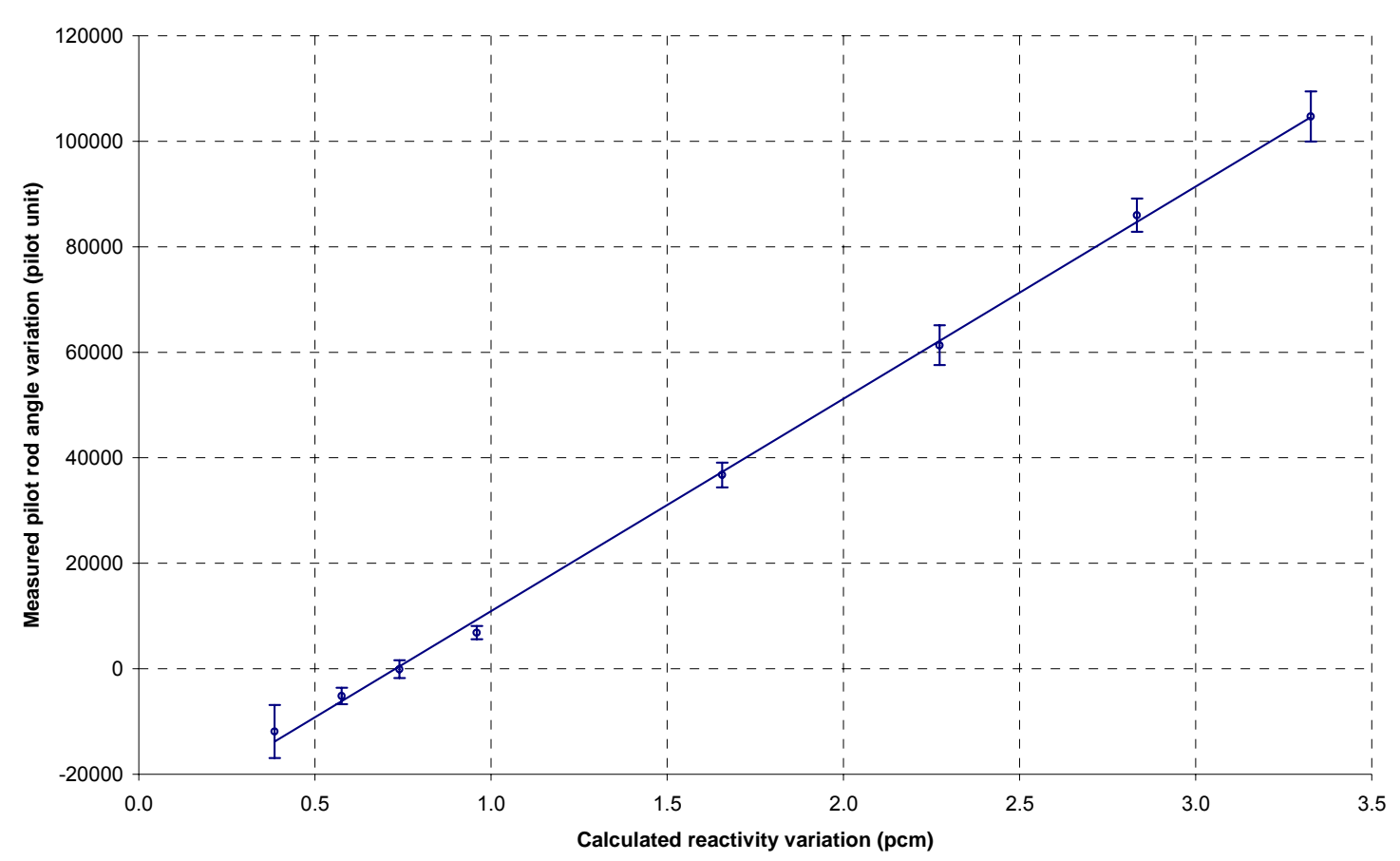

Borated calibration sample

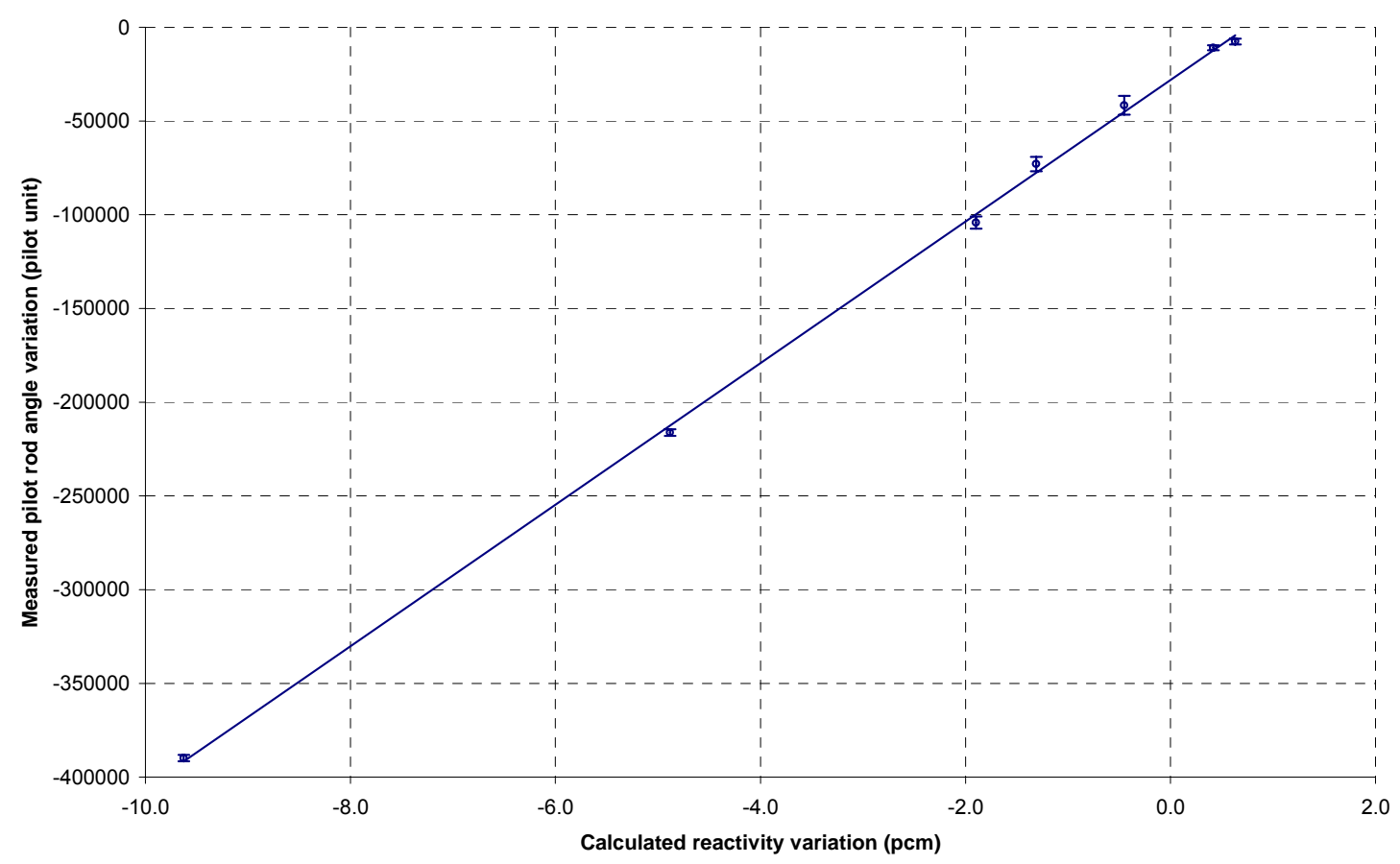

Figure 74: Experimental and calculated reactivity worth of the calibration samples in the R1MOX configuration 


\section{Appendix 1: MCNP input files}

MCNP input files representative of the R1UO2 and R1MOX configuration are listed in this appendix. The listed files are:

- R1UO2 configuration with the POLINE overclad in the oscillation channel [UO2I]

- R1MOX configuration with the POLINE overclad in the oscillation channel [MOXI] 


\section{File UO2I}

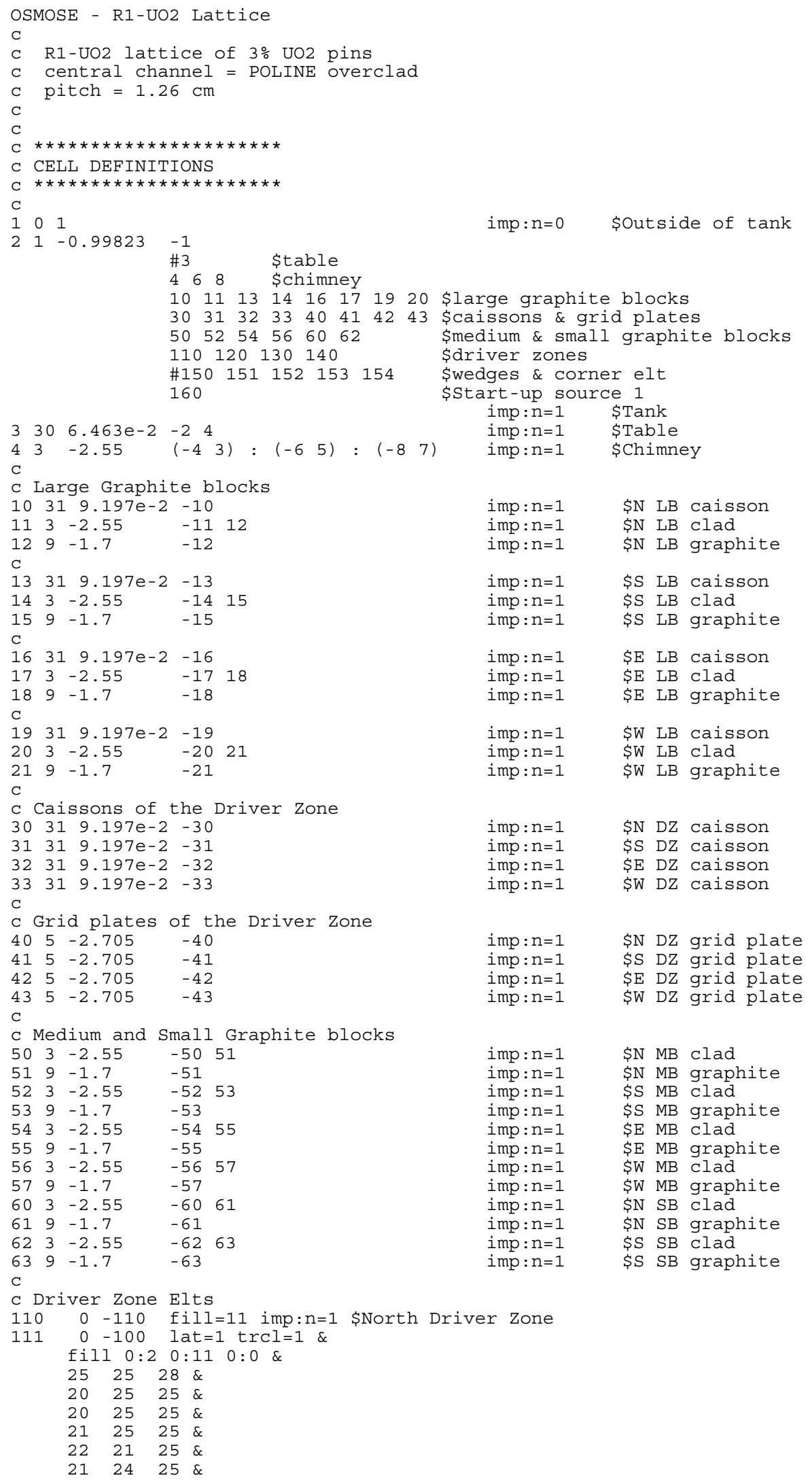




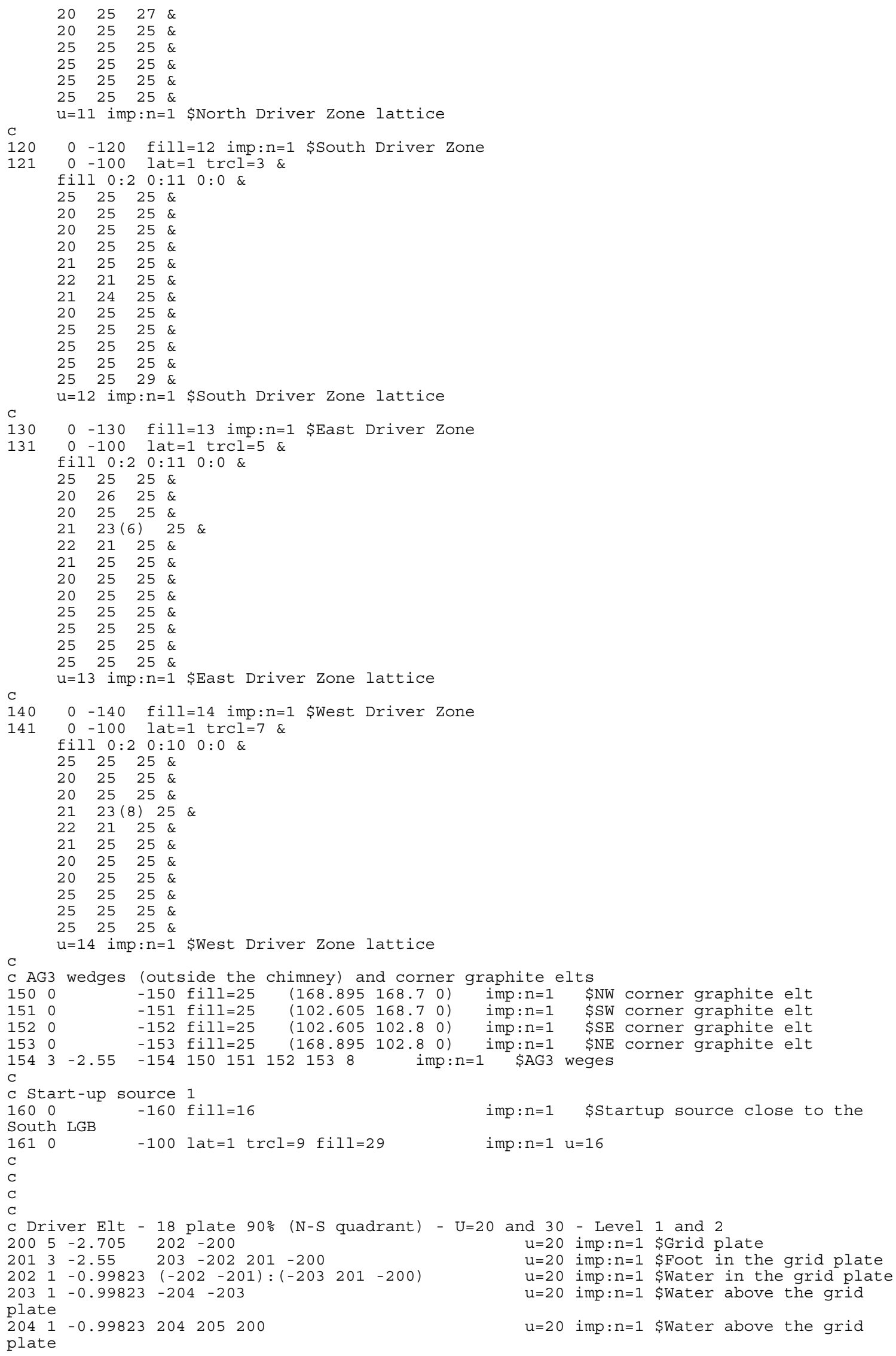




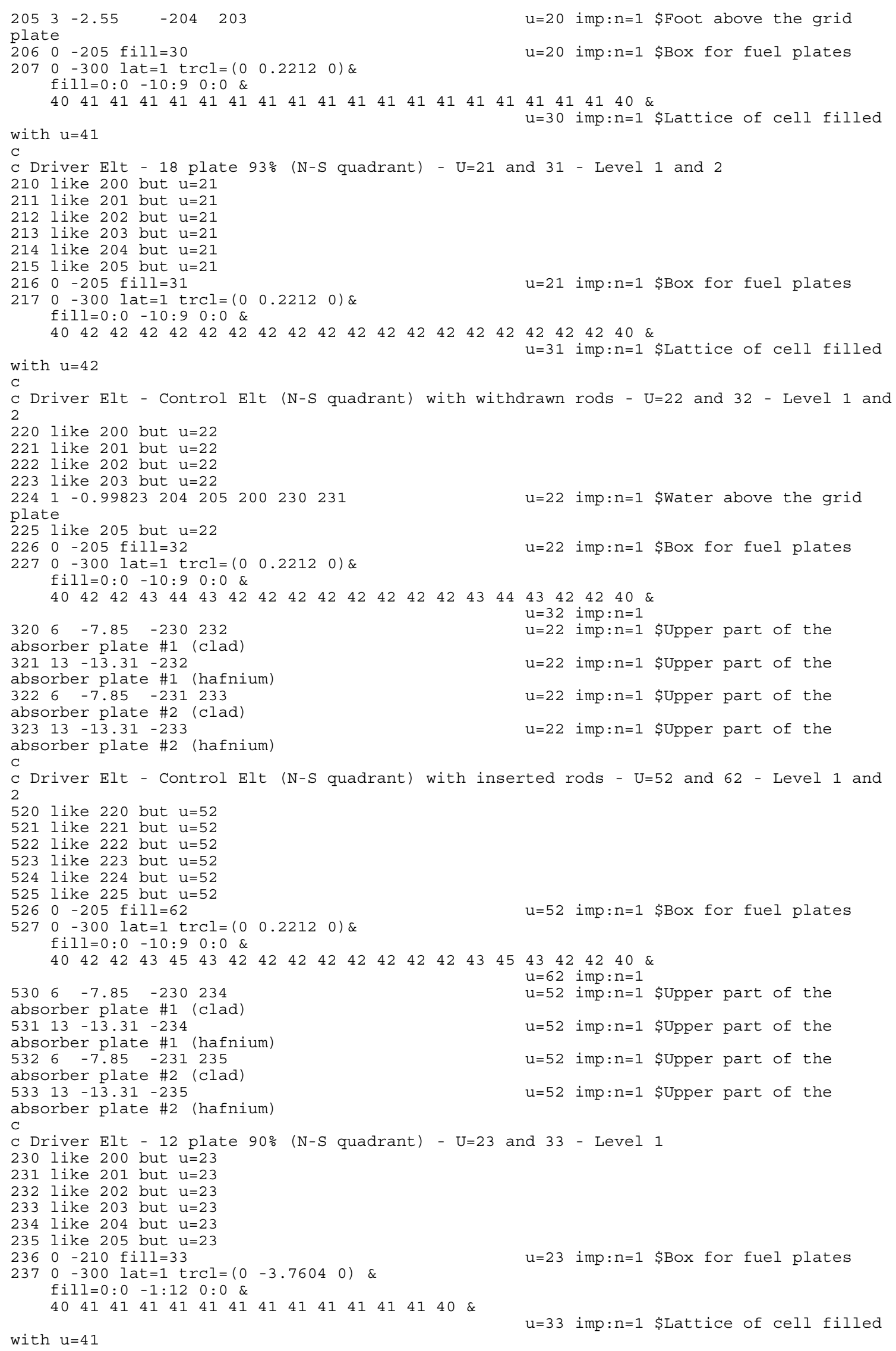




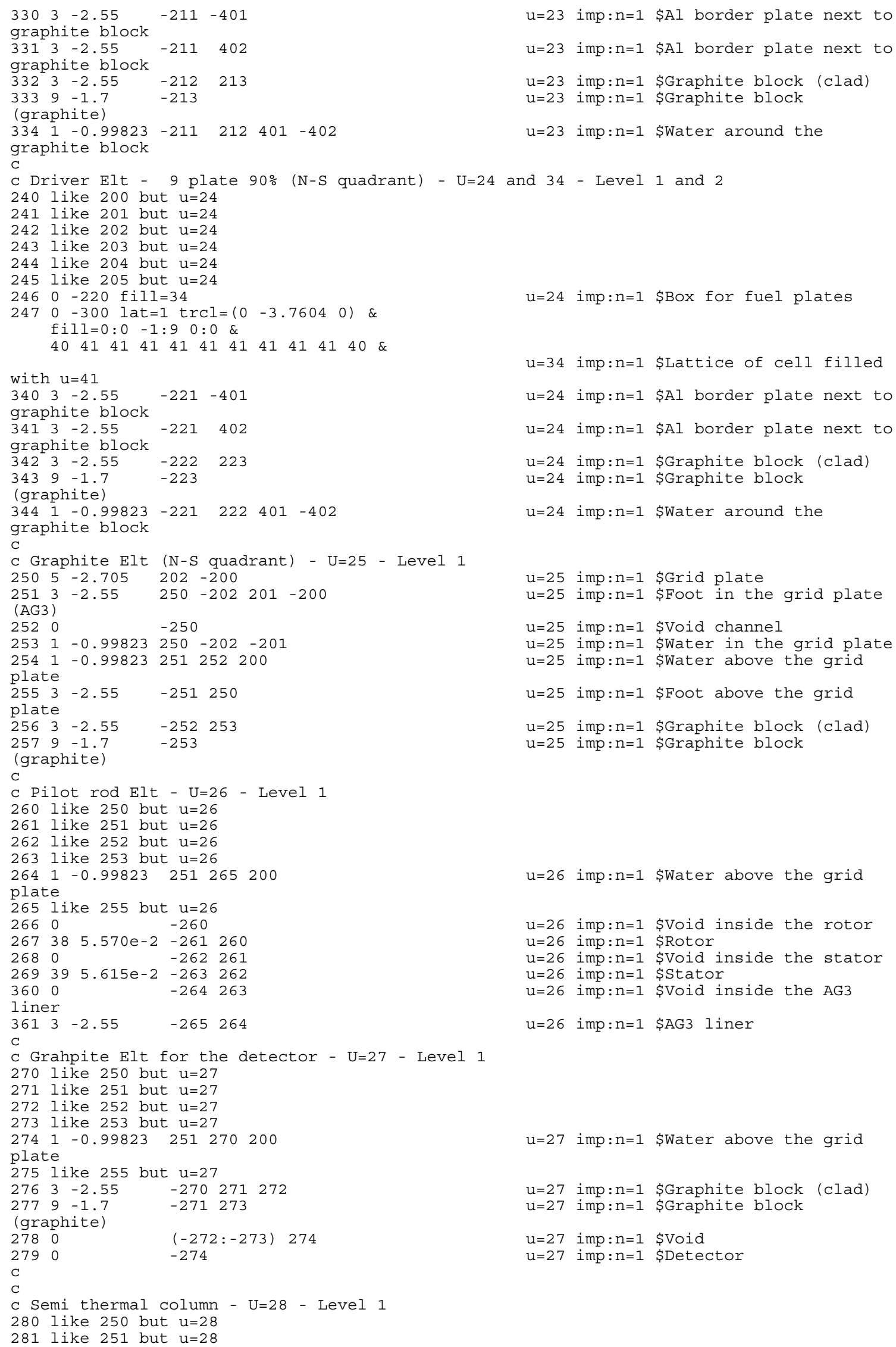


282 like 252 but $u=28$

283 like 253 but $u=28$

$\begin{array}{llllll}284 & 1 & -0.99823 & 251 & 280 & 200\end{array}$

$\mathrm{u}=28$ imp:n=1 \$Water above the grid

plate

285 like 255 but $u=28$

$\begin{array}{llllll}286 & 3 & -2.55 & -280 & 281\end{array}$

$\begin{array}{llllll}287 & 9 & -1.7 & -281 & 283 & 286\end{array}$

$\begin{array}{lllllll}288 & 12 & -0.9106 & -281 & -283 & 282\end{array}$

$\begin{array}{lllll}289 & 0 & -281 & -282 & 284\end{array}$

$\begin{array}{lllllll}380 & 0 & & -284 & & \\ 381 & 12 & -0.9106 & -281 & -286 & 285\end{array}$

$\begin{array}{lllll}382 & 0 & -281 & -285 & 287\end{array}$

$3830-287$

$\mathrm{C}$

C Source holder - U=29 - Level 1

290 like 250 but $u=29$

291 like 251 but $u=29$

292 like 252 but $u=29$

293 like 253 but $u=29$

$\begin{array}{lllllll}294 & 1 & -0.99823 & 251 & 290 & 292 & 200\end{array}$

plate

295 like 255 but $u=29$

$2963-2.55 \quad-290$

$\begin{array}{lllll}297 & 3 & -2.55 & -292 & 291\end{array}$

$\begin{array}{lllll}298 & 6 & -7.85 & -294 & 293\end{array}$

$2990 \quad-295$

$3900 \quad\left(\begin{array}{lllll}-291 & 294 & 295\end{array}\right):-293$

$\mathrm{u}=28$ imp: $\mathrm{n}=1$ \$Graphite block (clad)

$\mathrm{u}=28$ imp: $n=1$ \$Graphite block (clad)

$\mathrm{u}=28$ imp: $\mathrm{n}=1$ \$PVC Tube 1

$\mathrm{u}=28$ imp: $\mathrm{n}=1$ \$Detector channel 1

$\mathrm{u}=28$ imp: $\mathrm{n}=1$ \$Detector 1

$\mathrm{u}=28$ imp: $\mathrm{n}=1$ \$PVC Tube 2

$\mathrm{u}=28$ imp: $\mathrm{n}=1$ \$Detector channel 2

$\mathrm{u}=28$ imp: $\mathrm{n}=1$ \$Detector 2

$\mathrm{C}$

C

C

C Border plate \& water for the Driver Elts (N-S quadrant) - U=40 - Level 3

$4021-0.99823 \quad 401-402 \quad u=40$ imp:n=1 \$Water gap

$4033-2.55 \quad-401 \quad u=40$ imp:n=1 \$Border plate

$4043-2.55 \quad 402 \quad u=40$ imp:n=1 \$Border plate

C $90 \%$ U-5 plate for the Driver Elt (N-S quadrant) - U=41 - Level 3

$41020 \quad 5 \quad 985 e-2$

$41126.026 e-2 \quad 404-403$

$\begin{array}{llllll}412 & 1 & -0.99823 & 401 & -402 & 403\end{array}$

$\begin{array}{lllll}413 & 3 & -2.55 & -401 & 403\end{array}$

$\mathrm{u}=41$ imp: $\mathrm{n}=1$ \$Fuel meat

$\mathrm{u}=41$ imp:n=1 \$Fuel clad

$\mathrm{u}=41$ imp: $\mathrm{n}=1$ \$Water gap

$\mathrm{u}=41$ imp:n=1 \$Border plate

$\begin{array}{lllll}414 & 3 & -2.55 & 402 \quad 403\end{array}$

$\mathrm{u}=41$ imp:n=1 \$Border plate

C 93\% U-5 plate for the Driver Elt (N-S quadrant) - U=42 - Level 3

$420215.973 e-2-404$

421 like 411 but $\mathrm{u}=42$

422 like 412 but $u=42$

423 like 413 but $u=42$

424 like 414 but $u=42$

C

C Al plate for the Driver Elt (N-S quadrant) - U=43 - Level 3

$43126.026 e-2-403 \quad u=43$ imp:n=1 \$Inertial Al plate

432 like 412 but $u=43$

433 like 413 but $u=43$

434 like 414 but $u=43$

C Absorber plate for the Driver Elt (N-S quadrant) - Withdrawn - U=44 - Level 3

$44013-13.31 \quad-406 \quad u=44$ imp:n=1 \$Hafnium rod withdrawn

$4416-7.85 \quad-405 \quad 406$

(clad)

$44740 \quad 9.354 e-2 \quad-409$

(bevel)

$\begin{array}{lllllll}442 & 1 & -0.99823 & 405 & 401 & -402 & 409\end{array}$

$4451-0.99823-401-403$

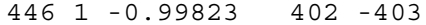

443 like 413 but $u=44$

444 like 414 but $u=44$

C

C Absorber plate for the Driver Elt (N-S quadrant) - Inserted - U=45 - Level 3

$45013-13.31 \quad-408$

$60 \mathrm{~cm}$ in the fuel plates (hafnium)

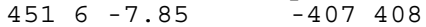

$60 \mathrm{~cm}$ in the fuel plates (clad)

$457409.354 e-2-410$

$60 \mathrm{~cm}$ in the fuel plates (bevel)

$\begin{array}{lllllll}452 & 1 & -0.99823 & 407 & 401 & -402 & 410\end{array}$

$\begin{array}{lllll}455 & 1 & -0.99823 & -401 & -403\end{array}$

$4561-0.99823 \quad 402-403$

453 like 413 but $u=45$

454 like 414 but $u=45$

$\mathrm{u}=44$ imp:n=1 \$Hafnium rod withdrawn

$\mathrm{u}=44$ imp:n=1 \$Hafnium rod withdrawn

$\mathrm{u}=44$ imp: $\mathrm{n}=1$ \$Water gap

$\mathrm{u}=44$ imp: $\mathrm{n}=1$ \$Water gap

$\mathrm{u}=44$ imp: $\mathrm{n}=1$ \$Water gap 


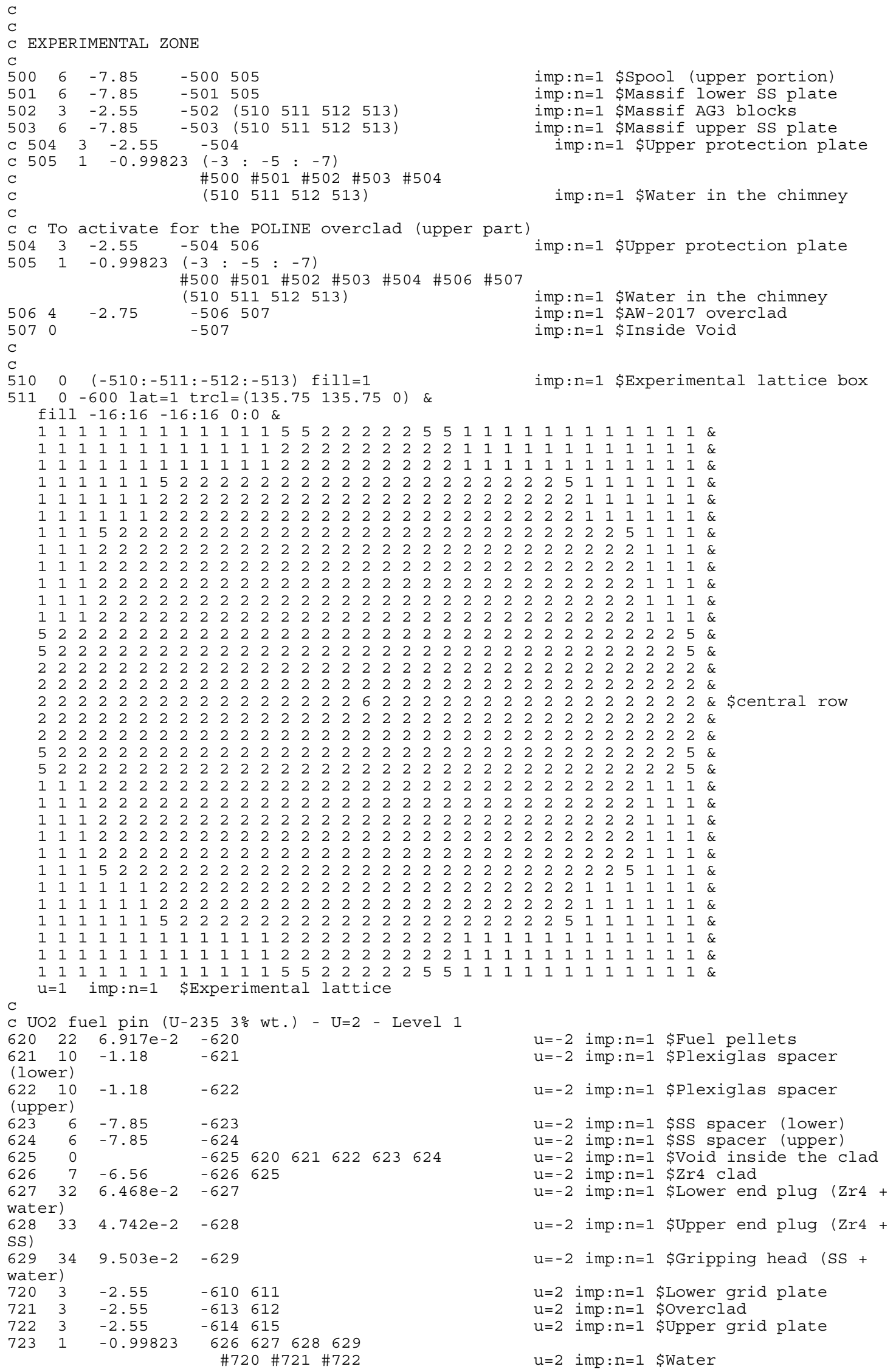




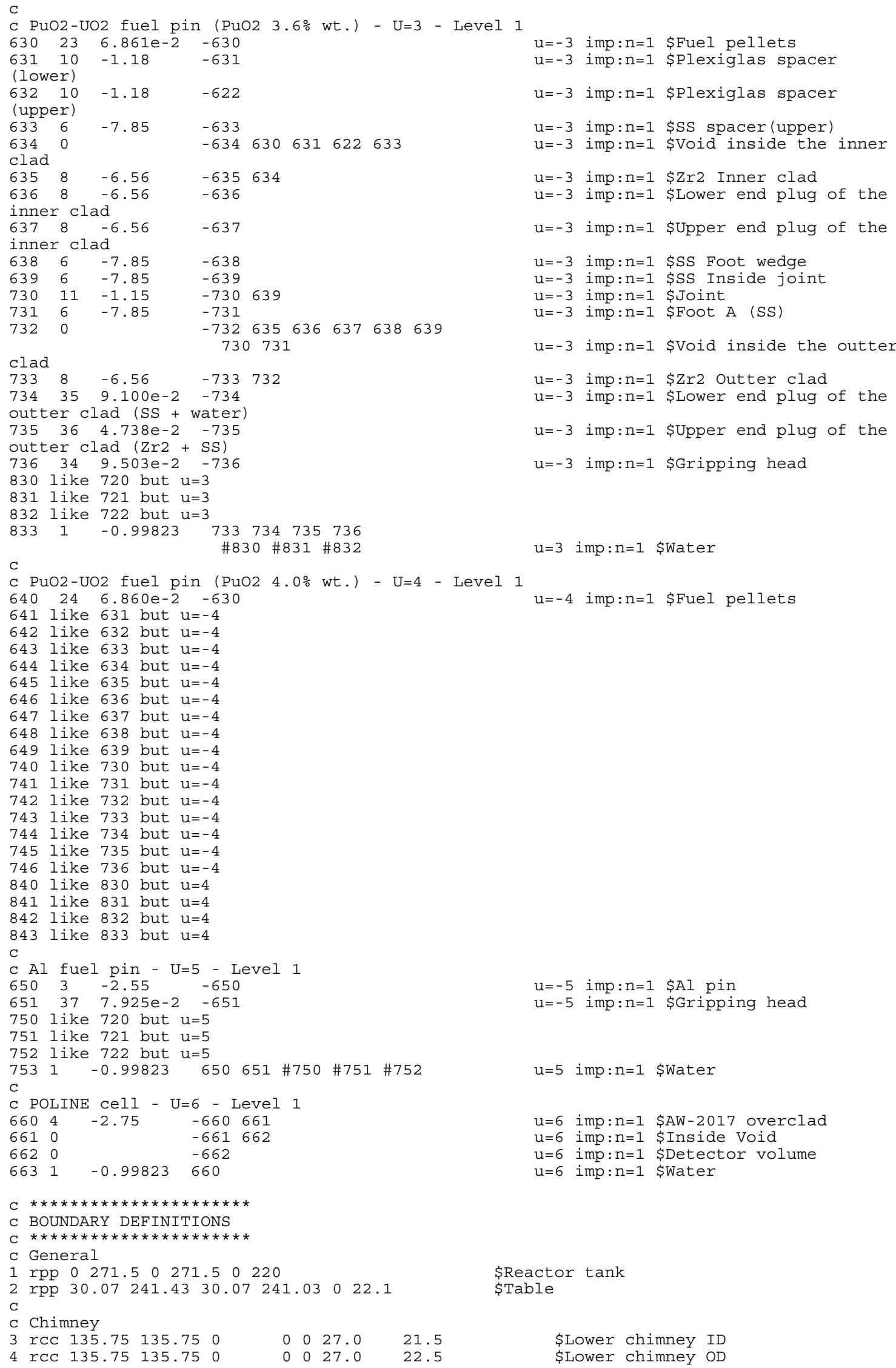

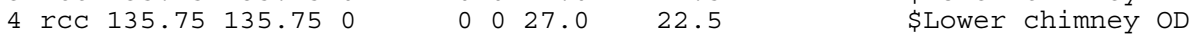

$\mathrm{u}=-5$ imp: $\mathrm{n}=1$ \$Al pin $\mathrm{u}=-5$ imp:n=1 \$Gripping head

$\mathrm{u}=6$ imp: $\mathrm{n}=1$ \$AW-2017 overclad

$\mathrm{u}=6$ imp: $\mathrm{n}=1$ \$Inside Void

$\mathrm{u}=6$ imp: $\mathrm{n}=1$ \$Detector volume

$\mathrm{u}=6$ imp: $\mathrm{n}=1$ \$Water

\$Reactor tank

\$Table 


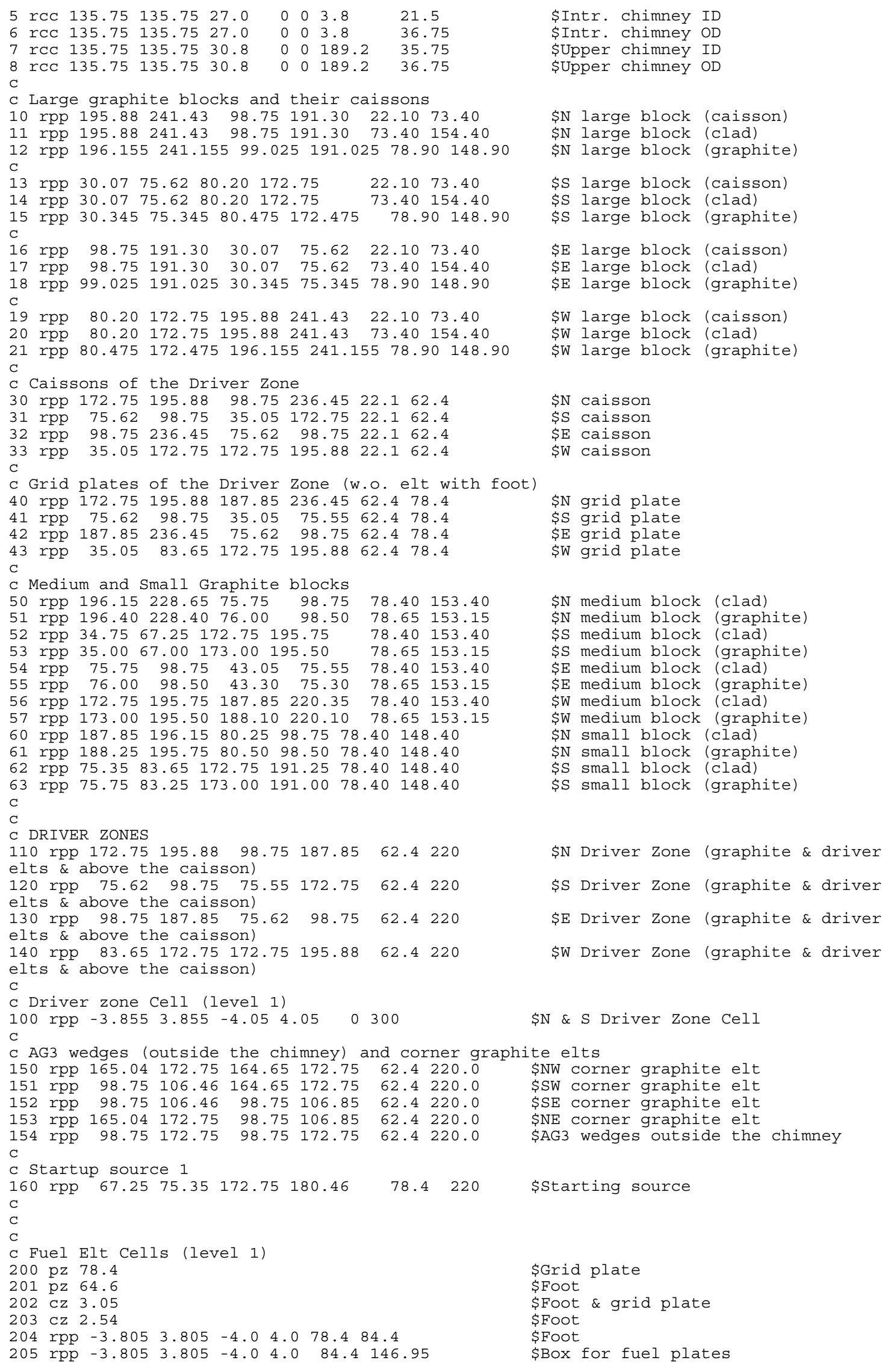


C 12-plate fuel elt cell

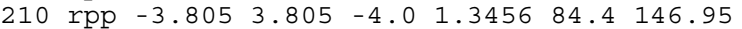

plate elt

$211 \begin{array}{lllllll}\text { rpp } & -3.805 & 3.805 & 1.3456 & 4.0 & 84.4 & 146.95\end{array}$

Al border plate

$\begin{array}{llllllll}212 & \text { rpp } & -3.329 & 3.329 & 1.495 & 3.855 & 84.4 & 146.95\end{array}$

$\begin{array}{llllllll}213 & \mathrm{rpp} & -3.29 & 3.29 & 1.50 & 3.85 & 84.45 & 146.90\end{array}$

(graphite)

C

C 9-plate fuel elt cell

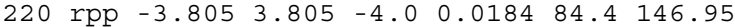

plate elt

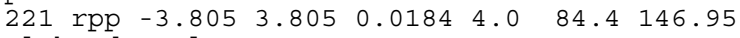

Al border plate

$\begin{array}{llllllll}222 & \text { rpp } & -3.329 & 3.329 & 0.18 & 3.87 & 84.4 & 146.95\end{array}$

$\begin{array}{llllllll}223 & \text { rpp } & -3.29 & 3.29 & 0.185 & 3.865 & 84.45 & 146.90\end{array}$

(graphite)

c Control elt cell

$\begin{array}{llllllll}230 & \mathrm{rpp} & -3.25 & 3.25 & 2.2137 & 2.6527 & 146.95 & 220\end{array}$

$146.95, \quad Z \max =220$ )

$231 \quad \mathrm{rpp} \quad-3.25 \quad 3.25 \quad-2.6527 \quad-2.2137 \quad 146.95 \quad 220$

$146.95, Z \max =220$ )

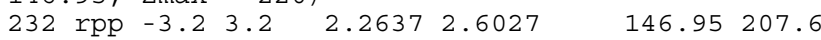

$(\mathrm{Zmin}=146.95, \mathrm{Zmax}=145.7+61.9)$

233 rpp $-3.2 \quad 3.2 \quad-2.6027-2.2637 \quad 146.95 \quad 207.6$

$(\mathrm{Zmin}=146.95, \quad \mathrm{Zmax}=145.7+61.9)$

$234 \mathrm{rpp}-3.23 .2 \quad 2.26372 .6027 \quad 146.95147 .6$

(hafnium) $(\mathrm{Zmin}=146.95, \mathrm{Zmax}=145.7-\mathrm{Zin}+61.9)$

$($ hafnium $)(\operatorname{Zmin}=146.95, \quad \mathrm{Zmax}=145.7-\mathrm{Zin}+61.9)$

C

Graphite Elt Cells (level 1$)$

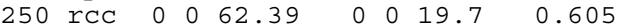

$\begin{array}{llllllll}251 & \text { rpp } & -3.805 & 3.805 & -4.0 & 4.0 & 78.4 & 82.1\end{array}$

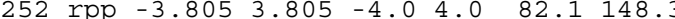

$\begin{array}{llllllll}253 & \mathrm{rpp} & -3.6 & 3.6 & -3.75 & 3.75 & 82.1 & 145.35\end{array}$ $\mathrm{C}$

C Pilot rod Elt Cell (level 1)

$\begin{array}{lllllllll}260 & \text { rCC } & 0 & 0 & 82.1 & 0 & 0 & 72.2 & 2.0\end{array}$

$\begin{array}{llllllllll}261 & \mathrm{rCC} & 0 & 0 & 82.1 & 0 & 0 & 72.2 & 2.1\end{array}$

$\begin{array}{lllllllll}262 & \text { rCC } & 0 & 0 & 82.1 & 0 & 0 & 72.2 & 2.25\end{array}$

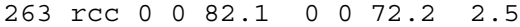

$\begin{array}{lllllllll}264 & \operatorname{rCC} & 0 & 0 & 82.1 & 0 & 0 & 72.2 & 3.15\end{array}$

$\begin{array}{lllllllll}265 & \text { rCC } & 0 & 0 & 82.1 & 0 & 0 & 72.2 & 3.45\end{array}$

C

C Graphite Elt for detector Cell (level 1)

$\begin{array}{lllllllll}270 & \text { rpp } & -3.805 & 3.805 & -4.0 & 4.0 & 82.1 & 157.8\end{array}$

271 rpp $-3.6 \quad 3.6 \quad-3.75 \quad 3.75 \quad 82.1 \quad 153.2$

$\begin{array}{lllllllll}272 & \text { rpp } & -3.6 & 3.6 & -3.75 & 3.75 & 153.2 & 156.2\end{array}$

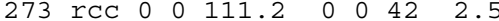

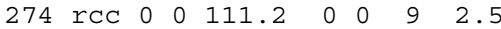

C

C Semi thermal column Cell (level 1)

$280 \quad$ rpp $-3.805 \quad 3.805 \quad-4.0 \quad 4.0 \quad 82.1220$

$\begin{array}{llllllll}281 & \text { rpp } & -3.6 & 3.6 & -3.75 & 3.75 & 82.1 & 220\end{array}$

$282 \mathrm{C} / \mathrm{z}-1.739 \quad 1.654 \quad 0.8$

$283 \mathrm{C} / \mathrm{z}-1.739 \quad 1.654 \quad 0.925$

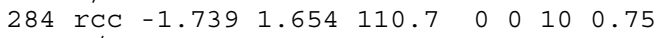

$285 \mathrm{C} / \mathrm{z} \quad 1.739-1.654 \quad 0.8$

$286 \mathrm{C} / \mathrm{z} \quad 1.739-1.654 \quad 0.925$

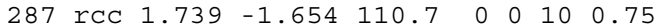

C

C Source holder Cell (level 1)

290 rpp $-3.705 \quad 3.705-3.705 \quad 3.705 \quad 82.1 \quad 84.6$

$\begin{array}{llllllllll}291 & \text { rCC } & 0 & 0 & 84.6 & 0 & 0 & 88 & 1.6\end{array}$

292 rCC $000084.6 \quad 00088 \quad 1.8$

293 rCC $000 \begin{array}{llllll}04.6 & 0 & 0 & 45 & 1.15\end{array}$

294 rCC $000 \begin{array}{llllll}04.6 & 0 & 0 & 45 & 1.25\end{array}$

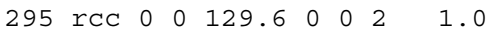

C

C

C Fuel Plates Cells (level 2)

$300 \quad$ rpp $-10 \quad 10-0.2212 \quad 0.2212 \quad 1301$

in $\mathrm{X}$ and $\mathrm{Z}$ )

$401 \mathrm{px}-3.329$

$402 \mathrm{px} 3.329$

$\begin{array}{llllllll}403 & \text { rpp } & -3.551 & 3.551 & -0.0762 & 0.0762 & 84.39 & 146.96\end{array}$

404 rpp $-3.25 \quad 3.25 \quad-0.0254 \quad 0.0254$
\$Box for the fuel plate of the 12-

\$Box for the graphite block \& water \&

\$Box for the graphite block (clad)

\$Box for the graphite block

\$Box for the fuel plate of the 9-

\$Box for the graphite block \& water \&

\$Box for the graphite block (clad)

$\$ B o x$ for the graphite block

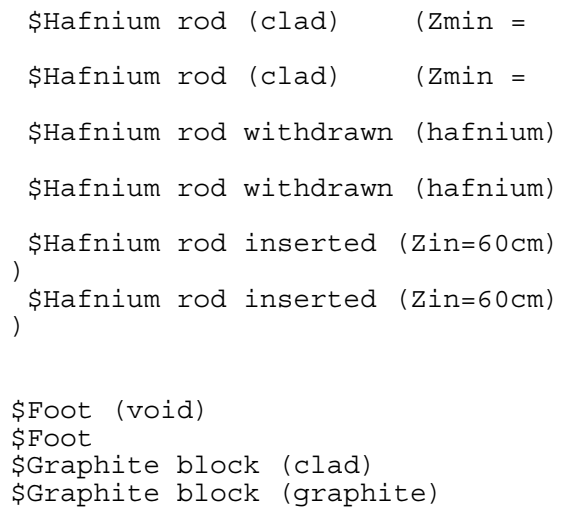

\$Rotor ID

\$Rotor OD

\$Stator ID

\$Stator OD

\$AG3 Liner ID

\$AG3 Liner OD

SGraphite block (clad)

\$Graphite block (graphite)

\$Upper void

\$Detector location

\$Detector

SGraphite block (clad)

\$Graphite block (graphite)

\$Tube 1 (ID)

\$Tube 1 (OD)

\$Detector 1

\$Tube 2 (ID)

\$Tube 2 (OD)

\$Detector 2

\$Support

\$AG3 Tube (ID)

\$AG3 Tube (OD)

\$Source support (ID)

\$Source support (OD)

\$Source

\$Box for the fuel plate cell (infinte

\$Al border plate

\$Al border plate

$\$ B o x$ for Al clad (infinite in $\mathrm{Z}$ )

\$Box for fuel meat (infinite in $\mathrm{Z}$ ) 


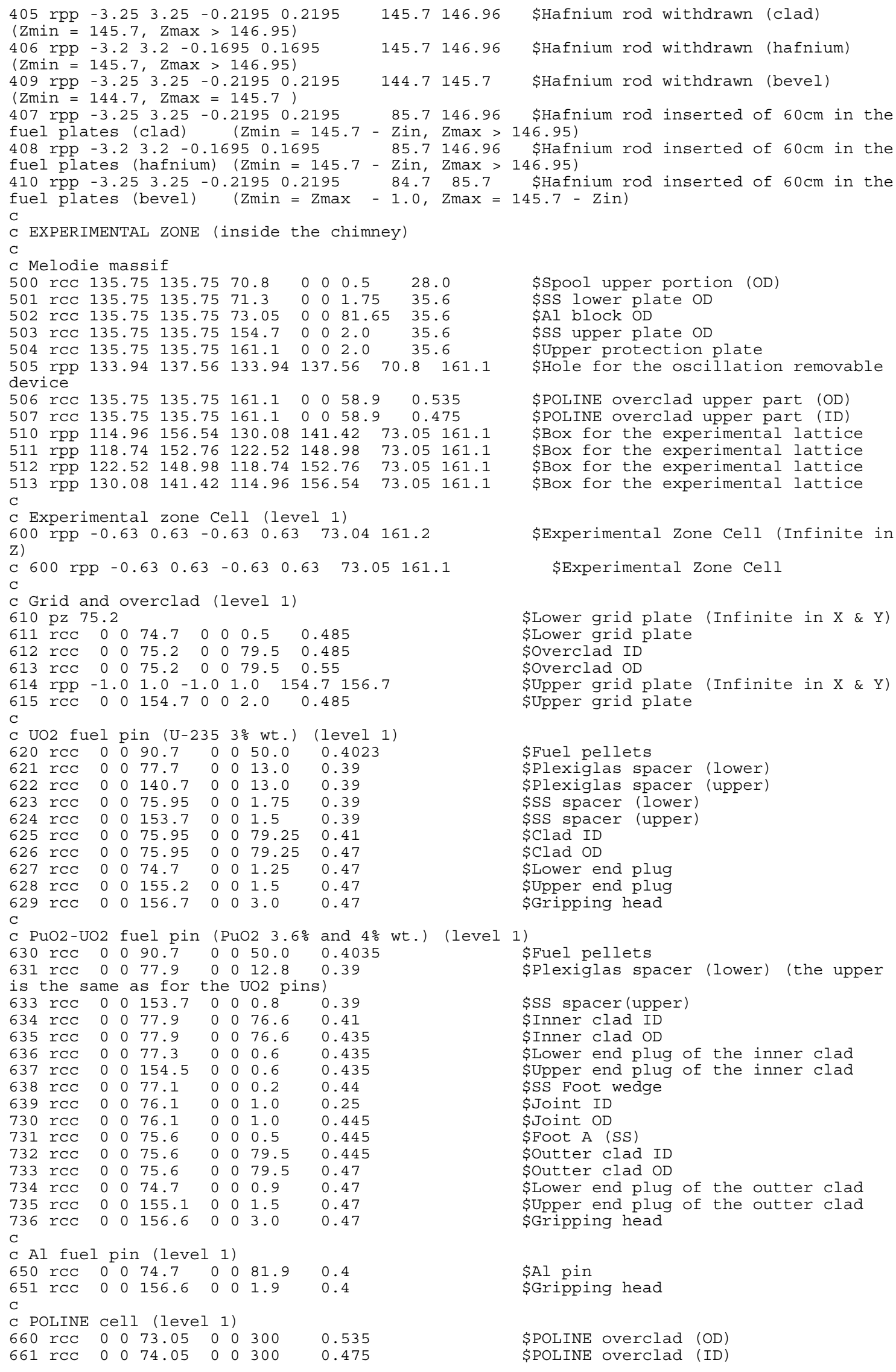




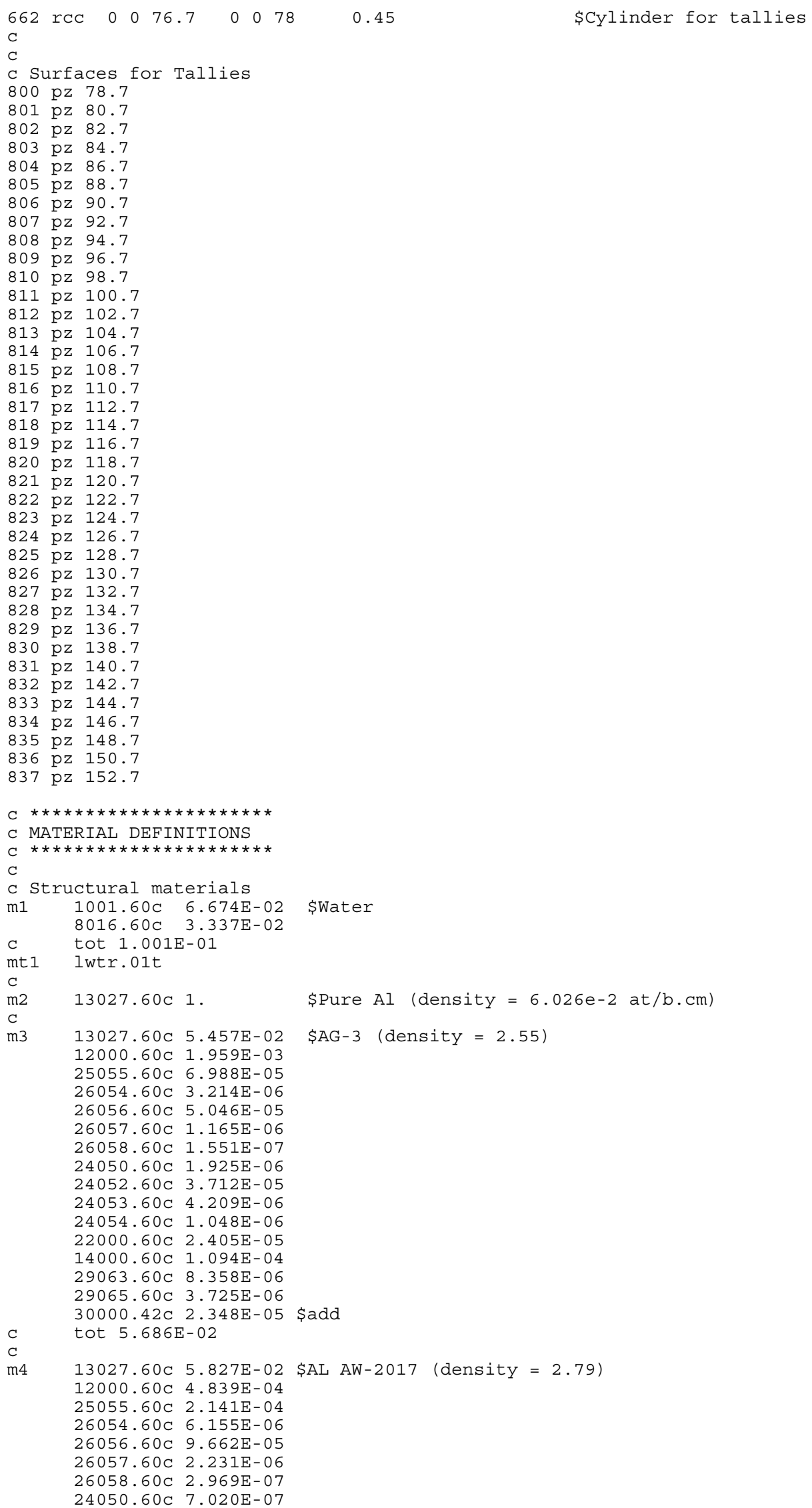




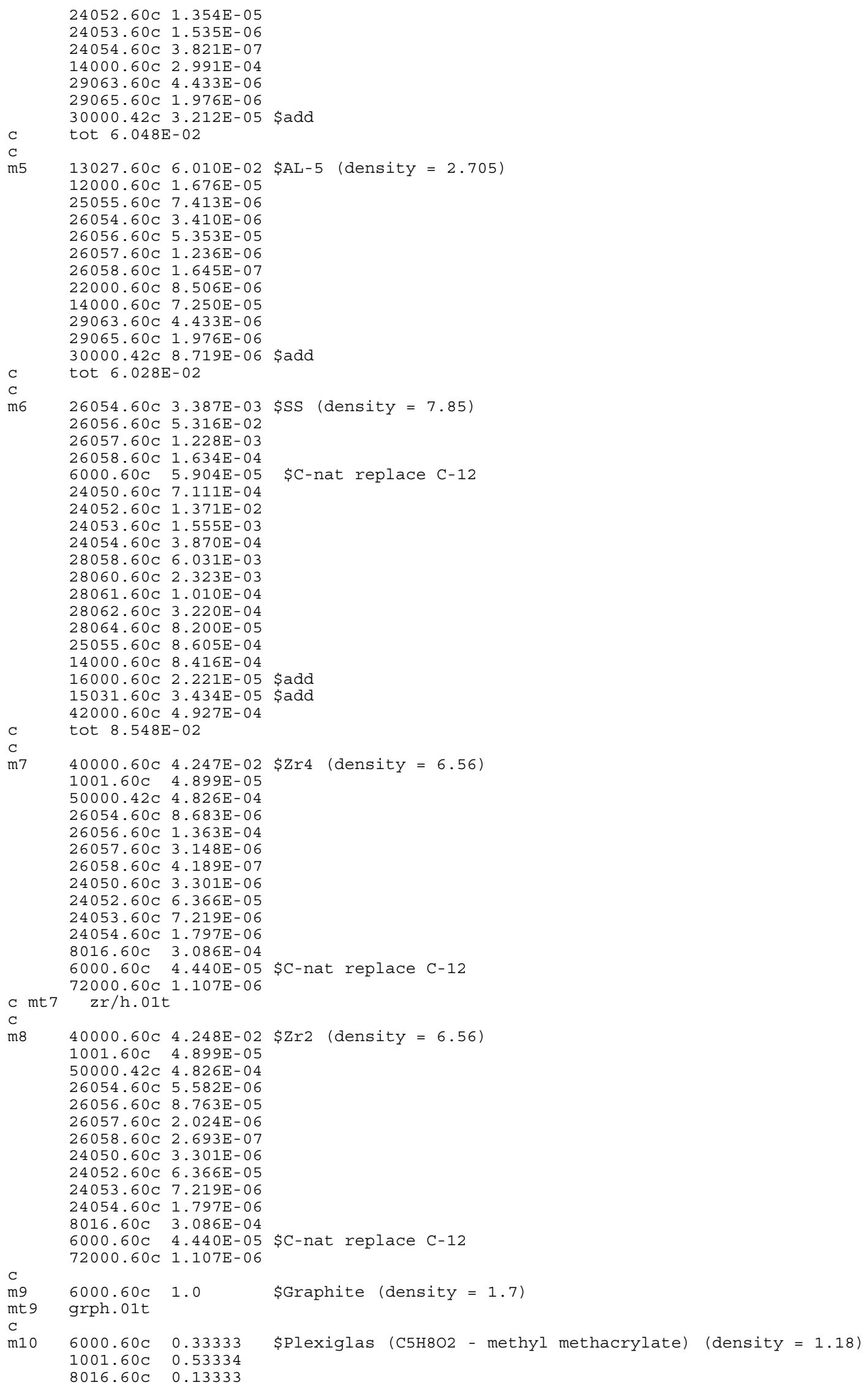




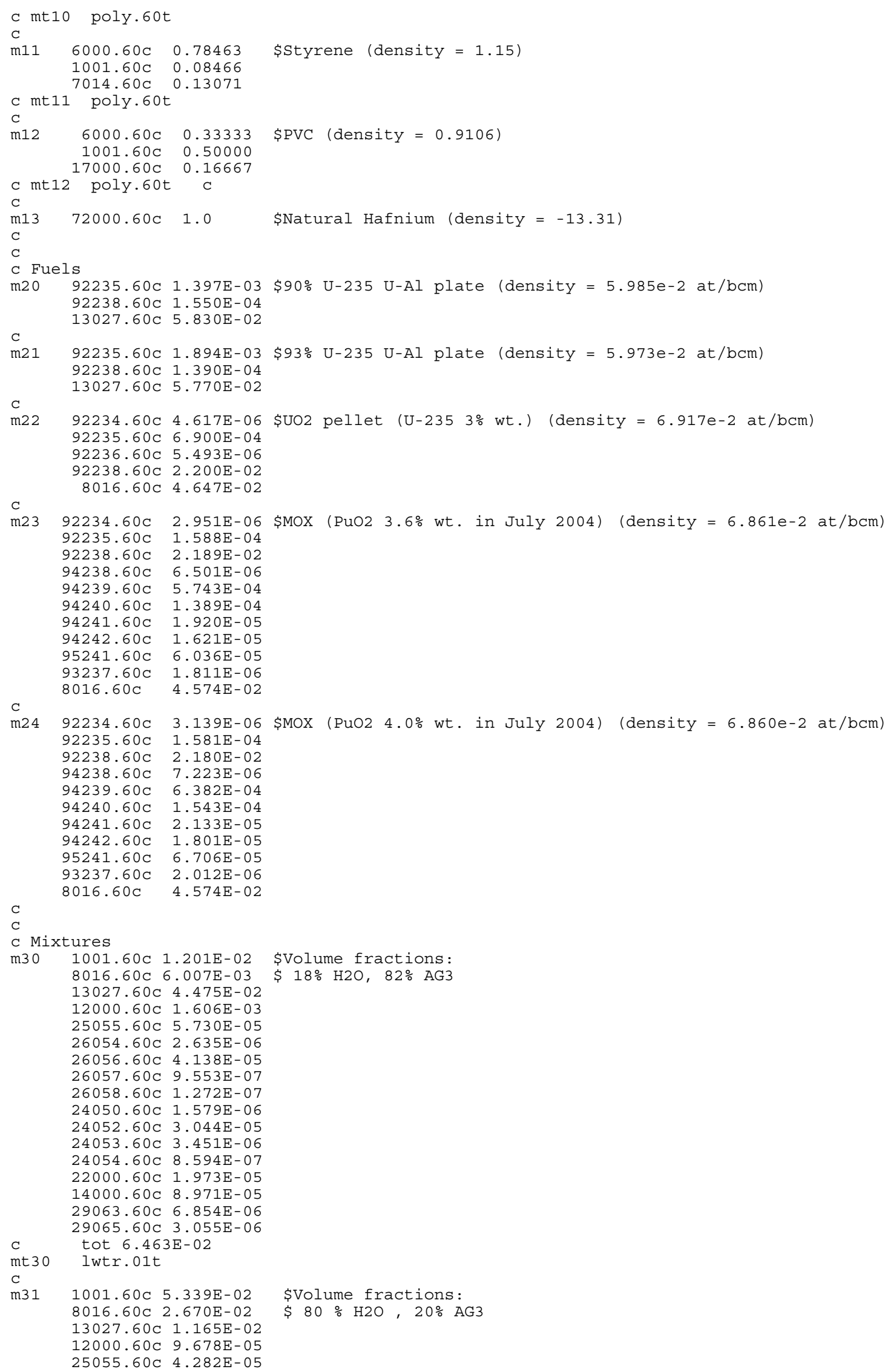

SVolume fractions:

$\$ 80 \% \mathrm{H} 2 \mathrm{O}, 20 \% \mathrm{AG} 3$ 


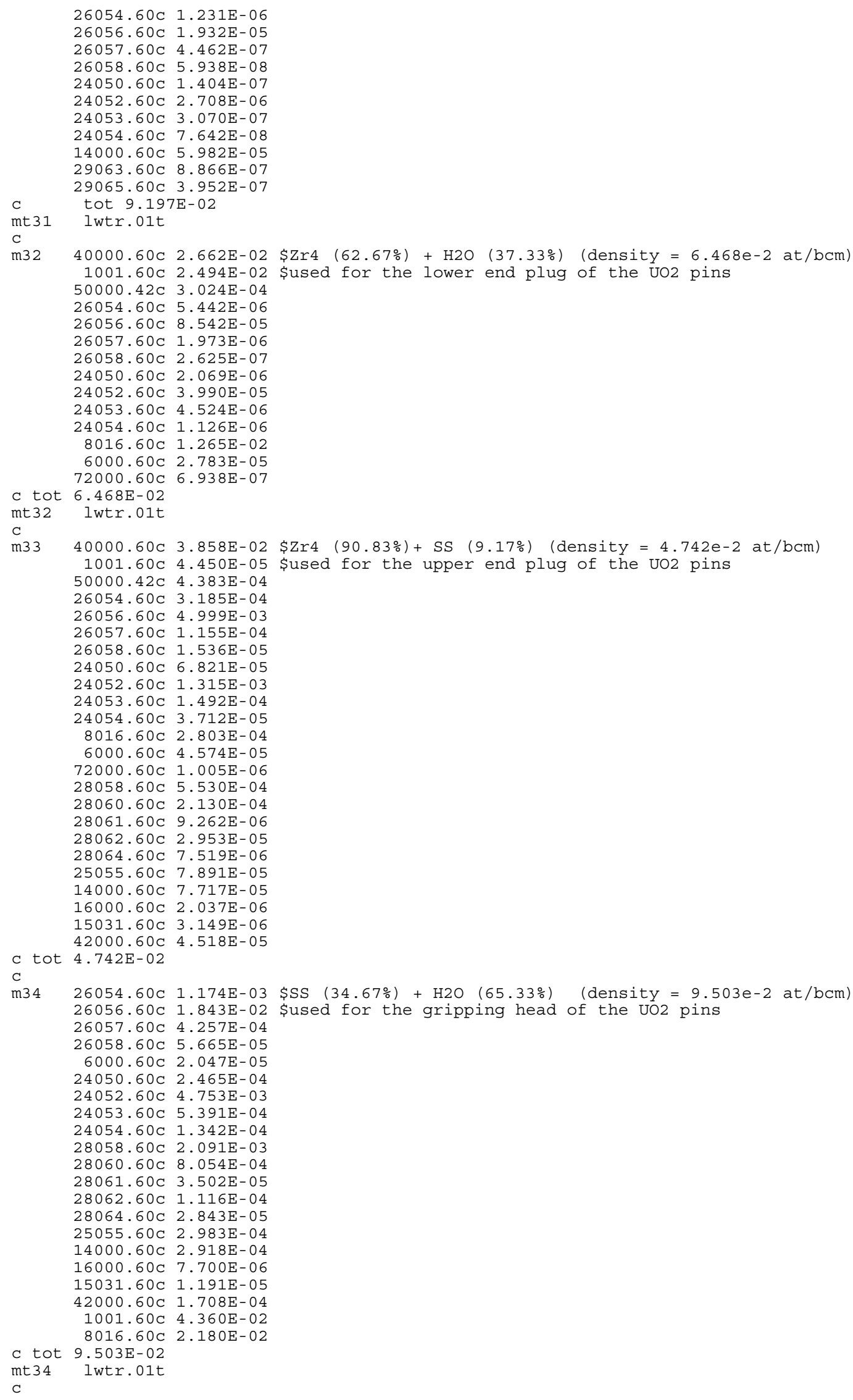




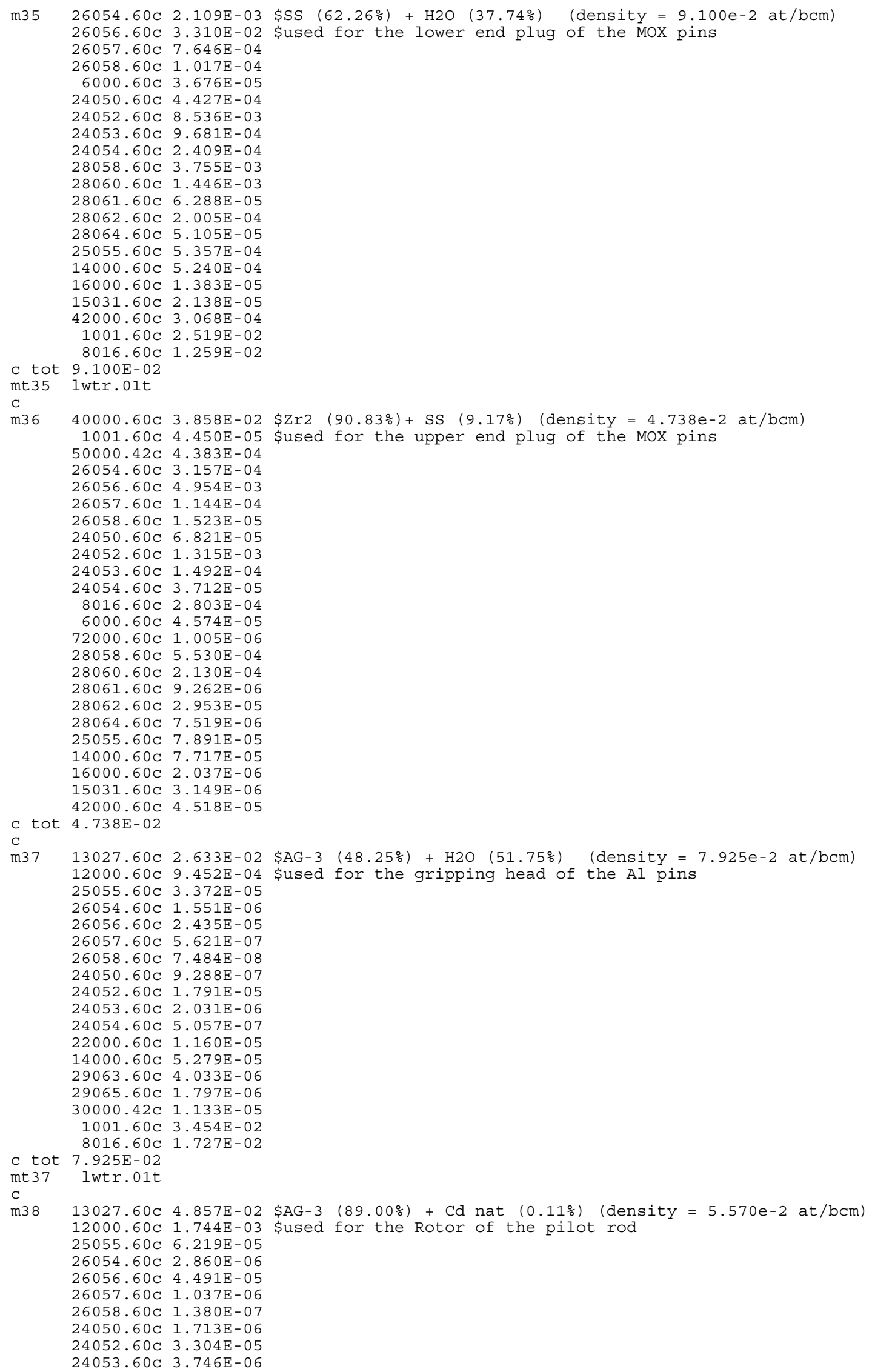




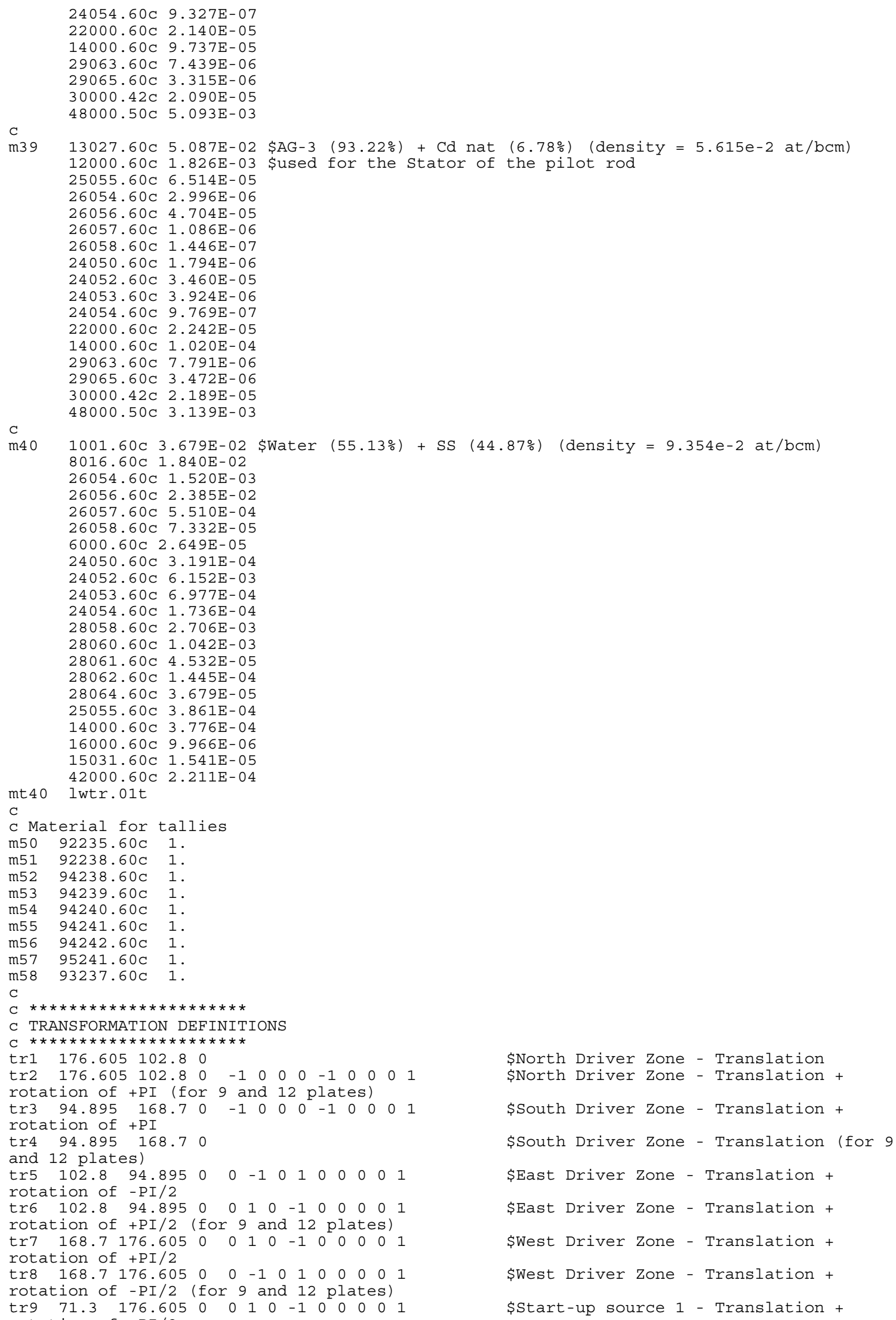




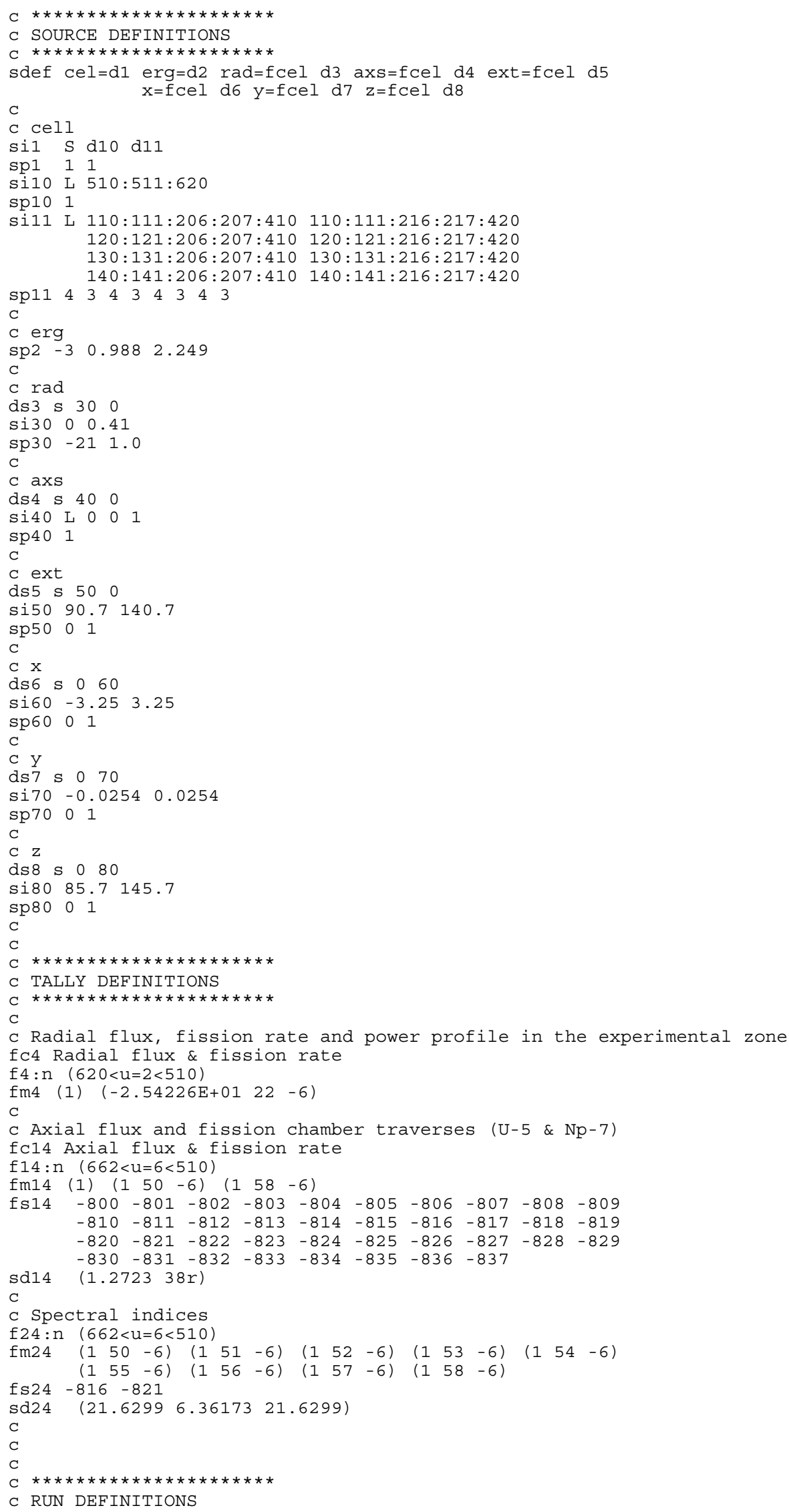




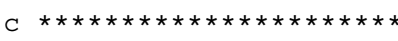

mode $n$

totnu

C kcode $1000 \quad 1.0 \quad 20 \quad 1202000 \quad 0$

kcode $100000 \quad 1.0202702000 \quad 0$

prdmp $1 j-24012$

lost 5050

print 


\section{File MOXI}

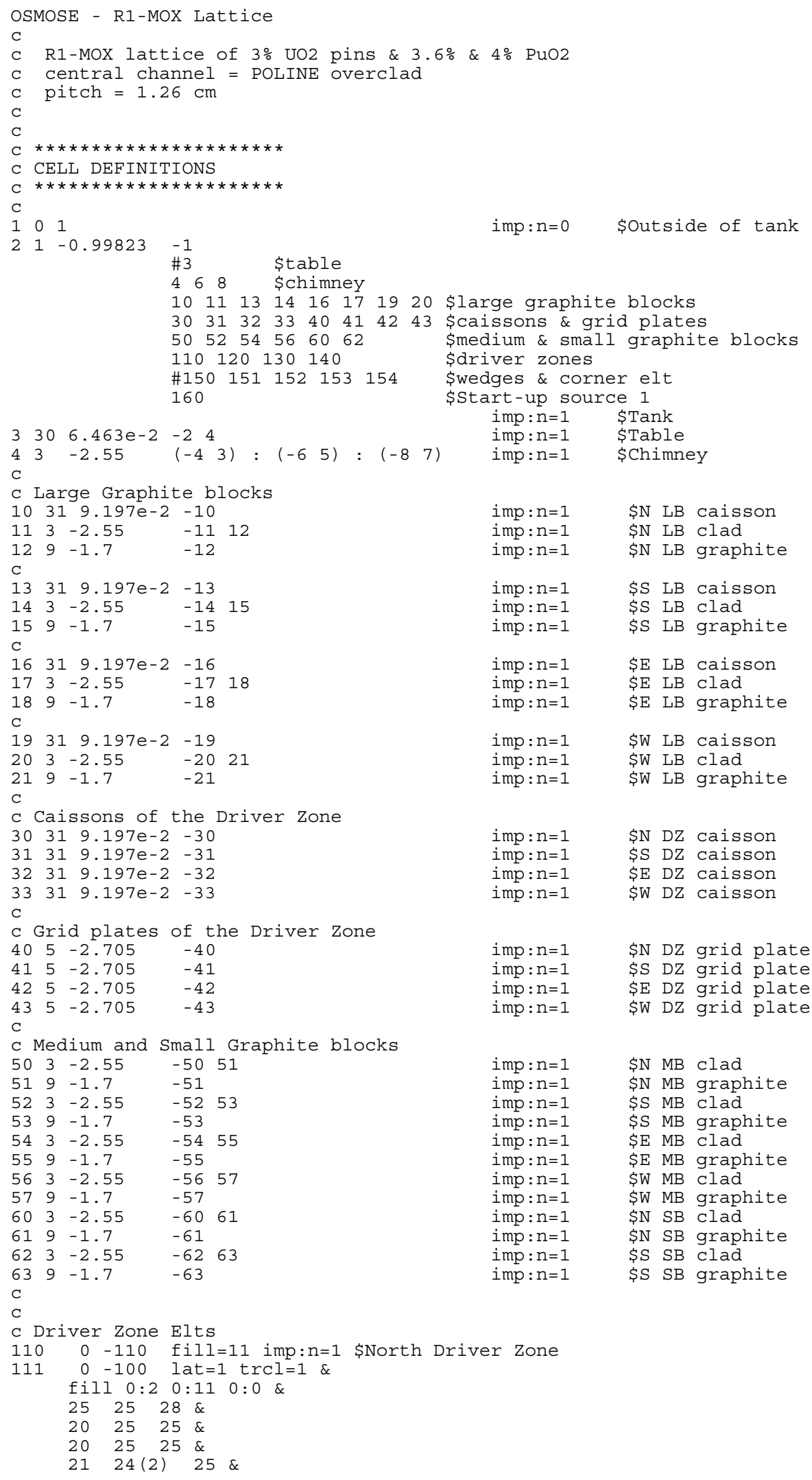




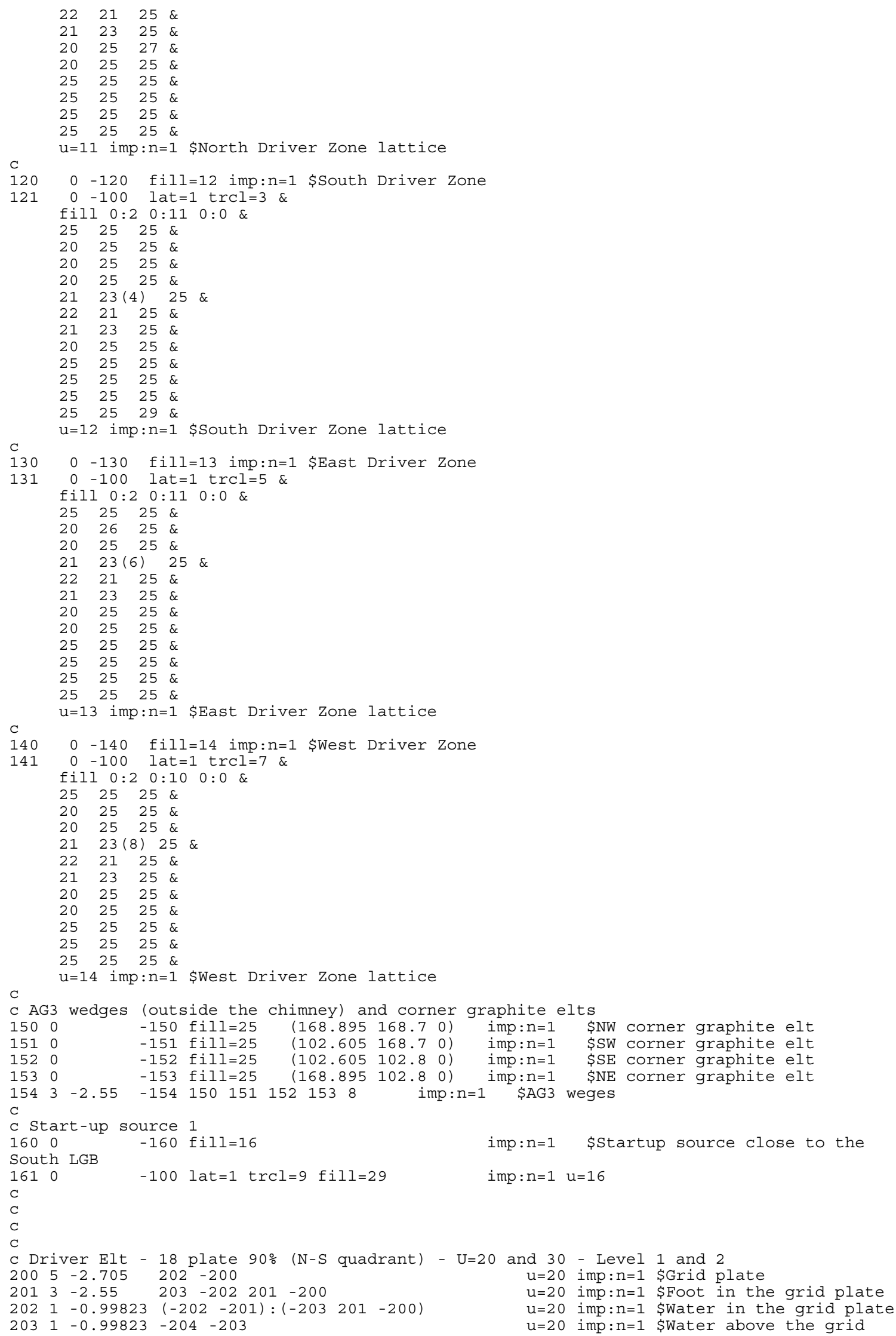




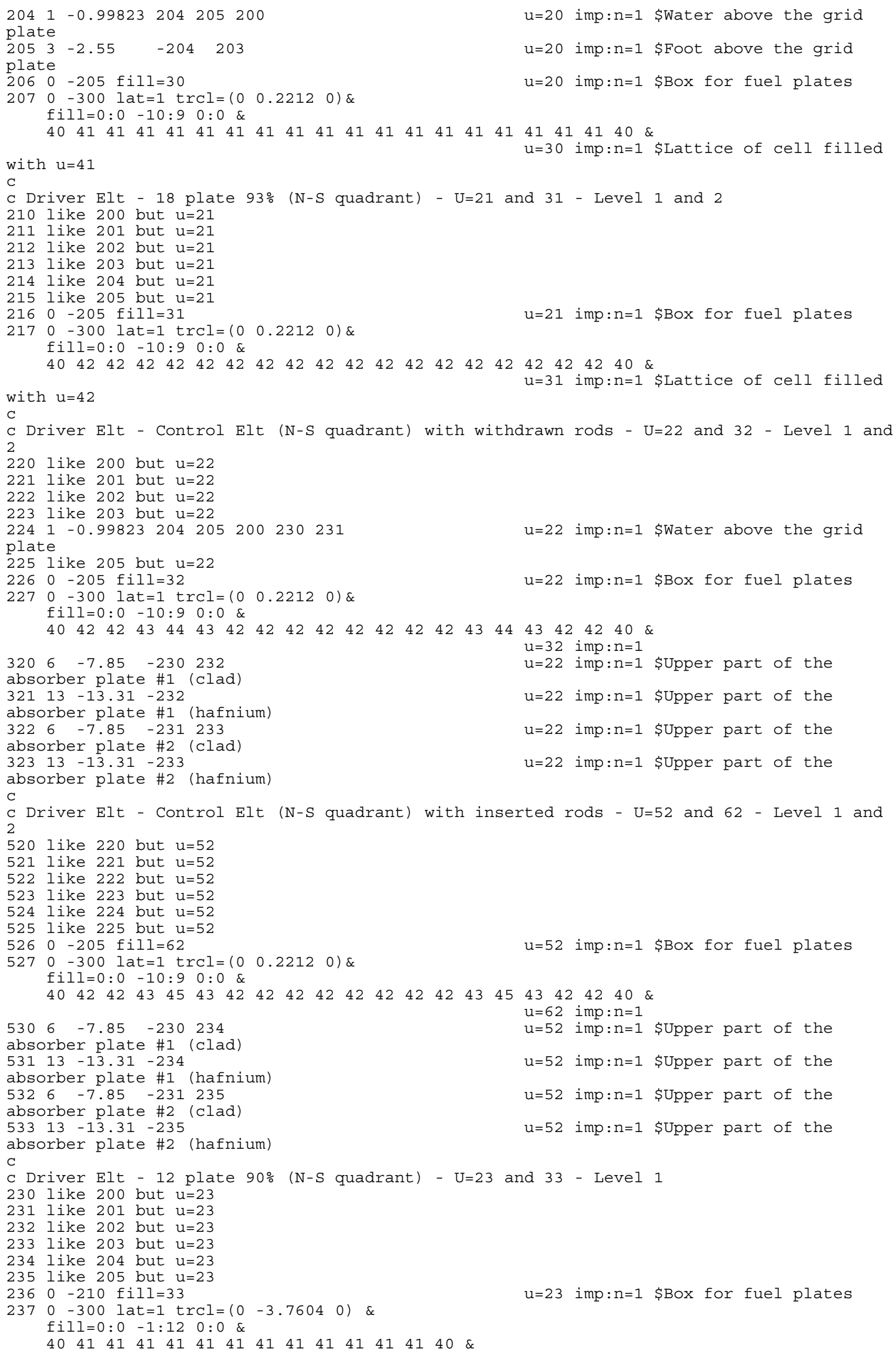


with $u=41$

$3303-2.55 \quad-211-401$

graphite block

$\begin{array}{llll}331 & 3-2.55 & -211 & 402\end{array}$

graphite block

$3323-2.55 \quad-212 \quad 213$

$3339-1.7 \quad-213$

(graphite)

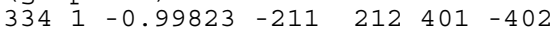

graphite block

9 plate 90\% (N-S quadrant) - U=24 and 34 - Level 1 and 2

240 like 200 but $u=24$

241 like 201 but $u=24$

242 like 202 but $u=24$

243 like 203 but $u=24$

244 like 204 but $u=24$

245 like 205 but $u=24$

$2460-220$ fill=34

$2470-300$ lat $=1$ trcl $=\left(\begin{array}{lll}0 & -3.7604 & 0\end{array}\right) \&$ fill=0:0 - $1: 9 \quad 0: 0$ \&

$\begin{array}{llllllllllll}40 & 41 & 41 & 41 & 41 & 41 & 41 & 41 & 41 & 41 & 40 & \&\end{array}$

with $\mathrm{u}=41$

$340 \quad 3-2.55 \quad-221-401$

graphite block

$\begin{array}{lllll}341 & 3 & -2.55 & -221 & 402\end{array}$

graphite block

$\begin{array}{lllll}342 & 3 & -2.55 & -222 & 223\end{array}$

$\begin{array}{llll}343 & 9 & -1.7 & -223\end{array}$

(graphite)

$\begin{array}{lllllll}344 & 1 & -0.99823 & -221 & 222 & 401 & -402\end{array}$

graphite block

C

C Graphite Elt (N-S quadrant) - U=25 - Level 1

$\begin{array}{lllll}250 & 5 & -2.705 & 202 & -200\end{array}$

$\begin{array}{lllllll}251 & 3 & -2.55 & 250 & -202 & 201 & -200\end{array}$

(AG3)

2520

$254 \quad 1 \quad-0.99823251252 \quad 200$

plate

$255 \quad 3-2.55 \quad-251 \quad 250$

plate

$256 \quad 3-2.55 \quad-252 \quad 253$

$2579-1.7 \quad-253$

(graphite)

C Pilot rod Elt - U=26 - Level 1

260 like 250 but $u=26$

261 like 251 but $u=26$

262 like 252 but $u=26$

263 like 253 but $u=26$

$\begin{array}{llllll}264 & 1 & -0.99823 & 251 & 265 & 200\end{array}$

plate

265 like 255 but $u=26$

$2660 \quad-260$

$267385.570 e-2 \quad-261260$

$\begin{array}{llll}268 & 0 & -262 & 261\end{array}$

$269395.615 e-2-263262$

$3600 \quad-264263$

liner

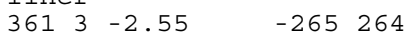

C Grahpite Elt for the detector - U=27 - Level 1

270 like 250 but $u=27$

271 like 251 but $u=27$

272 like 252 but $u=27$

273 like 253 but $u=27$

$\begin{array}{llllll}274 & 1 & -0.99823 & 251 & 270 & 200\end{array}$

plate

275 like 255 but $u=27$

$\begin{array}{llllll}276 & 3 & -2.55 & -270 & 271 & 272\end{array}$

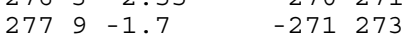

(graphite)

$2780 \quad(-272:-273) 274$

$2790 \quad-274$

C

C Semi thermal column - U=28 - Level 1 u=33 imp:n=1 \$Lattice of cell filled

$\mathrm{u}=23$ imp:n=1 \$Al border plate next to

$\mathrm{u}=23$ imp:n=1 \$Al border plate next to

$\mathrm{u}=23$ imp:n=1 \$Graphite block (clad)

$\mathrm{u}=23$ imp: $n=1$ \$Graphite block

$\mathrm{u}=23$ imp:n=1 \$Water around the $\mathrm{u}=24$ imp:n=1 \$Box for fuel plates

$\mathrm{u}=34$ imp:n=1 \$Lattice of cell filled

$\mathrm{u}=24$ imp:n=1 \$Al border plate next to

$\mathrm{u}=24$ imp:n=1 \$Al border plate next to

$\mathrm{u}=24$ imp: $\mathrm{n}=1$ \$Graphite block (clad)

$\mathrm{u}=24$ imp:n=1 \$Graphite block

$\mathrm{u}=24$ imp:n=1 \$Water around the

$\mathrm{u}=25$ imp: $\mathrm{n}=1$ \$Grid plate

$\mathrm{u}=25$ imp: $\mathrm{n}=1$ \$Foot in the grid plate

$\mathrm{u}=25$ imp: $\mathrm{n}=1$ \$Void channel

$\mathrm{u}=25$ imp:n=1 \$Water in the grid plate

$\mathrm{u}=25$ imp:n=1 \$Water above the grid

$u=25$ imp:n=1 \$Foot above the grid

$\mathrm{u}=25$ imp: $\mathrm{n}=1$ \$Graphite block (clad)

$\mathrm{u}=25$ imp: $\mathrm{n}=1$ \$Graphite block

$\mathrm{u}=26$ imp:n=1 \$Water above the grid

$\mathrm{u}=26$ imp:n=1 \$Void inside the rotor

$\mathrm{u}=26$ imp: $\mathrm{n}=1$ \$Rotor

$\mathrm{u}=26$ imp: $\mathrm{n}=1$ \$Void inside the stator

$\mathrm{u}=26$ imp: $\mathrm{n}=1$ \$Stator

$\mathrm{u}=26$ imp: $\mathrm{n}=1$ \$Void inside the AG3

$\mathrm{u}=26$ imp: $\mathrm{n}=1$ \$AG3 liner

$\mathrm{u}=27$ imp:n=1 \$Water above the grid

$\mathrm{u}=27$ imp:n=1 \$Graphite block (clad)

$\mathrm{u}=27$ imp:n=1 \$Graphite block

$\mathrm{u}=27$ imp: $\mathrm{n}=1$ \$Void

$\mathrm{u}=27$ imp: $\mathrm{n}=1$ \$Detector 
280 like 250 but $u=28$

281 like 251 but $u=28$

282 like 252 but $u=28$

283 like 253 but $u=28$

$\begin{array}{llllll}284 & 1 & -0.99823 & 251 & 280 & 200\end{array}$

plate

285 like 255 but $u=28$

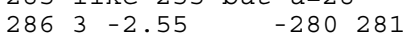

$\begin{array}{llllll}287 & 9 & -1.7 & -281 & 283 & 286\end{array}$

$\begin{array}{llllll}288 & 12 & -0.9106 & -281 & -283 & 282\end{array}$

$\begin{array}{lllll}289 & 0 & -281 & -282 & 284\end{array}$

3800

$-284$

$\begin{array}{llllll}381 & 12 & -0.9106 & -281 & -286 & 285\end{array}$

$\begin{array}{lllll}382 & 0 & -281 & -285 & 287\end{array}$

$3830-287$

C Source holder - U=29 - Level 1

290 like 250 but $u=29$

291 like 251 but $u=29$

292 like 252 but $u=29$

293 like 253 but $u=29$

$2941-0.99823251290292200$

plate

295 like 255 but $u=29$

$2963-2.55 \quad-290$

$\begin{array}{lllll}297 & 3 & -2.55 & -292 & 291\end{array}$

$\begin{array}{lllll}298 & 6 & -7.85 & -294 & 293\end{array}$

$2990 \quad-295$

$3900 \quad\left(\begin{array}{lllll}-291 & 294 & 295\end{array}\right) \quad:-293$

u=28 imp:n=1 \$Water above the grid

C

C

C

C Border plate \& water for the Driver Elts (N-S quadrant) - U=40 - Level 3

$4021-0.99823 \quad 401-402 \quad u=40$ imp:n=1 \$Water gap

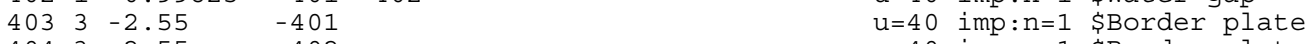

$4043-2.55 \quad 402 \quad u=40$ imp:n=1 \$Border plate

C $90 \%$ U-5 plate for the Driver Elt (N-S quadrant) - U=41 - Level 3

$410205.985 e-2-404$

$41126.026 e-2 \quad 404-403$

$\begin{array}{llllll}412 & 1 & -0.99823 & 401 & -402 & 403\end{array}$

$\begin{array}{lllll}413 & 3 & -2.55 & -401 & 403\end{array}$

$\begin{array}{lllll}414 & 3 & -2.55 & 402 \quad 403\end{array}$

$\mathrm{u}=28$ imp: $\mathrm{n}=1$ \$Graphite block (clad)

u=28 imp: $n=1$ \$Graphite block (clad)

$\mathrm{u}=28$ imp: $\mathrm{n}=1$ \$PVC Tube 1

$\mathrm{u}=28$ imp: $n=1$ \$Detector channel 1

28 imp: $n=1$ \$Detector 1

$\mathrm{u}=28$ imp: $n=1$ \$Detector channel 2

$\mathrm{u}=28$ imp: $\mathrm{n}=1$ \$Detector 2

$\mathrm{u}=29$ imp:n=1 \$Water above the grid

$\mathrm{u}=29$ imp: $\mathrm{n}=1$ \$Support

$\mathrm{u}=29$ imp: $\mathrm{n}=1$ \$AG-3 Tube

u=29 imp: $n=1$ SSource support

$\mathrm{u}=29$ imp: $\mathrm{n}=1$ \$Source

$\mathrm{u}=29$ imp:n=1 \$Void

C 93\% U-5 plate for the Driver Elt (N-S quadrant) - U=42 - Level 3

$420215.973 e-2-404$

421 like 411 but $u=42$

422 like 412 but $u=42$

423 like 413 but $u=42$

424 like 414 but $u=42$

C Al plate for the Driver Elt (N-S quadrant) - U=43 - Level 3

$43126.026 e-2-403$

432 like 412 but $u=43$

433 like 413 but $u=43$

434 like 414 but $u=43$

$\mathrm{C}$

C Absorber plate for the Driver Elt (N-S quadrant) - Withdrawn - U=44 - Level 3

$44013-13.31 \quad-406$

$10 \mathrm{~cm}$ in the fuel plates (hafnium)

$4416-7.85 \quad-405 \quad 406$

$10 \mathrm{~cm}$ in the fuel plates (clad)

$44740 \quad 9.354 \mathrm{e}-2 \quad-409$

in the fuel plates (bevel)

$\begin{array}{lllllll}442 & 1 & -0.99823 & 405 & 401 & -402 & 409\end{array}$

$4451-0.99823-401-403$

$4461-0.99823 \quad 402-403$

443 like 413 but $u=44$

444 like 414 but $u=44$

$\mathrm{C}$

C Absorber plate for the Driver Elt (N-S quadrant) - Inserted - U=45 - Level 3

$\begin{array}{llll}450 & 13 & -13.31 \quad-408\end{array}$

$10 \mathrm{~cm}$ in the fuel plates (hafnium)

$4516-7.85 \quad-407 \quad 408$

$10 \mathrm{~cm}$ in the fuel plates (clad)

$45740 \quad 9.354 e-2 \quad-410$

$10 \mathrm{~cm}$ in the fuel plates (bevel)

$\begin{array}{llll}452 & 1-0.99823 & 407401 & -402410\end{array}$

$\begin{array}{lllll}455 & 1 & -0.99823 & -401 & -403\end{array}$

$\begin{array}{lllll}456 & 1 & -0.99823 & 402 & -403\end{array}$ $\mathrm{u}=44$ imp: $\mathrm{n}=1$ \$Hafnium rod inserted of $\mathrm{u}=44$ imp:n=1 \$Hafnium rod inserted of $\mathrm{u}=44$ imp:n=1 \$Hafnium rod withdrawn

$\mathrm{u}=44$ imp: $\mathrm{n}=1$ \$Water gap $\mathrm{u}=44$ imp: $\mathrm{n}=1$ \$Water gap $\mathrm{u}=44$ imp: $\mathrm{n}=1$ \$Water gap

$456-0.99823-402-403$ $\mathrm{u}=45$ imp:n=1 \$Hafnium rod inserted of $\mathrm{u}=45$ imp:n=1 \$Hafnium rod inserted of $\mathrm{u}=45$ imp:n=1 \$Hafnium rod inserted of $\mathrm{u}=45$ imp: $\mathrm{n}=1$ \$Water gap $\mathrm{u}=45$ imp: $\mathrm{n}=1$ \$Water gap $\mathrm{u}=45$ imp:n=1 \$Water gap 
453 like 413 but $u=45$

454 like 414 but $u=45$

C

C EXPERIMENTAL ZONE

\begin{tabular}{|c|c|c|c|}
\hline 500 & -7.85 & $-500 \quad 505$ & imp:n=1 \$Spool (upper portion) \\
\hline 01 & -7.85 & -501505 & imp:n=1 \$Massif lower SS plate \\
\hline 2 & -2.55 & $-502 \quad\left(\begin{array}{llll}510 & 511 & 512 & 513\end{array}\right)$ & imp:n=1 \$Massif AG3 blocks \\
\hline & -7.85 & $-503\left(\begin{array}{llll}510 & 511 & 512 & 513\end{array}\right)$ & imp:n=1 \$Massif upper SS plate \\
\hline 504 & -2.55 & -504 & imp:n=1 \$Upper protection plate \\
\hline 505 & -0.9982 & $23(-3:-5:-7)$ & \\
\hline & & \#500 \#501 \#502 \#503 \#504 & \\
\hline & & |ر & waler \\
\hline & To activate $\mathrm{f}$ & Eor the POLINE overclad (upper part) & \\
\hline & -2.55 & -504506 & imp:n=1 \$Upper protection plate \\
\hline & -0.99823 & $\begin{array}{l}(-3:-5:-7) \\
\# 500 \text { \#501 \#502 \#503 \#504 \#506 \#507 } \\
(510511512 \quad 513)\end{array}$ & $y$ \\
\hline $\begin{array}{l}4 \\
0\end{array}$ & -2.75 & $\begin{array}{l}-506 \quad 507 \\
-507\end{array}$ & $\begin{array}{ll}\text { imp: } n=1 & \$ A W-2017 \text { overclad } \\
\text { imp:n=1 } & \text { \$Inside Void }\end{array}$ \\
\hline
\end{tabular}

C $510-0 \quad(-510:-511:-512:-513)$ fi11 1

$5110-600$ lat $=1$ trcl $=\left(\begin{array}{lll}135.75 & 135.75 & 0\end{array}\right) \&$

imp:n=1 \$Experimental lattice box fill - 16:16 - 16:16 0:0 \&

$\begin{array}{llllllllllllllllllllllllllllllllll}1 & 1 & 1 & 1 & 1 & 1 & 1 & 1 & 1 & 1 & 1 & 1 & 5 & 5 & 5 & 5 & 5 & 5 & 5 & 5 & 5 & 1 & 1 & 1 & 1 & 1 & 1 & 1 & 1 & 1 & 1 & 1 & 1 & \varepsilon\end{array}$ $\begin{array}{llllllllllllllllllllllllllllllllll}1 & 1 & 1 & 1 & 1 & 1 & 1 & 1 & 1 & 1 & 1 & 1 & 2 & 2 & 2 & 2 & 2 & 2 & 2 & 2 & 2 & 1 & 1 & 1 & 1 & 1 & 1 & 1 & 1 & 1 & 1 & 1 & 1 & \&\end{array}$ $\begin{array}{llllllllllllllllllllllllllllllllll}1 & 1 & 1 & 1 & 1 & 1 & 1 & 1 & 1 & 1 & 1 & 1 & 2 & 2 & 2 & 2 & 2 & 2 & 2 & 2 & 2 & 1 & 1 & 1 & 1 & 1 & 1 & 1 & 1 & 1 & 1 & 1 & 1 & \&\end{array}$ $\begin{array}{llllllllllllllllllllllllllllllllll}1 & 1 & 1 & 1 & 1 & 1 & 5 & 5 & 2 & 2 & 2 & 2 & 2 & 2 & 2 & 2 & 2 & 2 & 2 & 2 & 2 & 2 & 2 & 2 & 2 & 5 & 5 & 1 & 1 & 1 & 1 & 1 & 1 & \&\end{array}$ $\begin{array}{lllllllllllllllllllllllllllllllllll}1 & 1 & 1 & 1 & 1 & 1 & 5 & 2 & 2 & 2 & 2 & 2 & 2 & 2 & 2 & 2 & 2 & 2 & 2 & 2 & 2 & 2 & 2 & 2 & 2 & 2 & 5 & 1 & 1 & 1 & 1 & 1 & 1 & \&\end{array}$ $\begin{array}{llllllllllllllllllllllllllllllllll}1 & 1 & 1 & 1 & 1 & 1 & 2 & 2 & 2 & 2 & 2 & 2 & 2 & 2 & 2 & 2 & 2 & 2 & 2 & 2 & 2 & 2 & 2 & 2 & 2 & 2 & 2 & 1 & 1 & 1 & 1 & 1 & 1 & \&\end{array}$ $\begin{array}{llllllllllllllllllllllllllllllllll}1 & 1 & 1 & 5 & 5 & 2 & 2 & 2 & 2 & 2 & 2 & 2 & 2 & 2 & 2 & 2 & 2 & 2 & 2 & 2 & 2 & 2 & 2 & 2 & 2 & 2 & 2 & 2 & 5 & 5 & 1 & 1 & 1 & \&\end{array}$ $\begin{array}{llllllllllllllllllllllllllllllllll}1 & 1 & 1 & 5 & 2 & 2 & 2 & 2 & 2 & 2 & 2 & 2 & 2 & 2 & 2 & 2 & 2 & 2 & 2 & 2 & 2 & 2 & 2 & 2 & 2 & 2 & 2 & 2 & 2 & 5 & 1 & 1 & 1 & \varepsilon\end{array}$ $\begin{array}{llllllllllllllllllllllllllllllllll}1 & 1 & 1 & 2 & 2 & 2 & 2 & 2 & 2 & 2 & 2 & 2 & 2 & 2 & 2 & 2 & 2 & 2 & 2 & 2 & 2 & 2 & 2 & 2 & 2 & 2 & 2 & 2 & 2 & 2 & 1 & 1 & 1 & \&\end{array}$ $\begin{array}{llllllllllllllllllllllllllllllllll}1 & 1 & 1 & 2 & 2 & 2 & 2 & 2 & 2 & 2 & 2 & 2 & 2 & 2 & 2 & 2 & 2 & 2 & 2 & 2 & 2 & 2 & 2 & 2 & 2 & 2 & 2 & 2 & 2 & 2 & 1 & 1 & 1 & \varepsilon\end{array}$ $\begin{array}{llllllllllllllllllllllllllllllllll}1 & 1 & 1 & 2 & 2 & 2 & 2 & 2 & 2 & 2 & 2 & 2 & 3 & 3 & 3 & 4 & 4 & 4 & 3 & 3 & 3 & 2 & 2 & 2 & 2 & 2 & 2 & 2 & 2 & 2 & 1 & 1 & 1 & \&\end{array}$ $\begin{array}{llllllllllllllllllllllllllllllllll}1 & 1 & 1 & 2 & 2 & 2 & 2 & 2 & 2 & 2 & 2 & 3 & 4 & 4 & 4 & 4 & 4 & 4 & 4 & 4 & 4 & 3 & 2 & 2 & 2 & 2 & 2 & 2 & 2 & 2 & 1 & 1 & 1 & \&\end{array}$ $\begin{array}{lllllllllllllllllllllllllllllllllll}5 & 2 & 2 & 2 & 2 & 2 & 2 & 2 & 2 & 2 & 3 & 4 & 4 & 4 & 4 & 4 & 4 & 4 & 4 & 4 & 4 & 4 & 3 & 2 & 2 & 2 & 2 & 2 & 2 & 2 & 2 & 2 & 5 & \&\end{array}$ $\begin{array}{llllllllllllllllllllllllllllllllll}5 & 2 & 2 & 2 & 2 & 2 & 2 & 2 & 2 & 2 & 3 & 4 & 4 & 4 & 4 & 4 & 4 & 4 & 4 & 4 & 4 & 4 & 3 & 2 & 2 & 2 & 2 & 2 & 2 & 2 & 2 & 2 & 5 & \&\end{array}$ $\begin{array}{llllllllllllllllllllllllllllllllll}5 & 2 & 2 & 2 & 2 & 2 & 2 & 2 & 2 & 2 & 3 & 4 & 4 & 4 & 4 & 4 & 4 & 4 & 4 & 4 & 4 & 4 & 3 & 2 & 2 & 2 & 2 & 2 & 2 & 2 & 2 & 2 & 5 & \varepsilon\end{array}$ $\begin{array}{llllllllllllllllllllllllllllllllllll}5 & 2 & 2 & 2 & 2 & 2 & 2 & 2 & 2 & 2 & 4 & 4 & 4 & 4 & 4 & 4 & 4 & 4 & 4 & 4 & 4 & 4 & 4 & 2 & 2 & 2 & 2 & 2 & 2 & 2 & 2 & 2 & 5 & \&\end{array}$ $\begin{array}{llllllllllllllllllllllllllllllllll}5 & 2 & 2 & 2 & 2 & 2 & 2 & 2 & 2 & 2 & 4 & 4 & 4 & 4 & 4 & 4 & 6 & 4 & 4 & 4 & 4 & 4 & 4 & 2 & 2 & 2 & 2 & 2 & 2 & 2 & 2 & 2 & 5 & \&\end{array}$ \$central row $\begin{array}{lllllllllllllllllllllllllllllllllll}5 & 2 & 2 & 2 & 2 & 2 & 2 & 2 & 2 & 2 & 4 & 4 & 4 & 4 & 4 & 4 & 4 & 4 & 4 & 4 & 4 & 4 & 4 & 2 & 2 & 2 & 2 & 2 & 2 & 2 & 2 & 2 & 5 & \&\end{array}$ $\begin{array}{llllllllllllllllllllllllllllllllll}5 & 2 & 2 & 2 & 2 & 2 & 2 & 2 & 2 & 2 & 3 & 4 & 4 & 4 & 4 & 4 & 4 & 4 & 4 & 4 & 4 & 4 & 3 & 2 & 2 & 2 & 2 & 2 & 2 & 2 & 2 & 2 & 5 & \&\end{array}$ $\begin{array}{llllllllllllllllllllllllllllllllll}5 & 2 & 2 & 2 & 2 & 2 & 2 & 2 & 2 & 2 & 3 & 4 & 4 & 4 & 4 & 4 & 4 & 4 & 4 & 4 & 4 & 4 & 3 & 2 & 2 & 2 & 2 & 2 & 2 & 2 & 2 & 2 & 5 & \&\end{array}$ $\begin{array}{llllllllllllllllllllllllllllllllll}5 & 2 & 2 & 2 & 2 & 2 & 2 & 2 & 2 & 2 & 3 & 4 & 4 & 4 & 4 & 4 & 4 & 4 & 4 & 4 & 4 & 4 & 3 & 2 & 2 & 2 & 2 & 2 & 2 & 2 & 2 & 2 & 5 & \&\end{array}$ $\begin{array}{llllllllllllllllllllllllllllllllll}1 & 1 & 1 & 2 & 2 & 2 & 2 & 2 & 2 & 2 & 2 & 3 & 4 & 4 & 4 & 4 & 4 & 4 & 4 & 4 & 4 & 3 & 2 & 2 & 2 & 2 & 2 & 2 & 2 & 2 & 1 & 1 & 1 & \&\end{array}$ $\begin{array}{llllllllllllllllllllllllllllllllll}1 & 1 & 1 & 2 & 2 & 2 & 2 & 2 & 2 & 2 & 2 & 2 & 3 & 3 & 3 & 4 & 4 & 4 & 3 & 3 & 3 & 2 & 2 & 2 & 2 & 2 & 2 & 2 & 2 & 2 & 1 & 1 & 1 & \&\end{array}$ $\begin{array}{llllllllllllllllllllllllllllllllll}1 & 1 & 1 & 2 & 2 & 2 & 2 & 2 & 2 & 2 & 2 & 2 & 2 & 2 & 2 & 2 & 2 & 2 & 2 & 2 & 2 & 2 & 2 & 2 & 2 & 2 & 2 & 2 & 2 & 2 & 1 & 1 & 1 & \&\end{array}$ $\begin{array}{llllllllllllllllllllllllllllllllll}1 & 1 & 1 & 2 & 2 & 2 & 2 & 2 & 2 & 2 & 2 & 2 & 2 & 2 & 2 & 2 & 2 & 2 & 2 & 2 & 2 & 2 & 2 & 2 & 2 & 2 & 2 & 2 & 2 & 2 & 1 & 1 & 1 & \varepsilon\end{array}$ $\begin{array}{llllllllllllllllllllllllllllllllll}1 & 1 & 1 & 5 & 2 & 2 & 2 & 2 & 2 & 2 & 2 & 2 & 2 & 2 & 2 & 2 & 2 & 2 & 2 & 2 & 2 & 2 & 2 & 2 & 2 & 2 & 2 & 2 & 2 & 5 & 1 & 1 & 1 & \&\end{array}$ $\begin{array}{llllllllllllllllllllllllllllllllll}1 & 1 & 1 & 5 & 5 & 2 & 2 & 2 & 2 & 2 & 2 & 2 & 2 & 2 & 2 & 2 & 2 & 2 & 2 & 2 & 2 & 2 & 2 & 2 & 2 & 2 & 2 & 2 & 5 & 5 & 1 & 1 & 1 & \&\end{array}$ $\begin{array}{llllllllllllllllllllllllllllllllll}1 & 1 & 1 & 1 & 1 & 1 & 2 & 2 & 2 & 2 & 2 & 2 & 2 & 2 & 2 & 2 & 2 & 2 & 2 & 2 & 2 & 2 & 2 & 2 & 2 & 2 & 2 & 1 & 1 & 1 & 1 & 1 & 1 & \&\end{array}$

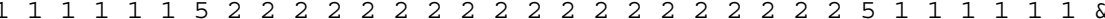
$\begin{array}{llllllllllllllllllllllllllllllllll}1 & 1 & 1 & 1 & 1 & 1 & 5 & 5 & 2 & 2 & 2 & 2 & 2 & 2 & 2 & 2 & 2 & 2 & 2 & 2 & 2 & 2 & 2 & 2 & 2 & 5 & 5 & 1 & 1 & 1 & 1 & 1 & 1 & \&\end{array}$ $\begin{array}{llllllllllllllllllllllllllllllllll}1 & 1 & 1 & 1 & 1 & 1 & 1 & 1 & 1 & 1 & 1 & 1 & 2 & 2 & 2 & 2 & 2 & 2 & 2 & 2 & 2 & 1 & 1 & 1 & 1 & 1 & 1 & 1 & 1 & 1 & 1 & 1 & 1 & \&\end{array}$ $\begin{array}{llllllllllllllllllllllllllllllllll}1 & 1 & 1 & 1 & 1 & 1 & 1 & 1 & 1 & 1 & 1 & 1 & 2 & 2 & 2 & 2 & 2 & 2 & 2 & 2 & 2 & 1 & 1 & 1 & 1 & 1 & 1 & 1 & 1 & 1 & 1 & 1 & 1 & \varepsilon\end{array}$ $\begin{array}{llllllllllllllllllllllllllllllllll}1 & 1 & 1 & 1 & 1 & 1 & 1 & 1 & 1 & 1 & 1 & 1 & 5 & 5 & 5 & 5 & 5 & 5 & 5 & 5 & 5 & 1 & 1 & 1 & 1 & 1 & 1 & 1 & 1 & 1 & 1 & 1 & 1 & \&\end{array}$ $\mathrm{u}=1$ imp: $\mathrm{n}=1$ \$Experimental lattice

C UO2 fuel pin (U-235 3\% wt.) - U=2 - Level 1

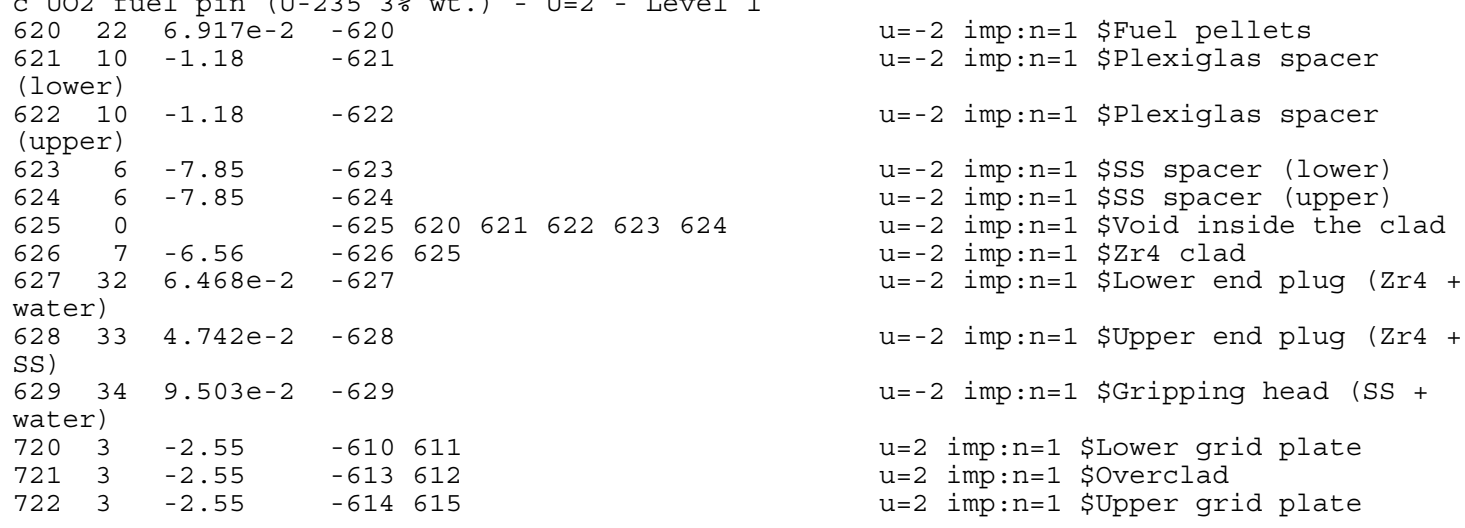




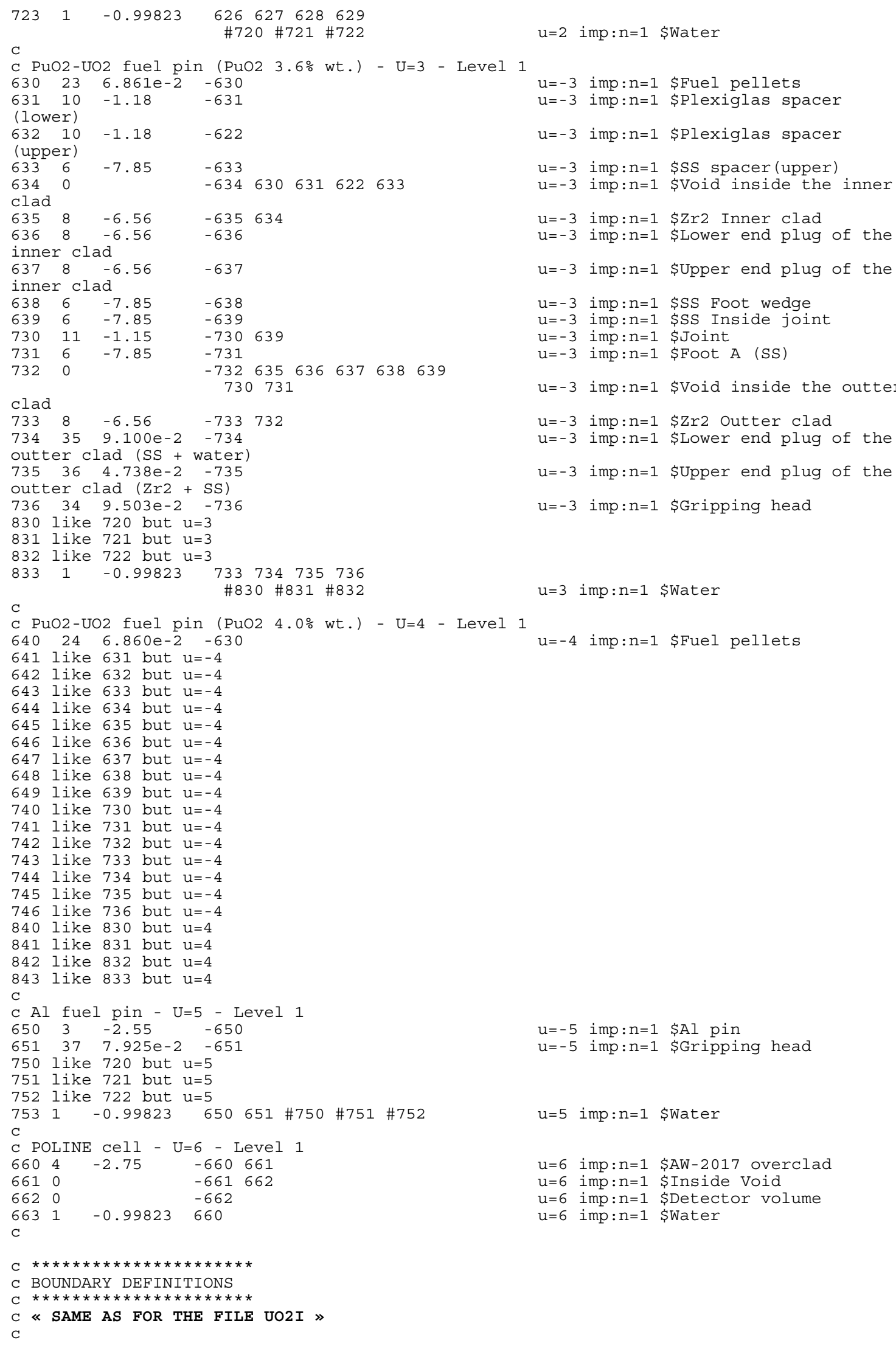




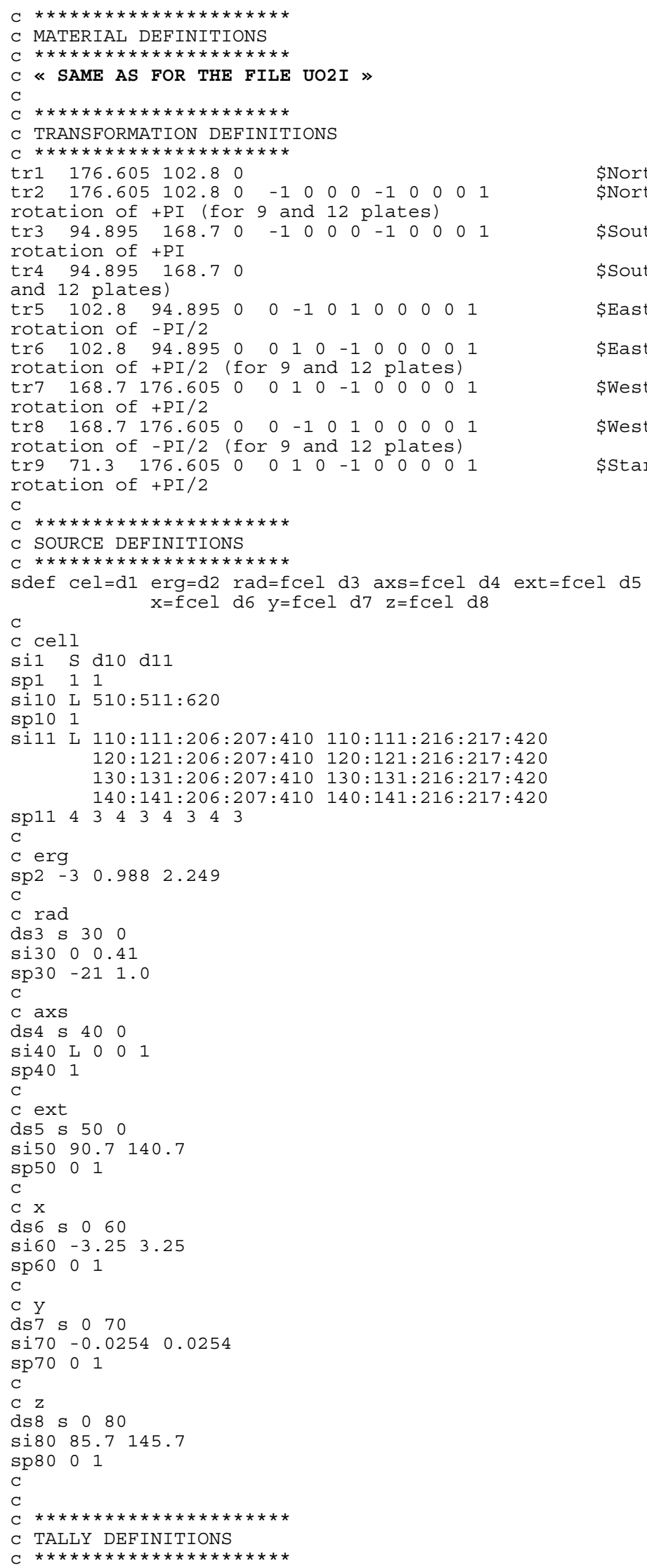


C Radial flux, fission rate and power profile in the experimental zone fc4 UO2 Radial flux \& fission rate

f $4: \mathrm{n} \quad(620<\mathrm{u}=2<510)$

fm4 (1) (-2.54226E+01 $22-6)$

fc14 PuO2 (3.6\%) Radial flux \& fission rate

f14:n $\quad(630<\mathrm{u}=3<510)$

fm14 (1) (-2.55745E+01 $23-6)$

C

fc2 4 PuO2 (4.0\%) Radial flux \& fission rate

f $24: \mathrm{n} \quad(640<\mathrm{u}=4<510)$

fm24 (1) (-2.55745E+01 $24-6)$

C

C Axial flux and fission chamber traverses (U-5 \& Np-7)

fc34 Axial flux \& fission rate

f $34: \mathrm{n} \quad(662<\mathrm{u}=6<510)$

fm34 (1) (1 $50-6)\left(\begin{array}{lll}1 & 58 & -6\end{array}\right)$

$\begin{array}{lllllllllll}\mathrm{f} 34 & -800 & -801 & -802 & -803 & -804 & -805 & -806 & -807 & -808 & -809\end{array}$

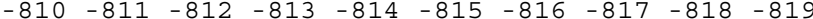

$\begin{array}{llllllllll}-820 & -821 & -822 & -823 & -824 & -825 & -826 & -827 & -828 & -829\end{array}$

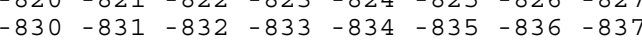

$\operatorname{sd34}(1.2723 \quad 38 r)$

C Spectral indices

f $44: \mathrm{n} \quad(662<\mathrm{u}=6<510)$

fm44 (1 $50-6) \quad\left(\begin{array}{lll}1 & 51 & -6\end{array}\right)\left(\begin{array}{lll}1 & 52 & -6\end{array}\right)\left(\begin{array}{lll}1 & 53 & -6\end{array}\right)\left(\begin{array}{lll}1 & 54 & -6\end{array}\right)$ $\left.\begin{array}{lll}(1 & 55 & -6\end{array}\right)\left(\begin{array}{lll}1 & 56 & -6\end{array}\right)\left(\begin{array}{lll}1 & 57 & -6\end{array}\right)\left(\begin{array}{lll}1 & 58 & -6\end{array}\right)$

fs $44-816-821$

sd44 (21.6299 6.36173 21.6299)

C

C Axial flux and fission rate in the pins (17-18 and 17-21 (MOX 4\%))

fc54 In pin Axial flux \& fission rate

f54:n $\left(640<511\left[\begin{array}{lll}1 & 0 & 0\end{array}\right] 511\left[\begin{array}{lll}3 & 0 & 0\end{array}\right]<510\right)$

fm54 (1) $\left(\begin{array}{lll}-1 & 24 & -6\end{array}\right)$

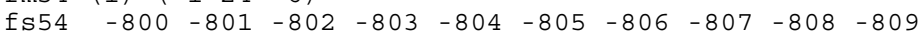

$\begin{array}{llllllllll}-810 & -811 & -812 & -813 & -814 & -815 & -816 & -817 & -818 & -819\end{array}$

$\begin{array}{llllllllll}-820 & -821 & -822 & -823 & -824 & -825 & -826 & -827 & -828 & -829\end{array}$

$\begin{array}{llllllll}-830 & -831 & -832 & -833 & -834 & -835 & -836 & -837\end{array}$

$\operatorname{sd54}(1.022938 r)(1.022938 r)$

C

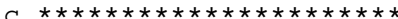

C RUN DEFINITIONS

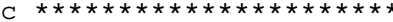

C

mode $\mathrm{n}$

totnu

C kcode $1000 \quad 1.020 \quad 1202000 \quad 0$

kcode $1000001.0202702000 \quad 0$

prdmp $1 j-240 \quad 12$

lost 5050

print 


\section{Appendix 2: REBUS input files}

REBUS input files representative of the R1UO2 and R1MOX configuration are listed in this appendix. The listed files are:

- R1UO2 configuration with a calibration sample in the oscillation channel [UO2C]

- R1MOX configuration with the POLINE overclad in the oscillation channel [MOXI]

For the UO2H and MOXI files, special regions have been modeled to calculate South-North and SouthEast - NorthWest power profile traverses. The regions have the size of a pin cell $(1.26 \times 1.26$ $\mathrm{cm}^{2}$ ) to calculate an averaged fission rate on each pin cell of the traverses. 


\section{File UO2C}

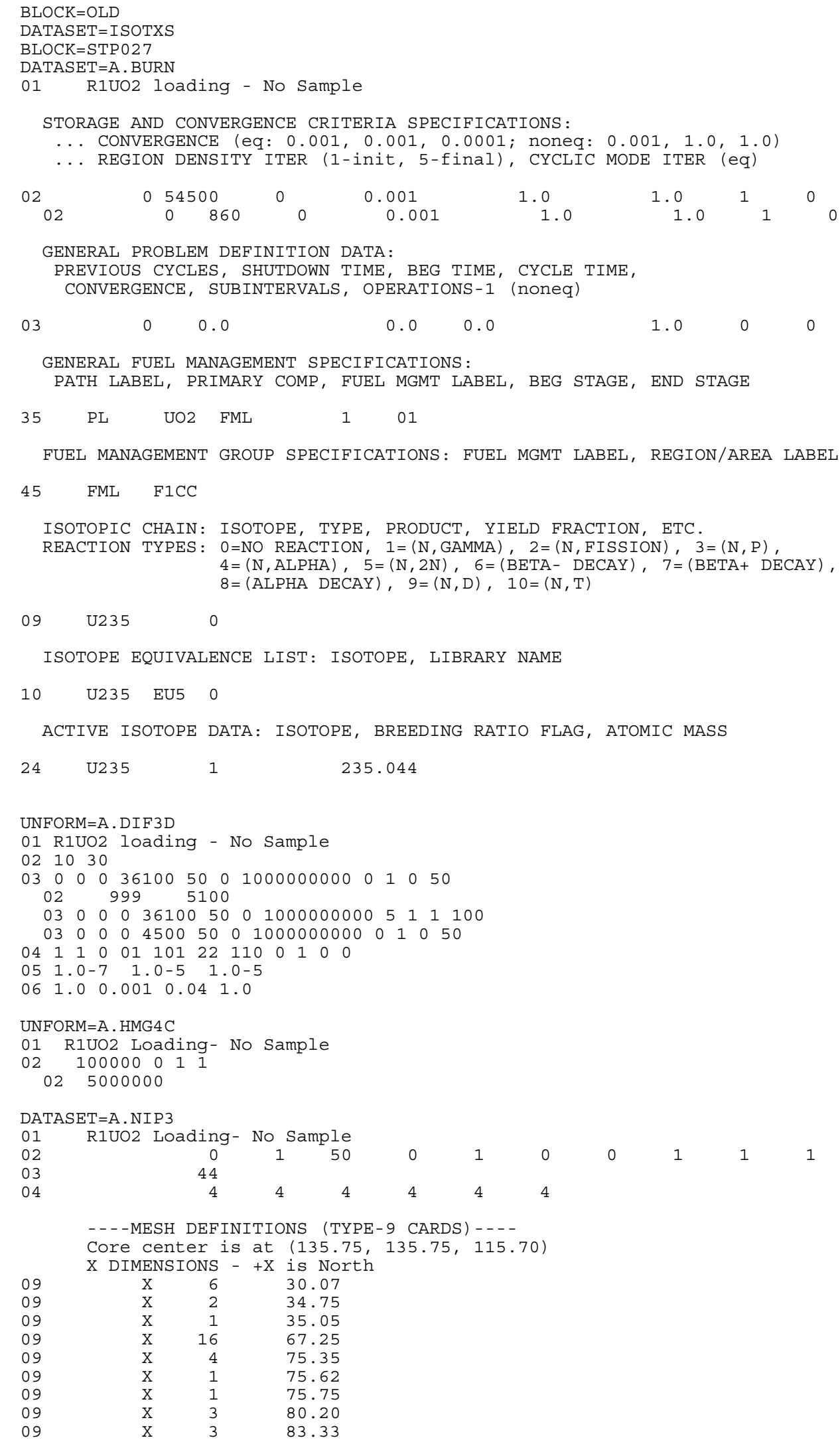




$\begin{array}{llll}09 & \mathrm{X} & 1 & 83.65 \\ 09 & \mathrm{X} & 8 & 91.04 \\ 09 & \mathrm{X} & 1 & 91.75 \\ 09 & \mathrm{X} & 8 & 98.75 \\ 09 & \mathrm{X} & 1 & 99.85 \\ 09 & \mathrm{X} & 7 & 106.46 \\ 09 & \mathrm{X} & 1 & 106.85 \\ 09 & \mathrm{X} & 1 & 107.95 \\ 09 & \mathrm{X} & 8 & 114.95 \\ 09 & \mathrm{X} & 1 & 114.96 \\ 09 & \mathrm{X} & 1 & 116.05 \\ 09 & \mathrm{X} & 1 & 116.22 \\ 09 & \mathrm{X} & 1 & 117.48 \\ 09 & \mathrm{X} & 1 & 118.74 \\ 09 & \mathrm{X} & 1 & 120.00 \\ 09 & \mathrm{X} & 1 & 121.26 \\ 09 & \mathrm{X} & 1 & 122.52 \\ 09 & \mathrm{X} & 1 & 123.05 \\ 09 & \mathrm{X} & 1 & 123.78 \\ 09 & \mathrm{X} & 1 & 124.15 \\ 09 & \mathrm{X} & 1 & 125.04\end{array}$

Add-on for the east 12 plate

$\begin{array}{llll}09 & \mathrm{X} & 1 & 125.75 \\ 09 & \mathrm{X} & 1 & 126.30 \\ 09 & \mathrm{X} & 1 & 127.56 \\ 09 & \mathrm{X} & 1 & 128.82 \\ 09 & \mathrm{X} & 1 & 130.08 \\ 09 & \mathrm{X} & 1 & 131.15 \\ 09 & \mathrm{X} & 1 & 131.34 \\ 09 & \mathrm{X} & 1 & 132.25 \\ 09 & \mathrm{X} & 1 & 132.60 \\ 09 & \mathrm{X} & 1 & 133.86 \\ 09 & \mathrm{X} & 1 & 135.12 \\ 09 & \mathrm{X} & 1 & 136.38 \\ 09 & \mathrm{X} & 1 & 137.64 \\ 09 & \mathrm{X} & 1 & 138.90 \\ 09 & \mathrm{X} & 1 & 139.25 \\ 09 & \mathrm{X} & 1 & 140.16 \\ 09 & \mathrm{X} & 1 & 140.35 \\ 09 & \mathrm{X} & 1 & 141.42 \\ 09 & \mathrm{X} & 1 & 142.68 \\ 09 & \mathrm{X} & 1 & 143.94 \\ 09 & \mathrm{X} & 1 & 145.20\end{array}$

$\begin{array}{rrrr}\text { Add-on for the west } & 12 \text { plate } \\ 09 & \mathrm{X} & 1 & 145.75\end{array}$

$\begin{array}{llrl}09 & \mathrm{X} & 1 & 146.46 \\ 09 & \mathrm{X} & 1 & 147.35 \\ 09 & \mathrm{X} & 1 & 147.72 \\ 09 & \mathrm{X} & 1 & 148.45 \\ 09 & \mathrm{X} & 1 & 148.98 \\ 09 & \mathrm{X} & 1 & 150.24 \\ 09 & \mathrm{X} & 1 & 151.50 \\ 09 & \mathrm{X} & 1 & 152.76 \\ 09 & \mathrm{X} & 1 & 154.02 \\ 09 & \mathrm{X} & 1 & 155.28 \\ 09 & \mathrm{X} & 1 & 155.45 \\ 09 & \mathrm{X} & 1 & 156.54 \\ 09 & \mathrm{X} & 1 & 156.55 \\ 09 & \mathrm{X} & 8 & 163.55 \\ 09 & \mathrm{X} & 1 & 164.65 \\ 09 & \mathrm{X} & 1 & 165.04 \\ 09 & \mathrm{X} & 7 & 171.65 \\ 09 & \mathrm{X} & 1 & 172.75 \\ 09 & \mathrm{X} & 8 & 179.75 \\ 09 & \mathrm{X} & 1 & 180.46 \\ 09 & \mathrm{X} & 8 & 187.85 \\ 09 & \mathrm{X} & 1 & 188.17 \\ 09 & \mathrm{X} & 2 & 191.30 \\ 09 & \mathrm{X} & 2 & 195.75 \\ 09 & \mathrm{X} & 1 & 195.88 \\ 09 & \mathrm{X} & 1 & 196.15 \\ 09 & \mathrm{X} & 16 & 228.65 \\ 09 & \mathrm{X} & 4 & 236.45 \\ 09 & \mathrm{X} & 2 & 241.43 \\ 09 & \mathrm{X} & 6 & 271.50 \\ & & & \\ & & & \end{array}$ 


$\begin{array}{lrrr}09 & Y & 6 & 30.07 \\ 09 & Y & 3 & 35.05 \\ 09 & Y & 4 & 43.05 \\ 09 & Y & 16 & 75.55 \\ 09 & Y & 1 & 75.62 \\ 09 & Y & 1 & 75.75 \\ 09 & Y & 3 & 80.20 \\ 09 & Y & 1 & 80.25 \\ 09 & Y & 2 & 83.33 \\ 09 & Y & 1 & 83.65 \\ 09 & Y & 8 & 91.04 \\ 09 & Y & 1 & 91.75 \\ 09 & Y & 8 & 98.75 \\ 09 & Y & 1 & 99.85 \\ 09 & Y & 8 & 106.85 \\ 09 & Y & 1 & 107.95 \\ 09 & Y & 8 & 114.95 \\ 09 & Y & 1 & 114.96 \\ 09 & Y & 1 & 116.05 \\ 09 & Y & 1 & 116.22 \\ 09 & Y & 1 & 117.48 \\ 09 & Y & 1 & 118.74 \\ 09 & Y & 1 & 120.00\end{array}$

Add-on for the south 9 plate $09 \quad Y \quad 1 \quad 120.05$

$\begin{array}{llll}09 & \mathrm{Y} & 1 & 121.26 \\ 09 & \mathrm{Y} & 1 & 122.52 \\ 09 & \mathrm{Y} & 1 & 123.05 \\ 09 & \mathrm{Y} & 1 & 123.78 \\ 09 & \mathrm{Y} & 1 & 124.15 \\ 09 & \mathrm{Y} & 1 & 125.04 \\ 09 & \mathrm{Y} & 1 & 126.30 \\ 09 & \mathrm{Y} & 1 & 127.56 \\ 09 & \mathrm{Y} & 1 & 130.82 \\ 09 & \mathrm{Y} & 1 & 131.15 \\ 09 & \mathrm{Y} & 1 & 131.34 \\ 09 & \mathrm{Y} & 1 & 132.25 \\ 09 & \mathrm{Y} & 1 & 132.60 \\ 09 & \mathrm{Y} & 1 & 133.86 \\ 09 & \mathrm{Y} & 1 & 135.12 \\ 09 & \mathrm{Y} & 1 & 136.38 \\ 09 & \mathrm{Y} & 1 & 137.64 \\ 09 & \mathrm{Y} & 1 & 139.25 \\ 09 & \mathrm{Y} & 1 & 140.16 \\ 09 & \mathrm{Y} & 1 & 140.35 \\ 09 & \mathrm{Y} & 1 & 141.42 \\ 09 & \mathrm{Y} & 1 & 142.68\end{array}$

Add-on for the north 9 plate $\begin{array}{llll}09 & Y & 1 & 143.35 \\ 09 & Y & 1 & 143.94 \\ 09 & Y & 1 & 145.20 \\ 09 & Y & 1 & 146.46 \\ 09 & Y & 1 & 147.35 \\ 09 & Y & 1 & 147.72 \\ 09 & Y & 1 & 148.45 \\ 09 & Y & 1 & 148.98 \\ 09 & Y & 1 & 150.24 \\ 09 & Y & 1 & 151.50 \\ 09 & Y & 1 & 152.76 \\ 09 & Y & 1 & 154.02 \\ 09 & Y & 1 & 155.28 \\ 09 & Y & 1 & 155.45 \\ 09 & Y & 1 & 156.54 \\ 09 & Y & 1 & 156.55 \\ 09 & Y & 8 & 163.55 \\ 09 & Y & 1 & 164.65 \\ 09 & Y & 8 & 171.65 \\ 09 & Y & 1 & 172.75 \\ 09 & Y & 8 & 179.75 \\ 09 & Y & 1 & 180.46 \\ 09 & Y & 8 & 187.85 \\ 09 & Y & 1 & 188.17 \\ 09 & Y & 2 & 191.25 \\ 09 & Y & 1 & 191.30 \\ 09 & Y & 2 & 195.75\end{array}$ 


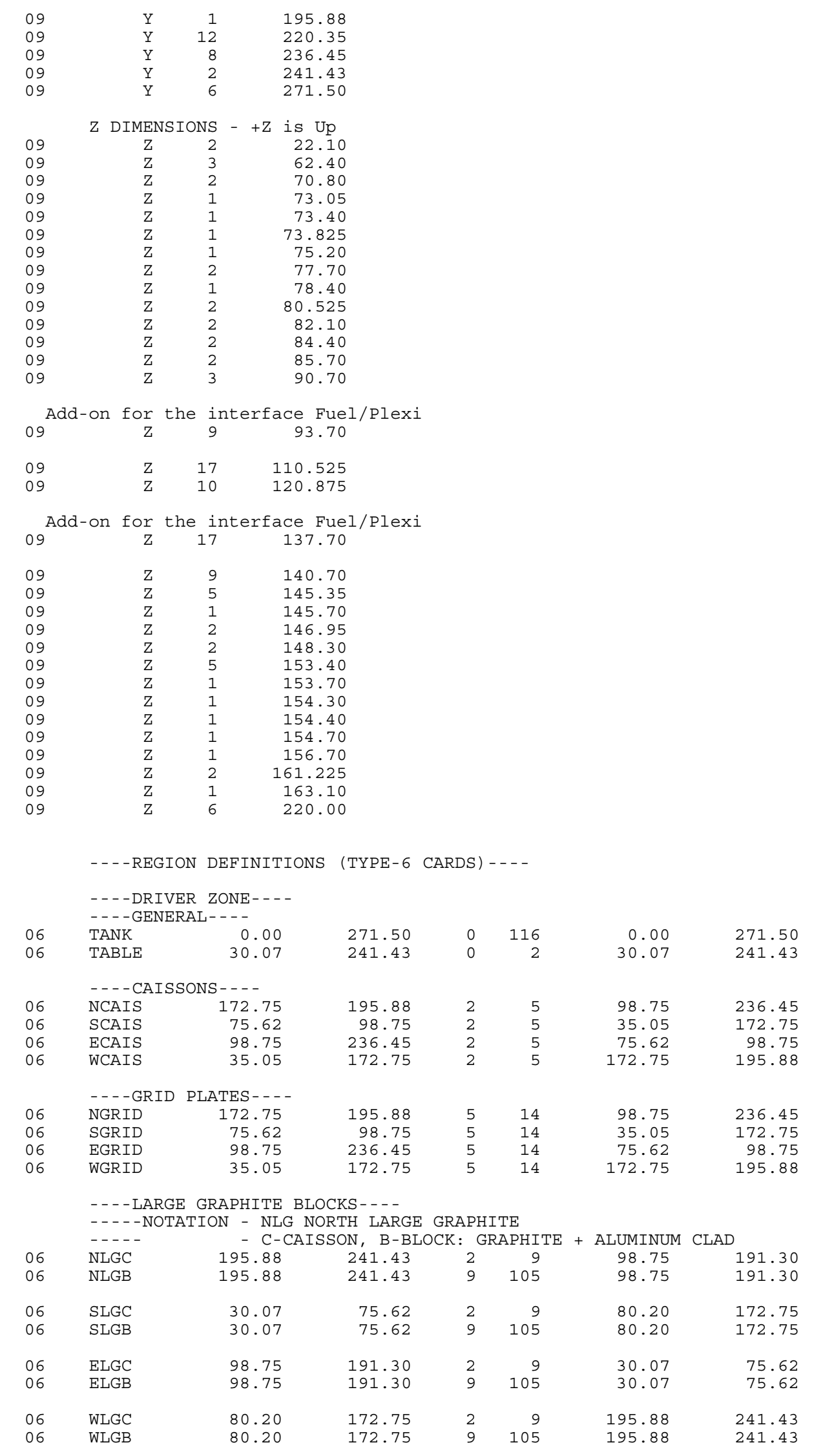




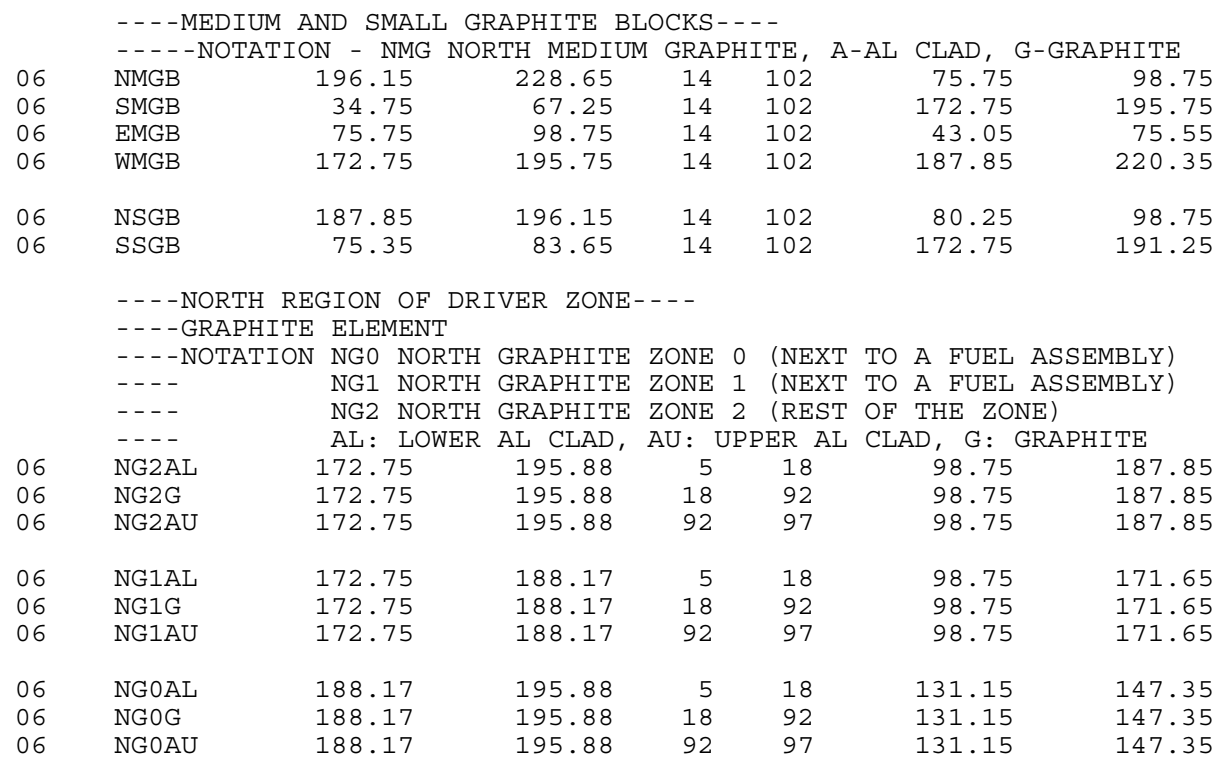

- - - FUEL ELEMENT

---NOTATION NO1 - NORTH 1 OF 9 NUMBERED FROM INNER ROW - LEFT SIDE ---LAST LETTER IS REGION IN Z DIRECTION

---B-BOTTOM, AL-AL CLAD LOWER, F-FUEL， AU-AL CLAD UPPER, WU-WATER UP

$\begin{array}{ll}172.75 & 180.46\end{array}$

$172.75 \quad 180.46$

$\begin{array}{lll}N 01 F & 172.75 & 180.46\end{array}$

NOIAU $\quad 172.75 \quad 180.46$

N01WU $\quad 172.75$

180.46

5
20

$20 \quad 22$

22

106.85

114.95

172.75

N02B

N02AL

172.75

$\mathrm{NO} 2 \mathrm{~F}$

172.75

$\mathrm{N} 02 \mathrm{AU}$

172.75

N02WU

172.75

180.46

180.46

180.46

180.46

22
93
95

$106.85 \quad 114.95$

N03B $\quad 172.75$

N03AL

N03F

172.75
172.75

N03AU $\quad 172.75$

N03WU $\quad 172.75$

180.46

52

180.46

180.46

180.46

180.46

180.46

106.85

114.95

N04B $\quad 172.75$

180.46

180.46

180.46

180.46

106.85

114.95

$\begin{array}{ll}\text { NO4AL } & 172.75 \\ \text { NO4 } & 172.75\end{array}$

N04AU $\quad 172.75$

N04WU

172.75

180.46

180.46

N05B

172.75

SAL

172.75

NO5F

172.75

N05AU

172.75

106

172.75

N06AL

172.75

N06F

172.75

172.75

N0 6WU

172.75

180.46

180.46

180.46

180.46

20

20
22

2293

93

114.95

114.95

123.05

114.95

123.05

123.05

$114.95 \quad 123.05$

$\begin{array}{ll}114.95 & 123.05\end{array}$

180.46

180.46

180.46

180.46

520

5
20

123.05

123.05

123.05

123.05

123.05

131.15

131.15

131.15

131.15

131.15

180.46

$$
20
$$

20

131.15

139.25

131.15

131.15

$\begin{array}{lll}93 & 95 & 131.15 \\ 95 & 97 & 131.15\end{array}$

139.25

139.25

139.25

139.25

N07B

N07AL

172.75

NO7AU $\quad 172.75$

N07WU

172.75

180.46

180.46

180.46

180.46

520

139.25

147.35

147.35

147.35

$\begin{array}{ll}139.25 & 147.35 \\ 139.25 & 147.35\end{array}$

$\begin{array}{ll}139.25 & 147.35 \\ 139.25 & 147.35\end{array}$

N08B

N08AL

180.46

180.46

147.35

147.35

147.35

147.35

155.45

155.45

155.45

155.45

155.45

NO8F 180.46

180.46

N0 8WU

180.46
180.46

188.17

188.17

188.17

188.17

188.17

180.46

188.17

5
20

147.35

163.55

155.45

155.45

155.45

155.45

163.55

163.55

163.55

163.55

131.15

139.25

131.15

139.25

$\begin{array}{ll}131.15 & 139.25\end{array}$

$131.15 \quad 139.25$

N09B

93
95

97

139.25

147.35 


$\begin{array}{llllllll}06 & \text { N09AL } & 180.46 & 188.17 & 20 & 22 & 139.25 & 147.35 \\ 06 & \text { N09F } & 180.46 & 188.17 & 22 & 93 & 139.25 & 143.35 \\ 06 & \text { N09GR } & 180.46 & 188.17 & 22 & 93 & 143.35 & 147.35 \\ 06 & \text { NO9AU } & 180.46 & 188.17 & 93 & 95 & 139.25 & 147.35 \\ 06 & \text { NO9WU } & 180.46 & 188.17 & 95 & 97 & 139.25 & 147.35\end{array}$

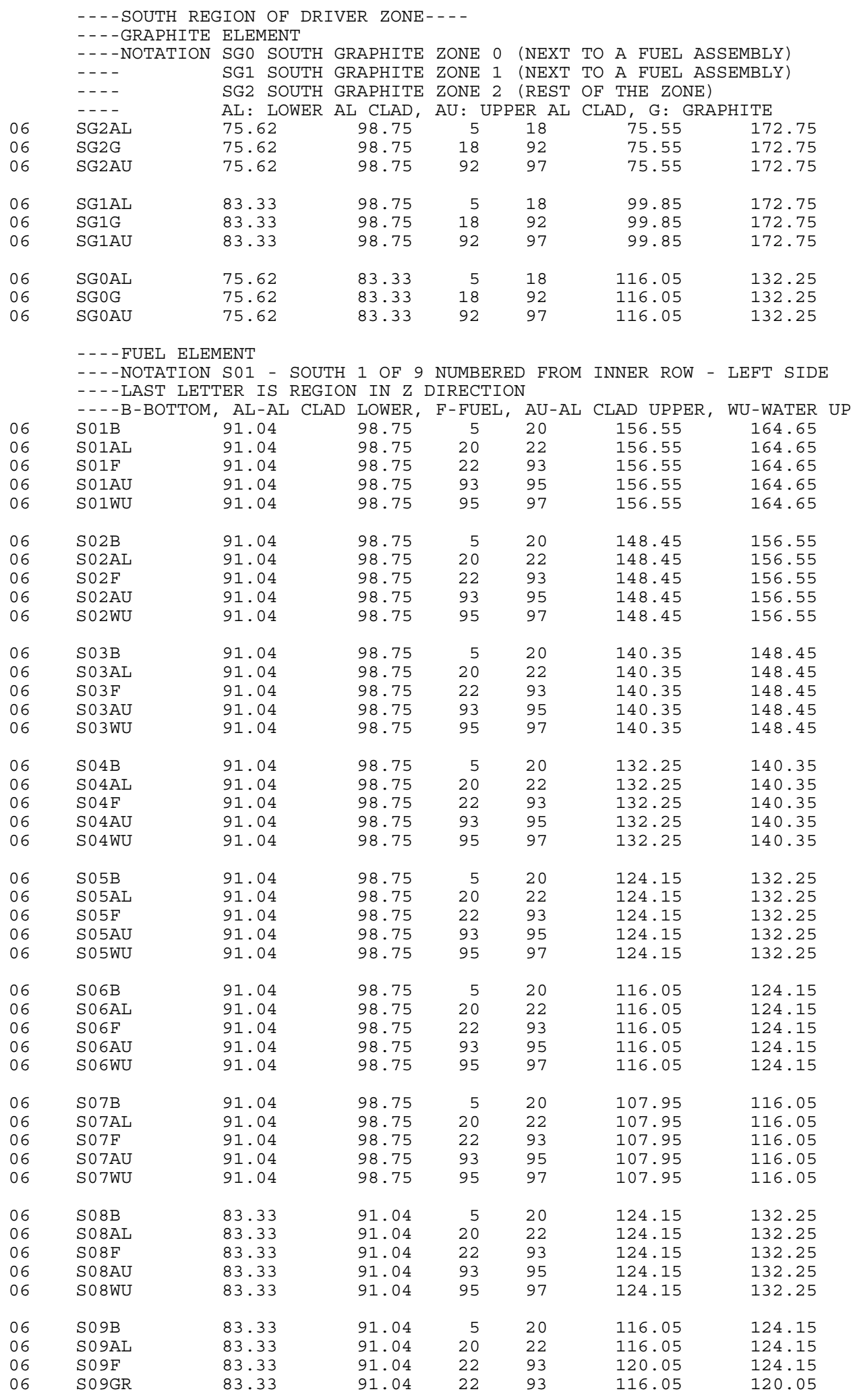




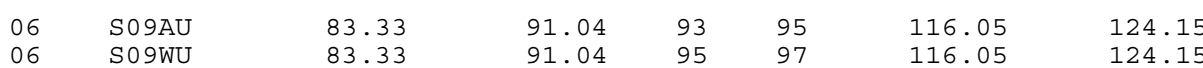

----EAST REGION OF DRIVER ZONE----

- - -GRAPHITE ELEMENT

---NOTATION EGO EAST GRAPHITE ZONE O (NEXT TO A FUEL ASSEMBLY)

-.. $\quad$ EGI EAST GRAPHITE ZONE 1 (NEXT TO A FUEL ASSEMBLY)

-..- EG2 EAST GRAPHITE ZONE 2 (REST OF THE ZONE)

AL: LOWER AL CLAD, AU: UPPER AL CLAD, G: GRAPHITE

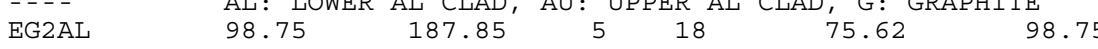

EG2AU

$98.75 \quad 187.85$

$98.75 \quad 187.85$

$92 \quad 97$

75.62

98.75

EG1AL

98.75

171.65

EG1G

98.75

171.65

5
18

75.62

98.75

EGIAU

98.75

139.25

$92 \quad 97$

83.33

98.75

EGOAL

123.05

139.25

5
18

83.33

98.75

EGOAU

123.05

139.25

$92 \quad 97$

75.62

83.33

- - - FUEL ELEMENT

---NOTATION EO1 - EAST 1 OF 9 NUMBERED FROM INNER ROW - LEFT SIDE ----LAST LETTER IS REGION IN Z DIRECTION ---B-BOTTOM, AL-AL CLAD LOWER, F-FUEL, AU-AL CLAD UPPER, WU-WATER UP $106.85 \quad 114.95$

$\begin{array}{lllll}\text { E01AL } & 106.85 & 114.95 & 20 & 22 \\ \text { E01F } & 106.85 & 114.95 & 22 & 93\end{array}$

$\begin{array}{lllll}\text { E01F } & 106.85 & 114.95 & 22 & 93 \\ \text { E01AU } & 106.85 & 114.95 & 93 & 95\end{array}$

106.85

114.95

95

E02B

114.95

E02AL

114.95

123.05

123.05

123.05

123.05

$5 \quad 20$

E02F
E02AU

114.95

E02WU

114.95

123.05

$22 \quad 93$

E03B

E03AL

123.05

E03F

123.05

131.15

131.15

131.15

131.15

131.15

93
95

91.04

98.75

91.04

98.75

$91.04 \quad 98.75$

$91.04 \quad 98.75$

E03AU

123.05

E03WU

123.05

139.25

E04B
E04AL

131.15

$\mathrm{E} 04 \mathrm{AL}$
$\mathrm{E} 04 \mathrm{~F}$

131.15

131.15

E04AU

131.15

139.25

139.25

139.25

139.25

91.04

98.75

E04WU

139.25

E05AL

139.25

147.35

147.35

147.35

147.35

520

$20 \quad 22$

22

93

$95 \quad 97$

91.04

98.75

98.75

$91.04 \quad 98.75$

$91.04 \quad 98.75$

$91.04 \quad 98.75$

E05F 139.25

E05AU $\quad 139.25$

147.35

$5 \quad 20$

5
20

$22 \quad 93$

93

$95 \quad 97$

91.04

91.04

91.04

98.75

91.04

$91.04 \quad 98.75$

E06B

E06AL

147.35

E06F

147.35

155.45

155.45

155.45

155.45

155.45

91.04

91.04

91.04

98.75

98.75

$91.04 \quad 98.75$

E06WU

147.35

E07B

E07AL

155.45

E07F

E07AU

155.45

155.45

155.45

163.55

163.55

163.55

163.55

$5 \quad 20$

91.04

98.75

91.04

98.75

$91.04 \quad 98.75$

$91.04 \quad 98.75$

$91.04 \quad 98.75$

E07WU

155.45

163.55

131.15

131.15

131.15

125.75

E08AL

123.05

E08F 125.75

E08GR

123.05

E08AU

123.05

131.15

131.15

91.04

91.04

98.75

91.04

98.75

98.75

$91.04 \quad 98.75$

$91.04 \quad 98.75$

$91.04 \quad 98.75$

$91.04 \quad 98.75$

$91.04 \quad 98.75$

$91.04 \quad 98.75$

$91.04 \quad 98.75$

$\begin{array}{lll}\text { E09B } & 131.15 & 139.25\end{array}$

E09AL

131.15

139.25

139.25

139.25

131.15

139.25

83.33

91.04

83.33

83.33

83.33

91.04

83.33

91.04

91.04

83.33

91.04

83.33

91.04

520

83.33

83.33

83.33

91.04

E09AU

131.15

93
95

97

83.33

91.04 
-WEST REGION OF DRIVER ZONE-...

----GRAPHITE ELEMENT

---NOTATION WGO WEST GRAPHITE ZONE O (NEXT TO A FUEL ASSEMBLY)

-..- WGI WEST GRAPHITE ZONE 1 (NEXT TO A FUEL ASSEMBLY)

-.. WG2 WEST GRAPHITE ZONE 2 (REST OF THE ZONE)

AL: LOWER AL CLAD, AU: UPPER AL CLAD, G: GRAPHITE

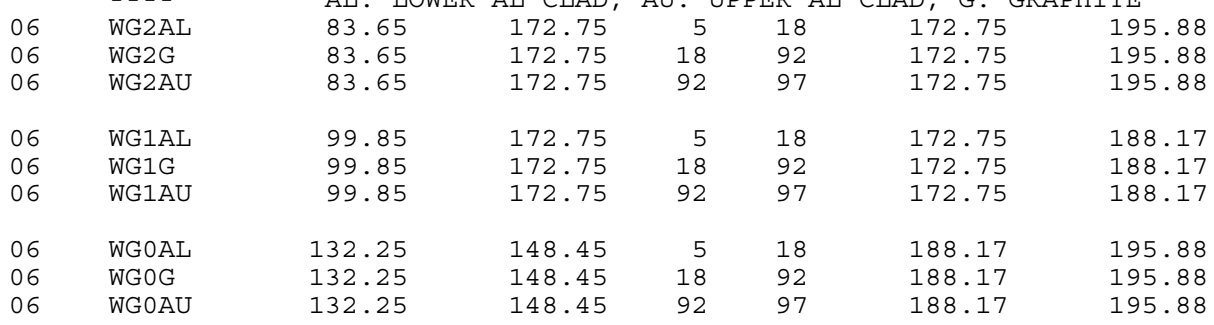

----FUEL ELEMENT

- --NOTATION WO1 - WEST 1 OF 9 NUMBERED FROM INNER ROW - LEFT SIDE ---LAST LETTER IS REGION IN Z DIRECTION

---B-BOTTOM, AL-AL CLAD LOWER, F-FUEL, AU-AL CLAD UPPER, WU-WATER UP

\begin{tabular}{|c|}
\hline $101 \mathrm{~B}$ \\
\hline
\end{tabular}

$\begin{array}{lllll}\text { W01B } & 156.55 & 164.65 & 5 & 20\end{array}$

$\begin{array}{lllllll}\text { WO1AL } & 156.55 & 164.65 & 20 & 22 & 172.75 & 180.46\end{array}$

$\begin{array}{lllllll}\text { WOIF } & 156.55 & 164.65 & 22 & 93 & 172.75 & 180.46\end{array}$

$\begin{array}{lllll}\text { WO1AU } & 156.55 & 164.65 & 93 & 95\end{array}$

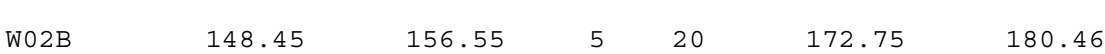

WO2AI

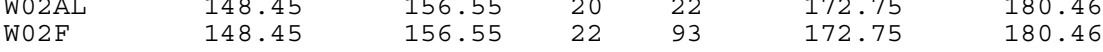

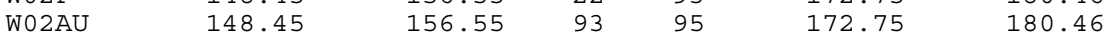

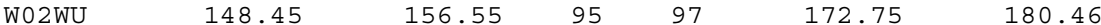

$\begin{array}{lllllll}\text { W03B } & 140.35 & 148.45 & 5 & 20 & 172.75 & 180.46\end{array}$

$\begin{array}{lllllll}\text { W03AL } & 140.35 & 148.45 & 20 & 22 & 172.75 & 180.46\end{array}$

$\begin{array}{lllllll}\text { W03F } & 140.35 & 148.45 & 22 & 93 & 172.75 & 180.46\end{array}$

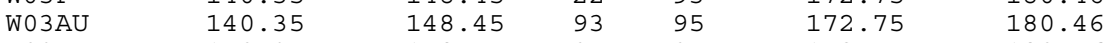

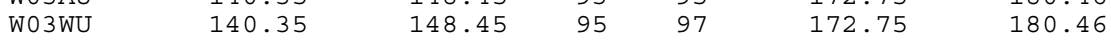

$\begin{array}{lllllll}\text { W04B } & 132.25 & 140.35 & 5 & 20 & 172.75 & 180.46\end{array}$

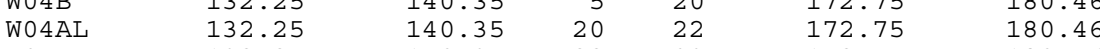

$\begin{array}{lllllll}\text { W04F } & 132.25 & 140.35 & 22 & 93 & 172.75 & 180.46\end{array}$

$\begin{array}{llll}140.35 & 93 & 95 & 172.75\end{array}$

$\begin{array}{lllllll}\text { W0 } 4 \text { WU } & 132.25 & 140.35 & 95 & 97 & 172.75 & 180.46\end{array}$

$\begin{array}{lllllll}\text { W05B } & 124.15 & 132.25 & 5 & 20 & 172.75 & 180.46\end{array}$

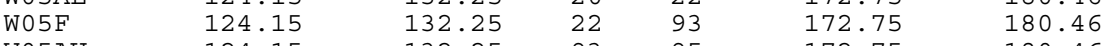

$\begin{array}{lllllll}\text { W05AU } & 124.15 & 132.25 & 93 & 95 & 172.75 & 180.46\end{array}$

$\begin{array}{llllll}\text { W05WU } & 124.15 & 132.25 & 95 & 97 & 172.75\end{array}$

$\begin{array}{lllllll}\text { W06B } & 116.05 & 124.15 & 5 & 20 & 172.75 & 180.46\end{array}$

$\begin{array}{lllllll}\text { W06AL } & 116.05 & 124.15 & 20 & 22 & 172.75 & 180.46\end{array}$

$\begin{array}{lllllll}\text { W06F } & 116.05 & 124.15 & 22 & 93 & 172.75 & 180.46\end{array}$

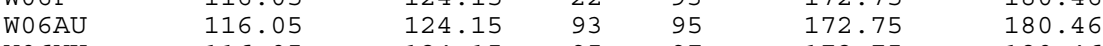

$\begin{array}{lllllll}\text { W06WU } & 116.05 & 124.15 & 95 & 97 & 172.75 & 180.46\end{array}$

$\begin{array}{lllllll}\text { W07B } & 107.95 & 116.05 & 5 & 20 & 172.75 & 180.46\end{array}$

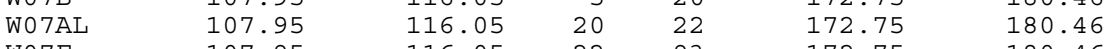

$\begin{array}{lllllll}\text { W07F } & 107.95 & 116.05 & 22 & 93 & 172.75 & 180.46\end{array}$

$\begin{array}{lllllll}\text { W07AU } & 107.95 & 116.05 & 93 & 95 & 172.75 & 180.46\end{array}$

$\begin{array}{lllllll}\text { W07WU } & 107.95 & 116.05 & 95 & 97 & 172.75 & 180.46\end{array}$

$\begin{array}{lllllll}\text { W08B } & 140.35 & 148.45 & 5 & 20 & 180.46 & 188.17\end{array}$

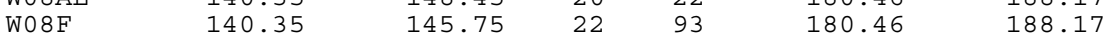

$\begin{array}{lllllll}\text { W08GR } & 145.75 & 148.45 & 22 & 93 & 180.46 & 188.17\end{array}$

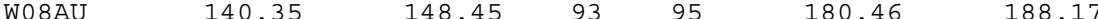

$\begin{array}{lllllll}\text { W08WU } & 140.35 & 148.45 & 95 & 97 & 180.46 & 188.17\end{array}$

$\begin{array}{lllllll}\text { W09B } & 132.25 & 140.35 & 5 & 20 & 180.46 & 188.17\end{array}$

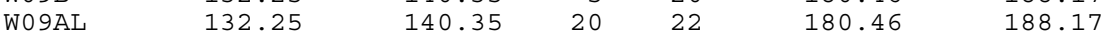

$\begin{array}{lllllll}\text { W09F } & 132.25 & 140.35 & 22 & 93 & 180.46 & 188.17\end{array}$

$\begin{array}{lllllll}\text { W09AU } & 132.25 & 140.35 & 93 & 95 & 180.46 & 188.17\end{array}$

$\begin{array}{lllllll}\text { W09WU } & 132.25 & 140.35 & 95 & 97 & 180.46 & 188.17\end{array}$

- - -EXPERIMENTAL ZONE--.

----WEDGE IS THE ALUMINUM CORNERS OUTSIDE THE CHIMNEY 
----PLATES INSIDE THE CHIMNEY : SSL- LOWER SS PLATES,

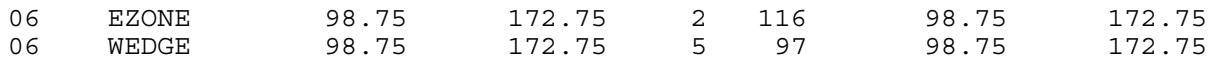

- - - ANGLE GRAPHITE ELEMENTS - - -

---NOTATION G-GRAPHITE ELEMENT, 1-ELEMENT ARE NUMBERED 1-4 ---AXIAL LOCATION AL-LOWER AL CLAD, AU-UPPER AL CLAD, G-GRAPHITE

\begin{tabular}{|c|c|c|c|c|c|c|}
\hline GIAL & 165.04 & 172.75 & 5 & 18 & 164.65 & 172.75 \\
\hline G1G & 165.04 & 172.75 & 18 & 92 & 164.65 & 172.75 \\
\hline GIAU & 165.04 & 172.75 & 92 & 97 & 164.65 & 172.75 \\
\hline G2AL & 98.75 & 106.46 & 5 & 18 & 98.75 & 106.8 \\
\hline $\mathrm{G} 2 \mathrm{G}$ & 98.75 & 106.46 & 18 & 92 & 98.75 & 106.8 \\
\hline G2AU & 98.75 & 106.46 & 92 & 97 & 98.75 & 106.85 \\
\hline G3AL & 165.04 & 172.75 & 5 & 18 & 98.75 & 106. \\
\hline G3G & 165.04 & 172.75 & 18 & 92 & 98.75 & 106. \\
\hline G3AU & 165.04 & 172.75 & 92 & 97 & 98.75 & 106.8 \\
\hline G4AL & 98.75 & 106.46 & 5 & 18 & 164.65 & 172. \\
\hline G4G & 98.75 & 106.46 & 18 & 92 & 164.65 & 72 . \\
\hline G4AU & 98.75 & 106.46 & 92 & 97 & 164.65 & 172. \\
\hline
\end{tabular}

- - - ALUMINUM MASSIF-...

---NOTATION ALB-ALUMINUM BLOCK, A-E ARE AXIAL SEGMENTS

$\begin{array}{llrrrrr}\text { ALBA } & 106.85 & 164.65 & 0 & 7 & 106.85 & 164.65 \\ \text { ALBB } & 106.85 & 164.65 & 7 & 8 & 106.85 & 164.65 \\ \text { ALBC } & 106.85 & 164.65 & 8 & 106 & 106.85 & 164.65 \\ \text { ALBD } & 106.85 & 164.65 & 106 & 107 & 106.85 & 164.65 \\ \text { ALBE } & 106.85 & 164.65 & 107 & 110 & 106.85 & 164.65\end{array}$

----CHIMNEY PIECES--.

- - -NOTATION CHI-CHIMNEY, 1-PIECES ARE NUMBERED 1-8

--- A-G ARE AXIAL SEGMENTS EXCEPT FOR T- TABLE

\begin{tabular}{|c|c|c|c|c|c|c|c|}
\hline 06 & CHI1T & 164.65 & 172.75 & 0 & 2 & 114.95 & 156.55 \\
\hline 06 & CHIIA & 164.65 & 172.75 & 2 & 7 & 114.95 & 156.55 \\
\hline 06 & CHIIB & 164.65 & 172.75 & 7 & 8 & 114.95 & 156.55 \\
\hline 06 & $\mathrm{CHI} 1 \mathrm{C}$ & 164.65 & 172.75 & 8 & 97 & 114.95 & 156.55 \\
\hline 06 & CHIID & 164.65 & 172.75 & 97 & 106 & 114.95 & 156.55 \\
\hline 06 & CHIIE & 164.65 & 172.75 & 106 & 107 & 114.95 & 156.55 \\
\hline 06 & CHIIF & 164.65 & 172.75 & 107 & 110 & 114.95 & 156.55 \\
\hline 06 & CHI2T & 98.75 & 106.85 & 0 & 2 & 114.95 & 156.55 \\
\hline 06 & $\mathrm{CHI} 2 \mathrm{~A}$ & 98.75 & 106.85 & 2 & 7 & 114.95 & 156.55 \\
\hline 06 & $\mathrm{CHI} 2 \mathrm{~B}$ & 98.75 & 106.85 & 7 & 8 & 114.95 & 156.55 \\
\hline 06 & $\mathrm{CHI} 2 \mathrm{C}$ & 98.75 & 106.85 & 8 & 97 & 114.95 & 156.55 \\
\hline 06 & CHI2D & 98.75 & 106.85 & 97 & 106 & 114.95 & 156.55 \\
\hline 06 & $\mathrm{CHI} 2 \mathrm{E}$ & 98.75 & 106.85 & 106 & 107 & 114.95 & 156.55 \\
\hline 06 & $\mathrm{CHI} 2 \mathrm{~F}$ & 98.75 & 106.85 & 107 & 110 & 114.95 & 156.55 \\
\hline 06 & CHI3T & 114.95 & 156.55 & 0 & 2 & 98.75 & 106.85 \\
\hline 06 & CHI3A & 114.95 & 156.55 & 2 & 7 & 98.75 & 106.85 \\
\hline 06 & CHI3B & 114.95 & 156.55 & 7 & 8 & 98.75 & 106.85 \\
\hline 06 & $\mathrm{CHI} 3 \mathrm{C}$ & 114.95 & 156.55 & 8 & 97 & 98.75 & 106.85 \\
\hline 06 & CHI3D & 114.95 & 156.55 & 97 & 106 & 98.75 & 106.85 \\
\hline 06 & CHI3E & 114.95 & 156.55 & 106 & 107 & 98.75 & 106.85 \\
\hline 06 & CHI $3 \mathrm{~F}$ & 114.95 & 156.55 & 107 & 110 & 98.75 & 106.85 \\
\hline 06 & CHI $4 \mathrm{~T}$ & 114.95 & 156.55 & 0 & 2 & 164.65 & 172.75 \\
\hline 06 & $\mathrm{CHI} 4 \mathrm{~A}$ & 114.95 & 156.55 & 2 & 7 & 164.65 & 172.75 \\
\hline 06 & $\mathrm{CHI} 4 \mathrm{~B}$ & 114.95 & 156.55 & 7 & 8 & 164.65 & 172.75 \\
\hline 06 & $\mathrm{CHI} 4 \mathrm{C}$ & 114.95 & 156.55 & 8 & 97 & 164.65 & 172.75 \\
\hline 06 & CHI4D & 114.95 & 156.55 & 97 & 106 & 164.65 & 172.75 \\
\hline 06 & $\mathrm{CHI} 4 \mathrm{E}$ & 114.95 & 156.55 & 106 & 107 & 164.65 & 172.75 \\
\hline 06 & $\mathrm{CHI} 4 \mathrm{~F}$ & 114.95 & 156.55 & 107 & 110 & 164.65 & 172.75 \\
\hline 06 & CHI5T & 156.55 & 164.65 & 0 & 2 & 156.55 & 164.65 \\
\hline 06 & CHI5A & 156.55 & 164.65 & 2 & 7 & 156.55 & 164.65 \\
\hline 06 & CHI5B & 156.55 & 164.65 & 7 & 8 & 156.55 & 164.65 \\
\hline 06 & CHI5C & 156.55 & 164.65 & 8 & 97 & 156.55 & 164.65 \\
\hline 06 & CHI5D & 156.55 & 164.65 & 97 & 106 & 156.55 & 164.65 \\
\hline 06 & CHI5E & 156.55 & 164.65 & 106 & 107 & 156.55 & 164.65 \\
\hline 06 & CHI5F & 156.55 & 164.65 & 107 & 110 & 156.55 & 164.65 \\
\hline 06 & CHI6T & 106.85 & 114.95 & 0 & 2 & 106.85 & 114.9 \\
\hline 06 & CHI6A & 106.85 & 114.95 & 2 & 7 & 106.85 & 114.95 \\
\hline 06 & CHI6B & 106.85 & 114.95 & 7 & 8 & 106.85 & 114.95 \\
\hline 06 & $\mathrm{CHI} 6 \mathrm{C}$ & 106.85 & 114.95 & 8 & 97 & 106.85 & 114.95 \\
\hline 06 & CHI6D & 106.85 & 114.95 & 97 & 106 & 106.85 & 114.9 \\
\hline
\end{tabular}




$\begin{array}{llrrrrrr}06 & \text { CHI6E } & 106.85 & 114.95 & 106 & 107 & 106.85 & 114.95 \\ 06 & \text { CHI6F } & 106.85 & 114.95 & 107 & 110 & 106.85 & 114.95 \\ 06 & \text { CHI7T } & 156.55 & 164.65 & 0 & 2 & 106.85 & 114.95 \\ 06 & \text { CHI7A } & 156.55 & 164.65 & 2 & 7 & 106.85 & 114.95 \\ 06 & \text { CHI7B } & 156.55 & 164.65 & 7 & 8 & 106.85 & 114.95 \\ 06 & \text { CHI7C } & 156.55 & 164.65 & 8 & 97 & 106.85 & 114.95 \\ 06 & \text { CHI7D } & 156.55 & 164.65 & 97 & 106 & 106.85 & 114.95 \\ 06 & \text { CHI7E } & 156.55 & 164.65 & 106 & 107 & 106.85 & 114.95 \\ 06 & \text { CHI7F } & 156.55 & 164.65 & 107 & 110 & 106.85 & 114.95 \\ & & & & & & & \\ 06 & \text { CHI8T } & 106.85 & 114.95 & 0 & 2 & 156.55 & 164.65 \\ 06 & \text { CHI8A } & 106.85 & 114.95 & 2 & 7 & 156.55 & 164.65 \\ 06 & \text { CHI8B } & 106.85 & 114.95 & 7 & 8 & 156.55 & 164.65 \\ 06 & \text { CHI8C } & 106.85 & 114.95 & 8 & 97 & 156.55 & 164.65 \\ 06 & \text { CHI8D } & 106.85 & 114.95 & 97 & 106 & 156.55 & 164.65 \\ 06 & \text { CHI8E } & 106.85 & 114.95 & 106 & 107 & 156.55 & 164.65 \\ 06 & \text { CHI8F } & 106.85 & 114.95 & 107 & 110 & 156.55 & 164.65\end{array}$

----ELEMENTS IN MELODIE R1UO2 CONFIGURATION----

-.--R1UO2 FUEL PINS

---1 CENTRAL ZONE, 2 ZONES ON EACH SIDE

---NOTATION: F1C- FUEL TYPE-1 CENTRAL REGION

-.-F1W1- REGION WEST 1, F1W2- REGION WEST $2 \ldots$

- - - A LAST LETTER (A-Z) GIVES THE AXIAL LOCATION EXCEPT

----SS-STAINLESS STEEL LOWER PLATE, W-LOWER WATER

06
06
06
0
06
06
06
06
06
06
06
06
06
06
06
06
06
06
06

$\begin{array}{lrrll}148.98 & 0 & 7 & 122.52 & 148.98 \\ 148.98 & 7 & 8 & 122.52 & 148.98 \\ 148.98 & 8 & 13 & 122.52 & 148.98 \\ 148.98 & 13 & 25 & 122.52 & 148.98 \\ 148.98 & 25 & 87 & 122.52 & 148.98 \\ 148.98 & 87 & 103 & 122.52 & 148.98 \\ 148.98 & 103 & 107 & 122.52 & 148.98 \\ 148.98 & 107 & 110 & 122.52 & 148.98 \\ 152.76 & 0 & 7 & 122.52 & 148.98 \\ 152.76 & 7 & 8 & 122.52 & 148.98 \\ 152.76 & 8 & 13 & 122.52 & 148.98 \\ 152.76 & 13 & 25 & 122.52 & 148.98 \\ 152.76 & 25 & 87 & 122.52 & 148.98 \\ 152.76 & 87 & 103 & 122.52 & 148.98 \\ 152.76 & 103 & 107 & 122.52 & 148.98 \\ 152.76 & 107 & 110 & 122.52 & 148.98 \\ 156.54 & 0 & 7 & 130.08 & 141.42 \\ 156.54 & 7 & 8 & 130.08 & 141.42 \\ 156.54 & 8 & 13 & 130.08 & 141.42 \\ 156.54 & 13 & 25 & 130.08 & 141.42 \\ 156.54 & 25 & 87 & 130.08 & 141.42 \\ 156.54 & 87 & 103 & 130.08 & 141.42 \\ 156.54 & 103 & 107 & 130.08 & 141.42 \\ 156.54 & 107 & 110 & 130.08 & 141.42 \\ 122.52 & 0 & 7 & 122.52 & 148.98 \\ 122.52 & 7 & 8 & 122.52 & 148.98 \\ 122.52 & 8 & 13 & 122.52 & 148.98 \\ 122.52 & 13 & 25 & 122.52 & 148.98 \\ 122.52 & 25 & 87 & 122.52 & 148.98 \\ 122.52 & 87 & 103 & 122.52 & 148.98 \\ 122.52 & 103 & 107 & 122.52 & 148.98 \\ 122.52 & 107 & 110 & 122.52 & 148.98 \\ 118.74 & 0 & 7 & 130.08 & 141.42 \\ 118.74 & 7 & 8 & 130.08 & 141.42 \\ 118.74 & 8 & 13 & 130.08 & 141.42 \\ 118.74 & 13 & 25 & 130.08 & 141.42 \\ 118.74 & 25 & 87 & 130.08 & 141.42 \\ 118.74 & 87 & 103 & 130.08 & 141.42 \\ 118.74 & 103 & 107 & 130.08 & 141.42 \\ 118.74 & 107 & 110 & 130.08 & 141.42 \\ 148.98 & 0 & 788 & 118.74 & 122.52 \\ 148.98 & 7 & 8 & 118.74 & 122.52 \\ 148.98 & 8 & 13 & 118.74 & 122.52 \\ 148.98 & 13 & 25 & 118.74 & 122.52 \\ 148 & 25 & 87 & 118.74 & 122.52 \\ 103 & 107 & 118.74 & 122.52 \\ 103 & & & & 122.52\end{array}$




\begin{tabular}{|c|c|c|c|c|c|c|c|}
\hline 06 & F1E1F & 122.52 & 148.98 & 107 & 110 & 118.74 & 122.52 \\
\hline 06 & F1E2W & 130.08 & 141.42 & 0 & 7 & 114.96 & 118.74 \\
\hline 06 & F1E2SS & 130.08 & 141.42 & 7 & 8 & 114.96 & 118.74 \\
\hline 06 & F1E2A & 130.08 & 141.42 & 8 & 13 & 114.96 & 118.74 \\
\hline 06 & F1E2B & 130.08 & 141.42 & 13 & 25 & 114.96 & 118.74 \\
\hline 06 & F1E2C & 130.08 & 141.42 & 25 & 87 & 114.96 & 118.74 \\
\hline 06 & F1E2D & 130.08 & 141.42 & 87 & 103 & 114.96 & 118.74 \\
\hline 06 & F1E2E & 130.08 & 141.42 & 103 & 107 & 114.96 & 118.74 \\
\hline 06 & F1E2F & 130.08 & 141.42 & 107 & 110 & 114.96 & 118.74 \\
\hline 06 & F1W1W & 122.52 & 148.98 & 0 & 7 & 148.98 & 152.76 \\
\hline 06 & F1WISS & 122.52 & 148.98 & 7 & 8 & 148.98 & 152.76 \\
\hline 06 & F1W1A & 122.52 & 148.98 & 8 & 13 & 148.98 & 152.76 \\
\hline 06 & F1W1B & 122.52 & 148.98 & 13 & 25 & 148.98 & 152.76 \\
\hline 06 & F1W1C & 122.52 & 148.98 & 25 & 87 & 148.98 & 152.76 \\
\hline 06 & F1W1D & 122.52 & 148.98 & 87 & 103 & 148.98 & 152.76 \\
\hline 06 & F1W1E & 122.52 & 148.98 & 103 & 107 & 148.98 & 152.76 \\
\hline 06 & F1W1F & 122.52 & 148.98 & 107 & 110 & 148.98 & 152.76 \\
\hline 06 & F1W2W & 130.08 & 141.42 & 0 & 7 & 152.76 & 156.54 \\
\hline 06 & F1W2SS & 130.08 & 141.42 & 7 & 8 & 152.76 & 156.54 \\
\hline 06 & F1W2A & 130.08 & 141.42 & 8 & 13 & 152.76 & 156.54 \\
\hline 06 & F1W2B & 130.08 & 141.42 & 13 & 25 & 152.76 & 156.54 \\
\hline 06 & F1W2C & 130.08 & 141.42 & 25 & 87 & 152.76 & 156.54 \\
\hline 06 & F1W2D & 130.08 & 141.42 & 87 & 103 & 152.76 & 156.54 \\
\hline 06 & F1W2E & 130.08 & 141.42 & 103 & 107 & 152.76 & 156.54 \\
\hline 06 & F1W2F & 130.08 & 141.42 & 107 & 110 & 152.76 & 156.54 \\
\hline
\end{tabular}

----R1UO2 ALUMINUM PINS

---NOTATION: ALC- FUEL TYPE-1 CENTRAL REGION

---ALW1- AL PIN \#1 REGION WEST, NUMBERED FROM LEFT AND INNER MOST ---A LAST LETTER (A-Z) GIVES THE AXIAL LOCATION EXCEPT

---SS-STAINLESS STEEL LOWER PLATE, W-LOWER WATER

\begin{tabular}{|c|c|c|c|c|c|c|c|}
\hline & & & & & & & \\
\hline 06 & ALN1W & 151.50 & 152.76 & 0 & 7 & 147.72 & 148.98 \\
\hline 06 & ALN1SS & 151.50 & 152.76 & 7 & 8 & 147.72 & 148.98 \\
\hline 06 & ALN1A & 151.50 & 152.76 & 8 & 11 & 147.72 & 148.98 \\
\hline 06 & ALN1B & 151.50 & 152.76 & 11 & 106 & 147.72 & 148.98 \\
\hline 06 & ALN1C & 151.50 & 152.76 & 106 & 107 & 147.72 & 148.98 \\
\hline 06 & ALN1D & 151.50 & 152.76 & 107 & 110 & 147.72 & 148.98 \\
\hline 06 & ALN2W & 151.50 & 152.76 & 0 & 7 & 122.52 & 123.78 \\
\hline 06 & ALN2SS & 151.50 & 152.76 & 7 & 8 & 122.52 & 123.78 \\
\hline 06 & ALN2A & 151.50 & 152.76 & 8 & 11 & 122.52 & 123.78 \\
\hline 06 & ALN2B & 151.50 & 152.76 & 11 & 106 & 122.52 & 123.78 \\
\hline 06 & ALN2C & 151.50 & 152.76 & 106 & 107 & 122.52 & 123.78 \\
\hline 06 & ALN2D & 151.50 & 152.76 & 107 & 110 & 122.52 & 123.78 \\
\hline 06 & ALN3W & 155.28 & 156.54 & 0 & 7 & 138.90 & 141.42 \\
\hline 06 & ALN3SS & 155.28 & 156.54 & 7 & 8 & 138.90 & 141.42 \\
\hline 06 & ALN3A & 155.28 & 156.54 & 8 & 11 & 138.90 & 141.42 \\
\hline 06 & ALN3B & 155.28 & 156.54 & 11 & 106 & 138.90 & 141.42 \\
\hline 06 & ALN3C & 155.28 & 156.54 & 106 & 107 & 138.90 & 141.42 \\
\hline 06 & ALN3D & 155.28 & 156.54 & 107 & 110 & 138.90 & 141.42 \\
\hline 06 & ALN4W & 155.28 & 156.54 & 0 & 7 & 130.08 & 132.60 \\
\hline 06 & ALN4SS & 155.28 & 156.54 & 7 & 8 & 130.08 & 132.60 \\
\hline 06 & ALN4A & 155.28 & 156.54 & 8 & 11 & 130.08 & 132.60 \\
\hline 06 & ALN4B & 155.28 & 156.54 & 11 & 106 & 130.08 & 132.60 \\
\hline 06 & ALN4 C & 155.28 & 156.54 & 106 & 107 & 130.08 & 132.60 \\
\hline 06 & ALN4D & 155.28 & 156.54 & 107 & 110 & 130.08 & 132.60 \\
\hline 06 & ALS1W & 118.74 & 120.00 & 0 & 7 & 122.52 & 123.78 \\
\hline 06 & ALS1SS & 118.74 & 120.00 & 7 & 8 & 122.52 & 123.78 \\
\hline 06 & ALS1A & 118.74 & 120.00 & 8 & 11 & 122.52 & 123.78 \\
\hline 06 & ALS1B & 118.74 & 120.00 & 11 & 106 & 122.52 & 123.78 \\
\hline 06 & ALS1C & 118.74 & 120.00 & 106 & 107 & 122.52 & 123.78 \\
\hline 06 & ALS1D & 118.74 & 120.00 & 107 & 110 & 122.52 & 123.78 \\
\hline 06 & ALS2W & 118.74 & 120.00 & 0 & 7 & 147.72 & 148.98 \\
\hline 06 & ALS2SS & 118.74 & 120.00 & 7 & 8 & 147.72 & 148.98 \\
\hline 06 & $\mathrm{ALS} 2 \mathrm{~A}$ & 118.74 & 120.00 & 8 & 11 & 147.72 & 148.98 \\
\hline 06 & ALS2B & 118.74 & 120.00 & 11 & 106 & 147.72 & 148.98 \\
\hline 06 & ALS2C & 118.74 & 120.00 & 106 & 107 & 147.72 & 148.98 \\
\hline 06 & ALS2D & 118.74 & 120.00 & 107 & 110 & 147.72 & 148.98 \\
\hline 06 & ALS3W & 114.96 & 116.22 & 0 & 7 & 130.08 & 132.60 \\
\hline 06 & ALS3SS & 114.96 & 116.22 & 7 & 8 & 130.08 & 132.60 \\
\hline 06 & ALS3A & 114.96 & 116.22 & 8 & 11 & 130.08 & 132.60 \\
\hline 06 & ALS3B & 114.96 & 116.22 & 11 & 106 & 130.08 & 132.60 \\
\hline
\end{tabular}




\begin{tabular}{|c|c|c|c|c|c|c|c|}
\hline 06 & ALS3C & 114.96 & 116.22 & 106 & 107 & 130.08 & 132.60 \\
\hline 06 & ALS3D & 114.96 & 116.22 & 107 & 110 & 130.08 & 132.60 \\
\hline 06 & ALS4W & 114.96 & 116.22 & 0 & 7 & 138.90 & 141.42 \\
\hline 06 & ALS4SS & 114.96 & 116.22 & 7 & 8 & 138.90 & 141.42 \\
\hline 06 & ALS4A & 114.96 & 116.22 & 8 & 11 & 138.90 & 141.42 \\
\hline 06 & $\mathrm{ALS} 4 \mathrm{~B}$ & 114.96 & 116.22 & 11 & 106 & 138.90 & 141.42 \\
\hline 06 & ALS4C & 114.96 & 116.22 & 106 & 107 & 138.90 & 141.42 \\
\hline 06 & ALS4D & 114.96 & 116.22 & 107 & 110 & 138.90 & 141.42 \\
\hline 06 & ALE1W & 147.72 & 148.98 & 0 & 7 & 118.74 & 120.00 \\
\hline 06 & ALEISS & 147.72 & 148.98 & 7 & 8 & 118.74 & 120.00 \\
\hline 06 & ALEIA & 147.72 & 148.98 & 8 & 11 & 118.74 & 120.00 \\
\hline 06 & ALE1B & 147.72 & 148.98 & 11 & 106 & 118.74 & 120.00 \\
\hline 06 & ALE1C & 147.72 & 148.98 & 106 & 107 & 118.74 & 120.00 \\
\hline 06 & ALE1D & 147.72 & 148.98 & 107 & 110 & 118.74 & 120.00 \\
\hline 06 & ALE2W & 122.52 & 123.78 & 0 & 7 & 118.74 & 120.00 \\
\hline 06 & ALE2SS & 122.52 & 123.78 & 7 & 8 & 118.74 & 120.00 \\
\hline 06 & ALE2A & 122.52 & 123.78 & 8 & 11 & 118.74 & 120.00 \\
\hline 06 & ALE2B & 122.52 & 123.78 & 11 & 106 & 118.74 & 120.00 \\
\hline 06 & ALE2C & 122.52 & 123.78 & 106 & 107 & 118.74 & 120.00 \\
\hline 06 & ALE2D & 122.52 & 123.78 & 107 & 110 & 118.74 & 120.00 \\
\hline 06 & ALE3W & 138.90 & 141.42 & 0 & 7 & 114.96 & 116.22 \\
\hline 06 & ALE3SS & 138.90 & 141.42 & 7 & 8 & 114.96 & 116.22 \\
\hline 06 & ALE3A & 138.90 & 141.42 & 8 & 11 & 114.96 & 116.22 \\
\hline 06 & ALE3B & 138.90 & 141.42 & 11 & 106 & 114.96 & 116.22 \\
\hline 06 & ALE3C & 138.90 & 141.42 & 106 & 107 & 114.96 & 116.22 \\
\hline 06 & ALE3D & 138.90 & 141.42 & 107 & 110 & 114.96 & 116.22 \\
\hline 06 & ALE4W & 130.08 & 132.60 & 0 & 7 & 114.96 & 116.22 \\
\hline 06 & ALE4SS & 130.08 & 132.60 & 7 & 8 & 114.96 & 116.22 \\
\hline 06 & ALE4A & 130.08 & 132.60 & 8 & 11 & 114.96 & 116.22 \\
\hline 06 & ALE4B & 130.08 & 132.60 & 11 & 106 & 114.96 & 116.22 \\
\hline 06 & $\mathrm{ALE} 4 \mathrm{C}$ & 130.08 & 132.60 & 106 & 107 & 114.96 & 116.22 \\
\hline 06 & ALE4D & 130.08 & 132.60 & 107 & 110 & 114.96 & 116.22 \\
\hline 06 & $A L W 1 W$ & 122.52 & 123.78 & 0 & 7 & 151.50 & 152.76 \\
\hline 06 & ALWISS & 122.52 & 123.78 & 7 & 8 & 151.50 & 152.76 \\
\hline 06 & ALWIA & 122.52 & 123.78 & 8 & 11 & 151.50 & 152.76 \\
\hline 06 & ALW1B & 122.52 & 123.78 & 11 & 106 & 151.50 & 152.76 \\
\hline 06 & $\mathrm{ALW} 1 \mathrm{C}$ & 122.52 & 123.78 & 106 & 107 & 151.50 & 152.76 \\
\hline 06 & ALW1D & 122.52 & 123.78 & 107 & 110 & 151.50 & 152.76 \\
\hline 06 & ALW2W & 147.72 & 148.98 & 0 & 7 & 151.50 & 152.76 \\
\hline 06 & ALW2SS & 147.72 & 148.98 & 7 & 8 & 151.50 & 152.76 \\
\hline 06 & ALW2A & 147.72 & 148.98 & 8 & 11 & 151.50 & 152.76 \\
\hline 06 & ALW2B & 147.72 & 148.98 & 11 & 106 & 151.50 & 152.76 \\
\hline 06 & ALW2C & 147.72 & 148.98 & 106 & 107 & 151.50 & 152.76 \\
\hline 06 & ALW2D & 147.72 & 148.98 & 107 & 110 & 151.50 & 152.76 \\
\hline 06 & ALW3W & 130.08 & 132.60 & 0 & 7 & 155.28 & 156.54 \\
\hline 06 & ALW3SS & 130.08 & 132.60 & 7 & 8 & 155.28 & 156.54 \\
\hline 06 & ALW3A & 130.08 & 132.60 & 8 & 11 & 155.28 & 156.54 \\
\hline 06 & ALW3B & 130.08 & 132.60 & 11 & 106 & 155.28 & 156.54 \\
\hline 06 & ALW3C & 130.08 & 132.60 & 106 & 107 & 155.28 & 156.54 \\
\hline 06 & ALW3D & 130.08 & 132.60 & 107 & 110 & 155.28 & 156.54 \\
\hline 06 & ALW4W & 138.90 & 141.42 & 0 & 7 & 155.28 & 156.54 \\
\hline 06 & ALW4SS & 138.90 & 141.42 & 7 & 8 & 155.28 & 156.54 \\
\hline 06 & ALW4A & 138.90 & 141.42 & 8 & 11 & 155.28 & 156.54 \\
\hline 06 & ALW4 B & 138.90 & 141.42 & 11 & 106 & 155.28 & 156.54 \\
\hline 06 & ALW4C & 138.90 & 141.42 & 106 & 107 & 155.28 & 156.54 \\
\hline \multirow[t]{2}{*}{06} & ALW4D & 138.90 & 141.42 & 107 & 110 & 155.28 & 156.54 \\
\hline & \multicolumn{6}{|c|}{$\begin{array}{l}\text {----RIUO2 CENTRAL CHANNEL } \\
---- \text { OSCILLATION TUBE (UP) }\end{array}$} & \\
\hline 06 & ORW & 135.12 & 136.38 & 0 & 10 & 135.12 & 136.38 \\
\hline 06 & ORB & 135.12 & 136.38 & 10 & 16 & 135.12 & 136.38 \\
\hline 06 & ORL & 135.12 & 136.38 & 16 & 51 & 135.12 & 136.38 \\
\hline 06 & ORSAM & 135.12 & 136.38 & 51 & 61 & 135.12 & 136.38 \\
\hline \multirow{2}{*}{$\begin{array}{l}06 \\
06\end{array}$} & ORU & 135.12 & 136.38 & 61 & 116 & 135.12 & 136.38 \\
\hline & $----\mathrm{E}$ & OVERCL & & & & & \\
\hline 06 & POLW & 135.1 & 136.38 & 0 & 11 & 135.12 & 136.38 \\
\hline 06 & POLC & 135.1 & 136.38 & 11 & 116 & 135.12 & 136.38 \\
\hline
\end{tabular}




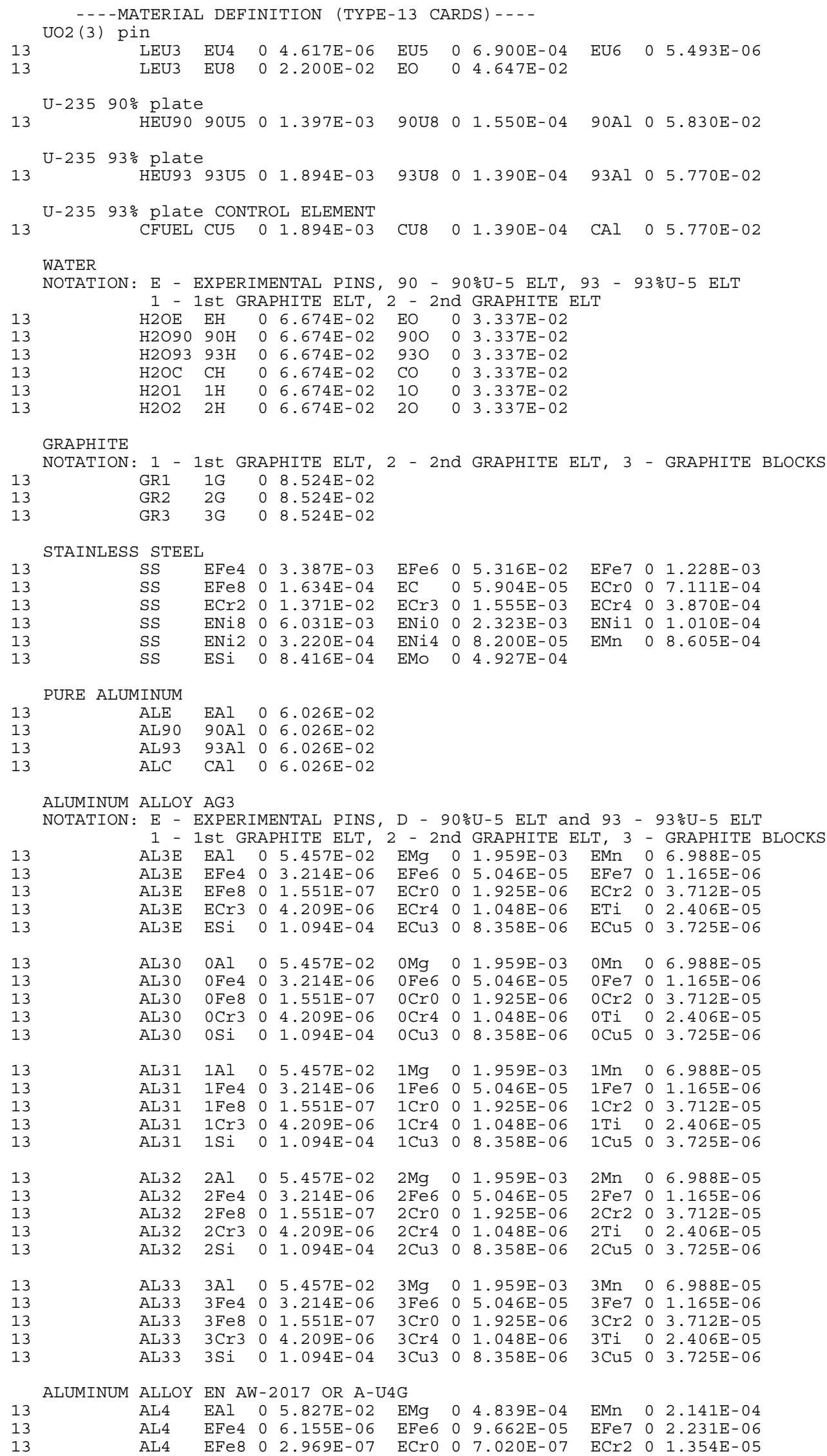




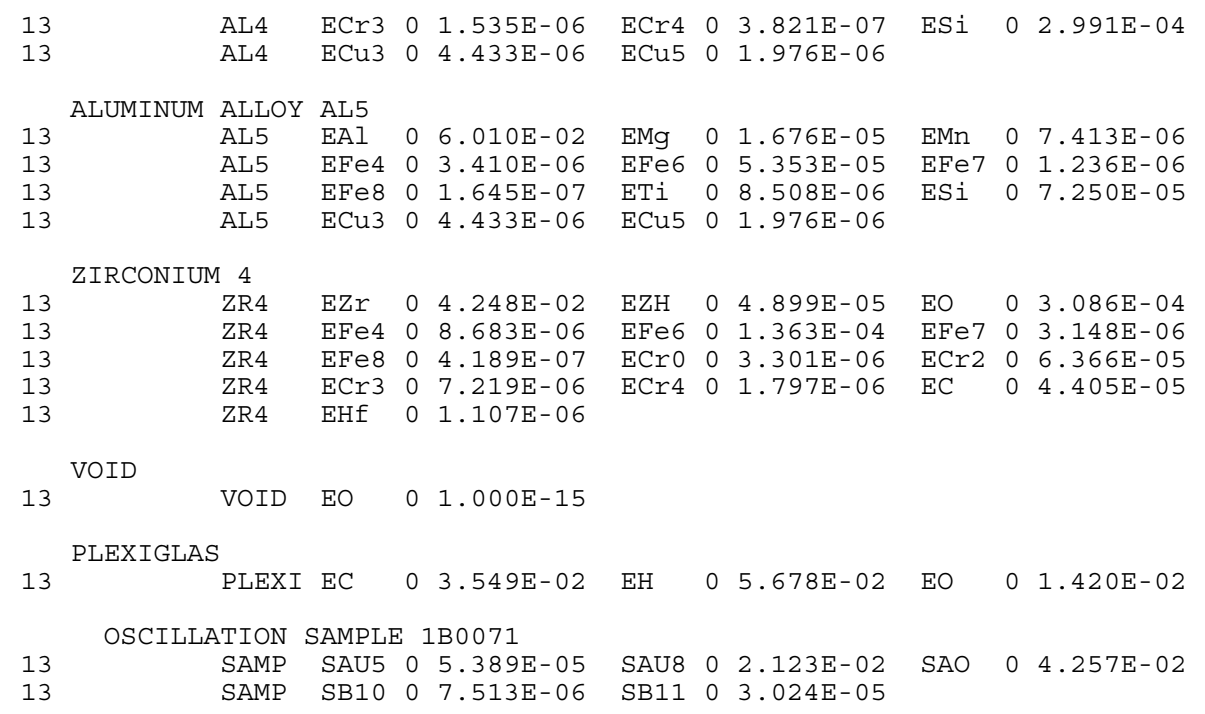




\begin{tabular}{|c|c|c|c|c|c|c|c|c|c|}
\hline 14 & & GAL09 & GR1 & 0.363 & & AL90 & 0.1560 & $\mathrm{H} 2090$ & 0.3384 \\
\hline 14 & & GAL09 & AL30 & 0.142 & & & & & \\
\hline 14 & & ALCRUE & PALC & 0.277 & & $\mathrm{H} 2 \mathrm{OC}$ & 0.6182 & AL30 & 0.1046 \\
\hline 14 & & ALWM1 & $\mathrm{H} 2 \mathrm{OE}$ & 0.653 & & AL3E & 0.0658 & ALWT & 0.2806 \\
\hline 14 & & ALWM2 & $\mathrm{H} 2 \mathrm{OE}$ & 0.687 & & AL3E & 0.3125 & & \\
\hline 14 & & SSWM1 & $\mathrm{H} 2 \mathrm{OE}$ & 0.138 & & SS & 0.8617 & & \\
\hline 14 & & ALWC1 & $\mathrm{H} 2 \mathrm{OE}$ & 0.777 & & AL 3E & 0.2224 & & \\
\hline 14 & & ALWC2 & $\mathrm{H} 2 \mathrm{OE}$ & 0.020 & & $\mathrm{AL} 3 \mathrm{E}$ & 0.9796 & & \\
\hline 14 & & ALWC3 & $\mathrm{H} 2 \mathrm{OE}$ & 0.303 & & $A L 3 E$ & 0.6961 & & \\
\hline 14 & & ALWC4 & $\mathrm{H} 2 \mathrm{OE}$ & 0.689 & & AL 3E & 0.3102 & & \\
\hline 14 & & SSWC1 & $\mathrm{H} 2 \mathrm{OE}$ & 0.145 & & AL 3E & 0.4184 & SS & 0.4365 \\
\hline 14 & & SSWC2 & $\mathrm{H} 2 \mathrm{OE}$ & 0.303 & & AL $3 E$ & 0.1348 & SS & 0.5613 \\
\hline 14 & & F1PPG & PLEXI & 0.300 & & VOID & 0.0317 & ZR4 & 0.1045 \\
\hline 14 & & F1PPG & $\mathrm{AL} 3 \mathrm{E}$ & 0.133 & & $\mathrm{H} 2 \mathrm{OE}$ & 0.4298 & & \\
\hline 14 & & F1LPG & SS & 0.113 & & VOID & 0.0119 & ZR4 & 0.0393 \\
\hline 14 & & F1LPG & ZRW & 0.117 & & AL3E & 0.4839 & $\mathrm{H} 2 \mathrm{OE}$ & 0.2342 \\
\hline 14 & & F1UPG & SS & 0.150 & & VOID & 0.0158 & ZR4 & 0.0523 \\
\hline 14 & & F1UPG & ZRSS & 0.218 & & AL3E & 0.4007 & $\mathrm{H} 2 \mathrm{OE}$ & 0.1622 \\
\hline 14 & & F1UP & SSW & 0.058 & & $A L 3 E$ & 0.3125 & $\mathrm{H} 2 \mathrm{OE}$ & 0.6295 \\
\hline 14 & & SUO2 & LEU3 & 0.320 & & VOID & 0.0123 & $\mathrm{ZR} 4$ & 0.1045 \\
\hline 14 & & SUO2 & $\mathrm{AL} 3 \mathrm{E}$ & 0.133 & & $\mathrm{H} 2 \mathrm{OE}$ & 0.4298 & & \\
\hline 14 & & UO2 & SUO2 & 1.00 & & & & & \\
\hline 14 & & ALWP1 & $\mathrm{H} 2 \mathrm{OE}$ & 0.034 & & $A L 3 E$ & 0.9654 & & \\
\hline 14 & & ALWP2 & $\mathrm{H} 2 \mathrm{OE}$ & 0.550 & & $\mathrm{AL} 3 \mathrm{E}$ & 0.4497 & & \\
\hline 14 & & ALWP 3 & $\mathrm{H} 2 \mathrm{OE}$ & 0.148 & & $\mathrm{AL} 3 \mathrm{E}$ & 0.8511 & & \\
\hline 14 & & ALWP4 & $\mathrm{H} 2 \mathrm{OE}$ & 0.644 & & AL3E & 0.3555 & & \\
\hline 14 & & ASWO1 & $\mathrm{H} 2 \mathrm{OE}$ & 0.490 & & AL $3 E$ & 0.3615 & SS & 0.1479 \\
\hline 14 & & ASWO2 & $\mathrm{H} 2 \mathrm{OE}$ & 0.330 & & AL 3E & 0.5559 & SS & 0.1138 \\
\hline 14 & & SAMPL & SAMP & 0.312 & & $\mathrm{H} 2 \mathrm{OE}$ & 0.3304 & SS & 0.1138 \\
\hline 14 & & SAMPL & ZR4 & 0.158 & & VOID & 0.0849 & & \\
\hline 14 & & POLC & CLDH2O & 0.4 & 4336 & $\mathrm{AL} 4 \mathrm{E}$ & 0.1199 & VOID & 0.4465 \\
\hline & $---\mathrm{A} S$ & SIGN & COMPOS I & ITIONS & TO REC & GIONS (T & TYPE-15 C & CARDS ) - - - - & \\
\hline & $\begin{array}{l}----\mathrm{DF} \\
----\mathrm{GF}\end{array}$ & $\begin{array}{l}\text { RIVER } \\
\text { INERAL }\end{array}$ & $\mathrm{ZONE}--$ & & & & & & \\
\hline 15 & WATER & TANK & & & & & & & \\
\hline 15 & ALW1 & TABLE & & & & & & & \\
\hline 15 & ALW2 & NCAIS & SCAIS & ECAIS & WCAIS & & & & \\
\hline 15 & A5 & NGRID & SGRID & EGRID & WGRID & & & & \\
\hline & $----\mathrm{GF}$ & RAPHITE & E BLOCK & $K S----$ & & & & & \\
\hline 15 & ALW2 & NLGC & SLGC & ELGC & WLGC & & & & \\
\hline 15 & GAL1 & NLGB & SLGB & ELGB & WLGB & & & & \\
\hline 15 & GAL2 & NMGB & SMGB & EMGB & WMGB & & & & \\
\hline 15 & GAL3 & NSGB & SSGB & & & & & & \\
\hline & $----G F$ & RAPHITE & E ELEME & ENTS - - - & & & & & \\
\hline 15 & GFOOT & NGOAL & SGOAL & EGOAL & WGOAL & & & & \\
\hline 15 & GFOOT & NG1AL & SG1AL & EG1AL & WG1AL & & & & \\
\hline 15 & GFOOT & NG2AL & SG2AL & EG2AL & WG2AL & & & & \\
\hline 15 & GELT1 & NGOG & SGOG & EGOG & WGOG & & & & \\
\hline 15 & GELT1 & NG1G & SG1G & EG1G & WG1G & & & & \\
\hline 15 & GELT2 & $\mathrm{NG} 2 \mathrm{G}$ & SG2G & EG2G & WG2G & & & & \\
\hline 15 & GCLAD & NGOAU & SGOAU & EGOAU & WGOAU & & & & \\
\hline 15 & GCLAD & NG1AU & SG1AU & EG1AU & WGIAU & & & & \\
\hline 15 & GCLAD & NG2AU & SG2AU & EG2AU & WG2AU & & & & \\
\hline & $----\mathrm{FL}$ & JEL ELE & EMENTS - & --- & & & & & \\
\hline &.---1 & $\angle 8-\mathrm{PLAT}$ & TE $90 \%$ & $U-235$ & FUEL & ELEMENT & & & \\
\hline 15 & FFOOT & No1B & No2B & N06B & N07B & & & & \\
\hline 15 & ALW90 & N01AL & No2AL & N06AL & N07AL & & & & \\
\hline 15 & D9018 & N01F & $\mathrm{N} 02 \mathrm{~F}$ & $\mathrm{~N} 06 \mathrm{~F}$ & N07F & & & & \\
\hline 15 & ALW90 & N01AU & No $2 A U$ & N06AU & N07AU & & & & \\
\hline 15 & WATER & N01WU & No2WU & N0 $6 \mathrm{WU}$ & N07WU & & & & \\
\hline 15 & FFOOT & S01B & S02B & S03B & S07B & & & & \\
\hline 15 & ALW9 0 & S01AL & S02AL & S03AL & SO7AL & & & & \\
\hline 15 & D9018 & S01F & S02F & $\mathrm{S} 03 \mathrm{~F}$ & S07F & & & & \\
\hline 15 & ALW90 & S01AU & S02AU & S03AU & S07AU & & & & \\
\hline 15 & WATER & S01WU & So2WU & S03WU & S07WU & & & & \\
\hline 15 & FFOOT & $\mathrm{E} 01 \mathrm{~B}$ & E02B & $\mathrm{E} 06 \mathrm{~B}$ & E07B & & & & \\
\hline 15 & ALW90 & E01AL & E02AL & $\mathrm{E} 06 \mathrm{AL}$ & E07AL & & & & \\
\hline 15 & D9018 & $\mathrm{E} 01 \mathrm{~F}$ & $\mathrm{E} 02 \mathrm{~F}$ & $\mathrm{E} 06 \mathrm{~F}$ & $\mathrm{E} 07 \mathrm{~F}$ & & & & \\
\hline 15 & ALW90 & E01AU & E02AU & E06AU & E07AU & & & & \\
\hline 15 & WATER & E01WU & E02WU & E06WU & E07WU & & & & \\
\hline 15 & FFOOT & W01B & W02B & W0 $6 \mathrm{~B}$ & W07B & & & & \\
\hline 15 & ALW90 & W01AL & W02AL & W06AL & W07AL & & & & \\
\hline 15 & D9018 & W01F & W02F & W06F & W07F & & & & \\
\hline
\end{tabular}


15 ALW90 W01AU W02AU W06AU W07AU

-.- 18-PLATE 93\% U-235 FUEL ELEMENT

FFOOT N03B N05B N08B

ALW93 N03AL N05AL N08AL

D9318 N03F N05F N08F

ALW93 N03AU N05AU N08AU

WATER N03WU N05WU N08WU

FFOOT S04B S06B S08B

ALW93 S04AL S06AL S08AL

D9318 S04F S06F S08F

ALW93 S04AU S06AU S08AU

WATER S04WU S06WU SO8WU

FFOOT E03B E05B E09B

ALW93 E03AL E05AL E09AL

D9318 E03F E05F E09F

ALW93 E03AU E05AU E09AU

WATER E03WU E05WU E09WU

FFOOT W03B W05B W09B

ALW93 W03AL W05AL W09AL

D9318 W03F W05F W09F

ALW93 W03AU W05AU W09AU

WATER W03WU W05WU WO9WU

-..- 9-PLATE 90\% U-235 FUEL ELEMENT

FFOOT N09B S09B

GAL09 N09AL SO9AL

D9009 N09F S09F

G9009 N09GR S09GR

GAL09 N09AU S09AU

WATER NO9WU SO9WU

- . - 12 -PLATE 90\% U-235 FUEL ELEMENT

FFOOT E08B W08B

GAL12 E08AL W08AL

D9012 E08F W08F

G9012 E08GR W08GR

GAL12 E08AU W08AU

WATER E08WU W08WU

- . - CONTROL ELEMENT - ROD UP

FFOOT N04B S05B E04B W04B

ALCRUPN04AL S05AL E04AL W04AL

DCRUP N04F S05F E04F W04F

ALCRUPN04AU S05AU EO4AU W04AU

WATER NO4WU SO5WU EO4WU WO4WU

-.--EXPERIMENTAL ZONE-..

- - - GENERAL- - -

15 WATER EZONE

15 AG3 WEDGE

- - - ANGLE GRAPHITE ELEMENTS - - -

GFOOT G1AL G2AL G3AL G4AL

GCLAD G1AU G2AU G3AU G4AU

GELT2 G1G G2G G3G G4G

- - - ALUMINUM MASSIF--.-

ALWM1 ALBA

SSWM1 ALBB

AG3 ALBC

SS1 ALBD

ALWM2 ALBE

----CHIMNEY PIECES---

ALW1 CHI1T CHI2T CHI3T CHI4T CHI5T CHI6T CHI7T CHI8T

ALWC1 CHI1A CHI2A CHI3A CHI4A CHI5A CHI6A CHI7A CHI8A

SSWC1 CHI1B CHI2B CHI3B CHI4B CHI5B CHI6B CHI7B CHI8B

ALWC2 CHI1C CHI2C CHI3C CHI4C CHI5C CHI6C CHI7C CHI8C

ALWC3 CHI1D CHI2D CHI3D CHI4D CHI5D CHI6D CHI7D CHI8D

SSWC2 CHI1E CHI2E CHI3E CHI4E CHI5E CHI6E CHI7E CHI8E

ALWC4 CHIIF CHI2F CHI3F CHI4F CHI5F CHI6F CHI7F CHI8F

----UO2 FUEL PINS----

WATER F1CW F1N1W F1N2W F1S1W F1S2W F1E1W F1E2W F1W1W F1W2W

SS1 F1CSS F1N1SSF1N2SSF1S1SSF1S2SSF1E1SSF1E2SSF1W1SSF1W2SS

F1LPG F1CA F1N1A F1N2A F1S1A F1S2A F1E1A F1E2A F1W1A F1W2A

F1PPG F1CB F1N1B F1N2B F1S1B F1S2B F1E1B F1E2B F1W1B F1W2B 
UO2 F1CC F1N1C F1N2C F1S1C F1S2C F1E1C F1E2C F1W1C F1W2C F1PPG F1CD F1N1D F1N2D F1S1D F1S2D F1E1D F1E2D F1W1D F1W2D F1UPG F1CE F1N1E F1N2E F1S1E F1S2E F1E1E F1E2E F1W1E F1W2E F1UP F1CF F1N1F F1N2F F1S1F F1S2F F1E1F F1E2F F1W1F F1W2F

- - -AL PINS- - -

WATER ALN1W ALN2W ALN3W ALN4W ALS1W ALS2W ALS3W ALS4W

WATER ALE1W ALE2W ALE3W ALE4W ALW1W ALW2W ALW3W ALW4W

SS1 ALN1SSALN2 SSALN3SSALN4SSALS1SSALS2 SSALS3SSALS4SS

SS1 ALE1SSALE2SSALE3SSALE4 SSALW1SSALW2 SSALW3 SSALW4 SS

ALWP1 ALN1A ALN2A ALN3A ALN4A ALS1A ALS2A ALS3A ALS4A

ALWP1 ALE1A ALE2A ALE3A ALE4A ALW1A ALW2A ALW3A ALW4A

ALWP2 ALN1B ALN2B ALN3B ALN4B ALS1B ALS2B ALS3B ALS4B

ALWP2 ALE1B ALE2B ALE3B ALE4B ALW1B ALW2B ALW3B ALW4B

ALWP3 ALN1C ALN2C ALN3C ALN4C ALS1C ALS2C ALS3C ALS4C

ALWP3 ALE1C ALE2C ALE3C ALE4C ALW1C ALW2C ALW3C ALW4C

ALWP4 ALN1D ALN2D ALN3D ALN4D ALS1D ALS2D ALS3D ALS4D

ALWP4 ALE1D ALE2D ALE3D ALE4D ALW1D ALW2D ALW3D ALW4D

- - - CENTRAL CHANNEL- - -

- --OSCILLATION TUBE (UP)

WATER ORW

ASWO1 ORB

ASWO2 ORL

SAMPL ORSAM

--- POLINE OVERCLAD

15 WATER POLW

15 POLCLDPOLC

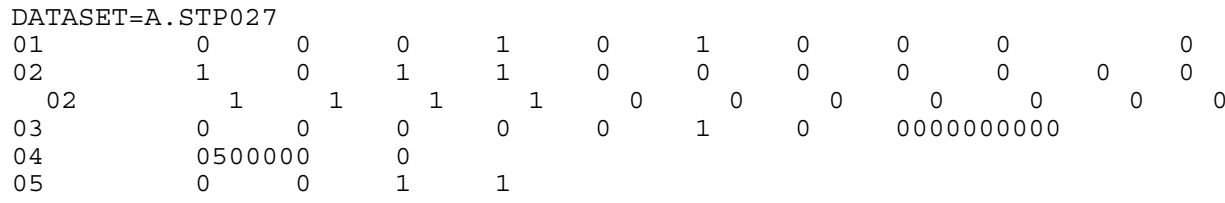




\section{File MOXI}

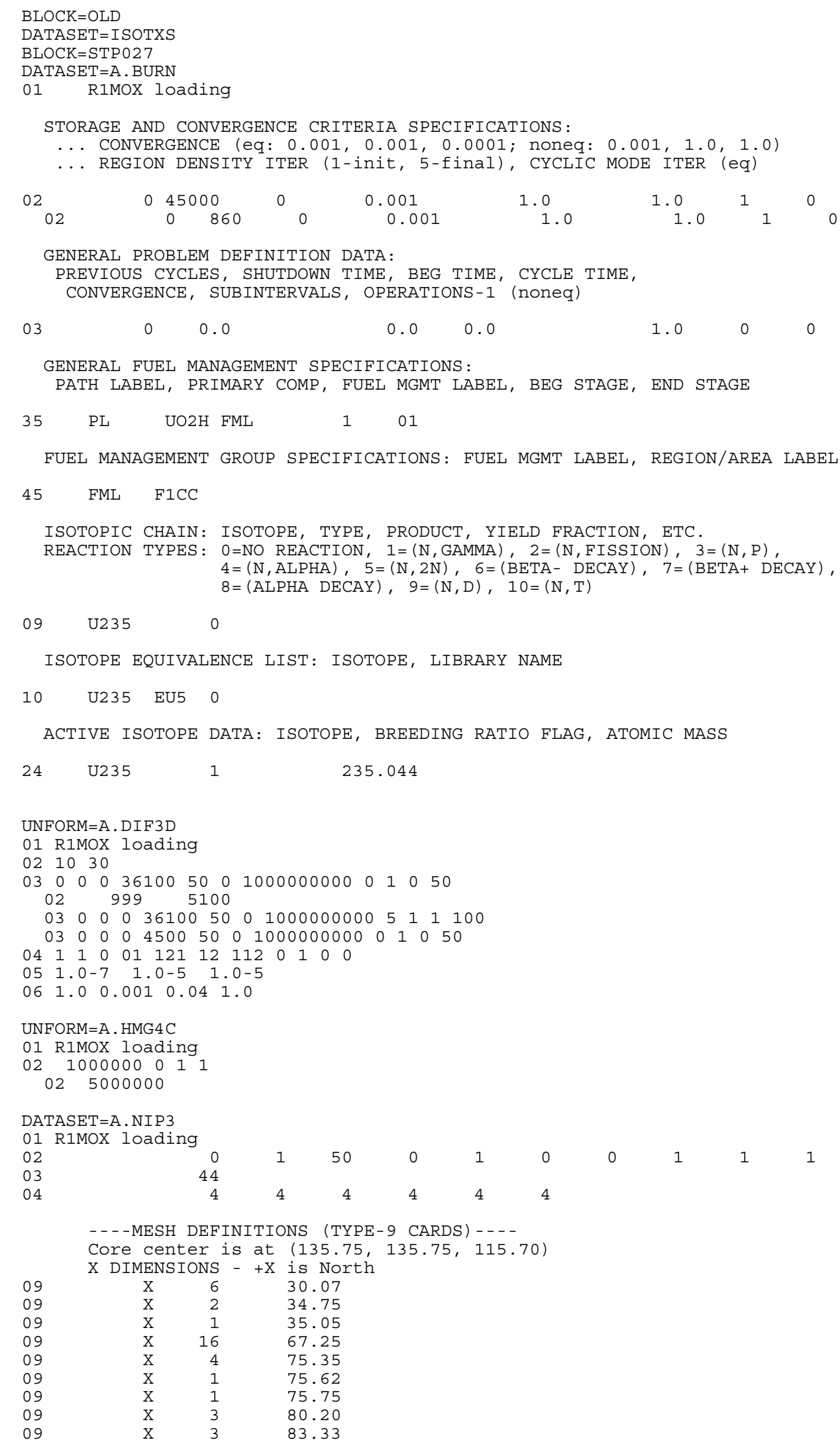




$\begin{array}{llll}09 & \mathrm{X} & 1 & 83.65 \\ 09 & \mathrm{X} & 8 & 91.04 \\ 09 & \mathrm{X} & 1 & 91.75 \\ 09 & \mathrm{X} & 8 & 98.75 \\ 09 & \mathrm{X} & 1 & 99.85 \\ 09 & \mathrm{X} & 7 & 106.46 \\ 09 & \mathrm{X} & 1 & 106.85 \\ 09 & \mathrm{X} & 1 & 107.95 \\ 09 & \mathrm{X} & 8 & 114.95 \\ 09 & \mathrm{X} & 1 & 114.96 \\ 09 & \mathrm{X} & 1 & 116.05 \\ 09 & \mathrm{X} & 1 & 116.22 \\ 09 & \mathrm{X} & 1 & 117.48 \\ 09 & \mathrm{X} & 1 & 118.74 \\ 09 & \mathrm{X} & 1 & 120.00 \\ 09 & \mathrm{X} & 1 & 121.26 \\ 09 & \mathrm{X} & 1 & 122.52 \\ 09 & \mathrm{X} & 1 & 123.05 \\ 09 & \mathrm{X} & 1 & 123.78 \\ 09 & \mathrm{X} & 1 & 124.15 \\ 09 & \mathrm{X} & 1 & 125.04\end{array}$

Add-on for the east 12 plate

$\begin{array}{cccc}09 & \mathrm{X} & 1 & 125.75 \\ 09 & \mathrm{X} & 1 & 126.30\end{array}$

Add-on for the west 12 plate $09 \mathrm{X} \quad 1 \quad 126.85$

$\begin{array}{llll}09 & \mathrm{X} & 2 & 127.56 \\ 09 & \mathrm{X} & 3 & 128.82 \\ 09 & \mathrm{X} & 3 & 130.08 \\ 09 & \mathrm{X} & 1 & 131.15 \\ 09 & \mathrm{X} & 1 & 131.34 \\ 09 & \mathrm{X} & 1 & 132.25 \\ 09 & \mathrm{X} & 1 & 132.60 \\ 09 & \mathrm{X} & 1 & 133.86 \\ 09 & \mathrm{X} & 1 & 135.12 \\ 09 & \mathrm{X} & 1 & 136.38 \\ 09 & \mathrm{X} & 1 & 137.64 \\ 09 & \mathrm{X} & 1 & 138.90 \\ 09 & \mathrm{X} & 1 & 139.25 \\ 09 & \mathrm{X} & 1 & 140.16 \\ 09 & \mathrm{X} & 1 & 140.35 \\ 09 & \mathrm{X} & 1 & 141.42 \\ 09 & \mathrm{X} & 3 & 142.68 \\ 09 & & 3 & 143.94\end{array}$

Add-on for the east 12 plate $09 \quad \mathrm{X} \quad 2 \quad 144.65$ $\begin{array}{llll}09 & \mathrm{X} & 1 & 145.20\end{array}$ Add-on for the west 12 plate

$\begin{array}{llll}09 & \mathrm{X} & 1 & 145.75 \\ 09 & \mathrm{X} & 1 & 146.46 \\ 09 & \mathrm{X} & 1 & 147.35 \\ 09 & \mathrm{X} & 1 & 147.72 \\ 09 & \mathrm{X} & 1 & 148.45 \\ 09 & \mathrm{X} & 1 & 148.98 \\ 09 & \mathrm{X} & 1 & 150.24 \\ 09 & \mathrm{X} & 1 & 151.50 \\ 09 & \mathrm{X} & 1 & 152.76 \\ 09 & \mathrm{X} & 1 & 154.02 \\ 09 & \mathrm{X} & 1 & 155.28 \\ 09 & \mathrm{X} & 1 & 155.45 \\ 09 & \mathrm{X} & 1 & 156.54 \\ 09 & \mathrm{X} & 1 & 156.55 \\ 09 & \mathrm{X} & 8 & 163.55 \\ 09 & \mathrm{X} & 1 & 164.65 \\ 09 & \mathrm{X} & 1 & 165.04 \\ 09 & \mathrm{X} & 7 & 171.65 \\ 09 & \mathrm{X} & 1 & 172.75 \\ 09 & \mathrm{X} & 8 & 179.75 \\ 09 & \mathrm{X} & 1 & 180.46 \\ 09 & \mathrm{X} & 8 & 187.85 \\ 09 & \mathrm{X} & 1 & 188.17 \\ 09 & \mathrm{X} & 2 & 191.30 \\ 09 & \mathrm{X} & 2 & 195.75\end{array}$




$\begin{array}{lrrl}09 & \mathrm{X} & 1 & 195.88 \\ 09 & \mathrm{X} & 1 & 196.15 \\ 09 & \mathrm{X} & 16 & 228.65 \\ 09 & \mathrm{X} & 4 & 236.45 \\ 09 & \mathrm{X} & 2 & 241.43 \\ 09 & \mathrm{X} & 6 & 271.50 \\ & & & \\ 09 & \mathrm{DIMENSIONS} & +\mathrm{Y} & \text { is West } \\ 09 & \mathrm{Y} & 6 & 30.07 \\ 09 & \mathrm{Y} & 3 & 35.05 \\ 09 & \mathrm{Y} & 4 & 43.05 \\ 09 & \mathrm{Y} & 16 & 75.55 \\ 09 & \mathrm{Y} & 1 & 75.62 \\ 09 & \mathrm{Y} & 1 & 75.75 \\ 09 & \mathrm{Y} & 3 & 80.20 \\ 09 & \mathrm{Y} & 1 & 80.25 \\ 09 & \mathrm{Y} & 2 & 83.33 \\ 09 & \mathrm{Y} & 1 & 83.65 \\ 09 & \mathrm{Y} & 8 & 91.04 \\ 09 & \mathrm{Y} & 1 & 91.75 \\ 09 & \mathrm{Y} & 8 & 98.75 \\ 09 & \mathrm{Y} & 1 & 99.85 \\ 09 & \mathrm{Y} & 8 & 106.85 \\ 09 & \mathrm{Y} & 1 & 107.95 \\ 09 & \mathrm{Y} & 8 & 114.95 \\ 09 & \mathrm{Y} & 1 & 114.96 \\ 09 & \mathrm{Y} & 1 & 116.05 \\ 09 & \mathrm{Y} & 1 & 116.22 \\ 09 & \mathrm{Y} & 1 & 117.48 \\ & \mathrm{Y} & 1 & 118.74\end{array}$

Add-on for the south 12 plate $09 \mathrm{Y} \quad 1 \quad 118.75$

$\begin{array}{llll}09 & Y & 1 & 120.00 \\ 09 & Y & 1 & 121.26 \\ 09 & Y & 1 & 122.52 \\ 09 & Y & 1 & 123.05 \\ 09 & Y & 1 & 123.78 \\ 09 & Y & 1 & 124.15 \\ 09 & Y & 1 & 125.04 \\ 09 & Y & 1 & 126.30\end{array}$

Add-on for the north 9 plate $\begin{array}{llll}09 & Y & 2 & 127.05\end{array}$

$\begin{array}{llll}09 & Y & 1 & 127.56 \\ 09 & Y & 3 & 128.82 \\ 09 & Y & 3 & 130.08 \\ 09 & Y & 1 & 131.15 \\ 09 & Y & 1 & 131.34 \\ 09 & Y & 1 & 132.25 \\ 09 & Y & 1 & 132.60 \\ 09 & Y & 1 & 133.86 \\ 09 & Y & 1 & 135.12 \\ 09 & Y & 1 & 136.38 \\ 09 & Y & 1 & 137.64\end{array}$

Add-on for the south 12 plate $09 \quad \mathrm{Y} \quad 1 \quad 137.65$

$\begin{array}{llll}09 & Y & 1 & 138.90 \\ 09 & Y & 1 & 139.25 \\ 09 & Y & 1 & 140.16 \\ 09 & Y & 1 & 140.35 \\ 09 & Y & 1 & 141.42 \\ 09 & Y & 3 & 142.68 \\ 09 & Y & 3 & 143.94\end{array}$

Add-on for the north 12 plate

$\begin{array}{llll}09 & Y & 2 & 144.65 \\ 09 & Y & 1 & 145.20 \\ 09 & Y & 1 & 146.46 \\ 09 & Y & 1 & 147.35 \\ 09 & Y & 1 & 147.72 \\ 09 & Y & 1 & 148.45 \\ 09 & Y & 1 & 148.98 \\ 09 & Y & 1 & 150.24 \\ 09 & Y & 1 & 151.50 \\ 09 & Y & 1 & 152.76\end{array}$




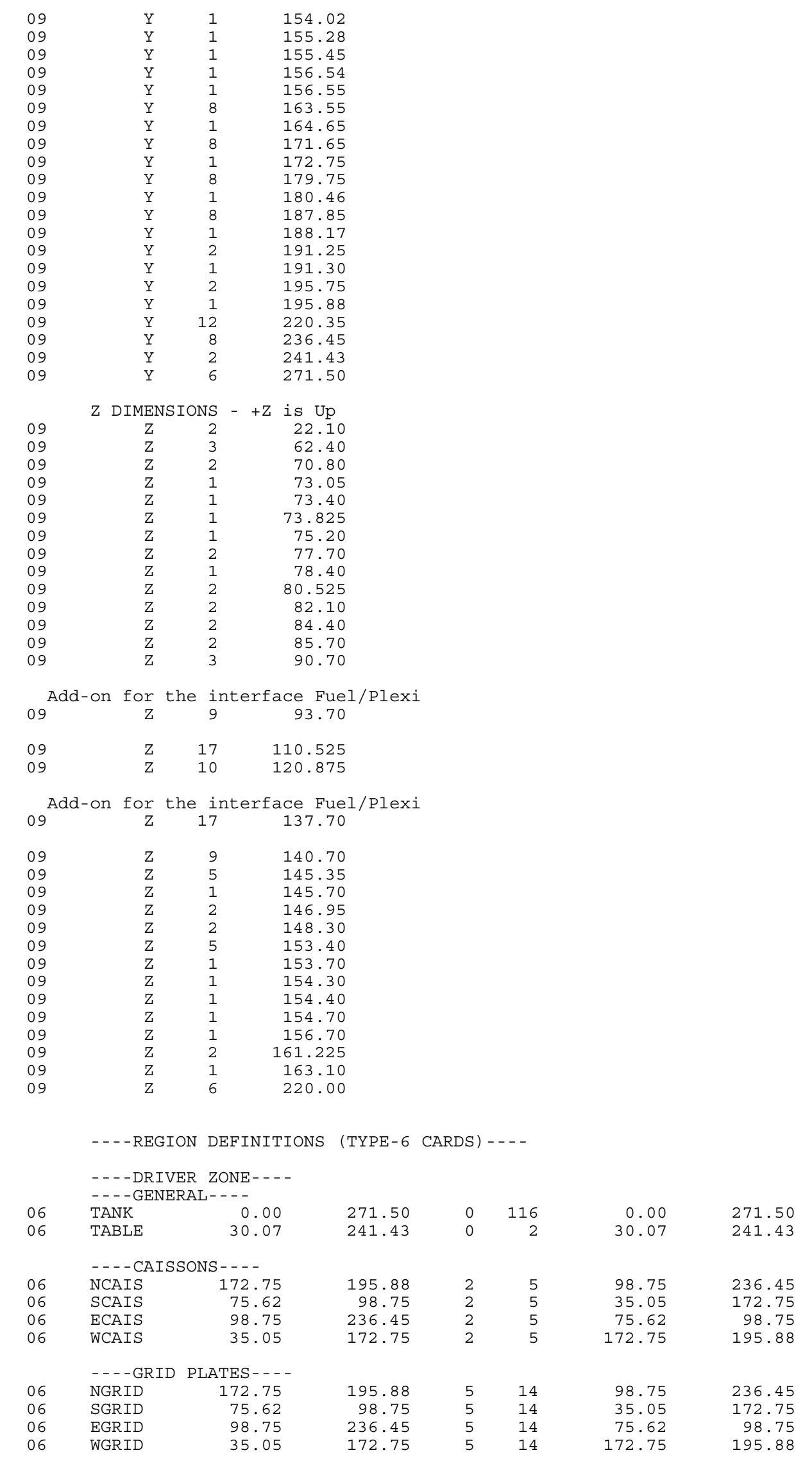


- - LARGE GRAPHITE BLOCKS - - -

-...-NOTATION - NLG NORTH LARGE GRAPHITE

\begin{tabular}{|c|c|c|c|c|c|c|c|}
\hline & ----- & $-\mathrm{C}-\mathrm{C}$ & $\mathrm{N}, \quad \mathrm{B}-\mathrm{BI}$ & & APHI & ALUMINUM & CLAD \\
\hline 06 & NLGC & 195.88 & 241.43 & 2 & 9 & 98.75 & 191.30 \\
\hline 06 & NLGB & 195.88 & 241.43 & 9 & 105 & 98.75 & 191.30 \\
\hline 06 & SLGC & 30.07 & 75.62 & 2 & 9 & 80.20 & 172.75 \\
\hline 06 & SLGB & 30.07 & 75.62 & 9 & 105 & 80.20 & 172.75 \\
\hline 06 & ELGC & 98.75 & 191.30 & 2 & 9 & 30.07 & 75.62 \\
\hline 06 & ELGB & 98.75 & 191.30 & 9 & 105 & 30.07 & 75.62 \\
\hline 06 & WLGC & 80.20 & 172.75 & 2 & 9 & 195.88 & 241.43 \\
\hline 06 & WLGB & 80.20 & 172.75 & 9 & 105 & 195.88 & 241.4 \\
\hline
\end{tabular}

-..-MEDIUM AND SMALL GRAPHITE BLOCKS-..-

----NOTATION - NMG NORTH MEDIUM GRAPHITE, A-AL CLAD, G-GRAPHITE

$\begin{array}{llll}\text { NMGB } & 196.15 & 228.65 & 14\end{array}$

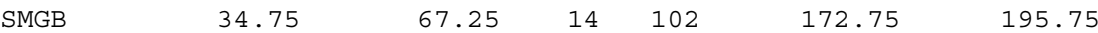

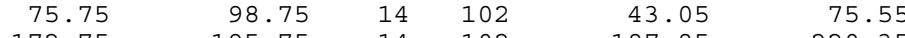

$\begin{array}{lllllll}\text { WMGB } & 172.75 & 195.75 & 14 & 102 & 187.85 & 220.35\end{array}$

$\begin{array}{lllllll}\text { NSGB } & 187.85 & 196.15 & 14 & 102 & 80.25 & 98.75\end{array}$

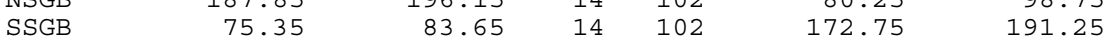

----NORTH REGION OF DRIVER ZONE----

- - -GRAPHITE ELEMENT

---NOTATION NGO NORTH GRAPHITE ZONE O (NEXT TO A FUEL ASSEMBLY)

NGI NORTH GRAPHITE ZONE 1 (NEXT TO A FUEL ASSEMBLY)

-.- NG2 NORTH GRAPHITE ZONE 2 (REST OF THE ZONE)

AL: LOWER AL CLAD, AU: UPPER AL CLAD, G: GRAPHITE

$\begin{array}{lllllll}\text { NG2AL } & 172.75 & 195.88 & 5 & 18 & 98.75 & 187.85\end{array}$

$\begin{array}{llllll}172.75 & 195.88 & 18 & 92 & 98.75 & 187.85\end{array}$

$\begin{array}{lllllll}\text { NG2AU } & 172.75 & 195.88 & 92 & 97 & 98.75 & 187.85\end{array}$

$\begin{array}{lllllll}\text { NGIAL } & 172.75 & 188.17 & 5 & 18 & 98.75 & 171.65\end{array}$

$\begin{array}{lll}188.17 & 18 & 92\end{array}$

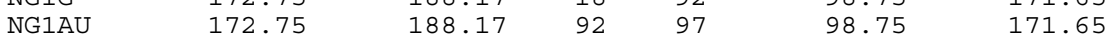

$\begin{array}{lllllll}\text { NGOAL } & 188.17 & 195.88 & 5 & 18 & 123.05 & 147.35\end{array}$

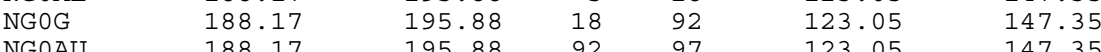

$\begin{array}{lllllll}\text { NGOAU } & 188.17 & 195.88 & 92 & 97 & 123.05 & 147.35\end{array}$

- - - FUEL ELEMENT

---NOTATION NO1 - NORTH 1 OF 10 NUMBERED FROM INNER ROW - LEFT SIDE ---LAST LETTER IS REGION IN Z DIRECTION

---B-BOTTOM, AL-AL CLAD LOWER, F-FUEL, AU-AL CLAD UPPER, WU-WATER UP

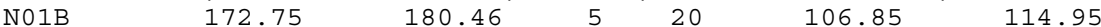

$\begin{array}{lllllll}\text { NOIAL } & 172.75 & 180.46 & 20 & 22 & 106.85 & 114.95\end{array}$

$\begin{array}{lllllll}\text { N01F } & 172.75 & 180.46 & 22 & 93 & 106.85 & 114.95\end{array}$

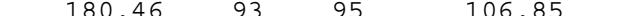

$\begin{array}{lllllll}\text { NOIWU } & 172.75 & 180.46 & 95 & 97 & 106.85 & 114.95\end{array}$

$\begin{array}{lllllll}\text { N02B } & 172.75 & 180.46 & 5 & 20 & 114.95 & 123.05\end{array}$

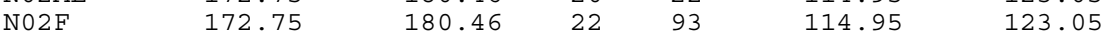

$\begin{array}{lllllll}\text { N02AU } & 172.75 & 180.46 & 93 & 95 & 114.95 & 123.05\end{array}$

$\begin{array}{lllllll}\text { N02WU } & 172.75 & 180.46 & 95 & 97 & 114.95 & 123.05\end{array}$

$\begin{array}{lllllll}\text { N03B } & 172.75 & 180.46 & 5 & 20 & 123.05 & 131.15\end{array}$

$\begin{array}{lllllll}\text { N03AL } & 172.75 & 180.46 & 20 & 22 & 123.05 & 131.15\end{array}$

$\begin{array}{lllllll}\text { N03F } & 172.75 & 180.46 & 22 & 93 & 123.05 & 131.15\end{array}$

$\begin{array}{lllllll}\text { N03AU } & 172.75 & 180.46 & 93 & 95 & 123.05 & 131.15\end{array}$

$\begin{array}{lllllll}\text { N03WU } & 172.75 & 180.46 & 95 & 97 & 123.05 & 131.15\end{array}$

$\begin{array}{lllllll}\text { N04B } & 172.75 & 180.46 & 5 & 20 & 131.15 & 139.25\end{array}$

NO4AL $\quad 172.75 \quad 180.46$

172.75

N04WU $\quad 172.75$

$\begin{array}{llll}22 & 93 & 131.15 & 139.25\end{array}$

$\begin{array}{lllll}180.46 & 93 & 95 & 131.15 & 139.25\end{array}$

$\begin{array}{lllll}180.46 & 95 & 97 & 131.15 & 139.25\end{array}$

$\begin{array}{lll}\text { N05B } & 172.75 & 180.46\end{array}$

N05AL $\quad 172.75$

N05F $\quad 172.75$

N05AU $\quad 172.75$

180.46

180.46

180.46

520

139.25

147.35

N05WU $\quad 172.75$

180.46

$22 \quad 93$

139.25

147.35

147.35

$\begin{array}{ll}139.25 & 147.35 \\ 139.25 & 147.35\end{array}$

$\begin{array}{lll}\text { N06B } & 172.75 & 180.46\end{array}$

N06AL $\quad 172.75 \quad 180.46$

N06F $\quad 172.75$

180.46

$\begin{array}{rr}5 & 20 \\ 20 & 22 \\ 22 & 93\end{array}$

147.35

147.35

155.45

155.45

155.45 


\begin{tabular}{|c|c|c|c|c|c|c|c|}
\hline 06 & N06AU & 172.75 & 180.46 & 93 & 95 & 147.35 & 155.45 \\
\hline 06 & N0 $6 \mathrm{WU}$ & 172.75 & 180.46 & 95 & 97 & 147.35 & 155.45 \\
\hline 06 & N07B & 172.75 & 180.46 & 5 & 20 & 155.45 & 163.55 \\
\hline 06 & N07AL & 172.75 & 180.46 & 20 & 22 & 155.45 & 163.55 \\
\hline 06 & N07F & 172.75 & 180.46 & 22 & 93 & 155.45 & 163.55 \\
\hline 06 & N07AU & 172.75 & 180.46 & 93 & 95 & 155.45 & 163.55 \\
\hline 06 & No7WU & 172.75 & 180.46 & 95 & 97 & 155.45 & 163.55 \\
\hline 06 & N08B & 180.46 & 188.17 & 5 & 20 & 123.05 & 131.15 \\
\hline 06 & N08AL & 180.46 & 188.17 & 20 & 22 & 123.05 & 131.15 \\
\hline 06 & No8F & 180.46 & 188.17 & 22 & 93 & 127.05 & 131.15 \\
\hline 06 & N0 8GR & 180.46 & 188.17 & 22 & 93 & 123.05 & 127.05 \\
\hline 06 & N08AU & 180.46 & 188.17 & 93 & 95 & 123.05 & 131.15 \\
\hline 06 & N08WU & 180.46 & 188.17 & 95 & 97 & 123.05 & 131.15 \\
\hline 06 & N09B & 180.46 & 188.17 & 5 & 20 & 131.15 & 139.25 \\
\hline 06 & N09AL & 180.46 & 188.17 & 20 & 22 & 131.15 & 139.25 \\
\hline 06 & No9F & 180.46 & 188.17 & 22 & 93 & 131.15 & 139.25 \\
\hline 06 & N09AU & 180.46 & 188.17 & 93 & 95 & 131.15 & 139.25 \\
\hline 06 & N09WU & 180.46 & 188.17 & 95 & 97 & 131.15 & 139.25 \\
\hline 06 & $\mathrm{~N} 10 \mathrm{~B}$ & 180.46 & 188.17 & 5 & 20 & 139.25 & 147.35 \\
\hline 06 & N10AL & 180.46 & 188.17 & 20 & 22 & 139.25 & 147.3 \\
\hline 06 & $\mathrm{~N} 10 \mathrm{~F}$ & 180.46 & 188.17 & 22 & 93 & 139.25 & 144.65 \\
\hline 06 & N10GR & 180.46 & 188.17 & 22 & 93 & 144.65 & 147.35 \\
\hline 06 & N10AU & 180.46 & 188.17 & 93 & 95 & 139.25 & 147.35 \\
\hline 06 & N1 0WU & 180.46 & 188.17 & 95 & 97 & 139.25 & 147.35 \\
\hline
\end{tabular}

-.--SOUTH REGION OF DRIVER ZONE-..-

- - - GRAPHITE ELEMENT

-.--NOTATION SGO SOUTH GRAPHITE ZONE 0 (NEXT TO A FUEL ASSEMBLY)

-..- SG1 SOUTH GRAPHITE ZONE 1 (NEXT TO A FUEL ASSEMBLY)

-.-- SG2 SOUTH GRAPHITE ZONE 2 (REST OF THE ZONE)

AL: LOWER AL CLAD, AU: UPPER AL CLAD, G: GRAPHITE

$\begin{array}{lllllll}\text { SG2AL } & 75.62 & 98.75 & 5 & 18 & 75.55 & 172.75\end{array}$

$\begin{array}{lllllll}\text { SG2G } & 75.62 & 98.75 & 18 & 92 & 75.55 & 172.75\end{array}$

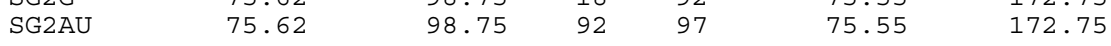

$\begin{array}{lllllll}\text { SG1AL } & 83.33 & 98.75 & 5 & 18 & 99.85 & 172.75\end{array}$

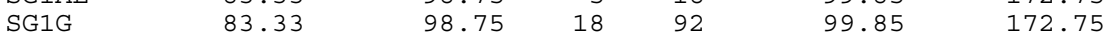

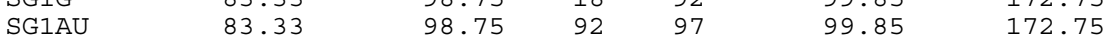

$\begin{array}{lllllll}\text { SGOAL } & 75.62 & 83.33 & 5 & 18 & 116.05 & 140.35\end{array}$

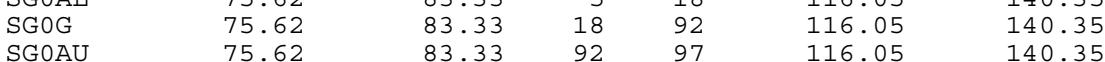

$\begin{array}{lllllll}\text { SGOAU } & 75.62 & 83.33 & 92 & 97 & 116.05 & 140.35\end{array}$

- - - FUEL ELEMENT

---NOTATION SO1 - SOUTH 1 OF 9 NUMBERED FROM INNER ROW - LEFT SIDE ---LAST LETTER IS REGION IN Z DIRECTION

---B-BOTTOM, AL-AL CLAD LOWER, F-FUEL, AU-AL CLAD UPPER, WU-WATER UP

SO1B

S01AL

S01F

SOIAU

91.04

91.04

91.04

S01WU

91.04

98.75

98.75

98.75

98.75

5
20
22

$\mathrm{S} 02 \mathrm{~B}$

S02AL

$\mathrm{S} 02 \mathrm{~F}$

S02AU

91.04

98.75

22
93

156.55

156.55

164.65
164.65

164.65

$156.55 \quad 164.65$

$156.55 \quad 164.65$

S02WU

98.75

91.04

91.04

91.04

91.04

98.75

98.75

98.75

98.75

$5 \quad 20$

148.45

148.45

148.45

148.45

156.55

156.55

156.55

156.55

$148.45 \quad 156.55$

S03B

91.04

98.75

S03AL

91.04

98.75

98.75

S03AU

91.04

91.04

98.75

98.75

5
20

140.35

140.35

148.45

$140.35 \quad 148.45$

S03WU

91.04

S0 $4 B$
S0 $4 A I$

S04F

91.04

98.75

91.04

98.75

98.75

98.75

91.04

98.75

91.04

S05B

S05AL

S05F

S05AU

91.04

91.04

91.04

98.75

98.75

98.75

98.75

93
95

140.35

148.45
148.45

148.45

S05WU

91.04

98.75

5
20
22
93
95

5
20
22
9
95

132.25

132.25

140.35

140.35

140.35

$132.25 \quad 140.35$

132.25

140.35

124.15

$\begin{array}{rll}5 & 20 & 124.15 \\ 20 & 22 & 124.15 \\ 22 & 93 & 124.15\end{array}$

132.25

132.25

132.25

$124.15 \quad 132.25$

$124.15 \quad 132.25$ 


$\begin{array}{llllrlll}06 & \text { S06B } & 91.04 & 98.75 & 5 & 20 & 116.05 & 124.15 \\ 06 & \text { S06AL } & 91.04 & 98.75 & 20 & 22 & 116.05 & 124.15 \\ 06 & \text { S06F } & 91.04 & 98.75 & 22 & 93 & 116.05 & 124.15 \\ 06 & \text { S06AU } & 91.04 & 98.75 & 93 & 95 & 116.05 & 124.15 \\ 06 & \text { S06WU } & 91.04 & 98.75 & 95 & 97 & 116.05 & 124.15 \\ 06 & \text { S07B } & 91.04 & 98.75 & 5 & 20 & 107.95 & 116.05 \\ 06 & \text { S07AL } & 91.04 & 98.75 & 20 & 22 & 107.95 & 116.05 \\ 06 & \text { S07F } & 91.04 & 98.75 & 22 & 93 & 107.95 & 116.05 \\ 06 & \text { S07AU } & 91.04 & 98.75 & 93 & 95 & 107.95 & 116.05 \\ 06 & \text { S07WU } & 91.04 & 98.75 & 95 & 97 & 107.95 & 116.05 \\ & & & & & & & \\ 06 & \text { S08B } & 83.33 & 91.04 & 5 & 20 & 132.25 & 140.35 \\ 06 & \text { S08AL } & 83.33 & 91.04 & 20 & 22 & 132.25 & 140.35 \\ 06 & \text { S08F } & 83.33 & 91.04 & 22 & 93 & 132.25 & 137.65 \\ 06 & \text { S08GR } & 83.33 & 91.04 & 22 & 93 & 137.65 & 140.35 \\ 06 & \text { S08AU } & 83.33 & 91.04 & 93 & 95 & 132.25 & 140.35 \\ 06 & \text { S08WU } & 83.33 & 91.04 & 95 & 97 & 132.25 & 140.35 \\ 06 & \text { S09B } & 83.33 & 91.04 & 5 & 20 & 124.15 & 132.25 \\ 06 & \text { S09AL } & 83.33 & 91.04 & 20 & 22 & 124.15 & 132.25 \\ 06 & \text { S09F } & 83.33 & 91.04 & 22 & 93 & 124.15 & 132.25 \\ 06 & \text { S09AU } & 83.33 & 91.04 & 93 & 95 & 124.15 & 132.25 \\ 06 & \text { S09WU } & 83.33 & 91.04 & 95 & 97 & 124.15 & 132.25 \\ 06 & \text { S10B } & 83.33 & 91.04 & 5 & 20 & 116.05 & 124.15 \\ 06 & \text { S10AL } & 83.33 & 91.04 & 20 & 22 & 116.05 & 124.15 \\ 06 & \text { S10F } & 83.33 & 91.04 & 22 & 93 & 118.75 & 124.15 \\ 06 & \text { S10GR } & 83.33 & 91.04 & 22 & 93 & 116.05 & 118.75 \\ 06 & \text { S10AU } & 83.33 & 91.04 & 93 & 95 & 116.05 & 124.15 \\ 06 & \text { S10WU } & 83.33 & 91.04 & 95 & 97 & 116.05 & 124.15\end{array}$

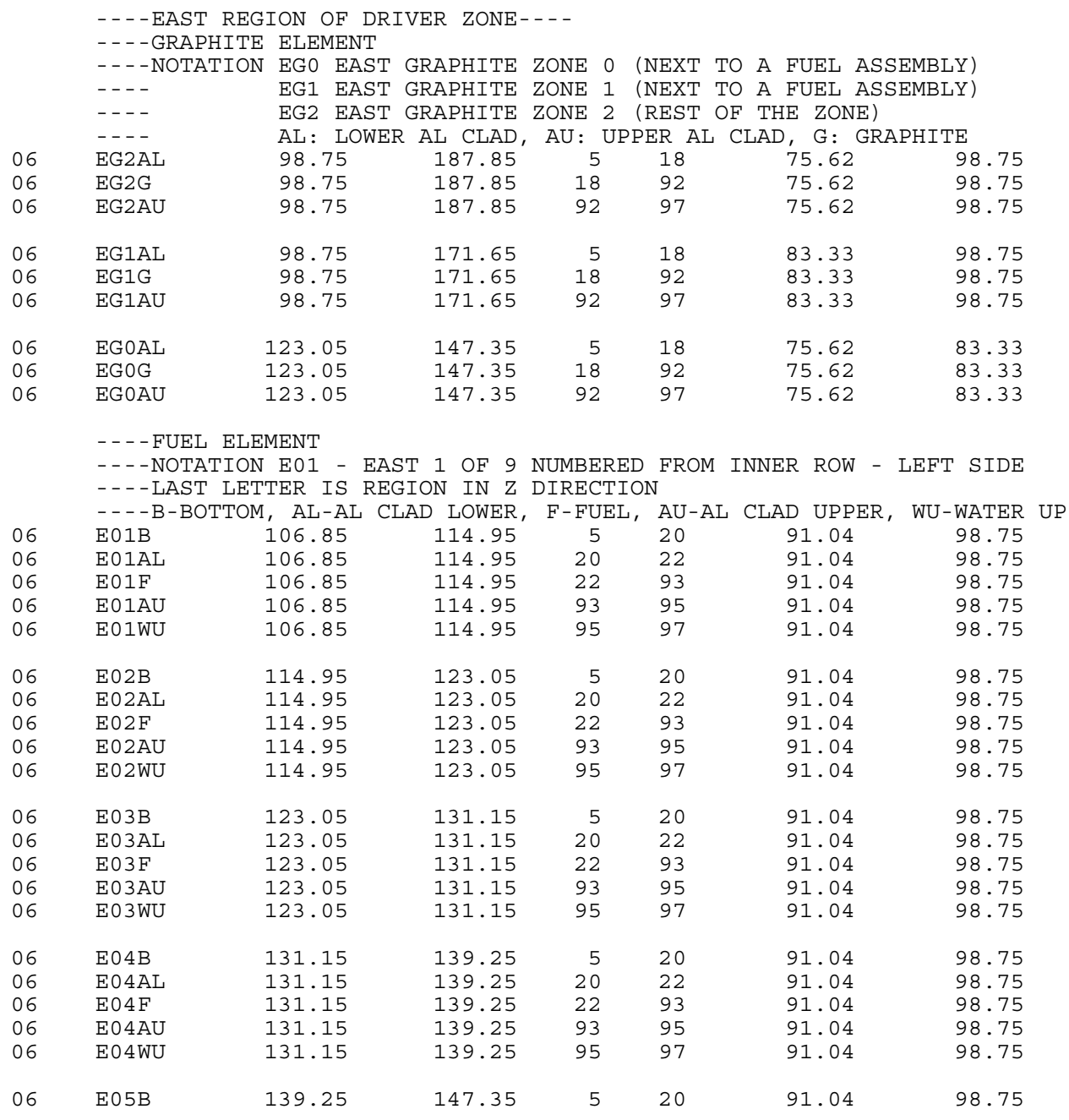




\begin{tabular}{|c|c|c|c|c|c|c|c|}
\hline 06 & E05AL & 139.25 & 147.35 & 20 & 22 & 91.04 & 98.75 \\
\hline 06 & E05F & 139.25 & 147.35 & 22 & 93 & 91.04 & 98.75 \\
\hline 06 & E05AU & 139.25 & 147.35 & 93 & 95 & 91.04 & 98.75 \\
\hline 06 & E05WU & 139.25 & 147.35 & 95 & 97 & 91.04 & 98.75 \\
\hline 06 & E06B & 147.35 & 155.45 & 5 & 20 & 91.04 & 98.75 \\
\hline 06 & E06AL & 147.35 & 155.45 & 20 & 22 & 91.04 & 98.75 \\
\hline 06 & $\mathrm{E} 06 \mathrm{~F}$ & 147.35 & 155.45 & 22 & 93 & 91.04 & 98.75 \\
\hline 06 & E06AU & 147.35 & 155.45 & 93 & 95 & 91.04 & 98.75 \\
\hline 06 & E06WU & 147.35 & 155.45 & 95 & 97 & 91.04 & 98.75 \\
\hline 06 & E07B & 155.45 & 163.55 & 5 & 20 & 91.04 & 98.75 \\
\hline 06 & E07AL & 155.45 & 163.55 & 20 & 22 & 91.04 & 98.75 \\
\hline 06 & E07F & 155.45 & 163.55 & 22 & 93 & 91.04 & 98.75 \\
\hline 06 & E07AU & 155.45 & 163.55 & 93 & 95 & 91.04 & 98.75 \\
\hline 06 & E07WU & 155.45 & 163.55 & 95 & 97 & 91.04 & 98.75 \\
\hline 06 & E08B & 123.05 & 131.15 & 5 & 20 & 83.33 & 91.04 \\
\hline 06 & E08AL & 123.05 & 131.15 & 20 & 22 & 83.33 & 91.04 \\
\hline 06 & E08F & 125.75 & 131.15 & 22 & 93 & 83.33 & 91.04 \\
\hline 06 & E08GR & 123.05 & 125.75 & 22 & 93 & 83.33 & 91.04 \\
\hline 06 & E08AU & 123.05 & 131.15 & 93 & 95 & 83.33 & 91.04 \\
\hline 06 & E08WU & 123.05 & 131.15 & 95 & 97 & 83.33 & 91.04 \\
\hline 06 & E09B & 131.15 & 139.25 & 5 & 20 & 83.33 & 91.04 \\
\hline 06 & E09AL & 131.15 & 139.25 & 20 & 22 & 83.33 & 91.04 \\
\hline 06 & E09F & 131.15 & 139.25 & 22 & 93 & 83.33 & 91.04 \\
\hline 06 & E09AU & 131.15 & 139.25 & 93 & 95 & 83.33 & 91.04 \\
\hline 06 & E09WU & 131.15 & 139.25 & 95 & 97 & 83.33 & 91.04 \\
\hline 06 & E10B & 139.25 & 147.35 & 5 & 20 & 83.33 & 91.04 \\
\hline 06 & E10AL & 139.25 & 147.35 & 20 & 22 & 83.33 & 91.04 \\
\hline 06 & E10F & 139.25 & 144.65 & 22 & 93 & 83.33 & 91.04 \\
\hline 06 & E10GR & 144.65 & 147.35 & 22 & 93 & 83.33 & 91.04 \\
\hline 06 & EIOAU & 139.25 & 147.35 & 93 & 95 & 83.33 & 91.04 \\
\hline 06 & E10WU & 139.25 & 147.35 & 95 & 97 & 83.33 & 91.04 \\
\hline
\end{tabular}

----WEST REGION OF DRIVER ZONE----

----GRAPHITE ELEMENT

---NOTATION WGO WEST GRAPHITE ZONE 0 (NEXT TO A FUEL ASSEMBLY)

WG1 WEST GRAPHITE ZONE 1 (NEXT TO A FUEL ASSEMBLY)

WG2 WEST GRAPHITE ZONE 2 (REST OF THE ZONE)

AL: LOWER AL CLAD, AU: UPPER AL CLAD, G: GRAPHITE

$\begin{array}{lllllll}\text { WG2AL } & 83.65 & 172.75 & 5 & 18 & 172.75 & 195.88\end{array}$

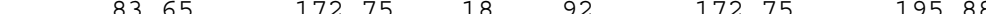

$\begin{array}{lllllll}\text { WG2AU } & 83.65 & 172.75 & 92 & 97 & 172.75 & 195.88\end{array}$

$\begin{array}{lllllll}\text { WGIAL } & 99.85 & 172.75 & 5 & 18 & 172.75 & 188.17\end{array}$

$\begin{array}{lllllll}\text { WG1G } & 99.85 & 172.75 & 18 & 92 & 172.75 & 188.17\end{array}$

$\begin{array}{lllllll}\text { WGIAU } & 99.85 & 172.75 & 92 & 97 & 172.75 & 188.17\end{array}$

$\begin{array}{lllllll}\text { WGOAL } & 124.15 & 148.45 & 5 & 18 & 188.17 & 195.88\end{array}$

$\begin{array}{lllllll}\text { WGOG } & 124.15 & 148.45 & 18 & 92 & 188.17 & 195.88 \\ \text { WGOAU } & 124.15 & 148.45 & 92 & 97 & 188.17 & 195.88\end{array}$

- --FUEL ELEMENT

---NOTATION WO1 - WEST 1 OF 9 NUMBERED FROM INNER ROW - LEFT SIDE ----LAST LETTER IS REGION IN Z DIRECTION

---B-BOTTOM, AL-AL CLAD LOWER, F-FUEL, AU-AL CLAD UPPER, WU-WATER UP

$\begin{array}{llllrlll}06 & \text { W01B } & 156.55 & 164.65 & 5 & 20 & 172.75 & 180.46 \\ 06 & \text { W01AL } & 156.55 & 164.65 & 20 & 22 & 172.75 & 180.46 \\ 06 & \text { W01F } & 156.55 & 164.65 & 22 & 93 & 172.75 & 180.46 \\ 06 & \text { W01AU } & 156.55 & 164.65 & 93 & 95 & 172.75 & 180.46 \\ 06 & \text { W01WU } & 156.55 & 164.65 & 95 & 97 & 172.75 & 180.46 \\ 06 & \text { W02B } & 148.45 & 156.55 & 5 & 20 & 172.75 & 180.46 \\ 06 & \text { W02AL } & 148.45 & 156.55 & 20 & 22 & 172.75 & 180.46 \\ 06 & \text { W02F } & 148.45 & 156.55 & 22 & 93 & 172.75 & 180.46 \\ 06 & \text { W02AU } & 148.45 & 156.55 & 93 & 95 & 172.75 & 180.46 \\ 06 & \text { W02WU } & 148.45 & 156.55 & 95 & 97 & 172.75 & 180.46 \\ 06 & \text { W03B } & 140.35 & 148.45 & 5 & 20 & 172.75 & 180.46 \\ 06 & \text { W03AL } & 140.35 & 148.45 & 20 & 22 & 172.75 & 180.46 \\ 06 & \text { W03F } & 140.35 & 148.45 & 22 & 93 & 172.75 & 180.46 \\ 06 & \text { W03AU } & 140.35 & 148.45 & 93 & 95 & 172.75 & 180.46 \\ 06 & \text { W03WU } & 140.35 & 148.45 & 95 & 97 & 172.75 & 180.46 \\ 06 & \text { W04B } & 132.25 & 140.35 & 5 & 20 & 172.75 & 180.46 \\ 06 & \text { W04AL } & 132.25 & 140.35 & 20 & 22 & 172.75 & 180.46 \\ 06 & \text { W04F } & 132.25 & 140.35 & 22 & 93 & 172.75 & 180.46 \\ 06 & \text { W04AU } & 132.25 & 140.35 & 93 & 95 & 172.75 & 180.46\end{array}$




\begin{tabular}{|c|c|c|c|c|c|c|c|}
\hline 06 & W04WU & 132.25 & 140.35 & 95 & 97 & 172.75 & 180.46 \\
\hline 06 & W05B & 124.15 & 132.25 & 5 & 20 & 172.75 & 180.46 \\
\hline 06 & W05AL & 124.15 & 132.25 & 20 & 22 & 172.75 & 180.46 \\
\hline 06 & W05F & 124.15 & 132.25 & 22 & 93 & 172.75 & 180.46 \\
\hline 06 & W05AU & 124.15 & 132.25 & 93 & 95 & 172.75 & 180.46 \\
\hline 06 & W05WU & 124.15 & 132.25 & 95 & 97 & 172.75 & 180.46 \\
\hline 06 & W06B & 116.05 & 124.15 & 5 & 20 & 172.75 & 180.46 \\
\hline 06 & W06AL & 116.05 & 124.15 & 20 & 22 & 172.75 & 180.46 \\
\hline 06 & W06F & 116.05 & 124.15 & 22 & 93 & 172.75 & 180.46 \\
\hline 06 & W06AU & 116.05 & 124.15 & 93 & 95 & 172.75 & 180.46 \\
\hline 06 & W0 6WU & 116.05 & 124.15 & 95 & 97 & 172.75 & 180.46 \\
\hline 06 & W07B & 107.95 & 116.05 & 5 & 20 & 172.75 & 180.46 \\
\hline 06 & W07AL & 107.95 & 116.05 & 20 & 22 & 172.75 & 180.46 \\
\hline 06 & W07F & 107.95 & 116.05 & 22 & 93 & 172.75 & 180.46 \\
\hline 06 & W07AU & 107.95 & 116.05 & 93 & 95 & 172.75 & 180.46 \\
\hline 06 & W0 7WU & 107.95 & 116.05 & 95 & 97 & 172.75 & 180.46 \\
\hline 06 & W08B & 140.35 & 148.45 & 5 & 20 & 180.46 & 188.17 \\
\hline 06 & W0 8AL & 140.35 & 148.45 & 20 & 22 & 180.46 & 188.17 \\
\hline 06 & W08F & 140.35 & 145.75 & 22 & 93 & 180.46 & 188.17 \\
\hline 06 & W0 8GR & 145.75 & 148.45 & 22 & 93 & 180.46 & 188.17 \\
\hline 06 & W0 8AU & 140.35 & 148.45 & 93 & 95 & 180.46 & 188.17 \\
\hline 06 & W0 8WU & 140.35 & 148.45 & 95 & 97 & 180.46 & 188.17 \\
\hline 06 & W09B & 132.25 & 140.35 & 5 & 20 & 180.46 & 188.17 \\
\hline 06 & W09AL & 132.25 & 140.35 & 20 & 22 & 180.46 & 188.17 \\
\hline 06 & W09F & 132.25 & 140.35 & 22 & 93 & 180.46 & 188.17 \\
\hline 06 & W09AU & 132.25 & 140.35 & 93 & 95 & 180.46 & 188.17 \\
\hline 06 & W09WU & 132.25 & 140.35 & 95 & 97 & 180.46 & 188.17 \\
\hline 06 & $\mathrm{~W} 10 \mathrm{~B}$ & 124.15 & 132.25 & 5 & 20 & 180.46 & 188.17 \\
\hline 06 & W1 OAL & 124.15 & 132.25 & 20 & 22 & 180.46 & 188.17 \\
\hline 06 & W10F & 126.85 & 132.25 & 22 & 93 & 180.46 & 188.17 \\
\hline 06 & W1 0GR & 124.15 & 126.85 & 22 & 93 & 180.46 & 188.17 \\
\hline 06 & W1 0AU & 124.15 & 132.25 & 93 & 95 & 180.46 & 188.17 \\
\hline 06 & W1 OWU & 124.15 & 132.25 & 95 & 97 & 180.46 & 188.17 \\
\hline
\end{tabular}

- - -EXPERIMENTAL ZONE--.-

---WEDGE IS THE ALUMINUM CORNERS OUTSIDE THE CHIMNEY ---PLATES INSIDE THE CHIMNEY : SSL- LOWER SS PLATES,

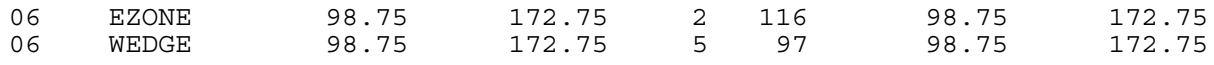

- - - ANGLE GRAPHITE ELEMENTS - - -

---NOTATION G-GRAPHITE ELEMENT, 1-ELEMENT ARE NUMBERED 1-4

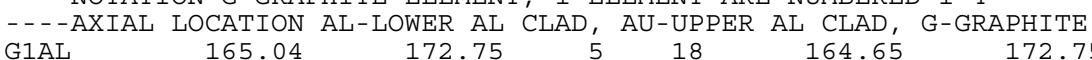

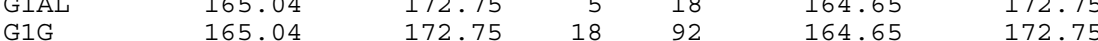

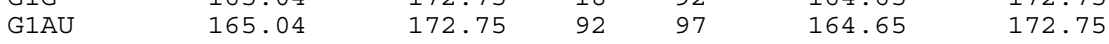

$\begin{array}{lllllll}\text { G2AL } & 98.75 & 106.46 & 5 & 18 & 98.75 & 106.85\end{array}$

$98.75-106.46-18098.75$

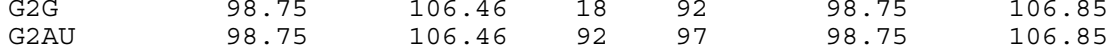

$\begin{array}{lllllll}\text { G3AL } & 165.04 & 172.75 & 5 & 18 & 98.75 & 106.85\end{array}$

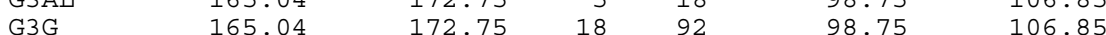

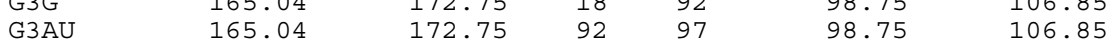

$\begin{array}{lllllll}\text { G4AL } & 98.75 & 106.46 & 5 & 18 & 164.65 & 172.75\end{array}$

$\begin{array}{lllrlll}\text { G4G } & 98.75 & 106.46 & 5 & 18 & 164.65 & 172.75 \\ \text { G4AU } & 98.75 & 106.46 & 18 & 92 & 164.65 & 172.75 \\ & 98.75 & 106.46 & 92 & 97 & 164.65 & 172.75\end{array}$

- - - ALUMINUM MASSIF- - -

---NOTATION ALB-ALUMINUM BLOCK, A-E ARE AXIAL SEGMENTS

$\begin{array}{llrrrrr}\text { ALBA } & 106.85 & 164.65 & 0 & 7 & 106.85 & 164.65 \\ \text { ALBB } & 106.85 & 164.65 & 7 & 8 & 106.85 & 164.65 \\ \text { ALBC } & 106.85 & 164.65 & 8 & 106 & 106.85 & 164.65 \\ \text { ALBD } & 106.85 & 164.65 & 106 & 107 & 106.85 & 164.65 \\ \text { ALBE } & 106.85 & 164.65 & 107 & 110 & 106.85 & 164.65\end{array}$

----CHIMNEY PIECES----

-.-NOTATION CHI-CHIMNEY, 1-PIECES ARE NUMBERED 1-8 ---A-G ARE AXIAL SEGMENTS EXCEPT FOR T- TABLE 


\begin{tabular}{|c|c|c|c|c|c|c|c|}
\hline 06 & CHIIC & 164.65 & 172.75 & 8 & 97 & 114.95 & 156.55 \\
\hline 06 & CHIID & 164.65 & 172.75 & 97 & 106 & 114.95 & 156.55 \\
\hline 06 & CHIIE & 164.65 & 172.75 & 106 & 107 & 114.95 & 156.55 \\
\hline 06 & CHIIF & 164.65 & 172.75 & 107 & 110 & 114.95 & 156.55 \\
\hline 06 & $\mathrm{CHI} 2 \mathrm{~T}$ & 98.75 & 106.85 & 0 & 2 & 114.95 & 156.55 \\
\hline 06 & $\mathrm{CHI} 2 \mathrm{~A}$ & 98.75 & 106.85 & 2 & 7 & 114.95 & 156.55 \\
\hline 06 & $\mathrm{CHI} 2 \mathrm{~B}$ & 98.75 & 106.85 & 7 & 8 & 114.95 & 156.55 \\
\hline 06 & $\mathrm{CHI} 2 \mathrm{C}$ & 98.75 & 106.85 & 8 & 97 & 114.95 & 156.55 \\
\hline 06 & CHI2D & 98.75 & 106.85 & 97 & 106 & 114.95 & 156.55 \\
\hline 06 & $\mathrm{CHI} 2 \mathrm{E}$ & 98.75 & 106.85 & 106 & 107 & 114.95 & 156.55 \\
\hline 06 & $\mathrm{CHI} 2 \mathrm{~F}$ & 98.75 & 106.85 & 107 & 110 & 114.95 & 156.55 \\
\hline 06 & CHI3T & 114.95 & 156.55 & 0 & 2 & 98.75 & 106.85 \\
\hline 06 & CHI3A & 114.95 & 156.55 & 2 & 7 & 98.75 & 106.85 \\
\hline 06 & $\mathrm{CHI} 3 \mathrm{~B}$ & 114.95 & 156.55 & 7 & 8 & 98.75 & 106.85 \\
\hline 06 & $\mathrm{CHI} 3 \mathrm{C}$ & 114.95 & 156.55 & 8 & 97 & 98.75 & 106.85 \\
\hline 06 & CHI3D & 114.95 & 156.55 & 97 & 106 & 98.75 & 106.85 \\
\hline 06 & CHI3E & 114.95 & 156.55 & 106 & 107 & 98.75 & 106.85 \\
\hline 06 & $\mathrm{CHI} 3 \mathrm{~F}$ & 114.95 & 156.55 & 107 & 110 & 98.75 & 106.85 \\
\hline 06 & $\mathrm{CHI} 4 \mathrm{~T}$ & 114.95 & 156.55 & 0 & 2 & 164.65 & 172.75 \\
\hline 06 & $\mathrm{CHI} 4 \mathrm{~A}$ & 114.95 & 156.55 & 2 & 7 & 164.65 & 172.75 \\
\hline 06 & $\mathrm{CHI} 4 \mathrm{~B}$ & 114.95 & 156.55 & 7 & 8 & 164.65 & 172.75 \\
\hline 06 & $\mathrm{CHI} 4 \mathrm{C}$ & 114.95 & 156.55 & 8 & 97 & 164.65 & 172.75 \\
\hline 06 & CHI4D & 114.95 & 156.55 & 97 & 106 & 164.65 & 172.75 \\
\hline 06 & $\mathrm{CHI} 4 \mathrm{E}$ & 114.95 & 156.55 & 106 & 107 & 164.65 & 172.75 \\
\hline 06 & $\mathrm{CHI} 4 \mathrm{~F}$ & 114.95 & 156.55 & 107 & 110 & 164.65 & 172.75 \\
\hline 06 & CHI5T & 156.55 & 164.65 & 0 & 2 & 156.55 & 164.65 \\
\hline 06 & CHI5A & 156.55 & 164.65 & 2 & 7 & 156.55 & 164.65 \\
\hline 06 & CHI5B & 156.55 & 164.65 & 7 & 8 & 156.55 & 164.65 \\
\hline 06 & CHI5C & 156.55 & 164.65 & 8 & 97 & 156.55 & 164.65 \\
\hline 06 & CHI5D & 156.55 & 164.65 & 97 & 106 & 156.55 & 164.65 \\
\hline 06 & CHI5E & 156.55 & 164.65 & 106 & 107 & 156.55 & 164.65 \\
\hline 06 & CHI5F & 156.55 & 164.65 & 107 & 110 & 156.55 & 164.65 \\
\hline 06 & CHI6T & 106.85 & 114.95 & 0 & 2 & 106.85 & 114.95 \\
\hline 06 & CHI6A & 106.85 & 114.95 & 2 & 7 & 106.85 & 114.95 \\
\hline 06 & CHI6B & 106.85 & 114.95 & 7 & 8 & 106.85 & 114.95 \\
\hline 06 & CHI 6C & 106.85 & 114.95 & 8 & 97 & 106.85 & 114.95 \\
\hline 06 & CHI6D & 106.85 & 114.95 & 97 & 106 & 106.85 & 114.95 \\
\hline 06 & CHI6E & 106.85 & 114.95 & 106 & 107 & 106.85 & 114.95 \\
\hline 06 & CHI6F & 106.85 & 114.95 & 107 & 110 & 106.85 & 114.95 \\
\hline 06 & CHI7T & 156.55 & 164.65 & 0 & 2 & 106.85 & 114.95 \\
\hline 06 & CHI 7A & 156.55 & 164.65 & 2 & 7 & 106.85 & 114.95 \\
\hline 06 & CHI 7B & 156.55 & 164.65 & 7 & 8 & 106.85 & 114.95 \\
\hline 06 & CHI7C & 156.55 & 164.65 & 8 & 97 & 106.85 & 114.95 \\
\hline 06 & CHI 7D & 156.55 & 164.65 & 97 & 106 & 106.85 & 114.95 \\
\hline 06 & CHI 7E & 156.55 & 164.65 & 106 & 107 & 106.85 & 114.95 \\
\hline 06 & CHI 7F & 156.55 & 164.65 & 107 & 110 & 106.85 & 114.95 \\
\hline 06 & CHI8T & 106.85 & 114.95 & 0 & 2 & 156.55 & 164.65 \\
\hline 06 & CHI 8A & 106.85 & 114.95 & 2 & 7 & 156.55 & 164.65 \\
\hline 06 & CHI 8B & 106.85 & 114.95 & 7 & 8 & 156.55 & 164.65 \\
\hline 06 & CHI 8C & 106.85 & 114.95 & 8 & 97 & 156.55 & 164.65 \\
\hline 06 & CHI 8D & 106.85 & 114.95 & 97 & 106 & 156.55 & 164.65 \\
\hline 06 & CHI 8E & 106.85 & 114.95 & 106 & 107 & 156.55 & 164.65 \\
\hline 06 & CHI $8 \mathrm{~F}$ & 106.85 & 114.95 & 107 & 110 & 156.55 & 164.65 \\
\hline
\end{tabular}

----ELEMENTS IN MELODIE RIMOX CONFIGURATION----

- - -UO2 FUEL PINS

-.-1 CENTRAL ZONE, 2 ZONES ON EACH SIDE

---NOTATION: FIC- FUEL TYPE-1 CENTRAL REGION

----F1C1- REGION CENTRAL 1, F1C2-, F1C3 (SELF SHIELDING INTERFACE UO2/PuO2)

- - - F1W1 - REGION WEST 1, F1W2 - REGION WEST 2

--- F1W3, F1W8, F1W9 (SELF SHIELDING INTERFACE UO2/AL PIN)

----F1W4, F1W5, F1W6, F1W7, F1WA, F1WB (SELF SHIELDING INTERFACE UO2/AL BLOCK)

---A LAST LETTER (A-Z) GIVES THE AXIAL LOCATION EXCEPT

----SS-STAINLESS STEEL LOWER PLATE, W-LOWER WATER

$\begin{array}{llrrrrr}\text { F1CW } & 122.52 & 148.98 & 0 & 7 & 122.52 & 148.98 \\ \text { F1CSS } & 122.52 & 148.98 & 7 & 8 & 122.52 & 148.98 \\ \text { F1CA } & 122.52 & 148.98 & 8 & 13 & 122.52 & 148.98 \\ \text { F1CB } & 122.52 & 148.98 & 13 & 25 & 122.52 & 148.98 \\ \text { F1CC } & 122.52 & 148.98 & 25 & 87 & 122.52 & 148.98 \\ \text { F1CD } & 122.52 & 148.98 & 87 & 103 & 122.52 & 148.98 \\ \text { F1CE } & 122.52 & 148.98 & 103 & 107 & 122.52 & 148.98\end{array}$




\begin{tabular}{|c|c|c|c|c|c|c|c|}
\hline 06 & $\mathrm{~F} 1 \mathrm{CF}$ & 122.52 & 148.98 & 107 & 110 & 122.52 & 148.98 \\
\hline 06 & $\mathrm{~F} 1 \mathrm{C} 1 \mathrm{~W}$ & 127.56 & 143.94 & 0 & 7 & 127.56 & 143.94 \\
\hline 06 & FICISS & 127.56 & 143.94 & 7 & 8 & 127.56 & 143.94 \\
\hline 06 & $\mathrm{~F} 1 \mathrm{C} \perp \mathrm{A}$ & 127.56 & 143.94 & 8 & 13 & 127.56 & 143.94 \\
\hline 06 & F1C1B & 127.56 & 143.94 & 13 & 25 & 127.56 & 143.94 \\
\hline 06 & $\mathrm{~F} 1 \mathrm{C} 1 \mathrm{C}$ & 127.56 & 143.94 & 25 & 87 & 127.56 & 143.94 \\
\hline 06 & F1C1D & 127.56 & 143.94 & 87 & 103 & 127.56 & 143.94 \\
\hline 06 & F1C1E & 127.56 & 143.94 & 103 & 107 & 127.56 & 143.94 \\
\hline 06 & $\mathrm{~F} 1 \mathrm{C} 1 \mathrm{~F}$ & 127.56 & 143.94 & 107 & 110 & 127.56 & 143.94 \\
\hline 06 & $\mathrm{~F} 1 \mathrm{C} 2 \mathrm{~W}$ & 128.82 & 142.68 & 0 & 7 & 126.30 & 145.20 \\
\hline 06 & F1C2SS & 128.82 & 142.68 & 7 & 8 & 126.30 & 145.20 \\
\hline 06 & F1C2A & 128.82 & 142.68 & 8 & 13 & 126.30 & 145.20 \\
\hline 06 & $\mathrm{~F} 1 \mathrm{C} 2 \mathrm{~B}$ & 128.82 & 142.68 & 13 & 25 & 126.30 & 145.20 \\
\hline 06 & $\mathrm{~F} 1 \mathrm{C} 2 \mathrm{C}$ & 128.82 & 142.68 & 25 & 87 & 126.30 & 145.20 \\
\hline 06 & F1C2D & 128.82 & 142.68 & 87 & 103 & 126.30 & 145.20 \\
\hline 06 & $\mathrm{~F} 1 \mathrm{C} 2 \mathrm{E}$ & 128.82 & 142.68 & 103 & 107 & 126.30 & 145.20 \\
\hline 06 & $\mathrm{~F} 1 \mathrm{C} 2 \mathrm{~F}$ & 128.82 & 142.68 & 107 & 110 & 126.30 & 145.20 \\
\hline 06 & F1C $3 W$ & 126.30 & 145.20 & 0 & 7 & 128.82 & 142.68 \\
\hline 06 & F1C3SS & 126.30 & 145.20 & 7 & 8 & 128.82 & 142.68 \\
\hline 06 & F1C3A & 126.30 & 145.20 & 8 & 13 & 128.82 & 142.68 \\
\hline 06 & F1C3B & 126.30 & 145.20 & 13 & 25 & 128.82 & 142.68 \\
\hline 06 & $\mathrm{~F} 1 \mathrm{C} 3 \mathrm{C}$ & 126.30 & 145.20 & 25 & 87 & 128.82 & 142.68 \\
\hline 06 & F1C3D & 126.30 & 145.20 & 87 & 103 & 128.82 & 142.68 \\
\hline 06 & F1C3E & 126.30 & 145.20 & 103 & 107 & 128.82 & 142.68 \\
\hline 06 & $\mathrm{~F} 1 \mathrm{C} 3 \mathrm{~F}$ & 126.30 & 145.20 & 107 & 110 & 128.82 & 142.68 \\
\hline 06 & $\mathrm{~F} 1 \mathrm{~N} 1 \mathrm{~W}$ & 148.98 & 152.76 & 0 & 7 & 122.52 & 148.98 \\
\hline 06 & FINISS & 148.98 & 152.76 & 7 & 8 & 122.52 & 148.98 \\
\hline 06 & F1N1A & 148.98 & 152.76 & 8 & 13 & 122.52 & 148.98 \\
\hline 06 & F1N1B & 148.98 & 152.76 & 13 & 25 & 122.52 & 148.98 \\
\hline 06 & F1N1C & 148.98 & 152.76 & 25 & 87 & 122.52 & 148.98 \\
\hline 06 & F1N1D & 148.98 & 152.76 & 87 & 103 & 122.52 & 148.98 \\
\hline 06 & F1N1E & 148.98 & 152.76 & 103 & 107 & 122.52 & 148.98 \\
\hline 06 & $\mathrm{~F} 1 \mathrm{~N} 1 \mathrm{~F}$ & 148.98 & 152.76 & 107 & 110 & 122.52 & 148.98 \\
\hline 06 & $\mathrm{~F} 1 \mathrm{~N} 2 \mathrm{~W}$ & 152.76 & 156.54 & 0 & 7 & 130.08 & 141.42 \\
\hline 06 & F1N2SS & 152.76 & 156.54 & 7 & 8 & 130.08 & 141.42 \\
\hline 06 & $\mathrm{~F} 1 \mathrm{~N} 2 \mathrm{~A}$ & 152.76 & 156.54 & 8 & 13 & 130.08 & 141.42 \\
\hline 06 & F1N2B & 152.76 & 156.54 & 13 & 25 & 130.08 & 141.42 \\
\hline 06 & $\mathrm{~F} 1 \mathrm{~N} 2 \mathrm{C}$ & 152.76 & 156.54 & 25 & 87 & 130.08 & 141.42 \\
\hline 06 & F1N2D & 152.76 & 156.54 & 87 & 103 & 130.08 & 141.42 \\
\hline 06 & $\mathrm{~F} 1 \mathrm{~N} 2 \mathrm{E}$ & 152.76 & 156.54 & 103 & 107 & 130.08 & 141.42 \\
\hline 06 & $\mathrm{~F} 1 \mathrm{~N} 2 \mathrm{~F}$ & 152.76 & 156.54 & 107 & 110 & 130.08 & 141.42 \\
\hline 06 & F1N3W & 154.02 & 155.28 & 0 & 7 & 130.08 & 141.42 \\
\hline 06 & F1N3SS & 154.02 & 155.28 & 7 & 8 & 130.08 & 141.42 \\
\hline 06 & F1N3A & 154.02 & 155.28 & 8 & 13 & 130.08 & 141.42 \\
\hline 06 & F1N3B & 154.02 & 155.28 & 13 & 25 & 130.08 & 141.42 \\
\hline 06 & $\mathrm{~F} 1 \mathrm{~N} 3 \mathrm{C}$ & 154.02 & 155.28 & 25 & 87 & 130.08 & 141.42 \\
\hline 06 & F1N3D & 154.02 & 155.28 & 87 & 103 & 130.08 & 141.42 \\
\hline 06 & F1N3E & 154.02 & 155.28 & 103 & 107 & 130.08 & 141.42 \\
\hline 06 & F1N3F & 154.02 & 155.28 & 107 & 110 & 130.08 & 141.42 \\
\hline 06 & $\mathrm{~F} 1 \mathrm{~N} 4 \mathrm{~W}$ & 152.76 & 155.28 & 0 & 7 & 140.16 & 141.42 \\
\hline 06 & F1N4SS & 152.76 & 155.28 & 7 & 8 & 140.16 & 141.42 \\
\hline 06 & $\mathrm{~F} 1 \mathrm{~N} 4 \mathrm{~A}$ & 152.76 & 155.28 & 8 & 13 & 140.16 & 141.42 \\
\hline 06 & $\mathrm{~F} 1 \mathrm{~N} 4 \mathrm{~B}$ & 152.76 & 155.28 & 13 & 25 & 140.16 & 141.42 \\
\hline 06 & $\mathrm{~F} 1 \mathrm{~N} 4 \mathrm{C}$ & 152.76 & 155.28 & 25 & 87 & 140.16 & 141.42 \\
\hline 06 & F1N4D & 152.76 & 155.28 & 87 & 103 & 140.16 & 141.42 \\
\hline 06 & F1N4E & 152.76 & 155.28 & 103 & 107 & 140.16 & 141.42 \\
\hline 06 & $\mathrm{~F} 1 \mathrm{~N} 4 \mathrm{~F}$ & 152.76 & 155.28 & 107 & 110 & 140.16 & 141.42 \\
\hline 06 & F1N5W & 152.76 & 155.28 & 0 & 7 & 130.08 & 131.34 \\
\hline 06 & F1N5SS & 152.76 & 155.28 & 7 & 8 & 130.08 & 131.34 \\
\hline 06 & F1N5A & 152.76 & 155.28 & 8 & 13 & 130.08 & 131.34 \\
\hline 06 & F1N5B & 152.76 & 155.28 & 13 & 25 & 130.08 & 131.34 \\
\hline 06 & F1N5C & 152.76 & 155.28 & 25 & 87 & 130.08 & 131.34 \\
\hline 06 & F1N5D & 152.76 & 155.28 & 87 & 103 & 130.08 & 131.34 \\
\hline 06 & F1N5E & 152.76 & 155.28 & 103 & 107 & 130.08 & 131.34 \\
\hline 06 & F1N5F & 152.76 & 155.28 & 107 & 110 & 130.08 & 131.34 \\
\hline 06 & F1N6W & 151.50 & 152.76 & 0 & 7 & 141.42 & 146.46 \\
\hline 06 & F1N6SS & 151.50 & 152.76 & 7 & 8 & 141.42 & 146.46 \\
\hline 06 & F1N6A & 151.50 & 152.76 & 8 & 13 & 141.42 & 146.46 \\
\hline 06 & F1N6B & 151.50 & 152.76 & 13 & 25 & 141.42 & 146.46 \\
\hline 06 & $\mathrm{~F} 1 \mathrm{~N} 6 \mathrm{C}$ & 151.50 & 152.76 & 25 & 87 & 141.42 & 146.46 \\
\hline 06 & F1N6D & 151.50 & 152.76 & 87 & 103 & 141.42 & 146.46 \\
\hline
\end{tabular}




\begin{tabular}{|c|c|c|c|c|c|c|c|}
\hline 06 & F1N6E & 151.50 & 152.76 & 103 & 107 & 141.42 & 146.46 \\
\hline 06 & F1N6F & 151.50 & 152.76 & 107 & 110 & 141.42 & 146.46 \\
\hline 06 & F1N7W & 151.50 & 152.76 & 0 & 7 & 125.04 & 130.08 \\
\hline 06 & F1N7SS & 151.50 & 152.76 & 7 & 8 & 125.04 & 130.08 \\
\hline 06 & F1N7A & 151.50 & 152.76 & 8 & 13 & 125.04 & 130.08 \\
\hline 06 & F1N7B & 151.50 & 152.76 & 13 & 25 & 125.04 & 130.08 \\
\hline 06 & F1N7C & 151.50 & 152.76 & 25 & 87 & 125.04 & 130.08 \\
\hline 06 & F1N7D & 151.50 & 152.76 & 87 & 103 & 125.04 & 130.08 \\
\hline 06 & F1N7E & 151.50 & 152.76 & 103 & 107 & 125.04 & 130.08 \\
\hline 06 & F1N7F & 151.50 & 152.76 & 107 & 110 & 125.04 & 130.08 \\
\hline 06 & F1N8W & 150.24 & 151.50 & 0 & 7 & 146.46 & 147.72 \\
\hline 06 & FIN8SS & 150.24 & 151.50 & 7 & 8 & 146.46 & 147.72 \\
\hline 06 & F1N8A & 150.24 & 151.50 & 8 & 13 & 146.46 & 147.72 \\
\hline 06 & F1N8B & 150.24 & 151.50 & 13 & 25 & 146.46 & 147.72 \\
\hline 06 & F1N8C & 150.24 & 151.50 & 25 & 87 & 146.46 & 147.72 \\
\hline 06 & F1N8D & 150.24 & 151.50 & 87 & 103 & 146.46 & 147.72 \\
\hline 06 & F1N8E & 150.24 & 151.50 & 103 & 107 & 146.46 & 147.72 \\
\hline 06 & F1N8F & 150.24 & 151.50 & 107 & 110 & 146.46 & 147.72 \\
\hline 06 & F1N9W & 150.24 & 151.50 & 0 & 7 & 123.78 & 125.04 \\
\hline 06 & F1N9SS & 150.24 & 151.50 & 7 & 8 & 123.78 & 125.04 \\
\hline 06 & F1N9A & 150.24 & 151.50 & 8 & 13 & 123.78 & 125.04 \\
\hline 06 & F1N9B & 150.24 & 151.50 & 13 & 25 & 123.78 & 125.04 \\
\hline 06 & F1N9C & 150.24 & 151.50 & 25 & 87 & 123.78 & 125.04 \\
\hline 06 & F1N9D & 150.24 & 151.50 & 87 & 103 & 123.78 & 125.04 \\
\hline 06 & F1N9E & 150.24 & 151.50 & 103 & 107 & 123.78 & 125.04 \\
\hline 06 & F1N9F & 150.24 & 151.50 & 107 & 110 & 123.78 & 125.04 \\
\hline 06 & F1NAW & 148.98 & 150.24 & 0 & 7 & 147.72 & 148.98 \\
\hline 06 & FINASS & 148.98 & 150.24 & 7 & 8 & 147.72 & 148.98 \\
\hline 06 & FINAA & 148.98 & 150.24 & 8 & 13 & 147.72 & 148.98 \\
\hline 06 & FINAB & 148.98 & 150.24 & 13 & 25 & 147.72 & 148.98 \\
\hline 06 & FINAC & 148.98 & 150.24 & 25 & 87 & 147.72 & 148.98 \\
\hline 06 & F1NAD & 148.98 & 150.24 & 87 & 103 & 147.72 & 148.98 \\
\hline 06 & FINAE & 148.98 & 150.24 & 103 & 107 & 147.72 & 148.98 \\
\hline 06 & F1NAF & 148.98 & 150.24 & 107 & 110 & 147.72 & 148.98 \\
\hline 06 & F1NBW & 148.98 & 150.24 & 0 & 7 & 122.52 & 123.78 \\
\hline 06 & FINBSS & 148.98 & 150.24 & 7 & 8 & 122.52 & 123.78 \\
\hline 06 & F1NBA & 148.98 & 150.24 & 8 & 13 & 122.52 & 123.78 \\
\hline 06 & F1NBB & 148.98 & 150.24 & 13 & 25 & 122.52 & 123.78 \\
\hline 06 & FINBC & 148.98 & 150.24 & 25 & 87 & 122.52 & 123.78 \\
\hline 06 & F1NBD & 148.98 & 150.24 & 87 & 103 & 122.52 & 123.78 \\
\hline 06 & F1NBE & 148.98 & 150.24 & 103 & 107 & 122.52 & 123.78 \\
\hline 06 & F1NBF & 148.98 & 150.24 & 107 & 110 & 122.52 & 123.78 \\
\hline 06 & F1S1W & 118.74 & 122.52 & 0 & 7 & 122.52 & 148.98 \\
\hline 06 & F1SISS & 118.74 & 122.52 & 7 & 8 & 122.52 & 148.98 \\
\hline 06 & FISIA & 118.74 & 122.52 & 8 & 13 & 122.52 & 148.98 \\
\hline 06 & F1S1B & 118.74 & 122.52 & 13 & 25 & 122.52 & 148.98 \\
\hline 06 & FIS1C & 118.74 & 122.52 & 25 & 87 & 122.52 & 148.98 \\
\hline 06 & FISID & 118.74 & 122.52 & 87 & 103 & 122.52 & 148.98 \\
\hline 06 & F1S1E & 118.74 & 122.52 & 103 & 107 & 122.52 & 148.98 \\
\hline 06 & $\mathrm{~F} 1 \mathrm{~S} 1 \mathrm{~F}$ & 118.74 & 122.52 & 107 & 110 & 122.52 & 148.98 \\
\hline 06 & $\mathrm{~F} 1 \mathrm{~S} 2 \mathrm{~W}$ & 114.96 & 118.74 & 0 & 7 & 130.08 & 141.42 \\
\hline 06 & F1S2SS & 114.96 & 118.74 & 7 & 8 & 130.08 & 141.42 \\
\hline 06 & $\mathrm{~F} 1 \mathrm{~S} 2 \mathrm{~A}$ & 114.96 & 118.74 & 8 & 13 & 130.08 & 141.42 \\
\hline 06 & F1S2B & 114.96 & 118.74 & 13 & 25 & 130.08 & 141.42 \\
\hline 06 & F1S2C & 114.96 & 118.74 & 25 & 87 & 130.08 & 141.42 \\
\hline 06 & F1S2D & 114.96 & 118.74 & 87 & 103 & 130.08 & 141.42 \\
\hline 06 & F1S2E & 114.96 & 118.74 & 103 & 107 & 130.08 & 141.42 \\
\hline 06 & F1S2F & 114.96 & 118.74 & 107 & 110 & 130.08 & 141.42 \\
\hline 06 & FIS $3 W$ & 116.22 & 117.48 & 0 & 7 & 130.08 & 141.42 \\
\hline 06 & F1S3SS & 116.22 & 117.48 & 7 & 8 & 130.08 & 141.42 \\
\hline 06 & F1S3A & 116.22 & 117.48 & 8 & 13 & 130.08 & 141.42 \\
\hline 06 & F1S3B & 116.22 & 117.48 & 13 & 25 & 130.08 & 141.42 \\
\hline 06 & F1S3C & 116.22 & 117.48 & 25 & 87 & 130.08 & 141.42 \\
\hline 06 & F1S3D & 116.22 & 117.48 & 87 & 103 & 130.08 & 141.42 \\
\hline 06 & F1S3E & 116.22 & 117.48 & 103 & 107 & 130.08 & 141.42 \\
\hline 06 & F1S3F & 116.22 & 117.48 & 107 & 110 & 130.08 & 141.42 \\
\hline 06 & F1S4W & 116.22 & 118.74 & 0 & 7 & 140.16 & 141.42 \\
\hline 06 & F1S4SS & 116.22 & 118.74 & 7 & 8 & 140.16 & 141.42 \\
\hline 06 & F1S4A & 116.22 & 118.74 & 8 & 13 & 140.16 & 141.42 \\
\hline 06 & F1S4B & 116.22 & 118.74 & 13 & 25 & 140.16 & 141.42 \\
\hline 06 & F1S4C & 116.22 & 118.74 & 25 & 87 & 140.16 & 141.42 \\
\hline 06 & F1S4D & 116.22 & 118.74 & 87 & 103 & 140.16 & 141.42 \\
\hline
\end{tabular}




\begin{tabular}{|c|c|c|c|c|c|c|c|}
\hline 06 & F1S4E & 116.22 & 118.74 & 103 & 107 & 140.16 & 141.42 \\
\hline 06 & F1S4F & 116.22 & 118.74 & 107 & 110 & 140.16 & 141.42 \\
\hline 06 & F1S5W & 116.22 & 118.74 & 0 & 7 & 130.08 & 131.34 \\
\hline 06 & F1S5SS & 116.22 & 118.74 & 7 & 8 & 130.08 & 131.34 \\
\hline 06 & F1S5A & 116.22 & 118.74 & 8 & 13 & 130.08 & 131.34 \\
\hline 06 & F1S5B & 116.22 & 118.74 & 13 & 25 & 130.08 & 131.34 \\
\hline 06 & F1S5C & 116.22 & 118.74 & 25 & 87 & 130.08 & 131.34 \\
\hline 06 & F1S5D & 116.22 & 118.74 & 87 & 103 & 130.08 & 131.34 \\
\hline 06 & F1S5E & 116.22 & 118.74 & 103 & 107 & 130.08 & 131.34 \\
\hline 06 & F1S5F & 116.22 & 118.74 & 107 & 110 & 130.08 & 131.34 \\
\hline 06 & F1S6W & 118.74 & 120.00 & 0 & 7 & 141.42 & 146.46 \\
\hline 06 & F1S6SS & 118.74 & 120.00 & 7 & 8 & 141.42 & 146.46 \\
\hline 06 & F1S6A & 118.74 & 120.00 & 8 & 13 & 141.42 & 146.46 \\
\hline 06 & F1S6B & 118.74 & 120.00 & 13 & 25 & 141.42 & 146.46 \\
\hline 06 & F1S6C & 118.74 & 120.00 & 25 & 87 & 141.42 & 146.46 \\
\hline 06 & F1S6D & 118.74 & 120.00 & 87 & 103 & 141.42 & 146.46 \\
\hline 06 & F1S6E & 118.74 & 120.00 & 103 & 107 & 141.42 & 146.46 \\
\hline 06 & F1S6F & 118.74 & 120.00 & 107 & 110 & 141.42 & 146.46 \\
\hline 06 & F1S7W & 118.74 & 120.00 & 0 & 7 & 125.04 & 130.08 \\
\hline 06 & F1S7SS & 118.74 & 120.00 & 7 & 8 & 125.04 & 130.08 \\
\hline 06 & F1S7A & 118.74 & 120.00 & 8 & 13 & 125.04 & 130.08 \\
\hline 06 & F1S7B & 118.74 & 120.00 & 13 & 25 & 125.04 & 130.08 \\
\hline 06 & F1S7C & 118.74 & 120.00 & 25 & 87 & 125.04 & 130.08 \\
\hline 06 & F1S7D & 118.74 & 120.00 & 87 & 103 & 125.04 & 130.08 \\
\hline 06 & F1S7E & 118.74 & 120.00 & 103 & 107 & 125.04 & 130.08 \\
\hline 06 & F1S7F & 118.74 & 120.00 & 107 & 110 & 125.04 & 130.08 \\
\hline 06 & F1S8W & 120.00 & 121.26 & 0 & 7 & 146.46 & 147.72 \\
\hline 06 & FIS8SS & 120.00 & 121.26 & 7 & 8 & 146.46 & 147.72 \\
\hline 06 & F1S8A & 120.00 & 121.26 & 8 & 13 & 146.46 & 147.72 \\
\hline 06 & F1S8B & 120.00 & 121.26 & 13 & 25 & 146.46 & 147.72 \\
\hline 06 & F1S8C & 120.00 & 121.26 & 25 & 87 & 146.46 & 147.72 \\
\hline 06 & F1S8D & 120.00 & 121.26 & 87 & 103 & 146.46 & 147.72 \\
\hline 06 & F1S8E & 120.00 & 121.26 & 103 & 107 & 146.46 & 147.72 \\
\hline 06 & F1S8F & 120.00 & 121.26 & 107 & 110 & 146.46 & 147.72 \\
\hline 06 & F1S9W & 120.00 & 121.26 & 0 & 7 & 123.78 & 125.04 \\
\hline 06 & F1S9SS & 120.00 & 121.26 & 7 & 8 & 123.78 & 125.04 \\
\hline 06 & F1S9A & 120.00 & 121.26 & 8 & 13 & 123.78 & 125.04 \\
\hline 06 & F1S9B & 120.00 & 121.26 & 13 & 25 & 123.78 & 125.04 \\
\hline 06 & F1S9C & 120.00 & 121.26 & 25 & 87 & 123.78 & 125.04 \\
\hline 06 & F1S9D & 120.00 & 121.26 & 87 & 103 & 123.78 & 125.04 \\
\hline 06 & F1S9E & 120.00 & 121.26 & 103 & 107 & 123.78 & 125.04 \\
\hline 06 & F1S9F & 120.00 & 121.26 & 107 & 110 & 123.78 & 125.04 \\
\hline 06 & FISAW & 121.26 & 122.52 & 0 & 7 & 147.72 & 148.98 \\
\hline 06 & FISASS & 121.26 & 122.52 & 7 & 8 & 147.72 & 148.98 \\
\hline 06 & FISAA & 121.26 & 122.52 & 8 & 13 & 147.72 & 148.98 \\
\hline 06 & F1SAB & 121.26 & 122.52 & 13 & 25 & 147.72 & 148.98 \\
\hline 06 & F1SAC & 121.26 & 122.52 & 25 & 87 & 147.72 & 148.98 \\
\hline 06 & FISAD & 121.26 & 122.52 & 87 & 103 & 147.72 & 148.98 \\
\hline 06 & FISAE & 121.26 & 122.52 & 103 & 107 & 147.72 & 148.98 \\
\hline 06 & FISAF & 121.26 & 122.52 & 107 & 110 & 147.72 & 148.98 \\
\hline 06 & F1SBW & 121.26 & 122.52 & 0 & 7 & 122.52 & 123.78 \\
\hline 06 & F1SBSS & 121.26 & 122.52 & 7 & 8 & 122.52 & 123.78 \\
\hline 06 & F1SBA & 121.26 & 122.52 & 8 & 13 & 122.52 & 123.78 \\
\hline 06 & F1SBB & 121.26 & 122.52 & 13 & 25 & 122.52 & 123.78 \\
\hline 06 & F1SBC & 121.26 & 122.52 & 25 & 87 & 122.52 & 123.78 \\
\hline 06 & F1SBD & 121.26 & 122.52 & 87 & 103 & 122.52 & 123.78 \\
\hline 06 & F1SBE & 121.26 & 122.52 & 103 & 107 & 122.52 & 123.78 \\
\hline 06 & F1SBF & 121.26 & 122.52 & 107 & 110 & 122.52 & 123.78 \\
\hline 06 & F1E1W & 122.52 & 148.98 & 0 & 7 & 118.74 & 122.52 \\
\hline 06 & F1E1SS & 122.52 & 148.98 & 7 & 8 & 118.74 & 122.52 \\
\hline 06 & F1E1A & 122.52 & 148.98 & 8 & 13 & 118.74 & 122.52 \\
\hline 06 & F1E1B & 122.52 & 148.98 & 13 & 25 & 118.74 & 122.52 \\
\hline 06 & F1E1C & 122.52 & 148.98 & 25 & 87 & 118.74 & 122.52 \\
\hline 06 & F1E1D & 122.52 & 148.98 & 87 & 103 & 118.74 & 122.52 \\
\hline 06 & F1E1E & 122.52 & 148.98 & 103 & 107 & 118.74 & 122.52 \\
\hline 06 & FIEIF & 122.52 & 148.98 & 107 & 110 & 118.74 & 122.52 \\
\hline 06 & F1E2W & 130.08 & 141.42 & 0 & 7 & 114.96 & 118.74 \\
\hline 06 & F1E2SS & 130.08 & 141.42 & 7 & 8 & 114.96 & 118.74 \\
\hline 06 & F1E2A & 130.08 & 141.42 & 8 & 13 & 114.96 & 118.74 \\
\hline 06 & F1E2B & 130.08 & 141.42 & 13 & 25 & 114.96 & 118.74 \\
\hline 06 & F1E2C & 130.08 & 141.42 & 25 & 87 & 114.96 & 118.74 \\
\hline 06 & F1E2D & 130.08 & 141.42 & 87 & 103 & 114.96 & 118.74 \\
\hline
\end{tabular}




\begin{tabular}{|c|c|c|c|c|c|c|c|}
\hline 06 & F1E2E & 130.08 & 141.42 & 103 & 107 & 114.96 & 118.74 \\
\hline 06 & F1E2F & 130.08 & 141.42 & 107 & 110 & 114.96 & 118.74 \\
\hline 06 & F1E3W & 130.08 & 141.42 & 0 & 7 & 116.22 & 117.48 \\
\hline 06 & F1E3SS & 130.08 & 141.42 & 7 & 8 & 116.22 & 117.48 \\
\hline 06 & F1E3A & 130.08 & 141.42 & 8 & 13 & 116.22 & 117.48 \\
\hline 06 & F1E3B & 130.08 & 141.42 & 13 & 25 & 116.22 & 117.48 \\
\hline 06 & F1E3C & 130.08 & 141.42 & 25 & 87 & 116.22 & 117.48 \\
\hline 06 & F1E3D & 130.08 & 141.42 & 87 & 103 & 116.22 & 117.48 \\
\hline 06 & F1E3E & 130.08 & 141.42 & 103 & 107 & 116.22 & 117.48 \\
\hline 06 & F1E3F & 130.08 & 141.42 & 107 & 110 & 116.22 & 117.48 \\
\hline 06 & F1E4W & 130.08 & 131.34 & 0 & 7 & 116.22 & 118.74 \\
\hline 06 & F1E4SS & 130.08 & 131.34 & 7 & 8 & 116.22 & 118.74 \\
\hline 06 & F1E4A & 130.08 & 131.34 & 8 & 13 & 116.22 & 118.74 \\
\hline 06 & F1E4B & 130.08 & 131.34 & 13 & 25 & 116.22 & 118.74 \\
\hline 06 & F1E4C & 130.08 & 131.34 & 25 & 87 & 116.22 & 118.74 \\
\hline 06 & F1E4D & 130.08 & 131.34 & 87 & 103 & 116.22 & 118.74 \\
\hline 06 & F1E4E & 130.08 & 131.34 & 103 & 107 & 116.22 & 118.74 \\
\hline 06 & F1E4F & 130.08 & 131.34 & 107 & 110 & 116.22 & 118.74 \\
\hline 06 & F1E5W & 140.16 & 141.42 & 0 & 7 & 116.22 & 118.74 \\
\hline 06 & F1E5SS & 140.16 & 141.42 & 7 & 8 & 116.22 & 118.74 \\
\hline 06 & F1E5A & 140.16 & 141.42 & 8 & 13 & 116.22 & 118.74 \\
\hline 06 & F1E5B & 140.16 & 141.42 & 13 & 25 & 116.22 & 118.74 \\
\hline 06 & F1E5C & 140.16 & 141.42 & 25 & 87 & 116.22 & 118.74 \\
\hline 06 & F1E5D & 140.16 & 141.42 & 87 & 103 & 116.22 & 118.74 \\
\hline 06 & F1E5E & 140.16 & 141.42 & 103 & 107 & 116.22 & 118.74 \\
\hline 06 & F1E5F & 140.16 & 141.42 & 107 & 110 & 116.22 & 118.74 \\
\hline 06 & F1E6W & 125.04 & 130.08 & 0 & 7 & 118.74 & 120.00 \\
\hline 06 & F1E6SS & 125.04 & 130.08 & 7 & 8 & 118.74 & 120.00 \\
\hline 06 & F1E6A & 125.04 & 130.08 & 8 & 13 & 118.74 & 120.00 \\
\hline 06 & F1E6B & 125.04 & 130.08 & 13 & 25 & 118.74 & 120.00 \\
\hline 06 & F1E6C & 125.04 & 130.08 & 25 & 87 & 118.74 & 120.00 \\
\hline 06 & F1E6D & 125.04 & 130.08 & 87 & 103 & 118.74 & 120.00 \\
\hline 06 & F1E6E & 125.04 & 130.08 & 103 & 107 & 118.74 & 120.00 \\
\hline 06 & F1E6F & 125.04 & 130.08 & 107 & 110 & 118.74 & 120.00 \\
\hline 06 & F1E7W & 141.42 & 146.46 & 0 & 7 & 118.74 & 120.00 \\
\hline 06 & F1E7SS & 141.42 & 146.46 & 7 & 8 & 118.74 & 120.00 \\
\hline 06 & F1E7A & 141.42 & 146.46 & 8 & 13 & 118.74 & 120.00 \\
\hline 06 & F1E7B & 141.42 & 146.46 & 13 & 25 & 118.74 & 120.00 \\
\hline 06 & F1E7C & 141.42 & 146.46 & 25 & 87 & 118.74 & 120.00 \\
\hline 06 & F1E7D & 141.42 & 146.46 & 87 & 103 & 118.74 & 120.00 \\
\hline 06 & F1E7E & 141.42 & 146.46 & 103 & 107 & 118.74 & 120.00 \\
\hline 06 & F1E7F & 141.42 & 146.46 & 107 & 110 & 118.74 & 120.00 \\
\hline 06 & F1E8W & 123.78 & 125.04 & 0 & 7 & 120.00 & 121.26 \\
\hline 06 & F1E8SS & 123.78 & 125.04 & 7 & 8 & 120.00 & 121.26 \\
\hline 06 & F1E8A & 123.78 & 125.04 & 8 & 13 & 120.00 & 121.26 \\
\hline 06 & F1E8B & 123.78 & 125.04 & 13 & 25 & 120.00 & 121.26 \\
\hline 06 & F1E8C & 123.78 & 125.04 & 25 & 87 & 120.00 & 121.26 \\
\hline 06 & F1E8D & 123.78 & 125.04 & 87 & 103 & 120.00 & 121.26 \\
\hline 06 & F1E8E & 123.78 & 125.04 & 103 & 107 & 120.00 & 121.26 \\
\hline 06 & F1E8F & 123.78 & 125.04 & 107 & 110 & 120.00 & 121.26 \\
\hline 06 & F1E9W & 146.46 & 147.72 & 0 & 7 & 120.00 & 121.26 \\
\hline 06 & F1E9SS & 146.46 & 147.72 & 7 & 8 & 120.00 & 121.26 \\
\hline 06 & F1E9A & 146.46 & 147.72 & 8 & 13 & 120.00 & 121.26 \\
\hline 06 & F1E9B & 146.46 & 147.72 & 13 & 25 & 120.00 & 121.26 \\
\hline 06 & F1E9C & 146.46 & 147.72 & 25 & 87 & 120.00 & 121.26 \\
\hline 06 & F1E9D & 146.46 & 147.72 & 87 & 103 & 120.00 & 121.26 \\
\hline 06 & F1E9E & 146.46 & 147.72 & 103 & 107 & 120.00 & 121.26 \\
\hline 06 & F1E9F & 146.46 & 147.72 & 107 & 110 & 120.00 & 121.26 \\
\hline 06 & F1EAW & 122.52 & 123.78 & 0 & 7 & 121.26 & 122.52 \\
\hline 06 & F1EASS & 122.52 & 123.78 & 7 & 8 & 121.26 & 122.52 \\
\hline 06 & F1EAA & 122.52 & 123.78 & 8 & 13 & 121.26 & 122.52 \\
\hline 06 & F1EAB & 122.52 & 123.78 & 13 & 25 & 121.26 & 122.52 \\
\hline 06 & F1EAC & 122.52 & 123.78 & 25 & 87 & 121.26 & 122.52 \\
\hline 06 & F1EAD & 122.52 & 123.78 & 87 & 103 & 121.26 & 122.52 \\
\hline 06 & FIEAE & 122.52 & 123.78 & 103 & 107 & 121.26 & 122.52 \\
\hline 06 & FIEAF & 122.52 & 123.78 & 107 & 110 & 121.26 & 122.52 \\
\hline 06 & F1EBW & 147.72 & 148.98 & 0 & 7 & 121.26 & 122.52 \\
\hline 06 & F1EBSS & 147.72 & 148.98 & 7 & 8 & 121.26 & 122.52 \\
\hline 06 & F1EBA & 147.72 & 148.98 & 8 & 13 & 121.26 & 122.52 \\
\hline 06 & F1EBB & 147.72 & 148.98 & 13 & 25 & 121.26 & 122.52 \\
\hline 06 & F1EBC & 147.72 & 148.98 & 25 & 87 & 121.26 & 122.52 \\
\hline 06 & F1EBD & 147.72 & 148.98 & 87 & 103 & 121.26 & 122.52 \\
\hline
\end{tabular}




\begin{tabular}{|c|c|c|c|c|c|c|c|}
\hline 06 & F1EBE & 147.72 & 148.98 & 103 & 107 & 121.26 & 122.52 \\
\hline 06 & F1EBF & 147.72 & 148.98 & 107 & 110 & 121.26 & 122.52 \\
\hline 06 & F1W1W & 122.52 & 148.98 & 0 & 7 & 148.98 & 152.76 \\
\hline 06 & F1W1SS & 122.52 & 148.98 & 7 & 8 & 148.98 & 152.76 \\
\hline 06 & F1W1A & 122.52 & 148.98 & 8 & 13 & 148.98 & 152.76 \\
\hline 06 & F1W1B & 122.52 & 148.98 & 13 & 25 & 148.98 & 152.76 \\
\hline 06 & F1W1C & 122.52 & 148.98 & 25 & 87 & 148.98 & 152.76 \\
\hline 06 & F1W1D & 122.52 & 148.98 & 87 & 103 & 148.98 & 152.76 \\
\hline 06 & F1W1E & 122.52 & 148.98 & 103 & 107 & 148.98 & 152.76 \\
\hline 06 & F1W1F & 122.52 & 148.98 & 107 & 110 & 148.98 & 152.76 \\
\hline 06 & F1W2W & 130.08 & 141.42 & 0 & 7 & 152.76 & 156.54 \\
\hline 06 & F1W2SS & 130.08 & 141.42 & 7 & 8 & 152.76 & 156.54 \\
\hline 06 & F1W2A & 130.08 & 141.42 & 8 & 13 & 152.76 & 156.54 \\
\hline 06 & F1W2B & 130.08 & 141.42 & 13 & 25 & 152.76 & 156.54 \\
\hline 06 & F1W2C & 130.08 & 141.42 & 25 & 87 & 152.76 & 156.54 \\
\hline 06 & F1W2D & 130.08 & 141.42 & 87 & 103 & 152.76 & 156.54 \\
\hline 06 & F1W2E & 130.08 & 141.42 & 103 & 107 & 152.76 & 156.54 \\
\hline 06 & F1W2F & 130.08 & 141.42 & 107 & 110 & 152.76 & 156.54 \\
\hline 06 & F1W3W & 130.08 & 141.42 & 0 & 7 & 154.02 & 155.28 \\
\hline 06 & F1W3SS & 130.08 & 141.42 & 7 & 8 & 154.02 & 155.28 \\
\hline 06 & F1W3A & 130.08 & 141.42 & 8 & 13 & 154.02 & 155.28 \\
\hline 06 & F1W3B & 130.08 & 141.42 & 13 & 25 & 154.02 & 155.28 \\
\hline 06 & F1W3C & 130.08 & 141.42 & 25 & 87 & 154.02 & 155.28 \\
\hline 06 & F1W3D & 130.08 & 141.42 & 87 & 103 & 154.02 & 155.28 \\
\hline 06 & F1W3E & 130.08 & 141.42 & 103 & 107 & 154.02 & 155.28 \\
\hline 06 & F1W3F & 130.08 & 141.42 & 107 & 110 & 154.02 & 155.28 \\
\hline 06 & F1W4W & 130.08 & 131.34 & 0 & 7 & 152.76 & 155.28 \\
\hline 06 & F1W4SS & 130.08 & 131.34 & 7 & 8 & 152.76 & 155.28 \\
\hline 06 & F1W4A & 130.08 & 131.34 & 8 & 13 & 152.76 & 155.28 \\
\hline 06 & F1W4B & 130.08 & 131.34 & 13 & 25 & 152.76 & 155.28 \\
\hline 06 & F1W4C & 130.08 & 131.34 & 25 & 87 & 152.76 & 155.28 \\
\hline 06 & F1W4D & 130.08 & 131.34 & 87 & 103 & 152.76 & 155.28 \\
\hline 06 & F1W4E & 130.08 & 131.34 & 103 & 107 & 152.76 & 155.28 \\
\hline 06 & F1W4F & 130.08 & 131.34 & 107 & 110 & 152.76 & 155.28 \\
\hline 06 & F1W5W & 140.16 & 141.42 & 0 & 7 & 152.76 & 155.28 \\
\hline 06 & F1W5SS & 140.16 & 141.42 & 7 & 8 & 152.76 & 155.28 \\
\hline 06 & F1W5A & 140.16 & 141.42 & 8 & 13 & 152.76 & 155.28 \\
\hline 06 & F1W5B & 140.16 & 141.42 & 13 & 25 & 152.76 & 155.28 \\
\hline 06 & F1W5C & 140.16 & 141.42 & 25 & 87 & 152.76 & 155.28 \\
\hline 06 & F1W5D & 140.16 & 141.42 & 87 & 103 & 152.76 & 155.28 \\
\hline 06 & F1W5E & 140.16 & 141.42 & 103 & 107 & 152.76 & 155.28 \\
\hline 06 & F1W5F & 140.16 & 141.42 & 107 & 110 & 152.76 & 155.28 \\
\hline 06 & F1W6W & 125.04 & 130.08 & 0 & 7 & 151.50 & 152.76 \\
\hline 06 & F1W6SS & 125.04 & 130.08 & 7 & 8 & 151.50 & 152.76 \\
\hline 06 & F1W6A & 125.04 & 130.08 & 8 & 13 & 151.50 & 152.76 \\
\hline 06 & F1W6B & 125.04 & 130.08 & 13 & 25 & 151.50 & 152.76 \\
\hline 06 & F1W6C & 125.04 & 130.08 & 25 & 87 & 151.50 & 152.76 \\
\hline 06 & F1W6D & 125.04 & 130.08 & 87 & 103 & 151.50 & 152.76 \\
\hline 06 & F1W6E & 125.04 & 130.08 & 103 & 107 & 151.50 & 152.76 \\
\hline 06 & $\mathrm{~F} 1 \mathrm{~W} 6 \mathrm{~F}$ & 125.04 & 130.08 & 107 & 110 & 151.50 & 152.76 \\
\hline 06 & F1W7W & 141.42 & 146.46 & 0 & 7 & 151.50 & 152.76 \\
\hline 06 & F1W7SS & 141.42 & 146.46 & 7 & 8 & 151.50 & 152.76 \\
\hline 06 & F1W7A & 141.42 & 146.46 & 8 & 13 & 151.50 & 152.76 \\
\hline 06 & F1W7B & 141.42 & 146.46 & 13 & 25 & 151.50 & 152.76 \\
\hline 06 & F1W7C & 141.42 & 146.46 & 25 & 87 & 151.50 & 152.76 \\
\hline 06 & F1W7D & 141.42 & 146.46 & 87 & 103 & 151.50 & 152.76 \\
\hline 06 & F1W7E & 141.42 & 146.46 & 103 & 107 & 151.50 & 152.76 \\
\hline 06 & F1W7F & 141.42 & 146.46 & 107 & 110 & 151.50 & 152.76 \\
\hline 06 & F1W8W & 123.78 & 125.04 & 0 & 7 & 150.24 & 151.50 \\
\hline 06 & F1W8SS & 123.78 & 125.04 & 7 & 8 & 150.24 & 151.50 \\
\hline 06 & F1W8A & 123.78 & 125.04 & 8 & 13 & 150.24 & 151.50 \\
\hline 06 & F1W8B & 123.78 & 125.04 & 13 & 25 & 150.24 & 151.50 \\
\hline 06 & F1W8C & 123.78 & 125.04 & 25 & 87 & 150.24 & 151.50 \\
\hline 06 & F1W8D & 123.78 & 125.04 & 87 & 103 & 150.24 & 151.50 \\
\hline 06 & F1W8E & 123.78 & 125.04 & 103 & 107 & 150.24 & 151.50 \\
\hline 06 & F1W8F & 123.78 & 125.04 & 107 & 110 & 150.24 & 151.50 \\
\hline 06 & F1W9W & 146.46 & 147.72 & 0 & 7 & 150.24 & 151.50 \\
\hline 06 & F1W9SS & 146.46 & 147.72 & 7 & 8 & 150.24 & 151.50 \\
\hline 06 & F1W9A & 146.46 & 147.72 & 8 & 13 & 150.24 & 151.50 \\
\hline 06 & F1W9B & 146.46 & 147.72 & 13 & 25 & 150.24 & 151.50 \\
\hline 06 & F1W9C & 146.46 & 147.72 & 25 & 87 & 150.24 & 151.50 \\
\hline 06 & F1W9D & 146.46 & 147.72 & 87 & 103 & 150.24 & 151.50 \\
\hline
\end{tabular}




\begin{tabular}{|c|c|c|c|c|c|c|c|}
\hline 06 & F1W9E & 146.46 & 147.72 & 103 & 107 & 150.24 & 151.50 \\
\hline 06 & F1W9F & 146.46 & 147.72 & 107 & 110 & 150.24 & 151.50 \\
\hline 06 & F1WAW & 122.52 & 123.78 & 0 & 7 & 148.98 & 150.24 \\
\hline 06 & F1WASS & 122.52 & 123.78 & 7 & 8 & 148.98 & 150.24 \\
\hline 06 & F1WAA & 122.52 & 123.78 & 8 & 13 & 148.98 & 150.24 \\
\hline 06 & F1WAB & 122.52 & 123.78 & 13 & 25 & 148.98 & 150.24 \\
\hline 06 & F1WAC & 122.52 & 123.78 & 25 & 87 & 148.98 & 150.24 \\
\hline 06 & F1WAD & 122.52 & 123.78 & 87 & 103 & 148.98 & 150.24 \\
\hline 06 & F1WAE & 122.52 & 123.78 & 103 & 107 & 148.98 & 150.24 \\
\hline 06 & F1WAF & 122.52 & 123.78 & 107 & 110 & 148.98 & 150.24 \\
\hline 06 & F1WBW & 147.72 & 148.98 & 0 & 7 & 148.98 & 150.24 \\
\hline 06 & F1WBSS & 147.72 & 148.98 & 7 & 8 & 148.98 & 150.24 \\
\hline 06 & F1WBA & 147.72 & 148.98 & 8 & 13 & 148.98 & 150.24 \\
\hline 06 & F1WBB & 147.72 & 148.98 & 13 & 25 & 148.98 & 150.24 \\
\hline 06 & F1WBC & 147.72 & 148.98 & 25 & 87 & 148.98 & 150.24 \\
\hline 06 & F1WBD & 147.72 & 148.98 & 87 & 103 & 148.98 & 150.24 \\
\hline 06 & F1WBE & 147.72 & 148.98 & 103 & 107 & 148.98 & 150.24 \\
\hline 06 & F1WBF & 147.72 & 148.98 & 107 & 110 & 148.98 & 150.24 \\
\hline
\end{tabular}

---MOX 4\% FUEL PINS

-.-1 CENTRAL ZONE, 2 ZONES ON EACH SIDE

----NOTATION: F2C1- FUEL TYPE-2 CENTRAL REGION \#1

----F2C1- FUEL TYPE-2 CENTRAL REGION \#2

-.-F2W- (SELF SHIELDING INTERFACE Pu4\%/UO2)

----F2O- (SELF SHIELDING INTERFACE Pu4\%/OSCILLATION CHANNEL)

---A LAST LETTER (A-Z) GIVES THE AXIAL LOCATION EXCEPT

----SS-STAINLESS STEEL LOWER PLATE, W-LOWER WATER

\begin{tabular}{|c|c|c|c|c|c|c|c|}
\hline 06 & $\mathrm{~F} 2 \mathrm{C} 1 \mathrm{~W}$ & 128.82 & 142.68 & 0 & 7 & 130.08 & 141.42 \\
\hline 06 & F2C1SS & 128.82 & 142.68 & 7 & 8 & 130.08 & 141.42 \\
\hline 06 & $\mathrm{~F} 2 \mathrm{C} 1 \mathrm{~A}$ & 128.82 & 142.68 & 8 & 13 & 130.08 & 141.42 \\
\hline 06 & $\mathrm{~F} 2 \mathrm{C} 1 \mathrm{~B}$ & 128.82 & 142.68 & 13 & 25 & 130.08 & 141.42 \\
\hline 06 & $\mathrm{~F} 2 \mathrm{C} 1 \mathrm{C}$ & 128.82 & 142.68 & 25 & 87 & 130.08 & 141.42 \\
\hline 06 & F2C1D & 128.82 & 142.68 & 87 & 103 & 130.08 & 141.42 \\
\hline 06 & $\mathrm{~F} 2 \mathrm{C} 1 \mathrm{E}$ & 128.82 & 142.68 & 103 & 107 & 130.08 & 141.42 \\
\hline 06 & $\mathrm{~F} 2 \mathrm{C} 1 \mathrm{~F}$ & 128.82 & 142.68 & 107 & 110 & 130.08 & 141.42 \\
\hline 06 & $\mathrm{~F} 2 \mathrm{C} 2 \mathrm{~W}$ & 130.08 & 141.42 & 0 & 7 & 128.82 & 142.68 \\
\hline 06 & F2C2SS & 130.08 & 141.42 & 7 & 8 & 128.82 & 142.68 \\
\hline 06 & $\mathrm{~F} 2 \mathrm{C} 2 \mathrm{~A}$ & 130.08 & 141.42 & 8 & 13 & 128.82 & 142.68 \\
\hline 06 & $\mathrm{~F} 2 \mathrm{C} 2 \mathrm{~B}$ & 130.08 & 141.42 & 13 & 25 & 128.82 & 142.68 \\
\hline 06 & $\mathrm{~F} 2 \mathrm{C} 2 \mathrm{C}$ & 130.08 & 141.42 & 25 & 87 & 128.82 & 142.68 \\
\hline 06 & $\mathrm{~F} 2 \mathrm{C} 2 \mathrm{D}$ & 130.08 & 141.42 & 87 & 103 & 128.82 & 142.68 \\
\hline 06 & $\mathrm{~F} 2 \mathrm{C} 2 \mathrm{E}$ & 130.08 & 141.42 & 103 & 107 & 128.82 & 142.68 \\
\hline 06 & $\mathrm{~F} 2 \mathrm{C} 2 \mathrm{~F}$ & 130.08 & 141.42 & 107 & 110 & 128.82 & 142.68 \\
\hline 06 & F2NW & 142.68 & 143.94 & 0 & 7 & 133.86 & 137.64 \\
\hline 06 & F2NSS & 142.68 & 143.94 & 7 & 8 & 133.86 & 137.64 \\
\hline 06 & $\mathrm{~F} 2 \mathrm{NA}$ & 142.68 & 143.94 & 8 & 13 & 133.86 & 137.64 \\
\hline 06 & $\mathrm{~F} 2 \mathrm{NB}$ & 142.68 & 143.94 & 13 & 25 & 133.86 & 137.64 \\
\hline 06 & $\mathrm{~F} 2 \mathrm{NC}$ & 142.68 & 143.94 & 25 & 87 & 133.86 & 137.64 \\
\hline 06 & F2ND & 142.68 & 143.94 & 87 & 103 & 133.86 & 137.64 \\
\hline 06 & $\mathrm{~F} 2 \mathrm{NE}$ & 142.68 & 143.94 & 103 & 107 & 133.86 & 137.64 \\
\hline 06 & $\mathrm{~F} 2 \mathrm{NF}$ & 142.68 & 143.94 & 107 & 110 & 133.86 & 137.64 \\
\hline 06 & F2SW & 127.56 & 128.82 & 0 & 7 & 133.86 & 137.64 \\
\hline 06 & F2SSS & 127.56 & 128.82 & 7 & 8 & 133.86 & 137.64 \\
\hline 06 & F2SA & 127.56 & 128.82 & 8 & 13 & 133.86 & 137.64 \\
\hline 06 & F2SB & 127.56 & 128.82 & 13 & 25 & 133.86 & 137.64 \\
\hline 06 & F2SC & 127.56 & 128.82 & 25 & 87 & 133.86 & 137.64 \\
\hline 06 & F2SD & 127.56 & 128.82 & 87 & 103 & 133.86 & 137.64 \\
\hline 06 & F2SE & 127.56 & 128.82 & 103 & 107 & 133.86 & 137.64 \\
\hline 06 & F2SF & 127.56 & 128.82 & 107 & 110 & 133.86 & 137.64 \\
\hline 06 & F2EW & 133.86 & 137.64 & 0 & 7 & 127.56 & 128.82 \\
\hline 06 & F2ESS & 133.86 & 137.64 & 7 & 8 & 127.56 & 128.82 \\
\hline 06 & F2EA & 133.86 & 137.64 & 8 & 13 & 127.56 & 128.82 \\
\hline 06 & F2EB & 133.86 & 137.64 & 13 & 25 & 127.56 & 128.82 \\
\hline 06 & $\mathrm{~F} 2 \mathrm{EC}$ & 133.86 & 137.64 & 25 & 87 & 127.56 & 128.82 \\
\hline 06 & F2ED & 133.86 & 137.64 & 87 & 103 & 127.56 & 128.82 \\
\hline 06 & $\mathrm{~F} 2 \mathrm{EE}$ & 133.86 & 137.64 & 103 & 107 & 127.56 & 128.82 \\
\hline 06 & $\mathrm{~F} 2 \mathrm{EF}$ & 133.86 & 137.64 & 107 & 110 & 127.56 & 128.82 \\
\hline 06 & F2WW & 133.86 & 137.64 & 0 & 7 & 142.68 & 143.94 \\
\hline 06 & F2WSS & 133.86 & 137.64 & 7 & 8 & 142.68 & 143.94 \\
\hline 06 & F2WA & 133.86 & 137.64 & 8 & 13 & 142.68 & 143.94 \\
\hline 06 & F2WB & 133.86 & 137.64 & 13 & 25 & 142.68 & 143.94 \\
\hline 06 & F2WC & 133.86 & 137.64 & 25 & 87 & 142.68 & 143.94 \\
\hline 06 & F2WD & 133.86 & 137.64 & 87 & 103 & 142.68 & 143.94 \\
\hline
\end{tabular}




$\begin{array}{llrrrrrr}06 & \text { F2WE } & 133.86 & 137.64 & 103 & 107 & 142.68 & 143.94 \\ 06 & \text { F2WF } & 133.86 & 137.64 & 107 & 110 & 142.68 & 143.94 \\ 06 & \text { F2OW } & 133.86 & 137.64 & 0 & 7 & 133.86 & 137.64 \\ 06 & \text { F2OSS } & 133.86 & 137.64 & 7 & 8 & 133.86 & 137.64 \\ 06 & \text { F2OA } & 133.86 & 137.64 & 8 & 13 & 133.86 & 137.64 \\ 06 & \text { F2OB } & 133.86 & 137.64 & 13 & 25 & 133.86 & 137.64 \\ 06 & \text { F2OC } & 133.86 & 137.64 & 25 & 87 & 133.86 & 137.64 \\ 06 & \text { F2OD } & 133.86 & 137.64 & 87 & 103 & 133.86 & 137.64 \\ 06 & \text { F2OE } & 133.86 & 137.64 & 103 & 107 & 133.86 & 137.64 \\ 06 & \text { F2OF } & 133.86 & 137.64 & 107 & 110 & 133.86 & 137.64\end{array}$

-.-MOX 3.6\% FUEL PINS

---2 ZONES ON EACH SIDE, 4 CORNER ELTS

-.--NOTATION: F3W1 - FUEL TYPE-3 REGION WEST 1 (SELF SHIELDING Pu4\%/Pu3.6\%/UO2) ----F3NW- CORNER NORTH-WEST (SELF SHIELDING Pu4\%/Pu3.6\%/UO2)

---A LAST LETTER (A-Z) GIVES THE AXIAL LOCATION EXCEPT

06
0
0
0
0
0
0
0
0
0
06
06
0
06
06
06
06
06
06
06
06
06

06

06

06

06

06

06

06

06

06

06

06

06
06

06

06

06

06
06

06

06

06

06

06

----SS-STAINLESS STEEL LOWER PLATE, W-LOWER WATER

\begin{tabular}{|c|c|c|c|c|c|c|}
\hline & & & & & & \\
\hline F3N1W & 142.68 & 143.94 & 0 & 7 & 137.64 & 141.42 \\
\hline F3N1SS & 142.68 & 143.94 & 7 & 8 & 137.64 & 141.42 \\
\hline F3N1A & 142.68 & 143.94 & 8 & 13 & 137.64 & 141.42 \\
\hline F3N1B & 142.68 & 143.94 & 13 & 25 & 137.64 & 141.42 \\
\hline F3N1C & 142.68 & 143.94 & 25 & 87 & 137.64 & 141.42 \\
\hline F3N1D & 142.68 & 143.94 & 87 & 103 & 137.64 & 141.42 \\
\hline F $3 N 1 E$ & 142.68 & 143.94 & 103 & 107 & 137.64 & 141.42 \\
\hline F3N1F & 142.68 & 143.94 & 107 & 110 & 137.64 & 141.42 \\
\hline F 3 N2W & 142.68 & 143.94 & 0 & 7 & 130.08 & 133.86 \\
\hline F3N2SS & 142.68 & 143.94 & 7 & 8 & 130.08 & 133.86 \\
\hline F 3 N2A & 142.68 & 143.94 & 8 & 13 & 130.08 & 133.86 \\
\hline F 3 N2B & 142.68 & 143.94 & 13 & 25 & 130.08 & 133.86 \\
\hline F 3 N2C & 142.68 & 143.94 & 25 & 87 & 130.08 & 133.86 \\
\hline F3N2D & 142.68 & 143.94 & 87 & 103 & 130.08 & 133.86 \\
\hline F3N2E & 142.68 & 143.94 & 103 & 107 & 130.08 & 133.86 \\
\hline F $3 N 2 F$ & 142.68 & 143.94 & 107 & 110 & 130.08 & 133.86 \\
\hline F3S1W & 127.56 & 128.82 & 0 & 7 & 130.08 & 133.86 \\
\hline F3SISS & 127.56 & 128.82 & 7 & 8 & 130.08 & 133.86 \\
\hline F3S1A & 127.56 & 128.82 & 8 & 13 & 130.08 & 133.86 \\
\hline F3S1B & 127.56 & 128.82 & 13 & 25 & 130.08 & 133.86 \\
\hline F3S1C & 127.56 & 128.82 & 25 & 87 & 130.08 & 133.86 \\
\hline F3S1D & 127.56 & 128.82 & 87 & 103 & 130.08 & 133.86 \\
\hline F3S1E & 127.56 & 128.82 & 103 & 107 & 130.08 & 133.86 \\
\hline F3S1F & 127.56 & 128.82 & 107 & 110 & 130.08 & 133.86 \\
\hline F3S2W & 127.56 & 128.82 & 0 & 7 & 137.64 & 141.42 \\
\hline F3S2SS & 127.56 & 128.82 & 7 & 8 & 137.64 & 141.42 \\
\hline F3S2A & 127.56 & 128.82 & 8 & 13 & 137.64 & 141.42 \\
\hline F3S2B & 127.56 & 128.82 & 13 & 25 & 137.64 & 141.42 \\
\hline F3S2C & 127.56 & 128.82 & 25 & 87 & 137.64 & 141.42 \\
\hline F3S2D & 127.56 & 128.82 & 87 & 103 & 137.64 & 141.4 \\
\hline F3S2E & 127.56 & 128.82 & 103 & 107 & 137.64 & 141.4 \\
\hline F3S2F & 127.56 & 128.82 & 107 & 110 & 137.64 & 141.4 \\
\hline F3E1W & 137.64 & 141.42 & 0 & 7 & 127.56 & 128.82 \\
\hline F3EISS & 137.64 & 141.42 & 7 & 8 & 127.56 & 128.82 \\
\hline F3E1A & 137.64 & 141.42 & 8 & 13 & 127.56 & 128.82 \\
\hline F $3 E 1 B$ & 137.64 & 141.42 & 13 & 25 & 127.56 & 128.82 \\
\hline F3E1C & 137.64 & 141.42 & 25 & 87 & 127.56 & 128.82 \\
\hline F3E1D & 137.64 & 141.42 & 87 & 103 & 127.56 & 128.82 \\
\hline F3E1E & 137.64 & 141.42 & 103 & 107 & 127.56 & 128.82 \\
\hline F3E1F & 137.64 & 141.42 & 107 & 110 & 127.56 & 128.82 \\
\hline F3E2W & 130.08 & 133.86 & 0 & 7 & 127.56 & 128.82 \\
\hline F3E2SS & 130.08 & 133.86 & 7 & 8 & 127.56 & 128.8 \\
\hline F3E2A & 130.08 & 133.86 & 8 & 13 & 127.56 & 128.82 \\
\hline F3E2B & 130.08 & 133.86 & 13 & 25 & 127.56 & 128.8 \\
\hline F $3 E 2 C$ & 130.08 & 133.86 & 25 & 87 & 127.56 & 128.8 \\
\hline F3E2D & 130.08 & 133.86 & 87 & 103 & 127.56 & 128.8 \\
\hline F3E2E & 130.08 & 133.86 & 103 & 107 & 127.56 & 128.8 \\
\hline F3E2F & 130.08 & 133.86 & 107 & 110 & 127.56 & 128.8 \\
\hline F3W1W & 130.08 & 133.86 & 0 & 7 & 142.68 & 143.94 \\
\hline F3W1SS & 130.08 & 133.86 & 7 & 8 & 142.68 & 143.9 \\
\hline F3W1A & 130.08 & 133.86 & 8 & 13 & 142.68 & 143.94 \\
\hline F3W1B & 130.08 & 133.86 & 13 & 25 & 142.68 & 143.94 \\
\hline F3W1C & 130.08 & 133.86 & 25 & 87 & 142.68 & 143.94 \\
\hline F3W1D & 130.08 & 133.86 & 87 & 103 & 142.68 & 143.9 \\
\hline F3W1E & 130.08 & 133.86 & 103 & 107 & 142.68 & 143.9 \\
\hline F3W1F & 13 & 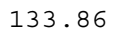 & 107 & 110 & 142.68 & 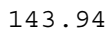 \\
\hline
\end{tabular}




\begin{tabular}{|c|c|c|c|c|c|c|c|}
\hline 06 & F3W2W & 137.64 & 141.42 & 0 & 7 & 142.68 & 143.94 \\
\hline 06 & F3W2SS & 137.64 & 141.42 & 7 & 8 & 142.68 & 143.94 \\
\hline 06 & F3W2A & 137.64 & 141.42 & 8 & 13 & 142.68 & 143.94 \\
\hline 06 & F3W2B & 137.64 & 141.42 & 13 & 25 & 142.68 & 143.94 \\
\hline 06 & F3W2C & 137.64 & 141.42 & 25 & 87 & 142.68 & 143.94 \\
\hline 06 & F3W2D & 137.64 & 141.42 & 87 & 103 & 142.68 & 143.94 \\
\hline 06 & F3W2E & 137.64 & 141.42 & 103 & 107 & 142.68 & 143.94 \\
\hline 06 & F3W2F & 137.64 & 141.42 & 107 & 110 & 142.68 & 143.94 \\
\hline 06 & F3NWW & 141.42 & 142.68 & 0 & 7 & 141.42 & 142.68 \\
\hline 06 & F3NWSS & 141.42 & 142.68 & 7 & 8 & 141.42 & 142.68 \\
\hline 06 & F3NWA & 141.42 & 142.68 & 8 & 13 & 141.42 & 142.68 \\
\hline 06 & F3NWB & 141.42 & 142.68 & 13 & 25 & 141.42 & 142.68 \\
\hline 06 & F3NWC & 141.42 & 142.68 & 25 & 87 & 141.42 & 142.68 \\
\hline 06 & F3NWD & 141.42 & 142.68 & 87 & 103 & 141.42 & 142.68 \\
\hline 06 & F3NWE & 141.42 & 142.68 & 103 & 107 & 141.42 & 142.68 \\
\hline 06 & F3NWF & 141.42 & 142.68 & 107 & 110 & 141.42 & 142.68 \\
\hline 06 & F3SWW & 128.82 & 130.08 & 0 & 7 & 141.42 & 142.68 \\
\hline 06 & F3SWSS & 128.82 & 130.08 & 7 & 8 & 141.42 & 142.68 \\
\hline 06 & F3SWA & 128.82 & 130.08 & 8 & 13 & 141.42 & 142.68 \\
\hline 06 & F3SWB & 128.82 & 130.08 & 13 & 25 & 141.42 & 142.68 \\
\hline 06 & F3SWC & 128.82 & 130.08 & 25 & 87 & 141.42 & 142.68 \\
\hline 06 & F3SWD & 128.82 & 130.08 & 87 & 103 & 141.42 & 142.68 \\
\hline 06 & F3SWE & 128.82 & 130.08 & 103 & 107 & 141.42 & 142.68 \\
\hline 06 & F3SWF & 128.82 & 130.08 & 107 & 110 & 141.42 & 142.68 \\
\hline 06 & F3SEW & 128.82 & 130.08 & 0 & 7 & 128.82 & 130.08 \\
\hline 06 & F3SESS & 128.82 & 130.08 & 7 & 8 & 128.82 & 130.08 \\
\hline 06 & F3SEA & 128.82 & 130.08 & 8 & 13 & 128.82 & 130.08 \\
\hline 06 & F3SEB & 128.82 & 130.08 & 13 & 25 & 128.82 & 130.08 \\
\hline 06 & F3SEC & 128.82 & 130.08 & 25 & 87 & 128.82 & 130.08 \\
\hline 06 & F3SED & 128.82 & 130.08 & 87 & 103 & 128.82 & 130.08 \\
\hline 06 & F3SEE & 128.82 & 130.08 & 103 & 107 & 128.82 & 130.08 \\
\hline 06 & F3SEF & 128.82 & 130.08 & 107 & 110 & 128.82 & 130.08 \\
\hline 06 & F3NEW & 141.42 & 142.68 & 0 & 7 & 128.82 & 130.08 \\
\hline 06 & F3NESS & 141.42 & 142.68 & 7 & 8 & 128.82 & 130.08 \\
\hline 06 & F3NEA & 141.42 & 142.68 & 8 & 13 & 128.82 & 130.08 \\
\hline 06 & F3NEB & 141.42 & 142.68 & 13 & 25 & 128.82 & 130.08 \\
\hline 06 & F3NEC & 141.42 & 142.68 & 25 & 87 & 128.82 & 130.08 \\
\hline 06 & F3NED & 141.42 & 142.68 & 87 & 103 & 128.82 & 130.08 \\
\hline 06 & F3NEE & 141.42 & 142.68 & 103 & 107 & 128.82 & 130.08 \\
\hline 06 & F3NEF & 141.42 & 142.68 & 107 & 110 & 128.82 & 130.08 \\
\hline
\end{tabular}

\begin{tabular}{|c|c|c|c|c|c|c|c|}
\hline & \multicolumn{7}{|c|}{$\begin{array}{l}--- \text { ALUMINUM PINS } \\
--- \text { NOTATION : ALC- FUEL TYPE-1 CENTRAL REGION } \\
--- \text { ALWI-AL PIN \#I REGION WEST, NUMBERED FROM LEFT AND } \\
----A \text { LAST LETTER (A-Z) GIVES THE AXIAL LOCATION EXCEPT } \\
---- \text { SS-STAINLESS STEEL LOWER PLATE, W-LOWER WATER }\end{array}$} \\
\hline 06 & ALN1W & 150.24 & 151.50 & 0 & 7 & 147.72 & 148.98 \\
\hline 06 & ALN1SS & 150.24 & 151.50 & 7 & 8 & 147.72 & 148.98 \\
\hline 06 & ALN1A & 150.24 & 151.50 & 8 & 11 & 147.72 & 148.98 \\
\hline 06 & ALN1B & 150.24 & 151.50 & 11 & 106 & 147.72 & 148.98 \\
\hline 06 & ALN1C & 150.24 & 151.50 & 106 & 107 & 147.72 & 148.98 \\
\hline 06 & ALN1D & 150.24 & 151.50 & 107 & 110 & 147.72 & 148.98 \\
\hline 06 & ALN2W & 151.50 & 152.76 & 0 & 7 & 146.46 & 148.98 \\
\hline 06 & ALN2SS & 151.50 & 152.76 & 7 & 8 & 146.46 & 148.98 \\
\hline 06 & ALN2A & 151.50 & 152.76 & 8 & 11 & 146.46 & 148.98 \\
\hline 06 & ALN2B & 151.50 & 152.76 & 11 & 106 & 146.46 & 148.98 \\
\hline 06 & ALN2C & 151.50 & 152.76 & 106 & 107 & 146.46 & 148.98 \\
\hline 06 & ALN2D & 151.50 & 152.76 & 107 & 110 & 146.46 & 148.98 \\
\hline 06 & ALN3W & 150.24 & 151.50 & 0 & 7 & 122.52 & 123.78 \\
\hline 06 & ALN3SS & 150.24 & 151.50 & 7 & 8 & 122.52 & 123.78 \\
\hline 06 & ALN3A & 150.24 & 151.50 & 8 & 11 & 122.52 & 123.78 \\
\hline 06 & ALN3B & 150.24 & 151.50 & 11 & 106 & 122.52 & 123.78 \\
\hline 06 & ALN3C & 150.24 & 151.50 & 106 & 107 & 122.52 & 123.78 \\
\hline 06 & ALN3D & 150.24 & 151.50 & 107 & 110 & 122.52 & 123.78 \\
\hline 06 & ALN4W & 151.50 & 152.76 & 0 & 7 & 122.52 & 125.04 \\
\hline 06 & ALN4SS & 151.50 & 152.76 & 7 & 8 & 122.52 & 125.04 \\
\hline 06 & ALN4A & 151.50 & 152.76 & 8 & 11 & 122.52 & 125.04 \\
\hline 06 & ALN4B & 151.50 & 152.76 & 11 & 106 & 122.52 & 125.04 \\
\hline 06 & ALN4C & 151.50 & 152.76 & 106 & 107 & 122.52 & 125.04 \\
\hline 06 & ALN4D & 151.50 & 152.76 & 107 & 110 & 122.52 & 125.04 \\
\hline 06 & ALN5W & 155.28 & 156.54 & 0 & 7 & 130.08 & 141.42 \\
\hline 06 & ALN5SS & 155.28 & 156.54 & 7 & 8 & 130.08 & 141.42 \\
\hline
\end{tabular}




\begin{tabular}{|c|c|c|c|c|c|c|c|}
\hline 06 & ALN5A & 155.28 & 156.54 & 8 & 11 & 130.08 & 141.42 \\
\hline 06 & ALN5B & 155.28 & 156.54 & 11 & 106 & 130.08 & 141.42 \\
\hline 06 & ALN5C & 155.28 & 156.54 & 106 & 107 & 130.08 & 141.42 \\
\hline 06 & ALN5D & 155.28 & 156.54 & 107 & 110 & 130.08 & 141.42 \\
\hline 06 & ALS1W & 120.00 & 121.26 & 0 & 7 & 122.52 & 123.78 \\
\hline 06 & ALSISS & 120.00 & 121.26 & 7 & 8 & 122.52 & 123.78 \\
\hline 06 & $A L S 1 A$ & 120.00 & 121.26 & 8 & 11 & 122.52 & 123.78 \\
\hline 06 & ALS1B & 120.00 & 121.26 & 11 & 106 & 122.52 & 123.78 \\
\hline 06 & ALS1C & 120.00 & 121.26 & 106 & 107 & 122.52 & 123.78 \\
\hline 06 & ALSID & 120.00 & 121.26 & 107 & 110 & 122.52 & 123.78 \\
\hline 06 & $\mathrm{ALS} 2 \mathrm{~W}$ & 118.74 & 120.00 & 0 & 7 & 122.52 & 125.04 \\
\hline 06 & ALS2SS & 118.74 & 120.00 & 7 & 8 & 122.52 & 125.04 \\
\hline 06 & ALS2A & 118.74 & 120.00 & 8 & 11 & 122.52 & 125.04 \\
\hline 06 & $\mathrm{ALS} 2 \mathrm{~B}$ & 118.74 & 120.00 & 11 & 106 & 122.52 & 125.04 \\
\hline 06 & $\mathrm{ALS} 2 \mathrm{C}$ & 118.74 & 120.00 & 106 & 107 & 122.52 & 125.04 \\
\hline 06 & ALS2D & 118.74 & 120.00 & 107 & 110 & 122.52 & 125.04 \\
\hline 06 & ALS3W & 120.00 & 121.26 & 0 & 7 & 147.72 & 148.98 \\
\hline 06 & ALS3SS & 120.00 & 121.26 & 7 & 8 & 147.72 & 148.98 \\
\hline 06 & ALS3A & 120.00 & 121.26 & 8 & 11 & 147.72 & 148.98 \\
\hline 06 & $\mathrm{ALS} 3 \mathrm{~B}$ & 120.00 & 121.26 & 11 & 106 & 147.72 & 148.98 \\
\hline 06 & $\mathrm{ALS} 3 \mathrm{C}$ & 120.00 & 121.26 & 106 & 107 & 147.72 & 148.98 \\
\hline 06 & ALS3D & 120.00 & 121.26 & 107 & 110 & 147.72 & 148.98 \\
\hline 06 & ALS4W & 118.74 & 120.00 & 0 & 7 & 146.46 & 148.98 \\
\hline 06 & ALS4SS & 118.74 & 120.00 & 7 & 8 & 146.46 & 148.98 \\
\hline 06 & ALS4A & 118.74 & 120.00 & 8 & 11 & 146.46 & 148.98 \\
\hline 06 & $\mathrm{ALS} 4 \mathrm{~B}$ & 118.74 & 120.00 & 11 & 106 & 146.46 & 148.98 \\
\hline 06 & $\mathrm{ALS} 4 \mathrm{C}$ & 118.74 & 120.00 & 106 & 107 & 146.46 & 148.98 \\
\hline 06 & ALS4D & 118.74 & 120.00 & 107 & 110 & 146.46 & 148.98 \\
\hline 06 & ALS5W & 114.96 & 116.22 & 0 & 7 & 130.08 & 141.42 \\
\hline 06 & ALS5SS & 114.96 & 116.22 & 7 & 8 & 130.08 & 141.42 \\
\hline 06 & ALS5A & 114.96 & 116.22 & 8 & 11 & 130.08 & 141.42 \\
\hline 06 & ALS5B & 114.96 & 116.22 & 11 & 106 & 130.08 & 141.42 \\
\hline 06 & ALS5C & 114.96 & 116.22 & 106 & 107 & 130.08 & 141.42 \\
\hline 06 & ALS5D & 114.96 & 116.22 & 107 & 110 & 130.08 & 141.42 \\
\hline 06 & ALEIW & 147.72 & 148.98 & 0 & 7 & 118.74 & 121.26 \\
\hline 06 & ALEISS & 147.72 & 148.98 & 7 & 8 & 118.74 & 121.26 \\
\hline 06 & ALE1A & 147.72 & 148.98 & 8 & 11 & 118.74 & 121.26 \\
\hline 06 & ALE1B & 147.72 & 148.98 & 11 & 106 & 118.74 & 121.26 \\
\hline 06 & ALEIC & 147.72 & 148.98 & 106 & 107 & 118.74 & 121.26 \\
\hline 06 & ALEID & 147.72 & 148.98 & 107 & 110 & 118.74 & 121.26 \\
\hline 06 & ALE2W & 146.46 & 147.72 & 0 & 7 & 118.74 & 120.00 \\
\hline 06 & ALE2SS & 146.46 & 147.72 & 7 & 8 & 118.74 & 120.00 \\
\hline 06 & $\mathrm{ALE} 2 \mathrm{~A}$ & 146.46 & 147.72 & 8 & 11 & 118.74 & 120.00 \\
\hline 06 & ALE2B & 146.46 & 147.72 & 11 & 106 & 118.74 & 120.00 \\
\hline 06 & $\mathrm{ALE} 2 \mathrm{C}$ & 146.46 & 147.72 & 106 & 107 & 118.74 & 120.00 \\
\hline 06 & ALE2D & 146.46 & 147.72 & 107 & 110 & 118.74 & 120.00 \\
\hline 06 & ALE3W & 122.52 & 123.78 & 0 & 7 & 118.74 & 121.26 \\
\hline 06 & ALE3SS & 122.52 & 123.78 & 7 & 8 & 118.74 & 121.26 \\
\hline 06 & ALE3A & 122.52 & 123.78 & 8 & 11 & 118.74 & 121.26 \\
\hline 06 & ALE3B & 122.52 & 123.78 & 11 & 106 & 118.74 & 121.26 \\
\hline 06 & ALE3C & 122.52 & 123.78 & 106 & 107 & 118.74 & 121.26 \\
\hline 06 & ALE3D & 122.52 & 123.78 & 107 & 110 & 118.74 & 121.26 \\
\hline 06 & ALE4W & 123.78 & 125.04 & 0 & 7 & 118.74 & 120.00 \\
\hline 06 & ALE4SS & 123.78 & 125.04 & 7 & 8 & 118.74 & 120.00 \\
\hline 06 & ALE4A & 123.78 & 125.04 & 8 & 11 & 118.74 & 120.00 \\
\hline 06 & ALE4B & 123.78 & 125.04 & 11 & 106 & 118.74 & 120.00 \\
\hline 06 & $\mathrm{ALE} 4 \mathrm{C}$ & 123.78 & 125.04 & 106 & 107 & 118.74 & 120.00 \\
\hline 06 & ALE4D & 123.78 & 125.04 & 107 & 110 & 118.74 & 120.00 \\
\hline 06 & ALE5W & 130.08 & 141.42 & 0 & 7 & 114.96 & 116.22 \\
\hline 06 & ALE5SS & 130.08 & 141.42 & 7 & 8 & 114.96 & 116.22 \\
\hline 06 & ALE5A & 130.08 & 141.42 & 8 & 11 & 114.96 & 116.22 \\
\hline 06 & ALE5B & 130.08 & 141.42 & 11 & 106 & 114.96 & 116.22 \\
\hline 06 & ALE5C & 130.08 & 141.42 & 106 & 107 & 114.96 & 116.22 \\
\hline 06 & ALE5D & 130.08 & 141.42 & 107 & 110 & 114.96 & 116.22 \\
\hline 06 & ALW1W & 122.52 & 123.78 & 0 & 7 & 150.24 & 152.76 \\
\hline 06 & ALWISS & 122.52 & 123.78 & 7 & 8 & 150.24 & 152.76 \\
\hline 06 & ALW1A & 122.52 & 123.78 & 8 & 11 & 150.24 & 152.76 \\
\hline 06 & ALW1B & 122.52 & 123.78 & 11 & 106 & 150.24 & 152.76 \\
\hline 06 & $\mathrm{ALW} 1 \mathrm{C}$ & 122.52 & 123.78 & 106 & 107 & 150.24 & 152.76 \\
\hline 06 & ALW1D & 122.52 & 123.78 & 107 & 110 & 150.24 & 152.76 \\
\hline
\end{tabular}




\begin{tabular}{|c|c|c|c|c|c|c|c|}
\hline 06 & ALW2W & 123.78 & 125.04 & 0 & 7 & 151.50 & 152.76 \\
\hline 06 & ALW2SS & 123.78 & 125.04 & 7 & 8 & 151.50 & 152.76 \\
\hline 06 & ALW2A & 123.78 & 125.04 & 8 & 11 & 151.50 & 152.76 \\
\hline 06 & ALW2B & 123.78 & 125.04 & 11 & 106 & 151.50 & 152.76 \\
\hline 06 & $\mathrm{ALW} 2 \mathrm{C}$ & 123.78 & 125.04 & 106 & 107 & 151.50 & 152.76 \\
\hline 06 & ALW2D & 123.78 & 125.04 & 107 & 110 & 151.50 & 152.76 \\
\hline 06 & ALW3W & 147.72 & 148.98 & 0 & 7 & 150.24 & 152.76 \\
\hline 06 & ALW3SS & 147.72 & 148.98 & 7 & 8 & 150.24 & 152.76 \\
\hline 06 & ALW3A & 147.72 & 148.98 & 8 & 11 & 150.24 & 152.76 \\
\hline 06 & ALW3B & 147.72 & 148.98 & 11 & 106 & 150.24 & 152.76 \\
\hline 06 & $\mathrm{ALW} 3 \mathrm{C}$ & 147.72 & 148.98 & 106 & 107 & 150.24 & 152.76 \\
\hline 06 & ALW3D & 147.72 & 148.98 & 107 & 110 & 150.24 & 152.76 \\
\hline 06 & ALW4W & 146.46 & 147.72 & 0 & 7 & 151.50 & 152.76 \\
\hline 06 & ALW4SS & 146.46 & 147.72 & 7 & 8 & 151.50 & 152.76 \\
\hline 06 & ALW4A & 146.46 & 147.72 & 8 & 11 & 151.50 & 152.76 \\
\hline 06 & ALW4B & 146.46 & 147.72 & 11 & 106 & 151.50 & 152.76 \\
\hline 06 & $\mathrm{ALW} 4 \mathrm{C}$ & 146.46 & 147.72 & 106 & 107 & 151.50 & 152.76 \\
\hline 06 & ALW4D & 146.46 & 147.72 & 107 & 110 & 151.50 & 152.76 \\
\hline 06 & ALW5W & 130.08 & 141.42 & 0 & 7 & 155.28 & 156.54 \\
\hline 06 & ALW5SS & 130.08 & 141.42 & 7 & 8 & 155.28 & 156.54 \\
\hline 06 & ALW5A & 130.08 & 141.42 & 8 & 11 & 155.28 & 156.54 \\
\hline 06 & ALW5B & 130.08 & 141.42 & 11 & 106 & 155.28 & 156.54 \\
\hline 06 & ALW5C & 130.08 & 141.42 & 106 & 107 & 155.28 & 156.54 \\
\hline 06 & ALW5D & 130.08 & 141.42 & 107 & 110 & 155.28 & 156.54 \\
\hline
\end{tabular}

- - - TRAVERSE SOUTH-NORTH

\begin{tabular}{|c|c|c|c|c|c|c|c|}
\hline 06 & P01W & 114.96 & 116.22 & 0 & 7 & 135.12 & 136.38 \\
\hline 06 & P01SS & 114.96 & 116.22 & 7 & 8 & 135.12 & 136.38 \\
\hline 06 & P01A & 114.96 & 116.22 & 8 & 11 & 135.12 & 136.38 \\
\hline 06 & P01B & 114.96 & 116.22 & 11 & 106 & 135.12 & 136.38 \\
\hline 06 & P01C & 114.96 & 116.22 & 106 & 107 & 135.12 & 136.38 \\
\hline 06 & P01D & 114.96 & 116.22 & 107 & 110 & 135.12 & 136.38 \\
\hline 06 & $\mathrm{P} 02 \mathrm{~W}$ & 116.22 & 117.48 & 0 & 7 & 135.12 & 136.38 \\
\hline 06 & P02SS & 116.22 & 117.48 & 7 & 8 & 135.12 & 136.38 \\
\hline 06 & P02A & 116.22 & 117.48 & 8 & 13 & 135.12 & 136.38 \\
\hline 06 & $\mathrm{P} 02 \mathrm{~B}$ & 116.22 & 117.48 & 13 & 25 & 135.12 & 136.38 \\
\hline 06 & $\mathrm{P} 02 \mathrm{C}$ & 116.22 & 117.48 & 25 & 87 & 135.12 & 136.38 \\
\hline 06 & P02D & 116.22 & 117.48 & 87 & 103 & 135.12 & 136.38 \\
\hline 06 & P02E & 116.22 & 117.48 & 103 & 107 & 135.12 & 136.38 \\
\hline 06 & $\mathrm{P} 02 \mathrm{~F}$ & 116.22 & 117.48 & 107 & 110 & 135.12 & 136.38 \\
\hline 06 & P03W & 117.48 & 118.74 & 0 & 7 & 135.12 & 136.38 \\
\hline 06 & P03SS & 117.48 & 118.74 & 7 & 8 & 135.12 & 136.38 \\
\hline 06 & P03A & 117.48 & 118.74 & 8 & 13 & 135.12 & 136.38 \\
\hline 06 & P03B & 117.48 & 118.74 & 13 & 25 & 135.12 & 136.38 \\
\hline 06 & P03C & 117.48 & 118.74 & 25 & 87 & 135.12 & 136.38 \\
\hline 06 & P03D & 117.48 & 118.74 & 87 & 103 & 135.12 & 136.38 \\
\hline 06 & P03E & 117.48 & 118.74 & 103 & 107 & 135.12 & 136.38 \\
\hline 06 & P03F & 117.48 & 118.74 & 107 & 110 & 135.12 & 136.38 \\
\hline 06 & $\mathrm{P} 04 \mathrm{~W}$ & 118.74 & 120.00 & 0 & 7 & 135.12 & 136.38 \\
\hline 06 & P04SS & 118.74 & 120.00 & 7 & 8 & 135.12 & 136.38 \\
\hline 06 & P04A & 118.74 & 120.00 & 8 & 13 & 135.12 & 136.38 \\
\hline 06 & P0 4B & 118.74 & 120.00 & 13 & 25 & 135.12 & 136.38 \\
\hline 06 & P04C & 118.74 & 120.00 & 25 & 87 & 135.12 & 136.38 \\
\hline 06 & P04D & 118.74 & 120.00 & 87 & 103 & 135.12 & 136.38 \\
\hline 06 & P04E & 118.74 & 120.00 & 103 & 107 & 135.12 & 136.38 \\
\hline 06 & P04F & 118.74 & 120.00 & 107 & 110 & 135.12 & 136.38 \\
\hline 06 & P05W & 120.00 & 121.26 & 0 & 7 & 135.12 & 136.38 \\
\hline 06 & P05SS & 120.00 & 121.26 & 7 & 8 & 135.12 & 136.38 \\
\hline 06 & P05A & 120.00 & 121.26 & 8 & 13 & 135.12 & 136.38 \\
\hline 06 & P05B & 120.00 & 121.26 & 13 & 25 & 135.12 & 136.38 \\
\hline 06 & P05C & 120.00 & 121.26 & 25 & 87 & 135.12 & 136.38 \\
\hline 06 & P05D & 120.00 & 121.26 & 87 & 103 & 135.12 & 136.38 \\
\hline 06 & P05E & 120.00 & 121.26 & 103 & 107 & 135.12 & 136.38 \\
\hline 06 & P05F & 120.00 & 121.26 & 107 & 110 & 135.12 & 136.38 \\
\hline 06 & P06W & 121.26 & 122.52 & 0 & 7 & 135.12 & 136.38 \\
\hline 06 & P06SS & 121.26 & 122.52 & 7 & 8 & 135.12 & 136.38 \\
\hline 06 & P06A & 121.26 & 122.52 & 8 & 13 & 135.12 & 136.38 \\
\hline 06 & P06B & 121.26 & 122.52 & 13 & 25 & 135.12 & 136.38 \\
\hline 06 & P06C & 121.26 & 122.52 & 25 & 87 & 135.12 & 136.38 \\
\hline 06 & P06D & 121.26 & 122.52 & 87 & 103 & 135.12 & 136.38 \\
\hline
\end{tabular}




\begin{tabular}{|c|c|c|c|c|c|c|c|}
\hline 06 & P06E & 121.26 & 122.52 & 103 & 107 & 135.12 & 136.38 \\
\hline 06 & $\mathrm{P} 06 \mathrm{~F}$ & 121.26 & 122.52 & 107 & 110 & 135.12 & 136.38 \\
\hline 06 & P07W & 122.52 & 123.78 & 0 & 7 & 135.12 & 136.38 \\
\hline 06 & P07SS & 122.52 & 123.78 & 7 & 8 & 135.12 & 136.38 \\
\hline 06 & P07A & 122.52 & 123.78 & 8 & 13 & 135.12 & 136.38 \\
\hline 06 & P07B & 122.52 & 123.78 & 13 & 25 & 135.12 & 136.38 \\
\hline 06 & P07C & 122.52 & 123.78 & 25 & 87 & 135.12 & 136.38 \\
\hline 06 & P07D & 122.52 & 123.78 & 87 & 103 & 135.12 & 136.38 \\
\hline 06 & P07E & 122.52 & 123.78 & 103 & 107 & 135.12 & 136.38 \\
\hline 06 & P07F & 122.52 & 123.78 & 107 & 110 & 135.12 & 136.38 \\
\hline 06 & P08W & 123.78 & 125.04 & 0 & 7 & 135.12 & 136.38 \\
\hline 06 & P08SS & 123.78 & 125.04 & 7 & 8 & 135.12 & 136.38 \\
\hline 06 & P08A & 123.78 & 125.04 & 8 & 13 & 135.12 & 136.38 \\
\hline 06 & P0 8B & 123.78 & 125.04 & 13 & 25 & 135.12 & 136.38 \\
\hline 06 & P08C & 123.78 & 125.04 & 25 & 87 & 135.12 & 136.38 \\
\hline 06 & P08D & 123.78 & 125.04 & 87 & 103 & 135.12 & 136.38 \\
\hline 06 & P08E & 123.78 & 125.04 & 103 & 107 & 135.12 & 136.38 \\
\hline 06 & P08F & 123.78 & 125.04 & 107 & 110 & 135.12 & 136.38 \\
\hline 06 & P09W & 125.04 & 126.30 & 0 & 7 & 135.12 & 136.38 \\
\hline 06 & P09SS & 125.04 & 126.30 & 7 & 8 & 135.12 & 136.38 \\
\hline 06 & P09A & 125.04 & 126.30 & 8 & 13 & 135.12 & 136.38 \\
\hline 06 & P09B & 125.04 & 126.30 & 13 & 25 & 135.12 & 136.38 \\
\hline 06 & P09C & 125.04 & 126.30 & 25 & 87 & 135.12 & 136.38 \\
\hline 06 & P09D & 125.04 & 126.30 & 87 & 103 & 135.12 & 136.38 \\
\hline 06 & P09E & 125.04 & 126.30 & 103 & 107 & 135.12 & 136.38 \\
\hline 06 & P09F & 125.04 & 126.30 & 107 & 110 & 135.12 & 136.38 \\
\hline 06 & P10W & 126.30 & 127.56 & 0 & 7 & 135.12 & 136.38 \\
\hline 06 & P1OSS & 126.30 & 127.56 & 7 & 8 & 135.12 & 136.38 \\
\hline 06 & P10A & 126.30 & 127.56 & 8 & 13 & 135.12 & 136.38 \\
\hline 06 & $\mathrm{P} 10 \mathrm{~B}$ & 126.30 & 127.56 & 13 & 25 & 135.12 & 136.38 \\
\hline 06 & $\mathrm{P} 10 \mathrm{C}$ & 126.30 & 127.56 & 25 & 87 & 135.12 & 136.38 \\
\hline 06 & P10D & 126.30 & 127.56 & 87 & 103 & 135.12 & 136.38 \\
\hline 06 & P10E & 126.30 & 127.56 & 103 & 107 & 135.12 & 136.38 \\
\hline 06 & P10F & 126.30 & 127.56 & 107 & 110 & 135.12 & 136.38 \\
\hline 06 & $\mathrm{P} 11 \mathrm{~W}$ & 127.56 & 128.82 & 0 & 7 & 135.12 & 136.38 \\
\hline 06 & P11SS & 127.56 & 128.82 & 7 & 8 & 135.12 & 136.38 \\
\hline 06 & $\mathrm{P} 11 \mathrm{~A}$ & 127.56 & 128.82 & 8 & 13 & 135.12 & 136.38 \\
\hline 06 & $\mathrm{P} 11 \mathrm{~B}$ & 127.56 & 128.82 & 13 & 25 & 135.12 & 136.38 \\
\hline 06 & P11C & 127.56 & 128.82 & 25 & 87 & 135.12 & 136.38 \\
\hline 06 & P11D & 127.56 & 128.82 & 87 & 103 & 135.12 & 136.38 \\
\hline 06 & P11E & 127.56 & 128.82 & 103 & 107 & 135.12 & 136.38 \\
\hline 06 & $\mathrm{P} 11 \mathrm{~F}$ & 127.56 & 128.82 & 107 & 110 & 135.12 & 136.38 \\
\hline 06 & $\mathrm{P} 12 \mathrm{~W}$ & 128.82 & 130.08 & 0 & 7 & 135.12 & 136.38 \\
\hline 06 & P12SS & 128.82 & 130.08 & 7 & 8 & 135.12 & 136.38 \\
\hline 06 & P12A & 128.82 & 130.08 & 8 & 13 & 135.12 & 136.38 \\
\hline 06 & $\mathrm{P} 12 \mathrm{~B}$ & 128.82 & 130.08 & 13 & 25 & 135.12 & 136.38 \\
\hline 06 & $\mathrm{P} 12 \mathrm{C}$ & 128.82 & 130.08 & 25 & 87 & 135.12 & 136.38 \\
\hline 06 & P12D & 128.82 & 130.08 & 87 & 103 & 135.12 & 136.38 \\
\hline 06 & $\mathrm{P} 12 \mathrm{E}$ & 128.82 & 130.08 & 103 & 107 & 135.12 & 136.38 \\
\hline 06 & $\mathrm{P} 12 \mathrm{~F}$ & 128.82 & 130.08 & 107 & 110 & 135.12 & 136.38 \\
\hline 06 & P13W & 130.08 & 131.34 & 0 & 7 & 135.12 & 136.38 \\
\hline 06 & P13SS & 130.08 & 131.34 & 7 & 8 & 135.12 & 136.38 \\
\hline 06 & P13A & 130.08 & 131.34 & 8 & 13 & 135.12 & 136.38 \\
\hline 06 & $\mathrm{P} 13 \mathrm{~B}$ & 130.08 & 131.34 & 13 & 25 & 135.12 & 136.38 \\
\hline 06 & $\mathrm{P} 13 \mathrm{C}$ & 130.08 & 131.34 & 25 & 87 & 135.12 & 136.38 \\
\hline 06 & P13D & 130.08 & 131.34 & 87 & 103 & 135.12 & 136.38 \\
\hline 06 & P13E & 130.08 & 131.34 & 103 & 107 & 135.12 & 136.38 \\
\hline 06 & P13F & 130.08 & 131.34 & 107 & 110 & 135.12 & 136.38 \\
\hline 06 & $\mathrm{P} 14 \mathrm{~W}$ & 131.34 & 132.60 & 0 & 7 & 135.12 & 136.38 \\
\hline 06 & P14SS & 131.34 & 132.60 & 7 & 8 & 135.12 & 136.38 \\
\hline 06 & $\mathrm{P} 14 \mathrm{~A}$ & 131.34 & 132.60 & 8 & 13 & 135.12 & 136.38 \\
\hline 06 & $\mathrm{P} 14 \mathrm{~B}$ & 131.34 & 132.60 & 13 & 25 & 135.12 & 136.38 \\
\hline 06 & $\mathrm{P} 14 \mathrm{C}$ & 131.34 & 132.60 & 25 & 87 & 135.12 & 136.38 \\
\hline 06 & P14D & 131.34 & 132.60 & 87 & 103 & 135.12 & 136.38 \\
\hline 06 & P14E & 131.34 & 132.60 & 103 & 107 & 135.12 & 136.38 \\
\hline 06 & $\mathrm{P} 14 \mathrm{~F}$ & 131.34 & 132.60 & 107 & 110 & 135.12 & 136.38 \\
\hline 06 & P15W & 132.60 & 133.86 & 0 & 7 & 135.12 & 136.38 \\
\hline 06 & P15SS & 132.60 & 133.86 & 7 & 8 & 135.12 & 136.38 \\
\hline 06 & P15A & 132.60 & 133.86 & 8 & 13 & 135.12 & 136.38 \\
\hline 06 & P15B & 132.60 & 133.86 & 13 & 25 & 135.12 & 136.38 \\
\hline 06 & P15C & 132.60 & 133.86 & 25 & 87 & 135.12 & 136.38 \\
\hline 06 & P15D & 132.60 & 133.86 & 87 & 103 & 135.12 & 136.38 \\
\hline
\end{tabular}




\begin{tabular}{|c|c|c|c|c|c|c|c|}
\hline 06 & P15E & 132.60 & 133.86 & 103 & 107 & 135.12 & 136.38 \\
\hline 06 & P15F & 116.22 & 117.48 & 107 & 110 & 135.12 & 136.38 \\
\hline 06 & $\mathrm{P} 16 \mathrm{~W}$ & 133.86 & 135.12 & 0 & 7 & 135.12 & 136.38 \\
\hline 06 & P16SS & 133.86 & 135.12 & 7 & 8 & 135.12 & 136.38 \\
\hline 06 & P16A & 133.86 & 135.12 & 8 & 13 & 135.12 & 136.38 \\
\hline 06 & P16B & 133.86 & 135.12 & 13 & 25 & 135.12 & 136.38 \\
\hline 06 & P16C & 133.86 & 135.12 & 25 & 87 & 135.12 & 136.38 \\
\hline 06 & P16D & 133.86 & 135.12 & 87 & 103 & 135.12 & 136.38 \\
\hline 06 & P16E & 133.86 & 135.12 & 103 & 107 & 135.12 & 136.38 \\
\hline 06 & $\mathrm{P} 16 \mathrm{~F}$ & 133.86 & 135.12 & 107 & 110 & 135.12 & 136.38 \\
\hline 06 & $\mathrm{P} 18 \mathrm{~W}$ & 136.38 & 137.64 & 0 & 7 & 135.12 & 136.38 \\
\hline 06 & P18SS & 136.38 & 137.64 & 7 & 8 & 135.12 & 136.38 \\
\hline 06 & P18A & 136.38 & 137.64 & 8 & 13 & 135.12 & 136.38 \\
\hline 06 & P18B & 136.38 & 137.64 & 13 & 25 & 135.12 & 136.38 \\
\hline 06 & $\mathrm{P} 18 \mathrm{C}$ & 136.38 & 137.64 & 25 & 87 & 135.12 & 136.38 \\
\hline 06 & P18D & 136.38 & 137.64 & 87 & 103 & 135.12 & 136.38 \\
\hline 06 & $\mathrm{P} 18 \mathrm{E}$ & 136.38 & 137.64 & 103 & 107 & 135.12 & 136.38 \\
\hline 06 & $\mathrm{P} 18 \mathrm{~F}$ & 136.38 & 137.64 & 107 & 110 & 135.12 & 136.38 \\
\hline 06 & P19W & 137.64 & 138.90 & 0 & 7 & 135.12 & 136.38 \\
\hline 06 & P19SS & 137.64 & 138.90 & 7 & 8 & 135.12 & 136.38 \\
\hline 06 & P19A & 137.64 & 138.90 & 8 & 13 & 135.12 & 136.38 \\
\hline 06 & P19B & 137.64 & 138.90 & 13 & 25 & 135.12 & 136.38 \\
\hline 06 & P19C & 137.64 & 138.90 & 25 & 87 & 135.12 & 136.38 \\
\hline 06 & P19D & 137.64 & 138.90 & 87 & 103 & 135.12 & 136.38 \\
\hline 06 & P19E & 137.64 & 138.90 & 103 & 107 & 135.12 & 136.38 \\
\hline 06 & P19F & 137.64 & 138.90 & 107 & 110 & 135.12 & 136.38 \\
\hline 06 & P2 OW & 138.90 & 140.16 & 0 & 7 & 135.12 & 136.38 \\
\hline 06 & P2OSS & 138.90 & 140.16 & 7 & 8 & 135.12 & 136.38 \\
\hline 06 & P2 $0 A$ & 138.90 & 140.16 & 8 & 13 & 135.12 & 136.38 \\
\hline 06 & P2 OB & 138.90 & 140.16 & 13 & 25 & 135.12 & 136.38 \\
\hline 06 & P20C & 138.90 & 140.16 & 25 & 87 & 135.12 & 136.38 \\
\hline 06 & P2 OD & 138.90 & 140.16 & 87 & 103 & 135.12 & 136.38 \\
\hline 06 & P2 OE & 138.90 & 140.16 & 103 & 107 & 135.12 & 136.38 \\
\hline 06 & P20F & 138.90 & 140.16 & 107 & 110 & 135.12 & 136.38 \\
\hline 06 & P21W & 140.16 & 141.42 & 0 & 7 & 135.12 & 136.38 \\
\hline 06 & P21SS & 140.16 & 141.42 & 7 & 8 & 135.12 & 136.38 \\
\hline 06 & P21A & 140.16 & 141.42 & 8 & 13 & 135.12 & 136.38 \\
\hline 06 & P21B & 140.16 & 141.42 & 13 & 25 & 135.12 & 136.38 \\
\hline 06 & P21C & 140.16 & 141.42 & 25 & 87 & 135.12 & 136.38 \\
\hline 06 & P21D & 140.16 & 141.42 & 87 & 103 & 135.12 & 136.38 \\
\hline 06 & P21E & 140.16 & 141.42 & 103 & 107 & 135.12 & 136.38 \\
\hline 06 & P21F & 140.16 & 141.42 & 107 & 110 & 135.12 & 136.38 \\
\hline 06 & P22W & 141.42 & 142.68 & 0 & 7 & 135.12 & 136.38 \\
\hline 06 & P22SS & 141.42 & 142.68 & 7 & 8 & 135.12 & 136.38 \\
\hline 06 & P22A & 141.42 & 142.68 & 8 & 13 & 135.12 & 136.38 \\
\hline 06 & P2 2B & 141.42 & 142.68 & 13 & 25 & 135.12 & 136.38 \\
\hline 06 & P22C & 141.42 & 142.68 & 25 & 87 & 135.12 & 136.38 \\
\hline 06 & P2 2D & 141.42 & 142.68 & 87 & 103 & 135.12 & 136.38 \\
\hline 06 & P22E & 141.42 & 142.68 & 103 & 107 & 135.12 & 136.38 \\
\hline 06 & P2 $2 \mathrm{~F}$ & 141.42 & 142.68 & 107 & 110 & 135.12 & 136.38 \\
\hline 06 & P23W & 142.68 & 143.94 & 0 & 7 & 135.12 & 136.38 \\
\hline 06 & P23SS & 142.68 & 143.94 & 7 & 8 & 135.12 & 136.38 \\
\hline 06 & P23A & 142.68 & 143.94 & 8 & 13 & 135.12 & 136.38 \\
\hline 06 & P23B & 142.68 & 143.94 & 13 & 25 & 135.12 & 136.38 \\
\hline 06 & P23C & 142.68 & 143.94 & 25 & 87 & 135.12 & 136.38 \\
\hline 06 & P23D & 142.68 & 143.94 & 87 & 103 & 135.12 & 136.38 \\
\hline 06 & P23E & 142.68 & 143.94 & 103 & 107 & 135.12 & 136.38 \\
\hline 06 & P2 $3 \mathrm{~F}$ & 142.68 & 143.94 & 107 & 110 & 135.12 & 136.38 \\
\hline 06 & P24W & 143.94 & 145.20 & 0 & 7 & 135.12 & 136.38 \\
\hline 06 & P24SS & 143.94 & 145.20 & 7 & 8 & 135.12 & 136.38 \\
\hline 06 & P2 $4 \mathrm{~A}$ & 143.94 & 145.20 & 8 & 13 & 135.12 & 136.38 \\
\hline 06 & P2 $4 B$ & 143.94 & 145.20 & 13 & 25 & 135.12 & 136.38 \\
\hline 06 & P2 4C & 143.94 & 145.20 & 25 & 87 & 135.12 & 136.38 \\
\hline 06 & P2 4D & 143.94 & 145.20 & 87 & 103 & 135.12 & 136.38 \\
\hline 06 & P24E & 143.94 & 145.20 & 103 & 107 & 135.12 & 136.38 \\
\hline 06 & P2 $4 \mathrm{~F}$ & 143.94 & 145.20 & 107 & 110 & 135.12 & 136.38 \\
\hline 06 & P25W & 145.20 & 146.46 & 0 & 7 & 135.12 & 136.38 \\
\hline 06 & P25SS & 145.20 & 146.46 & 7 & 8 & 135.12 & 136.38 \\
\hline 06 & P2 5A & 145.20 & 146.46 & 8 & 13 & 135.12 & 136.38 \\
\hline 06 & P25B & 145.20 & 146.46 & 13 & 25 & 135.12 & 136.38 \\
\hline 06 & P25C & 145.20 & 146.46 & 25 & 87 & 135.12 & 136.38 \\
\hline 06 & P25D & 145.20 & 146.46 & 87 & 103 & 135.12 & 136.38 \\
\hline
\end{tabular}




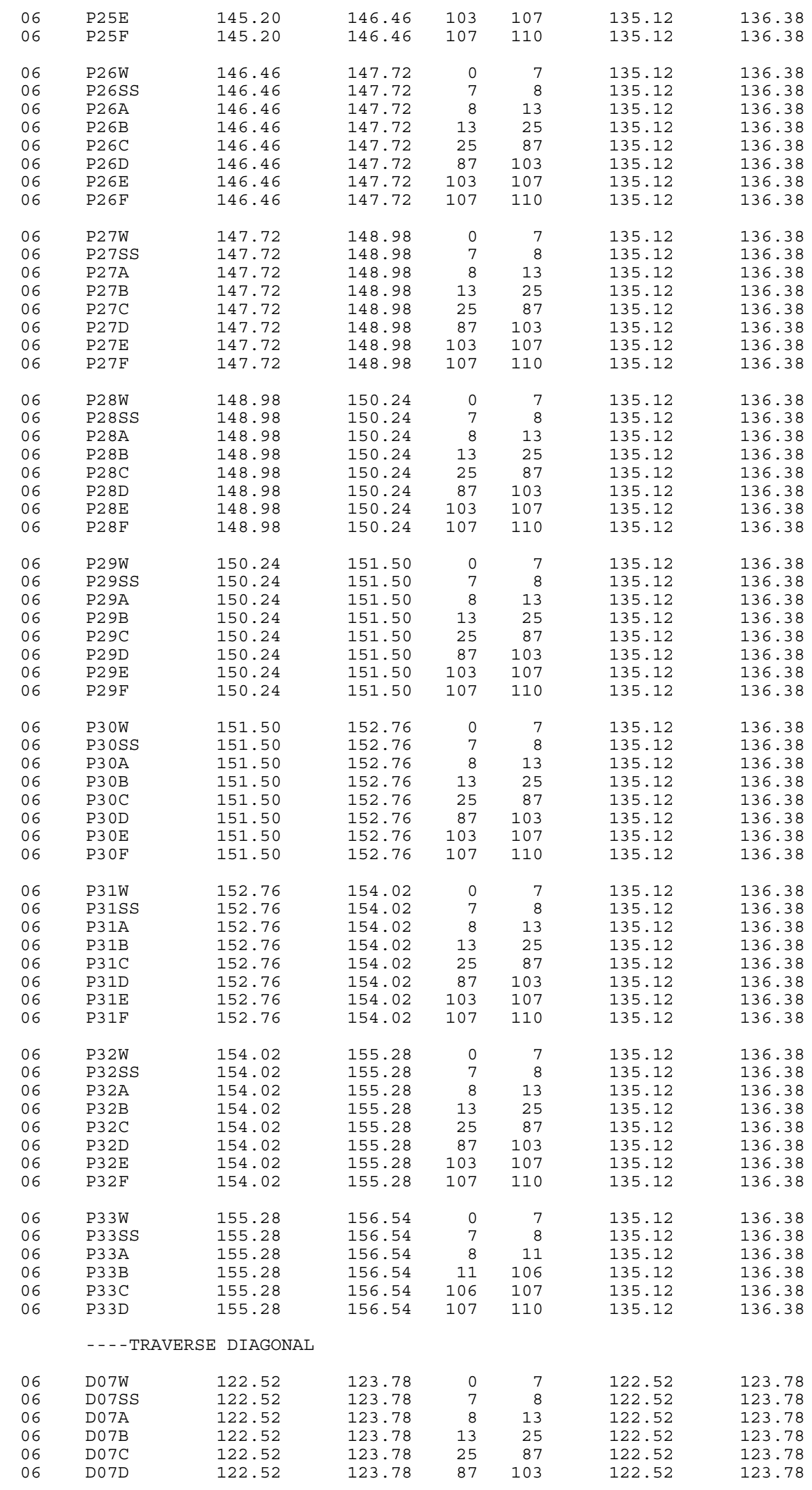




\begin{tabular}{|c|c|c|c|c|c|c|c|}
\hline 06 & D07E & 122.52 & 123.78 & 103 & 107 & 122.52 & 123.78 \\
\hline 06 & D07F & 122.52 & 123.78 & 107 & 110 & 122.52 & 123.78 \\
\hline 06 & $\mathrm{D} 08 \mathrm{~W}$ & 123.78 & 125.04 & 0 & 7 & 123.78 & 125.04 \\
\hline 06 & D08SS & 123.78 & 125.04 & 7 & 8 & 123.78 & 125.04 \\
\hline 06 & D08A & 123.78 & 125.04 & 8 & 13 & 123.78 & 125.04 \\
\hline 06 & D08B & 123.78 & 125.04 & 13 & 25 & 123.78 & 125.04 \\
\hline 06 & D08C & 123.78 & 125.04 & 25 & 87 & 123.78 & 125.04 \\
\hline 06 & D08D & 123.78 & 125.04 & 87 & 103 & 123.78 & 125.04 \\
\hline 06 & D08E & 123.78 & 125.04 & 103 & 107 & 123.78 & 125.04 \\
\hline 06 & $\mathrm{D} 08 \mathrm{~F}$ & 123.78 & 125.04 & 107 & 110 & 123.78 & 125.04 \\
\hline 06 & D09W & 125.04 & 126.30 & 0 & 7 & 125.04 & 126.30 \\
\hline 06 & D09SS & 125.04 & 126.30 & 7 & 8 & 125.04 & 126.30 \\
\hline 06 & D09A & 125.04 & 126.30 & 8 & 13 & 125.04 & 126.30 \\
\hline 06 & D09B & 125.04 & 126.30 & 13 & 25 & 125.04 & 126.30 \\
\hline 06 & D09C & 125.04 & 126.30 & 25 & 87 & 125.04 & 126.30 \\
\hline 06 & D09D & 125.04 & 126.30 & 87 & 103 & 125.04 & 126.30 \\
\hline 06 & D09E & 125.04 & 126.30 & 103 & 107 & 125.04 & 126.30 \\
\hline 06 & D09F & 125.04 & 126.30 & 107 & 110 & 125.04 & 126.30 \\
\hline 06 & D10W & 126.30 & 127.56 & 0 & 7 & 126.30 & 127.56 \\
\hline 06 & D10SS & 126.30 & 127.56 & 7 & 8 & 126.30 & 127.56 \\
\hline 06 & D10A & 126.30 & 127.56 & 8 & 13 & 126.30 & 127.56 \\
\hline 06 & $\mathrm{D} 10 \mathrm{~B}$ & 126.30 & 127.56 & 13 & 25 & 126.30 & 127.56 \\
\hline 06 & $\mathrm{D} 10 \mathrm{C}$ & 126.30 & 127.56 & 25 & 87 & 126.30 & 127.56 \\
\hline 06 & D10D & 126.30 & 127.56 & 87 & 103 & 126.30 & 127.56 \\
\hline 06 & D10E & 126.30 & 127.56 & 103 & 107 & 126.30 & 127.56 \\
\hline 06 & D10F & 126.30 & 127.56 & 107 & 110 & 126.30 & 127.56 \\
\hline 06 & $\mathrm{D} 11 \mathrm{~W}$ & 127.56 & 128.82 & 0 & 7 & 127.56 & 128.82 \\
\hline 06 & D11SS & 127.56 & 128.82 & 7 & 8 & 127.56 & 128.82 \\
\hline 06 & D11A & 127.56 & 128.82 & 8 & 13 & 127.56 & 128.82 \\
\hline 06 & $\mathrm{D} 11 \mathrm{~B}$ & 127.56 & 128.82 & 13 & 25 & 127.56 & 128.82 \\
\hline 06 & $\mathrm{D} 11 \mathrm{C}$ & 127.56 & 128.82 & 25 & 87 & 127.56 & 128.82 \\
\hline 06 & D11D & 127.56 & 128.82 & 87 & 103 & 127.56 & 128.82 \\
\hline 06 & $\mathrm{D} 11 \mathrm{E}$ & 127.56 & 128.82 & 103 & 107 & 127.56 & 128.82 \\
\hline 06 & $\mathrm{D} 11 \mathrm{~F}$ & 127.56 & 128.82 & 107 & 110 & 127.56 & 128.82 \\
\hline 06 & $\mathrm{D} 12 \mathrm{~W}$ & 128.82 & 130.08 & 0 & 7 & 128.82 & 130.08 \\
\hline 06 & D12SS & 128.82 & 130.08 & 7 & 8 & 128.82 & 130.08 \\
\hline 06 & $\mathrm{D} 12 \mathrm{~A}$ & 128.82 & 130.08 & 8 & 13 & 128.82 & 130.08 \\
\hline 06 & $\mathrm{D} 12 \mathrm{~B}$ & 128.82 & 130.08 & 13 & 25 & 128.82 & 130.08 \\
\hline 06 & $\mathrm{D} 12 \mathrm{C}$ & 128.82 & 130.08 & 25 & 87 & 128.82 & 130.08 \\
\hline 06 & D12D & 128.82 & 130.08 & 87 & 103 & 128.82 & 130.08 \\
\hline 06 & $\mathrm{D} 12 \mathrm{E}$ & 128.82 & 130.08 & 103 & 107 & 128.82 & 130.08 \\
\hline 06 & $\mathrm{D} 12 \mathrm{~F}$ & 128.82 & 130.08 & 107 & 110 & 128.82 & 130.08 \\
\hline 06 & D13W & 130.08 & 131.34 & 0 & 7 & 130.08 & 131.34 \\
\hline 06 & D13SS & 130.08 & 131.34 & 7 & 8 & 130.08 & 131.34 \\
\hline 06 & D13A & 130.08 & 131.34 & 8 & 13 & 130.08 & 131.34 \\
\hline 06 & D13B & 130.08 & 131.34 & 13 & 25 & 130.08 & 131.34 \\
\hline 06 & D13C & 130.08 & 131.34 & 25 & 87 & 130.08 & 131.34 \\
\hline 06 & D13D & 130.08 & 131.34 & 87 & 103 & 130.08 & 131.34 \\
\hline 06 & D13E & 130.08 & 131.34 & 103 & 107 & 130.08 & 131.34 \\
\hline 06 & D13F & 130.08 & 131.34 & 107 & 110 & 130.08 & 131.34 \\
\hline 06 & $\mathrm{D} 14 \mathrm{~W}$ & 131.34 & 132.60 & 0 & 7 & 131.34 & 132.60 \\
\hline 06 & D14SS & 131.34 & 132.60 & 7 & 8 & 131.34 & 132.60 \\
\hline 06 & $\mathrm{D} 14 \mathrm{~A}$ & 131.34 & 132.60 & 8 & 13 & 131.34 & 132.60 \\
\hline 06 & $\mathrm{D} 14 \mathrm{~B}$ & 131.34 & 132.60 & 13 & 25 & 131.34 & 132.60 \\
\hline 06 & $\mathrm{D} 14 \mathrm{C}$ & 131.34 & 132.60 & 25 & 87 & 131.34 & 132.60 \\
\hline 06 & D14D & 131.34 & 132.60 & 87 & 103 & 131.34 & 132.60 \\
\hline 06 & $\mathrm{D} 14 \mathrm{E}$ & 131.34 & 132.60 & 103 & 107 & 131.34 & 132.60 \\
\hline 06 & $\mathrm{D} 14 \mathrm{~F}$ & 131.34 & 132.60 & 107 & 110 & 131.34 & 132.60 \\
\hline 06 & D15W & 132.60 & 133.86 & 0 & 7 & 132.60 & 133.86 \\
\hline 06 & D15SS & 132.60 & 133.86 & 7 & 8 & 132.60 & 133.86 \\
\hline 06 & D15A & 132.60 & 133.86 & 8 & 13 & 132.60 & 133.86 \\
\hline 06 & D15B & 132.60 & 133.86 & 13 & 25 & 132.60 & 133.86 \\
\hline 06 & D15C & 132.60 & 133.86 & 25 & 87 & 132.60 & 133.86 \\
\hline 06 & D15D & 132.60 & 133.86 & 87 & 103 & 132.60 & 133.86 \\
\hline 06 & D15E & 132.60 & 133.86 & 103 & 107 & 132.60 & 133.86 \\
\hline 06 & $\mathrm{D} 15 \mathrm{~F}$ & 132.60 & 133.86 & 107 & 110 & 132.60 & 133.86 \\
\hline 06 & D16W & 133.86 & 135.12 & 0 & 7 & 133.86 & 135.12 \\
\hline 06 & D16SS & 133.86 & 135.12 & 7 & 8 & 133.86 & 135.12 \\
\hline 06 & D16A & 133.86 & 135.12 & 8 & 13 & 133.86 & 135.12 \\
\hline 06 & D16B & 133.86 & 135.12 & 13 & 25 & 133.86 & 135.12 \\
\hline 06 & $\mathrm{D} 16 \mathrm{C}$ & 133.86 & 135.12 & 25 & 87 & 133.86 & 135.12 \\
\hline 06 & D16D & 133.86 & 135.12 & 87 & 103 & 133.86 & 135.12 \\
\hline
\end{tabular}




\begin{tabular}{|c|c|c|c|c|c|c|c|}
\hline 06 & $\mathrm{D} 16 \mathrm{E}$ & 133.86 & 135.12 & 103 & 107 & 133.86 & 135.12 \\
\hline 06 & $\mathrm{D} 16 \mathrm{~F}$ & 133.86 & 135.12 & 107 & 110 & 133.86 & 135.12 \\
\hline 06 & D18W & 136.38 & 137.64 & 0 & 7 & 136.38 & 137.64 \\
\hline 06 & D18SS & 136.38 & 137.64 & 7 & 8 & 136.38 & 137.64 \\
\hline 06 & D18A & 136.38 & 137.64 & 8 & 13 & 136.38 & 137.64 \\
\hline 06 & D18B & 136.38 & 137.64 & 13 & 25 & 136.38 & 137.64 \\
\hline 06 & $\mathrm{D} 18 \mathrm{C}$ & 136.38 & 137.64 & 25 & 87 & 136.38 & 137.64 \\
\hline 06 & D18D & 136.38 & 137.64 & 87 & 103 & 136.38 & 137.64 \\
\hline 06 & $\mathrm{D} 18 \mathrm{E}$ & 136.38 & 137.64 & 103 & 107 & 136.38 & 137.64 \\
\hline 06 & $\mathrm{D} 18 \mathrm{~F}$ & 136.38 & 137.64 & 107 & 110 & 136.38 & 137.64 \\
\hline 06 & D19W & 137.64 & 138.90 & 0 & 7 & 137.64 & 138.90 \\
\hline 06 & D19SS & 137.64 & 138.90 & 7 & 8 & 137.64 & 138.90 \\
\hline 06 & D19A & 137.64 & 138.90 & 8 & 13 & 137.64 & 138.90 \\
\hline 06 & D19B & 137.64 & 138.90 & 13 & 25 & 137.64 & 138.90 \\
\hline 06 & D19C & 137.64 & 138.90 & 25 & 87 & 137.64 & 138.90 \\
\hline 06 & D19D & 137.64 & 138.90 & 87 & 103 & 137.64 & 138.90 \\
\hline 06 & D19E & 137.64 & 138.90 & 103 & 107 & 137.64 & 138.90 \\
\hline 06 & D19F & 137.64 & 138.90 & 107 & 110 & 137.64 & 138.90 \\
\hline 06 & D2 OW & 138.90 & 140.16 & 0 & 7 & 138.90 & 140.16 \\
\hline 06 & D20SS & 138.90 & 140.16 & 7 & 8 & 138.90 & 140.16 \\
\hline 06 & $\mathrm{D} 20 \mathrm{~A}$ & 138.90 & 140.16 & 8 & 13 & 138.90 & 140.16 \\
\hline 06 & D20B & 138.90 & 140.16 & 13 & 25 & 138.90 & 140.16 \\
\hline 06 & $\mathrm{D} 20 \mathrm{C}$ & 138.90 & 140.16 & 25 & 87 & 138.90 & 140.16 \\
\hline 06 & $\mathrm{D} 20 \mathrm{D}$ & 138.90 & 140.16 & 87 & 103 & 138.90 & 140.16 \\
\hline 06 & $\mathrm{D} 20 \mathrm{E}$ & 138.90 & 140.16 & 103 & 107 & 138.90 & 140.16 \\
\hline 06 & D20F & 138.90 & 140.16 & 107 & 110 & 138.90 & 140.16 \\
\hline 06 & $\mathrm{D} 21 \mathrm{~W}$ & 140.16 & 141.42 & 0 & 7 & 140.16 & 141.42 \\
\hline 06 & D21SS & 140.16 & 141.42 & 7 & 8 & 140.16 & 141.42 \\
\hline 06 & D21A & 140.16 & 141.42 & 8 & 13 & 140.16 & 141.42 \\
\hline 06 & D21B & 140.16 & 141.42 & 13 & 25 & 140.16 & 141.42 \\
\hline 06 & D21C & 140.16 & 141.42 & 25 & 87 & 140.16 & 141.42 \\
\hline 06 & D21D & 140.16 & 141.42 & 87 & 103 & 140.16 & 141.42 \\
\hline 06 & D21E & 140.16 & 141.42 & 103 & 107 & 140.16 & 141.42 \\
\hline 06 & $\mathrm{D} 21 \mathrm{~F}$ & 140.16 & 141.42 & 107 & 110 & 140.16 & 141.42 \\
\hline 06 & $\mathrm{D} 22 \mathrm{~W}$ & 141.42 & 142.68 & 0 & 7 & 141.42 & 142.68 \\
\hline 06 & D22SS & 141.42 & 142.68 & 7 & 8 & 141.42 & 142.68 \\
\hline 06 & $\mathrm{D} 22 \mathrm{~A}$ & 141.42 & 142.68 & 8 & 13 & 141.42 & 142.68 \\
\hline 06 & D22B & 141.42 & 142.68 & 13 & 25 & 141.42 & 142.68 \\
\hline 06 & $\mathrm{D} 22 \mathrm{C}$ & 141.42 & 142.68 & 25 & 87 & 141.42 & 142.68 \\
\hline 06 & D22D & 141.42 & 142.68 & 87 & 103 & 141.42 & 142.68 \\
\hline 06 & $\mathrm{D} 22 \mathrm{E}$ & 141.42 & 142.68 & 103 & 107 & 141.42 & 142.68 \\
\hline 06 & D22F & 141.42 & 142.68 & 107 & 110 & 141.42 & 142.68 \\
\hline 06 & D23W & 142.68 & 143.94 & 0 & 7 & 142.68 & 143.94 \\
\hline 06 & D23SS & 142.68 & 143.94 & 7 & 8 & 142.68 & 143.94 \\
\hline 06 & D23A & 142.68 & 143.94 & 8 & 13 & 142.68 & 143.94 \\
\hline 06 & D23B & 142.68 & 143.94 & 13 & 25 & 142.68 & 143.94 \\
\hline 06 & D23C & 142.68 & 143.94 & 25 & 87 & 142.68 & 143.94 \\
\hline 06 & D23D & 142.68 & 143.94 & 87 & 103 & 142.68 & 143.94 \\
\hline 06 & D23E & 142.68 & 143.94 & 103 & 107 & 142.68 & 143.94 \\
\hline 06 & D23F & 142.68 & 143.94 & 107 & 110 & 142.68 & 143.94 \\
\hline 06 & $\mathrm{D} 24 \mathrm{~W}$ & 143.94 & 145.20 & 0 & 7 & 143.94 & 145.20 \\
\hline 06 & $\mathrm{D} 24 \mathrm{SS}$ & 143.94 & 145.20 & 7 & 8 & 143.94 & 145.20 \\
\hline 06 & D24A & 143.94 & 145.20 & 8 & 13 & 143.94 & 145.20 \\
\hline 06 & D2 4B & 143.94 & 145.20 & 13 & 25 & 143.94 & 145.20 \\
\hline 06 & $\mathrm{D} 24 \mathrm{C}$ & 143.94 & 145.20 & 25 & 87 & 143.94 & 145.20 \\
\hline 06 & D2 4D & 143.94 & 145.20 & 87 & 103 & 143.94 & 145.20 \\
\hline 06 & $\mathrm{D} 24 \mathrm{E}$ & 143.94 & 145.20 & 103 & 107 & 143.94 & 145.20 \\
\hline 06 & $\mathrm{D} 24 \mathrm{~F}$ & 143.94 & 145.20 & 107 & 110 & 143.94 & 145.20 \\
\hline 06 & $\mathrm{D} 25 \mathrm{~W}$ & 145.20 & 146.46 & 0 & 7 & 145.20 & 146.46 \\
\hline 06 & D25SS & 145.20 & 146.46 & 7 & 8 & 145.20 & 146.46 \\
\hline 06 & D25A & 145.20 & 146.46 & 8 & 13 & 145.20 & 146.46 \\
\hline 06 & D25B & 145.20 & 146.46 & 13 & 25 & 145.20 & 146.46 \\
\hline 06 & D25C & 145.20 & 146.46 & 25 & 87 & 145.20 & 146.46 \\
\hline 06 & D25D & 145.20 & 146.46 & 87 & 103 & 145.20 & 146.46 \\
\hline 06 & D25E & 145.20 & 146.46 & 103 & 107 & 145.20 & 146.46 \\
\hline 06 & D25F & 145.20 & 146.46 & 107 & 110 & 145.20 & 146.46 \\
\hline 06 & $\mathrm{D} 26 \mathrm{~W}$ & 146.46 & 147.72 & 0 & 7 & 146.46 & 147.72 \\
\hline 06 & D26SS & 146.46 & 147.72 & 7 & 8 & 146.46 & 147.72 \\
\hline 06 & D26A & 146.46 & 147.72 & 8 & 13 & 146.46 & 147.72 \\
\hline 06 & D26B & 146.46 & 147.72 & 13 & 25 & 146.46 & 147.72 \\
\hline 06 & $\mathrm{D} 26 \mathrm{C}$ & 146.46 & 147.72 & 25 & 87 & 146.46 & 147.72 \\
\hline 06 & D26D & 146.46 & 147.72 & 87 & 103 & 146.46 & 147.72 \\
\hline
\end{tabular}




\begin{tabular}{|c|c|c|c|c|c|c|c|}
\hline 06 & $\mathrm{D} 26 \mathrm{E}$ & 146.46 & 147.72 & 103 & 107 & 146.46 & 147.72 \\
\hline 06 & $\mathrm{D} 26 \mathrm{~F}$ & 146.46 & 147.72 & 107 & 110 & 146.46 & 147.72 \\
\hline 06 & D2 7W & 147.72 & 148.98 & 0 & 7 & 147.72 & 148.98 \\
\hline 06 & D27SS & 147.72 & 148.98 & 7 & 8 & 147.72 & 148.98 \\
\hline 06 & D27A & 147.72 & 148.98 & 8 & 13 & 147.72 & 148.98 \\
\hline 06 & D27B & 147.72 & 148.98 & 13 & 25 & 147.72 & 148.98 \\
\hline 06 & D27C & 147.72 & 148.98 & 25 & 87 & 147.72 & 148.98 \\
\hline 06 & D27D & 147.72 & 148.98 & 87 & 103 & 147.72 & 148.98 \\
\hline 06 & D27E & 147.72 & 148.98 & 103 & 107 & 147.72 & 148.98 \\
\hline 06 & D27F & 147.72 & 148.98 & 107 & 110 & 147.72 & 148.98 \\
\hline & $\begin{array}{r}--- \text { RIMOX } \\
----O S C I I\end{array}$ & $\begin{array}{ll}\text { CENTRAL CHANN } \\
\text { LLATION TUBE }\end{array}$ & $\begin{array}{l}\mathrm{EL} \\
\text { (UP) }\end{array}$ & & & & \\
\hline 06 & ORW & 135.12 & 136.38 & 0 & 10 & 135.12 & 136.38 \\
\hline 06 & ORB & 135.12 & 136.38 & 10 & 16 & 135.12 & 136.38 \\
\hline 06 & ORL & 135.12 & 136.38 & 16 & 51 & 135.12 & 136.38 \\
\hline 06 & ORSAM & 135.12 & 136.38 & 51 & 61 & 135.12 & 136.38 \\
\hline 06 & $\begin{array}{c}\text { ORU } \\
--- \text { POLINE }\end{array}$ & $\begin{array}{l}135.12 \\
\text { OVERCLAD }\end{array}$ & 136.38 & 61 & 116 & 135.12 & 136.38 \\
\hline 06 & POLW & 135.12 & 136.38 & 0 & 11 & 135.12 & 136.38 \\
\hline 06 & POLC & 135.12 & 136.38 & 11 & 116 & 135.12 & 136.38 \\
\hline
\end{tabular}

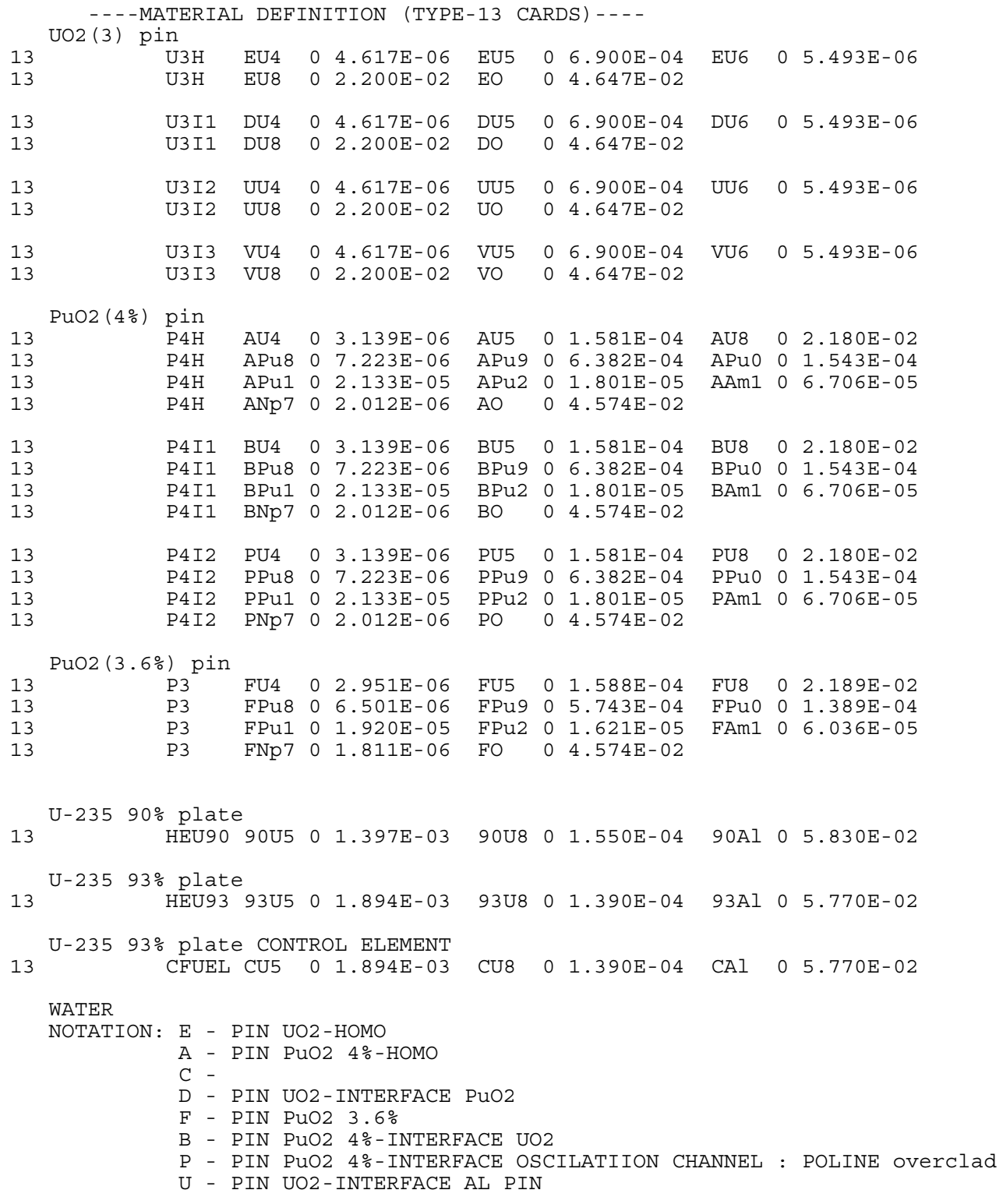




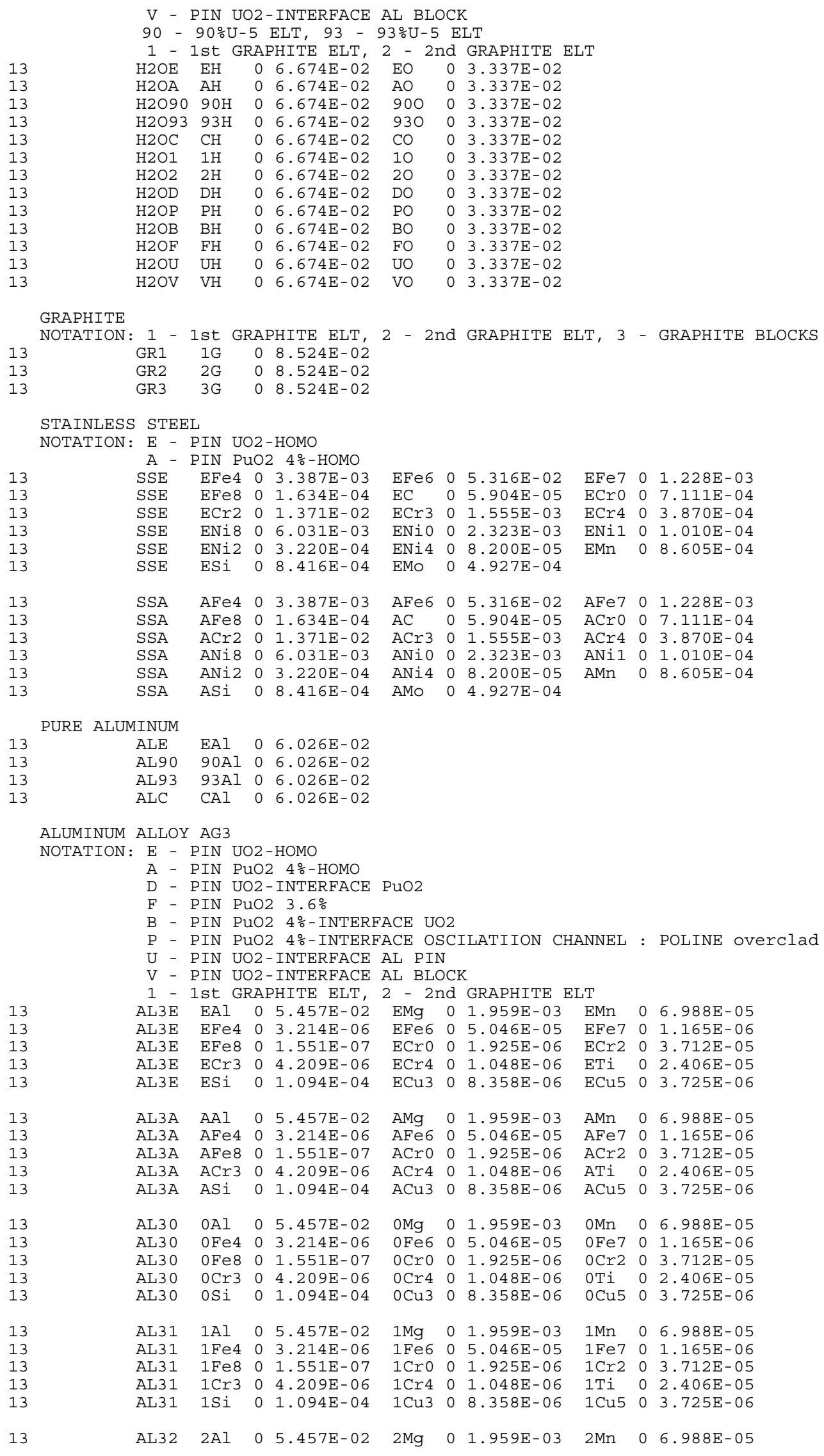




\begin{tabular}{|c|c|c|c|c|c|c|c|c|c|c|c|}
\hline 13 & & AL32 & $2 \mathrm{Fe} 4$ & 0 & $3.214 E-06$ & $2 \mathrm{Fe} 6$ & 0 & $5.046 E-05$ & $2 \mathrm{Fe} 7$ & 0 & $1.165 \mathrm{E}-06$ \\
\hline 13 & & AL32 & $2 \mathrm{Fe} 8$ & 0 & $1.551 E-07$ & $2 \mathrm{CrO}$ & 0 & $1.925 E-06$ & $2 \mathrm{Cr} 2$ & 0 & $3.712 E-05$ \\
\hline 13 & & AL32 & $2 \mathrm{Cr} 3$ & 0 & $4.209 E-06$ & $2 \mathrm{Cr} 4$ & 0 & $1.048 E-06$ & $2 \mathrm{Ti}$ & 0 & $2.406 E-05$ \\
\hline 13 & & AL32 & $2 \mathrm{Si}$ & 0 & $1.094 \mathrm{E}-04$ & $2 \mathrm{Cu} 3$ & 0 & $8.358 E-06$ & $2 \mathrm{Cu} 5$ & 0 & $3.725 E-06$ \\
\hline 13 & & AL33 & $3 \mathrm{Al}$ & 0 & $5.457 \mathrm{E}-02$ & $3 \mathrm{Mg}$ & 0 & $1.959 \mathrm{E}-03$ & $3 \mathrm{Mn}$ & 0 & $6.988 E-05$ \\
\hline 13 & & AL33 & $3 \mathrm{Fe} 4$ & 0 & $3.214 \mathrm{E}-06$ & $3 \mathrm{Fe} 6$ & 0 & $5.046 \mathrm{E}-05$ & $3 \mathrm{Fe} 7$ & 0 & $1.165 E-06$ \\
\hline 13 & & AL33 & $3 \mathrm{Fe} 8$ & 0 & $1.551 E-07$ & $3 \mathrm{CrO}$ & 0 & 1.925E-06 & $3 \mathrm{Cr} 2$ & 0 & $3.712 \mathrm{E}-05$ \\
\hline 13 & & AL33 & $3 \mathrm{Cr} 3$ & 0 & $4.209 E-06$ & $3 \operatorname{Cr} 4$ & 0 & $1.048 E-06$ & $3 \mathrm{Ti}$ & 0 & $2.406 \mathrm{E}-05$ \\
\hline 13 & & AL33 & $3 S i$ & 0 & $1.094 \mathrm{E}-04$ & $3 \mathrm{Cu} 3$ & 0 & $8.358 E-06$ & $3 \mathrm{Cu} 5$ & 0 & $3.725 E-06$ \\
\hline 13 & & AL3D & DAl & 0 & $5.457 E-02$ & DMg & 0 & $1.959 \mathrm{E}-03$ & $\mathrm{DMn}$ & 0 & $6.988 E-05$ \\
\hline 13 & & AL3D & DFe4 & 0 & $3.214 E-06$ & DFe 6 & 0 & $5.046 E-05$ & DFe7 & 0 & $1.165 E-06$ \\
\hline 13 & & AL3D & DFe8 & 0 & $1.551 E-07$ & $\mathrm{DCr} 0$ & 0 & 1.925E-06 & $\mathrm{DCr} 2$ & 0 & $3.712 \mathrm{E}-05$ \\
\hline 13 & & AL3D & $\mathrm{DCr} 3$ & 0 & $4.209 E-06$ & $\mathrm{DCr} 4$ & 0 & $1.048 E-06$ & DTi & 0 & $2.406 E-05$ \\
\hline 13 & & AL3D & DSi & 0 & $1.094 \mathrm{E}-04$ & DCu3 & 0 & $8.358 E-06$ & DCu5 & 0 & $3.725 \mathrm{E}-06$ \\
\hline 13 & & AL3F & FAl & 0 & $5.457 \mathrm{E}-02$ & FMg & 0 & $1.959 \mathrm{E}-03$ & FMn & 0 & $6.988 E-05$ \\
\hline 13 & & AL3F & $\mathrm{FFe} 4$ & 0 & $3.214 E-06$ & FFe6 & 0 & $5.046 E-05$ & FFe7 & 0 & $1.165 E-06$ \\
\hline 13 & & AL3F & FFe 8 & 0 & $1.551 \mathrm{E}-07$ & FCro & 0 & 1. $925 \mathrm{E}-06$ & $\mathrm{FCr} 2$ & 0 & $3.712 \mathrm{E}-05$ \\
\hline 13 & & AL3F & $\mathrm{FCr} 3$ & 0 & $4.209 E-06$ & $\mathrm{FCr} 4$ & 0 & $1.048 \mathrm{E}-06$ & FTi & 0 & $2.406 E-05$ \\
\hline 13 & & $\operatorname{AL} 3 \mathrm{~F}$ & FSi & 0 & $1.094 \mathrm{E}-04$ & FCu3 & 0 & $8.358 E-06$ & FCu5 & 0 & $3.725 E-06$ \\
\hline 13 & & $A L 3 B$ & $\mathrm{BAl}$ & 0 & $5.457 \mathrm{E}-02$ & $\mathrm{BMg}$ & 0 & $1.959 \mathrm{E}-03$ & $\mathrm{BMn}$ & 0 & $6.988 E-05$ \\
\hline 13 & & AL3B & $\mathrm{BFe} 4$ & $=0$ & $3.214 E-06$ & BFe6 & 0 & $5.046 E-05$ & BFe7 & 0 & $1.165 E-06$ \\
\hline 13 & & AL3B & $\mathrm{BFe} 8$ & 0 & $1.551 E-07$ & BCro & 0 & $1.925 \mathrm{E}-06$ & $\mathrm{BCr} 2$ & 0 & $3.712 E-05$ \\
\hline 13 & & AL3B & $\mathrm{BCr} 3$ & 0 & $4.209 E-06$ & $\mathrm{BCr} 4$ & 0 & $1.048 E-06$ & $\mathrm{BTi}$ & 0 & $2.406 E-05$ \\
\hline 13 & & AL 3B & $\mathrm{BSi}$ & 0 & $1.094 \mathrm{E}-04$ & $\mathrm{BCu} 3$ & 0 & $8.358 E-06$ & $\mathrm{BCu} 5$ & 0 & $3.725 E-06$ \\
\hline 13 & & AL3U & UAI & 0 & $5.457 E-02$ & UMg & 0 & $1.959 \mathrm{E}-03$ & UMn & 0 & $6.988 E-05$ \\
\hline 13 & & AL3U & UFe4 & 0 & $3.214 E-06$ & UFe6 & 0 & $5.046 E-05$ & UFe7 & 0 & $1.165 E-06$ \\
\hline 13 & & AL3U & UFe 8 & 0 & $1.551 \mathrm{E}-07$ & $\mathrm{UCrO}$ & 0 & $1.925 \mathrm{E}-06$ & $\mathrm{UCr} 2$ & 0 & $3.712 \mathrm{E}-05$ \\
\hline 13 & & AL3U & $\mathrm{UCr} 3$ & 0 & $4.209 E-06$ & UCr4 & 0 & $1.048 E-06$ & UTi & 0 & $2.406 E-05$ \\
\hline 13 & & $\mathrm{AL} 3 \mathrm{U}$ & USi & 0 & $1.094 \mathrm{E}-04$ & UCu3 & 0 & $8.358 E-06$ & UCu5 & 0 & $3.725 E-06$ \\
\hline 13 & & AL3V & VAI & 0 & $5.457 E-02$ & VMg & 0 & $1.959 \mathrm{E}-03$ & VMn & 0 & $6.988 E-05$ \\
\hline 13 & & AL3V & VFe4 & 0 & $3.214 E-06$ & VFe6 & 0 & $5.046 E-05$ & VFe7 & 0 & $1.165 E-06$ \\
\hline 13 & & AL3V & VFe 8 & 0 & $1.551 E-07$ & VCro & 0 & 1. $925 E-06$ & $\mathrm{VCr} 2$ & 0 & $3.712 E-05$ \\
\hline 13 & & AL3V & $\mathrm{VCr} 3$ & 0 & $4.209 E-06$ & VCr4 & 0 & $1.048 E-06$ & VTi & 0 & $2.406 E-05$ \\
\hline 13 & & AL3V & VSi & 0 & $1.094 \mathrm{E}-04$ & VCu3 & 0 & $8.358 E-06$ & vCu5 & 0 & $3.725 E-06$ \\
\hline 13 & & AL3P & PAl & 0 & $5.457 \mathrm{E}-02$ & PMg & 0 & $1.959 \mathrm{E}-03$ & $\mathrm{PMn}$ & 0 & $6.988 E-05$ \\
\hline 13 & & AL3P & $\mathrm{PFe} 4$ & 0 & $3.214 E-06$ & PFe6 & 0 & $5.046 E-05$ & PFe7 & 0 & $1.165 E-06$ \\
\hline 13 & & AL3P & PFe 8 & 0 & $1.551 E-07$ & PCro & 0 & 1.925E-06 & $\mathrm{PCr} 2$ & 0 & $3.712 E-05$ \\
\hline 13 & & AL3P & $\mathrm{PCr} 3$ & 0 & $4.209 E-06$ & $\mathrm{PCr} 4$ & 0 & $1.048 \mathrm{E}-06$ & $\mathrm{PTi}$ & 0 & $2.406 E-05$ \\
\hline 13 & & AL3P & PSi & 0 & $1.094 \mathrm{E}-04$ & PCu3 & 0 & $8.358 E-06$ & PCu5 & 0 & $3.725 E-06$ \\
\hline \multicolumn{12}{|c|}{ EN AW-2017 OR A-U4G } \\
\hline 13 & & $\mathrm{AL} 4$ & $\mathrm{EAl}$ & 0 & $5.827 E-02$ & EMg & 0 & $4.839 E-04$ & EMn & 0 & $2.141 E-04$ \\
\hline 13 & & $\mathrm{AL} 4$ & $\mathrm{EFe} 4$ & 0 & $6.155 E-06$ & EFe6 & 0 & $9.662 \mathrm{E}-05$ & EFe7 & 0 & $2.231 E-06$ \\
\hline 13 & & $\mathrm{AL} 4$ & EFe8 & 0 & $2.969 E-07$ & ECro & 0 & $7.020 \mathrm{E}-07$ & $\mathrm{ECr} 2$ & 0 & $1.354 \mathrm{E}-05$ \\
\hline 13 & & $\mathrm{AL} 4$ & $\mathrm{ECr} 3$ & 0 & $1.535 E-06$ & $\mathrm{ECr} 4$ & 0 & $3.821 E-07$ & ESi & 0 & $2.991 E-04$ \\
\hline 13 & & $\mathrm{AL} 4$ & ECu3 & 0 & $4.433 E-06$ & ECu5 & 0 & $1.976 \mathrm{E}-06$ & & & \\
\hline & ALUMINUM & ALLOY & AL5 & & & & & & & & \\
\hline 13 & & AL5 & EAl & 0 & $6.010 E-02$ & EMg & 0 & $1.676 \mathrm{E}-05$ & EMn & 0 & $7.413 E-06$ \\
\hline 13 & & AL5 & $\mathrm{EFe} 4$ & 0 & $3.410 E-06$ & EFe6 & 0 & $5.353 E-05$ & EFe7 & 0 & $1.236 E-06$ \\
\hline 13 & & AL5 & EFe8 & 0 & $1.645 E-07$ & ETi & 0 & $8.508 E-06$ & ESi & 0 & $7.250 E-05$ \\
\hline \multirow[t]{6}{*}{13} & & AL5 & ECu3 & 0 & $4.433 E-06$ & ECu5 & 0 & $1.976 \mathrm{E}-06$ & & & \\
\hline & ZIRCONIUM & V 4 & & & & & & & & & \\
\hline & NOTATION : & $E-1$ & PIN U & $\mathrm{JO} 2$ & - HOMO & & & & & & \\
\hline & & $D-1$ & PIN U & $\mathrm{JO} 2-$ & - INTERFACE & $\mathrm{PuO} 2$ & & & & & \\
\hline & & $\mathrm{U}-1$ & PIN U & $\mathrm{JO} 2$ & - INTERFACE & AL PIN & & & & & \\
\hline & & $\mathrm{V}-\mathrm{I}$ & PIN U & $\mathrm{JO} 2$ & - INTERFACE & $\mathrm{AL} \mathrm{BLO}$ & $\mathrm{CK}$ & & & & \\
\hline 13 & & ZR4E & EZr & 0 & $4.248 E-02$ & $\mathrm{EZH}$ & 0 & $4.899 \mathrm{E}-05$ & $\mathrm{EO}$ & 0 & $3.086 E-04$ \\
\hline 13 & & ZR4E & $\mathrm{EFe} 4$ & 0 & $8.683 E-06$ & EFe6 & 0 & $1.363 E-04$ & EFe7 & 0 & $3.148 E-06$ \\
\hline 13 & & ZR4E & EFe8 & 0 & $4.189 E-07$ & ECro & 0 & $3.301 E-06$ & $\mathrm{ECr} 2$ & 0 & $6.366 E-05$ \\
\hline 13 & & ZR4E & $\mathrm{ECr} 3$ & 0 & $7.219 E-06$ & $\mathrm{ECr} 4$ & 0 & $1.797 \mathrm{E}-06$ & $\mathrm{EC}$ & 0 & $4.405 E-05$ \\
\hline 13 & & ZR4E & $\mathrm{EHf}$ & 0 & $1.107 \mathrm{E}-06$ & & & & & & \\
\hline 13 & & ZR4D & DZr & 0 & $4.248 E-02$ & $\mathrm{DZH}$ & 0 & $4.899 E-05$ & DO & 0 & $3.086 E-04$ \\
\hline 13 & & ZR4D & $\mathrm{DFe} 4$ & 0 & $8.683 E-06$ & DFe6 & 0 & $1.363 E-04$ & DFe7 & 0 & $3.148 E-06$ \\
\hline 13 & & ZR4D & DFe8 & 0 & $4.189 \mathrm{E}-07$ & $\mathrm{DCr} 0$ & 0 & $3.301 E-06$ & $\mathrm{DCr} 2$ & 0 & $6.366 \mathrm{E}-05$ \\
\hline 13 & & ZR4D & $\mathrm{DCr} 3$ & 0 & $7.219 E-06$ & $\mathrm{DCr} 4$ & 0 & $1.797 \mathrm{E}-06$ & $\mathrm{DC}$ & 0 & $4.405 E-05$ \\
\hline 13 & & ZR4D & $\mathrm{DHf}$ & 0 & $1.107 \mathrm{E}-06$ & & & & & & \\
\hline 13 & & ZR4U & UZr & 0 & $4.248 E-02$ & $\mathrm{UZH}$ & 0 & $4.899 E-05$ & UO & 0 & $3.086 E-04$ \\
\hline 13 & & ZR4U & UFe4 & 0 & $8.683 E-06$ & UFe6 & 0 & $1.363 E-04$ & UFe 7 & 0 & $3.148 E-06$ \\
\hline 13 & & ZR4U & UFe8 & 0 & $4.189 E-07$ & UCr0 & 0 & $3.301 E-06$ & $\mathrm{UCr} 2$ & 0 & $6.366 E-05$ \\
\hline
\end{tabular}




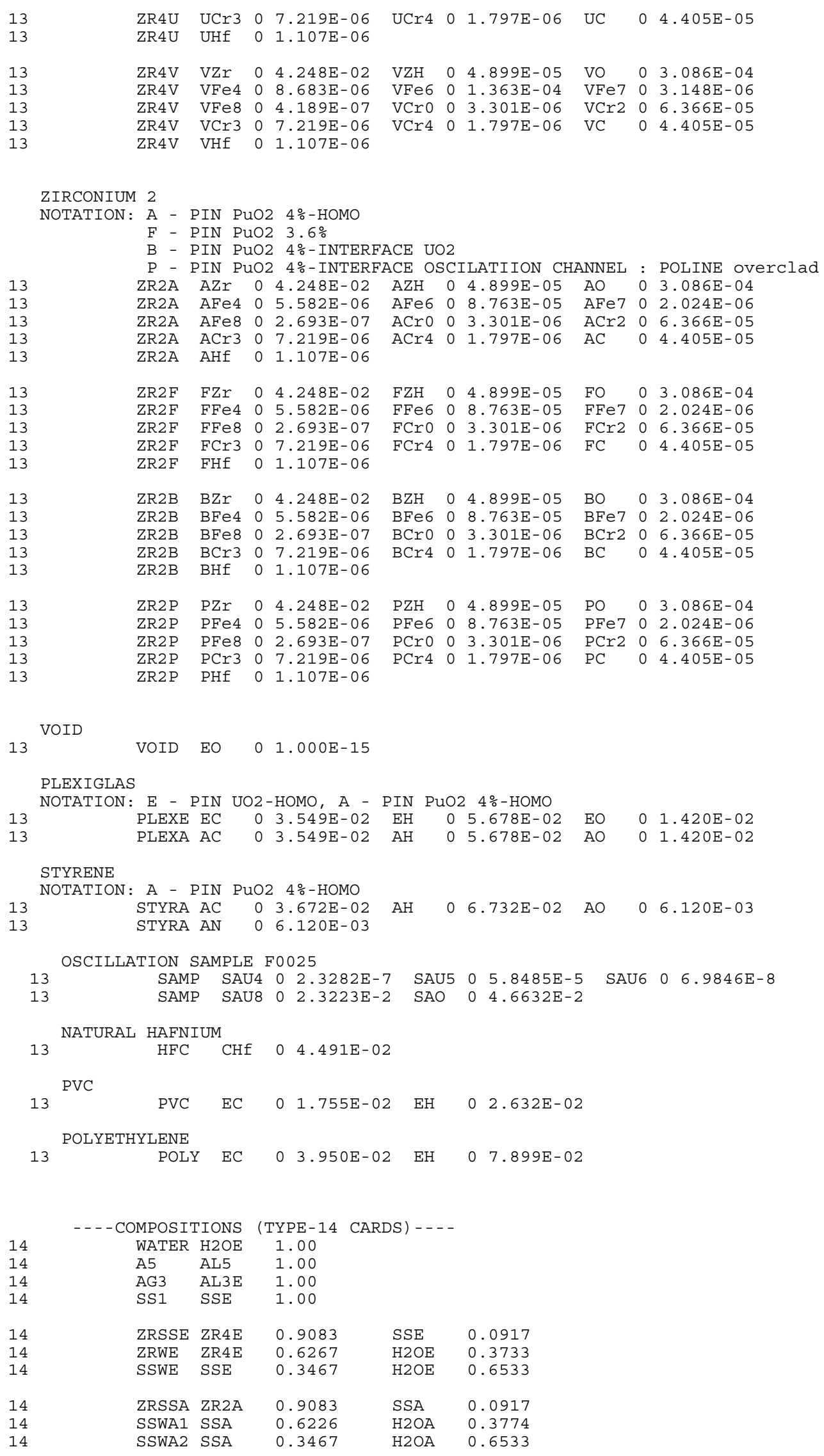




\begin{tabular}{|c|c|c|c|c|c|c|c|}
\hline 14 & ALW1 & $\mathrm{H} 2 \mathrm{OE}$ & 0.1800 & AL3E & 0.8200 & & \\
\hline 14 & ALWT & $\mathrm{H} 2 \mathrm{OE}$ & 0.1800 & $A L 3 E$ & 0.8200 & & \\
\hline 14 & ALW2 & $\mathrm{H} 2 \mathrm{OE}$ & 0.8000 & AL3E & 0.2000 & & \\
\hline 14 & GAL1 & GR3 & 0.8487 & AL3 3 & 0.1513 & & \\
\hline 14 & GAL2 & GR3 & 0.9568 & AL33 & 0.0432 & & \\
\hline 14 & GAL3 & GR3 & 0.8729 & AL33 & 0.1271 & & \\
\hline 14 & GFOOT & AL5 & 0.5258 & AL3E & 0.4110 & $\mathrm{H} 2 \mathrm{OE}$ & 0.0448 \\
\hline 14 & GFOOT & VOID & 0.0184 & & & & \\
\hline 14 & GELT1 & GR1 & 0.8647 & AL31 & 0.1102 & $\mathrm{H} 2 \mathrm{O} 1$ & 0.0251 \\
\hline 14 & GELT2 & GR2 & 0.8647 & AL32 & 0.1102 & $\mathrm{H} 2 \mathrm{O} 2$ & 0.0251 \\
\hline 14 & GCLAD & AL3E & 0.9749 & $\mathrm{H} 2 \mathrm{OE}$ & 0.0251 & & \\
\hline 14 & FFOOT & AL5 & 0.3858 & AL3E & 0.1796 & $\mathrm{H} 2 \mathrm{OE}$ & 0.4346 \\
\hline 14 & ALW9 0 & $\mathrm{H} 2090$ & 0.5856 & AL90 & 0.3120 & AL30 & 0.1024 \\
\hline 14 & ALW93 & H2093 & 0.5856 & AL93 & 0.3120 & AL30 & 0.1024 \\
\hline 14 & D9018 & HEU9O & 0.0952 & AL90 & 0.2168 & H2O90 & 0.5856 \\
\hline 14 & D9018 & AL30 & 0.1024 & & & & \\
\hline 14 & D9318 & HEU93 & 0.0952 & AL93 & 0.2168 & H2093 & 0.5856 \\
\hline 14 & D9318 & AL30 & 0.1024 & & & & \\
\hline 14 & D9009 & HEU90 & 0.0940 & AL90 & 0.2141 & H2090 & 0.5892 \\
\hline 14 & D9009 & AL30 & 0.1027 & & & & \\
\hline 14 & G9009 & GR1 & 0.7660 & AL30 & 0.1526 & H2090 & 0.0814 \\
\hline 14 & D9012 & HEU9O & 0.0952 & AL90 & 0.2168 & $\mathrm{H} 2090$ & 0.5246 \\
\hline 14 & D9012 & AL30 & 0.1634 & & & & \\
\hline 14 & G9012 & GR1 & 0.7144 & AL30 & 0.1616 & H2090 & 0.1240 \\
\hline 14 & DCRUP & CFUEL & 0.0634 & $\mathrm{ALC}$ & 0.2138 & $\mathrm{H} 2 \mathrm{OC}$ & 0.6182 \\
\hline 14 & DCRUP & AL30 & 0.1046 & & & & \\
\hline 14 & GAL12 & GR1 & 0.2286 & AL90 & 0.2079 & H2090 & 0.4316 \\
\hline 14 & GAL 12 & $\operatorname{AL} 30$ & 0.1319 & & & & \\
\hline 14 & GAL09 & GR1 & 0.3632 & AL90 & 0.1560 & H2090 & 0.3384 \\
\hline 14 & GAL09 & AL30 & 0.1424 & & & & \\
\hline 14 & ALCRUF & PALC & 0.2772 & $\mathrm{H} 2 \mathrm{OC}$ & 0.6182 & AL30 & 0.1046 \\
\hline 14 & ALWM1 & $\mathrm{H} 2 \mathrm{OE}$ & 0.6536 & AL3E & 0.0658 & ALWT & 0.2806 \\
\hline 14 & ALWM2 & $\mathrm{H} 2 \mathrm{OE}$ & 0.6875 & $A L 3 E$ & 0.3125 & & \\
\hline 14 & SSWM1 & $\mathrm{H} 2 \mathrm{OE}$ & 0.1383 & SSE & 0.8617 & & \\
\hline 14 & ALWC1 & $\mathrm{H} 2 \mathrm{OE}$ & 0.7776 & AL3E & 0.2224 & & \\
\hline 14 & ALWC2 & $\mathrm{H} 2 \mathrm{OE}$ & 0.0204 & $A L 3 E$ & 0.9796 & & \\
\hline 14 & ALWC3 & $\mathrm{H} 2 \mathrm{OE}$ & 0.3039 & AL $3 E$ & 0.6961 & & \\
\hline 14 & ALWC4 & $\mathrm{H} 2 \mathrm{OE}$ & 0.6898 & AL3E & 0.3102 & & \\
\hline 14 & SSWC1 & $\mathrm{H} 2 \mathrm{OE}$ & 0.1451 & $A L 3 E$ & 0.4184 & SSE & 0.4365 \\
\hline 14 & SSWC2 & $\mathrm{H} 2 \mathrm{OE}$ & 0.3039 & $A L 3 E$ & 0.1348 & SSE & 0.5613 \\
\hline 14 & F1PPG & PLEXE & 0.3009 & VOID & 0.0317 & ZR4E & 0.1045 \\
\hline 14 & F1PPG & AL3E & 0.1331 & $\mathrm{H} 2 \mathrm{OE}$ & 0.4298 & & \\
\hline 14 & F1LPG & SSE & 0.1132 & VOID & 0.0119 & ZR4E & 0.0393 \\
\hline 14 & F1LPG & ZRWE & 0.1175 & AL3E & 0.4839 & $\mathrm{H} 2 \mathrm{OE}$ & 0.2342 \\
\hline 14 & F1UPG & SSE & 0.1504 & VOID & 0.0158 & ZR4E & 0.0523 \\
\hline 14 & F1UPG & ZRSSE & 0.2186 & AL3E & 0.4007 & $\mathrm{H} 2 \mathrm{OE}$ & 0.1622 \\
\hline 14 & F1UP & SSWE & 0.0580 & AL3E & 0.3125 & $\mathrm{H} 2 \mathrm{OE}$ & 0.6295 \\
\hline 14 & SUO2H & $\mathrm{U} 3 \mathrm{H}$ & 0.3203 & VOID & 0.0123 & ZR4E & 0.1045 \\
\hline 14 & SUO2H & AL 3E & 0.1331 & $\mathrm{H} 2 \mathrm{OE}$ & 0.4298 & & \\
\hline 14 & $\mathrm{UO} 2 \mathrm{H}$ & SUO2H & 1.00 & & & & \\
\hline 14 & SUO2 I & 1U3 I1 & 0.3203 & VOID & 0.0123 & ZR4D & 0.1045 \\
\hline 14 & SUO2 I & $1 \mathrm{AL} 3 \mathrm{D}$ & 0.1331 & $\mathrm{H} 2 \mathrm{OD}$ & 0.4298 & & \\
\hline 14 & UO2 I 1 & SUO2 I1 & 1.00 & & & & \\
\hline 14 & SUO2 I 2 & 2U3 I2 & 0.3203 & VOID & 0.0123 & ZR4U & 0.1045 \\
\hline 14 & SUO2I2 & $2 \mathrm{AL} 3 \mathrm{U}$ & 0.1331 & $\mathrm{H} 2 \mathrm{OU}$ & 0.4298 & & \\
\hline 14 & UO2 I 2 & SUO2 I 2 & 1.00 & & & & \\
\hline 14 & SUO2I3 & $3 \mathrm{U} 3 \mathrm{I} 3$ & 0.3203 & VOID & 0.0123 & ZR4V & 0.1045 \\
\hline 14 & SUO2I3 & $3 \mathrm{AL} 3 \mathrm{~V}$ & 0.1331 & $\mathrm{H} 2 \mathrm{OV}$ & 0.4298 & & \\
\hline 14 & UO2 I 3 & SUO2I3 & 1.00 & & & & \\
\hline 14 & ALWP1 & $\mathrm{H} 2 \mathrm{OE}$ & 0.0346 & AL3E & 0.9654 & & \\
\hline 14 & ALWP2 & $\mathrm{H} 2 \mathrm{OE}$ & 0.5503 & AL3E & 0.4497 & & \\
\hline 14 & ALWP 3 & $\mathrm{H} 2 \mathrm{OE}$ & 0.1489 & $\mathrm{AL} 3 \mathrm{E}$ & 0.8511 & & \\
\hline 14 & ALWP4 & $\mathrm{H} 2 \mathrm{OE}$ & 0.6445 & AL3E & 0.3555 & & \\
\hline 14 & ASWO1 & $\mathrm{H} 2 \mathrm{OE}$ & 0.4906 & $A L 3 E$ & 0.3615 & SSE & 0.1479 \\
\hline 14 & ASWO2 & $\mathrm{H} 2 \mathrm{OE}$ & 0.3303 & $A L 3 E$ & 0.5559 & SSE & 0.1138 \\
\hline 14 & F2 PPG & PLEXA & 0.3009 & VOID & 0.0491 & ZR2A & 0.0871 \\
\hline 14 & F2PPG & $\mathrm{AL} 3 \mathrm{~A}$ & 0.1331 & $\mathrm{H} 2 \mathrm{OA}$ & 0.4298 & & \\
\hline 14 & F2LPG & SSA & 0.0817 & VOID & 0.0152 & ZR2A & 0.0678 \\
\hline 14 & F2LPG & SSWA1 & 0.0811 & AL3A & 0.4585 & $\mathrm{H} 2 \mathrm{OA}$ & 0.2422 \\
\hline 14 & F2LPG & STYRA & 0.0535 & & & & \\
\hline
\end{tabular}




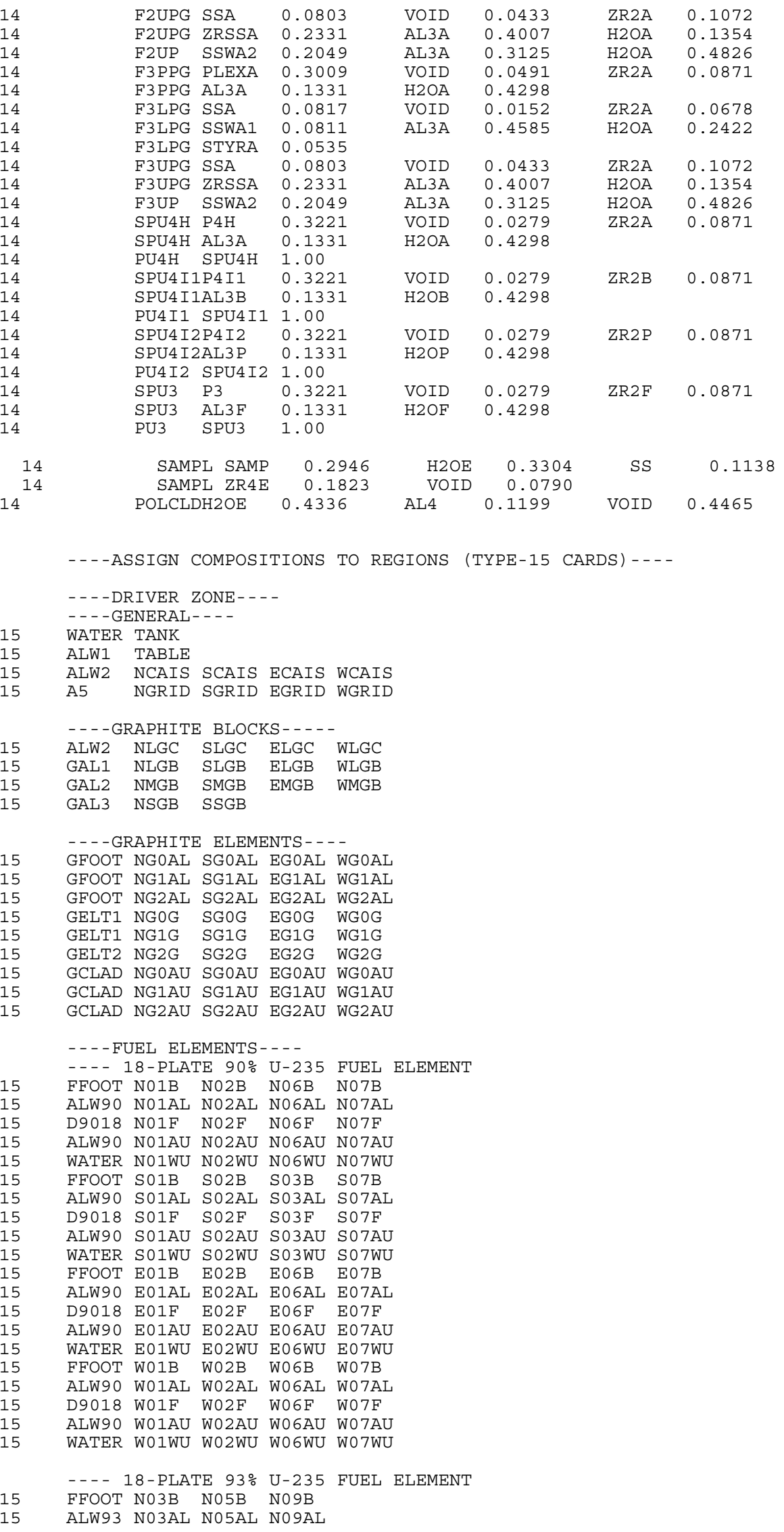


$\begin{array}{llll}\text { D9318 } & \text { N03F } & \text { N05F } & \text { N09F } \\ \text { ALW93 } & \text { N03AU } & \text { N05AU } & \text { N09AU } \\ \text { WATER } & \text { N03WU } & \text { N05WU } & \text { N09WU } \\ \text { FFOOT } & \text { S04B } & \text { S06B } & \text { S09B } \\ \text { ALW93 } & \text { S04AL } & \text { S06AL } & \text { S09AL } \\ \text { D9318 } & \text { S04F } & \text { S06F } & \text { S09F } \\ \text { ALW93 } & \text { S04AU } & \text { S06AU } & \text { S09AU } \\ \text { WATER } & \text { S04WU } & \text { S06WU } & \text { S09WU } \\ \text { FFOOT } & \text { E03B } & \text { E05B } & \text { E09B } \\ \text { ALW93 } & \text { E03AL } & \text { E05AL } & \text { E09AL } \\ \text { D9318 } & \text { E03F } & \text { E05F } & \text { E09F } \\ \text { ALW93 } & \text { E03AU } & \text { E05AU } & \text { E09AU } \\ \text { WATER } & \text { E03WU } & \text { E05WU } & \text { E09WU } \\ \text { FFO0T } & \text { W03B } & \text { W05B } & \text { W09B } \\ \text { ALW93 } & \text { W03AL } & \text { W05AL } & \text { W09AL } \\ \text { D9318 } & \text { W03F } & \text { W05F } & \text { W09F } \\ \text { ALW93 } & \text { W03AU } & \text { W05AU } & \text { W09AU } \\ \text { WATER } & \text { W03WU } & \text { W05WU } & \text { W09WU }\end{array}$

-..- 9-PLATE 90\% U-235 FUEL ELEMENT

FFOOT N08B

GAL09 N08AL

D9009 N08F

G9009 N08GR

GAL09 N08AU

WATER NO8WU

- . - 12 -PLATE 90\% U-235 FUEL ELEMENT

FFOOT N1OB S08B S1OB E08B E10B W08B W10B

GAL12 N10AL S08AL S10AL E08AL E1OAL W08AL W10AL

D9012 N10F S08F S10F E08F E10F W08F W10F

G9012 N10GR S08GR S10GR E08GR E10GR W08GR W10GR

GAL12 N10AU SO8AU SIOAU E08AU EIOAU WO8AU W1OAU

WATER N1OWU S08WU S10WU E08WU E1OWU W08WU W1OWU

- - - CONTROL ELEMENT - ROD UP

FFOOT N04B S05B E04B W04B

ALCRUPNO4AL SO5AL E04AL W04AL

DCRUP N04F S05F E04F W04F

ALCRUPNO4AU SO5AU EO4AU W04AU

WATER N04WU SO5WU E04WU W04WU

- - -EXPERIMENTAL ZONE-- -

- - - -GENERAL - - -

WATER EZONE

15

AG3 WEDGE

----ANGLE GRAPHITE ELEMENTS---

GFOOT G1AL G2AL G3AL G4AL

GCLAD G1AU G2AU G3AU G4AU

GELT2 G1G G2G G3G G4G

- - -ALUMINUM MASSIF- - -

ALWM1 ALBA

SSWM1 ALBB

AG3 ALBC

SS1 ALBD

ALWM2 ALBE

----CHIMNEY PIECES--.-

ALW1 CHI1T CHI2T CHI3T CHI4T CHI5T CHI6T CHI7T CHI8T

ALWC1 CHI1A CHI2A CHI3A CHI4A CHI5A CHI6A CHI7A CHI8A

SSWC1 CHI1B CHI2B CHI3B CHI4B CHI5B CHI6B CHI7B CHI8B

ALWC2 CHI1C CHI2C CHI3C CHI4C CHI5C CHI6C CHI7C CHI8C

ALWC3 CHI1D CHI2D CHI3D CHI4D CHI5D CHI6D CHI7D CHI8D

SSWC2 CHI1E CHI2E CHI3E CHI4E CHI5E CHI6E CHI7E CHI8E

ALWC4 CHIIF CHI2F CHI3F CHI4F CHI5F CHI6F CHI7F CHI8F

----UO2 FUEL PINS--.

TYPE HOMOGENOUS

WATER F1CW F1N1W F1N2W F1S1W F1S2W F1E1W F1E2W F1W1W F1W2W

SS1 F1CSS F1N1SSF1N2SSF1S1SSF1S2SSF1E1SSF1E2SSF1W1SSF1W2SS

F1LPG F1CA F1N1A F1N2A F1S1A F1S2A F1E1A F1E2A F1W1A F1W2A

F1PPG F1CB F1N1B F1N2B F1S1B F1S2B F1E1B F1E2B F1W1B F1W2B

UO2H F1CC F1N1C F1N2C F1S1C F1S2C F1E1C F1E2C F1W1C F1W2C

F1PPG F1CD F1N1D F1N2D F1S1D F1S2D F1E1D F1E2D F1W1D F1W2D

F1UPG F1CE F1N1E F1N2E F1S1E F1S2E F1E1E F1E2E F1W1E F1W2E

F1UP F1CF F1N1F F1N2F F1S1F F1S2F F1E1F F1E2F F1W1F F1W2F 


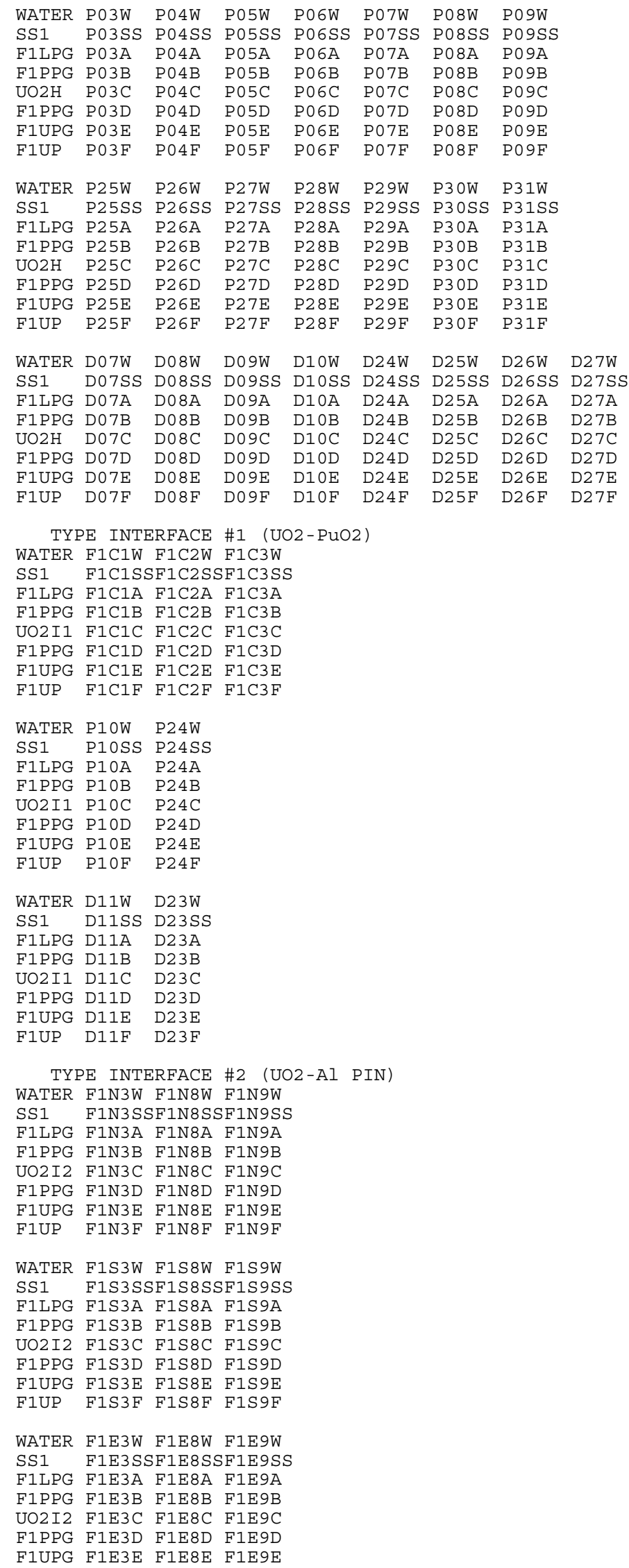

TYPE INTERFACE \#2 (UO2-A1 PIN)

WATER F1N3W F1N8W F1N9W

SS1 F1N3SSF1N8SSF1N9SS

F1LPG F1N3A F1N8A F1N9A

F1PPG F1N3B F1N8B F1N9B

UO2I2 F1N3C F1N8C F1N9C

F1PPG F1N3D F1N8D F1N9D

F1UPG F1N3E F1N8E F1N9E

F1UP F1N3F F1N8F F1N9F

WATER F1S3W F1S8W F1S9W

SS1 F1S3SSF1S8SSF1S9SS

F1LPG F1S3A F1S8A F1S9A

F1PPG F1S3B F1S8B F1S9B

UO2I2 F1S3C F1S8C F1S9C

F1PPG F1S3D F1S8D F1S9D

F1UPG F1S3E F1S8E F1S9E

F1UP F1S3F F1S8F F1S9F

WATER F1E3W F1E8W F1E9W

SS1 F1E3SSF1E8SSF1E9SS

F1LPG F1E3A F1E8A F1E9A

F1PPG F1E3B F1E8B F1E9B

UO2I2 F1E3C F1E8C F1E9C

F1PPG F1E3D F1E8D F1E9D

F1UPG F1E3E F1E8E F1E9E 
WATER F1W3W F1W8W F1W9W

SS1 F1W3SSF1W8SSF1W9SS

F1LPG F1W3A F1W8A F1W9A

F1PPG F1W3B F1W8B F1W9B

UO2I2 F1W3C F1W8C F1W9C

F1PPG F1W3D F1W8D F1W9D

F1UPG F1W3E F1W8E F1W9E

F1UP F1W3F F1W8F F1W9F

$\begin{array}{lll}\text { WATER } & \text { P02W } & \text { P32W } \\ \text { SS1 } & \text { P02SS } & \text { P32SS } \\ \text { F1LPG } & \text { P02A } & \text { P32A } \\ \text { F1PPG } & \text { P02B } & \text { P32B } \\ \text { UO2I2 } & \text { P02C } & \text { P32C } \\ \text { F1PPG } & \text { P02D } & \text { P32D } \\ \text { F1UPG } & \text { P02E } & \text { P32E } \\ \text { F1UP } & \text { P02F } & \text { P32F }\end{array}$

TYPE INTERFACE \#3 (UO2-Al)

WATER F1N4W F1N5W F1N6W F1N7W F1NAW F1NBW SS1 F1N4SSF1N5SSF1N6SSF1N7SSF1NASSF1NBSS F1LPG F1N4A F1N5A F1N6A F1N7A F1NAA F1NBA F1PPG F1N4B F1N5B F1N6B F1N7B F1NAB F1NBB UO2I3 F1N4C F1N5C F1N6C F1N7C F1NAC F1NBC F1PPG F1N4D F1N5D F1N6D F1N7D F1NAD F1NBD F1UPG F1N4E F1N5E F1N6E F1N7E F1NAE F1NBE F1UP F1N4F F1N5F F1N6F F1N7F F1NAF F1NBF

WATER F1S4W F1S5W F1S6W F1S7W F1SAW F1SBW SS1 F1S4SSF1S5SSF1S6SSF1S7SSF1SASSF1SBSS F1LPG F1S4A F1S5A F1S6A F1S7A F1SAA F1SBA F1PPG F1S4B F1S5B F1S6B F1S7B F1SAB F1SBB UO2I3 F1S4C F1S5C F1S6C F1S7C F1SAC F1SBC F1PPG F1S4D F1S5D F1S6D F1S7D F1SAD F1SBD F1UPG F1S4E F1S5E F1S6E F1S7E F1SAE F1SBE F1UP F1S4F F1S5F F1S6F F1S7F F1SAF F1SBF

WATER F1E4W F1E5W F1E6W F1E7W F1EAW F1EBW SS1 F1E4SSF1E5SSF1E6SSF1E7SSF1EASSF1EBSS F1LPG F1E4A F1E5A F1E6A F1E7A F1EAA F1EBA F1PPG F1E4B F1E5B F1E6B F1E7B F1EAB F1EBB UO2I3 F1E4C F1E5C F1E6C F1E7C F1EAC F1EBC F1PPG F1E4D F1E5D F1E6D F1E7D F1EAD F1EBD F1UPG F1E4E F1E5E F1E6E F1E7E F1EAE F1EBE F1UP F1E4F F1E5F F1E6F F1E7F F1EAF F1EBF

WATER F1W4W F1W5W F1W6W F1W7W F1WAW F1WBW SS1 F1W4SSF1W5SSF1W6SSF1W7SSF1WASSF1WBSS F1LPG F1W4A F1W5A F1W6A F1W7A F1WAA F1WBA F1PPG F1W4B F1W5B F1W6B F1W7B F1WAB F1WBB UO2I3 F1W4C F1W5C F1W6C F1W7C F1WAC F1WBC F1PPG F1W4D F1W5D F1W6D F1W7D F1WAD F1WBD F1UPG F1W4E F1W5E F1W6E F1W7E F1WAE F1WBE F1UP F1W4F F1W5F F1W6F F1W7F F1WAF F1WBF

----PuO2 FUEL PINS 4\%----

TYPE HOMOGENOUS

WATER F2C1W F2C2W

SS1 F2C1SSF2C2SS

F2LPG F2C1A F2C2A

F2PPG F2C1B F2C2B

PU4H F2C1C F2C2C

F2PPG F2C1D F2C2D

F2UPG F2C1E F2C2E

F2UP F2C1F F2C2F

$\begin{array}{lllllllll}\text { WATER } & \text { P12W } & \text { P13W } & \text { P14W } & \text { P15W } & \text { P19W } & \text { P20W } & \text { P21W } & \text { P22W } \\ \text { SS1 } & \text { P12SS } & \text { P13SS } & \text { P14SS } & \text { P15SS } & \text { P19SS } & \text { P20SS } & \text { P21SS } & \text { P22SS } \\ \text { F2LPG } & \text { P12A } & \text { P13A } & \text { P14A } & \text { P15A } & \text { P19A } & \text { P20A } & \text { P21A } & \text { P22A } \\ \text { F2PPG } & \text { P12B } & \text { P13B } & \text { P14B } & \text { P15B } & \text { P19B } & \text { P20B } & \text { P21B } & \text { P22B } \\ \text { PU4H } & \text { P12C } & \text { P13C } & \text { P14C } & \text { P15C } & \text { P19C } & \text { P20C } & \text { P21C } & \text { P22C } \\ \text { F2PPG } & \text { P12D } & \text { P13D } & \text { P14D } & \text { P15D } & \text { P19D } & \text { P20D } & \text { P21D } & \text { P22D } \\ \text { F2UPG } & \text { P12E } & \text { P13E } & \text { P14E } & \text { P15E } & \text { P19E } & \text { P20E } & \text { P21E } & \text { P22E } \\ \text { F2UP } & \text { P12F } & \text { P13F } & \text { P14F } & \text { P15F } & \text { P19F } & \text { P20F } & \text { P21F } & \text { P22F } \\ & & & & & & & & \\ \text { WATER } & \text { D13W } & \text { D14W } & \text { D15W } & \text { D19W } & \text { D20W } & \text { D21W } & & \\ \text { SS1 } & \text { D13SS } & \text { D14SS } & \text { D15SS } & \text { D19SS } & \text { D20SS } & \text { D21SS } & & \\ \text { F2LPG } & \text { D13A } & \text { D14A } & \text { D15A } & \text { D19A } & \text { D20A } & \text { D21A } & & \\ \text { F2 PPG } & \text { D13B } & \text { D14B } & \text { D15B } & \text { D19B } & \text { D20B } & \text { D21B } & & \end{array}$




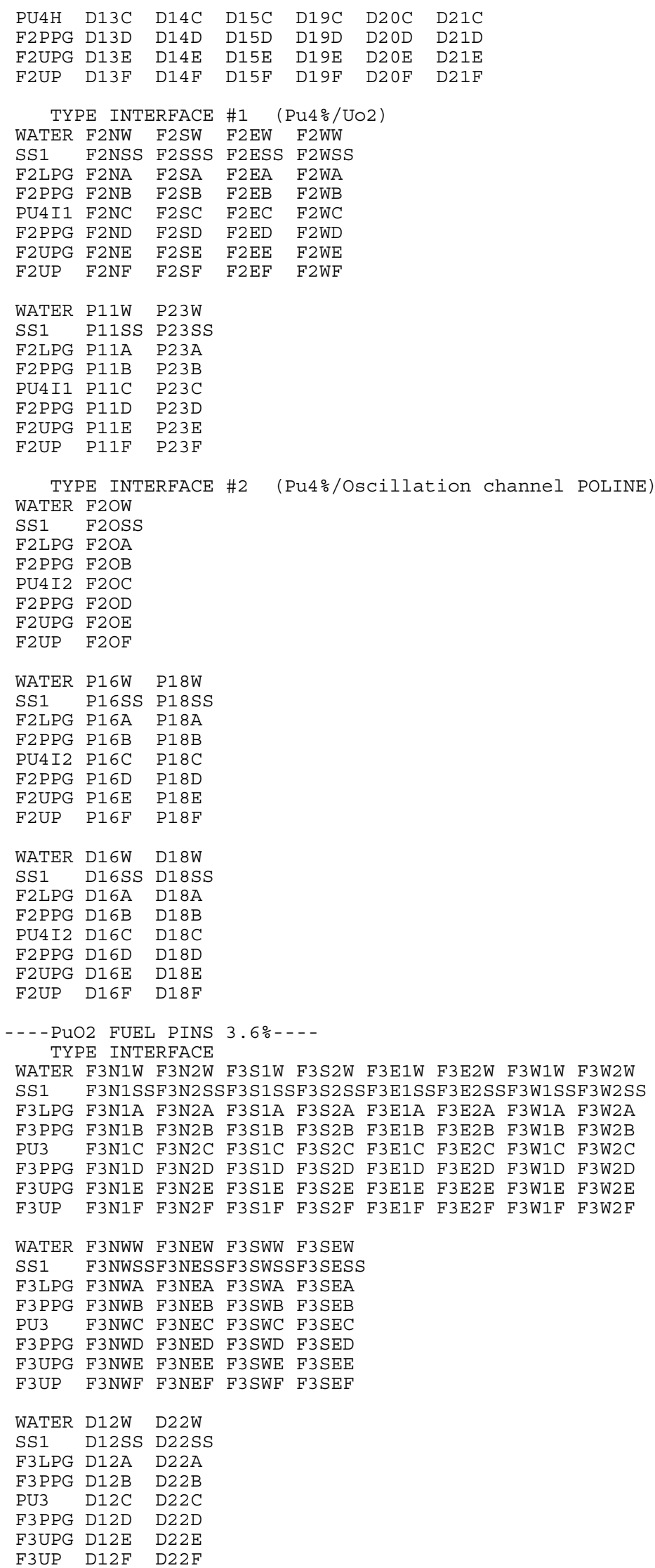




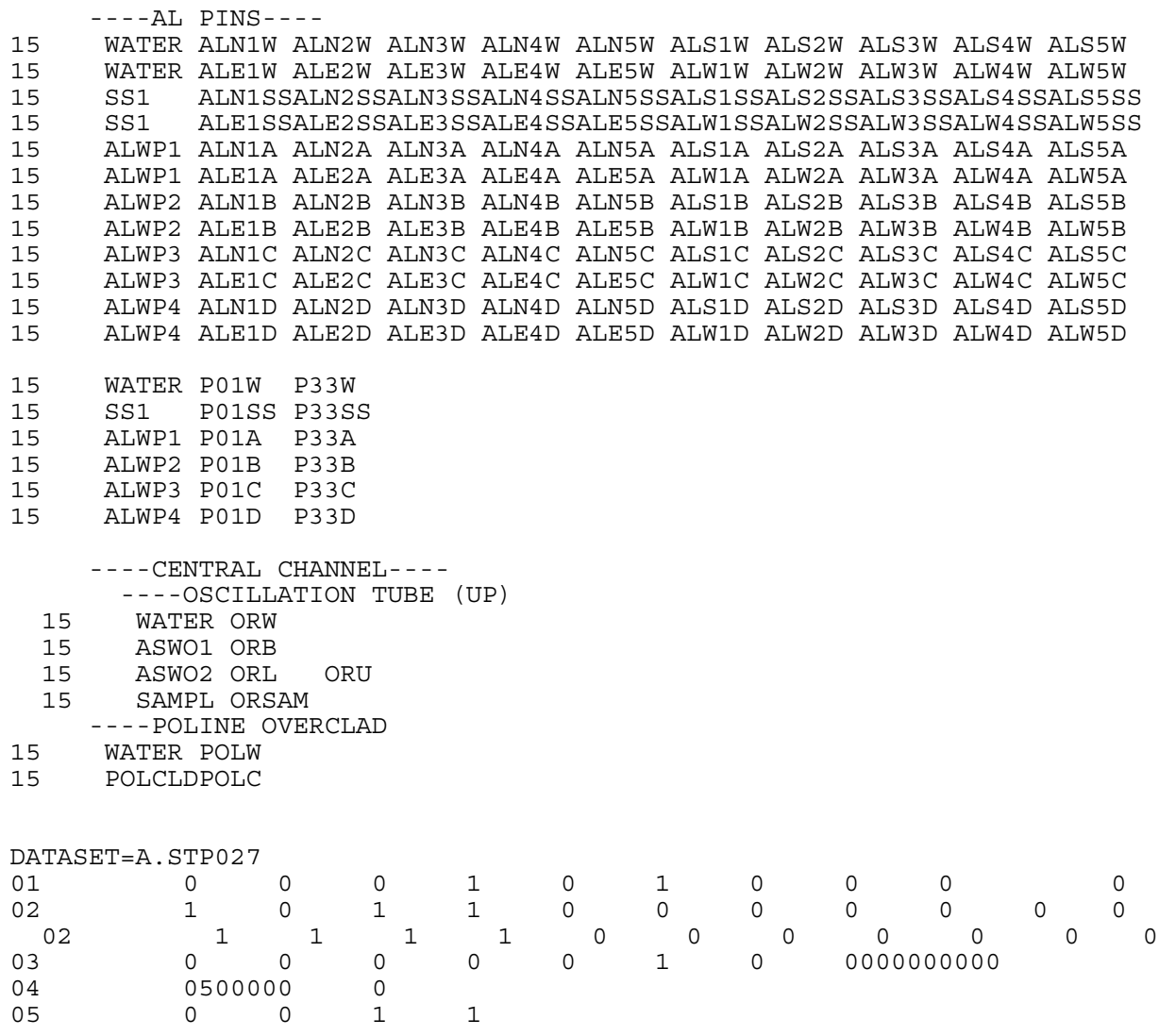

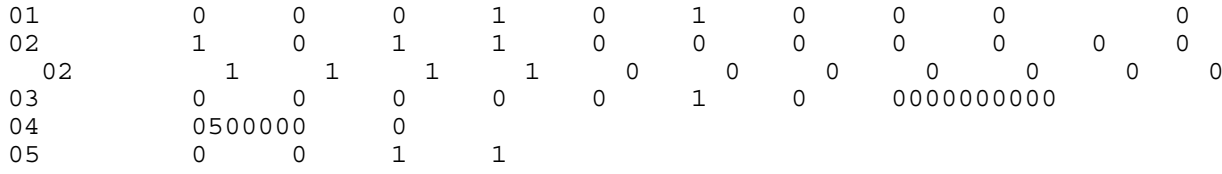




\section{Appendix 3: WIMS input files}

The WIMS input files used to generate cross sections for the driver zone are:

- [file 18p90]: The 18- 12- and 9- plate fuel element (90\% U-235 enrichment)

- [file 18p93]: The 18- plate fuel element (93\% U-235 enrichment)

- [file CElt]: The Control element with the rod withdrawn

- [file G18p90]: The Graphite element and blocks, namely

- [file rod ]: The Control element with the rod inserted

The WIMS input files used to generate cross section of the experimental zone for the R1MOX configuration are:

- [file UAl]: calculation $\mathrm{UO}_{2}$ fuel pin cell near $\mathrm{Al}$ fuel pin

- [file UAlB]: $\mathrm{UO}_{2}$ fuel pin cell near Al buffer

- [file UPuPu1]: $\mathrm{UO}_{2}$ fuel pin 8-adjacent to $\mathrm{UO}_{2} \mathrm{PuO}_{2}$ fuel pin

- $\quad$ file $\mathrm{U}(3)$ and $\mathrm{U}(3) \mathrm{Ax}]: \mathrm{UO}_{2}$ fuel pin cell surrounded by $\mathrm{UO}_{2}$ fuel pin cell

- [file UPu]: $\mathrm{UO}_{2}-\mathrm{PuO}_{2}(4 \%)$ fuel pin 4-adjacent to $\mathrm{UO}_{2}$ pin cell

- [file UPOL]: $\mathrm{UO}_{2}-\mathrm{PuO}_{2}(4 \%)$ fuel pin 8-adjacent to POLINE cell

- [file $\mathrm{Pu}(4)$ and $\mathrm{Pu}(4) \mathrm{Ax}$ ]: $\mathrm{UO}_{2}-\mathrm{PuO}_{2}(4 \%)$ fuel pin surrounded by $\mathrm{UO}_{2}-\mathrm{PuO}_{2}$ pin cell

- [file UPuPu2]: $\mathrm{UO}_{2}-\mathrm{PuO}_{2}(3.6 \%)$ fuel pin between a $\mathrm{UO}_{2}-\mathrm{PuO}_{2}(4 \%)$ pin cell and a $\mathrm{UO}_{2}$ pin cell

- [file Sample]: Calibration sample inside the oscillation channel : "Sample" calculation

Only some of the files are used for the R1UO2 configuration.

\section{File 18p90}

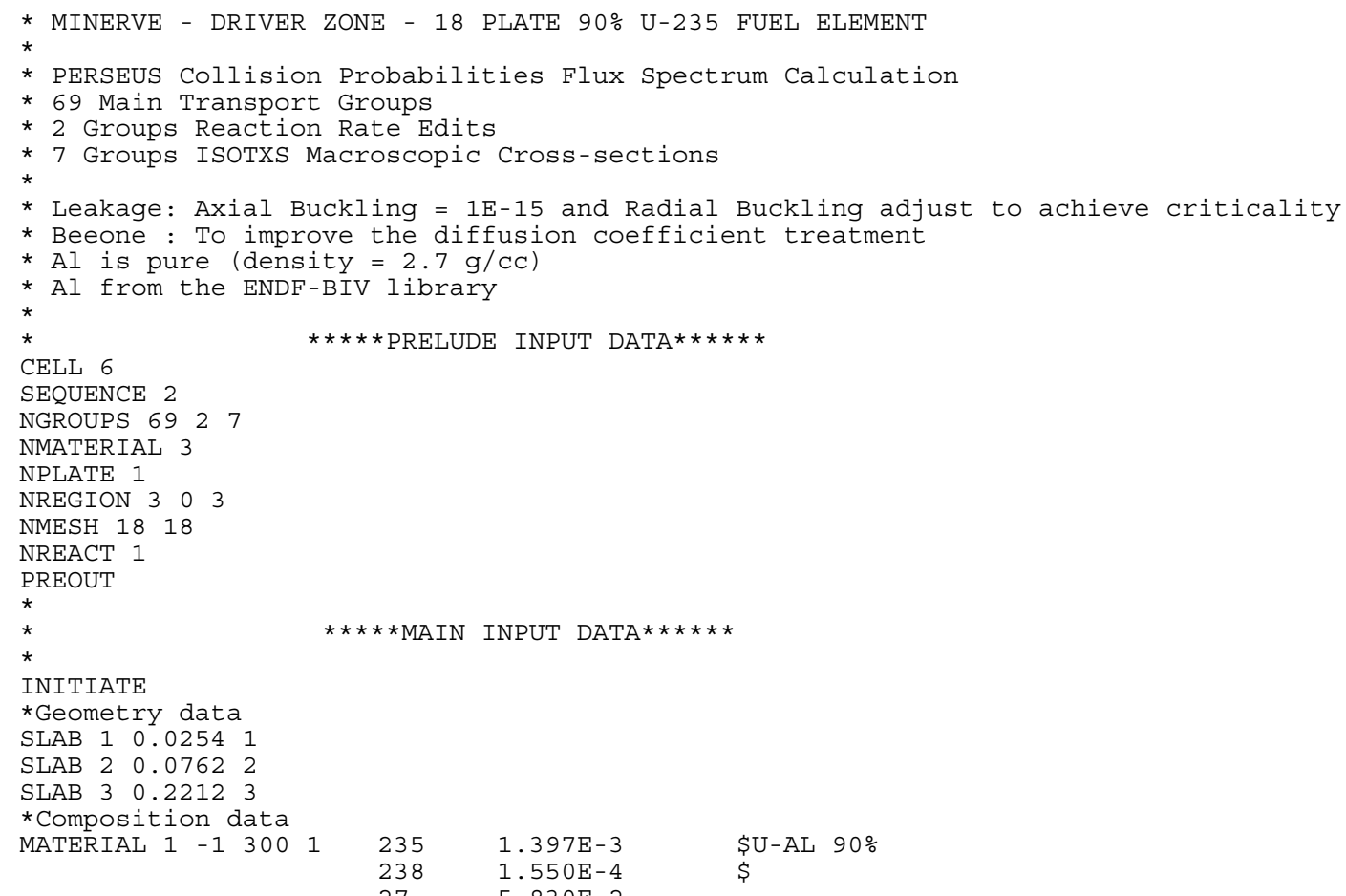




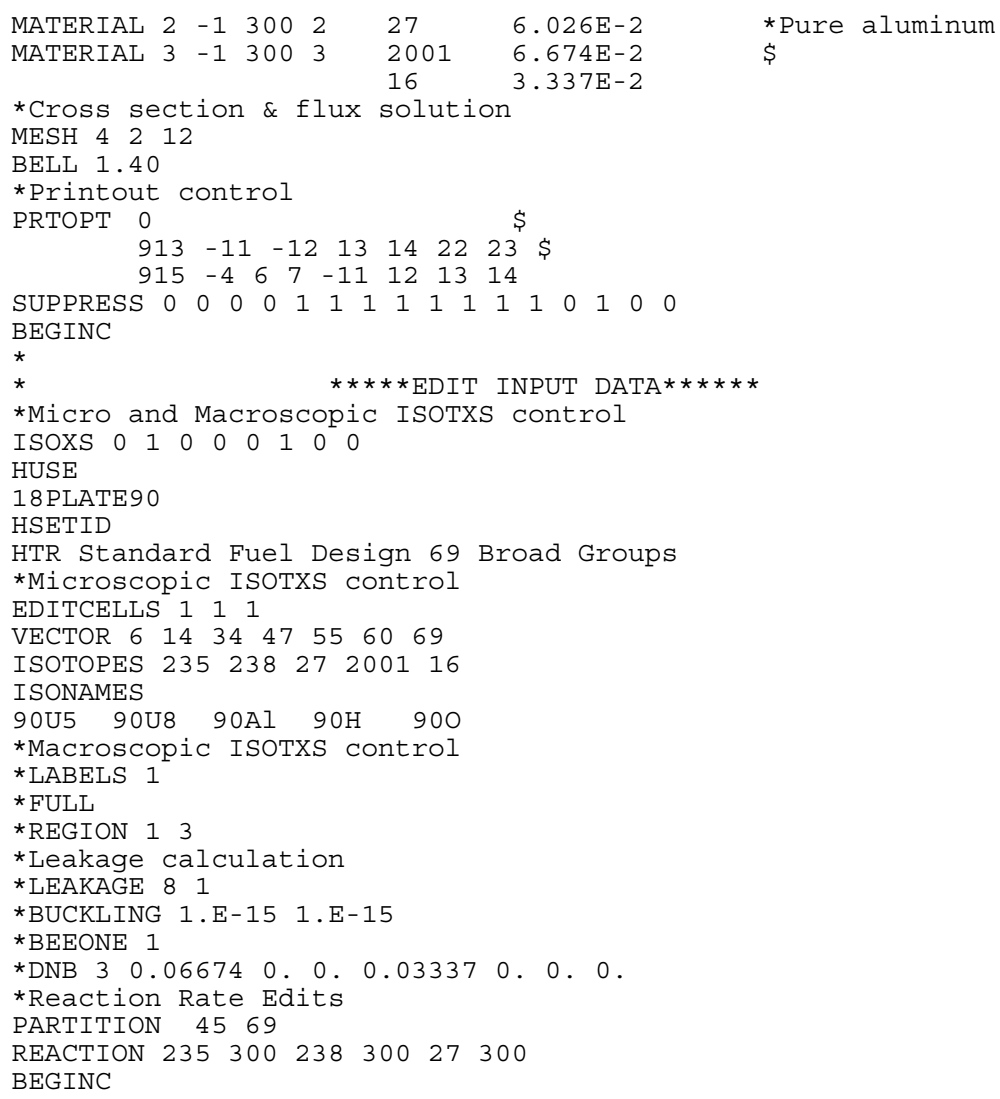

\section{File 18p93}

* MINERVE - DRIVER ZONE - 18 PLATE 93\% U-235 FUEL ELEMENT

* PERSEUS Collision Probabilities Flux Spectrum Calculation

* 69 Main Transport Groups

* 2 Groups Reaction Rate Edits

* 7 Groups ISOTXS Macroscopic Cross-sections

*NO Leakage: Axial Buckling = 1E-15 and Radial Buckling adjust to achieve criticality *NO Beeone : To improve the diffusion coefficient treatment

* Al is pure (density $=2.7 \mathrm{~g} / \mathrm{cc}$ )

* Al from the ENDF-BIV library

CELL 6

$\star * \star * *$ PRELUDE INPUT DATA $* * * \star * *$

SEQUENCE 2

NGROUPS $69 \begin{array}{lll}6 & 2 & 7\end{array}$

NMATERIAL 3

NPLATE 1

NREGION 3 C 03

NMESH $18 \quad 18$

NREACT 1

PREOUT

*

INITIATE

* Geometry data

SLAB $10.0254 \quad 1$

$\begin{array}{llll}\text { SLAB } 2 & 0.0762 \quad 2\end{array}$

SLAB $3 \quad 0.2212 \quad 3$

* Composition data

MATERIAL $1-1 \quad 300 \quad 1$

$\star \star \star * *$ MAIN INPUT DATA $* * * * * *$

$\begin{array}{lll}238 & 1.390 \mathrm{E}-4 & \$ \\ 27 & 5.770 \mathrm{E}-2 & \$\end{array}$




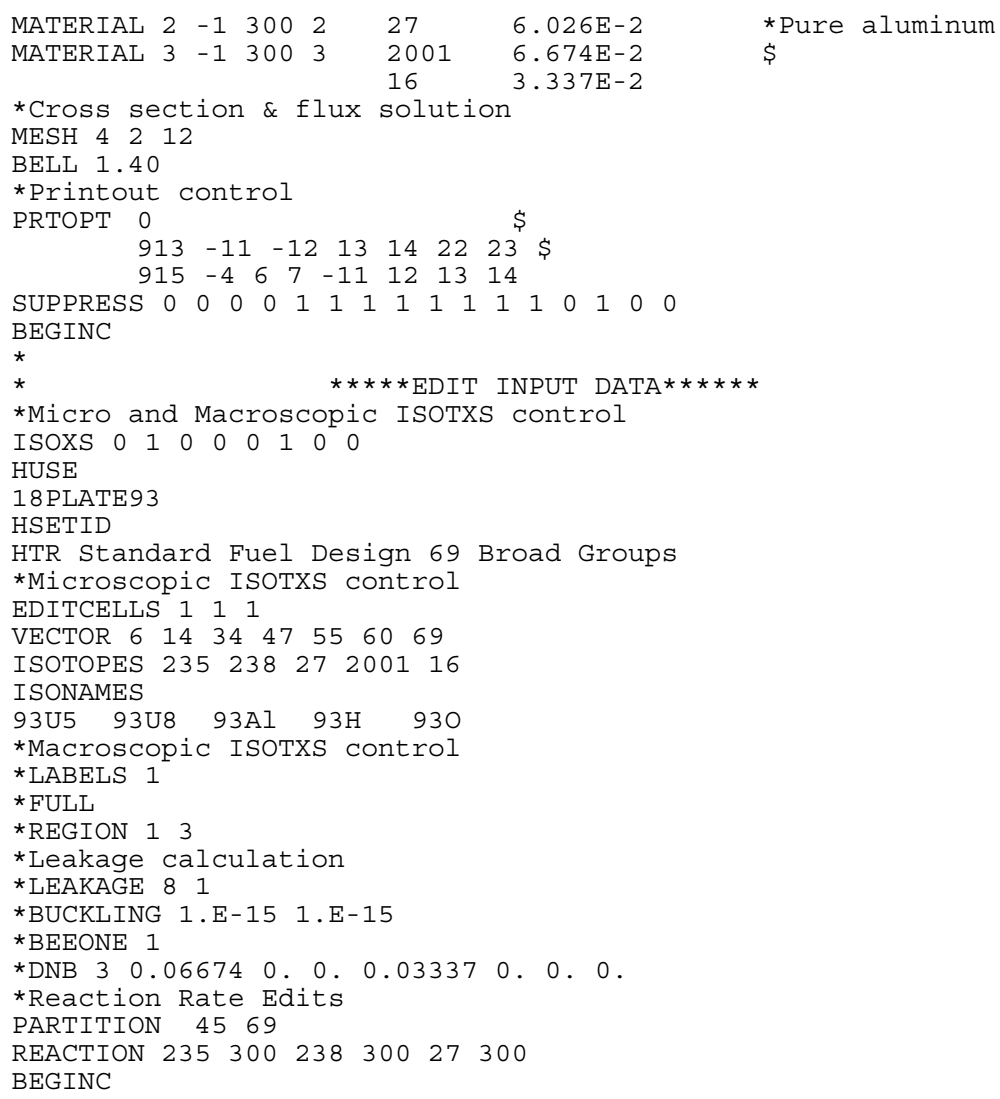

\section{File CElt}

* MINERVE - DRIVER ZONE - CONTROL ELEMENT 93\% U-235

* PERSEUS Collision Probabilities Flux Spectrum Calculation

* 69 Main Transport Groups

* 2 Groups Reaction Rate Edits

* 7 Groups ISOTXS Macroscopic Cross-sections

*NO Leakage: Axial Buckling = 1E-15 and Radial Buckling adjust to achieve criticality *NO Beeone : To improve the diffusion coefficient treatment

* Al is pure (density $=2.7 \mathrm{~g} / \mathrm{cc}$ )

* Al from the ENDF-BIV library

CELL 6

$\star \star \star \star *$ PRELUDE INPUT DATA $* \star * \star * *$

SEOUENCE 1

NGROUPS 69227

NMATERIAL 3

NPLATE 6

NREGION $27 \quad 0 \quad 27$

NMESH $310 \quad 310$

NREACT 1

PREOUT

*

*

INITIATE

* Geometry data

SLAB $10.0254 \quad 1$

SLAB 20.0762

$\begin{array}{llll}\text { SLAB } 3 & 0.3662 \quad 3\end{array}$

SLAB $4 \quad 0.4170 \quad 2$

$\begin{array}{llll}\text { SLAB } & 5 & 0.4678 & 1\end{array}$

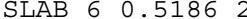

SLAB $7 \quad 0.8086 \quad 3$ 
$\begin{array}{llll}\text { SLAB } & 8 & 0.8594 \quad 2\end{array}$

$\begin{array}{llll}\text { SLAB } & 9 & 0.9102 & 1\end{array}$

SLAB $10 \quad 0.9610 \quad 2$

SLAB $11 \quad 1.2510 \quad 3$

SLAB 121.30182

SLAB $13 \quad 1.35261$

SLAB $14 \quad 1.4034 \quad 2$

SLAB $15 \quad 1.69343$

SLAB $16 \quad 1.8458 \quad 2$

SLAB $17 \quad 2.5782 \quad 3$

SLAB $18 \quad 2.7306 \quad 2$

SLAB $19 \quad 3.0206 \quad 3$

SLAB $20 \quad 3.0714 \quad 2$

SLAB $21 \quad 3.1222 \quad 1$

SLAB $22 \quad 3.17302$

SLAB $23 \quad 3.4630 \quad 3$

$\begin{array}{llll}\text { SLAB } & 24 & 3.5138 & 2\end{array}$

SLAB $25 \quad 3.5646 \quad 1$

SLAB $26 \quad 3.6154 \quad 2$

SLAB $27 \quad 3.7604 \quad 3$

* Composition data

MATERIAL $1-13001$

$\begin{array}{lll}235 & 1.894 \mathrm{E}-3 & \$ \\ 238 & 1.390 \mathrm{E}-4 & \$ \\ 27 & 5.770 \mathrm{E}-2 & \text { *Pure aluminum } \\ 27 & 6.026 \mathrm{E}-2 & \text { *Pure aluminum } \\ 2001 & 6.674 \mathrm{E}-2 & \$\end{array}$

MATERIAL $2-1 \quad 3002627 \quad 6.026 \mathrm{E}-2 \quad$ *Pure aluminum

MATERIAL $3-1 \quad 300 \quad 3 \quad 2001 \quad 6.674 \mathrm{E}-2 \quad$ \$

*Cross section \& flux solution

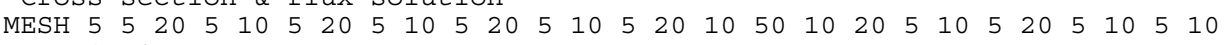

BELL 1.40

*Printout control

PRTOPT 0

$\begin{array}{llllllll}013 & -11 & -12 & 13 & 14 & 22 & 23^{\$} & \$\end{array}$

$\begin{array}{llllllll}915 & -4 & 6 & 7 & -11 & 12 & 13 & 14\end{array}$

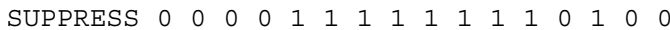

BEGINC

*

$\star \star * * \star$ EDIT INPUT DATA $* * \star * \star * *$

* Micro and Macroscopic ISOTXS control

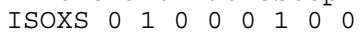

HUSE

CONTROL93

HSETID

HTR Control Element Design 69 Broad Groups

*Microscopic ISOTXS control

EDITCELLS 111

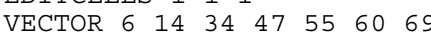

ISOTOPES $235238272001 \quad 16$

ISONAMES

CU5 CU8 CAl $\mathrm{CH} \quad \mathrm{CO}$

* Leakage calculation

* LEAKAGE 81

*BUCKLING 1.E-15 1.E-15

*BEEONE 1

$\begin{array}{llllllllll}* \text { DNB } & 3 & 0.06674 & 0.0 .0 & 0.03337 & 0.0 .0 .0 & 0 .\end{array}$

* Reaction Rate Edits

PARTITION $45 \quad 69$

REACTION $235 \quad 300238 \quad 300 \quad 16 \quad 300 \quad 2001300 \quad 27300$

*Miscellaneous Edit Control

BEGINC

\section{File G18p90}

* MINERVE - DRIVER ZONE

* GRAPHITE REFLECTOR ELEMENT NEAR 18 PLATE 90\% U-235 FUEL ELEMENT

*

* supercell calculation

* DSN

* 69 Main Transport Groups

* 2 Groups Reaction Rate Edits

* 7 Groups ISOTXS Macroscopic Cross-sections

*

* Leakage: Axial Buckling = 1E-15 and Radial Buckling adjust to achieve criticality

* Al from the ENDF-BIV library

*

$\star * \star * *$ PRELUDE INPUT DATA $* * * * * *$ 
CELL 8

SEQUENCE 1

NGROUPS 6926

NMATERIAL 16

NCELL 3

NREGION $39 \quad 0 \quad 39$

NMESH 186186

NREACT 1

NPLATE 1

PREOUT

*

INITIATE

*SUPERCELL 1 : All

CELL 11111

CSPECTRUM - 1

* Geometry data

*Elt0

SLAB 16.5001 *Fuel + Al + Water : homogenized

SLAB $26.6582 * A l$ + water (edge of the fuel plate)

SLAB $37.1343 *$ AG3 border plate

SLAB $4 \quad 7.184 \quad 4$ *Water

$\star$ Elt 1

SLAB $5 \quad 7.234 \quad 5$ *Water

SLAB $6 \quad 7.4396 *$ AG3 Clad

SLAB 714.6397 *Graphite 1

SLAB $814.844 \quad 6 *$ AG3 Clad

SLAB $914.894 \quad 5 *$ Water

$\star$ Elt2

SLAB $10 \quad 14.944 \quad 8$ *Water

SLAB $11 \quad 15.149 \quad 9 * A G 3$ Clad

SLAB $12 \quad 22.349 \quad 10 *$ Graphite 2

SLAB $1322.5549 *$ AG3 clad

SLAB $1422.604 \quad 8$ *Water

$\star$ Elt3

SLAB $15 \quad 22.80912 * A G 3$ Clad

SLAB $16 \quad 68.359 \quad 13 *$ Graphite 3

SLAB $17 \quad 68.564 \quad 12 * A G 3$ Clad

SLAB 1880.00011 *Water

*

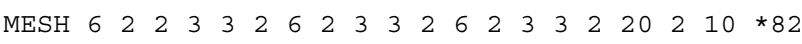

*SUPERCELL 2 : Homogenized fuel with resonance treatment included

CELL 2 2 1110

CSPECTRUM 2

* Geometry data

SLAB $10.0254 \quad 14 * \mathrm{U}-\mathrm{Al} \quad 90 \%$

SLAB $20.0762 \quad 15 * A 1$

SLAB $30.2212 \quad 16$ *water

MESH $5 \quad 2 \quad 15 * 22$

*SUPERCELL 3 : Improved reflector spectrum

CELL 3 r 111

CSPECTRUM 3

* Geometry data

* Geometry data

*Elto

SLAB $16.5001 *$ Fuel + Al + Water : homogenized

SLAB $26.6582 * A 1+$ water (edge of the fuel plate)

SLAB $37.1343 * A G 3$ border plate

SLAB $4 \quad 7.184 \quad 4$ *Water

*Elt 1

SLAB $5 \quad 7.234 \quad 5$ *Water

SLAB 67.4396 *AG3 clad

SLAB $714.6397 *$ Graphite 1

SLAB $814.8446 *$ AG3 Clad

SLAB 914.8945 *Water

*Elt2

SLAB 1014.9448 *Water

SLAB 11 15.149 9 *AG3 clad

SLAB 12 22.349 10 *Graphite 2

SLAB 1322.5549 *AG3 Clad

SLAB 1422.6048 *Water

*Elt 3

SLAB $15 \quad 22.80912$ *AG3 clad

SLAB 16 68.359 13 * Graphite 3

SLAB $1768.564 \quad 12$ *AG3 Clad

SLAB 1880.00011 *Water 


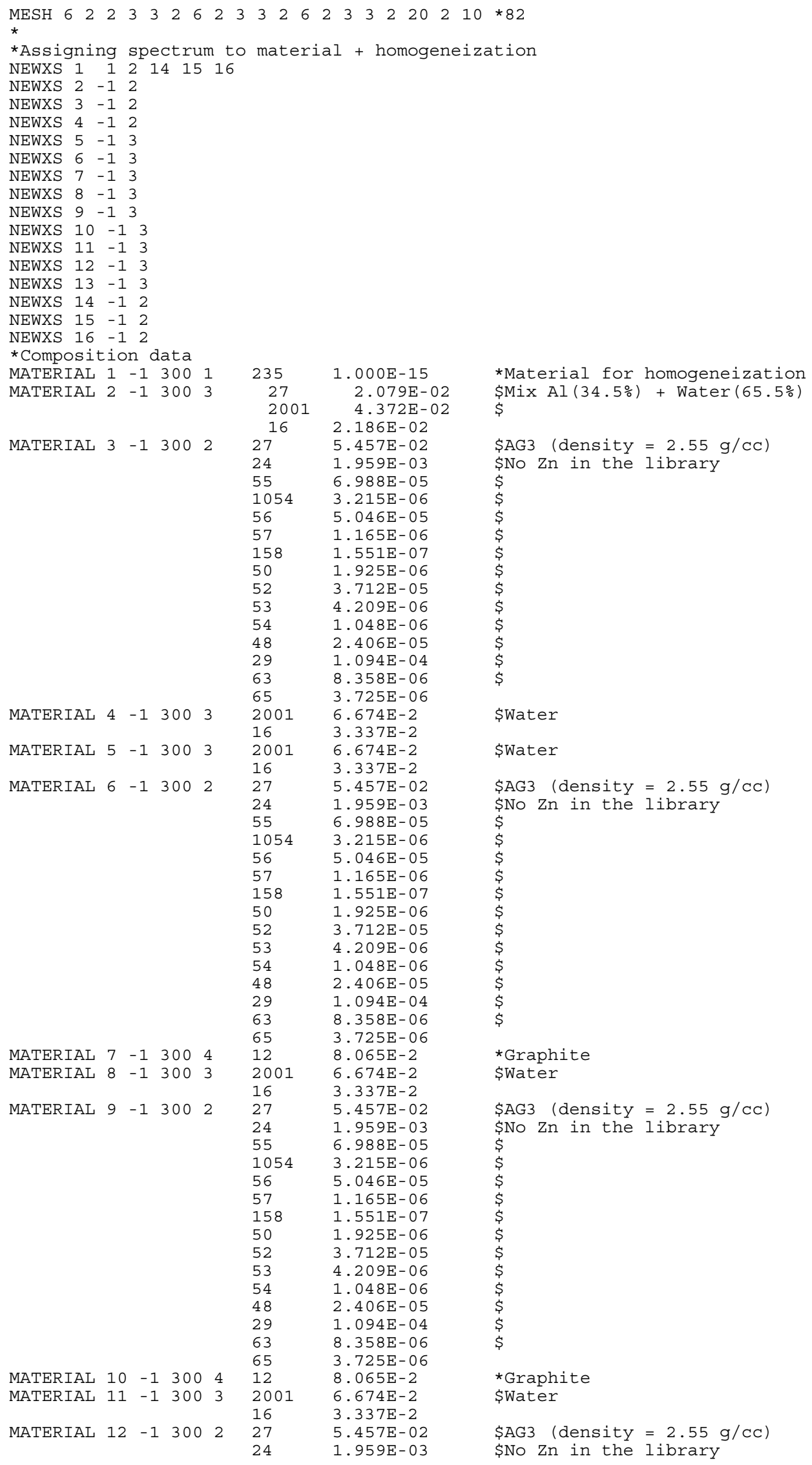




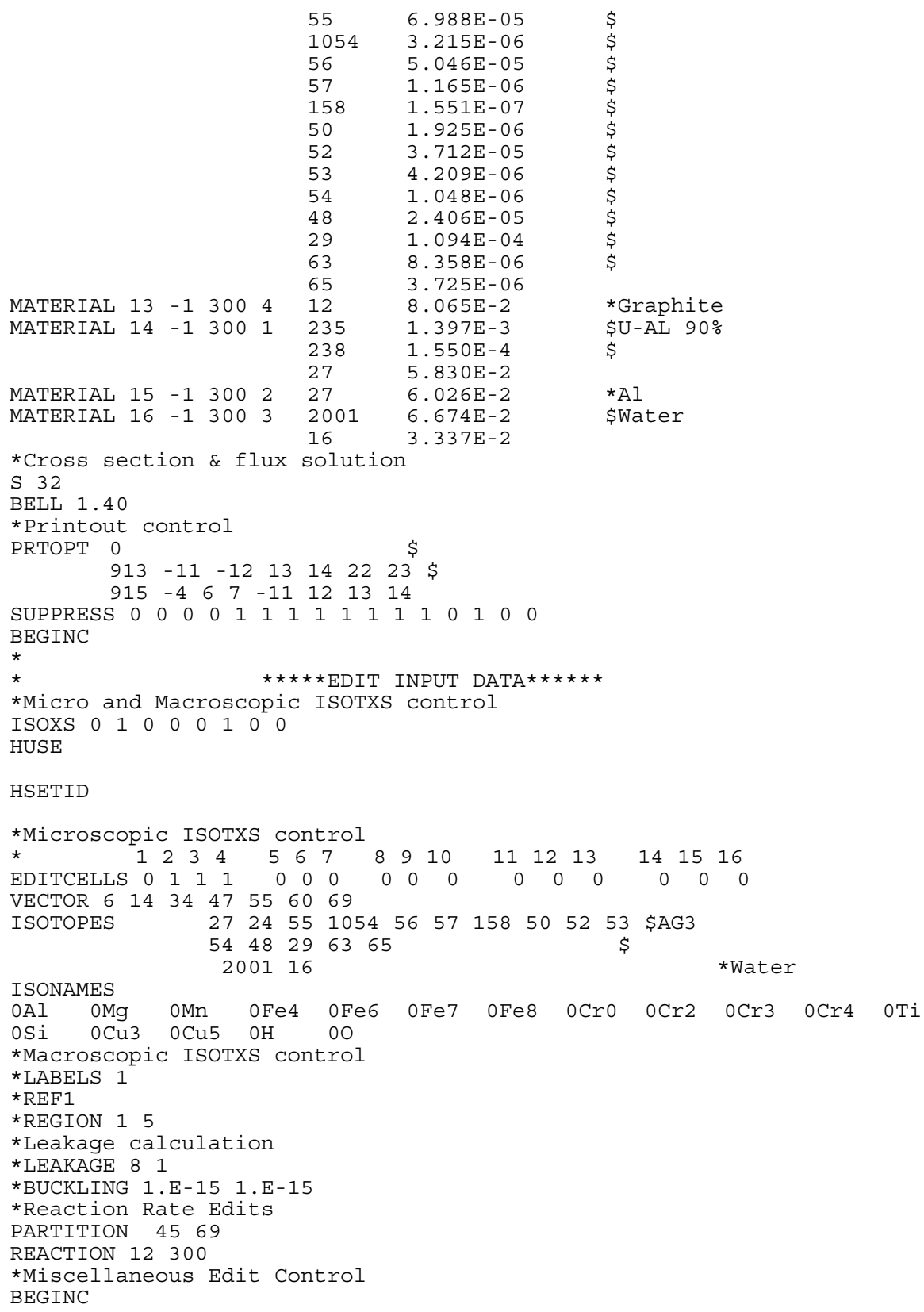

\section{File rod}

* MINERVE - DRIVER ZONE - CONTROL ELEMENT 93\% U-235 WITH HAFNIUM ROD

* SUPERcell Calculation

* DSN

* 69 Main Transport Groups

* 2 Groups Reaction Rate Edits

* 7 Groups ISOTXS Macroscopic Cross-sections

*NO Leakage: Axial Buckling = 1E-15 and Radial Buckling adjust to achieve criticality * NO Beeone : To improve the diffusion coefficient treatment

* Al from the ENDF-BIV library

*

CELL 8

$\star * * * *$ PRELUDE INPUT DATA $* * * * * *$ 


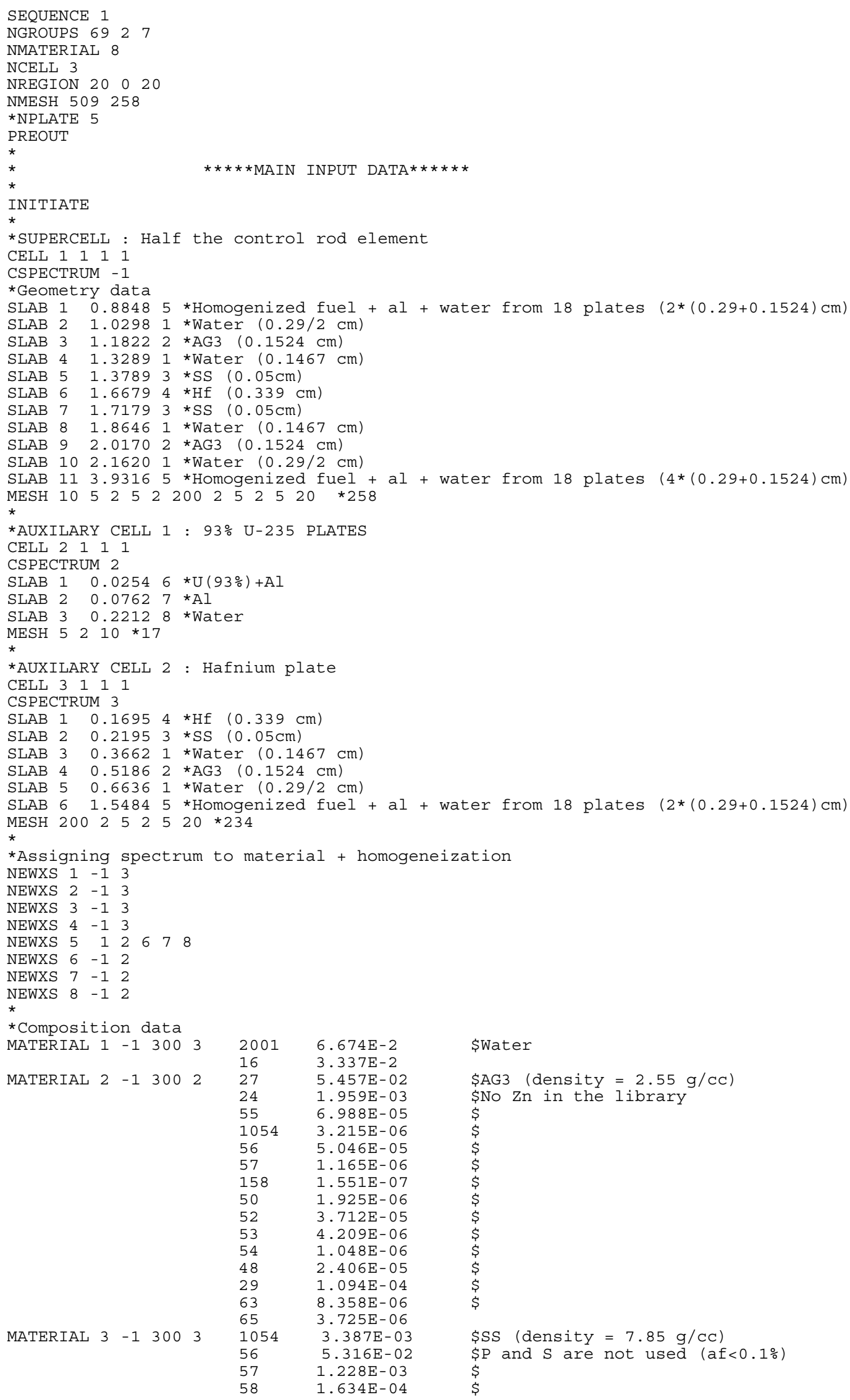




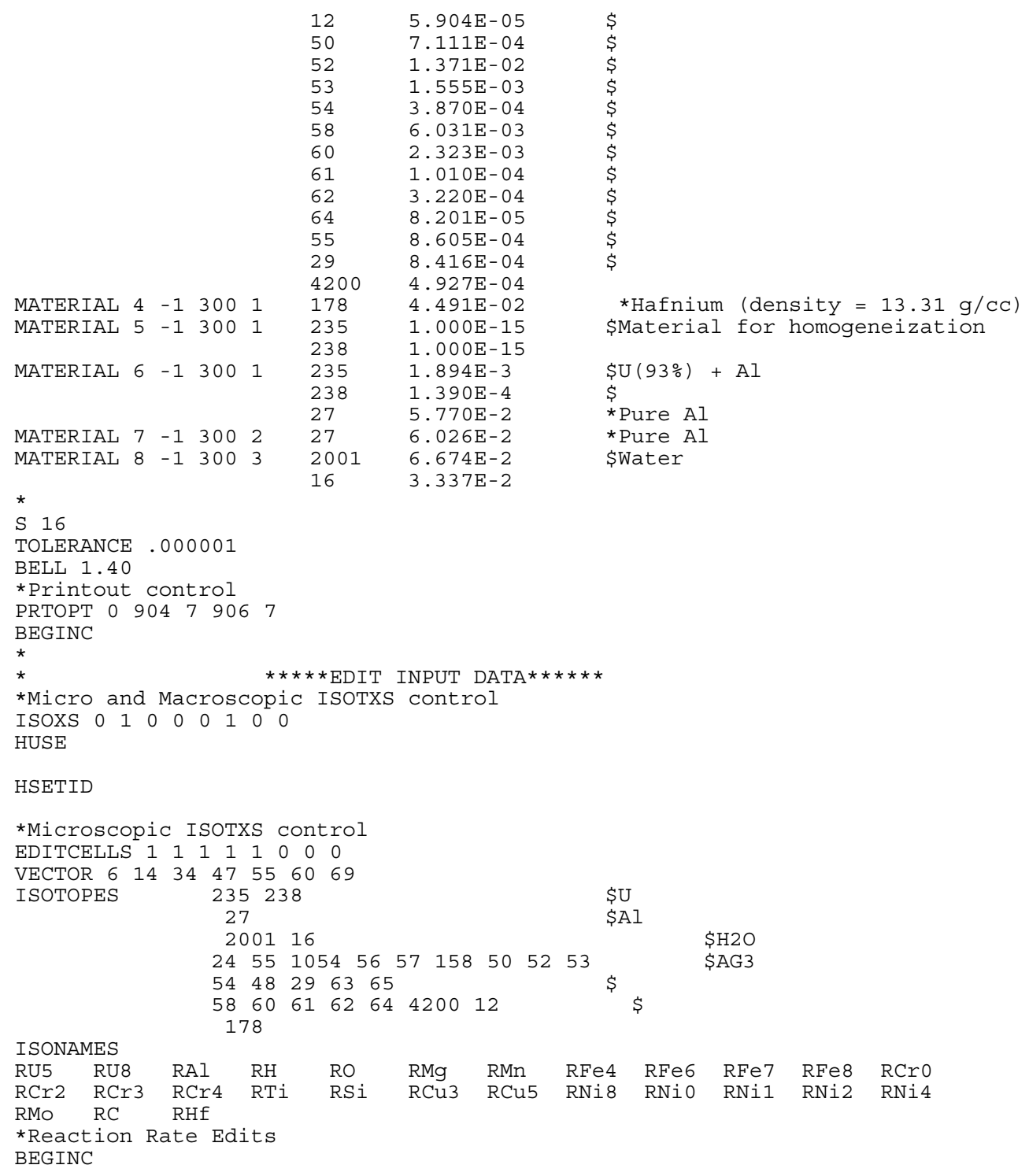

\section{File U(3)}

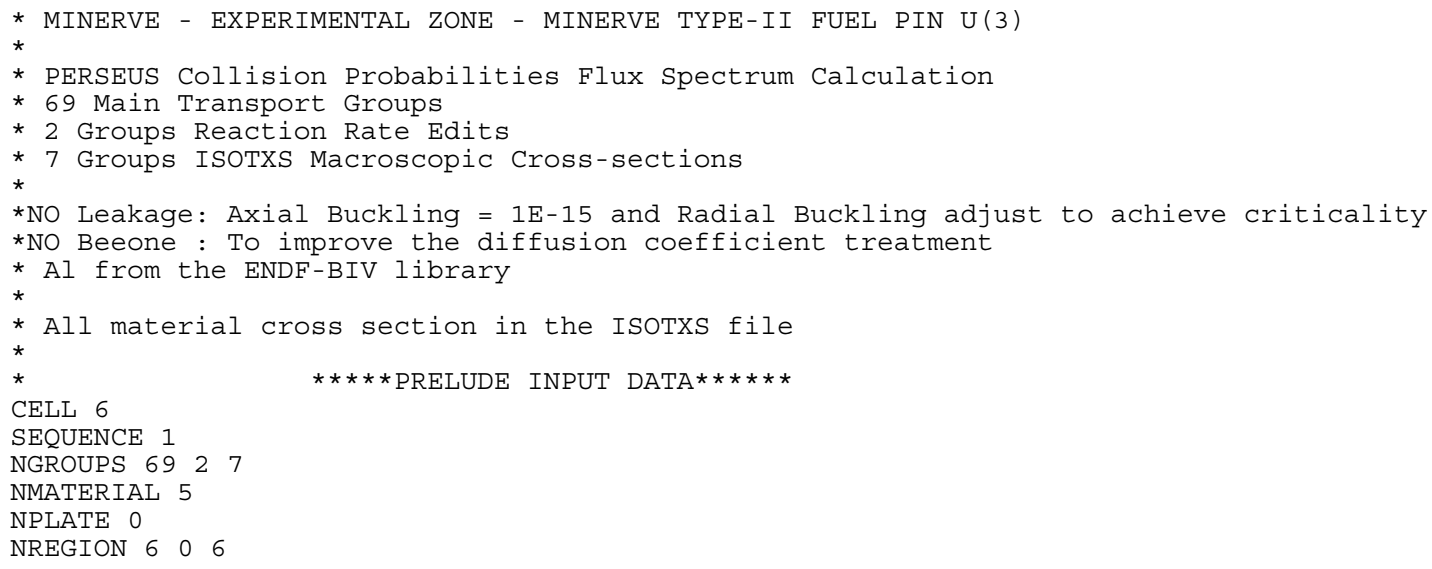




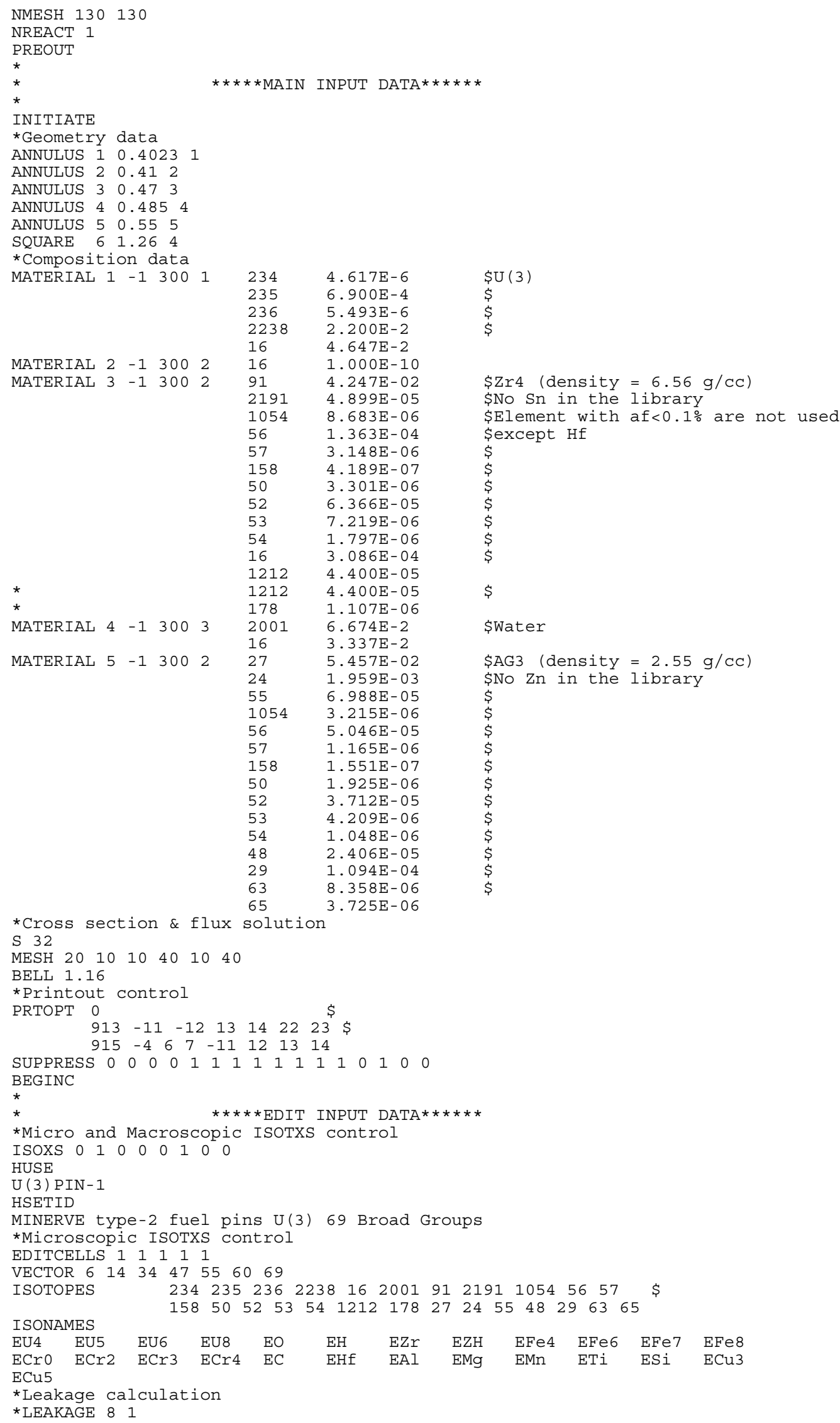


*BUCKLING 1.E-15 1.E-15

*BEEONE 1

*DNB $10.0 .0 .4 .647 \mathrm{E}-2$ 0. 0.0 .0$.

*DNB $30.0 .0 .3 .086 E-4$ 0. $0.683 E-60$.

$\begin{array}{llllllll}* \text { DNB } & 4 & 0.06674 & 0.0 .0 .0 .03337 & 0.0 .0 & 0.0 .\end{array}$

* Reaction Rate Edits

PARTITION 4569

REACTION $235 \quad 300 \quad 2238 \quad 300 \quad 234 \quad 300 \quad 236 \quad 300 \quad 16 \quad 300$

*Miscellaneous Edit Control

BEGINC

\section{File $\mathbf{U}(3) A x$}

* MINERVE - EXPERIMENTAL ZONE - AXIAL OF A PIN U(3)

* PERSEUS Collision Probabilities Flux Spectrum Calculation

* 69 Main Transport Groups

* 2 Groups Reaction Rate Edits

* 7 Groups Isotxs Macroscopic Cross-sections

*NO Leakage: Axial Buckling = 1E-15 and Radial Buckling adjust to achieve criticality

*NO Beeone : To improve the diffusion coefficient treatment

* Al is taken from the AG3 of the MSR w.o. impurities

* Al from the ENDF-BIV library

*

CELL 6

SEQUENCE 1

NGROUPS $6922 \quad 7$

NMATERIAL 3

NPLATE 1

NREGION $3 \quad 0 \quad 3$

NMESH 110110

NREACT 1

PREOUT

*

INITIATE

* Geometry data

SLAB $125.0 \quad 1$

SLAB 238.0

SLAB $3 \quad 39.5 \quad 3$

* Composition data

MATERTAL $1-1300$

$\star \star \star * *$ MAIN INPUT DATA $* * \star * \star *$

$\begin{array}{lllll}1 & -1 & 300 & 1\end{array}$

$4.617 E-6$
$6.900 E-4$
$5.493 E-6$

$\begin{array}{ll}2238 & 2.200 \mathrm{E}-2 \\ 16 & 4.647 \mathrm{E}-2\end{array}$

MATERIAL $2 \begin{array}{lllll}-1 & 300 & 2 & 12 & 3.549 \mathrm{E}-02\end{array}$

5. $678 \mathrm{E}-02$

1. $420 \mathrm{E}-02$

3. $387 \mathrm{E}-03$

5. $316 \mathrm{E}-02$

1. $228 \mathrm{E}-03$

1. $634 \mathrm{E}-04$

5. $904 \mathrm{E}-05$

7. $111 \mathrm{E}-04$

1. $371 \mathrm{E}-02$

1. 555E-03

3. $870 \mathrm{E}-04$

$6.031 \mathrm{E}-03$

2. $323 \mathrm{E}-03$

1. $010 \mathrm{E}-04$

3. $220 \mathrm{E}-04$

8. $201 \mathrm{E}-05$

8. $605 \mathrm{E}-04$

$8.416 \mathrm{E}-04$

$4200 \quad 4.927 \mathrm{E}-04$

*Cross section \& flux solution

S 32

MESH $50 \quad 50 \quad 10$

BELL 1.40

*Printout control

PRTOPT 0

$\begin{array}{llllllll}913 & -11 & -12 & 13 & 14 & 22 & 23^{\$} & \$\end{array}$

\$U (3)

$\$$
$\$$

\$PLEXI (density $=1.18 \mathrm{~g} / \mathrm{CC}$ )

\$SS (density $=7.85 \mathrm{~g} / \mathrm{CC}$ )

$\$ P$ and $S$ are not used $(a f<0.1 \%)$

$\$$

\$

$\$$

$\$$

$\$$ 


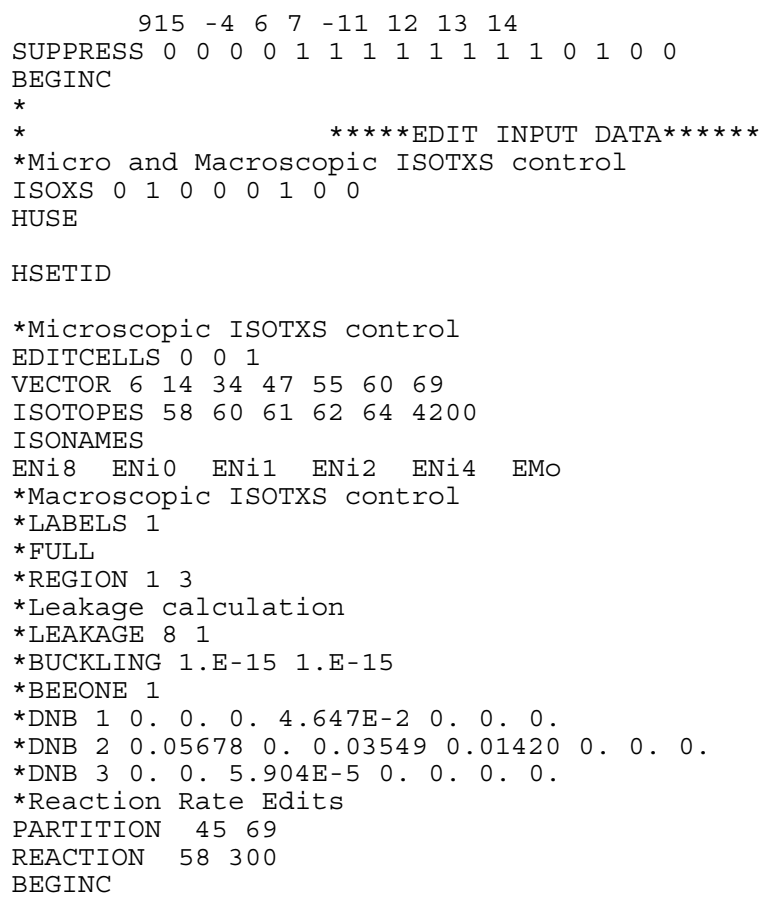

\section{File UAl}

* MINERVE - EXPERIMENTAL ZONE - INTERFACE MINERVE TYPE-II FUEL PIN U(3) / PIN AL

*

* 69 Main Transport Groups

* 2 Groups Reaction Rate Edits

* 7 Groups ISOTXS Macroscopic Cross-sections

*NO Leakage: Axial Buckling = 1E-15 and Radial Buckling adjust to achieve criticality

*NO Beeone : To improve the diffusion coefficient treatment

* Al from the ENDF-BIV library

* All material cross section in the IsoTXs file

CELL 6

$\star \star \star \star *$ PRELUDE INPUT DATA $* \star * \star * *$

SEQUENCE 1

NGROUPS $69 \quad 2 \quad 7$

NMATERIAL 6

NPLATE 0

NREGION $7 \quad 0 \quad 7$

NMESH $210 \quad 210$

NREACT 1

PREOUT

*

*

INITIATE

*Geometry data

ANNULUS 10.40231

$\begin{array}{llll}\text { ANNULUS } 2 & 0.41 & 2\end{array}$

$\begin{array}{llll}\text { ANNULUS } 3 & 0.47 & 3\end{array}$

ANNULUS $4 \quad 0.485 \quad 4$

ANNULUS $50.55 \quad 5$

SQUARE $6 \begin{array}{lll}6.26 & 4\end{array}$

SQUARE $7 \quad 3.78 \quad 6$

* Composition data

MATERIAL 1 - 1300

$\star * * * *$ MAIN INPUT DATA $* * * * * *$

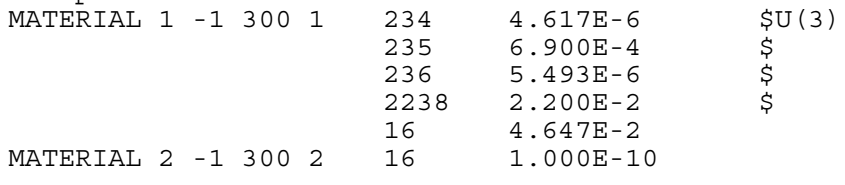




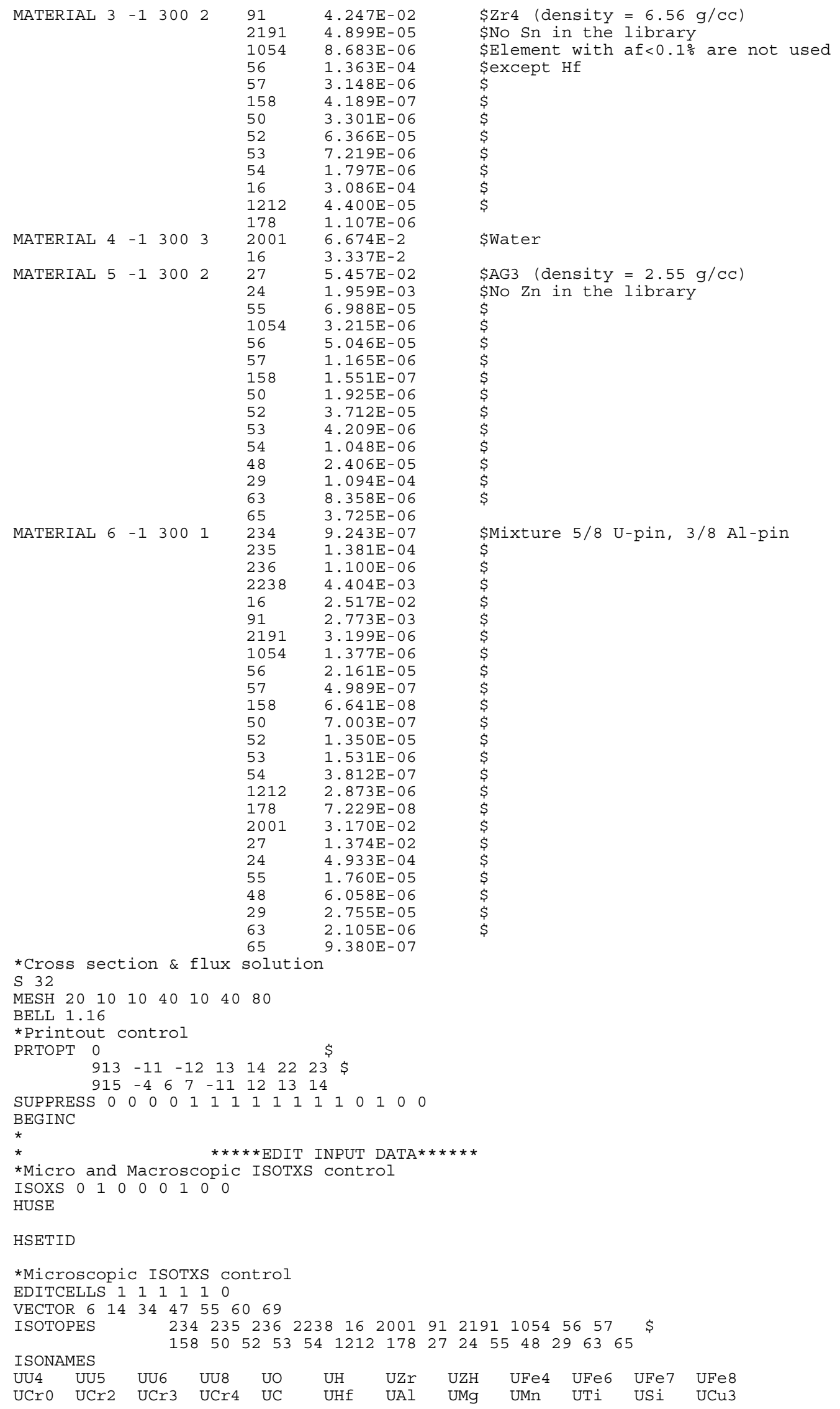


$\mathrm{UCu} 5$

* Leakage calculation

* LEAKAGE 81

*BUCKLING 1.E-15 1.E-15

* $\mathrm{BEEONE} 1$

*DNB $10.0 .0 .4 .647 E-2$ 0. 0.0.

*DNB $30.0 .0 .3 .086 \mathrm{E}-4$ - $0.8 .683 \mathrm{E}-60$.

$\begin{array}{llllllllll}* \text { DNB } & 4 & 0.06674 & 0.0 & 0.0 .03337 & 0.0 .0 & 0 .\end{array}$

* Reaction Rate Edits

PARTITION 4569

REACTION $235 \quad 300 \quad 2238 \quad 300 \quad 234 \quad 300 \quad 236 \quad 300 \quad 16300$

*Miscellaneous Edit Control

BEGINC

\section{File UALB}

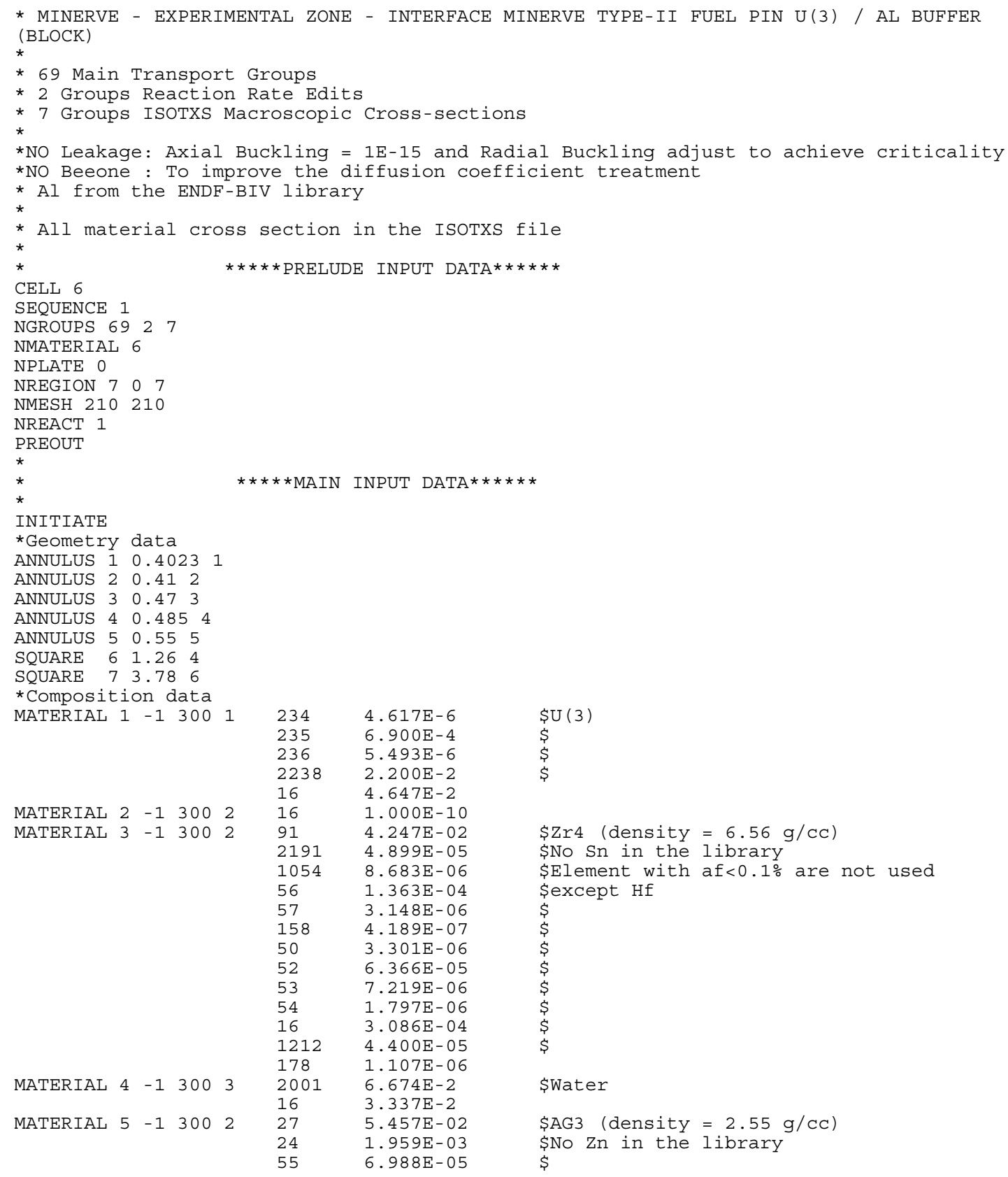




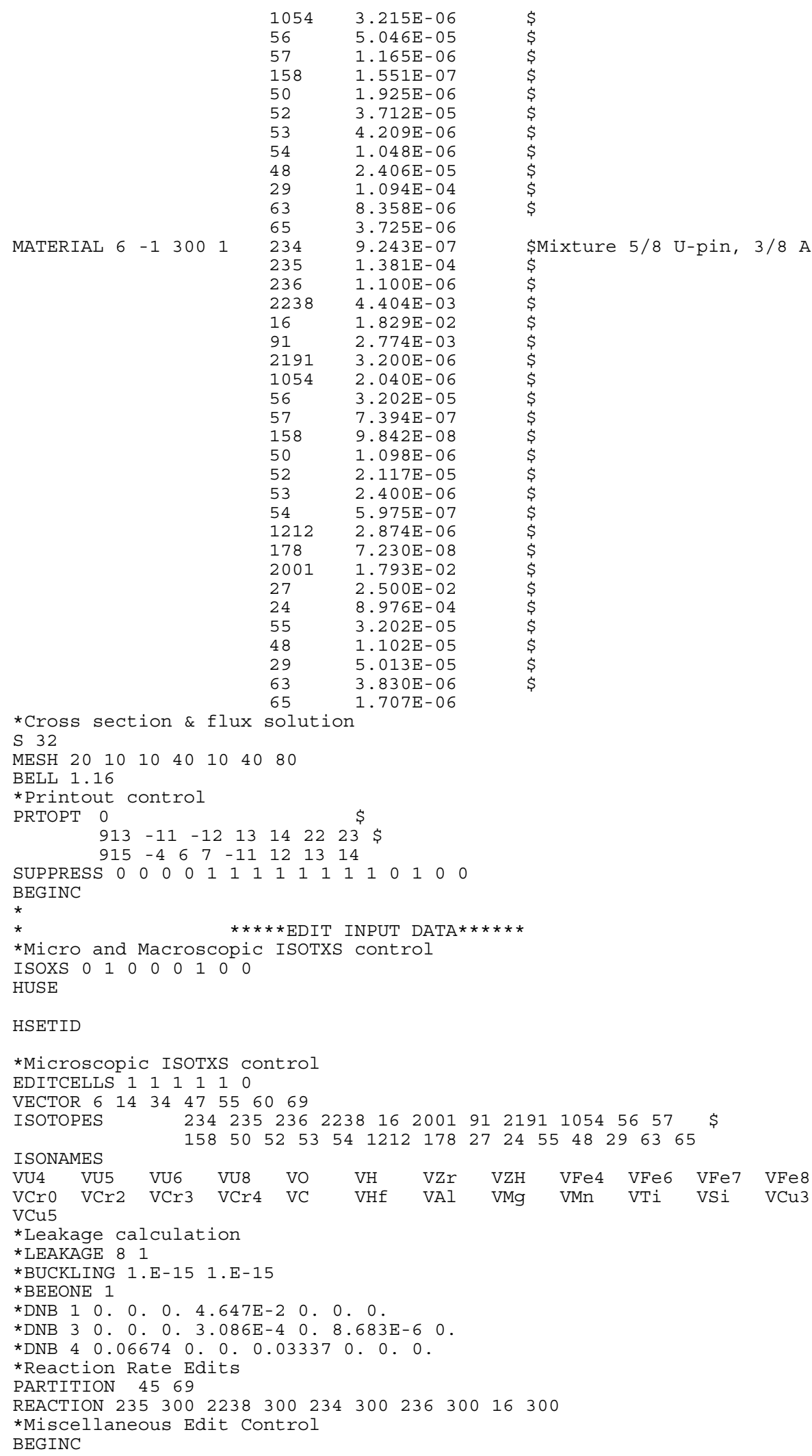




\section{File UPuPu1}

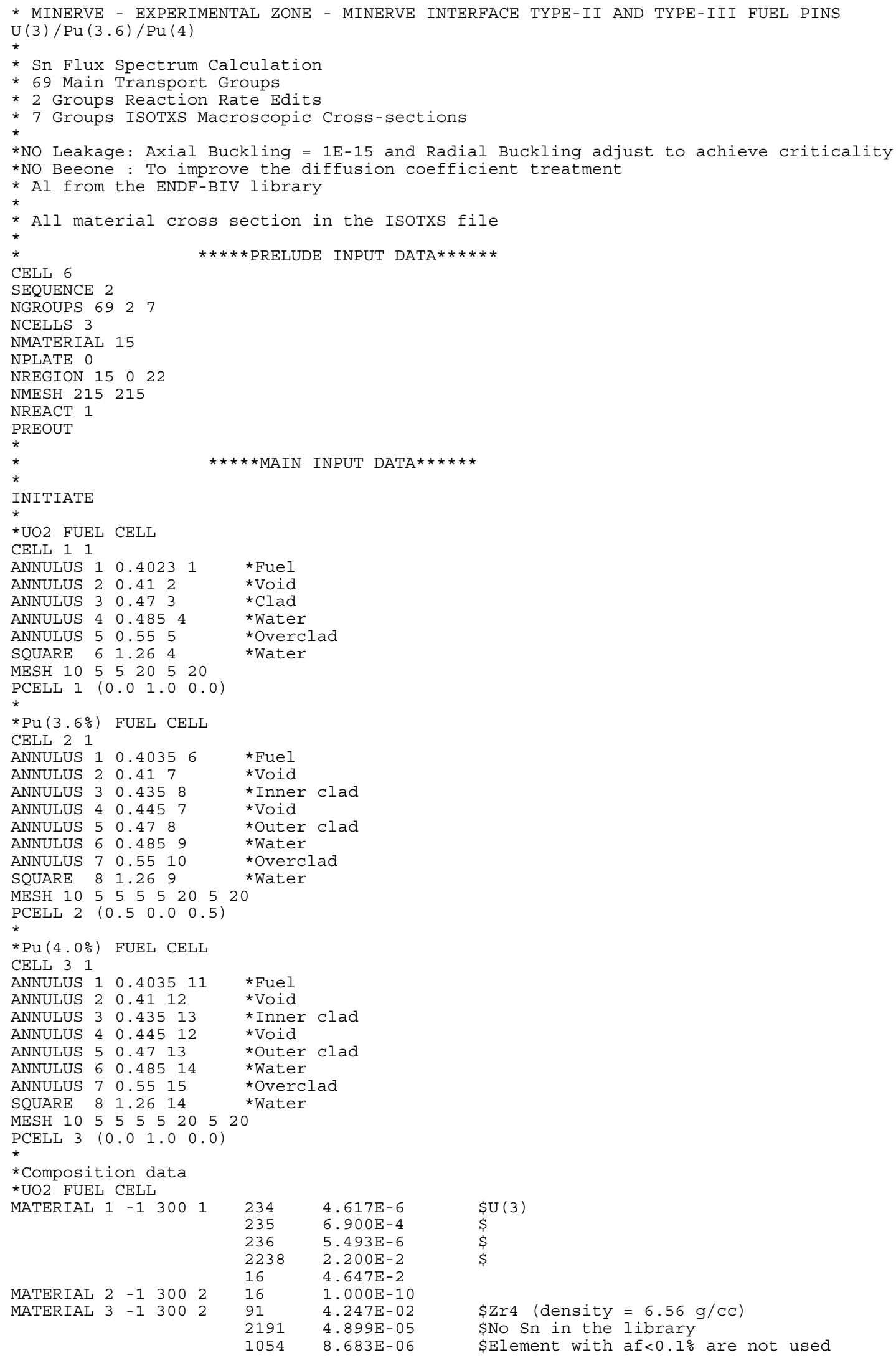




\begin{tabular}{|c|c|c|c|}
\hline & 56 & $1.363 E-04$ & \$except Hf \\
\hline & 57 & $3.148 \mathrm{E}-06$ & $\$$ \\
\hline & 158 & $4.189 \mathrm{E}-07$ & $\$$ \\
\hline & 50 & $3.301 \mathrm{E}-06$ & $\$$ \\
\hline & 52 & $6.366 \mathrm{E}-05$ & $\$$ \\
\hline & 53 & $7.219 \mathrm{E}-06$ & $\$$ \\
\hline & 54 & $1.797 \mathrm{E}-06$ & $\$$ \\
\hline & 16 & $3.086 \mathrm{E}-04$ & $\$$ \\
\hline & 1212 & $4.440 E-05$ & $\$$ \\
\hline & 178 & $1.107 \mathrm{E}-06$ & \\
\hline MATERIAL $4-1 \quad 3003$ & 2001 & $6.674 \mathrm{E}-2$ & \$Water \\
\hline & 16 & $3.337 \mathrm{E}-2$ & \\
\hline MATERIAL $5-1 \quad 300 \quad 2$ & 27 & $5.457 \mathrm{E}-02$ & \$AG3 (density $=2.55 \mathrm{~g} / \mathrm{CC})$ \\
\hline & 24 & $1.959 \mathrm{E}-03$ & \$No Zn in the library \\
\hline & 55 & $6.988 \mathrm{E}-05$ & $\$$ \\
\hline & 1054 & $3.215 \mathrm{E}-06$ & $\$$ \\
\hline & 56 & $5.046 E-05$ & $\$$ \\
\hline & 57 & $1.165 \mathrm{E}-06$ & $\$$ \\
\hline & 158 & $1.551 \mathrm{E}-07$ & $\$$ \\
\hline & 50 & $1.925 \mathrm{E}-06$ & $\$$ \\
\hline & 52 & $3.712 \mathrm{E}-05$ & $\$$ \\
\hline & 53 & $4.209 \mathrm{E}-06$ & $\$$ \\
\hline & 54 & $1.048 \mathrm{E}-06$ & $\$$ \\
\hline & 48 & $2.406 \mathrm{E}-05$ & $\$$ \\
\hline & 29 & $1.094 \mathrm{E}-04$ & $\$$ \\
\hline & 63 & $8.358 \mathrm{E}-06$ & $\$$ \\
\hline & 65 & $3.725 \mathrm{E}-06$ & \\
\hline$* \mathrm{Pu}(3.6 \%)$ FUEL CELL & & & \\
\hline MATERIAL $6-1300 \quad 1$ & 234 & $2.951 \mathrm{E}-6$ & $\$ \mathrm{Pu}(3.6)$ \\
\hline & 235 & $1.588 \mathrm{E}-4$ & $\$$ \\
\hline & 2238 & $2.189 \mathrm{E}-2$ & $\$$ \\
\hline & 1238 & $6.501 \mathrm{E}-6$ & $\$$ \\
\hline & 3239 & $5.743 E-4$ & $\$$ \\
\hline & 240 & $1.389 \mathrm{E}-4$ & $\$$ \\
\hline & 241 & $1.920 \mathrm{E}-5$ & $\$$ \\
\hline & 242 & $1.621 \mathrm{E}-5$ & $\$$ \\
\hline & 1241 & $6.036 \mathrm{E}-5$ & $\$$ \\
\hline & 237 & $1.811 \mathrm{E}-6$ & $\$$ \\
\hline & 16 & $4.574 \mathrm{E}-2$ & \\
\hline 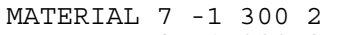 & 16 & $1.000 \mathrm{E}-10$ & \\
\hline MATERIAL $8-1 \quad 300 \quad 2$ & 91 & $4.248 \mathrm{E}-02$ & \$Zr2 $($ density $=6.56 \mathrm{~g} / \mathrm{CC})$ \\
\hline & 2191 & $4.899 \mathrm{E}-05$ & \$No $\mathrm{Sn}$ in the library \\
\hline & 1054 & $5.582 \mathrm{E}-06$ & $\$$ Element with af<0.1\% are not used \\
\hline & & $8.763 E-05$ & \$except Hf \\
\hline & 57 & $2.024 \mathrm{E}-06$ & $\$$ \\
\hline & 158 & $2.693 \mathrm{E}-07$ & $\$$ \\
\hline & 50 & $3.301 \mathrm{E}-06$ & $\$$ \\
\hline & 52 & $6.366 \mathrm{E}-05$ & $\$$ \\
\hline & 53 & $7.219 \mathrm{E}-06$ & $\$$ \\
\hline & 54 & $1.797 \mathrm{E}-06$ & $\$$ \\
\hline & 16 & $3.086 \mathrm{E}-04$ & $\$$ \\
\hline & 1212 & $4.440 \mathrm{E}-05$ & $\$$ \\
\hline & 178 & $1.107 \mathrm{E}-06$ & \\
\hline MATERIAL $9-13003$ & 2001 & $6.674 \mathrm{E}-2$ & \$Water \\
\hline & 16 & $3.337 \mathrm{E}-2$ & \\
\hline MATERIAL $10 \quad-1300 \quad 2$ & 27 & $5.457 \mathrm{E}-02$ & \$AG3 (density $=2.55 \mathrm{~g} / \mathrm{CC})$ \\
\hline & 24 & $1.959 \mathrm{E}-03$ & \$No $\mathrm{Zn}$ in the library \\
\hline & 55 & $6.988 \mathrm{E}-05$ & \\
\hline & 1054 & $3.215 \mathrm{E}-06$ & $\$$ \\
\hline & 56 & $5.046 \mathrm{E}-05$ & $\$$ \\
\hline & 57 & $1.165 \mathrm{E}-06$ & $\$$ \\
\hline & 158 & $1.551 \mathrm{E}-07$ & $\$$ \\
\hline & 50 & $1.925 \mathrm{E}-06$ & $\$$ \\
\hline & 52 & $3.712 E-05$ & $\$$ \\
\hline & 53 & $4.209 \mathrm{E}-06$ & $\$$ \\
\hline & 54 & $1.048 \mathrm{E}-06$ & $\$$ \\
\hline & 48 & $2.406 \mathrm{E}-05$ & $\$$ \\
\hline & 29 & $1.094 \mathrm{E}-04$ & $\$$ \\
\hline & 63 & $8.358 \mathrm{E}-06$ & $\$$ \\
\hline & 65 & $3.725 \mathrm{E}-06$ & \\
\hline *Pu $(4.0 \%) \quad$ FUEL CELL & & & \\
\hline MATERIAL $11-1 \quad 300 \quad 1$ & 234 & $3.139 \mathrm{E}-6$ & $\$ \mathrm{Pu}(4)$ \\
\hline & 235 & $1.581 \mathrm{E}-4$ & $\$$ \\
\hline & 2238 & $2.180 \mathrm{E}-2$ & $\$$ \\
\hline & 1238 & $7.223 E-6$ & $\$$ \\
\hline & 3239 & $6.382 \mathrm{E}-4$ & $\$$ \\
\hline & 240 & $1.543 \mathrm{E}-4$ & $\$$ \\
\hline & 241 & $2.133 E-5$ & $\$$ \\
\hline & 242 & $1.801 \mathrm{E}-5$ & $\$$ \\
\hline & 1241 & $6.706 \mathrm{E}-5$ & $\$$ \\
\hline & 237 & $2.012 \mathrm{E}-6$ & $\$$ \\
\hline
\end{tabular}




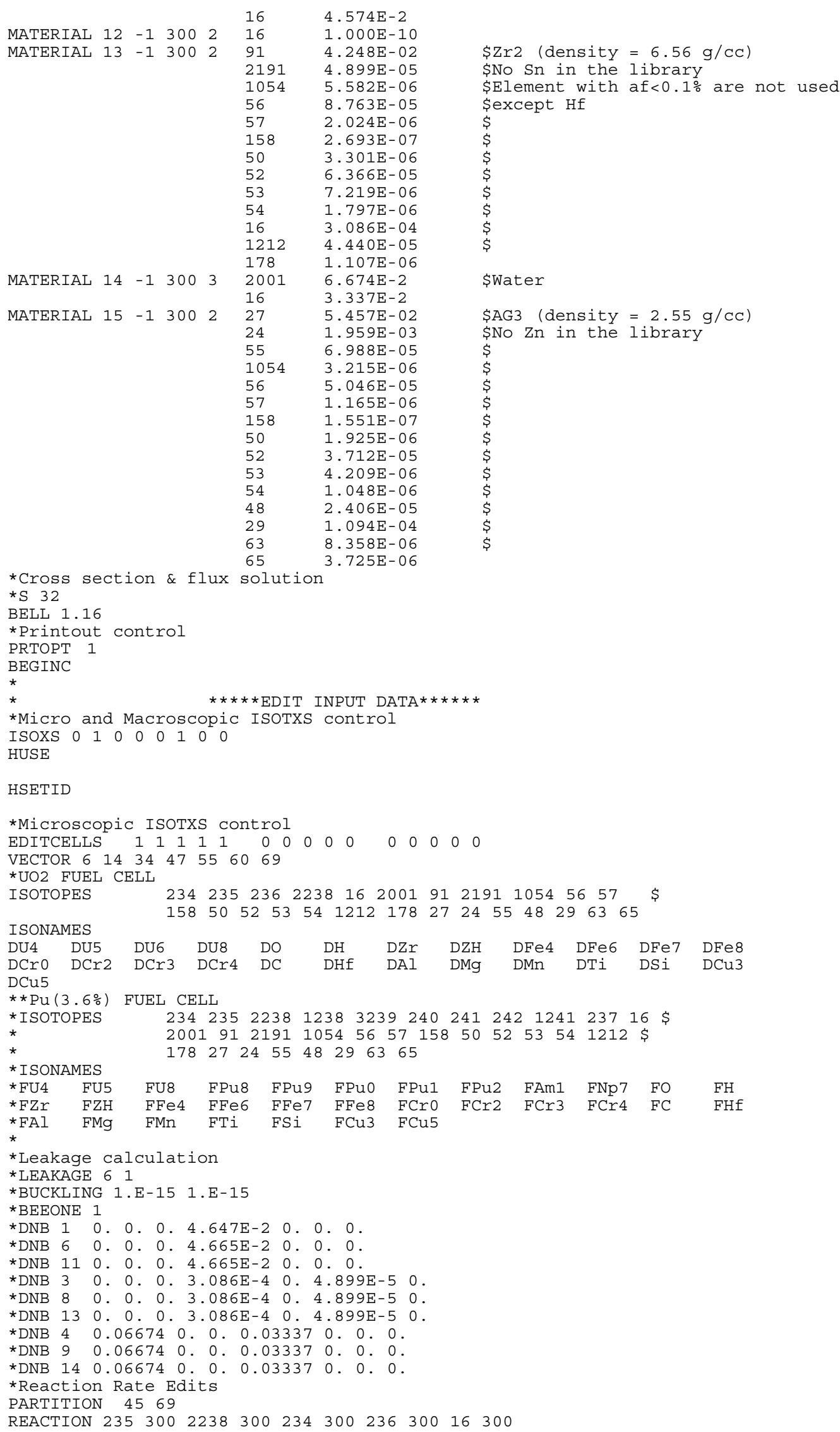

HSETID

*Microscopic IsOTXS control 
*Miscellaneous Edit Control

BEGINC

\section{File $\mathrm{Pu}(4)$}

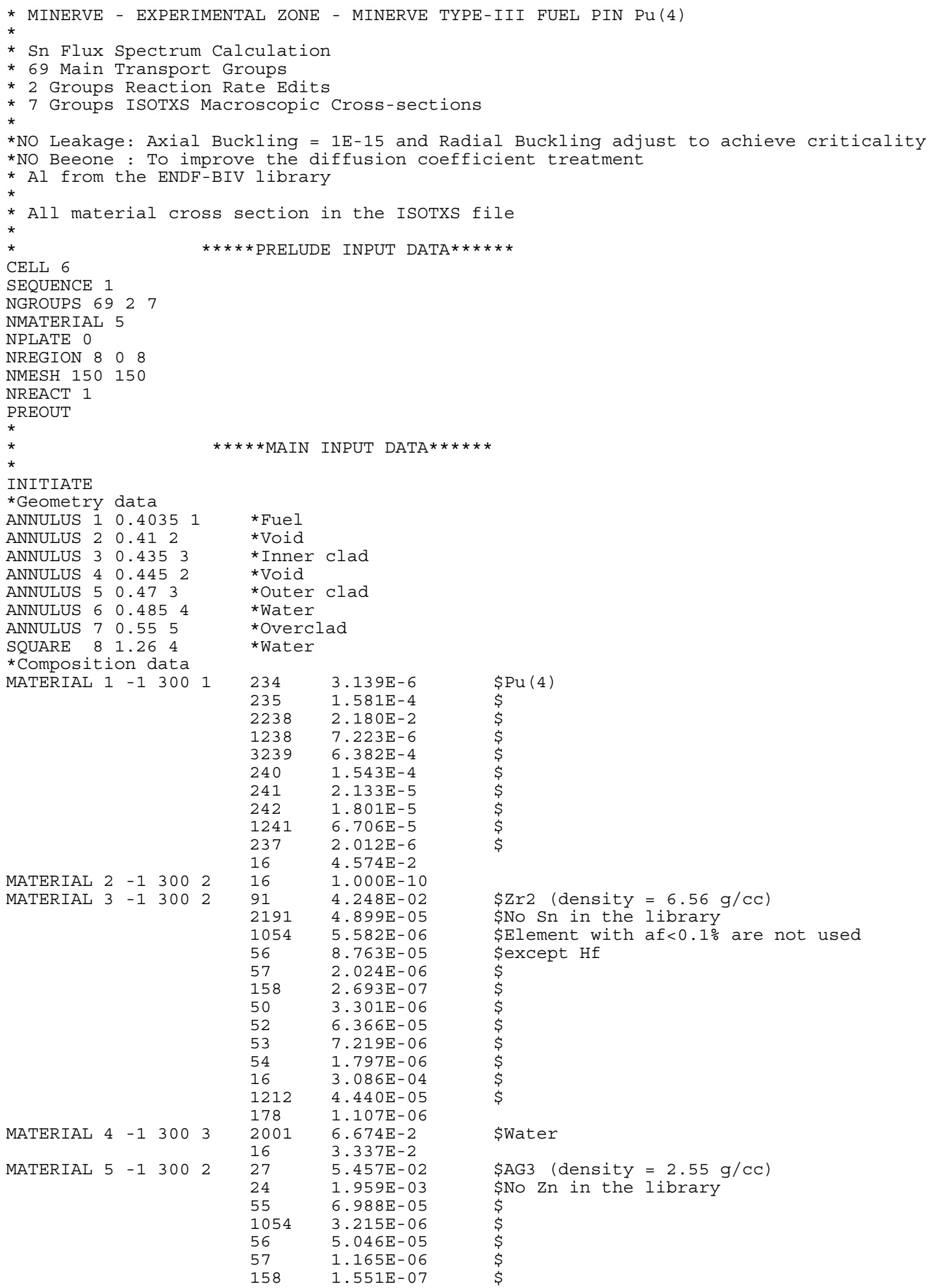




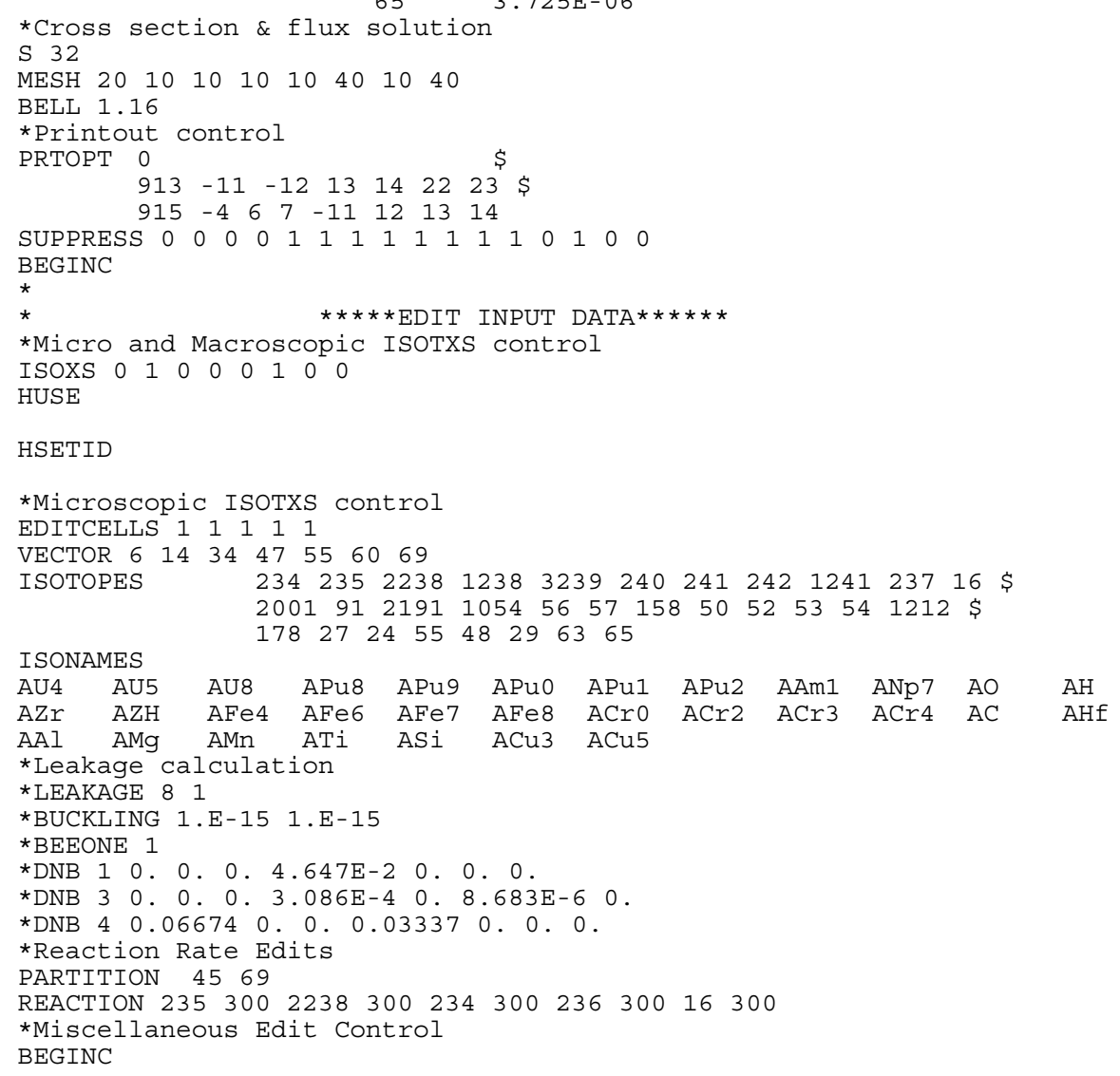

\section{File Pu(4)Ax}

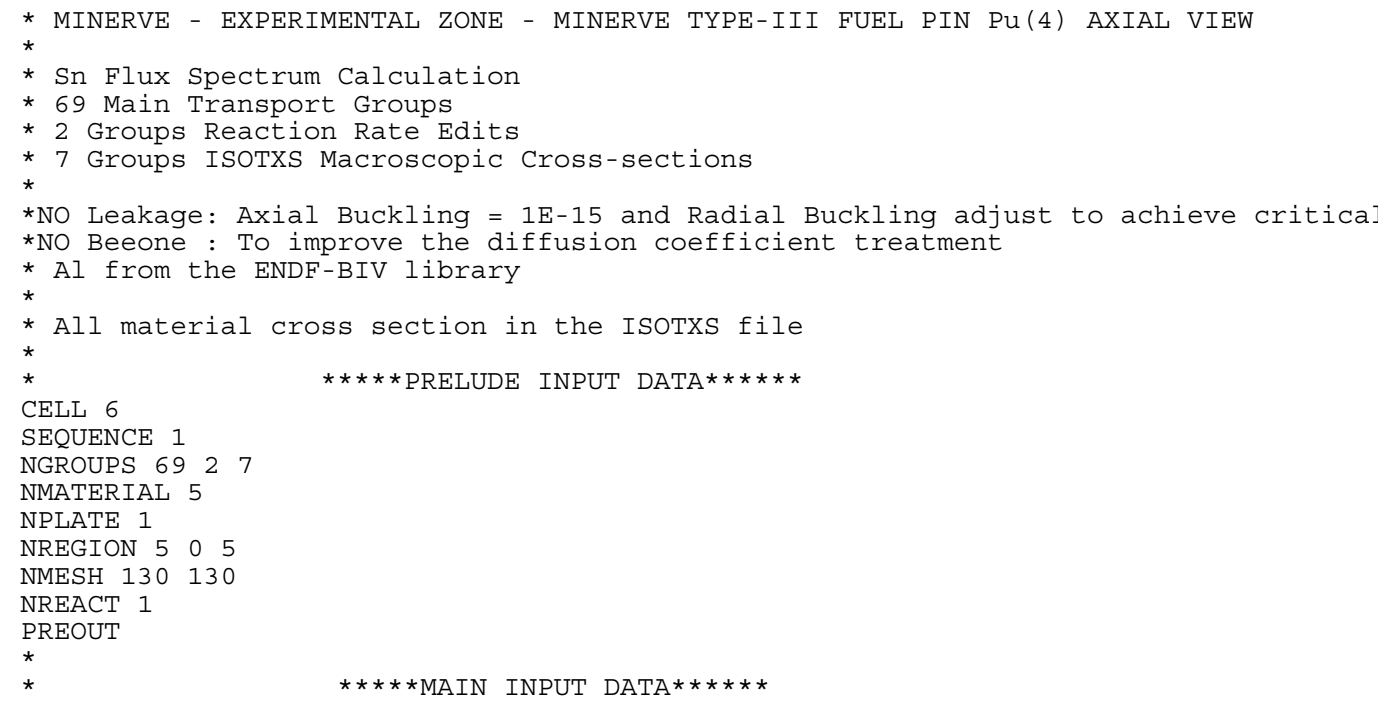




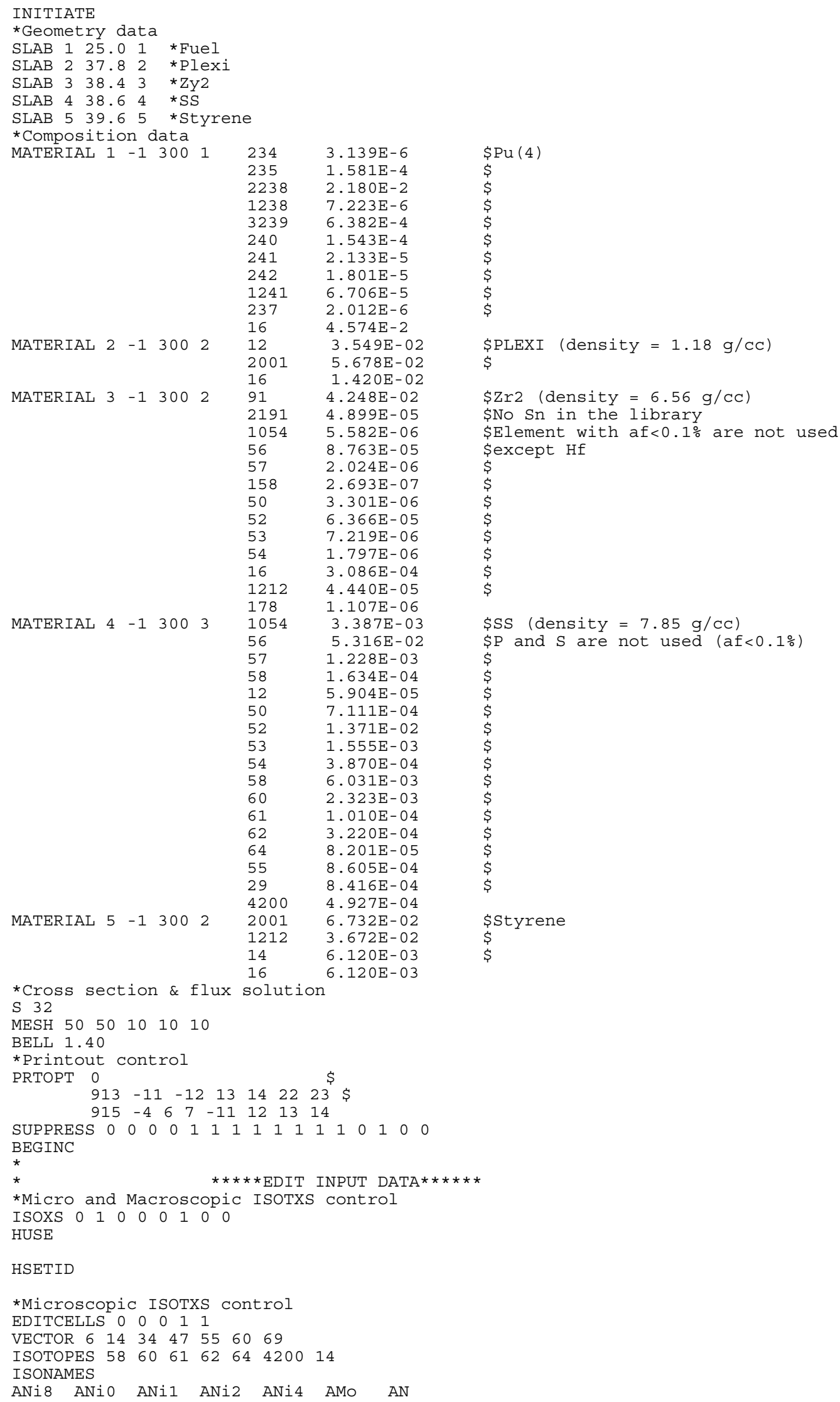


* Leakage calculation

* LEAKAGE 81

*BUCKLING 1.E-15 1.E-15

*BEEONE 1

*DNB $10.0 .0 .4 .647 E-2$ 0.0.0.0. 0.0.

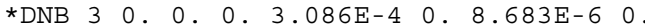

$\begin{array}{lllllllll}* \text { DNB } 4 & 0.06674 & 0.0 & 0.03337 & 0.0 .0 & 0 .\end{array}$

* Reaction Rate Edits

PARTITION 4569

REACTION $58 \quad 300$

*Miscellaneous Edit Control

BEGINC

\section{File UPu}

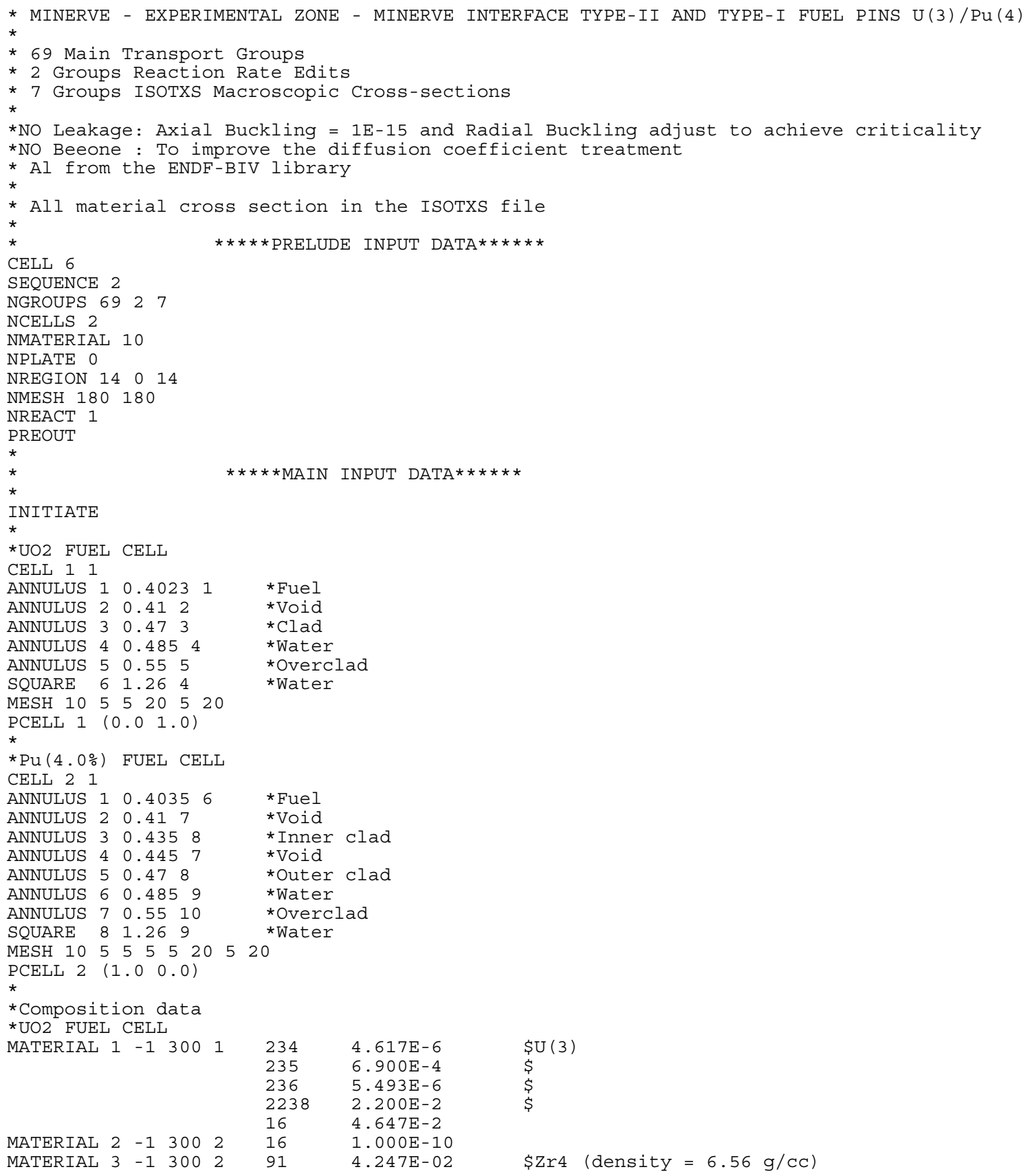




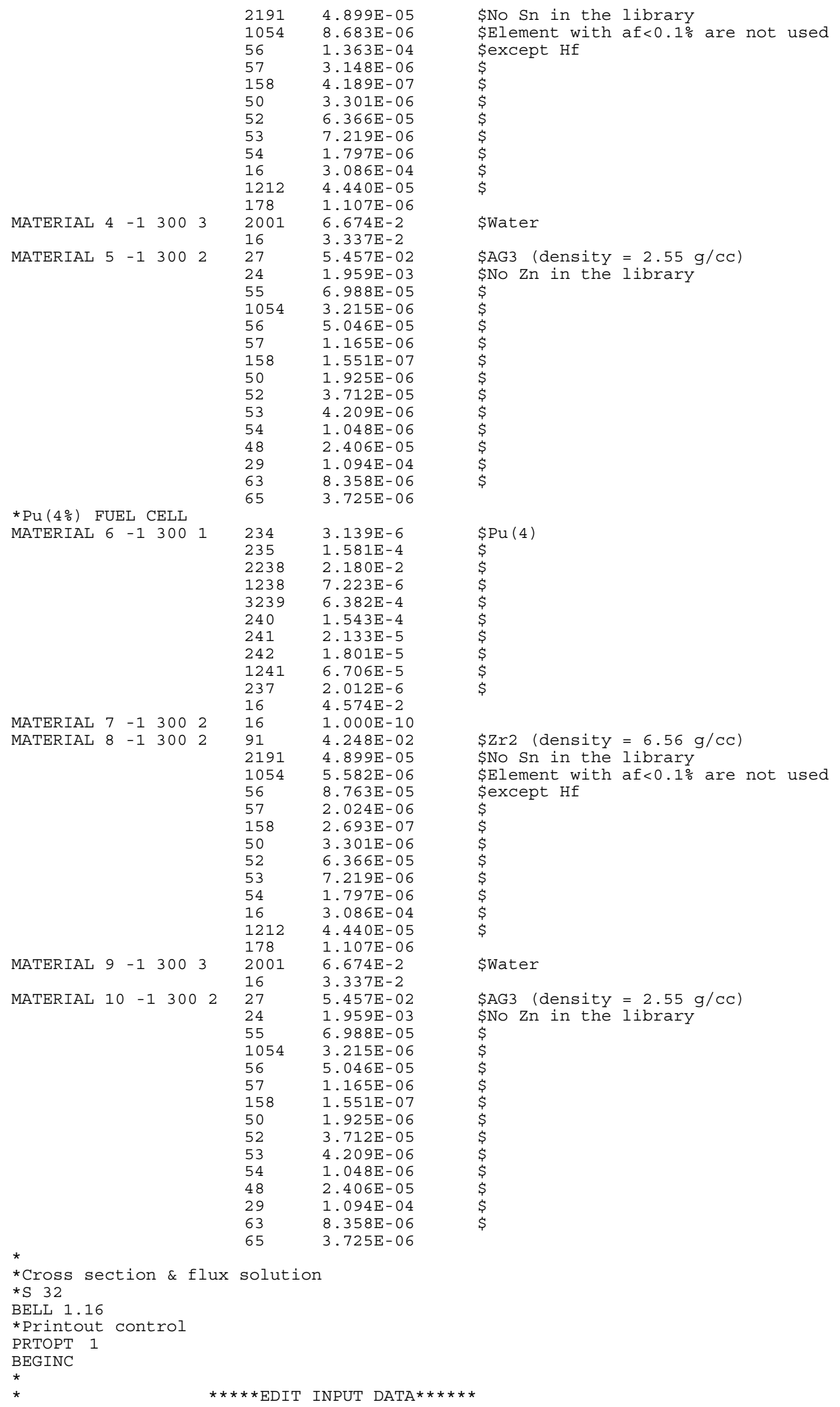




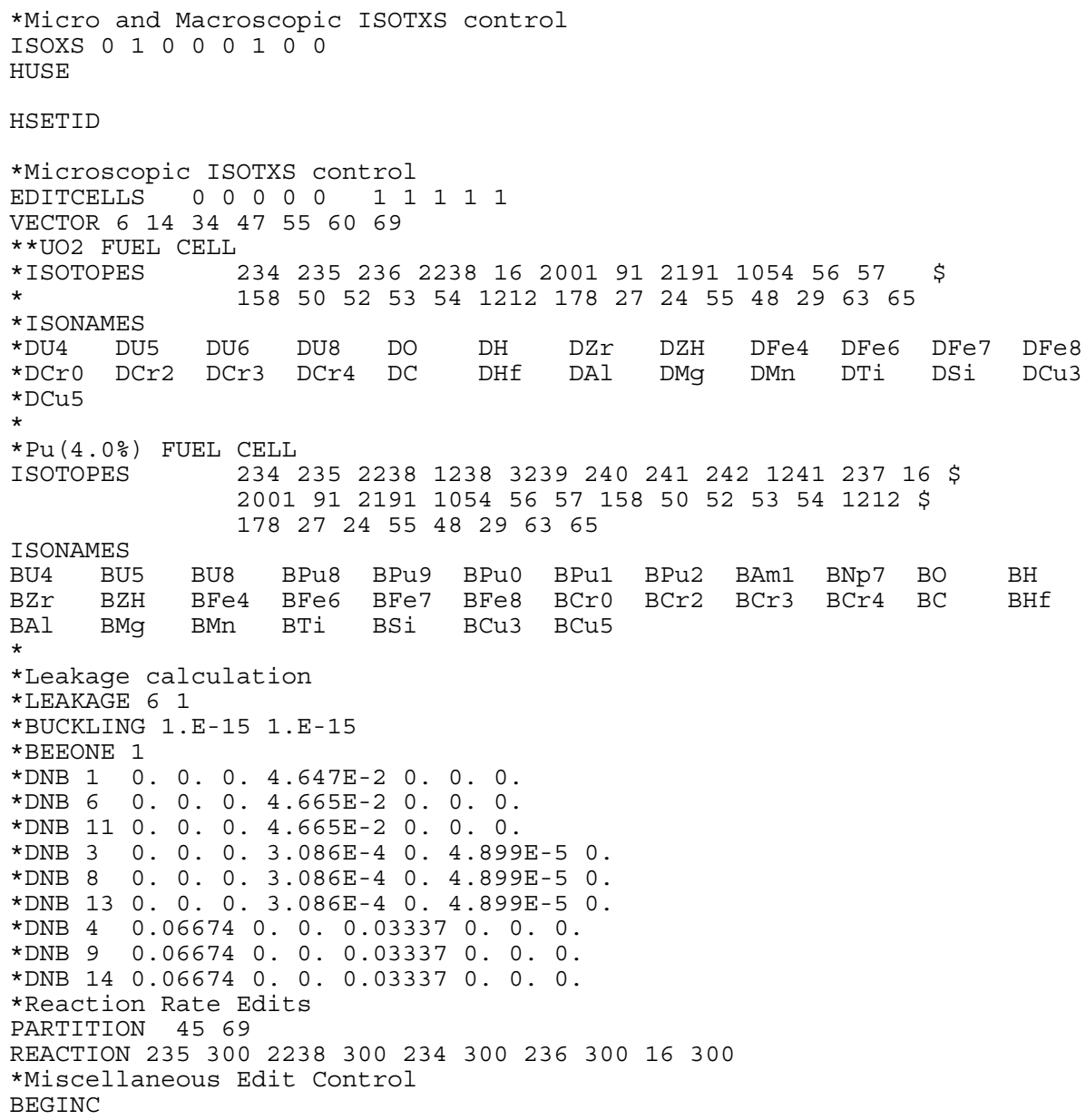

\section{File PuPOL}

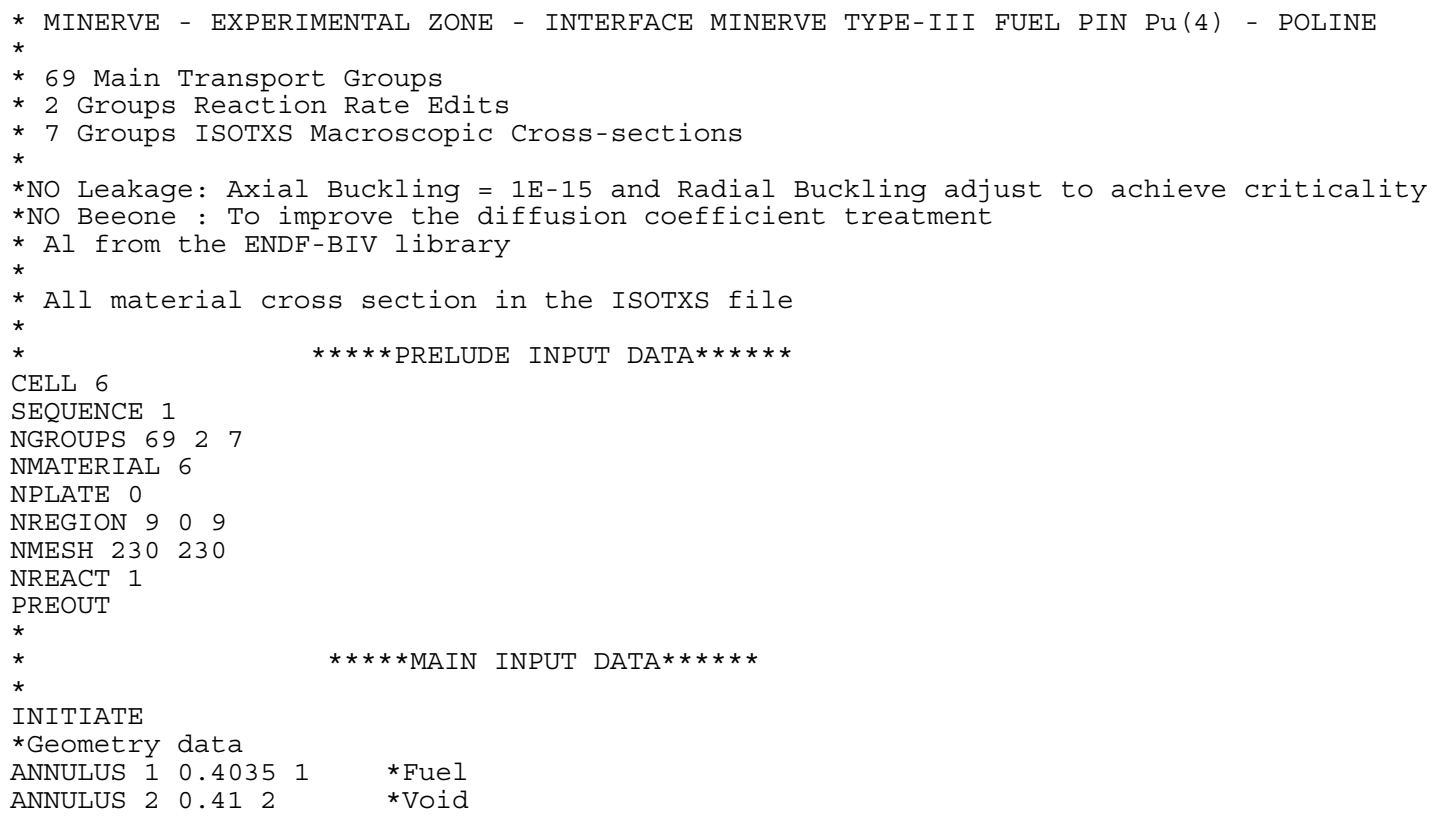




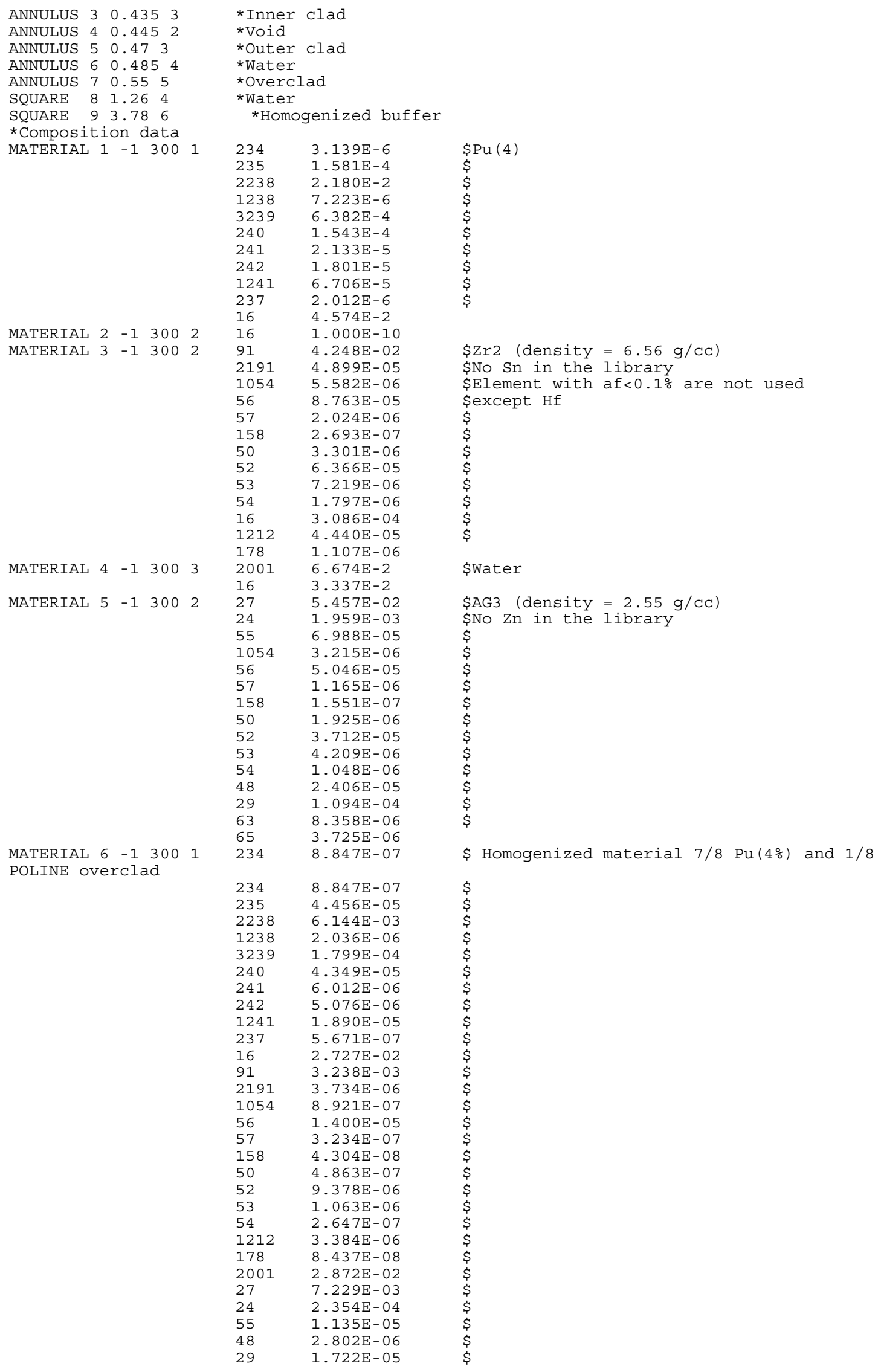




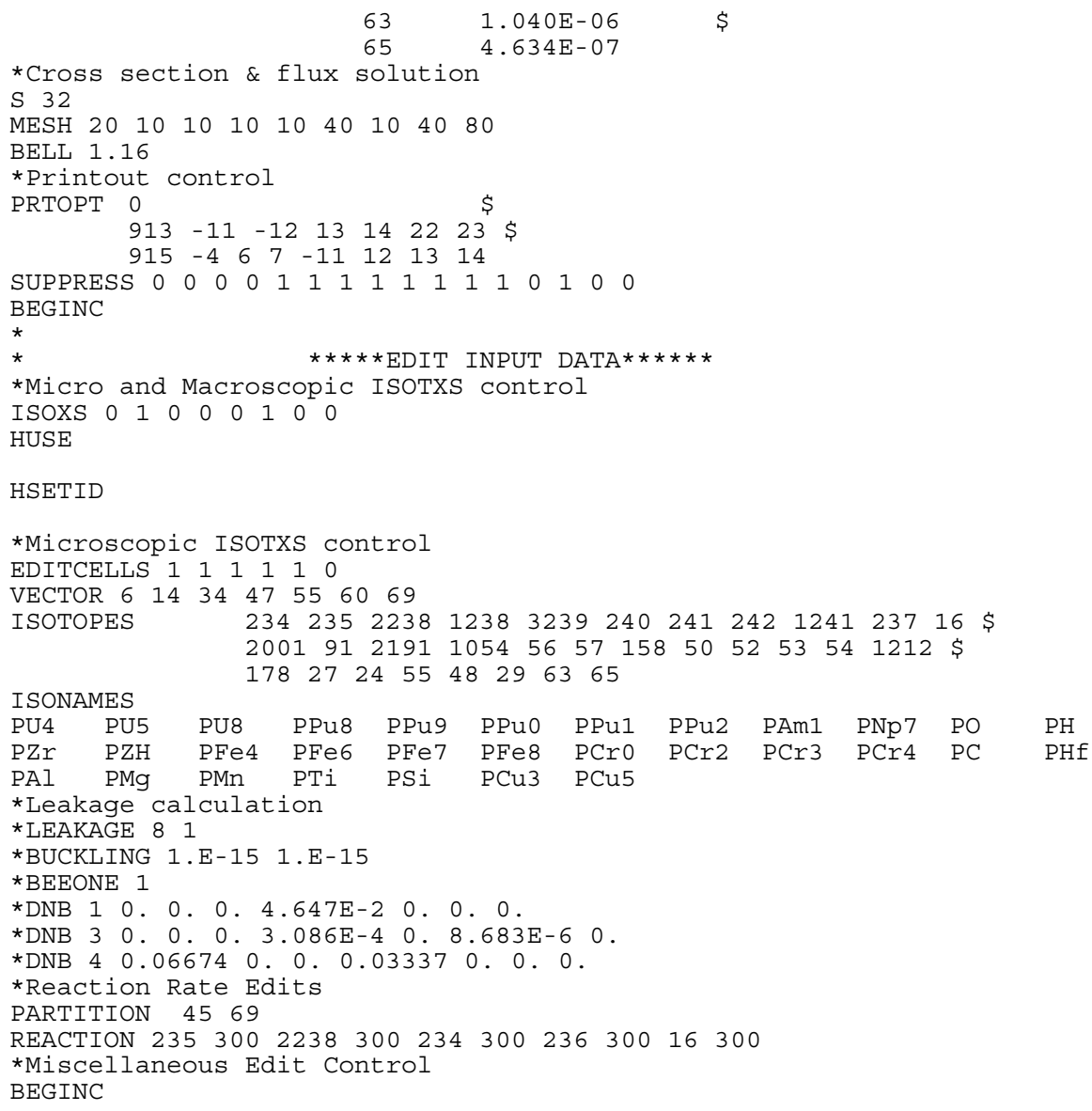

\section{File UPuPu2}

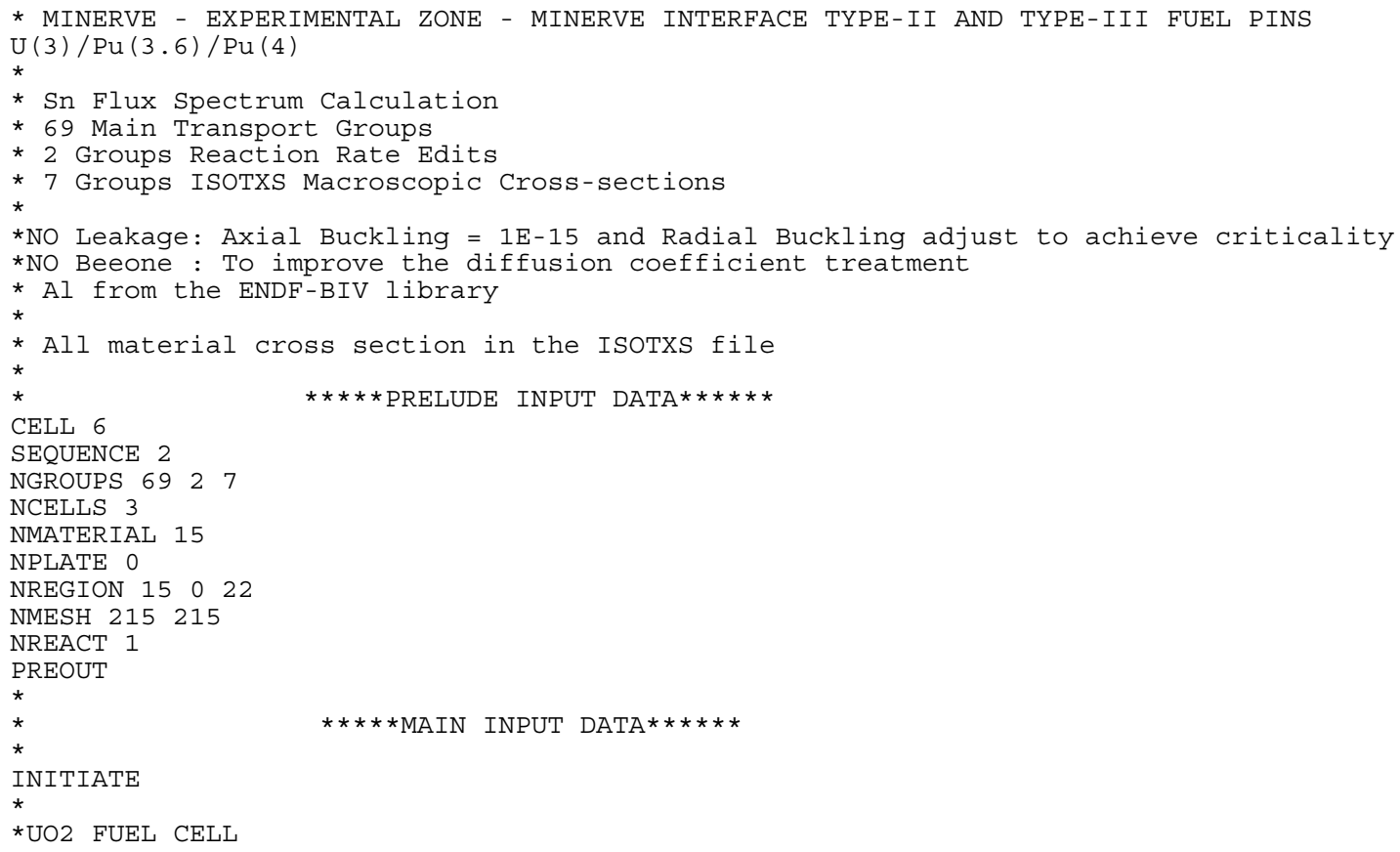


CELL 11

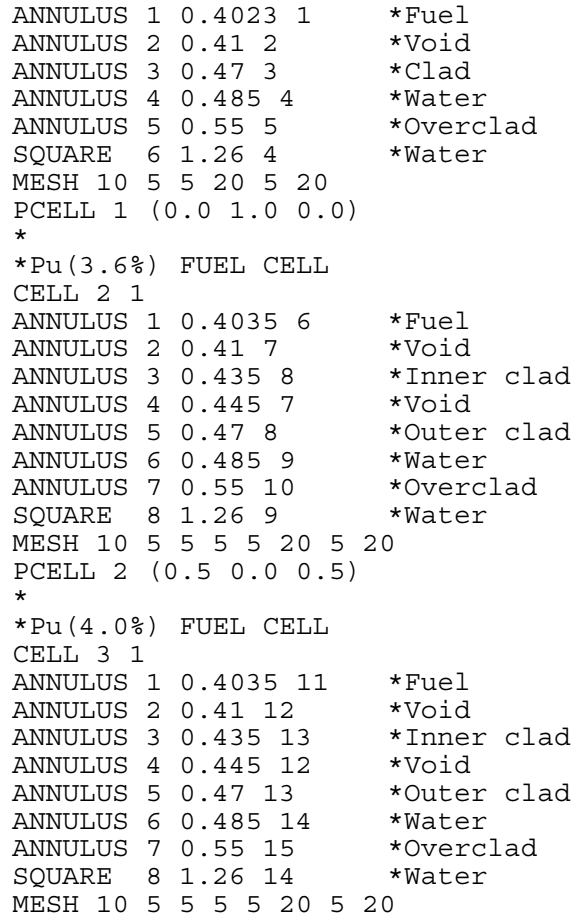

MESH $10 \quad \begin{array}{lllllll}5 & 5 & 5 & 5 & 20 & 5 & 20\end{array}$

PCELL $3 \quad\left(\begin{array}{llll}0.0 & 1.0 & 0.0\end{array}\right)$

* Composition data

*UO2 FUEL CELI

MATERIAL 1 - $1300 \quad 1$

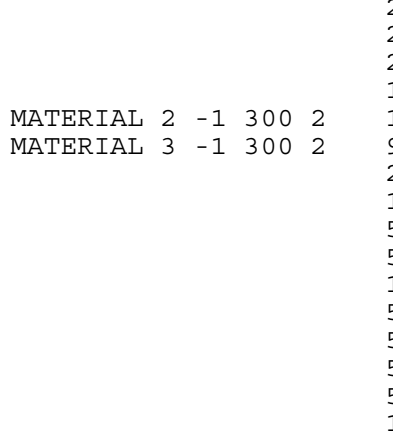

178

MATERIAL $4 \begin{array}{lllll}4 & -1 & 300 & 3 & 2001\end{array}$

MATERIAL $5 \quad-1300 \quad 2$

* $\mathrm{Pu}(3.6 \%)$ FUEL CELL MATERIAL $6-13001$
234

235

$-2$

2238

16

91

2191

1054

56

57
158

50

52

53

54

12

16
27
24

55

1054

56

57

158

50

52

53

54

48

29

234

235

2238

1238

3239

240
4. $617 \mathrm{E}-6$

6. $900 \mathrm{E}-4$

5. $493 \mathrm{E}-6$

2. $200 \mathrm{E}-2$

4. $647 \mathrm{E}-2$

1. $000 \mathrm{E}-10$

4. $247 \mathrm{E}-02$

4. 899E-05

8. $683 \mathrm{E}-06$

1. $363 \mathrm{E}-04$

3. $148 \mathrm{E}-06$

4. 189E-07

3. $301 \mathrm{E}-06$

$6.366 \mathrm{E}-05$

7. 219E-06

1. $797 \mathrm{E}-06$

3. $086 \mathrm{E}-04$

4. $440 \mathrm{E}-05$

1. $107 \mathrm{E}-06$

6. $674 \mathrm{E}-2$

3. $337 \mathrm{E}-2$

5. $457 \mathrm{E}-02$

1. $959 \mathrm{E}-03$

6. $988 \mathrm{E}-05$

3. $215 \mathrm{E}-06$

5. $046 \mathrm{E}-05$

1. $165 \mathrm{E}-06$

1. 551E-07

1.925E-06

3. $712 \mathrm{E}-05$

4. 209E-06

1.048E-06

2. $406 \mathrm{E}-05$

1. $094 \mathrm{E}-04$

$8.358 \mathrm{E}-06$

3. $725 \mathrm{E}-06$

2. $951 \mathrm{E}-6$

1. $588 \mathrm{E}-4$

2. $189 \mathrm{E}-2$

$6.501 \mathrm{E}-6$

5. $743 \mathrm{E}-4$

1. $389 \mathrm{E}-4$
$\$ U(3)$
$\$$
$\$$
$\$$

$\$$ Zr4 (density $=6.56 \mathrm{~g} / \mathrm{cc}$ )

\$No $\mathrm{Sn}$ in the library

$\$$ Element with af $<0.1 \%$ are not used Sexcept $\mathrm{Hf}$

$\$$

$\$$

\$

$\$$

\$

\$Water

\$AG3 (density $=2.55 \mathrm{~g} / \mathrm{CC}$ )

\$No $\mathrm{Zn}$ in the library

$\$$

$\$$

\$

$\$$

\$

$\$$

$\$ P u(3.6)$

$\$$
$\$$
$\$$
$\$$ 


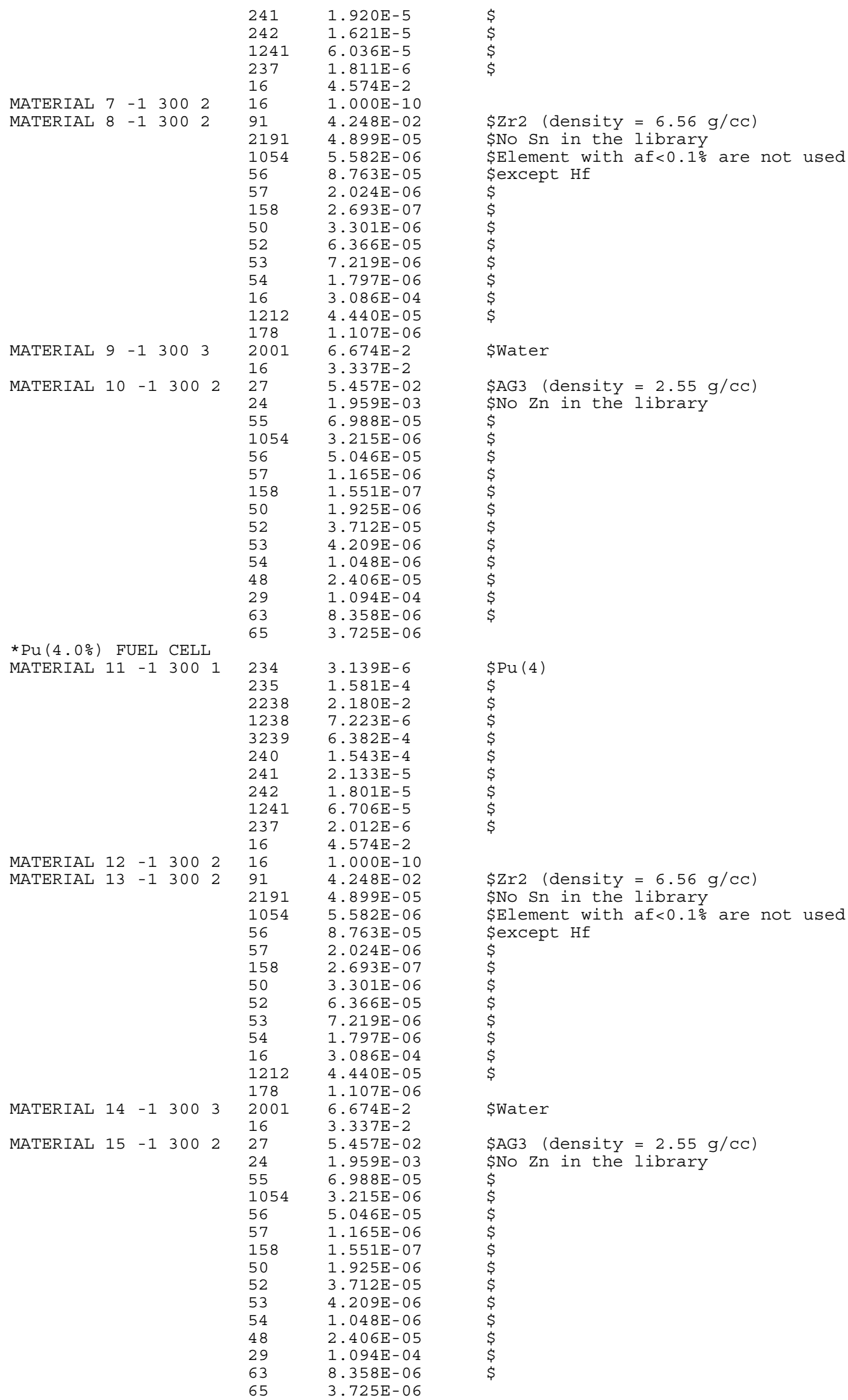

*Cross section \& flux solution

*S 32 
BELL 1.16

*Printout control

PRTOPT 1

BEGINC

*

$\star \star \star \star \star *$ EDIT INPUT DATA $* \star \star \star \star \star * *$

*Micro and Macroscopic ISOTXS control

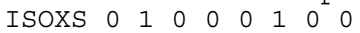

HUSE

HSETID

*Microscopic ISOTXS control

$\begin{array}{llllllllllllllll}\text { EDITCELLS } & 0 & 0 & 0 & 0 & 0 & 1 & 1 & 1 & 1 & 1 & 0 & 0 & 0 & 0 & 0\end{array}$

VECTOR $6 \quad 14 \quad 34 \quad 47 \quad 55 \quad 60 \quad 69$

**UO2 FUEL CELI

*ISOTOPES $\quad 234 \quad 235 \quad 2362238 \quad 162001 \quad 912191 \quad 1054 \quad 56 \quad 57 \quad$ \$

* $\quad 158 \quad 5052 \quad 53 \quad 54 \quad 1212 \quad 178 \quad 2724 \quad 5548 \quad 2963 \quad 65$

* ISONAMES

*DU4 DU5 DU6 DU8 DO DH $\mathrm{DZr} \quad \mathrm{DZH} \quad \mathrm{DFe} 4 \quad \mathrm{DFe} 6 \quad \mathrm{DFe} \quad$ DFe8

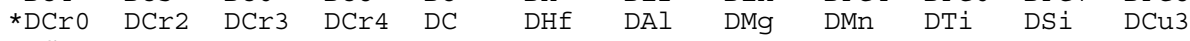

$\star \mathrm{DCu} 5$

* $\mathrm{Pu}(3.6 \%)$ FUEL CELT

$\begin{array}{llllllllllll}\text { ISOTOPES } & 234 & 235 & 2238 & 1238 & 3239 & 240 & 241 & 242 & 1241 & 237 & 16\end{array}$

$2001912191 \quad 1054 \quad 56 \quad 57 \quad 158 \quad 50 \quad 52 \quad 53 \quad 54 \quad 1212$ \$

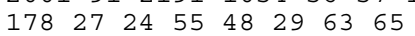

ISONAMES

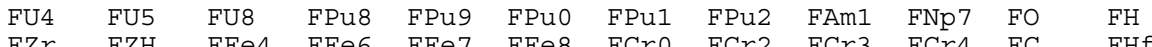

FZr FZH FFe4 FFe6 FFe7 FFe8 FCr0 FCr2 FCr3 FCr4 FC FHf

FAl FMg FMn FTi FSi FCu3 FCu5

* Leakage calculation

* LEAKAGE 61

*BUCKLING 1.E-15 1.E-15

*BEEONE 1

$\begin{array}{lllllllllll}* \mathrm{DNB} & 1 & 0 . & 0 . & 0 . & 4.647 \mathrm{E}-2 & 0 . & 0 . & 0 .\end{array}$

*DNB $6 \quad 0.0 .0 .4 .665 \mathrm{E}-2$ 2 0.0 .0 .0

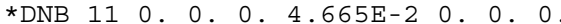

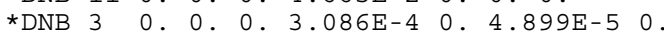

*DNB 8 0. $0.0 .3 .086 \mathrm{E}-4$ - $0.4 .899 \mathrm{E}-50$.

*DNB 13 0. 0. 0. 3.086E-4 0.4.899E-5 0.

$\begin{array}{lllllllllll}* \mathrm{DNB} & 4 & 0.06674 & 0.0 .0 .03337 & 0.0 .0 .0 . & 0.0 .\end{array}$

$\begin{array}{lllllllllllll}* \text { DNB } 9 & 0.06674 & 0.0 .0 .03337 & 0.0 .0 .0 & 0.0\end{array}$

*DNB 140.066740 .0 .0 .03337 0.0.0. 0.0.

* Reaction Rate Edits

PARTITION 4569

REACTION $235 \quad 300 \quad 2238 \quad 300 \quad 234 \quad 300 \quad 236 \quad 300 \quad 16 \quad 300$

*Miscellaneous Edit Control

BEGINC

\section{File Sample}

* MINERVE - EXPERIMENTAL ZONE - MINERVE TYPE-II FUEL PIN U(3)

* SAMPLE N0071: $0.71 \%$ of U-235

* Diameter $=0.80943 \mathrm{~mm}$

* 69 Main Transport Groups

* 2 Groups Reaction Rate Edits

* 7 Groups IsOTXS Microscopic Cross-sections

* NO Leakage: Axial Buckling = 1E-15 and Radial Buckling adjust to achieve criticality

* NO Beeone : To improve the diffusion coefficient treatment

* Al from the ENDF-BIV library

* All material cross section in the ISOTXS file

CELL 8

$\star \star \star \star \star$ PRELUDE INPUT DATA $* \star \star \star \star * *$

SEQUENCE 1

NGROUPS 6927

NCELT 2

NMATERIAL 8

NREGION $17 \quad 0 \quad 17$

NMESH 100100

NREACT 1

PREOUT 


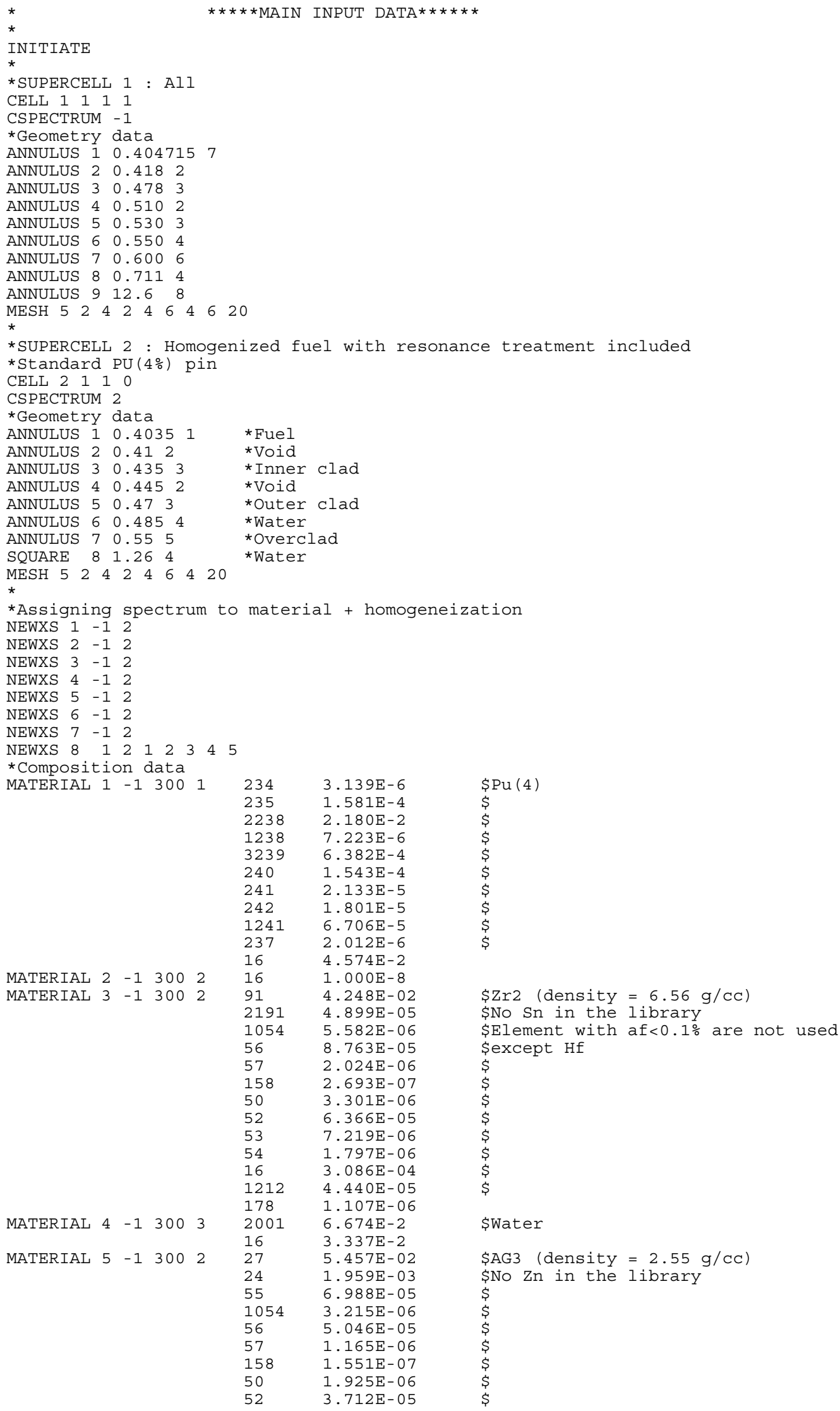




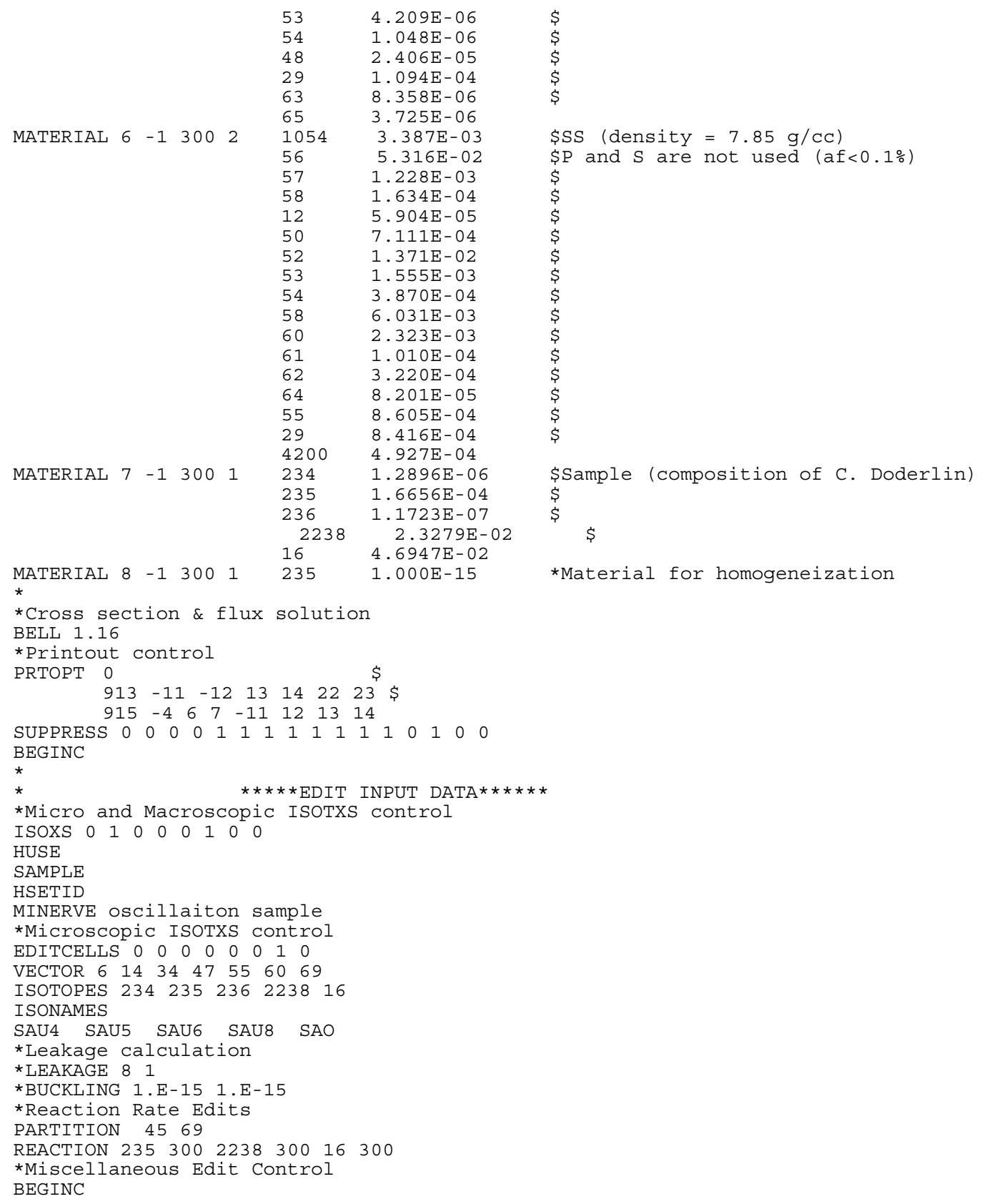




\section{Appendix 4: Elemental compositions}

\begin{tabular}{|c|c|}
\hline \multicolumn{2}{|c|}{ Table A1-1: Iron } \\
\hline Element & Abundance (atom \%) \\
\hline Fe-54 & 5.845 \\
\hline Fe-56 & 91.754 \\
\hline Fe-57 & 2.119 \\
\hline Fe-58 & 0.282 \\
\hline Fe & 100 \\
\hline
\end{tabular}

\begin{tabular}{|c|c|}
\hline \multicolumn{2}{|c|}{ Table A1-2: Chromium } \\
\hline Element & Abundance (atom \%) \\
\hline Cr-50 & 4.345 \\
\hline Cr-52 & 83.789 \\
\hline Cr-53 & 9.501 \\
\hline Cr-54 & 2.365 \\
\hline $\mathrm{Cr}$ & 100 \\
\hline
\end{tabular}

\begin{tabular}{|c|c|}
\hline \multicolumn{2}{|c|}{ Table A1-3: Nickel } \\
\hline Element & Abundance (atom \%) \\
\hline Ni-58 & 68.0769 \\
\hline Ni-60 & 26.2231 \\
\hline Ni-61 & 1.1399 \\
\hline Ni-62 & 3.6345 \\
\hline Ni-64 & 0.9256 \\
\hline Ni & 100 \\
\hline
\end{tabular}

Table A1-4: Copper

\begin{tabular}{|c|c|}
\hline Element & Abundance (atom \%) \\
\hline $\mathrm{Cu}-63$ & 69.17 \\
\hline $\mathrm{Cu}-65$ & 30.83 \\
\hline $\mathrm{Ni}$ & 100 \\
\hline
\end{tabular}

